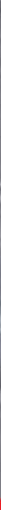

\title{
IntechOpen
}

\section{Environmental Health Risk}

Hazardous Factors to Living Species

\author{
Edited by Marcelo L. Larramendy \\ and Sonia Soloneski
}
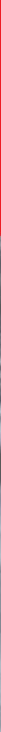



\section{ENVIRONMENTAL HEALTH RISK - HAZARDOUS FACTORS TO LIVING SPECIES}

Edited by Marcelo L. Larramendy and Sonia Soloneski 


\section{Environmental Health Risk - Hazardous Factors to Living Species}

http://dx.doi.org/10.5772/61472

Edited by Marcelo L. Larramendy and Sonia Soloneski

\section{Contributors}

T.T. Yen Le, Sabry Attia, Gamaleldin Harisa, M. Abd Allah Gamil, Pinar Erkekoglu, Belma Kocer-Gumusel, Poondy Gopalratnam Raman, Radim Vacha, Muhsin Konuk, Dilek Akyıl, Arzu Özkara, Rafael Valencia-Quintana, Juana Sánchez-Alarcón, J Mariano R Montiel-González, Sandra Gomez-Arroyo, Mirta Milić, Takemi Otsuki, Yasumitsu Nishimura, Leobardo Manuel Gómez-Oliván, Juliana Da Silva, Grethel Leon-Mejia, Milton Quintana, Katia Kvitko, Paula Rohr, Jose Antonio Pegas Henriques

\section{(c) The Editor(s) and the Author(s) 2016}

The moral rights of the and the author(s) have been asserted.

All rights to the book as a whole are reserved by INTECH. The book as a whole (compilation) cannot be reproduced, distributed or used for commercial or non-commercial purposes without INTECH's written permission.

Enquiries concerning the use of the book should be directed to INTECH rights and permissions department (permissions@intechopen.com).

Violations are liable to prosecution under the governing Copyright Law.

\section{(c) BY}

Individual chapters of this publication are distributed under the terms of the Creative Commons Attribution 3.0 Unported License which permits commercial use, distribution and reproduction of the individual chapters, provided the original author(s) and source publication are appropriately acknowledged. If so indicated, certain images may not be included under the Creative Commons license. In such cases users will need to obtain permission from the license holder to reproduce the material. More details and guidelines concerning content reuse and adaptation can be foundat http://www.intechopen.com/copyright-policy.html.

\section{Notice}

Statements and opinions expressed in the chapters are these of the individual contributors and not necessarily those of the editors or publisher. No responsibility is accepted for the accuracy of information contained in the published chapters. The publisher assumes no responsibility for any damage or injury to persons or property arising out of the use of any materials, instructions, methods or ideas contained in the book.

First published in Croatia, 2016 by INTECH d.o.o.

eBook (PDF) Published by IN TECH d.o.o.

Place and year of publication of eBook (PDF): Rijeka, 2019.

IntechOpen is the global imprint of IN TECH d.o.o.

Printed in Croatia

Legal deposit, Croatia: National and University Library in Zagreb

Additional hard and PDF copies can be obtained from orders@intechopen.com

Environmental Health Risk - Hazardous Factors to Living Species

Edited by Marcelo L. Larramendy and Sonia Soloneski

p. cm.

Print ISBN 978-953-51-2401-6

Online ISBN 978-953-51-2402-3

eBook (PDF) ISBN 978-953-51-5435-8 


\section{We are IntechOpen, \\ the world's leading publisher of Open Access books}

Built by scientists, for scientists

\section{$3,800+$}

Open access books available

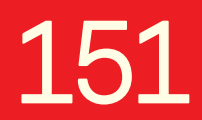

Countries delivered to

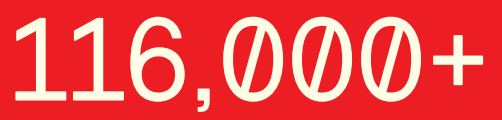

International authors and editors
$120 \mathrm{M}+$

Downloads

Our authors are among the

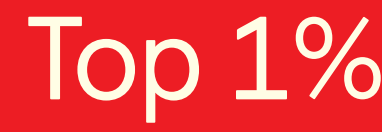

most cited scientists

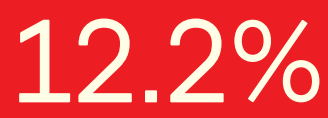

Contributors from top 500 universities

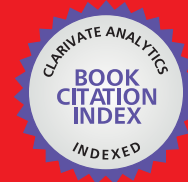

WEB OF SCIENCE ${ }^{\mathrm{TM}}$

Selection of our books indexed in the Book Citation Index in Web of Science ${ }^{\mathrm{TM}}$ Core Collection (BKCI)

Interested in publishing with us?

Contact book.department@intechopen.com

Numbers displayed above are based on latest data collected.

For more information visit www.intechopen.com

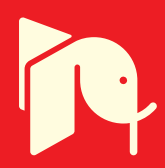





\section{Meet the editors}

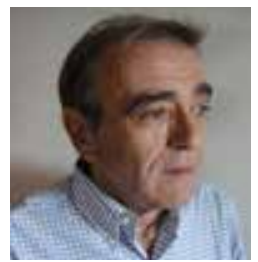

Marcelo L. Larramendy, Ph.D., serves as Professor of Molecular Cell Biology at the School of Natural Sciences and Museum (National University of La Plata, Argentina). He has been appointed senior researcher of the National Scientific and Technological Research Council of Argentina. He is also former member of the Executive Committee of the Latin American Association of Environmental Mutagenesis, Teratogenesis and Carcinogenesis. He is author of more than 470 contributions, including scientific publications, research communications and conferences worldwide. He is recipient of several national and international awards. Prof. Larramendy is a regular lecturer at the international A. Hollaender Courses organized by the IAEMS and is former guest scientist at the NIH, USA, and University of Helsinki, Finland. He is expert in genetic toxicology and is, or has been, referee for more than 30 international scientific journals. He is also member of the International Panel of Experts at the International Agency for Research on Cancer (IARC, WHO, Lyon, France) in 2015 for the evaluation of DDT, 2,4-D, and Lindane. Presently, Prof. Dr. Larramendy is Head of the Laboratory of Molecular Cytogenetics and Genotoxicology at the UNLP.

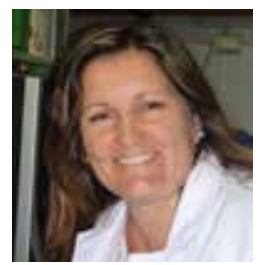

Sonia Soloneski is Ph.D. in natural sciences and professor assistant of molecular cell biology at the Faculty of Natural Sciences and Museum of La Plata, National University of La Plata, Argentina. She became a member of the National Scientific and Technological Research Council (CONICET) of Argentina in genetic toxicology field. Presently, she is member of the Latin American Association of Environmental Mutagenesis, Teratogenesis and Carcinogenesis (ALAMCTA), the Argentinean Society of Toxicology (ATA) and the Argentinean Society of Genetics (SAG). She has authored more than 290 scientific publications in the field, including scientific publications in research papers, reviewed journals and conferences worldwide. She is a referent for issues related to genetic toxicology, mutagenesis and ecotoxicology field. 



\section{Contents}

Preface XI

Section 1 General Background and Remarks 1

Chapter 1 Pesticides, Environmental Pollution, and Health 3

Arzu Özkara, Dilek Akyıl and Muhsin Konuk

Chapter 2 Modelling in Metal Risk Assessment 29

T.T. Yen Le

Section 2 Validated Methods and New Models of Evaluation 55

Chapter 3 Soil Contamination Health Risks in Czech Proposal of Soil Protection Legislation $\mathbf{5 7}$

Radim Vácha, Milan Sáňka, Jan Skála, Jarmila Čechmánková and Viera Horváthová

Chapter 4 Assessment of DNA Damage by Comet Assay in Buccal Epithelial Cells: Problems, Achievement, Perspectives 77 J. Sánchez-Alarcón, M. Milić, S. Gómez-Arroyo, J. M. R. MontielGonzález and R. Valencia-Quintana

Section 3 Specific Evaluation of Some Environmental Toxicants 137

Chapter 5 Risks of Environmental Genotoxicants 139

Sabry M. Attia and Gamaleldin I. Harisa

Chapter 6 Environmental Effects of Endocrine-Disrupting Chemicals: A Special Focus on Phthalates and Bisphenol A 155

Pinar Erkekoglu and Belma Kocer-Gumusel 
Chapter 7 Occupational Exposure to Coal, Genotoxicity, and

\section{Cancer Risk 191}

Grethel León-Mejía, Milton Quintana Sosa, Paula Rohr, Katia

Kvitko, João Antonio Pêgas Henriques and Juliana da Silva

Chapter 8 Immunological Risks Caused by Fibrous and Particulate Substances 211

Hidenori Matsuzaki, Suni Lee, Naoko Kumagai-Takei, Shoko

Yamamoto, Tamayo Hatayama, Kei Yoshitome, Hiroaki Hayashi, Megumi Maeda and Takemi Otsuki

Chapter 9 Environmental Factors in Causation of Diabetes Mellitus 231 P.G. Raman

Chapter 10 Amoxicillin in the Aquatic Environment, Its Fate and Environmental Risk 247

Armando Elizalde-Velázquez, Leobardo Manuel Gómez-Oliván, Marcela Galar-Martínez, Hariz Islas-Flores, Octavio Dublán-García and Nely SanJuan-Reyes 


\section{Preface}

Nowadays, health problems associated with the environment continue to be a major source of concern worldwide. Our global society needs to establish actions that will considerably reduce the real and potentially hazardous factors in the environment that can result in health risks for humans and other living species. Despite the progress in science, technology, and industrialization making immense positive contributions to health, the interaction between environmental risk and health is often intricate and can involve a variety of not only social and economic but also lifestyle factors. Public health depends on the good quality of environmental factors such as air, water, soil, and food, among others. However, the principal or even the ultimate challenge in environmental public health is to understand the risks that modern societies possess. They are exposed to heterogeneous xenobiotics, which are continuously released into human habitats, deliberately, inadvertently, or by nonregulated industrial discharges.

Environmental health, as a concept, is not easy to define. In this regard, according to the World Health Organization, the definition of environmental health is "all the physical, chemical, and biological factors external to a person, and all the related factors impacting behaviors. It encompasses the assessment and control of those environmental factors that can potentially affect health. It is targeted toward preventing disease and creating health-supportive environments..." However, for the National Environmental Health Association, this concept refers to "the protection against environmental factors that may adversely impact human health or the ecological balances essential to long-term human health and environmental quality, whether in the natural or man-made environment." Finally, the definition of environmental health according to the National Institute of Environmental Health Science also involves the criterion that "the social environment encompasses lifestyle factors like diet and exercise, socioeconomic status, and other societal influences that may affect health."

In general terms, our health and the health of many other species are negatively affected by five broad categories of environmental hazards, namely electromagnetic fields (produced by power lines, electrical wiring, appliances, cell phones, computers, and televisions), radiation (including nuclear fallout from weapons testing, fission materials from nuclear power plants, leaking radioactive disposal sites, flying at high altitudes, and mammograms and xrays), toxic chemicals (such as some organochlorines, phthalates, polybrominated flame retardants, perfluorinated substances, bisphenol-A, and several toxic metals, among others, which have been shown to have endocrine-disrupting properties), and, finally, soil mineral depletion as a complex environmental hazard.

By definition, risk assessment can be considered the quantitative and/or qualitative determination of a risk related to both a well-defined situation and a recognized threat (i.e., a hazard), and thus, health risk assessment includes variants such as risk as the type and severity of response, with or without a probabilistic context. In this context, risk-based methods play a strategic role in identifying and ranking the adverse responses or the structure of the effects of exposure against environmental factors. 
This book, Environmental Health Risk - Hazardous Factors to Living Species, is intended to provide a set of practical discussions and relevant tools for making risky decisions that require actions to reduce environmental health risk against environmental factors that may adversely impact human health or ecological balances. We aimed to compile information from diverse sources into a single volume to give some real examples extending concepts of those hazardous factors to living species that may stimulate new research ideas and trends in the relevant fields.

Although we are dealing with many diverse topics, we have tried to compile this "raw material" into three major parts in search of clarity and order. First, in General Background and Remarks, readers will find two chapters with background information about the nature of pesticides, their history, their classification, their risks, and their effects on health and environment, as well as general aspects of environmental pollution by metals as a serious problem in many areas of the planet, with a special emphasis on the assessment of metal bioaccumulation and toxicity. Second, in Validated Methods and New Models of Evaluation, we have included two chapters on, first, problems with the use, analysis, and interpretation of results obtained through the comet assay in human buccal cells and, second, a new system of hierarchical limit values to protect soil environments, food chains, and human health against contamination that reveals the areas where the soil does not meet the soil quality standards and where the human health is at risk. Finally, Specific Evaluation of Some Environmental Toxicants encloses six chapters describing specific examples of toxicants with potential risks to living species, such as humans. The first chapter describes the genotoxic properties of bisphenols and mycotoxins, which are prominent environmental contaminates and potential carcinogens. The second chapter reviews the toxic effects of different phthalate esters and bisphenols and their availability in the environment, mechanisms and modes of actions, biotransformation, and reproductive effects. Then, the next two chapters describe, respectively, the relationship between chronic exposure to coal and coal ash particles and cancer and a novel procedure for the early detection of previous asbestos exposure, its relation with mesothelioma, and chemoprevention of asbestos-related cancers. The last two chapters review, respectively, the accumulation of organic pollutants in the environment, with a special reference to the mechanism in the causation of type 2 diabetes mellitus, and risks that amoxicillin poses to the environment, focusing on detailed ecotoxicity testing using a wide range of aquatic organisms to fully understand the environmental toxicity of this antimicrobial product, and how it may affect both aquatic and terrestrial environments.

Many researchers have contributed to the publication of this book. Given the fast pace of new scientific publications shedding light on the matter, this book will probably be outdated very soon. We regard this as a positive and healthy fact. The editors hope that this book will continue to meet the expectations and needs of all those interested in the environmental risk assessment field of study.

Marcelo L. Larramendy and Sonia Soloneski School of Natural Sciences and Museum, National University of La Plata, La Plata, Argentina 
General Background and Remarks 



\title{
Chapter 1
}

\section{Pesticides, Environmental Pollution, and Health}

\author{
Arzu Özkara, Dilek Akyıl and Muhsin Konuk \\ Additional information is available at the end of the chapter \\ http://dx.doi.org/10.5772/63094
}

\begin{abstract}
In recent years, people have been exposed to several types of substances with broad spectrum due to the rapidly evolving technology. One of these chemical substance groups are pesticides. Pesticides have been an essential part of agriculture to protect crops and livestock from pest infestations and yield reduction for many decades. Despite their usefulness, pesticides could pose potential risks to food safety, the environment, and all living things. Concern about the environmental impact of repeated pesticide use has prompted research into the environmental fate of these agents, which can emigrate from treated fields to air, other land, and water bodies. The importance of agricultural pesticides for developing countries is undeniable. However, the issue of human health and environmental risks has emerged as a key problem for these countries in accordance to a number of studies. In the last five decades, pesticide usages increased the quantity and improved the quality of food. However, with the increasing amounts of their usage, concern about their adverse effects on nontarget organisms, including human beings, has also grown. The purpose of this publication is to explain the nature of pesticides and their history, classification, risks, and effects on health and the environment.
\end{abstract}

Keywords: organic pollution, health concern, environment, pesticides, environmental pollutant

\section{Introduction}

In thelast three decades, there has been an increasing global worry over the publichealthimpacts attributed to environmental pollution. It was the industrial revolution that gave birth to environmental pollution as we realize it today. Populations of developing countries are particularly vulnerable to toxic pollution resulting from industrial processes. 
Pollution is the introduction of contaminants into the environments that cause harm or discomfort to other living organisms or damage the environment, which can come in the form of chemical substances or energy, such as heat, light, or noise. Pollutants can be naturally occurring energies or substances but are considered contaminants when in excess of the natural levels. Santos divided environmental pollutants into biodegradable and nonbiodegradable ones. Biodegradable pollutants can be broken down and processed by living organisms, including organic waste products, phosphates, and inorganic salts. Nonbiodegradable pollutants cannot be decomposed by living organisms and therefore persist in the ecosphere for extremely long periods of time. They contain metals, plastics, glass, pesticides, and radioactive isotopes [1].

In recent years, people have been exposed to several types of substances with broad spectrum due to the rapidly evolving technology. Technology has brought us clear conveniences, and thousands of chemicals produced in different areas are up on the market every year. One of these chemical substance groups are pesticides $[2,3]$.

\subsection{Pesticides}

Through the ages, it seems increasingly that people find a need to minimize the damage of pests with the use of pesticide chemicals and by other means [4]. Of the many examples of how pests have impacted human society, one of the most infamous is the Black Plague in Europe in the 14th century, when millions of people died from mysterious diseases. At that time, the diseases were believed to be because of God's punishment. A number of reports in the literature, art, and public statues certify the fear and destruction of those epidemics. Many years later, scientific data proved that a bacterial disease spread by rat fleas was the cause of the plague, which ruined almost the whole of Europe. Today, this disease, known as bubonic plagues, can be easily treated if it is properly diagnosed. Hence, controlling rodents including rats as well as fleas can reduce the relative frequency of the occurrence of diseases [5].

Ireland's potato crop destruction by a pest in the 19th century is another story. At that time, late blight, a plant disease, wasted potatoes in Ireland. Up to 1 million Europeans starved to death during the Great Irish Famine of 1845 to 1847. Late blight is still one of the major potato pathogens that chemists aim to synthesize new pesticides against [5].

Pesticides are chemical substances used on agricultural land but also in private gardens, along railways, and in other public areas [6]. The use of pesticides for crop protection is expected to increase based on a growing world population and the need for more food supplies. While pesticides increase agricultural production, bioaccumulation through the food chain can eventually become a risk to mammals because pesticides induce certain negative effects [710]. Some parts of pesticides sprayed on crops will remain in farmland, but some of them will enter the surrounding soil, water, and air [11,12]. As artificial organic compounds, pesticides can remain in the environment for many years and may be transported over a long distance [13]. Pesticide residues in soil and water are significant environment threats and have been classified as carcinogen pollutants in many countries [14,15]. Hence, the excessive application of these compounds over the past half-century has posed serious risks to human health $[16,17]$. 
There have been numerous reports regarding pesticide residues detected in grains [8], milk [18], vegetables [19], and fish [20].

Although the benefits of pesticides have been immense, humans and other living organisms are often exposed to them in the environment [21]. Several epidemiological studies reported in the last two decades suggest harmful effects of pesticides on human health, including a possible relationship between pesticide use and cancers, such as non-Hodgkin's lymphoma, leukemia, and various types of solid tumor [22-24]. Public health concerns regarding the improper use of pesticides and poison have increased in recent years. To date, certain countries, regions, and international organizations have established maximum residue limits (MRLs) for foodstuffs. Additionally, national food monitoring programs for pesticides have been enacted worldwide [7-9] to ensure consumer health, improve the management of agricultural resources, and prevent economic losses [10].

Despite the adoption of the International Code of Conduct on the Distribution and Use of Pesticides (Code of Conduct) [25], the strict control of banned/legacy pesticides has been proven difficult in many developing countries. This could be attributed to weak regulations on importation and use of dangerous substances and the activity or absence of control agencies at international borders [26]. This scenario has led to the proliferation of banned chemicals in local markets located in agricultural areas, making large quantities of pesticides available to rural farmers, which eventually could pose potential threats to the environment and the health of the people [27-29].

The existence of persistent chemical substances in the environment and their effects on the wildlife and mankind has raised a serious global concern. In this case, we need to mention the risks of pesticides.

Pesticides are poisons and can be hazardous. Fortunately, people are becoming more aware of their danger, and even producers are trying to produce safer chemicals and better application methods. Even the awareness is improving for risk-benefit ratio side; the job has not been completed yet. Misuses of pesticides still occur. On the contrary, even if they are used correctly, some pesticides can harm nontargeted living organisms and the environment. Just as the benefits of pesticides are real, so are the risks. The purpose of this publication is to explain the nature of pesticides and their history, classification, risks, and effect on health and the environment [4].

\section{Historical perspective}

Pesticides are used for a number of decades. People have been fighting with pests for centuries [5]. Chemical experiments during the late 19th and early 20th centuries allowed human beings to develop modern pesticides. Producing new mixtures with a right proportion made it possible to control unwanted organisms. Paris green was one of the first chemical pesticides produced, marking the beginning of chemical insecticide use in the United States in 1867 [30]. By the late 19th century, U.S. farmers were using calcium arsenate, nicotine sulfate, and sulfur to control insect pests in field crops, except Paris green [4]. Since the middle of the 20th century, 
these chemicals have been widely used to control pests [31,32]. Ancient Romans controlled weeds with salt and killed insect pests by burning sulfur [4]. Sulfur, also known as brimstone, was used by pagan priests 2000 years before the birth of Christ. Additionally, sulfur was used to purify a sick room and cleanse its air of what was believed to be evil. In the 1600s, ants were controlled with mixtures of honey and arsenic. Early plant-derived insecticides included nicotine to control aphids, hellebore to control body lice, and pyrethrins to control a wide variety of insects [5].

The availability of dichlorodiphenyltrichloroethane (DDT), starting in 1945 for civilian/ agricultural usage, opened a new era of pest control, leading to not only its extensive usage but also the development of numerous other synthetic organic insecticides. DDT was especially favored for its broad-spectrum activity against insect pests of agriculture [4]. Unfortunately, its properties of persistence, along with its broad-spectrum biological activity against pests and beneficial insects alike, made it a poor choice for use in agriculture after World War II [33]. Except DDT, aldrin, BHC, endrin, dieldrin, and 2,4-D began to be used after World War II. These new chemicals were effective, inexpensive, and enormously popular [34]. However, with continuous usage of pesticides, some pests developed resistance to them. As a result, nontarget plants and animals were damaged; surprisingly, pesticide residues were observed to be present in unexpected places. Rachel Carson's book, Silent Spring in 1962, shook public confidence in pesticide usage. Carson presented a harsh picture of environmental consequences of careless pesticide employment. Although her report has been strictly criticized, Carson pointed out the risks of pesticides more than anyone [4].

As chemical controls became more and more common in agricultural, public health, and nuisance applications throughout the first half of the 20th century, a myriad of problems were being discovered. Chemically reliant methods had quickly resulted in pesticide resistance within the target species, harm to nontarget species, food contamination, water contamination, overall ecological degradation, and public health problems [30].

\section{Classification of pesticides}

The word "pesticide" is an umbrella term for all insecticides, fungicides, herbicides, rodenticides, garden chemicals, wood preservatives, and household disinfectants that may be used to kill some pests. Pesticides have different identities and physical and chemical properties. Synthetic pesticides are classified based on various ways. In general, there are three main ways to classify them: classification based on the (i) mode of action, (ii) targeted pest species, and (iii) chemical composition of pesticides [35].

\subsection{Classification based on the mode of action}

Pesticides are classified based on the way they act to bring about the desired effect in this classification. Under this type of classification, pesticides are classified as nonsystemic and systemic pesticides. Nonsystemic pesticides are those that do not appreciably penetrate plant tissues and consequently not transported within the plant vascular system. On the contrary, 
systemic pesticides are those that effectively penetrate plant tissues and transported within the plant vascular system to bring about the desired effect [36].

\subsection{Classification based on the targeted pest species}

Classification by target pest is perhaps the most familiar. For example, insecticides are pesticides that target insects, and herbicides target plants. The others are rodenticides, fungicides, acaricides and miticides, molluscicides, bactericides, avicides, and virucides.

\subsection{Classification based on the chemical composition}

In this type of classification, pesticides are characterized regarding their chemical nature and active ingredients. This is the most useful one for researchers studying the field of pesticides and the environment, because it is this kind of classification that gives the clue of the efficacy and physical and chemical properties of the respective pesticides and precautions that need to be taken during application and the application rates, the knowledge of which is important in the mode of application [37].

According to chemical properties, pesticides can be generally divided into about seven types, including organochlorines, organophosphorus, carbamates, pyrethroids, amides, anilins, and azotic heterocyclic compounds. Organochlorine chemicals are organic compounds with five or more chlorine atoms. Organochlorines were the first synthetic organic pesticides to be used in public health and in agriculture. These pesticides generally have a steady chemical structure and often accumulate and persist in the environment. Most of them are widely used as insecticides for the control of a wide range of insects. Organochlorine insecticides act as nervous system disruptors leading to convulsions and paralysis of the insect and its eventual death. They can cause serious endocrine disorders in mammals, fish, and birds, so most of them have been banned in agriculture worldwide [36,38]. Organophosphates are another type of highly toxic pesticides that contain a phosphate group and occupied up to $48.6 \%$ of all pesticides in 1997 [39]. The importance of synthetic organophosphates increased considerably during World War II with their use as warfare materials. Since then, these pesticides have been used in agriculture, industry, cosmetics, medicine, and many other areas [40,41]. These chemical compounds inhibit the acetylcholinesterase enzyme, which hydrolyses acetylcholine in the nervous system of a number of species, including humans [42]. Although they are easier to be degraded than organochlorines, organophosphate pesticide residues is one of the biggest threats to the ecosystem and food industry because their acute toxicities are irreversible [43].

Many people are exposed to pesticides occupationally, and pesticide self-poisoning is a major public health problem [44]. Annually, 3 million cases of acute poisoning have been reported from pesticide exposure, resulting in the deaths of 250 to 370,000 people every year $[45,46]$. Therefore, the usage of organophosphates has been restricted or banned all over the world [43].

Carbamates are organic pesticides, reversibly inactivating the enzyme acetylcholinesterase; these pesticides are derived from carbamic acid. The cholinesterase inhibition of carbamates differs from that of organophosphates in that it is species specific and is reversible [35,47]. Organochlorines, organophosphates, and carbamates are three generations of traditional 
highly toxic pesticides, and the later developed pyrethroids, anilines, amides, and azotic heterocyclic compounds are generally less toxic [48].

Pyrethroids are synthetic analogues of the naturally occurring pyrethrins, a product of flowers from pyrethrum plant (Chrysanthemum cinerariaefolium), and were detected in the 1980s to mimic the insecticidal activity of the natural pyrethrum. Pyrethroids are acknowledged for their fast knocking down effect against insect pests, facile biodegradation, and low mammalian toxicity [37]. These pesticides are nonpersistent sodium channel modulators and are much less toxic than carbamates and organophosphates to mammals. Therefore, the usage of pyrethroids has been increased greatly in the last 30 years. Unfortunately, pyrethroids are highly toxic to aquatic organisms such as mollusks, fish, and arthropods $[49,50]$.

Amide herbicides, such as acetochlor, butachlor, and metolachlor, are widely used in recent years. However, butachlor can persist in the environment for up to 10 weeks, and what's even worse is that butachlor and metolachlor have been identified as mutagens. Another type of pesticides is aniline and dinitroaniline. Trifluralin and pendimethalin are widely used in this group of pesticides. These pesticides show high toxicity to aquatic organisms and they can impair the thyroid gland and liver. Hence, these two aniline herbicides have been banned in many European countries. Nitrogen-containing heterocyclic compounds, especially for imidazole and triazole heterocyclic chemicals, have become the hotspot for new pesticide development. In the last 10 years, they occupied no less than $70 \%$ of all the newly developed chemical pesticides [48].

Except for these classifications, pesticides are classified according to the mode of formulation, activity spectrum, and toxicity level. According to the mode of formulation, pesticides are classified into six groups as wettable powders, emulsifiable concentrates, baits, granules, dusts, and fumigants. In active spectrum, pesticides are classified into two groups as broadspectrum pesticides and selective pesticides. Broad-spectrum pesticides are designed to kill a wide range of pests and other nontarget organisms. On the contrary, selective pesticides are designed to kill only specific pests. In toxicity level, the World Health Organization (WHO) has developed a classification system that group pesticides according to the potential risks to human health and they are grouped into the following classes: class Ia=extremely hazardous, class $\mathrm{Ib}=$ highly hazardous, class $\mathrm{II}=$ moderately hazardous, class $\mathrm{III}=$ slightly hazardous, and class IV=products unlikely to present acute hazards in normal use [37].

\section{Pesticide pollution}

Since the middle of the 19th century, pesticides have been commonly used to control pests [31,32] causing a widespread release of these xenobiotics into the environment [51]. The intensive use of pesticide leads to an increased risk of contamination of the environment and harmful effects on biodiversity, food security, and water resources [52,53].

Pests, such as insects, weeds, and plant diseases, are an ongoing challenge to agricultural producers. Oerke [54] reported that, globally, an average of 35\% of potential crop yield is lost 
to preharvest pests. With the expected 30\% increase of world population to 9.2 billion by 2050, there is a projected demand to increase food production by $70 \%$ according to Popp et al. [55]. Although nonpesticidal tools have a vital role, there will be a continuing need for pesticidebased solutions to pest control and food security in the future [55,56]. Figure 1 shows the average pesticide use intensity $\left(\mathrm{kg} \mathrm{ha}^{-1} \mathrm{yr}^{-1}\right)$ on the cultivable and permanent cropland worldwide. High use intensity countries above $10 \mathrm{~kg} \mathrm{ha}^{-1} \mathrm{yr}^{-1}$ include Surinam, Malta, Columbia, Palestinian, Japan, Korea, Chile, and China [57]. Figure 2 presents that pesticide sales are increasing in Europe, Asia, and Latin America [58,59].

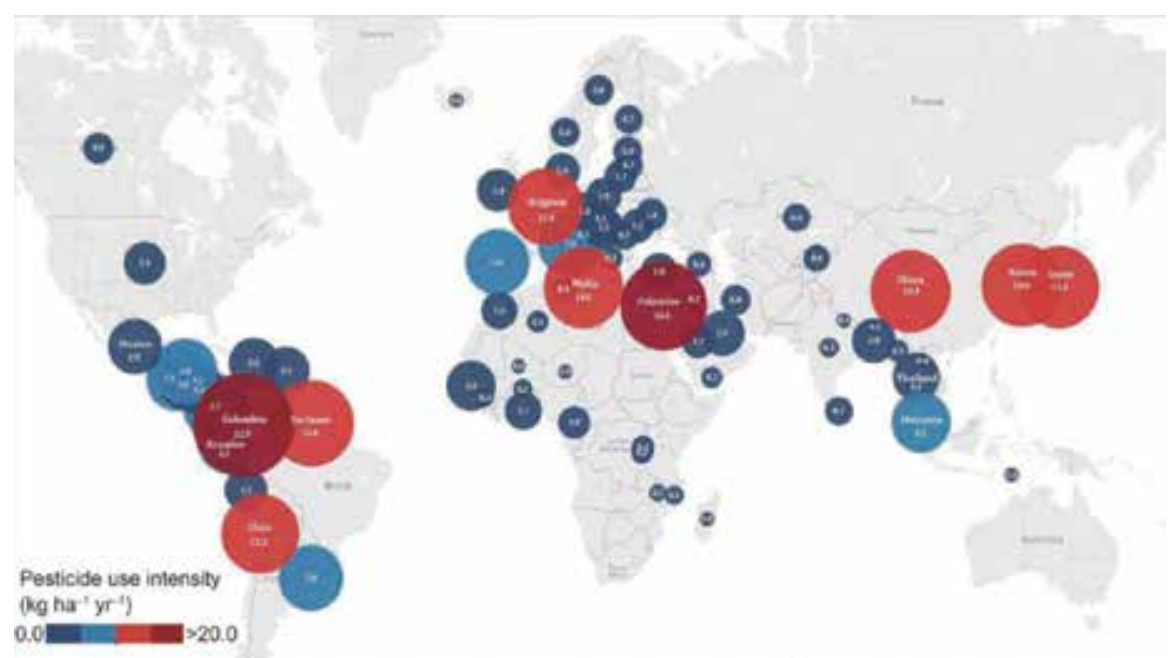

Figure 1. Average annual pesticide use intensity $\left(\mathrm{kg} \mathrm{ha}^{-1} \mathrm{yr}^{-1}\right)$ on arable and permanent cropland from 2005 to 2009. Data are from FAO [57].

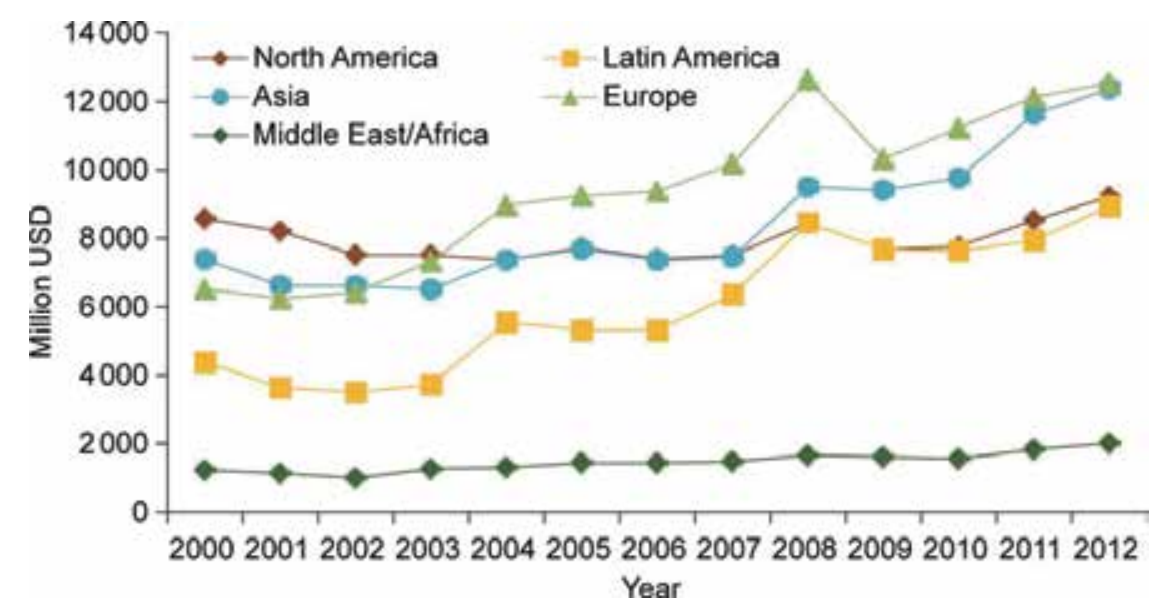

Figure 2. Annual pesticide sales by geographic regions. Data are from FAO [58]. 
More than 500 different pesticide formulations are being used in our environment, mostly in agriculture [60]. In the past five decades, pesticide usages increased the quantity and improved the quality of food. However, due to their usage with increasing amounts, the concern about their harmful effects on nontarget organisms, including human beings, has also been growing. Nontarget pesticide poisoning has been reported from fish, birds, and humans [61]. Although it is estimated that less than $0.1 \%$ of pesticide applied to crops actually reaches the target, the rest of it enters the environment [62]. Additionally, many pesticides can persist for long periods in an ecosystem; organochlorine insecticides, for instance, are still detectable in surface waters 30 years after their use and had been banned [63]. In the food chain, they meet with nontarget organisms, including mankind. They accumulate in the body tissues of organisms and cause a number of health problems $[64,65]$.

Pesticides and herbicides are heterogeneous chemicals used widely in agriculture. Their design as bioactive molecules to exterminate different animal, vegetal, or fungal species implies that they are toxic by definition. Due to this toxicity, their use is regulated in the European Union. Depending on the water solubility and polarity of each specific pesticide, they can follow different pathways to reach water bodies once applied in the crop fields. In the case of surface waters, the most common entry pathway for these pollutants is runoff from agriculture lands after precipitation or irrigation [66]. Pesticides could influence biological communities in lakes, forcing changes from a clear-water, macrophyte-dominated state to a turbid state due to their effect on zooplankton or macrophytes $[67,68]$.

As explained above, both point and diffuse pollution sources of pesticides, herbicides, and polycyclic aromatic hydrocarbons (PAHs) are usually anthropogenic. Therefore, it is expected that the concentration of some of these compounds in surface water is related to human activities that take place in the surroundings. The proportion of cultivated lands around the lake and the agricultural pressure and intensity are especially relevant, as certain substances such as herbicides and pesticides have a close relationship with agriculture. In fact, it has been observed that land uses are strongly related to nutrient concentrations in surface waters [69] and PAH concentrations in wetland sediments [70]. On the contrary, the distance between lakes and point or diffuse pollution sources such as urban areas, thermal power plants, industries and roads could also be related to the amount of these chemical compounds detected in aquatic ecosystems [68].

Pesticide fate in the environment is characterized by a number of complex processes occurring in different environmental compartments, such as air [71], soil [72], plant [73], and surface and groundwater $[53,74]$.

Pollution due to the uncontrolled use of pesticides has become one of the most alarming challenges when pursuing sustainable development. Although pesticides are directly applied in soils and plants, only $1 \%$ of pesticide sprayed is delivered to the intended target. An accidental release of pesticides due to leaking pipes, spills, waste dumps, underground storage tanks, and groundwater may lead to their persistence in the environment for a long time (due to long half-lives). For proper management of pesticides, one needs to accurately assess the status of their contamination in soil, water, and air $[75,76]$. 
Soil is a major reservoir for a variety of pollutants [77] and is a secondary emission source of contaminants to surface water, groundwater, and air [78]. Multiclass environmental endocrine disruptor compounds (EDCs), such as organochlorine pesticides (OCPs) phthalate esters (PAEs), and polybrominated diphenyl ethers (PBDEs) may coexist in soils and accumulate in crops and human bodies through food chains, posing risks to human health and the ecosystem [79]. In addition, soil plays an important role in pesticide residue in plants. There are two pathways for pesticide transfer between the plants and their planted soils. First, most of pesticides could shift or fall onto the soil when pesticide is applied onto plants. Next, most of the deposited pesticides on the plant could be washed off by rainfall to the soil. Second, the residues of adsorbed pesticides in soil, especially for organochlorine pollutants, remain as contaminants in the environment because of their long-term persistence and mobility, and they could enter into food again via the plant uptake effect [10,80,81].

Persistent organic pollutants (POPs), such as OCPs, are ubiquitous contaminants in different compartments of the environment [82,83]. Although a number of countries have been removed from the circulation of the usage of POPs for nearly 30 years, these synthetic chemicals are found in nature at considerable levels worldwide due to their persistence. These substances are mainly generated by anthropogenic processes and can be introduced into the environment through various routes. These pesticides are toxic, carcinogenic, and mutagenic features. They are extremely hazardous for the both biota and environment [84]. Hence, the investigation of POPs in aquatic environments is needed to provide relevant information on the anthropogenic impact on the environment, and concentrations serve as an indicator of contaminant load [85, 86].

Pesticides are major components of the modern agricultural production because of their reliability and high capability for crop protection against pests [87]. Approximately 5 billion kilograms of pesticides are applied worldwide per year, which can have serious effects on biodiversity, nontarget organisms, and the food chain, posing high risks to the environment and human health [88]. In rural areas of developing countries, 3 million farmers suffer annually from serious pesticide poisoning and 25 million farmers suffer from mild poisoning, resulting in approximately 180,000 fatalities among agricultural workers annually [89] because of incorrect perceptions, lack of knowledge, regulation, and education among farmers [90,91].

Unsafe pesticide use or misuse in developing countries includes the use of pesticides banned by the local government [92], lack of self-protection [93], incorrect pesticide storage [94], overspraying [95], improper handling of pesticide containers [96], and, in extreme cases, reuse of washed pesticide containers as containers for food and drinking water (as reported by $35.4 \%$ and $77.2 \%$ of farmers in Nigeria and Ethiopia, respectively) [97]. The local authorities, the WHO, the Food and Agriculture Organization (FAO), and various nongovernment organizations that focus on low- and middle-income countries (e.g. China, India, Vietnam, and African countries) have taken initiatives to improve the protective behaviors of farmers in pesticide use, including personal and environmental protection through education [98] and legislation and community intervention [99], although the results were often unsatisfactory [100]. The factors that affect farmers' behavior in pesticide use are far more complex than expected. 
Pesticide use can be influenced by age [101], gender [102], perceptions [90,91], level of knowledge, pesticide retailers [103], and even cultural or planting differences [92].

The chemical pesticide provides a necessary guarantee for the output increase, but pesticide abuse has led to daily worsening of the ecosystem of agricultural lands [104,105]. The use of large amount of pesticide is the main reason for agricultural pollution [106].

\section{Effect of pesticides on health and the environment}

The importance of agricultural pesticides for developing countries is undeniable. However, the issue of human health and environmental risks has emerged as a key problem for these countries in a number of studies [107-112]. Attention to the impacts of pesticide use on the environment and ecosystems has grown since the book Silent Spring was published in 1962. Extensive published literature has well documented the impacts of pesticide use to the ecosystem and human health [55]. Pesticides can move off-site to contaminate surface water and leach to groundwater. Damage to nontarget organisms and pollution to the soil and air are well documented [59].

The released pesticides into the environment and their impacts on many species have been known for a long time. The senseless and widespread use of OCPs between the 1960s and the 1970s caused a striking decrease in wildlife populations nearly all over the world [113]. DDT, dieldrin, and other toxic OCPs affected birds and other wild species during that time and have been finally banned from agricultural use. Since then, however, decline in birds, wild bees, and aquatic organism populations have been continuing [114]. This could be linked to usages of newly synthesized pesticides that are present in every kind of habitat on the world. Pesticides are still being discovered in marine, freshwater, and terrestrial communities [115].

Insecticides may kill not only the target species but also other invertebrates on which birds rely on for their food. In addition, herbicides are designed to control weed species and they can also kill many other plant species in fields, including the essentially beneficial species, which give both shelter and food for the members of wildlife. Amphibians are now considered the most threatened and rapidly decreasing species on Earth. Brühl et al. [116] suggested that frogs are sensitive to the toxicity of pesticides that are currently used in agriculture.

In addition, pesticide factory workers and agricultural farm workers have high risk to pesticide direct exposures [88]. In recent years, pesticide residues in food have become a focus for food safety and trade. Quarantine regulations sometimes require pesticide treatment of food shipments to prevent the establishment of exotic pests. Nonetheless, local consumers and international trading partners increasingly demand food that is free from unsafe pesticide residues. Therefore, many countries have initiated programs to monitor pesticide residues in food. In addition, many countries are implementing programs to reduce the use of pesticides and thereby minimize pesticide impacts [59].

Intensively used pesticides, despite their ability to protect crops, threaten the environment and human health $[88,117]$. Besides, the use of pesticides also results in residue problems. Pesticide 
residue is defined by the WHO as any substance or mixture of substances in the food of either humans or animals that is caused by the use of pesticides and any specified derivatives, such as degradation and conversion products, reaction products, metabolites, and impurities that are considered toxic [118].

\subsection{How are we exposed to pesticides?}

People who live in agricultural areas have a high disclosure to pesticides by inhalation of pesticide spray blow in urban areas and parks or in the houses after breathing contaminated air. Farmers and their families can have a higher exposure to pesticides than the general population. Besides, when nursing mothers and pregnant women are exposed to pesticides, their children may also be exposed. Some pesticides can pass through the placenta to the developing fetus in the womb and through breast milk to the nursing infant [119].

These "poisons by design" are prevalent and serious occupational hazards faced by farmers and agricultural workers [117]. The high levels of occupational exposure to pesticides are correlated with low educational levels, which would preclude the ability of farmers to follow the hazard warnings developed by the chemical industries and agencies [120]. Tragedies, such as acute and chronic intoxication and, in some extreme cases, suicide, have frequently been reported, especially in rural regions $[117,121]$. The lack of a legislative framework regulating the use of pesticides also contributes to the high incidence of poisoning in developing countries [117].

The present data seem to be too limited to analyze the full health effects of pesticide referable chronic exposures. On the contrary, suicide commitments in 2002 using pesticides resulted in 258,000 deaths [122]. In 2002, intentional poisoning from pesticides accounted for approximately one third of the world's suicides, and in $2004,71 \%$ of the unintentional poisonings were considered preventable by improving chemical safety methods [45]. The groups most at risk from unintentional pesticide poisoning are children, especially those between ages 0 and 4 years [123]. Human deaths induced by insecticides were mainly because of ingestion of OPPs. OPP poisoning is evident for "cholinergic syndrome". The symptoms in this syndrome are headache, slurred speech, coma, blurred vision, convulsions, blockage of the respiratory center, and delayed neuropathy [124]. In this sense, survivors of acute OPP poisoning may suffer long-term adverse effects to the nervous system [119].

Data show that there is a positive relationship between high pesticide exposures and occurrence of several types of cancer (e.g. prostate and lung) as well as the increase of neurodegenerative diseases, such as Alzheimer's and Parkinson's disease. There are also evidences that pesticides may impair endocrine function and the immune system. Although the mechanisms of such failures are not completely comprehended, there are some clear evidences showing the disruptions in enzymatic function and signaling mechanisms at cellular levels. DNA-based toxicity studies also indicate that pesticides affect gene expression and this may transferred to generations through epigenetic inheritance [119].

Organophosphate compounds (OCs) and OCPs have been widely used as pesticides in agricultural productivity. However, they have been proven to be extremely hazardous for 
human health. OCs and other pesticides may persist on Earth for a long time, adverse to the ecology. Therefore, pesticide residues in vegetables, fruits, water, and on Earth are drawing more and more attention [125-128]. Applied pesticide residues may persist within the tissues or on the surface of the crops when we buy from market. Scientists have developed a variety of techniques to both determine and quantify the pesticide levels in food. Data obtained from these studies suggested that nonstop monitoring is needed to ensure that pesticide residues do not exceed their acceptable values [99]. Most countries, on either a regional or a national basis, maintain a threshold maximum residue level (MRL) for each substance, above which the foodstuff is thought unacceptable for human consumption [119].

OCPs are among the substances restricted or banned globally under the Stockholm Convention on Persistent Organic Pollutants [129]. These compounds are environmentally persistent [130], toxic, and apt to bioaccumulation [131] and have adverse effects on animals and humans [132]. Some developing countries are still using these compounds because of their low cost and versatility in industry, agriculture, and public health [133]. Consequently, environmental problems associated with toxic contamination in these countries are of great concern [134]. As a result, organochlorines in various environmental media have received much attention [133]. They are well-known anthropogenic and lipophilic pollutants due to their high bioaccumulation potential in fatty tissues of living organisms [135]. Although these substances are generally stored in the fat and muscles of the animals, some can also be found in the brain, lungs, liver, and other offal. Additionally, because milk and other dairy products contain a range of fat, these foods may also contain a number of pesticides. This is important because cow's milk is one of the indispensable components of human diet $[119,136,137]$. OCPs can enter animal tissues through different pathways of ingestion, dermal contact of dust, and inhalation [138].

In the past decades, attention was focused on the determination and pollution levels of OCPs in human blood serum, maternal and cord serum, adipose tissue, human milk, and hair and other available tissues to study human exposure and assess health risk [139]. Human exposure to OCPs is through many routes: breathing OCP-contaminated air, working in or living beside OCP factories, drinking and taking a bath with OCP-polluted source water, eating vegetables and grains containing OCP residues, and eating especially fish and animal meats [140]. OCPs accumulated in the human body could cause various negative effects such as immunological function damage, endocrine disruption, female spontaneous abortions and preterm, and children neurodevelopmental delays [141].

Several studies showed that cancer risks could be induced by OCP exposures [142]. At the same time, OCPs could be transferred from maternal to fetal tissues through placenta and from mother to infant through breast milk. Exposure to OCPs could also lead to some adverse effects on human productivity, including spontaneous abortions and preterm [143], delayed neurodevelopment during childhood [144], and reproductive disorders of man [145] and other negative effects. In the fetus, as the rapid growth and development occur during early development, the organs of the baby can be sensitive to the toxic substances; especially, the brain is more susceptible to neurotoxicants [146]. Increasing evidence suggests that prenatal pesticide exposure may have a permanent effect on children's behavior and intelligence. Besides, organophosphates are also hazardous compounds in the environment and public 
health. When children are exposed to pesticides in various ways at a young age, there is an observed negative effect on the development of the central nervous system [147]. Developmental impacts were mainly described as behavioral or cognitive, particularly those related to attention-deficit disorders and motor skills [119].

Experimental research has shown that many pesticides are endocrine disruptors that can disturb the functioning of various hormones throughout the body [148]. The production of thyroid hormone is thought to be inhibited by substances such as cyhalothrin, amitrole, pyrimethanil, and fipronil. Other pesticides may also alter thyroid hormone levels and potentially cause thyroid disease. Experimental studies in vitro support observations that the balance of sex hormones can be disrupted by exposure to certain pesticides. There is also evidence that fertility of both women and men may be decreased with increased pesticide exposure [119].

Studies showed that there are evidences of pesticide exposure and disorders in both hormonal regulation imbalance and immune system activities. The statistical results are associated with pesticide exposure and occurrence of some diseases. This finding cannot be ignored. The mechanisms of pesticide-induced diseases are not yet fully understood, but we now know that some key enzymatic activities in main metabolic pathways and/or the permeability of the ion channels are affected by them [149].

Moreover, some people carry susceptibility genes to the health effects of pesticides, and for that reason, they are likely to be more at risk than others. The questions on these epigenetical differences and developing policy approaches to ensure a high level of protection for mankind may remain insurmountable for a long time. In the meantime, people will continue with the routine application of pesticides to get more crops. On the contrary, the next generations, even they if are not exposed to pesticides, may also be at risk to these diseases due to epigenetical inheritance [119].

As mentioned by Allsop et al., many synthetic pesticides used in agriculture are persistent and pervasive in the environment. As a result, mankind is exposed to the mixture of pesticides via the food consumed and the environment around. Evidences suggest that more exposure means more toxic effect we will face. Although assays have been made to describe the toxicity of these kinds of interactions, there are no validated international guidelines in assessing these risks. In this case, we need to essentially rethink and change our systems to get rid of the exposure of pesticides. We must protect the health of vulnerable groups as well as the general population and whole ecosystems [119].

Reducing the use of pesticide strategies will not help us protect human health, because there are enormous kinds of pesticides in the market to be sold. In this case, people need to go towards ecological farming. This is a critical act in avoiding all risks. Protecting crops via a multilevel approach will help us increase the heterogeneity of the agricultural areas and this will provide a natural habitat for pollinators and natural pest control species. Thus, a functional biodiversity can be created if we can achieve an active vegetation management. A variety of crop types and cultivars increase both the fertility of soils and resistance to pests. Natural 
control agents, such as beneficial bacteria, viruses, insects, and nematodes, can be used in improving crop protection successfully [150].

\section{Author details}

Arzu Özkara ${ }^{1}$, Dilek Aky1 ${ }^{1}$ and Muhsin Konuk ${ }^{2 *}$

*Address all correspondence to: mkonuk@gmail.com

1 Biology Department, Faculty of Sciences and Literatures, Afyon Kocatepe University, Afyonkarahisar, Turkey

2 Molecular Biology and Genetics Department, Faculty of Engineering and Natural Sciences, Uskudar University, Altunizade, Istanbul, Turkey

\section{References}

[1] Santos MA: Managing Planet Earth: Perspectives on Population, Ecology, and the Law. Bergin \& Garvey, Westport, Connecticut, 1990. p. 44.

[2] Pastor S, Creus A, Parrón T, Cebulska-Wasilewska A, Siffel C, Piperakis S, Mercos R: Biomonitoring of four European populations occupationally exposed to pesticides: Use of micronuclei as biomarkers. Mutagenesis. 2003;18(3):249-258.

[3] Erdoğmuş SF, Eren Y, Akyıl D, Özkara A, Konuk M, Sağlam E: Evaluation of in vitro genotoxic effects of benfuracarb in human peripheral blood lymphocytes. Fresenius Environmental Bulletin. 2015;24(3):796-799.

[4] Delaplane KS: Pesticide Usage in the United States: History, Benefits, Risks, and Trends [Internet]. 2000. Available at: http://pubs.caes.uga.edu/caespubs/pubs/PDF/B1121.pdf.

[5] Fishel FM: Pest Management and Pesticides: A Historical Perspective [Internet]. 2013. Available at: http://edis.ifas.ufl.edu

[6] Grube A, Donaldson D, Kiely T, Wu L: Pesticides industry sales and usage: 2006 and 2007 market estimates. Washington, DC: U.S. Environmental Protection Agency, 2011.

[7] Jardim ANO, Caldas ED: Brazilian monitoring programs for pesticide residues in food -Results from 2001 to 2010. Food Control. 2012;25:607-616.

[8] Lozowicka B, Kaczynski P, Paritova AE, Kuzembekova GB, Abzhalieva AB, Sarsembayeva NB, Alihan K: Pesticide residues in grain from Kazakhstan and potential health risks associated with exposure to detected pesticides. Food and Chemical Toxicology. 2014;64:238-248. 
[9] Skretteberg LG, Lyran B, Holen B, Jansson A, Fohgelberg P, Siivinen K, Andersen JH, Jensen $\mathrm{BH}$ : Pesticide residues in food of plant origin from Southeast Asia-A Nordic project. Food Control. 2015;51:225-235.

[10] Liu Y, Li S, Ni Z, Qu M, Zhong D, Ye C: Fubin Tang pesticides in persimmons, jujubes and soil from China: Residue levels, risk assessment and relationship between fruits and soils. Science of the Total Environment. 2016;542:620-628.

[11] Malone RW, Ahuja LR, Ma L, DonWauchope R, Ma Q, Rojas KW: Application of the root zone water quality model (RZWQM) to pesticide fate and transport: An overview. Pest Management Science. 2004;60(3):205-221.

[12] Lefrancq M, Imfeld G, Payraudeau S, Millet M: Kresoxim methyl deposition, drift and runoff in a vineyard catchment. Science of the Total Environment. 2013;442:503-508.

[13] Scholtz MT, Voldner E, McMillan AC, Van Heyst BJ: A pesticide emission model (PEM). Part I: Model development. Atmospheric Environment. 2002;36:5005-5013.

[14] Dich J, Zahm SH, Hanberg A, Adami HO: Pesticides and cancer. Cancer Causes \& Control. 1997;8(3):420-443.

[15] Bressa G, Sisti E, Cima F: PCBs and organochlorinated pesticides in eel (Anguilla anguilla L.) from the Po Delta. Marine Chemistry. 1997;58(3):261-266.

[16] Kolpin DW, Barbash JE, Gilliom RJ: Occurrence of pesticides in shallow groundwater of the United States: Initial results from the National Water-Quality Assessment Program. Environmental Science and Technology. 1998;32(5):558-566.

[17] Ouyang W, Cai G, Huang W, Hao F: Temporal-spatial loss of diffuse pesticide and potential risks for water quality in China. Science of the Total Environment. 2016;541:551-558.

[18] Tsakiris IN, Goumenou M, Tzatzarakis MN, Alegakis AK, Tsitsimpikou C, Ozcagli E, Vynias D, Tsatsakis AM: Risk assessment for children exposed to DDT residues in various milk types from the Greek market. Food and Chemical Toxicology. 2015;75:156-165.

[19] Shoiful A, Fujita H, Watanabe I, Honda K: Concentrations of organochlorine pesticides (OCPs) residues in foodstuffs collected from traditional markets in Indonesia. Chemosphere. 2013;90:1742-1750.

[20] Wu WJ, Qin N, Zhu Y, He QS, Ouyang HL, He W, Liu WX, Xu FL: The residual levels and health risks of hexachlorocyclohexanes (HCHs) and dichloro-diphenyltrichloroethanes (DDTs) in the fish from Lake Baiyangdian, North China. Environmental Science and Pollution Research. 2013;20:5950-5962.

[21] WHO: Public Health İmpacts of Pesticides Used in Agriculture. WHO in Collaboration with the United Nations Environment Programme. World Health Organization, Geneva, 1990. 
[22] Merhi M, Raynal H, Cahuzac E, Vinson F, Cravedi JP, Gamet-Payrastre L: Occupational exposure to pesticides and risk of hematopoietic cancers: Metaanalysis of case-control studies. Cancer Causes \& Control. 2007;18:1209-1226.

[23] Weichenthal SC, Moase C, Chan P: A review of pesticide exposure and cancer incidence in the Agricultural Health Study cohort. Environmental Health Perspectives. 2010;118:1117-1125.

[24] Akyıl D, Özkara A, Erdoğmuş SF, Eren Y, Konuk M, Sağlam E: Evaluation of cytotoxic and genotoxic effects of benodanil by using Allium and micronucleus assays. Drug and Chemical Toxicology. 2015;3:1-6. DOI: 10.3109/01480545.2015.1012211

[25] FAO: International Code of Conduct on the Distribution and Use of Pesticides, Revised Version. Food and Agriculture Organisation of the United Nations, Rome, 2002. Available at: http://www.fao.org/docrep/018/a0220e/a0220e00.pdf.

[26] Tijani AA: Pesticide use practices and safety issues: The case of cocoa farmers in Ondo State, Nigeria. Journal of Human Ecology. 2006;19(3):183-190.

[27] Williamson S: The Dependency Syndrome: Pesticide Use by African Small Holders. Pesticide Action Network (PAN), London, 2003.

[28] Pesticide Action Network Asia Pacific Communities in Peril (PANAP): Global Report on Health Impacts of Pesticide Use in Agriculture. Red Leaf Printing Press, Manila, Philippines, 2010. p. 182.

[29] Ogbeidea O, Tongoa I, Ezemonyea L: Assessing the distribution and human health risk of organochlorine pesticide residues in sediments from selected rivers. Chemosphere. 2016;144:1319-1326.

[30] Kogan M: Integrated pest management: Historical perspectives and contemporary developments. Annual Review of Entomology. 1998;43:243-270.

[31] Timmons FL: A history of weed control in the United States and Canada. Weed Science. 1970;18:294-307.

[32] Chauvel B, Guillemin JP, Gazquez J, Gauvrit C: History of chemical weeding from 1944 to 2011 in France: Changes and evolution of herbicide molecule. Crop Protection. 2012;42:320-326.

[33] Felsot AS: Pesticides \& Health-Myths vs. Realities. American Council on Science and Health, New York, NY, 2006. p. 107.

[34] Gribble GW: Naturally occurring organohalogen compounds. Accounts of Chemical Research. 1998;31:141-152.

[35] Drum C: Soil Chemistry of Pesticides. PPG Industries, Inc. USA, 1980.

[36] Buchel KH: Chemistry of Pesticides. John Wiley \& Sons, Inc., New York, USA, 1983.

[37] Tano ZJ: Identity, physical and chemical properties of pesticides. In: Pesticides in the Modern World-Trends in Pesticides Analysis. Stoytcheva M (ed.). InTech, 2011. ISBN 
978-953-307-437-5. Available from:http://www.intechopen.com/books/pesticides-inthe-modern-world-trendsinpesticidesanalysis/identity-physical-and-chemicalproperties-of-pesticides.

[38] Willet KL, Ulrich EM, Hites RA: Differential toxicity and environmental fates of hexachlorocyclohexane isomers. Environmental Science Technology. 1998;32:21972207.

[39] Zhang Y: New Progress in Pesticides in the World. Chemical Industry Press, Beijing, 2007.

[40] Zhang Z, Hong H, Wang X, Lin J, Chen W, Xu L: Determination and load of organophosphorus and organochlorine pesticides at water from Jiulong River estuary, China. Marine Pollution Bulletin. 2002;45:397-402.

[41] Zahran MM, Abdel-Aziz KB, Abdel-Raof A, Nahas EM: The effect of subacute doses of organophosphorus pesticide, Nuvacron, on the biochemical and cytogenetic parameters of mice and their embryos. Research Journal of Agriculture and Biological Sciences. 2005;1:277-283.

[42] Frasco MF, Fournier D, Carvalho F, Guilhermino L: Cholinesterase from the common prawn (Palaemon serratus) eyes: Catalytic properties and sensitivity to organophosphate and carbamate compounds. Aquatic Toxicology. 2006;77:412-421.

[43] AgroNews: China States Organophosphate Export Ban [Internet]. 2008. Available at: http://news.agropages.com/News/NewsDetail-873.htm.

[44] Eddleston M, Phillips MR: Self poisoning with pesticides. BMJ. 2004;328:42-44.

[45] Gunnell M, Eddleston M, Phillips MR, Konradsen F: The global distribution of fatal pesticide self-poisoning: Systematic review. BMC Public Health. 2007;7:357.

[46] Marrs TC: Organophosphate poisoning. Pharmacology \& Therapeutics. 1993;58:51-66.

[47] Morais S, Correia M, Domingues V, Delerue-Matos C (eds.). Urea pesticides. In: Pesticides-Strategies for Pesticides Analysis. Stoytcheva M (ed.) 2011. pp. 241-262.

[48] Zheng S, Chen B, Qiua X, Chen M, Ma Z, Yua X: Distribution and risk assessment of 82 pesticides in Jiulong River and estuary in South China. Chemosphere. 2016;144:1177-1192.

[49] Roberts JR, Routt RJ: Recognition and Management of Pesticide Poisonings. 6th ed. EPA27 Reports. Office of Pesticide Programs, U.S. Environmental Protection Agency, 1200 Pennsylvania Avenue, NW (7506P) Washington, DC 20460, 2013.

[50] Koureas M, Tsakalof A, Tsatsakis A, Hadjichristodoulou C: Systematic review of biomonitoring studies to determine the association between exposure to organophosphorus and pyrethroid insecticides and human health outcomes. Toxicology Letters. 2012;210:155-168. 
[51] Toccalino PL, Gilliom RJ, Lindsey BD, Rupert MG: Pesticides in groundwater of the United States: Decadal-scale changes, 1993-2011. Groundwater. 2014;52(1):112-125.

[52] Malaj E, von der Ohe PC, Grote M, Kühne R, Mondy CP, Usseglio-Polatera P, Brack W, Schäfer RB: Organic chemicals jeopardize the health of freshwater ecosystems on the continental scale. Proceedings of the National Academy of Science. 2014;111(26):95499554.

[53] Queyrel W, Habets F, Blanchoud H, Ripoche D, Launay M: Pesticide fate modeling in soils with the crop model STICS: Feasibility for assessment of agricultural practices. Science of the Total Environment. 2016;542:787-802.

[54] Oerke EC: Crop losses to pests. Journal of Agricultural Sciences. 2006;144:31-43.

[55] Popp J, Peto K, Nagy J: Pesticide productivity and food security: A review. Agronomy for Sustainable Development. 2013;33:243-255.

[56] Fisher MC, Henk DA, Briggs CJ, Brownstein JS, Madoff LC, McCraw SL, Gurr SJ: Emerging fungal threats to animal, plant and ecosystem health. Nature. 2012;484:186194.

[57] FAO: FAOSTAT Domain Pesticides 2005-2010. Food and Agriculture Organization of the United Nations, Rome, Italy, 2015. Available at: http://faostat3.fao.org/ download/E/EP/E

[58] FAO: FAO Statistical Yearbook 2013: World Food and Agriculture. Food and Agriculture Organization of the United Nations, Rome, Italy. 2015, p. 65. Available at: http:// www.fao.org/docrep/018/i3107e/i3107e00.htm

[59] Zhang M, Zeiss MR, Shu Geng S: Agricultural pesticide use and food safety: California's model. Journal of Integrative Agriculture. 2015;14(11):2340-2357.

[60] Azevedo ASON: Assessment and simulation of atrazine as influenced by drainage and irrigation. An interface between RZWQM and ArcView GIS. Doctorate thesis. Iowa State University, Ames, Iowa, 1998.

[61] Rao PSC, Bellin CA, Brusseau ML: In sorption and degradation of pesticides and organic chemicals in soil. SSSA Special Publication. 1993;32:1-26.

[62] Pimentel D, Levitan L: Pesticides: Amounts applied and amounts reaching pests. Bioscience. 1986;36:86-91.

[63] Larson SJ, Capel PD, Majewski MS: Pesticides in surface waters-distribution, trends, and governing factors. In: Series of Pesticides in Hydrologic System. Gilliom RJ (ed.). Ann Arbor Press, Chelsea, Michigan, 1997. p. 3.

[64] Brewer R: Principles of Ecology. Saunders College Publishing, Philadelphia, 1979. pp. 249-258. 
[65] Arias-Estevez M, Lopez-Periago E, Martinez-Carballo E, Simal-Gandara J, Mejuto JC, Garcia-Rio L: The mobility and degradation of pesticides in soils and the pollution of groundwater resources. Agriculture, Ecosystems and Environment. 2008;123:247-260.

[66] López-Flores R., Quintana XD, Salvadó V, Hidalgo M, Sala L, Moreno-Amich R: Comparison of nutrient and contaminant fluxes in two areas with different hydrological regimes (Empordà Wetlands, NE Spain). Water Research. 2003;37:3034-3046.

[67] Abrantes N, Pereira R, Gonçalve, F: First step for an ecological risk assessment to evaluate the impact of diffuse pollution in Lake Vela (Portugal). Environmental Monitoring Assessment. 2006;117:411-431.

[68] Hijosa-Valsero M, Bécares E, Fernández-Aláez C, Fernández-Aláez M, Mayo R, José Jiménez J: Chemical pollution in inland shallow lakes in the Mediterranean region (NW Spain): PAHs, insecticides and herbicides in water and sediments. Science of the Total Environment. 2016;544:797-810.

[69] Griffith JA: Geographic techniques and recent applications of remote sensing to landscape-water quality studies. Water Air and Soil Pollution. 2002;138:181-197.

[70] Kimbrough KL, Dickhut RM: Assessment of polycyclic aromatic hydrocarbon in put to urban wetlands in relation to adjacent land use. Marine Pollution Bulletin. 2006:52;1355-1363.

[71] Bedos C, Cellier P, Calvet R, Barriuso E, Gabrielle B: Mass transfer of pesticides into the atmosphere by volatilization from soils and plants: Overview. Agronomie. 2002;22(1):21-33.

[72] Barriuso E, Benoit P, Dubus IG: Formation of pesticide nonextractable (bound) residues in soil: Magnitude, controlling factors and reversibility. Environmental Science and Technology. 2008;42(6):1845-1854.

[73] Fantke P, Charles R, Felippe de Alencastro L, Friedrich R, Jolliet O: Plant uptake of pesticides and human health: Dynamic modeling of residues in wheat and ingestion intake. Chemosphere. 2011;85(10):1639-1647.

[74] Baran N, Lepiller M, Mouvet C: Agricultural diffuse pollution in a chalk aquifer (Trois Fontaines, France): Influence of pesticide properties and hydrodynamic constraints. Journal of Hydrology. 2008;358(1-2):56-69.

[75] Knapton D, Burnworth M, Rowan SJ: Fluorescent organometallic sensors for the detection of chemical-warfare-agent mimics. Angewandte Chemie International Edition. 2006;45(35):5825-5829.

[76] Kumar P, Kim KH, Deep A: Recent advancements in sensing techniques based on functional materials for organophosphate pesticides. Biosensors and Bioelectronics. 2015;70:469-481. 
[77] Zhang AP, Liu WP, Yuan HJ, Zhou SS, Su YS, Li YF: Spatial distribution of hexachlorocyclohexanes in agricultural soils in Zhejiang Province, China, and correlations with elevation and temperature. Environmental Science Technology. 2011;45:6303-6308.

[78] Tao S, Liu WX, Li Y, Yang Y, Zuo Q, Li BG, Cao J: Organochlorine pesticides contaminated surface soil as reemission source in the Haihe plain, China. Environmental Science Technology. 2008;42:8395-8400.

[79] Net S, Sempere R, Delmont A, Paluselli A, Ouddane B: Occurrence, fate, behavior and ecotoxicological state of phthalates in different environmental matrices. Environmental Science Technology. 2015;49:4019-4035.

[80] Fantke P, Jolliet O: Life cycle human health impacts of 875 pesticides. International Journal of Life Cycle Assessment. 2016;21:1-12

[81] Fantke P, Wieland P, Wannaz C, Friedrich R, Jolliet O: Dynamics of pesticide uptake into plants: From system functioning to parsimonious modeling. Environment Modelling and Software. 2013;40:316-324.

[82] Dietz R, Riget F, Cleemann M, Aarkrog A, Johansen P, Hansen JC: Comparison of contaminants from different trophic levels and ecosystems. Science of the Total Environment. 2000;245(1-3):221-231.

[83] Carvalho FP, Gonzalez-Farias F, Villenueve JP, Cantani C, Hernandez-Garza M, Mee L, Fowler SW: Distribution, fate and effects of pesticide residues in tropical coastal lagoons of northwestern Mexico. Environmental Technology. 2002;23(11):1257-1270.

[84] Gómez-Gutiérrez A, Garnacho E, Bayona JM, Albaiges J: Screening ecological risk assessment of persistent organic pollutants in Mediterranean Sea sediments. Environment International. 2007;33(867):876.

[85] Zhao L, Hou H, Zhou Y, Xue N, Li H, Li F: Distribution and ecological risk of polychlorinated biphenyls and organochlorine pesticides in surficial sediments from Haihe River and Haihe Estuary Area, China. Chemosphere. 2010;78(10):1285-1293.

[86] Alonso-Hernández CM, Tolosa I, Mesa-Albernas M, Díaz-Asencio M, Corcho-Alvarado JA, Sánchez-Cabeza JA: Historical trends of organochlorine pesticides in a sediment core from the Gulf of Batabanó, Cuba. Chemosphere. 2015;137:95-100.

[87] Damalas CA, Eleftherohorinos IG: Pesticide exposure, safety issues, and risk assessment indicators. International Journal of Environmental Research Public Health. 2011;8:1402-1419.

[88] Verger PJP, Boobis AR: Reevaluate pesticides for food security and safety. Science. 2013;341:717-718.

[89] Zhang XJ, Zhao WY, Jing RW, Wheeler K, Smith GA, Stallones L, Xiang HY: Workrelated pesticide poisoning among farmers in two villages of southern China: A crosssectional survey. BMC Public Health. 2011;11:429. 
[90] Hashemi SM, Rostami R, Hashemi MK, Damalas, CA: Pesticide use and risk perceptions among farmers in southwest Iran. Human and Ecological Risk Assessment. 2012;18:456-470.

[91] Khan M, Mahmood HZ, Damalas CA: Pesticide use and risk perceptions among farmers in the cotton belt of Punjab, Pakistan. Crop Protection. 2015;67:184-190.

[92] Van Hoi P, Mol APJ, Oosterveer P, van den Brink PJ: Pesticide distribution and use in vegetable production in the Red River Delta of Vietnam. Renewable Agriculture and Food Systems. 2009;24:174-185.

[93] Stadlinger N, Mmochi AJ, Dobo S: Pesticide use among smallholder rice farmers in Tanzania. Environment, Development and Sustainability. 2011;13:641-656.

[94] Ibitayo OO: Egyptian farmers' attitudes and behaviors regarding agricultural pesticides: Implications for pesticide risk communication. Risk Analysis. 2006;26:989-995.

[95] Grovermann C, Schreinemachers P, Berger T: Quantifying pesticide overuse from farmer and societal points of view: An application to Thailand. Crop Protection. 2013;53:161-168.

[96] Damalas CA, Telidis GK, Thanos SD: Assessing farmers' practices on disposal of pesticide waste after use. Science of the Total Environment. 2008;390:341-345.

[97] Karunamoorthi K, Mohammed M, Wassie F: Knowledge and practices of farmers with reference to pesticide management: Implications on human health. Archives of Environmental \& Occupational Health. 2012;67:109-116.

[98] Ahmed N, Englund JE, Ahman I, Lieberg M, Johansson E: Perception of pesticide use by farmers and neighbors in two periurban areas. Science of the Total Environment. 2011;412:77-86.

[99] Li HZ, Zeng EY, You J: Mitigating pesticide pollution in China requires law enforcement, farmer training, and technological innovation. Environmental Toxicology and Chemistry. 2014;33:963-971.

[100] Stadlinger N, Mmochi AJ, Kumblad L: Weak governmental institutions impair the management of pesticide import and sales in Zanzibar. Journal of the Human Environment. 2013;42:72-82.

[101] Damalas CA, Hashemi SM: Pesticide risk perception and use of personal protective equipment among young and old cotton growers in northern Greece. Agriculture in Mexico. 2010;44:363-371.

[102] Atreya K: Pesticide use knowledge and practices: A gender differences in Nepal. Environmental Research. 2007;104:305-311.

[103] Yang XM, Wang F, Meng L, Zhang WS, Fan LX, Geissen V, Ritsema CJ: Farmer and retailer knowledge and awareness of the risks from pesticide use: A case study in the Wei River catchment, China. Science of the Total Environment. 2014;497:172-179. 
[104] Buono S, Cristiano L, Angelo BD, Cimini A, Putti R: PPARalpha mediates the effects of the pesticide methyl thiophanate on liver of the lizard Podarcis sicula. Comparative Biochemistry Physiology C: Pharmacology Toxicology and Endocrinology. 2007;145:306-314.

[105] Manuel AE, Eugenio LP, Elena MC, Jesús SG, Juan CM, Luis GR: The mobility and degradation of pesticides in soils and the pollution of groundwater resources. Agriculture Ecosystems \& Environment. 2008;123:247-260.

[106] Jiang J, Wan N: A model for ecological assessment to pesticide pollution management. Ecological Modelling. 2009;220:1844-1851.

[107] Williamson S: Understanding the full costs of pesticides: Experience from the field with a focus on Africa, 2011. Available at: http://www.intechopen.com.

[108] Hoi PV, Mol APJ, Oosterveer P: State governance of pesticides use and trade in Vietnam. Wageningen Journal of Life Sciences. 2013;67:19-26.

[109] Akyıl D, Özkara A, Erdoğmuş SF, Eren Y, Konuk M, Sağlam E: Micronucleus assay in human lymphocytes after exposure to Alloxydim sodium herbicide in vitro. Cytotechnology. 2015; 67:1059-1066.

[110] Eren Y, Erdoğmuş SF, Akyıl D, Özkara : Mutagenic and cytotoxic activities of benfuracarb insecticide. Cytotechnology. DOI: 10.1007/s10616-014-9811-3, 2014;1-7.

[111] Konuk M, Akyıl D, Liman R, Özkara A: Examination of the mutagenic effects of some pesticides. Fresenius Environmental Bulletin. 2008;17(4):439-442.

[112] Özkara A, Akyıl D, Eren Y, Erdoğmuş SF, Konuk M, Sağlam E: Assessment of cytotoxic and genotoxic potential of pyracarbolid by Allium test and micronucleus assay. Drug and Chemical Toxicology. 2015;38(3):337-341.

[113] Köhler HR, Triebskorn R: Wildlife ecotoxicology of pesticides: Can we track effects to the population level and beyond. Science. 2013;341:759-765.

[114] Kennedy CM, Lonsdorf E, Neel MC, Williams NM, Ricketts TH, Winfree R, Bommarco R, Brittain C, Burley AL, Cariveau D, Carvalheiro LG, Chacoff NP, Cunningham SA, Danforth BN, Dudenhöffer JH, Elle E, Gaines HR, Gratton C, Garibaldi LA, Holzschuh A, Isaacs R, Javorek SK, Jha S, Klein AM, Krewenka K, Mandelik Y, Mayfield MM, Morandin L, Neame LA, Otieno M, Park M, Potts S, Rundlöf M, Saez A, SteffanDewenter I, Taki H, Viana BF, Westphal C, Wilson JK, Greenleaf SS, Kremen C: A global quantitative synthesis of local and landscape effects on wild bee pollinators in agroecosystems. Ecology Letters. 2013;16:584-599.

[115] Law RJ: An overview of time trends in organic contaminant concentrations in marine mammals: Going up or down. Marine Pollution Bulletin. 2014;82:7-10. 
[116] Brühl CA, Schmidlt T, Pieper S, Alscher A: Terrestrial pesticide exposure of amphibians: An underestimated cause of global decline. Scientific Reports 3, 2013;3:1135, DOI: 10.1038/srep01135.

[117] Hvistendahl M: In rural Asia, locking up poisons to prevent suicides. Science. 2013;341:738-9.

[118] Mani M, Shivaraju C, Kulkarni NS: Pesticide Residue Management in Grapes. The Grape Entomology. Chapter 6. Springer, India, 2014. pp. 181-186.

[119] Allsop M, Huxdorff C, Johnston P, Santillo D, Thompson K: Pesticides and Our Health a Growing Concern. Greenpeace Research Laboratories, School of Biosciences, Innovation Centre, University of Exeter, Exeter, UK, 2015.

[120] Recena MCP, Caldas ED: Risk perception, attitudes and practices on pesticide use among farmers of a city in midwestern Brazil. Rev Saude Publica. 2008;42:294-301.

[121] Kumar MS, Kuppast I, Mankani K, Prakash KC, Veershekar T: Use and awareness of pesticides in Malnad region of Karnataka. Journal of Pharmacology Research. 2012;5:3875.

[122] Pruss-Ustun A, Vickers C, Haefliger P, Bertollini R: Knowns and unknowns on burden of disease due to chemicals: A systematic review. Environmental Health. 2011;10:9-24.

[123] Perry L, Adams RD, Bennett AR, Lupton DJ, Jackson G, Good AM, Thomas SH, Vale JA, Thompson JP, Bateman DN, Eddleston M: National toxicovigilance for pesticide exposures resulting in health care contact-An example from the UK's National Poisons Information Service. Clinical Toxicology. 2014;52:549-555.

[124] Bjorling-Poulsen M, Andersen HR, Grandjean P: Potential developmental neurotoxicity of pesticides used in Europe. Environmental Health. 2008;7:50.

[125] Shi H, Wang R, Yang J, Ren H, Liu S, Guo T: Novel imprinted nanocapsule with highly enhanced hydrolytic activity for organophosphorus pesticide degradation and elimination. European Polymer Journal. 2015;72:190-201.

[126] Özkara A, Akyıl D, Eren Y, Erdoğmuş SF: Potential cytotoxic effect of Anilofos by using Allium cepa assay. Cytotechnology. 2015;67:783-791.

[127] Konuk M, Barış A, Liman R, Akyıl D: A study on mutagenicity of different types of pesticides by using of Ames/Salmonella/microsome test system. Fresenius Environmental Bulletin. 2008;17(4):463-466.

[128] Akyıl D, Konuk M: Detection of genotoxicity and mutagenicity of chlorthiophos using micronucleus, chromosome aberration, sister chromatid exchange, and Ames tests. Environmental Toxicology. 2015;30(8);937-945, DOI: 10.1002/tox.21968

[129] UNEP/UNDP: World Development Report. Making New Technologies Work for Human Development. Geneva, United Nations Development Programme (UNDP), New York, Oxford University Press, 2001. 
[130] Dimond JB, Owen RB: Long-term residue of DDT compounds in forest soils in Maine. Environmental Pollution. 1996;92:227-230.

[131] Nakata H, Kawazoe M, Arizono K, Abe S, Kitano T, Shimada H, Li W, Ding X: Organochlorine pesticides and polychlorinated biphenyl residues in foodstuffs and human tissues from China: Status of contamination, historical trend, and human dietary exposure. Archives of Environmental Contamination Toxicology. 2002;43:473480 .

[132] Jones KC, de Voogt P: Persistent organic pollutants (POPs): State of the science. Environmental Pollution. 1999;100:209-221.

[133] Tanabe S, Iwata H, Tatsukawa R: Global contamination by persistent organochlorines and their ecotoxicological impact on marine mammals. Science of the Total Environment. 1994;154:163-177.

[134] Guruge KS, Tanabe S: Contamination by persistent organochlorines and butylin compounds in the west coast of Sri Lanka. Marine Pollution Bulletin. 2001;42:179-186.

[135] Zhu Y, Huang B, Li QX, Wang J: Organochlorine pesticides in follicular fluid of women undergoing assisted reproductive technologies from central China. Environmental Pollution. 2015;207:266-272.

[136] Bulut S, Akkaya L, Gok V, Konuk M: Organochlorine pesticide residues in butter and kaymak in Afyonkarahisar-Turkey. Journal of Animal Science \& Advances. 2010;9(22): 2797-2801.

[137] Bulut S, Gok V, Akkaya L, Konuk M: Organochlorine pesticide (OCP) residues in cow, buffalo, and sheep milk from Afyonkarahisar region, Turkey. Environmental Monitoring Assessment. 2011;181(1-4):555-562.

[138] El-Shahawi M, Hamza A, Bashammakh A, Al-Saggaf W: An overview on the accumulation, distribution, transformations, toxicity and analytical methods for the monitoring of persistent organic pollutants. Talanta. 2010;80:1587-1597.

[139] Song XF, Chen ZY, Zang ZJ, Zhang YN, Zeng F, Peng YP: Investigation of polycyclic aromatic hydrocarbon level in blood and semen quality for residents in Pearl River Delta Region in China. Environmental International. 2013;60:97-105.

[140] Wang HS, Chen ZJ, Wei W, Man YB, Giesy JP, Du J: Concentrations of organochlorine pesticides (OCPs) in human blood plasma from Hong Kong: Markers of exposure and sources from fish. Environmental International. 2013;54:18-25.

[141] Cioroiu M, Tarcau D, Mocanu R, Cucu-Man S, Nechita B, Luca M: Organochlorine pesticides in colostrums in case of normal and preterm labor (Iasi, Romania). Science of the Total Environment. 2010;408:2639-2645.

[142] McGlynn KA, Abnet CC, Zhang M, Sun XD, Fan JH, O’Brien TR: Serum concentrations of 1,1,1-trichloro-2,2-bis (p-chlorophenyl) ethane (DDT) and 1,1-dichloro-2,2-bis (p- 
chlorophenyl) ethylene (DDE) and risk of primary liver cancer. Journal of the National Cancer Institute. 2006;98:1005-1010.

[143] Saxena M, Siddiqui M, Seth T, Murti CK, Bhargava A, Kutty D: Organochlorine pesticides in specimens from women undergoing spontaneous abortion, premature or full-term delivery. Journal of Analytical Toxicology. 1981;5:6-9.

[144] Eskenazi B, Marks AR, Bradman A, Fenster L, Johnson C, Barr DB: In utero exposure to dichlorodiphenyltrichloroethane (DDT) and dichlorodiphenyldichloroethylene (DDE) and neurodevelopment among young Mexican American children. Pediatrics. 2006;118:233-241.

[145] Dalvie MA, Myers JE, Thompson M, Dyer S, Robins TG, Omar S: The hormonal effects of long-term DDT exposure on malaria vector-control workers in Limpopo Province, South Africa. Environment Research. 2004;96:9-19.

[146] Weiss B: Vulnerability of children and the developing brain to neurotoxic hazards. Environmental Health Perspectives. 2000;108:375-381.

[147] Muñoz-Quezada MT, Iglesias V, Lucero B, Steenland K, Barr DB, Levy K, Ryan P, Alvarado S, Concha C: Predictors of exposure to organophosphate pesticides in schoolchildren in the Province of Talca, Chile. Environment International. 2012;47:2836.

[148] Mandrich L: Endocrine disrupters: The hazards for human health. Cloning \& Transgenesis. 2014;3:1.

[149] Mostafalou S, Abdollahi M: Pesticides and human chronic diseases: Evidences, mechanisms, and perspectives. Toxicology and Applied Pharmacology. 2013;268:157177.

[150] Forster D, Adamtey N, Messmer MM, Pfiffner L, Baker B, Huber B, Niggli U: Organic agriculture-driving innovations in crop research. In: Agricultural Sustainability: Progress and Prospects in Crop Research. Bhuller GS, Bhuller NK (eds.). Elsevier, Inc., Oxford, UK, 2013. ISBN 978-0-12-404560-6. 

Chapter 2

\title{
Modelling in Metal Risk Assessment
}

\author{
T.T. Yen Le \\ Additional information is available at the end of the chapter \\ http://dx.doi.org/10.5772/62911
}

\begin{abstract}
Unique properties of metals that are largely different from the characteristics of organic substances should be considered in risk assessment. The bioavailability and toxicity of metals depend on their chemical speciation, that is, physical-chemical forms, in the environment, which is largely influenced by the environmental chemistry. Since metals in the environment are not always available while organisms have developed different processes to actively regulate the body burden, assessment of metal bioaccumulation might provide a better understanding of potential risks. Metal bioaccumulation is a prerequisite for metal toxicity, but is not theonly determinant of metal toxicity. In addition to metal accumulation, metal toxicity is influenced by the subcellular partitioning of metals, which is controlled by the capacity of organisms to sequester and to detoxify metals. Different modelling approaches have been developed to address some of these factors. Both empirical and mechanistic equilibrium models have been developed and applied for characterising metal speciation in the environment. Metal bioaccumulation has been predicted by biodynamic models. The ability of organisms to detoxify metals has been taken into account in assessment based on the induction of metallothionein (MT) or subcellular partitioning. In addition, the interactions between organisms and metal ions have been taken into consideration in assessment of metal toxicity based on the accumulation of metal ions at biological surfaces.
\end{abstract}

Keywords: Metal, modelling, risk assessment, speciation, bioaccumulation, subcellular partitioning, toxicity

\section{Introduction}

Environmental pollution with metals is a serious problem in many areas in the world, and assessment of metal bioaccumulation and toxicity is of high concern. In such assessment, unique properties of metals that are largely different from the characteristics of organic substances 
should be considered. The bioavailability and toxicity of metals are controlled by their chemical speciation, which is heavily influenced by environmental chemistry [1-5]. Metals are an intrinsic component of the environment, naturally occurring with varying background concentrations [6, 7]. Several metals are essential elements, that is, the elements that are present in living organisms and able to interact with the living system, and an insufficient amount of these elements leads to preventable or reversible effects on certain biological function, which do not occur at a physiological amount of the elements [8]. There is a limit to the regulation by the homeostasis mechanisms. Biological functions of organisms are affected by either the deficiency (below the limit) or toxicity (above the limit) of the essential metals. Because of these unique properties, organisms have developed various regulatory mechanisms for uptake, metabolism, distribution, storage, and eliminationin response to metal exposure and to maintain metal homeostasis. The responses of organisms depend on a number of factors, from environmental conditions, bioaccumulation, to internal detoxification [9-11]. Metal bioaccumulation, a prerequisite for metal toxicity, is determined by the chemical speciation of metals in the environment, which depends on environmental conditions. In addition to metal accumulation, metal toxicity is influenced by metal subcellular partitioning. Different modelling approaches have been developed to address some of these factors as described in more detail in the following sections.

\section{Metal availability in the environment}

The bioavailability and toxicity of metals depend to a large extent on the chemical speciation of metals [12-15]. A widely recognised definition of the chemical speciation is that the chemical speciation of an element is the identification and quantification of the different, defined species, forms, or phases in which the element is present $[16,17]$. Each form of the element is defined by its isotopic composition, electronic or oxidation state, or molecular structure $[18,19]$. The mobility of metals in soil depends on the partition of metals between the solid and solution phases [20], which is determined by properties of the metals as well as composition of both solid and solution phases [21]. The most important soil properties include the total metal content, $\mathrm{pH}$, cation exchange capacity (CEC), contents of soil organic matter (SOM), clay, oxides, and exchangeable $\mathrm{Ca}$ and $\mathrm{Mg}$ [22-26]. Besides the chemical extraction for direct determination, the solid-solution partitioning of metals in soils can be characterised by equilibrium models, which allow for predicting the speciation of a metal based on soil properties. Generally, two main approaches have been applied for modelling the solidsolution partitioning of metals in soils. They are based on: (1) empirical relations or transfer functions between the concentration of metals in soil solution or in a specific form and soil and solution properties [22, 24, 26, 27] or (2) complex process-based (mechanistic) multi-surface complexation models incorporating a detailed simulation of soil surface complexation and solution chemistry [23, 26, 28-31]. 


\subsection{Transfer functions}

The partition of metals between the solid and solution phases in soil has been expressed by adsorption isotherms or a distribution coefficient $\left(K_{d} ; \mathrm{L} / \mathrm{kg}\right)$ :

$$
k_{\mathrm{d}}=\frac{\mathrm{c}}{\mathrm{c}_{\mathrm{ss}}}
$$

where $K_{\mathrm{d}}(\mathrm{L} / \mathrm{kg})$ is the distribution coefficient; $C(\mathrm{mg} / \mathrm{kg}$ or $\mathrm{mol} / \mathrm{kg})$ is the total or reactive concentration of the metal in soil; $C_{\mathrm{ss}}(\mathrm{mg} / \mathrm{L}$ or $\mathrm{mol} / \mathrm{L})$ is the solution concentration.

In aerobic conditions, metals occluded in mineral particles and organic matter that are not readily available are included in the total pool, whilst the reactive fraction (extracted with $0.43 \mathrm{M} \mathrm{HNO}_{3}$ ) represents the metals available for exchange with soil solution with a particular time span [32]. Therefore, the reactive concentration has been used to substitute the total concentration in the above equation [32,33]. The partitioning of metals in soil is usually expressed by sorption isotherms as described by a Freundlich equation:

$$
C=k \cdot C_{s s}^{n}
$$

where $k$ and $n$ are the Freundlich parameters. The exponent $n$ reflects the variation in the binding strength with varying total pools. Equation 2 can be rewritten and extended to take into account the influence of soil properties [22, 32, 34-36]:

$$
\log C=\log k+n \cdot \log C_{\mathrm{ss}}+\sum a_{i} \cdot \log \left(X_{i}\right)
$$

where $a_{i}$ is the coefficient that reflects the influence of soil parameter $X_{i}$ on the partitioning of metals between the solid and solution phases. The distribution coefficient has also been related to soil properties:

$$
\log K_{\mathrm{d}}=a_{0}+a \cdot \log C_{\mathrm{ss}}+\sum a_{i} \cdot \log \left(X_{i}\right)
$$

Empirical relationships have been established between the distribution coefficient or the dissolved concentration, on the one hand, and the total/reactive concentration and soil properties, on the other. Different equations have been derived, depending on the empirical data that they have been based on, whilst a full description of soil properties is usually not available. Among soil properties, $\mathrm{pH}$ is the most commonly integrated parameter in transfer functions, followed by soil organic carbon (SOC), while other soil properties are rarely included in. This reflects the importance of $\mathrm{pH}$ and organic matter in determining metal speciation as well as the partitioning of metals between the solid and solution phases. 


\subsection{Mechanistic multi-surface complexation models}

Substantial progress has been obtained in simulating the sorption of metal ions to soil and dissolved organic matter (DOM) with the development of different models, for example, MINEQL [37], GEOCHEM [38], NICADonnan [39], and WHAM V and VI [40,41]. Metal speciation in soil has been characterised by various models calculating metal movement and available fractions and simulating impacts of physicochemical properties on metal dynamics in soil. The movement of different metal species in an environment is characterised by fate and transport models, while the partitioning of metals into dissolved, colloidal, and particulate phases is predicted by speciation/complexation models. Assemblage models have been formed by incorporating various surface complexation models. These process-based models provide a detailed description of metal complexation on different sorption surfaces [39, 42]. Surface complexation models based on thermodynamic processes have been developed for describing reactions of metals on the surface of soil reactive phases, such as SOM [39, 41], oxides [42, 43], and clay minerals [44]. Multi-surface complexation models have been formed from individual surface complexation models, assuming that the adsorption properties of soil can be characterised by the sum of the individual adsorption properties of individual components. Metal concentrations in soil solution have been predicted by using mechanistic geochemical models accounting for interactions of metals with various reactive surfaces [23, 24, 26, 29, 30].

Originally developed to characterise metal speciation in oxic waters [40,41], WHAM has been applied to simulate the solid-solution partitioning [23, 45]. This model consists of several submodels: Humic Ion-Binding Model V and models of inorganic solution chemistry, adsorptiondesorption reactions of fulvic acids, precipitation of oxides, and cation exchange reactions on clays. In the Humic Ion-Binding Model V, humic substances are represented by molecules containing proton-dissociating groups that can bind to metal ions [40]. The binding of metal ions to humic substances is described in terms of complexation at discrete sites while taking into account both electrostatic interactions and competition among ions. In the application to soil systems, a fixed charge mineral cation exchanger was included to describe the presence of clays [46].

Weng et al. [29, 47] have proposed another multi-surface or mechanistic model for characterizing metal speciation in which soil is considered a set of independent sorption surfaces, that is, organic matter, clay silicates, and iron (hydr)oxides. Metal binding to these surfaces is simulated using advanced adsorption, cation exchange models, and default binding parameters. Humic acid is considered an analogue for SOM. The site density of SOM is assumed to be equal to $31 \%$ of the density of humic acid [47], while metal binding to SOM is described by using the non-ideal competitive consistent Adsorption (NICA)-Donnan model [39]. Clays are represented by illite because of their importance in Dutch soils [48]. The average charge of illite is assumed to be $\mathrm{pH}$ dependent $(0.25 \mathrm{~mol} / \mathrm{kg}$; [49]). An electrostatic Donnan model is used to describe metal binding to clay. For amorphous iron (hydr)oxides, their amount is predicted as the oxalate-extractable $\mathrm{Fe}$, and their surface area is considered similar to that of hydrous ferric oxices (HFO; 600 $\mathrm{m}^{2} / \mathrm{g}$ ) [42]. For crystalline iron (hydr)oxides, their surface area is assumed to be the same as that of goethite $\left(100 \mathrm{~m}^{2} / \mathrm{g}\right)$, and their amount is calculated as the difference between total (aqua regia) and oxalate-extractable Fe. Metal binding to the oxides is simulated 
using the two-site surface complexation diffuse double layer model [42]. The complexation of metals with carbonate and dissolved organic matter (DOM) is also taken into account in the model. DOM is assumed to consist of 30\% humic acid and 30\% fulvic acid [29].

The ORCHESTRA (Objective Representing CHEmical Speciation and TRAnsport) modelling framework $[50,51]$ is a combination of different sub-models. Thermodynamic data from the MINTEQA2 [52] were used to calculate solution speciation. The sorption of ions to SOM and DOM was simulated with the NICA-Donnan model $[39,53,54]$ using generic binding parameters and constants derived by Milne et al. $[55,56]$. When data on DOM were not available, DOM was assumed to consist of 50\% reactive humic substances. In addition, SOM and DOM were represented by humic acid assuming that humic acid consists of $50 \%$ carbon [56]. The sorption of ions on the surface of (hydr)oxides was described by the generalized two layer model (GTLM) of Dzombak and Morel [42]. Site densities of the amorphous iron and aluminium (hydr)oxides were calculated from the assumed specific surface area of $600 \mathrm{~m}^{2} / \mathrm{g}$ for hydrous ferric oxide [42]. Crystalline iron (hydr)oxides were represented by the hydrous ferric oxide, assuming the same reactivity. Moreover, a specific surface area of $100 \mathrm{~m}^{2} / \mathrm{g}$ was assumed for these (hydr)oxides [43]. The nonspecific sorption of ions to permanently charged clay surfaces was modelled with a Donnan model. The illitic clay mineral with an average charge density of $0.25 \mathrm{eq} / \mathrm{kg}$ and a fixed Donnan model of $1 \mathrm{~L} / \mathrm{kg}$ were used to represent the clay mineral [49].

\section{Metal bioaccumulation}

Since metals in the environment are not always available, assessing metal accumulation in sentinel species is one of the most effective methods for evaluating effects of metals on biota. The tendency of chemicals to be accumulated in organisms is usually expressed by the bioaccumulation factor (BAF) and the bioconcentration factor (BCF). These factors represent the ratio of the residue in the organisms versus the concentration in water at equilibrium, including or excluding the uptake from dietary sources, respectively. For metals, BCF and BAF vary widely and are inversely related to the external water concentration [57-59]. These characteristics of the accumulation factors for metals are attributed to the complex mechanisms of metal uptake and accumulation [60]. In a number of studies, uptake via saturable kineticsexhibiting mechanisms has been shown to be more common and toxicologically relevant than passive diffusion [61-65]. The concentration of metals accumulated in organisms is further influenced by different physiological and anatomical mechanisms in response to metal exposure [6]. For essential metals, organisms are able to actively regulate metal bioaccumulation and maintain homeostasis over a range of exposure via exclusion or increased elimination $[11,57,65]$. Organisms have also developed different mechanisms to sequester, detoxify, or store excess metals $[11,62,66]$. The dependence of BCF and BAF on exposure conditions as well their inverse relationship with the exposure concentration invalidates the use of these factors in risk assessment $[6,57,59]$.

Biodynamic models have been recommended as an alternative to single and generic values of $\mathrm{BCF}$ or BAF in the assessment of metal bioaccumulation [67]. Such models allow for integrating 
and distinguishing different exposure routes (e.g., water vs. diet) and the dynamic nature of bioaccumulation processes $[6,68,69]$. The models provide a better understanding of the extent of and the contributors to the variability in the bioaccumulation among metals in various species and at different conditions $[67,70]$. The biodynamic models are based on the concept of biodynamics that the accumulation of chemicals occurs as a result of a balance of different fluxes. The models assume that the rate of the fluxes can be realistically determined in controlled experiments with varying concentrations and conditions [67]. Uncertainties are inherent in the application of these empirical rates to different conditions, especially those that are extremely different from the conditions in which the rates have been derived. This limitation can be eliminated by integrating inverse phenomena into unifying concepts. The biokinetic model based on a unifying concept is considered 'mechanistic' from the perspective that physiological rates are estimated from chemical-specific properties of substances and species-specific physiological characteristics of organisms [71, 72]. This method facilitates extrapolation to a wide range of chemicals, organisms, and environmental conditions, without the necessity for case-specific calibration. Quantitative relations between uptake and elimination rate constants, on the one hand, and metal-specific properties and species-specific physiological characteristics, on the other hand, are required for the development of a mechanistic model. Some potential for meeting this requirement has been revealed from the findings during the last decades. Specifically, metal absorption and elimination rates have been related to the filtration rate and species weight, respectively [71, 73]. The affinity of metals for proteins, which are intensively involved in trafficking processes of metals, may explain the uptake rate constant from the dissolved phase [72]. The affinity of metals for the proteins depends on metal charge and atomic radius and reflects the preferences for coordination and ligands $[72,74,75]$. The suggestion on a potential correlation between uptake kinetics and the affinity of metals for protein has been substantiated by the reported relationship between the absorption efficiency and the binding of metals to membrane transport proteins [76]. Efforts have been put in developing bioaccumulation and toxicity models based on the affinity of metals for biological ligands [69, 72, 77]. Different indicators of metal binding to biological ligands and bioaccumulation have been related to various chemical properties of metals [7882].

The accumulation of metals in organisms occurs as a result of a balance of the uptake from food as well as water and losses. Moreover, metal concentrations in organisms are affected by the growth dilution. Taking these factors into consideration, the concentration of metals accumulated in organisms $(C ; \mu \mathrm{g} / \mathrm{g} \mathrm{dw})$ can be expressed by the following equation:

$$
\frac{d C}{d t}=\left(k_{u} \times C_{w}\right)+\left(I R \times A E \times C_{f}\right)-\left(k_{e w}+k_{e f}+g\right) \times C
$$

where $k_{\mathrm{u}}(\mathrm{L} / \mathrm{g} \mathrm{dw} / \mathrm{d})$ is the absorption rate; $C_{\mathrm{w}}(\mu \mathrm{g} / L)$ is the dissolved metal concentration; IR $(\mathrm{g} / \mathrm{g} \mathrm{dw} / \mathrm{d})$ is the ingestion rate; $\mathrm{AE}(/)$ is the assimilation efficiency; $C_{\mathrm{f}}(\mu \mathrm{g} / \mathrm{g})$ is the metal concentration in food; $k_{\text {ew }}(1 / \mathrm{d})$ is the excretion rate; $k_{\text {ef }}(1 / \mathrm{d})$ is the egestion rate; and $g(1 / \mathrm{d})$ is 
the growth rate. The instant concentration of metals in organisms can be solved from Equation 5 :

$$
C=\frac{\left(k_{u} \times C_{w}\right)+\left(I R \times A E \times C_{f}\right)}{k_{e w}+k_{e f}+g} \times\left(1-e^{-\left(k_{e w}+k_{e f}+g\right) \times t}\right)
$$

The first factor in Equation 5 represents the uptake from the dissolved phase and can be further elaborated based on the absorption efficiency and the filtration rate [69]. In the study of Le et al. [69], the filtration, ingestion, and growth rates were related to the species weight while the absorption and assimilation efficiency was considered metal specific. In addition, elimination rates were parameterised based on both chemical properties of metals and mussel size.

Such a mechanistic model has shown good potential for predicting metal accumulation in the zebra mussel with different size and from various sites. A mechanistic model, which is based on chemical properties of metals and physiological characteristics of organisms while taking site-specific contamination levels into consideration, facilitates a wide extrapolation to different conditions and metals. However, a number of disadvantages are inherent in the current model. The modelling is based on the dissolved metal concentrations without a specification of chemical species and forms of metals in the environment. Although different uptake pathways are included in the model, a distinction of tissue-specific accumulation of metals is not accounted for. Another disadvantage of the model is related to the derivation of the relationship between the rate of physiological processes and the chemical properties of metals. Despite the potential correlation between the uptake kinetics and some chemical properties of metals shown recently, quantitative relationships established between these two factors have hardly been validated. Moreover, relationships between uptake kinetics and chemical properties of metals have usually been derived based on limited experimental data, thereby leading to intrinsic uncertainties in the application of the derived relationships.

\section{Metal subcellular fates and partitioning}

\subsection{Subcellular partitioning}

Bioaccumulation is a prerequisite, but not necessarily a reliable indicator of metal toxicity due to the species-specific capacity of organisms to detoxify the metals accumulated $[9,59,82]$. The detoxifying mechanisms have been suggested to account for the tolerance of organisms [83]. Besides metal uptake, metal toxicity is determined by the subcellular partitioning of metals in organisms [83]. Metals accumulated are distributed to different cellular components and sequestered by binding to proteins or peptides (e.g., metallothionein and glutathione) and granules [10,83-86]. Therefore, only parts of meals are accumulated in sensitive cellular fractions [9]. From a toxicology perspective, metals accumulated have been divided into two fractions, that is, metal-sensitive fraction (MSF) and biologically detoxified metal (BDM) [83, 87, 88]. The former consists of metals in mitochondria, associated with heat-denaturable 
proteins (HDPs), lysosomes, and microsomes. The latter includes metals in association with heat-stable proteins (HSPs) or metallothionein (MT)-like proteins and metal-rich granules.

It has been suggested that sub-lethal toxicity is accompanied with changes in subcellular partitioning, especially when the threshold is exceeded, that is, saturation of detoxification mechanisms [83]. Eyckmans et al. [89] showed the relationship between the tolerance of three freshwater fish species to excess $\mathrm{Cu}$ and the subcellular partitioning of $\mathrm{Cu}$. The subcellular partitioning of metals may divulge potential mechanisms of toxicity as well as the fate of accumulated metals [90]. For instance, the binding of metals to cytosolic proteins such as MT has widely been demonstrated to alleviate toxic effects [91]. In contrast, the association of metals such as $\mathrm{Cd}$ to mitochondria modulates oxidative phosphorylation, followed by decreases in ATP production [92]. Similarly, the binding of $\mathrm{Cd}$ to the nucleus is potentially toxic because it can lead to DNA damage and stimulate mutagenesis [93, 94]. Different ligands are included in the HSP fraction, that is, amino acids, glutathione, and metallothioneins [95]. This fraction determines the tolerance and resistance of organisms to metals [83, 84, 87]. The relationships between subcellular partitioning and metal toxicity are complicated because of the different physiological functions of each fraction. The accumulation of metals in the lysosomes and microsomes might reflect the storage for eventual elimination if metals are mainly in the lysosomal fraction $[85,96]$. In contrast, metals associated with microsomes can indicate toxicity because of the presence of fragmented endoplasmic reticulum, which is involved in the synthesis and transport of proteins [85, 87]. In addition, mitochondria is the most sensitive fraction [85]. Because of these factors, subcellular partitioning has recently been included in the assessment of metal toxicity.

\subsection{Assessment based on metallothionein induction}

The induction of MT has been integrated in various monitoring programmes and ecotoxicological assessment. However, recent reviews on the use of MT induction as biomarkers of metal exposure and toxicity raise questions on the validity of this method [11,97]. The main concern comes from the lack of well-described time- and dose-dependent MT induction, while the induction of MT widely varies, depending on metals, species, and environmental conditions [97]. Further concern results from the lack of well-described relationships between MT induction and metal exposure, metal accumulation, and biological effects [11]. The validity of the use of MT induction as a biomarker is questionable because of the lack of enhancement in MT induction in response to metal exposure and/or the insignificant relationships between metal and MT concentrations [11]. As explained in the reviews by these authors, these results are attributed to different factors determining the cytosolic free metal ion concentrations, the presence of different MT isoforms in different tissues with various physiological functions, and turnover kinetics of MT as well as the high variability of MT induction and the basal level [11]. These factors should be taken into consideration in the assessment of metal exposure and toxicity based on MT induction. Another concern is related to the selection of organs/tissues as the target in the assessment. The digestive gland has widely been used as the target tissue $[98,99]$ from the point of view that this is the long-term storage organ. In addition, this organ plays an important role in different processes such as immune defence, homeostasis, xenobiotic 
mechanisms, elimination, and detoxification [100-103]. Another reason for the use of the digestive gland is that this organ has the highest amount of proteins, including MT [104]. However, the suitability of the digestive ligand is doubtful because of the influence of natural factors and physiological changes on the induction of MT in this organ [104, 105]. As a major tissue for metal uptake, the induction of MT in gills is expected to represent the response of organisms to the ongoing exposure or accidental pollution [106]. Because of these issues, a single value of MT concentrations in the whole soft tissue or in a specific tissue is not always good indicator of metal exposure or effects on biota. As suggested by Le et al. [11], the induction of MT needs to be considered in relation to a number of factors as briefly mentioned above.

\subsection{Assessment based on subcellular partitioning}

Binding to MT is not the only mechanism for organisms to detoxify and to sequester excess metals. Metals can be associated with insoluble complexes in granules or lysosomes as mentioned above. The proportion of metals bound to MT is not always the dominant fraction and so MT induction is not necessarily a reliable indicator of metal exposure and biological effects. According to Adams et al. [107], the kinetic partitioning of metals into MSF and BDM is the key factor for an understanding of the exposure-toxicity relationship. This has been demonstrated by the shift of $\mathrm{Cu}$ accumulated in gills of common carp from MSF to BDM in the first period of the Cu exposure [89]. The 'Spillover' hypothesis has been used to simulate the relationship between metal bioaccumulation and toxicity. This term indicates the situation when the capacity of organisms to detoxify excess metals is overwhelmed, thereby resulting in adverse effects [66]. From a broad perspective, spillover is assumed to occur when the uptake rate exceeds a combination of the detoxification and elimination rates, leading to the accumulation of metals in the MSF fractions $[9,108]$. This hypothesis has been used in some approaches for assessing metal toxicity.

The first approach is based on the ratio between MSF and MDP fractions or the relative contribution of the MSF and MDF fractions in other words $[89,90]$. This approach is simplistic and does not provide a full description of toxicity [90]. There is not constant partitioning between MSF and BDM. Metals can be exchanged between the two fractions, and only a small fraction of metals occurs as free ions [90]. The use of the relative distribution between these two pools may lead to misinterpretation of spillover [90, 92, 109]. For instance, the increase in the amount of metals bound to MSF might be hidden by the lack of changes in the relative proportion, while the accumulation in all compartments increases. This has been illustrated by increases in metal concentrations in both BDM and MSF fractions in yellow eels [110], mummichogs [111], or yellow perch [85].

The second approach is to develop a relationship between MSF and toxic effects [112], assuming that adverse impacts on organisms increase with increasing amounts of metals in MSF. This method is based on the hypothesis that spillover occurs when certain detoxification mechanisms are overwhelmed and excess metals are accumulated in MSF, leading to adverse effects.

The third approach is based on the kinetics of metal accumulation in MSF $[108,113,114]$. The accumulation of metals in MSF can be described as a balance of uptake (e.g., from the dis- 
solved), losses via elimination, and the partitioning of the metals to BDM, expressed by the detoxification rate:

$$
\operatorname{MIT}=\left(k_{u} \times C_{w}\right)=\left(k_{\text {detox }}+k_{e}\right) \times C_{I T}
$$

where MIT $(\mathrm{mol} / \mathrm{g} / \mathrm{d})$ is the metal influx threshold ; $k_{\mathrm{u}}(\mathrm{L} / \mathrm{g} / \mathrm{d})$ is the uptake rate constant; $C_{\mathrm{w}}$ $(\mathrm{mol} / \mathrm{L})$ is the dissolved metal concentration; $k_{\text {detox }}(1 / \mathrm{d})$ is the detoxification rate constant; $k_{\mathrm{e}}$ $(1 / \mathrm{d})$ is the elimination rate constant; $C_{\mathrm{IT}}(\mathrm{mol} / \mathrm{g})$ is the metal accumulation in MSF at the influx threshold.

This approach is supported by a negative correlation between elimination and detoxification $[113,115]$. However, disadvantages are inherent in the assumption of this method that spillover occurs when the uptake rate exceeds combination of the elimination and detoxification rates, that is, no metal is accumulated in MSF below the threshold. Previous studies have indicated that spillover does not happen at low-exposure concentrations. In other words, there is no threshold below which the accumulation of metals in the sensitive fractions does not occur [84, 85].

\section{Biological responses to metal exposure}

Available approaches based on the induction of MT or taking into account subcellular partitioning of metals have shown some limitations in predicting metal toxicity as mentioned in the previous section. Moreover, the target organ or tissue is species specific, depending on the kinetics of metal accumulation, that is, the differences in absorption, distribution, and excretion [6]. A method that has been demonstrated to be more applicable to different species is to predict metal toxicity based on the accumulation of metals at biological surfaces, which allows for taking into account interactions between organisms and metals at biological surfaces.

\subsection{Biotic Ligand Model}

Interactions at the water-organism interface have been integrated in the Biotic Ligand Model (BLM). The conceptual framework of the BLM originates from two models: the gill surface interaction model and the free ion activity model (FIAM) [116-118]. The FIAM model assumes that free ions are the main reactive species of metals, determining metal bioavailability and toxicity [116, 117]. The FIAM model has then been extended to take into account the interactions of metals with organisms. One example is the fish gill surface interaction model [119], which has been developed by integrating conditional metal-gill surface binding constants to a geochemical speciation model. On the basis of the fish gill surface interaction model, the BLM has been developed to facilitate the application to various species, metals, and exposure conditions as well. According to the concept of the BLM, environmental geochemistry as well as toxicology principles are taken into consideration in determining the fraction of metals that 
provokes effects on biota [119-121]. Initial toxicology bases of the model were effects of trace metals on ionoregulation. Apical (e.g., $\mathrm{Na}^{+}$and $\mathrm{Ca}^{2+}$ channels) and basolateral (e.g., $\mathrm{Na}^{+} / \mathrm{K}^{+}-$ and $\mathrm{Ca}^{2+}$-ATPase) transport channels, exchangers, and enzymes are negatively charged proteins that potentially bind to metal cations [122].

With the principles mentioned above, the BLM has shown substantial advantages in assessment of metal bioavailability. By including interactions of metal ions with both biotic and abiotic ligands, the BLM might provide more reliable estimates of metal bioavailability and toxicity. Moreover, the accumulation of metal ions at the physiological active sites of toxic actions, which determines toxic effect, is, in principle, distinguished from the total body burden [6]. Another advantage of the BLM is the inclusion of environmental conditions in estimating metal bioavailability and subsequent application to site-specific assessment [6]. Furthermore, the BLM provides a mechanistic understanding of metal-organism interactions as well as a mechanistic interpretation of metal toxicity, as illustrated by the results in the study of Le et al. [123]. The BLM has potential for assessing the toxicity of metal mixtures [123, 124]. Norwood et al. [124] suggested that metal-metal interactions can be predicted based on known stability constants. If two metals compete for the same binding site, the total amount of the metals bound to the biotic ligands determines combined effects [123]. Alternatively, the accumulation of individual metals at the biotic ligands can be used as inputs to the response addition model for estimating toxicity of metal mixtures [124, 125]. This suggestion has been demonstrated by the increasing application of the BLM for predicting joint toxicity of metals. Liu et al. [126] predicted the toxicity of metal mixtures based on the simple sum of the fraction of biotic ligands occupied by individual metals. This approach allows for taking into account the metal-specific affinity for binding sites of biotic ligands, but not the metal-specific toxic potency. In other studies, the BLM concepts are usually combined with conventional concepts of mixture toxicity such as concentration addition. As such, the specific toxic potency of metals is taken into account in the estimates. For instance, the toxicity of metal mixtures has been related to the toxic equivalent quotient (TEQ), which is based on the accumulation of metal ions at the binding sites of biotic ligands while giving consideration to the metal-specific toxic potency $[123,126]$. The toxic unit (TU) is the concept mostly integrated in the BLM-based approaches for estimating joint toxicity of metals.

\subsection{The electrostatic model}

The electrostatic model originates from the reported differences between the ion concentration at the root plasma membrane surface and the ion concentration in the external medium, which is induced by the negative charge at the plasma membrane surface $[127,128]$. The surface potential affects the activity of ions at the plasma membrane surface via electrostatic attraction or repulsion. In addition, the potential influences the difference in the electrical potential across the membrane, which stimulates the transport of ions through the membrane. A number of studies have shown the effects of electrical potential at the plasma membrane surface on cation uptake $[127,128]$. The principle effect of the electrical potential at the plasma membrane surface is to control the ion activity at the surface [129]. 
The model allows for integrating plant-ion interactions in predicting metal toxicity [130-132]. In addition, the model gives consideration to the interactions among ions while estimating metal toxicity [132]. The electrostatic model has been applied to simulate effects of major cations on the toxicity of trace metal ions [131-134]. According to the principle of the electrostatic model, additions of cations to the bulk medium reduce the negativity of the electrical potential at the plasma membrane surface, thereby leading to decreases in the negativity of the electrical potential at the plasma membrane surface accompanied by reduced accumulation of trace metal ions at the plasma membrane surface and subsequent alleviation of toxic effects [135]. The electrostatic approach therefore might provide additional explanation for interpreting ion-ion interactions as well as effects of major cations on the toxicity of trace metal ions besides the competitive binding assumed in the BLM. According to the electrostatic principles, three mechanisms have been suggested to account for ameliorative effects of $\mathrm{Ca}^{2+}$ on metal toxicity [128]. The first mechanism is the electrostatic displacement of trace metal ions at the plasma membrane surface by $\mathrm{Ca}^{2+}$. The second is the restoration of $\mathrm{Ca}^{2+}$ at the cell surface in response to low levels of surface $\mathrm{Ca}^{2+}$. This mechanism is mediated in order to avoid the inhibition of the plant growth induced by the low contents of $\mathrm{Ca}^{2+}$ at the cell surface. The third mechanism covers other types of interactions between $\mathrm{Ca}^{2+}$ and trace metal ions, such as the blockade of the ion channel [136]. Despite the toxicant- and major cation-specific relative importance of these mechanisms, mechanism 1 generally occurs in all cases while the contribution of mechanism 2 is minor [128]. The significance of mechanism 3 is trace metal ion specific. The relative influence of major cations such as $\mathrm{Ca}^{2+}$ and $\mathrm{Mg}^{2+}$ on the toxicity of trace metal ions varies, depending on the trace metal ions and species [128]. For instance, $\mathrm{Ca}^{2+}$ has stronger effects on the toxicity of $\mathrm{Al}^{3+}$ to soybean than $\mathrm{Mg}^{2+}[137,138]$. In wheat, $\mathrm{Mg}^{2+}$ is more effective than $\mathrm{Ca}^{2+}$ in inhibiting $\mathrm{Zn}^{2+}$ toxicity, whereas $\mathrm{Mg}^{2+}$ does not have effects on the toxicity of $\mathrm{Al}^{3+}[128]$.

\subsection{WHAM-based bioavailability model}

Originally developed for determining and quantifying chemical forms and species of metals in different phases in the environment, speciation models such as WHAM have recently been used for estimating metal bioavailability and toxicity (hereafter referred to as the WHAMbased model). In this method, humic acid is considered a surrogate to biological surfaces [139144]. As such, the amount of metals bound to humic acid computed by WHAM is used for estimating metal toxicity for different species. In the application of the WHAM-based model to plants, humic acid is used as a surrogate for the root surface [144]. In other words, the interactions of metal ions and the root surface are simulated by the interactions with humic acid.

The WHAM-based model was initiated from the similarities in terms of chemical structure between the root surface and humic acid. The root surface is a heterogeneous mixture of various metal-binding functional groups [145-147]. Similarly, humic acid possesses a heterogeneous mixture of functional groups, mainly carboxylic and phenolic acids [141]. Furthermore, the ratio of 1:2 between the site densities of phenolic and carboxylic groups assumed in WHAM $[40,41]$ lies in the range from 0.49:1 to 1:1 reported for root cell walls of different plant 
species [148]. Because of this similar structure of the root surface and humic acid, metal accumulation on the root surface and metal binding to humic acids are influenced by similar factors. These factors include electrostatic interactions and chemical heterogeneity [127, 128, $149,150]$. The relevance of using metal binding to humic acid to represent metal accumulation at biological surfaces is further substantiated by the nature of the sorption of metal cations to the biological surfaces [151].

The WHAM-based model allows for the interactions between metal ions to be integrated in modelling metal toxicity [144]. Specifically, interactions between ions are considered in modelling metal binding to humic acid in WHAM and therefore accounted for in estimating metal accumulation at the biological surfaces. Another advantage of the WHAM-based model is related to the availability of binding constants in WHAM, which facilitates a wide application to different metals [144]. Moreover, previous studies have shown small variations in the binding constants among different species [145, 147, 152, 153]. For instance, the logarithm of the binding constants of $\mathrm{Cd}$ to the carboxylic group on the membrane surface of bacteria, fungi, and plants were in the range 3.3-3.5. Moreover, the cell walls of algae, maize, soybeans, and higher plants have similar titration curves [154-156]. These results indicate the applicability of a single set of binding constants to different organisms.

In the study of Le et al. [144], the amount of metals bound to humic acid was computed with WHAM in which metal sorption to humic substances is simulated by using a structured formulation of discrete, chemically plausible binding sites for protons and metals. This allows the creation of regular arrays of bidentate and tridentate binding sites for metals. Metal aquo ions compete with their first hydrolysis products, protons, and other metals for binding sites. In addition to the intrinsic metal binding strength to uncharged molecules, electrostatic effects were taken into consideration while predicting metal binding to humic acid. Le et al. [144] showed the potential of the WHAM-HA model for predicting both total and internalised metal concentrations in roots. Another example of the approaches based on the geochemical equilibrium in WHAM is the WHAM- $F_{\text {TOx }}$ model for estimating metal toxicity [140, 143]. In this approach, mixture toxicity was simulated as a function of the metal-specific toxic potency and the amount of metal ions bound to the biological surfaces computed with WHAM.

\section{Author details}

\section{T.T. Yen Le}

Address all correspondence to: yen.le@uni-due.de

Department of Aquatic Ecology, University of Duisburg-Essen, Germany 


\section{References}

[1] Del Castillo P, Chardon WJ, Salomons W. Influence of cattle-manure slurry application on the solubility of cadmium, copper, and zinc in a manured acidic, loamy-sand soil. Journal of Environmental Quality. 1993;22:689-997.

[2] Janssen RPT. Speciation of heavy metal ions as influenced by interactions with montmorillonite, Al hydroxide polymers and citrate [thesis]. Landbouwuniversiteit Wageninen, ISBN 90 - 5485-399-9; 1995.

[3] John DA, Leventhal JS. Bioavailability of metals. In: Du Bray EA, editor. Preliminary Compilation of Descriptive Geoenvironmental Mineral Deposit Models. U.S. Department of the Interior. U.S. Geological survey; 1995.

[4] Gooddy DC, Shand P, Kinniburgh DG, Van Riemsdijk WH. Field-based partition coefficients for trace elements in soil solutions. European Journal of Soil Science. 1995;46:265-285.

[5] Landner L, Reuther R. Metals in society and in the environment: a critical review of current knowledge on fluxes, speciation, bioavailability and risk for adverse effects of copper, chromium, nickel and zinc. Dordrecht, the Netherlands: Kluwer Academic Publishers; 2004.

[6] Fairbrother A, Wenstel R, Sappinton K, Wood W. Framework for metals risk assessment. Ecotoxicology and Environmental Safety. 2007;68:145-227.

[7] Tchounwou PB, Yedjou CG, Patlolla AK, Sutton D. Heavy metals toxicity and the environment. EXS. 2012;101:133-164.

[8] Mertz W. Newer essential trace-elements, chromium, tin, vanadium, nickel and silicon. Proceedings of the Unitrition Society; 1974;33:307-313.

[9] Rainbow PS. Trace metal concentrations in aquatic invertebrates: why and so what? Environmental Pollution. 2002;120:497-507.

[10] Vijver MG, Van Gestel CAM, Lanno RP, Van Straalen NM, Peijnenburg WJGM. Internal metal sequestration and its ecotoxicological relevance: a review. Environmental Science and Technology. 2004;38:4705-4712.

[11] Le TTY, Zimmermann S, Sures B. How does the metallothionein induction in bivalves meet the criteria for biomarkers of metal exposure? Environmental Pollution. 2016;212:257-268.

[12] Sunda W, Guillard RRL. The relationship between cupric ion activity and the toxicity of copper to phytoplankton. Journal of Marine Research. 1976;34:511-529.

[13] Sunda W, Guillard RRL. The relationship between cupric ion activity and the toxicity of copper to phytoplankton. Journal of Marine Research. 1976;34:511-529. 
[14] Senesi N. 1992. Metal-humic substance complexes in the environment. Molecular and mechanistic aspects by multiple spectroscopic approach. In: Adriano DC, editor. Biogeochemistry of Trace Elements. Boca Raton, FL: Lewis; 1992. pp. 429-451.

[15] Uzu G, Sobanska S, Aliouane Y, Pradere P, Dumat C. Study of lead phytoavailability for atmospheric industrial micronic and sub-micronic particles in relation with lead speciation. Environmental Pollution. 2009;157:1178-1185.

[16] Ure AM. Trace elements in soil: their determination and speciation. Fresenius Journal of Analytical Chemistry. 1990;337:577-581.

[17] Tack FMG, Verloo MG. Chemical speciation and fractionation in soil and sediment heavy metal analysis: a review. International Journal of Environmental Analytical Chemistry. 1995;59:225-238.

[18] Carbonaro RF, Stone AT. Speciation of chromium(III) and cobalt(III) (amino)carboxylate complexes using capillary electrophoresis. Analytical Chemistry. 2005;77:155-164.

[19] Clough R, Lindsay R, Drennar H, Harrinton CF, Hill SJ, Tyson JF. Atomic spectrometry update: elemental speciation. Journal of Analytical Atomic Spectrometry. 2012;27:1185-1224.

[20] Rieuwerts J, Thornton I, Farago M, Ashmore M. Quantifying the influence of soil properties on the solubility of metals by predictive modeling of secondary data. Chemical Speciation and Bioavailability. 1998;10:83-94.

[21] Bonten LTC, Groenenberg JE, Weng L, Van Riemsdijk WH. Use of speciation and complexation models to estimate heavy metal sorption in soils. Geoderma. 2008;146:303-310.

[22] Sauve S, Hendershot W, Allen HE. Solid-solution partitioning of metals in contaminated soils: dependence on $\mathrm{pH}$, total metal burden, and organic matter. Environmental Science and Technology. 2000a;34:1125-1131.

[23] Cances B, Ponthieu M, Castre Rouelle M, Aubry E, Benedetti MF. Metal ions speciation in a soil and its solution: experimental data and model results. Geoderma. 2003;113:341355.

[24] Tipping E, Rieuwerts J, Pan G, Ashmore MR, Lofts S, Hill MTR, Farago ME, Thornton I. The solid-solution partitioning of heavy metals $(\mathrm{Cu}, \mathrm{Zn}, \mathrm{Cd}, \mathrm{Pb})$ in upland soils of England and Wales. Environmental Pollution. 2003;125:213-225.

[25] Smolders E, Buekers J, Oliver I, McLaughlin MJ. Soil properties affecting toxicity of zinc to soil microbial properties in laboratory-spiked and filed-contaminated soils. Environmental Toxicology and Chemistry. 2004;23:2633-2640.

[26] Le TTY, Hendriks AJ. Uncertainties associated with lacking data for predictions of solid-solution partitioning of metals in soil. Science of the Total Environment. 2014;490:44-49. 
[27] Voegelin A, Kretzschmar R. Modelling sorption and mobility of cadmium and zinc in soils with scaled exchange coefficients. European Journal of Soil Science. 2003;54:387400.

[28] Lofts S, Tipping E. An assemblage model for cation binding by natural particulate matter. Geochim Cosmochim Acta. 1998;62:2609-2625.

[29] Weng LP, Temminghoff EJ, Lofts S, Tipping E, Van Riemsdijk WH. Environmental Science and Technology. 2002;36:4804-4810.

[30] Gustafsson JP, Pechova P, Berggren D. Modeling metal binding to soils: the role of natural organic matter. Environmental Science and Technology. 2003;37:2767-2774.

[31] Dijkstra JJ, Meeussen JCL, Comans RNJ. Leaching of heavy etals from contaminated soils: an experimental and modeling study. Environmental Science and Technology. 2004;38:4390-4395.

[32] Rodrigues SM, Henriques B, da Silva EF, Pereira ME, Duarte AC, Groenenberg JE, Romkens PFAM. Evaluation of an approach for the characterization of reactive and available pools of 20 potentially toxic elements in soils: Part II - Solid-solution partition relationships and ion activity in soil solutions. Chemosphere. 2010;81:1560-1570.

[33] Gronenberg JE, Dijkstra JJ, Bonten LTC, de Vries W, Comans RNJ. 2012. Evaluation of the performamce and limitations of empirical partition-relations and process based multisurface models to predict trace element solubility in soils. Environmental Pollution. 2012;166:98-107.

[34] Sauve S, Norvell WA, McBride M, Hendershot W. Speciation and complexation of cadmium in extracted soil solutions. Environmetal Science and Technology. 2000b; 34:291-296.

[35] Degryse F, Smolders E, Parker DR. Partitioning of metals ( $\mathrm{Cd}, \mathrm{Co}, \mathrm{Cu}, \mathrm{Ni}, \mathrm{Pb}, \mathrm{Zn}$ ) in soils: concepts, methodologies, prediction and applications - a review. European Journal of Soil Science. 2009;60:590-612.

[36] Groenenberg JE, Romkens PFAM, Comans RNJ, Luster J, Pampura T, Shotbolt L, Tipping E, de Vries W. Transfer functions for solid-solution partitioning of cadmium, copper, nickel, lead and zinc in soils: derivation of relationships for free metal ion activities and validation with independent data. European Journal of Soil Science. 2010;61:58-73.

[37] Westall JC, Zachary JL, Morel FMM. MINEQL: A Computer Program for the Calculation of the Chemical Equilibrium Composition of Aqueous Systems. Tech Note No. 18, Ralph M. Parsons Laboratory, Massachusetts Institute of Technology, Cambridge, MA; 1976.

[38] Sposito G, Mattigod SV. GEOCHEM: a computer program for calculation of chemical equilibria in soil solutions and other natural water systems. Kearny Foundation of Soil Science, University of California, Riverside; 1980. 
[39] Kinniburgh DG, Van Riemsdijk WH, Koopal LK, Borkovic M, Benedetti MF, Avena MJ. Ion binding to natural organic matter: competition, heterogeneity, stoichiometry and thermodynamic consistency. Colloids and Surfaces A. 1999;151:147-166.

[40] Tipping E. WHAM - a chemical equilibrium model and computer code for waters, sediments, and soils incorporating a discrete site/electrostatic model of ion-binding by humic substances. Computers \& Geosciences. 1994;20:973-1023.

[41] Tipping E. Humic ion-binding Model VI: an improved description of the interactions of protons and metal ions with humic substances. Aquatic Geochemistry. 1998;4:3-48.

[42] Dzombak DA, Morel FMM. Surface Complexation Modeling: Hydrous Ferric Oxide. New York: John Wiley \& Sons; 1990.

[43] Hiemstra T, de Wit JCM, Van Riemsdijk WH. Multisite proton adsorption modeling at the solid-solution interface of (hydr)oxides: a new approach: II. Application to various important (hydr)oxides. Journal of Colloid and Interface Science. 1989;133:105-117.

[44] Evans LJ, Barabash SJ, Lumsdon DG, Gu X. Application of chemical speciation modelling to studies on toxic element behaviour in soils. In: Hooda PS, editor. Toxic Elements in Soils. Chichester, England: John Wiley \& Sons; 2010. pp. 199-226.

[45] Meers E, Unamuno V, Vandegehuchte M, Vanbroekhoven K, Geebelen W, Samson R, Vangronsveld J, Diels L, Ruttens A, Du Laing G, Tack F. Soil-solution speciation of Cd as affected by soil characteristics in unpolluted and polluted soils. Environmental Toxicology and Chemistry. 2005;24:499-509.

[46] Tipping E, Berggren D, Mulder J, Woof C. Modelling the solid-solution distributions of protons, aluminium, base cations and humic substances in acid soils. European Journal of Soil Science. 1995;46:77-94.

[47] Weng L, Temminghoff EJM, Van Riemsdijk WH. Contribution of individual sorbents to the control of heavy metal activity in sandy soil. Environmental Science and Technology. 2001;35:4436-4443.

[48] Kuipers SF. Bodemkunde. Culumborg, the Netherlands; 1984.

[49] McBride MB. Environmental Chemistry of Soils. New York: Oxford University Press; 1994.

[50] Meeussen JCL. ORCHESTRA: an object-oriented framework for implementing chemical equilibrium models. Environmental Science and Technology. 2003;37:11751182.

[51] Dijkstra JJ, Meeussen JCL, Comans RNJ. Evaulation of a generic multisurface sorption model for inorganic soil contaminants. Environmental Science and Technology. 2009;43:6196-6201. 
[52] Allison JD, Brown DS, Novo-gradac KJ. MINTEQA2/PRODEFA2, Geochemical assessment model for environmental systems: version 3.11 databases and version 3.0 user's manual Environmental Research Laboratory, US EPA, Athens, GA; 1991.

[53] Benedetti MF, Milne CJ, Kinniburgh DG, Van Riemsdijk WH, Koopal LK. Metal ion binding to humic substances: application of the non-ideal competitive adsorption model. Environmental Science and Technology. 1995;29:446-457.

[54] Kinniburgh DG, Milne CJ, Benedetti MF, Pinheiro JP, Filius J, Koopal LK, Van Riemsdijk W. Metal ion binding by humic acid: application of the NICA-Donnan Model. Environmental Science and Technology. 1996;30:1687-1698.

[55] Milne CJ, Kinniburgh DG, Tipping E. Generic NICA-Donnan model parameters for proton binding by humic substances. Environmental Science and Technology. 2001;35:2049-2059.

[56] Milne CJ, Kinniburgh DG, Van Riemsdijk WH, Tipping E. Generic NICA-Donnan model parameters for metal-ion binding by humic substances. Environmental Science and Technology. 2003;37:958-971.

[57] Chapman PM, Allen HE, Godtfredsen K, Z'Graggen MN. Evaluation of bioaccumulation factors in regulating metals. Environmental Science and Technology. 1996;30:448452.

[58] McGeer J, Brix KV, Skeafff JM, DeForest DK. The use of bioaccumulation criteria for hazard identification of metals. ICMM Fact Sheet on Environmental Risk Assessment. Published by the International Council on Mining and Metals (ICMM), London; 2002.

[59] McGeer JC, Brix KV, Skeaff JM, DeForest DK, Brigham SI, Adams WJ, Green A. Inverse relationship between bioconcentration factor and exposure concentration for metals: implications for hazard assessment of metals in the aquatic environment. Environmental Toxicology and Chemistry. 2003;22:1017-1037.

[60] Le TTY. Modelling bioaccumulation and toxicity of metal mixtures [thesis]. Radboud University Nijmegen, the Netherlands. ISBN: 978-94-91066-06-1; 2012. http://repository.ubn.ru.nl/bitstream/2066/100831/1/100831.pdf

[61] Simkiss K, Taylor MG. Metal fluxes across membranes of aquatic organisms. Reviews in Aquatic Science. 1989;1:173-188.

[62] McDonald DG, Wood CM. Branchial mechanisms of acclimation to metals in freshwater fish. In: Rankin JC, Jensen FB, editors. Fish Ecophysiology. London, UK: Chapman \& Hall; 1993. p. 297-321.

[63] McKim JM. Physiological and biochemical mechanisms that regulate the accumulation and toxicity of environmental chemicals in fish. In: Hamelink JL, Landrum PF, Bergman HL, Bensen WH, editors. Bioavailability: Physical, Chemical and Biological Interactions. Boca Raton, FL, US: CRC; 1994. pp. 179-201. 
[64] Newman MC. Bioaccumulation in Quantitative Methods in Aquatic Ecotoxicology. Boca Raton, FL, US: CRC; 1995.

[65] Wood CM. Toxic responses of the gill. In: Schlenk DW, Benson WH, editors. Target Organ Toxicity in Marine and Freshwater Teleosts. Washington, DC, US: Taylor \& Francis; Vol. 1: Organs; 2001.

[66] Mason AZ, Jenkins KD. Metal detoxification in aquatic organisms. In: Tessier A, Turner DR, editors. Metal Speciation and Bioavailability in Aquatic Systems. Chichester, UK: John Wiley \& Sons; 1995. pp. 479-608.

[67] Luoma SN, Rainbow PS. Why is metal bioaccumulation so variable? Biodynamics as a unifying concept. Environmental Science and Technology. 2005;39:1921-1931.

[68] Ahlf W, Drost W, Heise S. Incorporation of metal bioavailability into regulatory frameworks - metal exposure in water and sediment. Journal of Soils and Sediments. 2009;9:411-419.

[69] Le TTY, Leuven RSEW, Hendriks AJ. Modeling metal bioaccumulation in the invasive mussels Dreissena polymorpha and Dreissena rostriformis bugensis. Environmental Toxicology and Chemistry. 2011;30:2825-2830.

[70] Wang W-X, Fisher NS. Delineating metal accumulation pathways for marine invertebrates. Science of the Total Environment. 1999;237/238:459-472.

[71] Hendriks AJ, Heikens A. The power of size. 2. Rate constants and equilibrium ratios for accumulation of inorganic substances related to species weight. Environmental Toxicology and Chemistry. 2001;20:1421-1437.

[72] Veltman K, Huijbregts MAJ, Van Kolck M, Wang W-X, Hendriks AJ. Metal bioaccumulation in aquatic species: qualification of uptake and elimination rate constants using physicochemical properties of metals and physiological characteristics of species. Environmental Science and Technology. 2008;42:852-858.

[73] Baines SB, Fisher NS, Kinney EL. Effects of temperature on uptake of aqueous metals by blue mussels Mytilus edulis from Arctic and temperate waters. Marine Ecology Progress Series. 2006;308:117-128.

[74] Bell RA, Ogden N, Kramer JR. The biotic ligand model and a cellular approach to class B metal aquatic toxicity. Comparative Biochemistry and Physiology C. 2002;133:175188.

[75] Handy RD, Eddy FB. Transport of solutes across biological membranes in eukaryotes: an environmental perspective. In: van Leeuwen HP, Koster W, editors. Physicochemical Kinetics and Transport at Biointerfaces. IUPAC Series on Analytical and Physical Chemistry of Environmental Systems. New York: John Wiley \& Sons, Vol. 9; 2004. 
[76] Bryan GW. Pollution due to heavy metals and their compounds. In: Kinne O, editor. Marine Ecology. West Sussex, UK: John Wiley \& Sons; 1984.

[77] Newman MC, McCloskey JT. Predicting relative toxicity and interactions of divalent metal ions: microtox bioluminescence assay. Environmental Toxicology and Chemistry. 1996;15:275-281.

[78] Van Kolck M, Huijbregts MAJ, Veltman K, Hendriks AJ. Estimating bioconcentration factors, lethal concentrations and critical body residues of metals in the mollusks Perna viridis and Mytilus edulis using ion characteristics. Environmental Toxicology and Chemistry. 2008;27:272-276.

[79] Zhou D-M, Li L-Z, Peijnenburg WJGM, Ownby DR, Hendriks AJ, Wang P, Li D-D. A QICAR approach for quantifying binding constants for metal-ligand complexes. Ecotoxicology and Environmental Safety. 2011;74:1036-1042.

[80] McCloskey JT, Newman MC, Clark SB. Predicting the relative toxicity of metal ions using ion characteristics: microtox bioluminescene assay. Environmental Toxicology and Chemistry. 1996;15:1730-1737.

[81] Le TTY, Hendriks AJ. Relationships between absorption efficiency of elements in mammals and chemical properties. Critical Reviews in Toxicology. 2013;43:800-809.

[82] Rosen G, Rivera-Duarte I, Chadwick DB, Ryan A, Santore RC, Paquin PR. Critical tissue copper residues for marine bivalve (Mytilus galloprovincialis) and echinoderm (Strongylocentrotus purpuratus) embryonic development: conceptual, regulatory and environmental implications. Marine Environmental Research. 2008;66:327-336.

[83] Wallace WG, Lee B-G, Luoma SN. Subcellular compartmentalization of Cd and Zn in two bivalves. I. Significance of metal-sensitive fractions (MSF) and biologically detoxified metal (BDM). Marine Ecology Progress Series. 2003;249:183-197.

[84] Campbell PGC, Guguere A, Bonneris E, Hare L. Cadmium-handling strategies in two chronically exposed indigenous freshwater organisms-the yellow perch (Ferca flavescenes) and the floater mollusc (Pyganodon grandis). Aquatic Toxicology. 2005;72:83-97.

[85] Giguere A, Campbell PGC, Hare L, Couture P. Sub-cellular partitioning of cadmium, copper, nickel and zinc in indigenous yellow perch (Perca flavescenes) sampled along a polymetallic gradient. Aquatic Toxicology. 2006;77:178-189.

[86] Voets J, Redeker ES, Blust R, Bervoets L. Differences in metal sequestration between zebra mussels from clean and polluted filed locations. Aquatic Toxicology. 2009;93:5360.

[87] Bonneris E, Perceval O, Masson S, Hare L, Campbell P. Sub-cellular partitioning of Cd, $\mathrm{Cu}$ and $\mathrm{Zn}$ in tissues of indigenous unionid bivalves living along a metal exposed gradient and links a metal-induced effects. Environmental Pollution. 2005;135:195-208.

[88] Wadige CPMM, Taylor AM, Maher WA, Krikowa F. Bioavailability and toxicity of zinc from contaminated freshwater sediments: linking exposure-dose-response relation- 
ships of the freshwater bivalve Hyridella australis to zinc-spiked sediments. Aquatic Toxicology. 2014;156:179-190.

[89] Eyckmans M, Blust R, De Boeck G. Subcellular differences in handling Cu excess in three freshwater fish species contributes greatly to their differences in sensitivity to $\mathrm{Cu}$. Aquatic Toxicology. 2012;118-119:97-107.

[90] Kamunde C. Early subcellular partitioning of cadmium in gill and liver of rainbow trout (Oncorhynchus mykiss) following low-to-near-lethal waterborne cadmium exposure. Aquatic Toxicology. 2009;91:291-301.

[91] Roesijadi G. Metallothionein and its role in toxic metal regulation. Comparative Biochemistry and Physiology C. 1996;113:117-123.

[92] Sokolova IM, Ringwood AH, Johnson, C. Tissue-specific accumulation of cadmium in subcellular compartments of eastern osysters Crassostrea virginica Gmelin (Bivalvia: Ostreidae). Aquatic Toxicology. 2005;74:218-228.

[93] Risso-de Faverney C, Devaux A, Lafaurie M, Girar JP, Bailly B, Rahmani R. Cadmium induces apoptosis and genotoxicity in rainbow trout hepatocytes through generation of reactive oxygen species. Aquatic Toxicology. 2001;53:65-76.

[94] Pruski AM, Dixon DR. Effects of cadmium on nuclear integrity and DNA repair efficiency in the gill cells of Mytilus edulis L. Aquatic Toxicology. 2002;57:127-137.

[95] Kraemer LD, Campbell PGC, Hare L. A field study examining metal elimination kinetics in juvenile yellow perch (Perca flavescens). Aquatic Toxicology. 2005;75:108-126.

[96] Bustamante P, Cosson R, Gallien I, Caurant F, Miramand P. Cadmium detoxification processes in the digestive gland of cephalopods in relation to accumulated camium concentrations. Marine Environmental Research. 2002;53:227-241.

[97] Amiard JC, Amiard-Triquet C, Barka S, Pellerin J, Rainbow PS. Metallothioneins in aquatic invertebrates: their role in metal detoxification and their use as biomarkers. Aquatic Toxicology. 2006;76:160-202.

[98] Lionetto MG, Giordano ME, Caricato R, Pascariello MF, Marinosci L, Schettino T. Biomonitoring of heavy metal contamination along the Salento coast (Italy) by metallothionein evaluation in Mytilus galloprovincialis and Mullus barbatus. Aquatic Conservation Marine and Freshwater Ecosystems. 2001;11:305-310.

[99] Andreani G, Carpene E, Capranico G, Isani G. Metallothionein cDNA cloning, metallothionein expression and havy metals in Scapharca inaequivalvis along the Northern Adriatic coast of Italy. Ecotoxicology and Environmental Safety. 2011;74:366-372.

[100] Marigomez I, Soto M, Cajaraville MP, Angulo E, Giamberini L. Cellular and subcellular distribution of metals in molluscs. Microscopey Research and Technique. 2002;.56:358392. 
[101] Moore MN, Allen JI. A computational model of the digestive gland epithelial cells of marine mussels and its simulated responses to oil-derived aromatic hydrocarbons. Marine Environmental Research. 2002;54:579-584.

[102] McVeigh A, Allen JI, Moore MN, Dyke P, Noble D. A carbon and nitrogen flux model of mussel digestive epithelial cells and their simulated response to pollutants. Marine Environmental Research. 2004;58:821-827.

[103] Rajalakshmi S, Mohandas A. Copper-induced changes in tissue enzyme activity in a freshwater mussel. Ecotoxicology and Environmental Safety. 2005;62:140-143.

[104] Raspor B, Dragun Z, Erk M, Ivankovic D, Pavicic J. Is the digestive gland of Mytilus galloprovincialis a tissue of choice for estimating cadmium exposure by means of metallothioneins? Science of the Total Environment. 2004;333:99-108.

[105] Trinchella F, Esposito MG, Simoniello P, Scudiero R. Cadmium, lead and metallothionein contents in cultivated mussels (Mytilus galloprovincialis) from the Gulf of Naples (Southern Italy). Aquaculture Research. 2013;44:1076-1084.

[106] Cooper S, Hare L, Campbell PGC. Subcellular partitioning of cadmium in the freshwater bivalve, Pyganodon grandis, after separate short-term exposures to waterborne or diet-borne metal. Aquatic Toxicology. 2010;100:303-312.

[107] Adams WJ, Blust R, Borgmann U, Brix KV, DeForst DK, Green AS, Meyer JS, McGeer JC, Paquin PR, Rainbow PS, Wood CM. Utility of tissue residues for predicting effects of metals on aquatic organisms. Integrated Environmental Assessment and Management. 2011;7:75-98.

[108] Croteau M-N, Luoma SN. Predicting dietborne metal toxicity from metal influxes. Environmental Science and Technology. 2009;43:4915-4921.

[109] Wicklund Glynn A. The concentration dependency of branchial intracellular cadmium distribution and influx in the zebrafish (Brachydanio rerio). Aquatic Toxicology. 1996;35:47-58.

[110] Rosabal M, Pierron F, Counture P, Baudrimont M, Hare L, Campbell PGC. Subcellular partitioning of non-essential trace metals $(\mathrm{Ag}, \mathrm{As}, \mathrm{Cd}, \mathrm{Ni}, \mathrm{Pb}$, and $\mathrm{Tl}$ ) in livers of American (Anguilla rostrata) and European (Anguilla anguilla) yellow eels. Aquatic Toxicology. 2015;160:128-141.

[111] Goto D, Wallace WG. Metal intracellular partitioning as a detoxification mechanism for mummichogs (Fundulus heteroclitus) living in metal-polluted salt marshes. Marine Environmental Research. 2010;69:163-171.

[112] Dandan L, Dongmei Z, Peng W, Nanyan W, Xiangdong Z. Subcellular Cd distribution and its correlation with antioxidant enzymatic activities in wheat (Triticum aestivum) roots. Ecotoxicology and Environmental Safety. 2011;74:874-881. 
[113] Chen B-C, Chen W-Y, Ju Y-R, Tsai J-W, Jou L-J, Singh S, Liao C-M. Combining bioaccumulation and coping mechanism to enhance long-term site-specific risk assessment for zinc susceptibility of bivalves. Chemosphere. 2011;84:707-715.

[114] Liao C-M, Ju Y-R, Chen W-Y. Subcellular partitioning links BLM-based toxicokinetics for assessing cadmium toxicity to rainbow trout. Environmental Toxicology. 2011;26:600-609.

[115] Buchwalter DB, Cain DJ, Martin CA, Xie L, Luoma SN, Garland Jr T. Aquatic insect ecophysiological traits reveal phylogenetically based differences in dissolved cadmium susceptibility. Proceedings of the National Academy of Sciences of the United States of America. 2008;105:8321-8326.

[116] Morel FMM. Principles of Aquatic Chemistry. New York, US: Wiley-Interscience; 1983.

[117] Pagenkopf GK. Gill surface interaction model for trace metal toxicity to fishes: role of complexation, $\mathrm{pH}$ and water hardness. Environmental Science and Technology. 1983;17:342-347.

[118] Campbell PGC. Interactions between trace metals and aquatic organism: a critique of the free-ion activity model. In: Tessier A, Turner DR, editors. Metal Speciation and Bioavailability in Aquatic Systems. Chichester, UK: John Wiley \& Sons; 1995. pp. 45102.

[119] Playle RC. Modelling metal interactions at fish gills. Science of the Total Environment. 1998;219:147-163.

[120] McGeer JC, Playle RC, Wood CM, Galvez F. A physiologically based biotic ligand model for predicting the acute toxicity of waterborne silver to rainbow trout in freshwaters. Environmental Science and Technology. 2000;34:4199-4207.

[121] Di Toro DM, Allen HE, Bergman HL, Meyer JS, Paquin PR, Santore RC. Biotic ligand model of the acute toxicity of metals. 1. Technical basis. Environmental Toxicology and Chemistry. 2001;20:2382-2393.

[122] Niyogi S, Wood CM. Effects of chronic waterborne and dietary metal exposures on gill metal-binding: implications for the biotic ligand model. Human and Ecological Risk Assessment. 2003;4:813-846.

[123] Le TTY, Vijver MG, Hendriks AJ, Peijnenburg WJGM. Modeling toxicity of binary metal mixtures $\left(\mathrm{Cu}^{2+}-\mathrm{Ag}^{+}, \mathrm{Cu}^{2+}-\mathrm{Zn}^{2+}\right)$ to lettuce, Lactuca sativa, with the biotic ligand model. Environmental Toxicology and Chemistry. 2013;32:137-143.

[124] Norwood WP, Borgmann U, Dixon DG, Wallance A. Effects of metal mixtures on aquatic biota: a review of observations and methods. Human and Ecological Risk Assessment. 2003;4:795-811.

[125] Borgmann U, Norwood WP, Dixon DG. Modelling bioaccumulation and toxicity of metal mixtures. Human and Ecological Risk Assessment. 2008;14:266-289. 
[126] Liu Y, Vijver MG, Peijnenburg WJGM. Comparing three approaches in extending biotic ligan models to predict the toxicity of binary metal mixtures $(\mathrm{Cu}-\mathrm{Ni}, \mathrm{Cu}-\mathrm{Zn}$ and $\mathrm{Cu}-$ Ag) to lettuce (Lactuca sativa L.). Chemosphere. 2014;112:282-288.

[127] Wagatsuma T, Akiba R. Low surface ngativity of root protoplasts from aluminiumtolerant plant species. Soil Science and Plant Nutrition. 1989;35:443-452.

[128] Kinraide TB. Three mechanisms for the calcium alleviation of mineral toxicities. Plant Physiology. 1998;118:513-520.

[129] Nobel PS. Physicochemical and Environmental Plant Physiology. San Diego, CA: Academic; 1961.

[130] Wang P, Zhou D-M, Peijnenburg WJGM, Li L-Z, Weng N. Evaluating mechanisms for plant-ion $\left(\mathrm{Ca}^{2+}, \mathrm{Cu}^{2+}, \mathrm{Cd}^{2+}\right.$ or $\left.\mathrm{Ni}^{2+}\right)$ interactions and their effectiveness on rhizotoxicity. Plant and Soil. 2010;334:277-288.

[131] Kopittke PM, Blamey FPC, Wang P, Menzies NW. Calculated activity of $\mathrm{Mn}^{2+}$ at the outer surface of the roto cell plasma membrane governs Mn nutrition of cowpea seedlings. Journal of Experimental Botany. 2011;62:3393-4001.

[132] Le TTY, Wang P, Vijver MG, Kinraide TB, Hendriks AJ, Peijnenburg WJGM. Delineating ion-ion interactions by electrostatic modeling for predicting rhizotoxicity of metal mixtures to lettuce Lactuca sativa. Environmental Toxicology and Chemistry. 2014;33:1988-1995.

[133] Wang P, Kopittke PM, De Schamphelaere KAC, Zhao F-J, Zoud D-M, Lock K, Ma Y-B, Peijnenburg WJGM, McGrath SP. Evaluation of an electrostatic toxicity model for predicting $\mathrm{Ni}^{2+}$ toxicity to barley root elongation in hydroponic cultures and in soils. New Phytologist. 2011;192:414-427.

[134] Wang Y-M, Kinraide TB, Wang P, Hao X-Z, Zhou D-M. Surface electrical potentials of root cell plasma membranes: implications for ion interactions, rhizotoxicity, and uptake. International Journal of Molecular Sciences. 2014;15:22661-22677.

[135] Kinraide TB. Plasma membrane surface potential $\left(\Psi_{\mathrm{PM}}\right)$ as a determinant of ion bioavailability: a critical analysis of new and published toxicological studies and a simplified method for the computation of plant $\Psi_{\mathrm{PM}}$. Environmental Toxicology and Chemistry. 2006;25:3188-3198.

[136] Tyerman SD, Skerrett M, Garrill A, Findlay GP, Leigh RA. Pathways for the permeation of $\mathrm{Na}^{+}$and $\mathrm{Cl}^{-}$into protoplasts derived from the cortex of wheat roots. Journal of Experimental Botany. 1997;48:459-480.

[137] Silva IR, Smyth TJ, Israel DW, Raper CD, Rufty T. Magnesisum ameliorates aluminum rhizotoxicity in soybean by increasing citric acid production and exudation by roots. Plant and Cell Physiology. 2001a;42:546-554.

[138] Silva IR, Smyth TJ, Israel DW, Raper CD, Rufty TW. Magnesium is more efficient than calcium in alleviating aluminum rhizotoxicity in soybean and its ameliorative effect is 
not explained by the Gouy-Chapman-Stern model. Plant and Cell Physiology. 2001b; 42:538-545.

[139] Tipping E, Vincent CD, Lawlor AJ, Lofts S. Metal accumulation by stream bryophytes, related to chemical speciation. Environmental Pollution. 2008;156:936-943.

[140] Stockdale A, Tipping E, Lofts S, Ormerod S, Clements W, Blust R. Toxicity of protonmetal mixtures in the field: linking stream macroinvertebrate species diversity to chemical speciation and bioavailability. Aquatic Toxicology. 2010;100:112-119.

[141] Antunes PMC, Scornaienchi ML, Roshon HD. Copper toxicity to Lemna minor modelled using humic acid as a surrogate to the plant root. Chemosphere. 2012;88:389-394.

[142] Iwasaki Y, Cadmus P, Clements WH. Comparison of different predictors of exposure for modeling impacts of metal mixtures on macroinvertebrates in stream microcosms. Aquatic Toxicology. 2013;132-133:151-156.

[143] Tipping E, Lofts S. Metal mixture toxicity to aquatic biota in laboratory experiments: application of the WHAM- $F_{\text {TOx }}$ model. Aquatic Toxicology. 2013;142-143:114-122.

[144] Le TTY, Swartjes F, Romkens P, Groenenberg JE, Wang P, Lofts S, Hendriks AJ. Modelling metal accumulation using humic acid as a surrogate for plant roots. Chemosphere. 2015;124:61-69.

[145] Fein JB, Daughney CJ, Yee N, Davis T. A chemical equilibrium model for metal adsorption onto bacterial surfaces. Geochim Cosmochim Acta. 1997;61:3319-3328.

[146] Cox JS, Smith DS, Warren LA, Ferris FG. Characterizing heterogeneous bacterial surface functional groups using discrete affinity spectra for proton binding. Environmental Science and Technology. 1999; 33:4514-4521.

[147] Ginn BR, Szymanowski JS, Fein JB. Metal and proton binding onto the roots of Escue rubra. Chemical Geology. 2008;253:130-135.

[148] Meychik NR, Yermakov IP. Ion exchange properties of plant root cell walls. Plant and Soil. 2001;234:181-193.

[149] Milne CJ, Kinniburgh DG, de Wit JCM, van Riemsdijk WH, Koopal LK. Analysis of proton binding by a peat humic acid using a simple electrostatic model. Geochim Cosmochim Acta. 1995;59:1101-1112.

[150] Lindberg S, Landberg T, Greger M. A new method to detect cadmium uptake in protoplasts. Planta. 2004;214:526-532.

[151] Postma JWM, Keltjens WG, van Riemsdijk WH. Calcium-(organo)aluminium-proton competition for adsorption to tomato root cell walls: experimental data and exchange model calculations. Environmental Science and Technology. 2005;39:5247-5254. 
[152] Kaulbach ES, Szymanowski JES, Fein JB. Surface complexation modeling of proton and $\mathrm{Cd}$ adsorption onto an algal cell wall. Environmental Science and Technology; 2005;39:4060-4065.

[153] Naeem A, Woertz JR, Fein JB. Experimental measurement of proton, Cd, Pb, Sr, and $\mathrm{Zn}$ adsorption onto the fungal species Saccharomyces cerevisiae. Environmental Science and Technology. 2006;40:5724-5729.

[154] Morvan C, Demarty M, Thellier M. Titration of isolated cell walls of Lemna minor L. Plant Physiology. 1979;63:1117-1122.

[155] Dufey JE, Amory DE, Braun R. Proprietes electriques et selectivite d'echange ionique des racines. Pedologie. 1985;35:231-249.

[156] Allan DL, Jarrell WM. Proton and copper adsorption to maize and soybean root cell walls. Plant Physiology. 1989;89:823-832. 


\section{Section 2}

Validated Methods and New Models of Evaluation 

Chapter 3

\title{
Soil Contamination Health Risks in Czech Proposal of Soil Protection Legislation
}

\author{
Radim Vácha, Milan Sáňka, Jan Skála, \\ Jarmila Čechmánková and Viera Horváthová \\ Additional information is available at the end of the chapter
}

http://dx.doi.org/10.5772/62456

\begin{abstract}
A new system of soil contamination limit values proposed for Czech legislation is described. The system is based on the hierarchical limit values system with two levels. The first one - prevention limit-defined background values of risk elements (REs) and persistent organic pollutants (POPs) in Czech agricultural soils supported by the data from soil monitoring system. The second one-indication limit-is defined for human health protection by two principles, the protection of food chain and the protection of direct human health risks by inhalation, dermal and oral intake of RE and POPs in soil particles on the field. The practical application of limit values proposal was applied in the project focused on soil contamination influence on health and environmental risks in fluvial zones of Czech important river basins. The floodplain soils belong to the most contaminated soils in Europe generally and the project defined the potential fluvial areas with increased human health risks.
\end{abstract}

Keywords: soil contamination, health risks, risk elements, persistent organic pollutants, soil protection legislation

\section{Introduction}

The one of the important way of contamination risk elimination is the existence of legislative norms of contaminants in the environment. The soil is medium where the load from other environments can concentrate and interact. The limit values of main contaminants (risk elements (REs) and persistent organic pollutants (POPs) predominantly) were set in most of developed countries worldwide including the Czech Republic. The limits of REs and POPs concentra- 
tions in agricultural soil are set by the Decree No. 13/1994 Coll. in the Czech legislation [1]. These limit values have a status of maximum tolerable values in agricultural soils. The criteria were derived from available data in the Czech Republic at the beginning of 90th and the data were corresponding with the load of Czech agricultural soils and also of some European countries. The REs limit values stated in the decree were derived as rounded 90 percentile of the background valuesin soil(pseudototal contentinextract of Aqua regia). Someauthors [2,3] published the data concerning the total content of REs in the Czech soils before the proposal of background values of REs in Czech agricultural soils [4] was given. The history of POPs limit values assessment was different. The POPs limits were derived from available external data (especially from the Netherlands) since no relevant data for the Czech soils were available in 1994. As a result, limit values of some individual polycyclic aromatic hydrocarbons in the Decree No. 13/1994 Coll. are lower than their real background values in Czech agricultural soils proposed later [5]. This situation is misapplied by subjects demanding appropriation of agricultural land for construction purposes because there are assessed lower levies for the appropriation in the cases where the limit values are exceeded.

The described limit values were derived statistically and do not represent any specific risk in fact. The delimitation of soil suitability for agricultural use by the existence of one value of risk substance concentration is very questionable. For these reasons, the presented version of limit values can be considered as behind the time. The new version of limit values was proposed [6] and it is based on the principle of hierarchical limit values, differentiated in three levels. These individual levels present specific risks. The first one is derived from the background values of RE (POPs, respectively) in agricultural soils and the principles of limit construction follow German experiences [7], Regulation BGBl I, No. 36/1999 [8]. The principles of the assessment of nationals' soil background values of REs presented by [9] include following steps: The assessment of natural background given by the geology-REs contents in rocks and parent materials and REs contents in organic matter of soils; the assessment of diffusion load given by atmospheric deposition especially (determined the background values of organic pollutants) and the definition of practical questions connected with soil use and its relationship to environmental protection level. The suitable statistical methods for the assessment of element background levels in soils (defined as the first level) and of the higher levels of soil limits were described in detail in previous study [10].

The second level of limit values can be defined for specific risks (transfer into plants, transfer into ground water, or microbial activity inhibition for example). Considering the limits for transfer into plants, the Czech legislation proposal follows the German approach [11] using single extraction methods $\left(1 \mathrm{~mol} / \mathrm{L} \mathrm{NH}_{4} \mathrm{NO}_{3}, 0.01 \mathrm{~mol} / \mathrm{L} \mathrm{CaCl}\right)_{2}$ which were scientifically verified by several studies [12-15].

The third level of limit values is directly connected with an impact on human health (Maximum Permissible Concentrations-MPC in the Netherlands, Contaminated Land Exposure Assessment in Great Britain) or the threat of ground water contamination (US EPA) generally. The applications of soil decontamination technologies must be used when these limit values are exceeded. The limit for Czech legislation was based on the US EPA methodology [16]. The protection of direct human health risk by inhalation, dermal, and oral intake is based on the 
fact that zootoxic RE and POPs can cause the kind of mentioned risks to farmers spending the time on the field during agro technical activities. The zootoxic $\mathrm{RE}$ ( $\mathrm{As}, \mathrm{Cd}, \mathrm{Hg}, \mathrm{Pb}$, and $\mathrm{Tl}$ ) and POPs substances (sum of PAHs, benzo(a)pyrene, sum of 7 PCBs, sum of DDTs, HCB, HCH, and PCDDs/Fs) were chosen for their known negative impact on human health. The EPA methodology was applied for limit values calculation based on the toxicity of individual RE or POP substance (defined carcinogenic risk by WHO), the general soil properties and expected time period spending by the farmer on the field.

The limit values system is in legislative process in current days and validity is presumed since 2016. The practical application of limit values proposal was verified in the project focused on soil contamination influence on health and environmental risks in fluvial zones of Czech important river basins. The floodplain soils belong to the most contaminated soils in Europe generally and the project defined the potential fluvial areas with increased human health risks by the methodology described above. The results of project are presented as the practical application of proposed limit values in the methodology of selected risks in fluvial zones. The Fluvisols are soil group with specific soil properties and soil vulnerability by contamination (the sources of soil contamination) developed on fluvial sediments. The floods are the most serious way of soil contamination and soil properties show a high heterogeneity and variability. The heterogeneity is influenced by nature water stream dynamic (the gradient of erosion-deposition properties) with increased influence of neolitisation, it means acceleration of erosion-accumulation processes as the result of vegetation cover change and husbandry development in the landscape. The Fluvisols belong to fertile soils that has been used in agriculture historically. The husbandry in contaminated fluvial zones could cause increased risk and our study defines the risks on the most important fluvial zones in the Czech Republic.

\section{Material and methods}

Two levels of soil limit values were proposed for the Czech legislation, so-called prevention and indication limit. Their general characterisation is as follows:

Prevention limit was derived from the background values of REs and POPs in Czech agricultural soils when real data were calculated. The indication limits reflect two kinds of the risks. The first one is focused on increased REs transfer from soil into agricultural plants (POPs transfer was not calculated). The second one calculates direct impact on human health via their inhalation, dermal or oral intake on contaminated land for selected POPs and REs.

\subsection{The prevention limits of RE and POPs}

The prevention limit was derived from background values of RE and POPs in Czech agricultural soils proposed by [4] and [5]. REs background values are depending strongly on geochemical properties of the soil substrates and were proposed for 13 soil-lithological groups originally. The reduction into two groups was realised for pragmatic reasons. The background values are not valid for geochemically anomalous soils (mafic rocks, metallogenic zones of acid 
rocks, etc.). The RE background values were calculated for pseudototal REs contents (Aqua regia extract, ČSN EN 13346 [17]) finally.

The POPs background values were calculated by [5]. The research of 560 soil samples of agricultural soils from the area of the Czech Republic was utilised. The background values were statistically calculated as two multiples of the standard deviation of geometric means or $90 \%$ percentiles $-G_{M} . G^{2}$ ) for both groups (RE and POPs). The background values were set for every individual substance of observed POPs groups. Clearly, the simplification of limit values for legislative process was necessary in result of which summary limits were calculated for some POPs groups.

The sum of PAHs - calculated as the sum of 12 substances concentration (anthracene, benzo(a)anthracene, benzo(b)fluoranthene, benzo(k)fluoranthene, benzo(a)pyrene, benzo(ghi)perylene, phenanthrene, fluoranthene, chrysene, indeno(1,2,3-cd)pyrene, naphthalene, pyrene).

The polychlorinated hydrocarbons - limits for sum of seven indication congeners of polychlorinated biphenyls $-\mathrm{PCB}_{7}(28+52+101+118+138+153+180)$ and sum of DDTs (DDT, DDE, and DDD).

The hexachlorbenzene and hexachlorcyclohexane $((\Sigma \alpha+\beta+\gamma)$ and polychlorinated dibenzop-dioxines and dibenzofurans (PCDDs/Fs) should be analysed only in the case of suspicion of their contents in soil.

The background value of PCCDs/Fs was calculated separately because of different collection of soil samples. The used statistic was identical and 102 soil samples taken in the areas of the Czech Republic with different source of the load [18] were taken into account. The value of International Toxic Equivalent (I-TEQ PCCDs/Fs) of 17 toxic congeners was calculated [19].

\subsection{The indication limit values of food chain contamination and plant growth inhibition}

The separation on phytotoxic and zootoxic REs should be accepted. The limits for plant growth inhibition were proposed for this reason. The limits for food chain contamination regulate the transfer of zootoxic elements from the soil into plant production. The limits were supported by the research of RE transfer from the soil into selected plants (triticale, radish) in experimental conditions and into fodder plants (clover, alfalfa, and grass species) in field conditions [2023]) and the dependency of REs mobile contents and selected soil conditions ( $\mathrm{pH}$, Cox, soil texture) was evaluated by multidimensional statistical methods (factor analysis). The comparison of the selected $\mathrm{RE}$ total contents ( $\mathrm{As}, \mathrm{Cd}, \mathrm{Cu}, \mathrm{Hg}, \mathrm{Ni}, \mathrm{Pb}, \mathrm{Th}, \mathrm{Zn}$ ) and the content in the extract of $1 \mathrm{~mol} / \mathrm{L} \mathrm{NH}_{4} \mathrm{NO}_{3}(\mathrm{As}, \mathrm{Cd}, \mathrm{Cu}, \mathrm{Ni}, \mathrm{Pb}, \mathrm{Th}, \mathrm{Zn}$ ) characterised as RE mobile fraction (ISO DIS 19730 [24]) was the principle of RE indication values assessment. The limit values were referred to RE critical values in eatable and fodder plants (the Decree No. 305/2004 Coll. [25]). The other legislative norms for plant contamination (European legislation) are shown in our practical study focused on the husbandry in fluvial zones. 


\subsection{The indication limit values of human health protection}

The limit values were derived from the direct risk of increased POPs and $\mathrm{RE}$ ( $\mathrm{As}, \mathrm{Cd}, \mathrm{Hg}$, and $\mathrm{Pb}$ ) contents on human health by their inhalation, dermal, and oral intake on contaminated fields. The calculation corresponds with the US EPA methodology (US EPA 2002) and respects the toxicity of the selected substances or elements and the movement duration of farmers on the contaminated land (standard exposition scenario was applied). It is also supported by the experience following from the activities provided in Czech conditions [26].

\subsection{The case study of human health risks assessment from soil pollution in flood affected areas in the Czech Republic}

The evaluation of health risk was realised and verified in the research project focused on soil contamination of flood affected areas in the Czech Republic. The human health risk assessment is becoming relevant when the -proposed indication limit values are exceeded, because they are derived as "effect based" for worst-case scenario. The screening evaluation of exposition by Soil Screening Level (SSL) method was applied (see 3.3 of the chapter). The calculation approach is based on the application of exposition models of chemical substances inputs into human bodies followed by the comparison of this predicted chronical dose with referenced "effect-based" dose. This approach allows to assign individual exposition parameters to every locality and then calculate site-specific SSL values and risks following from the exposition. The calculation of human risk (RISK HUMAN $_{\text {) }}$ has been done for individual chemical substances first and there has been calculated total sum of all evaluated substances including the calculation of percentage of individual substances contributions to total sum. The RISK HUMAN $_{\text {values }}$ should not be higher than 1 . The values higher than 2 indicate the possible risk and in the dependency on detail evaluation of exposition scenarios up to significant. The other cases can be evaluated as non-significant considering selected exposition scenario.

The next step for the evaluation of contamination level in floodplain soils was a rigorous statistical evaluation of the results. The dataset for soil contamination of 100 floodplain soils in the Czech Republic was used to estimate the human health risks by presented methodology (Equations 1-3). ${ }^{1}$ Relative contributions of each risky element/substance to an overall hazard

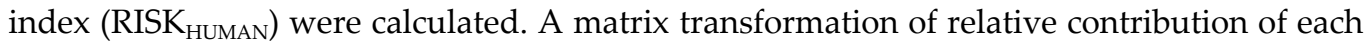

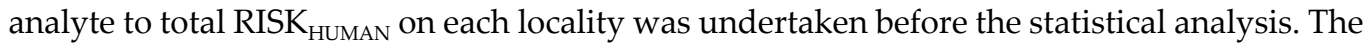
similarity of the soil pollution profiles in individual floodplain samples was assessed by a hierarchical cluster analysis using the average linkage clustering. The results of hierarchical cluster analyses are presented using technique of heatmap, where the similarity among the objects in a cluster dendrogram is visualised by the colour intensity in a square matrix of coloured pixels (R Core Team, Library Gplot).

\footnotetext{
${ }^{1}$ There were sampled 100 floodplain soils in various catchments of the Czech Republic. For each sampling site, a mixed sample consisting of 10 individual samples from the area of $100 \times 100 \mathrm{~m}$ was used. Samples are separated and homogenised by quartation. The sample depth was $0-10 \mathrm{~cm}$ for pastures and $0-30 \mathrm{~cm}$ for arable land. In the soil samples there was analysed a wide range of risky substances including seven indicator PCBs $(28,52,101,118,138,153,180), 7$ risky elements (As, $\mathrm{Cd}, \mathrm{Cu}, \mathrm{Hg}, \mathrm{Ni}, \mathrm{Pb}$, and $\mathrm{Zn}$ ), polycyclic aromatic hydrocarbons (29 PAHs compounds), and pesticides (DDT and metabolites; hexachlorcyclohexane isomers, HCHs; pentachlorbenzene, PeCB; hexachlorbenzene, HCB). The basic soil properties (e.g. total organic carbon, soil texture characteristics) were determined.
} 


\section{Results and discussion}

\subsection{Proposal of legislative limit values}

\subsubsection{Prevention limit}

The prevention limits of the RE for two soil texture units are presented in Table 1. This separation includes light texture soils (loamy-sandy soils and gravel-sandy soils) and standard soils (all the other soil). The values show REs contents in the extract of Aqua regia (pseudototal contents). These values were derived from the background values of REs in Czech agricultural soils - the soil geochemical background plus the average diffuse anthropogenic load [4]. The prevention limits were derived from the soils developed on different soil substrates of the Czech Republic except of the soils developed on geochemically anomalous substrates. These causes including the substrates with increased REs contents of lithogenic or chalcogenic origin [27] must be under an individual evaluation.

\begin{tabular}{lcccccccccccccc}
\hline \multicolumn{11}{c}{ Prevention value $\mathbf{( m g} / \mathbf{k g}$ of d.m.) } \\
\hline Soil category & $\mathrm{As}$ & $\mathrm{B}$ & $\mathrm{Cd}$ & $\mathrm{Co}$ & $\mathrm{Cr}$ & $\mathrm{Cu}$ & $\mathrm{Hg}$ & $\mathrm{Mn}$ & $\mathrm{Ni}$ & $\mathrm{Pb}$ & $\mathrm{V}$ & $\mathrm{Zn}$ & $\mathrm{Tl}$ \\
Standard texture soils $^{1}$ & 20 & 2.0 & 0.5 & 30 & 90 & 60 & 0,3 & 1200 & 50 & 60 & 130 & 120 & 0.5 \\
Light texture soils $^{2}$ & 15 & 1.5 & 0.4 & 20 & 55 & 45 & 0,3 & 1000 & 45 & 55 & 120 & 105 & 0.5 \\
\hline
\end{tabular}

${ }^{1}$ Soils except light texture soils.

${ }^{2}$ Sandy soils, loamy-sandy soils, gravel-sandy soils.

Table 1. Proposed RE prevention limits in agricultural soils.

The POPs prevention limits are shown in Table 2. The differentiation of the soil texture units has no relevant reason for POPs and was not done. The POPs limit values are given in the form of total POPs contents in the soil. The background values of POPs in soil were derived from the average diffuse anthropogenic load (the dependency of POPs soil contents on nature background values is marginal). The real Czech background values [5] were adopted for legislative proposal.

\begin{tabular}{ll}
\hline POPs & Prevention value $(\mathbf{m g} / \mathbf{k g}$ of d.m.) \\
\hline Polycyclic aromatic hydrocarbons & 1.0 \\
$\Sigma \mathrm{PAHs}^{1}$ & \\
Chlorinated hydrocarbons & 0.02 \\
$\Sigma \mathrm{PCB}^{2}$ & 0.075 \\
$\Sigma \mathrm{DDT}^{3}$ & 0.02 \\
$\mathrm{HCB}^{4}$ & 0.01 \\
$\mathrm{HCH}^{4}(\Sigma \alpha+\beta+\gamma)$ &
\end{tabular}




\begin{tabular}{ll}
\hline POPs & Prevention value $(\mathbf{m g} / \mathbf{k g}$ of $\mathbf{d . m})$. \\
\hline PCDDs/Fs & $1.0^{*}$ \\
Petroleum hydrocarbons & \\
Hydrocarbons C10-C40 & 100 \\
\hline
\end{tabular}

${ }^{1} \Sigma$ PAHS - polycyclic aromatic hydrocarbons (anthracene, benzo(a)anthracene, benzo(b)fluoranthene, benzo(k)fluoranthene, benzo(a)pyrene, benzo(ghi)perylene, phenanthrene, fluoranthene, chrysene, indeno(1,2,3cd)pyrene, naphthalene, pyrene).

${ }^{2} \Sigma$ PCB congeners $-28+52+101+118+138+153+180$

${ }^{3} \Sigma$ DDT, DDE, DDD.

${ }^{4} \mathrm{HCB}$ and $\mathrm{HCH}(\Sigma \alpha+\beta+\gamma)$-analysed only by suspicion of their contents in soil.

${ }^{5}$ International toxic equivalent value (I-TEQ PCDDs/Fs) (ng/kg) - analysed only by suspicion of increased PCDDs/Fs contents in soil.

Table 2. Proposed POPs prevention limits in agricultural soils.

The exceeding of RE or POPs prevention limits signalises the increased anthropogenic soil load (over the background values). In the cases of prevention limits exceeding, the precaution measure is proposed: the use of sludge, dredged sediments, or biosolids on the field will be forbidden. This level of limit values has already been partially implemented in the Czech legislation, namely in the Decrees No. 382/2001 Coll. [28] and No. 257/2009 Coll. [29] for sewage sludge and dredged sediments [30] application on agricultural soils. The proposed prevention limits should be valid for all types of substances applied on the agricultural land generally.

The system of so-called background values is not absolutely unified and can be partially different in individual EU countries. The Czech one is derived from German methodology where the background values are characterised as the concentration resulting from geological and pedological processes and including diffuse source inputs. This method is described in ISO 19258 (2005) [31] for RE and POPs and has international relevance. This methodology is used for the background value assessment in France and United Kingdom. Belgium, Luxembourg, and Netherlands derive the REs and POPS background values only from clean reference areas without any anthropogenic inputs (concentrations found in soil unaffected by any human activity, respectively, soils possibly contaminated by line/point source are exceeded). Nevertheless, the approaches can be different not only between the member countries but between the regions of individual countries in some of them (LABO 1995 [32]) because of different geological and pedological processes and anthropogenic inputs influencing the values and the differences in legislation systems.

\subsection{Indication limits}

\subsubsection{Indication limit of food chain contamination and plant growth inhibition}

The indication limit values reflect the mobility of REs. The comparison of RE (pseudo) total contents and their mobile fraction analysed in the extract of $1 \mathrm{~mol} / \mathrm{L} \mathrm{NH}_{4} \mathrm{NO}_{3}$ are the principle of indication limits. The limits of zootoxic REs ( $\mathrm{As}, \mathrm{Cd}, \mathrm{Pb}, \mathrm{Tl}, \mathrm{Hg}$ ) were proposed for the 
food chain protection purpose (Table 3). The mobility of REs dependency on soil properties complicates the limit values when indication values for $\mathrm{Cd}$ are most complicated because of $\mathrm{Cd}$ mobility dependency on soil texture and soil $\mathrm{pH}$. The evaluation of REs pseudototal and mobile form must be done if the limit values are available. The exceeding of limit value of pseudototal or of mobile form means exceeding of indication limit. The proposal of this level of limit value was based on the testing of selected plant species (fodder plants, vegetables, and corns) in experimental and field conditions and general validity of proposed values was derived. The statistical probabilities of critical values exceeding in eatable or fodder plants can be resulted when RE indication limits in the soil are exceeded. The real exceeding of indication limit value in local field conditions must be confirmed by the testing on individual crop.

\begin{tabular}{|c|c|c|c|c|}
\hline \multirow[t]{2}{*}{ Element } & \multirow[t]{2}{*}{ Soil texture } & \multirow[t]{2}{*}{$\mathrm{pH} / \mathrm{CaCl}_{2}$} & \multicolumn{2}{|c|}{ Indication value (mg/kg of d.m.) } \\
\hline & & & Aqua regia & $1 \mathrm{~mol} / \mathrm{L} \mathrm{NH}_{4} \mathrm{NO}_{3}$ \\
\hline As & - & - & - & 1.0 \\
\hline \multirow[t]{4}{*}{$\mathrm{Cd}$} & & $<5$ & 1 & - \\
\hline & & $5-6.5$ & 1.5 & - \\
\hline & Standard texture & $>6.5$ & 2.0 & 0.1 \\
\hline & Light texture & $>6.5$ & 2.0 & 0.04 \\
\hline \multirow[t]{4}{*}{$\mathrm{Ni}$} & & $<5$ & 90 & - \\
\hline & & $5-6.5$ & 150 & - \\
\hline & & $>6.5$ & 200 & - \\
\hline & & - & - & 1.0 \\
\hline $\mathrm{Pb}$ & & - & 300 & 1.5 \\
\hline $\mathrm{Tl}$ & & - & 10 & 0.2 \\
\hline $\mathrm{Hg}^{*}$ & & - & 1.5 & - \\
\hline
\end{tabular}

*Total content by AMA technique.

The exceeding of limit value is valid in the case of any exceeding, a) Aqua regia extraction, b) $1 \mathrm{~mol} / \mathrm{L} \mathrm{NH}_{4} \mathrm{NO}_{3}$ extraction when both analyses must be done if the limit values are available.

Table 3. Proposed indication limits of food chain contamination.

The indication limit values of plant growth inhibition (Table 4) were proposed for phytotoxic $\mathrm{REs}(\mathrm{Ni}, \mathrm{Cu}$, and $\mathrm{Zn}$ ) because the phytotoxicity can result into significant yield reduction. The limit values proposal was supported by the testing on plant species identical with previous indication limit value and the exceeding of indication limit values must be confirmed by the testing on individual crop in field conditions as well. In the cases of exceeding of both indication limit values the suitable remediation techniques for REs immobilisation (the liming, the application of inorganic or organic additives [33] are recommended). 


\begin{tabular}{|c|c|c|c|c|}
\hline \multirow[t]{2}{*}{ Element } & \multirow[t]{2}{*}{ Soil texture } & \multirow[t]{2}{*}{$\mathrm{pH} / \mathrm{CaCl}_{2}$} & \multicolumn{2}{|c|}{ Indication value (mg/kg of d.m.) } \\
\hline & & & Aqua regia & $1 \mathrm{~mol} / \mathrm{L} \mathrm{NH}_{4} \mathrm{NO}_{3}$ \\
\hline \multirow[t]{4}{*}{$\mathrm{Cu}$} & & $<5$ & 150 & - \\
\hline & & $5-6.5$ & 200 & - \\
\hline & & $>6.5$ & 300 & - \\
\hline & & - & - & 1.0 \\
\hline \multirow[t]{4}{*}{$\mathrm{Ni}$} & & $<5$ & 90 & - \\
\hline & & $5-6.5$ & 150 & - \\
\hline & & $>6.5$ & 200 & - \\
\hline & & - & - & 1.0 \\
\hline \multirow[t]{2}{*}{$\mathrm{Zn}$} & & & 400 & - \\
\hline & & & - & 20 \\
\hline
\end{tabular}

The exceeding of limit value is valid in the case of any exceeding, a) Aqua regia extraction, b) $1 \mathrm{~mol} / \mathrm{L} \mathrm{NH}_{4} \mathrm{NO}_{3}$ extraction when both analyses must be done if the limit values are available.

Table 4. Proposed indication limits of plant growth inhibition.

\subsubsection{The indication limit values of human health protection}

The limit was proposed for zootoxic REs (Table 5) and selected POPs (Table 6). The model calculation of exposition scenario (method US EPA [16] was used as the principle for limit values assessment. The scenario calculates the effect of individual element/substance, the input into human bodies by inhalation, dermal, and oral inputs and the time period of exposition (estimated number of days per year). The calculated value is maximum tolerable value and the exceeding of this level of limit values could cause human health risk. The precaution defined in the legislation is based on the risk analysis of the site confirmed or excluded human health risk. The similar approach is applied in some EU countries, for example, limit value for human health protection is defined as decontamination limit for chlorinated substances in the soils of Germany (Federal Ministry of Justice and Consumer Protection of Germany).

\begin{tabular}{ll}
\hline Element & Indication value (mg/kg of d.m.) \\
\hline $\mathrm{As}^{1}$ & 40 \\
$\mathrm{Cd}^{1}$ & 20 \\
$\mathrm{Hg}^{2}$ & 20 \\
$\mathrm{~Pb}^{1}$ & 400 \\
$\mathrm{Tl}$ & 60 \\
\hline
\end{tabular}

${ }^{1}$ Aqua regia extract-valid for all soil texture categories

${ }^{2}$ Total content by AMA method

Table 5. Proposed RE indication limits of human health protection. 


\begin{tabular}{ll}
\hline Substance & Indication value $(\mathbf{m g} / \mathbf{k g}$ of d.m.) \\
\hline$\sum \mathrm{PAHs}^{1}$ & 30 \\
Benzo(a)pyrene & 0.5 \\
$\Sigma \mathrm{PCB}^{2)}$ & 1.5 \\
$\Sigma \mathrm{DDT}^{3}$ & 8.0 \\
$\mathrm{HCB}^{4}$ & 1 \\
$\mathrm{HCH}^{4}(\Sigma \alpha+\beta+\gamma)$ & 1 \\
$\mathrm{PCDDs}^{2} \mathrm{Fs}^{5}$ & $100^{*}$ \\
\hline
\end{tabular}

${ }^{1} \Sigma$ PAHs - polycyclic aromatic hydrocarbons (anthracene, benzo(a)anthracene, benzo(b)fluoranthene, benzo(k)fluoranthene, benzo(a)pyrene, benzo(ghi)perylene, phenanthrene, fluoranthene, chrysene, indeno(1,2,3cd)pyrene, naphthalene, pyrene).

${ }^{2} \Sigma$ PCB congeners $-28+52+101+118+138+153+180$.

${ }^{3} \Sigma$ DDT, DDE, DDD.

${ }^{4} \mathrm{HCB}$ and $\mathrm{HCH}(\Sigma \alpha+\beta+\gamma)$-analysed only by suspicion of their contents in soil.

${ }^{5}$ International toxic equivalent value (I-TEQ PCDDs/Fs) (ng/kg) - analysed only by suspicion of increased PCDDs/Fs contents in soil.

Table 6. Proposed POPs indication limits of human health protection.

\subsection{The evaluation of health risks in floodplain soils in the Czech Republic}

The project proposed the methodology for evaluation of health risks in contaminated floodaffected soils useful in practical conditions [34]. The method of SSL was proposed for first screening evaluation. The method is based on the approaches of risk evaluation by US EPA [35] and EPA [36]. The methodology uses the exposition models of chemical inputs into human body. The predicted chronic daily doses are then compared with reference "effect-based" doses mathematically. The partial values of chemical substances concentrations and parameters of chosen exposition scenario (used in limit values assessment) for the main three exposition ways together are used in calculation:

Dust particles inhalation entering into air as secondary dust in the vicinity of evaluated localities.

- Soil ingestion (by consumption of insufficiently washed crops/eatables).

- Dermal contact with soil.

The SSL model was adopted for estimation of the human intake of soil contaminants and consequent risks. This method is based on the risk assessment procedure developed by US EPA. SSLs represent the risk-based soil concentrations derived for the individual chemicals of concern from equations combining exposure assumptions with toxicity criteria. 
For each chemical, SSL is back-calculated from the target risk level, whereas an excess lifetime cancer risk (ELCR) is $1 \times 10^{-6}$ for the soil exposure. Following equations are used to calculate SSL values for a residential population exposed to hazardous chemicals via all three exposure pathways. Default exposure parameters are provided whenever site-specific data are not available. The site specific exposure parameters were set out according to typical conditions of an intensive agriculture (arable land in alluvial areas). The detailed methodology is also described [37].

A. SSL based on non-carcinogenic risks

$$
C=\frac{T H Q \cdot B W_{c} \cdot A T_{n}}{E F_{r} \cdot E D_{c}\left[\left(\frac{1}{R f D_{o}} \cdot \frac{I R S_{c}}{10^{6} \mathrm{mg} / \mathrm{kg}}\right)+\left(\frac{1}{R f D_{o}} \cdot \frac{S A_{c} \cdot A F_{c} \cdot A B S}{10^{6} \mathrm{mg} / \mathrm{kg}}\right)+\left(\frac{1}{R f D_{i}} \cdot \frac{I R A_{c}}{V F_{s} o r P E F}\right)\right]}
$$

where

C Contaminant concentration (SSL) $\left(\mathrm{mg} \mathrm{kg}^{-1}\right) \quad$ Chemical-specific

THQ Target hazard quotient 1

BWc Body weight, child (kg) 15

ATn Averaging time, non-carcinogens (days) ED $\times 365$

EFr Exposure frequency, resident (day $\left.\mathrm{yr}^{-1}\right) \quad 250(8 \mathrm{~h} /$ day $)$

EDc Exposure duration, child (years) 25

IRSc Soil ingestion rate, child $\left(\mathrm{mg} \mathrm{day}^{-1}\right) \quad 100$

RfDo Oral reference dose $\left(\mathrm{mg} \mathrm{kg}^{-1}\right.$ day $\left.^{-1}\right)$ Chemical-specific

SA Dermal surface area, child $\left(\mathrm{cm}^{2}\right.$ day $\left.^{-1}\right) \quad 3470$

AF Soil adherence factor, child $\left(\mathrm{mg} \mathrm{cm}^{-2}\right) \quad 0.12$

ABS Skin absorption factor (unitless) Chemical-specific

IRAc Inhalation rate, child $\left(\mathrm{m}^{3}\right.$ day $\left.^{-1}\right) \quad 20$

RfDI Inhalation reference dose $\left(\mathrm{mg} \mathrm{kg}^{-1} \mathrm{day}^{-1}\right)$ Chemical-specific

VFs Volatilisation factor for soil $\left(\mathrm{m}^{3} \mathrm{~kg}^{-1}\right)$ Chemical-specific

PEF Particulate emission factor $\left(\mathrm{m}^{3} \mathrm{~kg}^{-1}\right) \quad$ Chemical-specific

B SSL based on carcinogenic risks 


$$
C=\frac{T R \cdot A T_{c}}{E F_{r}\left[\left(\frac{I F S_{a d j} \cdot C S F_{o}}{10^{6} \mathrm{mg} / \mathrm{kg}}\right)+\left(\frac{S F S_{a d j} \cdot A B S \cdot C S F_{o}}{10^{6} \mathrm{mg} / \mathrm{kg}}\right)+\left(\frac{I n h F_{a d j} \cdot C S F_{i}}{V F_{s} o r P E F}\right)\right]}
$$

where

C Contaminant concentration (SSL) $\left(\mathrm{mg} \mathrm{kg}^{-1}\right)$ Chemical-specific

TR Target cancer risk 1E-06

ATc Averaging time, carcinogens (days) 25,550

EFr Exposure frequency, resident (day $\left.\mathrm{yr}^{-1}\right) \quad 250(8 \mathrm{~h} /$ day $)$

IFSadj Age-adjusted soil ingest. factor $\left(\left[\mathrm{mg} \mathrm{yr}^{-1}\right] /[\mathrm{kg} \text { day }]\right)^{-1} 100$

CSFo Oral cancer slope factor $\left(\mathrm{mg} \mathrm{kg}^{-1} \mathrm{day}^{-1}\right)$ Chemical-specific

SFSadj Age-adjusted dermal factor $\left(\left[\mathrm{mg} \mathrm{yr}^{-1}\right] /\left[\mathrm{kg} \mathrm{day}^{-1}\right]\right) \quad 361$

ABS Skin absorption factor (unitless) Chemical-specific

InhFadj Age-adjusted inhalation factor $\left(\left[\mathrm{m} 3 \mathrm{yr}^{-1}\right] /\left[\mathrm{kg} \mathrm{day}^{-1}\right]\right) \quad 11$

CSFi Inhalation cancer slope factor $(\mathrm{mg} \mathrm{kg} \text { day })^{-1}$ Chemical-specific

VFs Volatilisation factor for soil $\left(\mathrm{m}^{3} \mathrm{~kg}^{-1}\right)$ Chemical-specific

PEF Particulate emission factor $\left(\mathrm{m}^{3} \mathrm{~kg}^{-1}\right)$ Chemical-specific

In case of the exposure to multiple chemicals, total risk is calculated as an additive value according to following equation:

$$
R I S K_{\text {HUMAN }}=\frac{c_{1}}{S S L_{1}}+\frac{c_{2}}{S S L_{2}}+\ldots . .+\frac{c_{i}}{S S L_{i}}
$$

Resulting ratio smaller than 1 indicates that the POP concentrations measured at the site are unlikely to result in an adverse health impact.

Following uncertainties must be taken into account in final result assessment:

- Other non-analysed substances can influence the real risk.

- Toxicological data of some substances are estimated from in vivo tests on animals or in vitro. Therefore, extrapolation for humans must be done; however, for some chemical substances, the indexes are not set out yet.

- The exposure coefficient can be a serious source of uncertainties. 


\section{The results of health risks assessment in floodplain soils in the Czech Republic}

Since the magnitude of the total estimation for human health risks on individual sampling localities was calculated (Equations 1-3) and cartographically represented (see Figure 2), the regional differentiation of potential human health impacts of complex soil pollution can be determined for floodplains soils in the Czech Republic. An increase of human health risk estimation was recorded for the Elbe River below the industrial centres (Opatovice, Pardubice, Neratovice, the Ohře River inflow) confirming the spatial patterns of pollution of various environmental compartments in the Elbe basin reported by previous studies [38, 39]. The high PAHs contributions together with an above-average RISK $_{\text {HUMAN }}$ were surprisingly found in the upper reaches of the Elbe River and Morava River. This could only be explained by a high propensity of PAHs to atmospheric transport resulting in high concentration of airborne POPs in remote and unpolluted freshwater ecosystems [40]. The higher magnitude of RISK HUMAN $_{\text {. }}$ was recorded in a consequence of some well-known hot spots in the Berounka catchment (the Litavka stream inflow [41, 42] or the influence of Ag-Pb-Zn deposit in Stříbro). Similarly, the

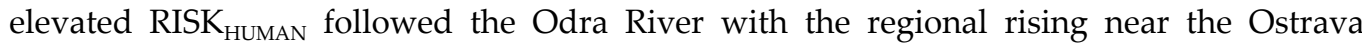
agglomeration where the long-term airborne pollution resulted in a higher PAHs and Cd contamination of agricultural soils [43]. The elevated level of quantified human risks was also recorded in soil samples near the confluence of the Morava and Drevnice River below the Otrokovice-Zlín agglomeration as a regional centre of industry that involves especially plastic and rubber manufacturing and historically established chemical industries for secondary manufacturing (shoemaking tradition). Several local contamination rising were detected in a consequence of spatially confined pollution sources (industrial centre of Mladá Boleslav or the Svitava River near Boskovice). A cluster analysis was processed for the transformed data matrix of relative contributions of each analyte to the total estimation of human health risk to reveal patterns of pollution profiles of floodplain samples in the Czech Republic. The results proved high cophenetic correlation coefficient $(r=0.92)$ with the optimal number of 11 clusters in the cluster analysis. One substantial cluster (covered 71 from 100 sampling localities) and several regional pollution abnormalities were detected in our analysis (see Figure 1). The dominant cluster was formed by the localities characteristic in a high contribution of polycyclic aromatic hydrocarbons (and especially benzo(a)pyrene, benzo(a)anthracene and benzo(b)fluoranthene) and in an elevated contribution of lead to total estimation of health risks. Some regional pollution abnormalities were connected to higher contribution of organochlorine pesticides (the Berounka and Ohře River), elevated contribution of PCBs (the Elbe River), or geochemical anomalies connected to local metallogenic zones (deposits). When combining both the magnitude of estimated RISK HUMAN and structural characteristics of pollution profiles (the cluster analysis results), the highest estimated humanotoxicological risks proved only several localities with a high content of polycyclic aromatic hydrocarbons accompanied by higher lead contents (there are depicted the predominant pollution profiles for the localities

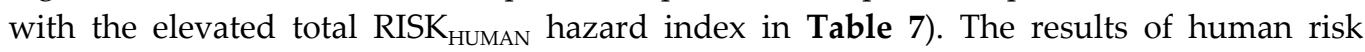
assessment well correspond with the exceedance of indication limit values for human protec- 
tion. The indication limits of human health protection for $\mathrm{PAHs}$ and $\mathrm{Pb}$ contents were exceeded for several localities of floodplain soils in our study.
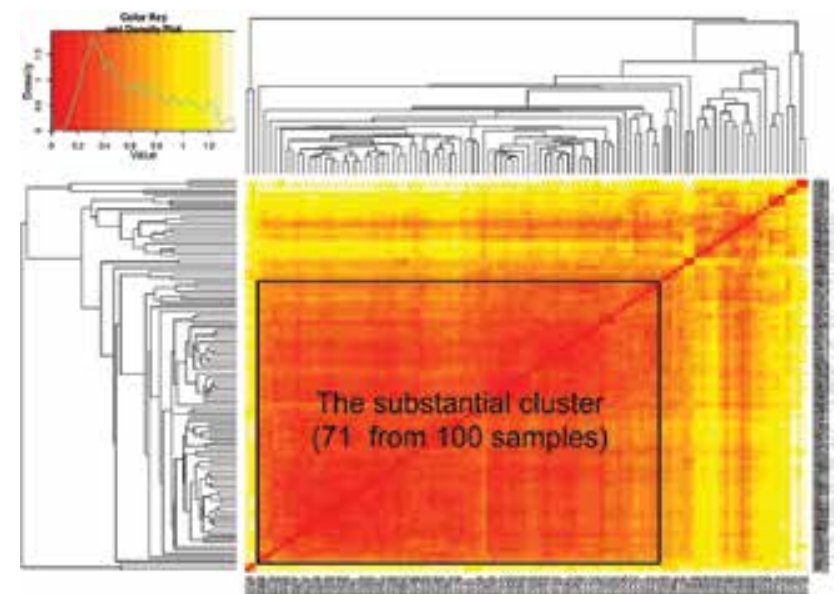

Figure 1. Similarity of the soil pollution profiles (relative contribution of pollutants to overall estimation of human

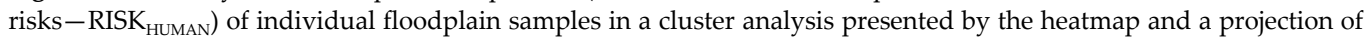
dominant cluster in our dataset. Note-the more intense red color the more similar samples.

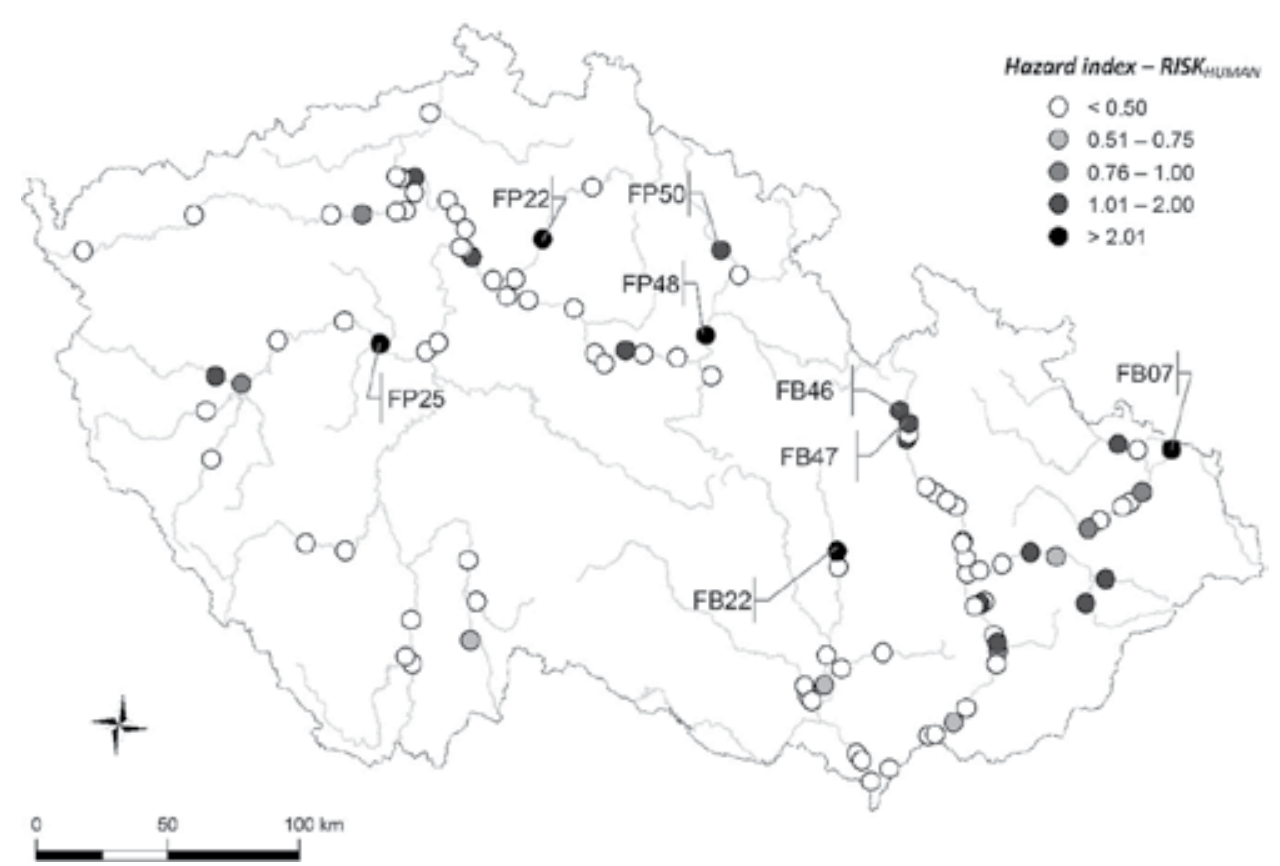

Figure 2. Spatial differentiation of magnitude of human health risks quantified using total RISK HUMAN $_{\text {(Equations } 1-3)}$ and visualisation of the regional hot spots (where RISK $_{\text {HUMAN }}>1.5$ ). 


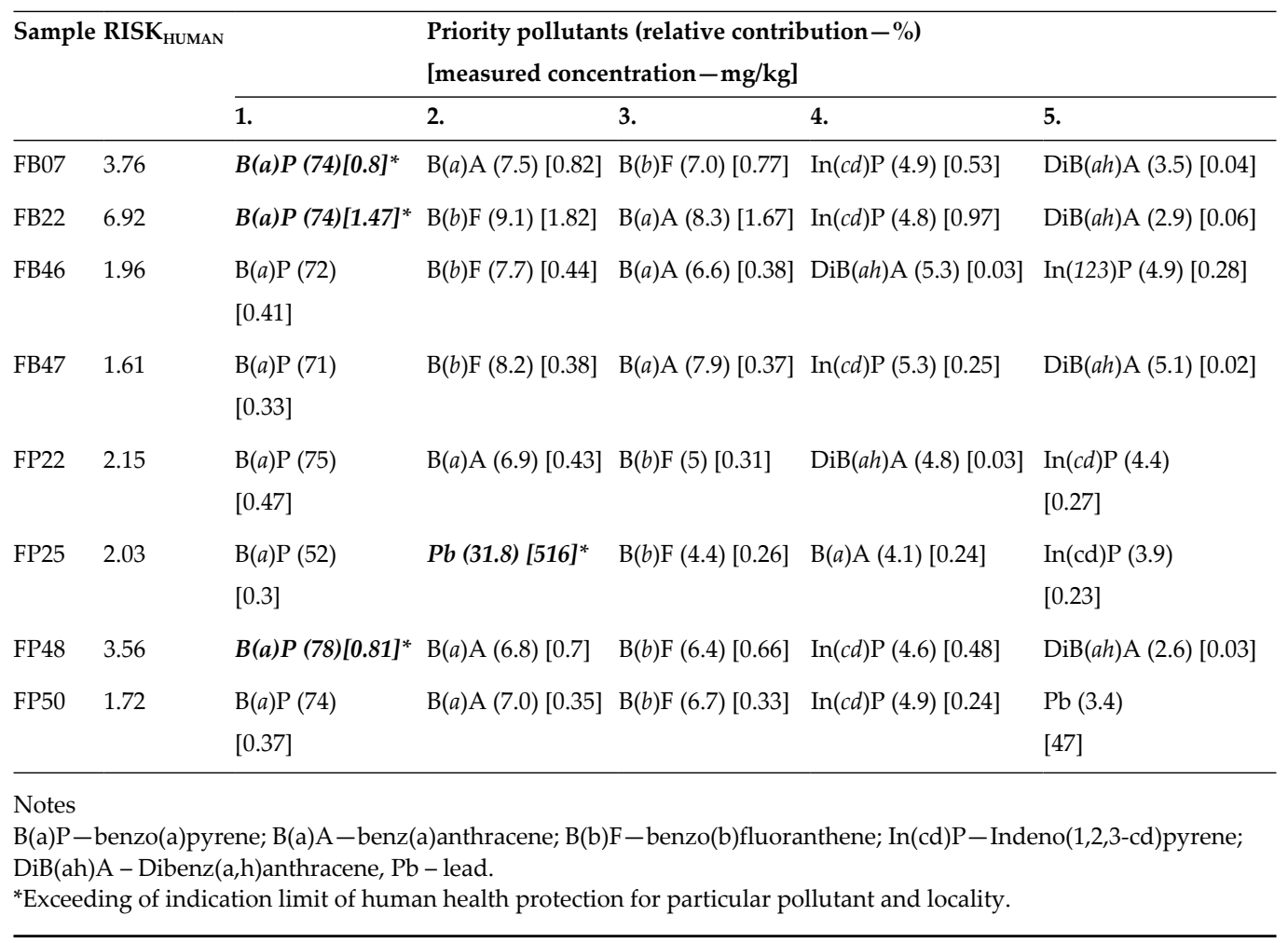

Table 7. Priority pollutants for floodplain samples with topmost estimation of human health risks (RISK HUMAN $>1.5$ ) and their pollution profiles (predominant pollutant concentrations and their relative contribution to RISK $_{\text {HUMAN }}$ ).

\section{Conclusion}

The proposed system of hierarchical limit values helps to protect soil environment, food chain, and human health against the contamination and will improve the current version fundamentally. The currently valid principle of maximally tolerable values presenting no actual risk (but selected agricultural soils on two categories-useful and non-useful by the existence of one limit value level) will be replaced by the system of hierarchical limit values referred to an individual level of the risks and followed by appropriate measures in the cases of limit exceeding. The case study of floodplains research proved the operability of the established methodology and verified relevancy of the human health limits (indication limits of human health protection) in Czech proposal of soil protection legislation. The established methodology helped to reveal the areas where the soil does not meet the soil quality standards and where the human health risks were elevated. The characteristic pollution profiles of floodplain soils with elevated human health risks were defined on the basis of the results. 


\section{Author details}

Radim Vácha ${ }^{1 *}$, Milan Sáňka ${ }^{2}$, Jan Skála ${ }^{1}$, Jarmila Čechmánková ${ }^{1}$ and Viera Horváthová ${ }^{1}$

*Address all correspondence to: vacha.radim@vumop.cz

1 Research Institute for Soil and Water Conservation, Prague, Czech Republic

2 Masaryk University Brno, Research Centre for Toxic Compounds in Environment RECETOX, Faculty of Science, Czech Republic

\section{References}

[1] Ministry of the Environment of the Czech Republic (1994): Decree No. 13/1994 Coll., setting some details of agricultural soil fund protection.

[2] Kulíková A., Hartmann V., Němeček J. (1989): Micro elements in Cambisols. Rostlinna vyroba, 35: 17-28.

[3] Beneš S. (1993): The element contents and balances in the spheres of the environment. I. Part. Ministry of the Agriculture of the Czech Republic, Prague, 88 p. (in Czech)

[4] Podlešáková E., Němeček J., Hálová G. The proposal of soil contamination limits by potentially risky elements for CR. Rostlinna vyroba, 1996, 42: 119-125.

[5] Němeček J., Podlešáková E., Pastuzsková M. (1996): The proposal of limits of soil contamination by persistent organic xenobiotic compounds in the Czech Republic. Rostlinna vyroba, 42: 49-53.

[6] Vácha R., Sáňka M., Hauptman I., Zimová M., Čechmánková J. (2014): Assessment of limit values of risk elements and persistent organic pollutants in soil for Czech legislation. Plant Soil and Environment, 60: 191-197.

[7] Ruppert H. (1987): Nature background values and anthropogenic enrichment of trace metals in Soils of Bayerns. GLA, Fachberichte 2, 97 p. (in German)

[8] Regulation BGBl I, No. 36/1999 of German government on soil protection and old burdens, based on Act BBodSchG.

[9] Hellmann H. (2002): Definitions of background-concentrations-An overview. Acta Hydrochimica et Hydrobiologica, 29: 391-398.

[10] Reimann C., Filzmoser P., Garrett R.G. (2005): Background and threshold: critical comparison of methods of determination. Science of the Total Environment, 346: 1-16. 
[11] Lubben S., Sauerbeck D. (1989): Incorporation of heavy metals by wheat and their distribution in the plant. 6th International Trace Elements Symposium 1989, 1-5: 12951302.

[12] Houba V.J.G., Novozamsky L., Lexmond T.M. (1990): Applicability of 0,01M CaCl 2 as a single extraction solution for the assessment of the nutrient status of soils and other diagnostic purposes. Communications in Soil Science and Plant Analysis, 21: 22812290.

[13] Száková J., Tlustoš P., Balík J., Pavlíková D., Balíková M. (2000): Efficiency of extractants to release As, Cd and Zn from main soil compartments. Analysis, 28: 808-812.

[14] Bakircioglu D., Kurtulus Y.B., Ibar H. (2011): Comparison of extraction procedures for assessing soil metal bioavailability to wheat grains. Clean-Soil Air Water, 39: 728-734.

[15] Zhu Q.H., Huang D.Y., Liu S.L., Luo Z.C., Zhu H.H., Zhou B., Lei M., Rao Z.X., Cao X.L. (2012): Assessment of single extraction methods for evaluating the immobilization effect of amendments on cadmium in contaminated acidic paddy soil. Plant, Soil and Environment, 58: 98-103.

[16] EPA (2002): Suplemental Guidance for Developing Soil Screening Levels for Superfund Sites. Office Solid Waste and Emergency Response, Washington, D.C. EPA Publication OSWER 9355.4.24, December, 2002.

[17] ČSN EN 13346 (2001) Characterization of sludges-determination of trace elements and phosphorus-Aqua regia extraction methods. Czech Normalisation Institute, Prague.

[18] Vácha R., Vysloužilová M., Horváthová V. (2005): Polychlorinated dibenzo-p-dioxines and dibenzofurans in agricultural soils of Czech Republic. Plant, Soil and Environment, 51 (10): 464-468.

[19] Van den Berg M., Birnbaum L.S., Denison M., De Vito M., Farland W., Feeley M., Fiedler H., Hakansson H., Hanberg A., Haws L., Rose M., Safe S., Schrenk D., Tohyama Ch., Tritscher A., Tuomisto J., Tysklind J., Walker N., Peterson R.E. (2006): The 2005 World Health Organization re-evaluation of human and mammalian toxic equivalency factors for dioxins and dioxin-like compounds. Toxicological Sciences, 93: 223-241.

[20] Němeček J., Podlešáková E., Vácha R. (2001): Prediction of the transfer of trace elements from soils into plants, Rostlinna vyroba, 47: 425-432.

[21] Podlešáková E., Němeček J., Vácha R. (2001): The transfer of less hazardous trace elements with high mobility from soils into plants. Rostlinna vyroba, 47: 433-439.

[22] Němeček J., Podlešáková E., Vácha R. (2002): Transfer of trace elements with low soil mobility into plants. Rostlinna vyroba, 48: 45-50.

[23] Podlešáková E., Němeček J., Vácha R. (2002): Critical values of trace elements in soils from the viewpoint of the transfer pathway soil-plant. Rostlinna vyroba, 48: 193-202. 
[24] DIN ISO 19730 (2008): Soil quality-extraction of trace elements from soil using ammonium nitrate solution. German Institute for Standardization, Beuth Verlag, $\mathrm{GmbH}$, Berlin.

[25] Ministry of Health of CR (2004): Decree No. 305/2004 Coll., maximum contents of contaminants in foods.

[26] Zimová M., Ďuriš M., Spěváčková V., Melicherčík J., Lepší P., Tesařová B., Knotek P., Kubínov R., Ronene Y. (2001): Health risk of urban soils contaminated by heavy metals. International Journal of Occupational Medicine and Environmental Health, 14: 231234.

[27] Vácha R., Němeček J., Podlešáková E. (2002): Geochemical and anthropogenic soil loads by potentially risky elements. Rostlinna vyroba, 48: 441-447.

[28] Ministry of Environment of Czech Republic (2001): Decree No. 382/2001 Coll., setting the conditions for application of sewage sludge on agricultural land.

[29] Ministry of Agriculture and Ministry of Environment of Czech Republic (2009): Decree No. 257/2009 Coll., on application of sediments on agricultural land.

[30] Vácha, R., Čechmánková, J., Skála, J., Hofman, J., Čermák, P., Sáňka M., Váchová, T. (2011): Use of dredged sediments on agricultural soils from viewpoint of potentially toxic substance. Plant, Soil and Environment, 57(8): 388-395.

[31] ISO 19258: Soil quality-guidance on the determination of background values, 2005. International Organization for Standardization, Geneva.

[32] LABO (1995): Soil background and reference values in Germany. Bavarian Ministry of Environment, 104 p.

[33] Puschenreiter M., Horak O., Friesl W., Hartl W. (2005): Low-cost agricultural measures to reduce heavy metal transfer into the food chain - a review. Plant, Soil and Environment, 51(1): 1-11.

[34] Sáňka M., Vácha R., Hofman J., Čupr P., Čechmánková J., Sáňka O., Mikeš O., Skála J., Horváthová V., Šindelářová L., Vašíčková J., Nečasová A. (2014): Methodological approaches for reduction of risk substances transfer into plant production in flood areas. Certified methodology, Masaryk University in Brno and Research Institute for Soil and Water Conservation in Prague.

[35] EPA (2001): Supplemental Guidance for Developing Soil Screening Levels for Superfund Sites.

[36] EPA (2014): IRIS - Integrated Risk Information Systém, http://www.epa.gov./iris/, US Environmental Protection Agency, 2014 update.

[37] Čupr P., Bartoš T., Sáňka M., Klánová J., Mikeš O., Holoubek I. (2010): Soil burdens of persistent organic pollutants - their levels, fate and risks part III. Quantification of the 
soil burdens and related health risks in the Czech Republic. Science of the Total Environment, 408: 486-494.

[38] Heinisch E., Kettrup A., Bergheim W., Wenzel S. (2007): Persistent chlorinated hydrocarbons (PCHCs), source-oriented monitoring in aquatic media. 6. Strikingly high contaminated sites. Fresenius Environmental Bulletin, 16(10): 1248-1273.

[39] Podlešáková E., Němeček J., Hálová G. (1994): The load of Fluvisols of the Labe river by risk substances. Rostlinna vyroba, 40: 69-80.

[40] Grimalt J.O., Van Drogge B.L., Ribes A., Fernández P., Appleby P. (2004): Polycyclic aromatic hydrocarbon composition in soils and sediments of high altitude lakes. Environmental. Pollution, 131: 13-24.

[41] Borůvka L., Huan-Wei C., Kozák J., Krištoufková S. (1996): Heavy contamination of soil with cadmium, lead and zinc in the alluvium of the Litavka river. Rostlinna vyroba, 42: 543-550.

[42] Žák K., Rohovec J., Navrátil T. (2009): Fluxes of heavy metals from a highly polluted watershed during flood events: a case study of the Litavka River, Czech Republic. Water, Air, and Soil Pollution, 203: 343-358.

[43] Vácha R., Skála J., Čechmánková J., Horváthová V., Hladík J. (2015): Toxic elements and persistent organic pollutants derived from industrial emissions in agricultural soils of the Northern Czech Republic. Journal of Soils and Sediments, 15(8): 1813-1824. 



\title{
Assessment of DNA Damage by Comet Assay in Buccal Epithelial Cells: Problems, Achievement, Perspectives
}

\author{
J. Sánchez-Alarcón, M. Milić, S. Gómez-Arroyo, \\ J. M. R. Montiel-González and R. Valencia-Quintana
}

Additional information is available at the end of the chapter

http://dx.doi.org/10.5772/62760

\begin{abstract}
DNA damage risk assessment in comet assay by the use of buccal mucosa cells has great advantages in comparison with other cell type sample due to more safely, easier, cheaper, and non-invasive method for in vivo studies. According to the OECD Guidelines, the in vivo mammalian alkaline comet assay is well-established and validated method for measuring DNA strand breaks in single eukaryotic cells. Considering exposure to xenobiotics and endogenous damage inductors, buccal mucosa cells are the first to be in direct contact after exposure and this makes them an ideal biomatrices in evaluation of thelevelofindividualgenotoxicity toseveralcompoundsalreadymentioned. Theirclinical diagnostic applicability confers a potential use in patients across time. However, the number of publications referring to the human buccal comet assay is low in the last two decades. This low growing interest may be explained by several factors, including its relative technical problems. Different procedures have been used in collecting and processing the samples. In order to have widespread acceptance and credibility in human populationstudies, the cometassay inbuccalcells requiresstandardization of the protocol, of parameters analyzed, and a better knowledge of critical features affecting the assay outcomes, including the definition of the values of spontaneous DNA damage. There is a need for further collaborative work as in the HUMN (micronucleus assay on lymphocytes) and HUMNxL (micronucleus assay on buccal cells) collaborative projects. The creation of a network of laboratories will allow more focused validation studies, including the design of a classic, historic, prospective cohort study in order to explore the link between measures of genetic instability in the buccal mucosa and the risk of cancer and other chronic-degenerative diseases. One such network connection will start in 2016 as a COST project under the name "hCOMET - The comet assay as a human biomonitoring tool" launched by Prof. Andrew Collins.
\end{abstract}

Keywords: SCGE assay, buccal mucosa cells, genotoxic risk assays, DNA damage, comet assay 


\section{Introduction}

Human exposure to environmental chemical agents occurs as a result of contaminated air, water, soil, and food. Although many chemical agents are in use for more than two centuries, nowadays, it is known that a number of them can cause genetic damage. Chemicals that can cause this type of damage are specified and identified as mutagens, carcinogens, or teratogens based on the diverse type of investigations. It is estimated that chemicals play a predominant role in the etiology of a majority of human diseases. The possible genetic health hazards associated with chemicals are more difficult to evaluate in the human environment. There are tens of thousands of untested chemicals in the human environment, and some attempt must be made to identify the ones that are potentially hazardous to man. From 1972 when first UN Conference on the Human Environment was organized, World Health Organization and International Agency for Research on Cancer (IARC) have published many monographic editions categorizing dangerous chemicals based on collected in vitro and in vivo results of investigations [1,2]. Also, unique tools (methods) for assessing the potential effects of chemicals on human health, and the environment have been established under the name The OECD Guidelines for the Testing of Chemicals, methods, and guidelines internationally accepted as standard methods for safety testing [3] in which standardized and validated techniques are described that can estimate the level of DNA damage after the exposure.

During the past half century, the focus has been shifted from identification of these compounds in the environment to the risk assessment and minimization or prevention of unnecessary exposure in the first place. For this reason, along with an increasing understanding of mechanisms of action by which these chemicals can cause DNA or cell damage, and also cancer [4], a variety of hazard identification screening models have been developed and established. These models can serve in risk assessment studies. Risk is defined as the probability of a given toxicological hazard producing actual biological harm. This idea involves some form of mathematical relationship between exposure and toxicology. In the field of environmental toxicity assessment, the need for in-time risk management decisions requires setting up a battery of standardized and relatively easy to perform tests, allowing quick answers to pressing questions [5]. The use of diverse genotoxic bioassays is therefore unavoidable. Application of biomarkers in both qualitative and quantitative aspects of risk assessment has been eagerly anticipated for over a decade, since Hattis [6] first proposed their use in this process.

Numerous assays have been developed as screens for genotoxicity, beginning with the Salmonella mutagenicity assay. Genomic damage is probably the most important fundamental cause of developmental and degenerative disease. It is also well established that genomic damage is produced by environmental exposure to genotoxins, medical procedures, micronutrient deficiency, lifestyle, and genetic factors [7]. It is essential to have reliable and relevant minimally invasive biomarkers to improve the implementation of biomonitoring, diagnostics, and treatment of diseases caused by, or associated with, genetic damage.

Since methods in molecular epidemiology have been improved with the use of reliable biomarkers of exposure in analysis, population biomonitoring has become an extremely 
powerful approach to determine the effect of environmental mutagens on human populations [8]. On this way, early effects may be highlighted in all accessible cell types, such as blood cells, epithelial cells and exfoliated buccal or urothelial cells; thus, genetic biomonitoring allows detecting adverse effects of mutagenic chemicals in human somatic cells [9].

Among different types of cells and especially of epithelial cells, the collection of buccal cells is arguably the least invasive method available for measuring DNA damage in humans, especially in comparison with obtaining blood samples for lymphocyte and erythrocyte assays, or tissue biopsies [7]. Without the need for cell culture establishing (cells do not divide, but just differentiate from basal cells), buccal cells analyzed by other techniques, such as micronucleus assay, have shown good correlation with the level of damage observed on lymphocytes after 72-h cell culture with DNA damage cytogenetic test called cytochalasin B blocked micronucleus (MN) assay [10]. Buccal micronucleus cytome assay can measure frequency of MN (its origin is either from chromosome breakage/loss of entire chromosome), nuclear buds and/or broken egg, binucleated cells, and various forms of cell death phase measured as condensed chromatin, karyorrhectic, pyknotic, or karyolitic cells [11]. Chronic exposure leads to a steady-state elevated expression level of $\mathrm{MN}$ regardless of the cell division rate if the period of exposure exceeds the time frame for one nuclear division, that is, 20-30 h. Carcinogens delivered primarily through blood stream influence equally DNA damage measured in buccal cells and lymphocytes. Since collection of buccal cells and their processing is easy, fast and low cost, and they do not divide just differentiate, they have potential to replace the tests that need cell culture establishment in order to estimate DNA damage. HUMNxL group (The HUman MicroNucleus project on eXfoLiated buccal cells group) has collected data from 30 different laboratories on 5424 subjects in order to evaluate the impact of host factors, occupation, lifestyle, disease status, and protocol features on the occurrence of $\mathrm{MN}$ in exfoliated buccal cells [12]. The results of this survey have shown high correlation of micronucleus detection in buccal cells with exposure for occupational groups reporting exposure to solvents, polycyclic aromatic hydrocarbons (PAHs) and gasoline, arsenic, and antineoplastic drugs. Also, significant association of higher $\mathrm{MN}$ frequency was found for oro-pharyngeal and respiratory cancers, and for all the other cancers pooled together. Although micronucleus assay in buccal cells does not need cell culture, it requires at least 3000 cells examined under the microscope. Since this can also be time consuming, one of the other methods for measuring DNA damage is alkaline comet assay, one of the newest OECD guideline tests (from 2014) for chemical exposure in vivo (No. 489), an easy and low-cost assay that measures primary DNA damage on any type of single-cell suspension sample [13]. The use of comet assay on buccal cells would be a potential new and reliable combination for chemical exposure and DNA damage assessment. The comet assay in buccal cell assay was first reported in 1996 [14]. Like in HUMNxL project, it will be necessary to develop and implement the results of an international collaborative validation group established to identify and quantify the key variables affecting the damage evaluation in buccal mucosa cells using the comet assay. In addition, an interlaboratory slide-scoring exercise could be undertaken to evaluate the intra- and inter-laboratory variability in the scoring of different parameters of comet assay in buccal cells, similar to the approach successfully used by the HUMN project for the MN assay in lymphocytes [1517] and the HUMNxL project in buccal cells $[7,12,17,18]$. One such groups with prof. Andrew 
Collins has started in 2016 a COST networking project under the name "hCOMET - The comet assay as a human biomonitoring tool", in order to give response to the questions discussed in this review.

\subsection{Comet assay}

The comet assay is a cheap, easy, fast, reliable, and sensitive method for measuring the level of primary DNA damage in single-cell suspension of any type and requires a small sample material. For these reasons, the comet assay in its various modifications (alkaline, neutral, and with lesion-specific enzymes to detect specific types of DNA damage such as $8 \mathrm{OHdG}$, formamidopyrimidine DNA glycosylase, endonuclease III, T4 endonuclease. V.) has few serious competitors. The cells are embedded into agarose, and after lysis, denaturation, electrophoresis, and staining, the amount of DNA damage is measured either visually by dividing the damaged cells into five groups, or by the help of camera and software image program that analyses the image. Measured parameters are usually tail length (measured in micrometers), tail intensity or tail DNA percentage (when there is damage, DNA has a shape of a comet), and tail moment (combination of the first two parameters). It is recommended to use tail intensity parameter since the agents sometimes produce few small breaks that make comet tail long, but in fact, there is not a high percentage of DNA in the damaged part of the comet. When standardized and validated, the comet assay can provide valuable information in the areas of hazard identification and risk assessment of environmental and occupational exposure, diseases linked with oxidative stress (e.g., diabetes and cardiovascular disease), nutrition, monitoring the effectiveness of medical treatment, and investigating individual variation in response to DNA damage that may reflect genetic or environmental influences. The information obtained could lead to individual advice on lifestyle changes to promote health and especially on relative risks of genotoxic exposure to environmental pollution [19].

In human biomonitoring studies, the comet assay can provide crucial information on risk assessment of environmental, occupational, and lifestyle exposures. Earlier reviews have dealt with different aspects of the use of the comet assay in human biomonitoring studies [20-26], but without providing any specific, practical guidance for using the comet assay in human biomonitoring. Several general articles on biomonitoring are available [27-31] that can be helpful when designing biomonitoring studies using the comet assay. To avoid obtaining falsepositive and false-negative results, certain basic principles should be respected and followed in study design and performing and these consider first of all matching of exposed and control group according to gender, age, alcohol, and smoking habits and their consumption, and also with other lifestyle and nutritional factors [19].

ComNet project group, established before last COST project that will make an effort in exposure type and DNA damage assessment, has made an effort to pool together data of all available comet assay biomonitoring studies, in order to establish baseline parameters of DNA damage, and to investigate associations between comet assay measurements and factors such as sex, age, smoking status, nutrition, lifestyle. Although this assay has been widely used in human biomonitoring for DNA damage measurement as a marker genotoxic agent's exposure or for investigation of genoprotective effects, single research studies had usually small 
numbers of subjects, with sub-optimal design also in other critical respects already mentioned, and also with the use of significantly different comet assay protocols. For these reasons, the ComNet project has recruited almost 100 research groups willing to share datasets. Collins et al. [32] provided a background of the ComNet project, and the history of the comet assay itself, and the most important, he has pointed out important practical issues that can critically affect its performance. The survey pointed out comet assays diverse applications in biomonitoring studies (environmental, occupational exposure to genotoxic agents), genoprotection studies that were controlled by dietary and other factors and DNA damage assessment studies associated with various diseases and intrinsic factors that affect DNA damage levels in humans. The survey also analyzed the quality of data from a random study selection, using epidemiological and statistical point of view. Most of the studies have been done on lymphocytes or whole blood, and they can show damage of DNA caused by long term exposure or also exposure in the past, since lymphocytes circulate through the body and can live for up to 3 years. A new step will be also to established basal levels of DNA damage in relation to different exposure, diseases, and cell types used, and to correlate them with long-term and short-term exposure. Considering the short term or recent exposure, buccal mucosa cell comet assay would be ideal since those cells among epithelial cells are short living cells with no division and DNA damage found in them can demonstrate recent exposure or direct contact exposure with oral mucosa, so the DNA damage measured by comet assay on buccal cells would be indication of recent exposure and severity of that exposure [33].

\subsection{Exfoliated oral mucosa cells}

Buccal cells form the first barrier for the inhalation or ingestion route and are capable of metabolizing proximate carcinogens to reactive products [34-37]. About $92 \%$ of human cancers are derived from the external and internal epithelium, that is, the skin, the bronchial epithelium, and the epithelia lining the alimentary canal $[7,38]$. Therefore, it could be argued that oral epithelial cells represent a preferred target site for early genotoxic events induced by carcinogenic agents entering the body via inhalation and ingestion [7,39].

In the early studies from the 1980s, exfoliated buccal mucosa cells were used with the MN assay to evaluate the genotoxic effects of multiple factors including environmental and occupational exposures, radiotherapy, chemoprevention, vitamin supplementation trials, lifestyle habits, cancer, and other diseases (see [7] for review), with possibility of cell degeneration in form of condensed/fragmented chromatin, pyknotic nuclei, loss of nuclear material in form of karyolitic or "ghost" cells [18,40,41]. In rare cases, some cells can also demonstrate other forms such as binucleated stage with two nucleus in the same cytoplasm, form of nuclear bud or "broken egg" or form small micronuclei (MN) near nuclei in the same cytoplasm. These biomarkers of genome damage (e.g., MN, nuclear buds) and cell death (e.g., apoptosis, karyolysis) can be observed in both the lymphocyte and buccal cell systems, and thus provide a more comprehensive assessment of genome damage then only $\mathrm{MN}$ in the context of cytotoxicity and cytostatic effects $[7,39,41]$. 


\section{The comet assay in mucosa buccal cells}

DNA damage assessment in exfoliated cells (buccal epithelium) may be an innovative promising tool for genotoxicity studies since sampling is easy. Some results indicate that alkaline single-cell gel electrophoresis, using buccal epithelial cells, could be a good biomarker of early effects, and can be utilized for human monitoring, since, in some cases, this kind of cell is the first to interact with xenobiotics [14]. Comet assay can detect DNA single-strand breaks and alkali labile sites at $\mathrm{pH} 13$ (alkaline version) or double-strand breaks under neutral conditions (neutral version) [42-44]. The relevance of SCGE lies in its requirement for very small cell samples, and in its ability to evaluate DNA damage in proliferating or non-proliferating cells [45].

While biomonitoring studies employing cytogenetic techniques are mainly done in lymphocytes, the SCGE technique can be applied to any cell population. Over the last years, exfoliated cells have been used for biomonitoring studies utilizing several genotoxicity endpoints [40]; however, there are few studies which apply SCGE on epithelial cells [14].

Over $90 \%$ of cancers are epithelial in their origin [47] and since crucial mechanism in cancer development is the level and amount of DNA damage [48], DNA damage assessment in buccal epithelial cells may prove as a good biomarker of early damage. In their work, Rojas et al. [14] established for first time, the conditions for using the comet assay in buccal epithelial cells.

The use of surrogate cells, other than lymphocytes, such as exfoliated cells from epithelial tissues is of particular interest due to the ability to be collected with non-invasive methods, and the cells are explored with the aim to evaluate their suitability in biomonitoring studies $[7,49]$. Beside the minimally invasive sample collection from the inner wall of the cheek, the cells have advantage in exposure assessment to inhaled or ingested genotoxic agents, and this all makes them a good model for large biomonitoring studies, and also in pediatric researches.

The application of the comet assay test in uncultured buccal exfoliated cells (since the test does not need cell culture conditions), started in the 1996, when Rojas et al. [14] by comparing DNA damage level between smokers and non-smokers group in exfoliated buccal mucosa cells, found that DNA tail length significantly increased in the smoker group $(89.30+16.18 \mu \mathrm{m}) \mathrm{vs}$. non-smoker group $(52.01+10.43 \mu \mathrm{m})$, indicating that the SCGE assay could be applied to human monitoring using exfoliated buccal epithelial cells.

In that moment, Rojas et al. [14] indicated that alkaline single-cell gel electrophoresis assay, using buccal epithelial cells could be a good biomarker of early effects, and can be utilized for human monitoring since; in some cases, this kind of cell is the first to interact with xenobiotics. However, 20 years later, $<40$ articles have been published with this bioassay. Table 1 represents the list of analyzed studies on buccal cells with comet assay with a point on sampling and preparation of slides for comet assay analysis. This table is extending the data collected in Rojas et al. [33] who only made observations in differences in preparing the slides, giving the highest impact on different lysis solution and enzyme digestion in preparation. 


\begin{tabular}{|c|c|c|c|}
\hline ๕ัٌّั & $\underset{\mathscr{\infty}}{\mathbb{\Phi}}$ & 㿣 & $\underline{\underline{\underline{x}}}$ \\
\hline 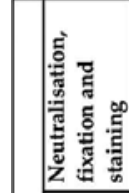 & 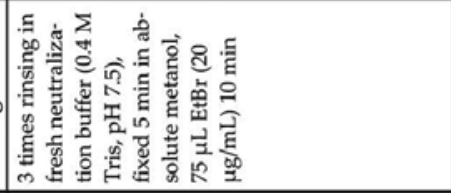 & 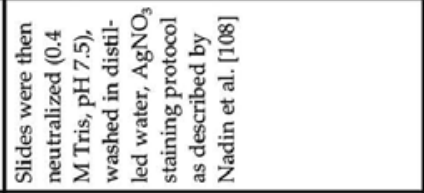 & 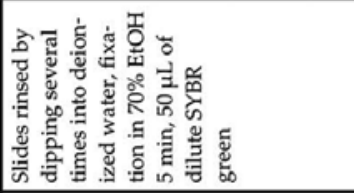 \\
\hline 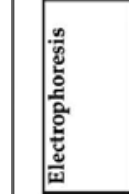 & 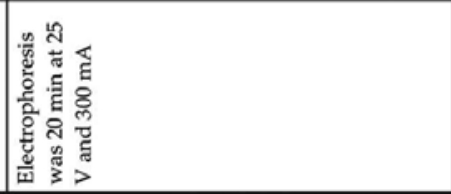 & 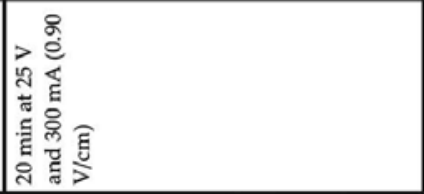 & 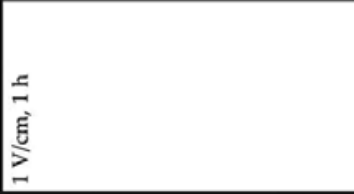 \\
\hline 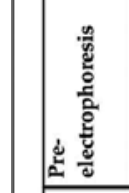 & 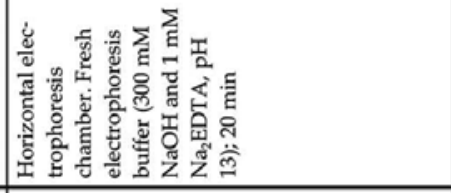 & 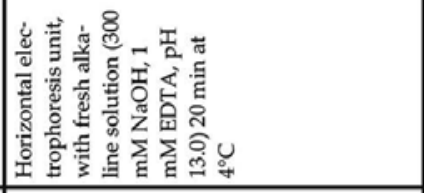 & 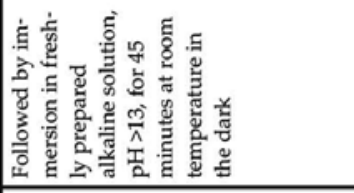 \\
\hline 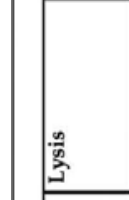 & 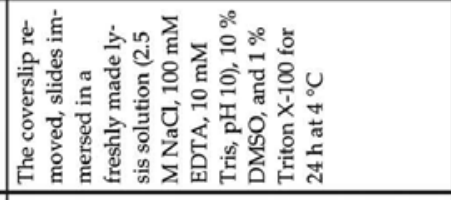 & 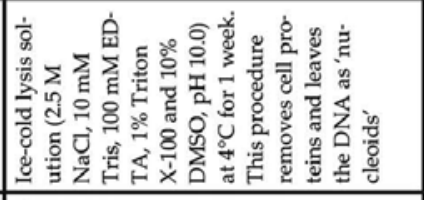 & 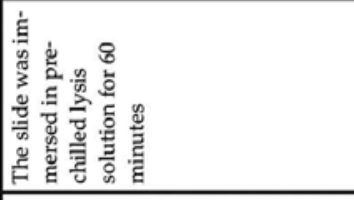 \\
\hline 苞 & & 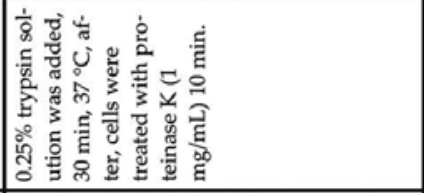 & \\
\hline 要 & 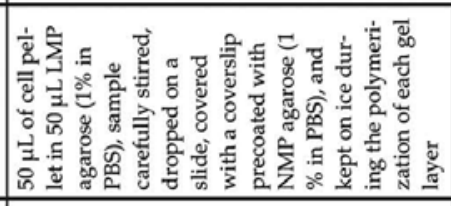 & 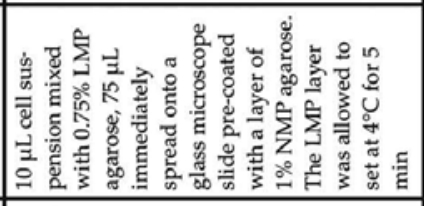 & 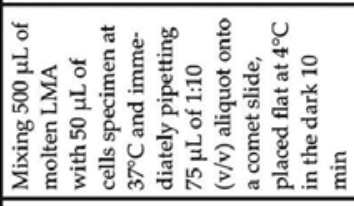 \\
\hline 聯 & 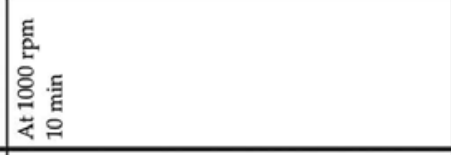 & 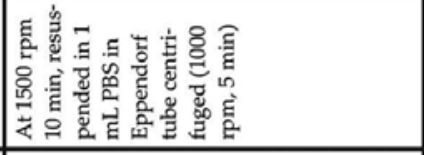 & 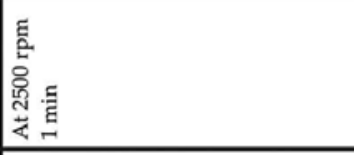 \\
\hline 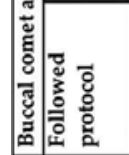 & 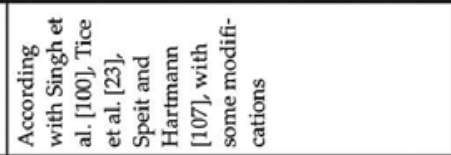 & 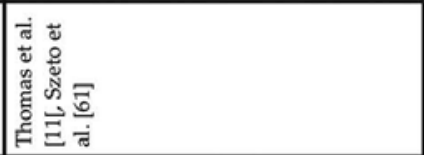 & \\
\hline 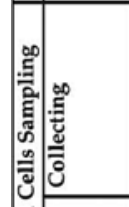 & 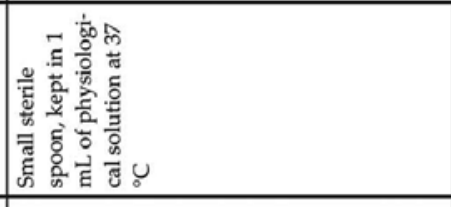 & 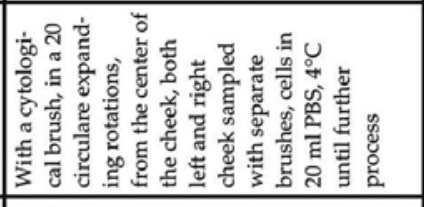 & 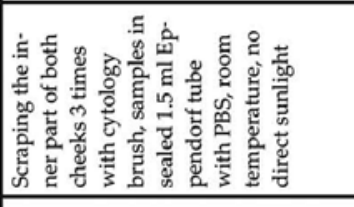 \\
\hline 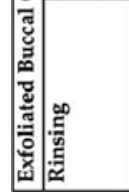 & & 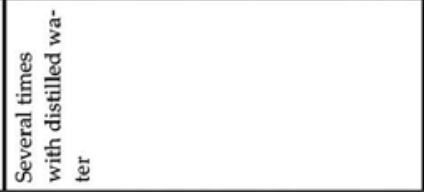 & 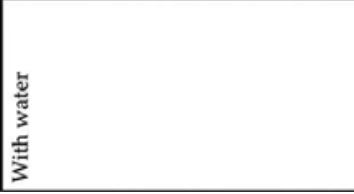 \\
\hline
\end{tabular}




\begin{tabular}{|c|c|c|c|c|}
\hline لَّ & $\overline{\underline{E}}$ & $\underline{\Omega}$ & 㿣 & $\underline{\mathscr{B}}$ \\
\hline 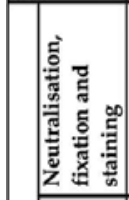 & 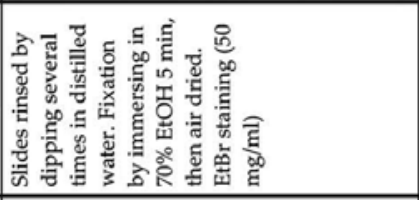 & 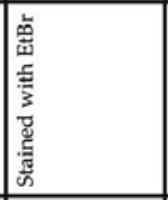 & & \\
\hline 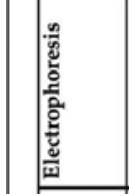 & 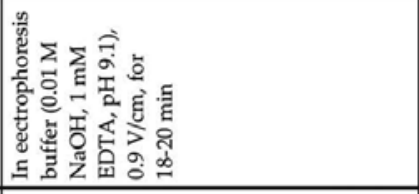 & 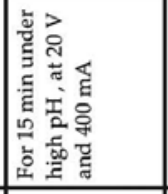 & & \\
\hline 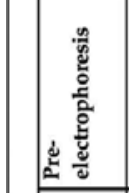 & 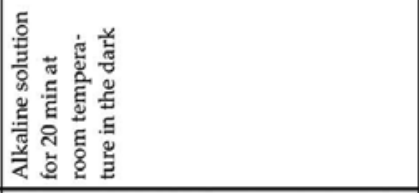 & & & \\
\hline 絭 & 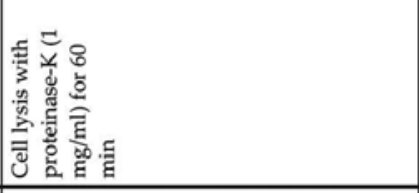 & 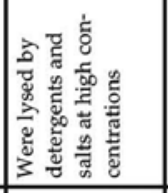 & & \\
\hline 蔍 & 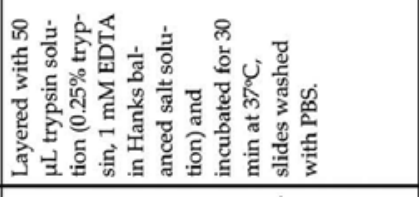 & & & \\
\hline 兘 & 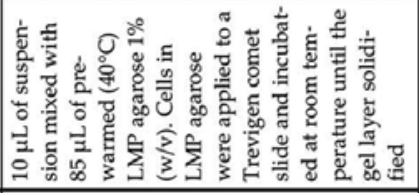 & 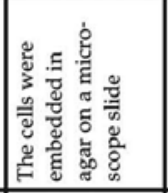 & & \\
\hline 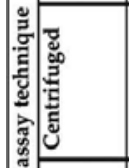 & 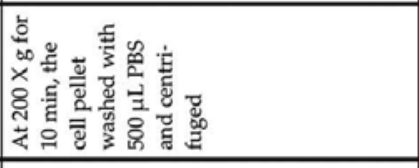 & & & \\
\hline 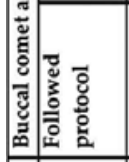 & 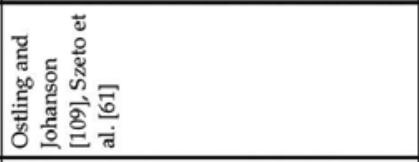 & 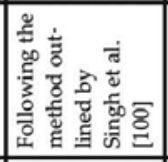 & 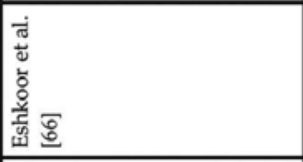 & 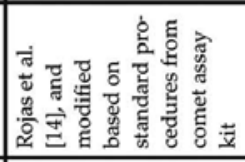 \\
\hline 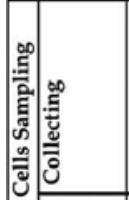 & 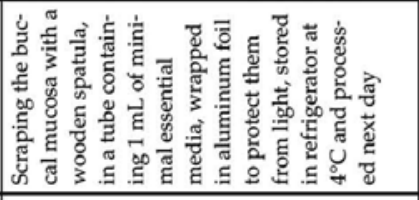 & & 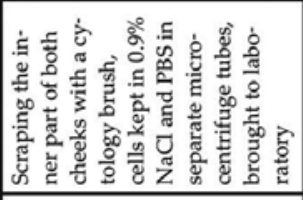 & 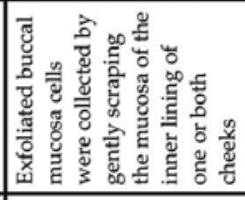 \\
\hline 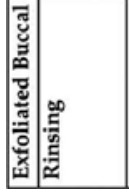 & . & & 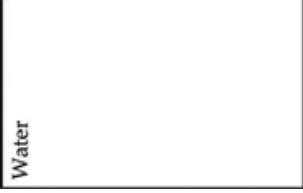 & \\
\hline
\end{tabular}




\begin{tabular}{|c|c|c|c|}
\hline & 要 & 熙 & 安 \\
\hline 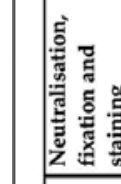 & 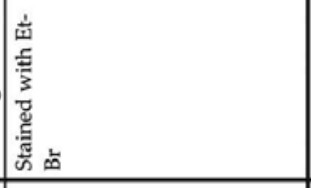 & 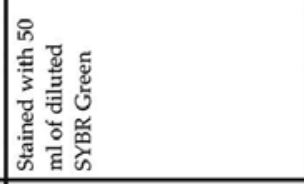 & \\
\hline 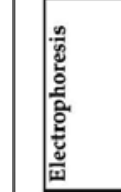 & & 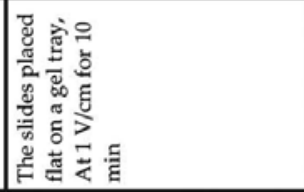 & \\
\hline 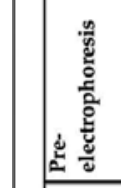 & & 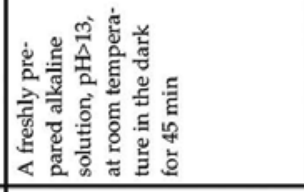 & \\
\hline 量 & & 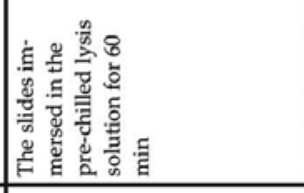 & \\
\hline & & & \\
\hline 童 & & 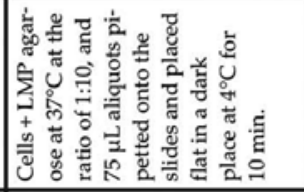 & \\
\hline 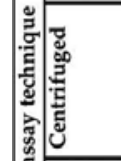 & 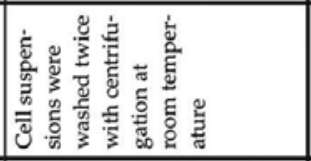 & & \\
\hline 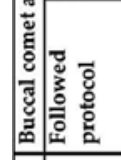 & 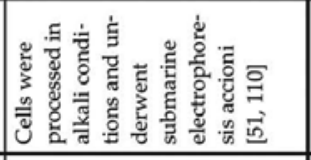 & 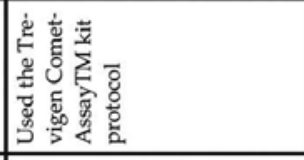 & 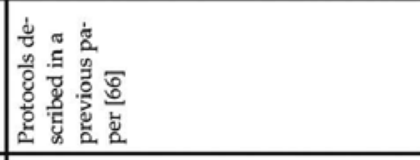 \\
\hline 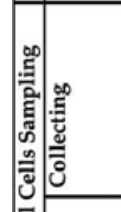 & 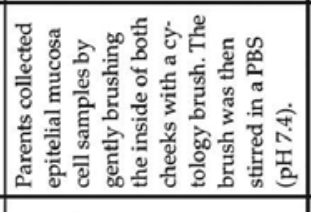 & 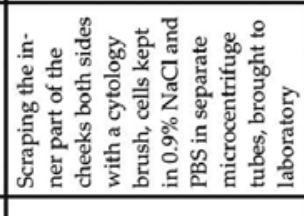 & 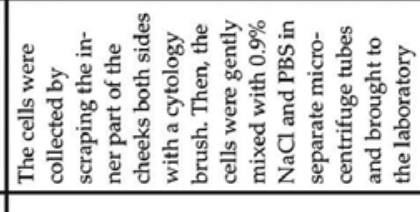 \\
\hline 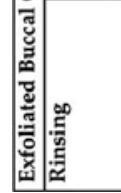 & 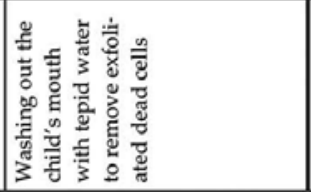 & 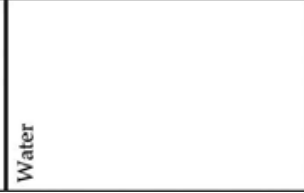 & $\begin{array}{l}\frac{y^{\circ}}{3} \\
3\end{array}$ \\
\hline
\end{tabular}




\begin{tabular}{|c|c|c|c|c|}
\hline 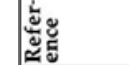 & 总 & $\bar{\Sigma}$ & 产 & 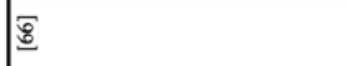 \\
\hline 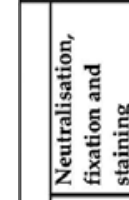 & 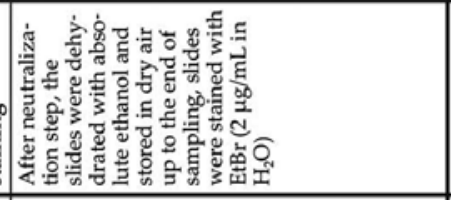 & 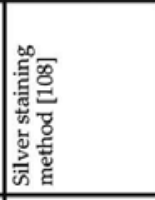 & 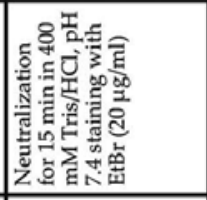 & 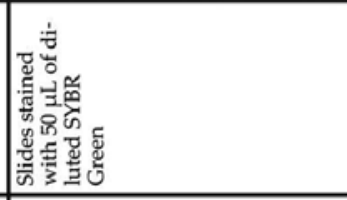 \\
\hline 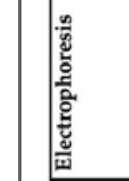 & 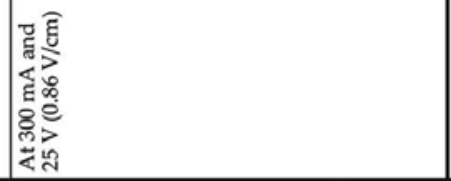 & & 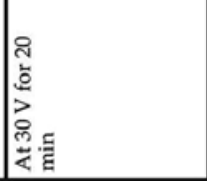 & 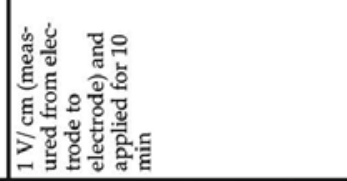 \\
\hline 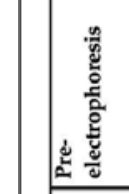 & 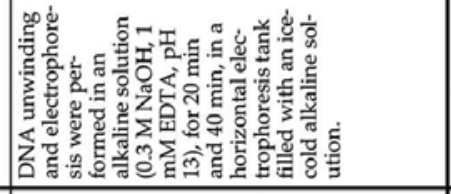 & & 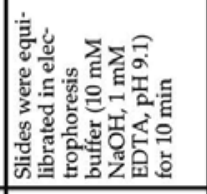 & 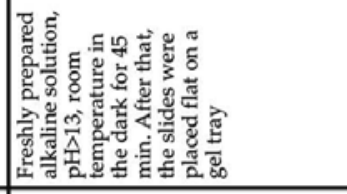 \\
\hline 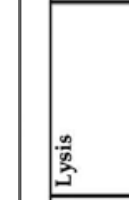 & 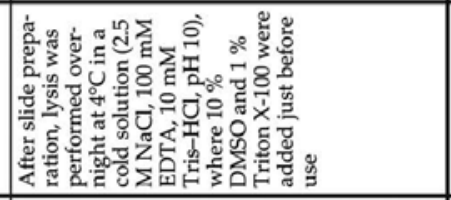 & & & 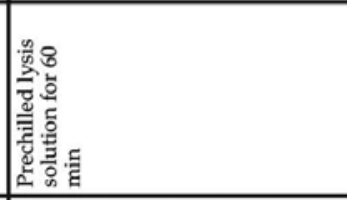 \\
\hline 茞 & 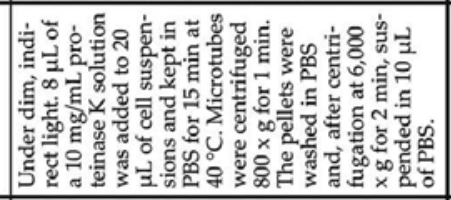 & & 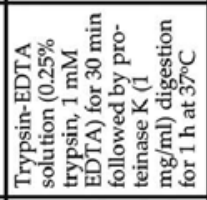 & \\
\hline 总 & 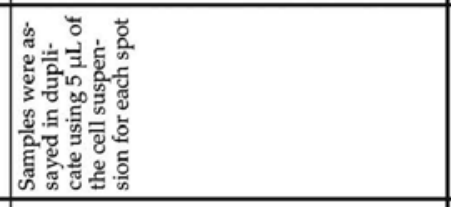 & & 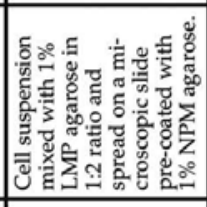 & 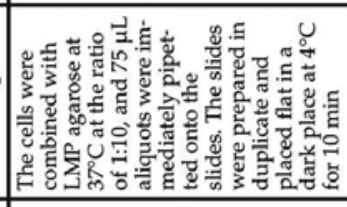 \\
\hline 递 & 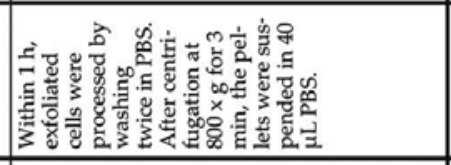 & & & \\
\hline 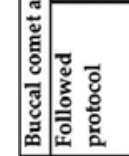 & & 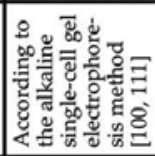 & 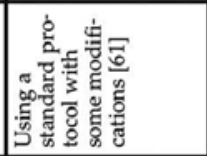 & 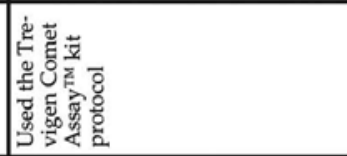 \\
\hline 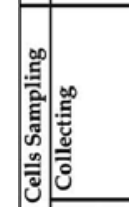 & 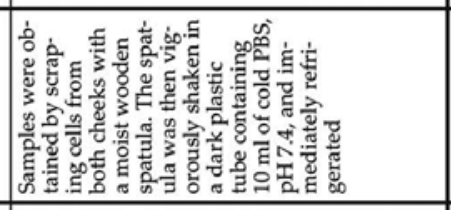 & & 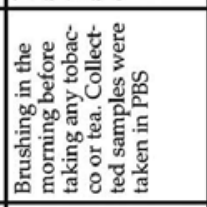 & 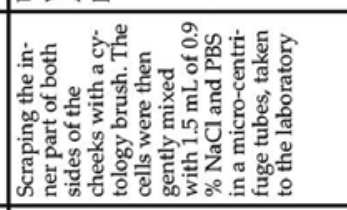 \\
\hline 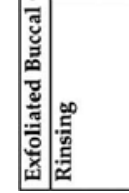 & 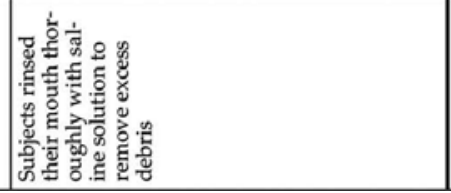 & & 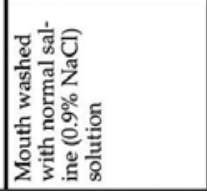 & 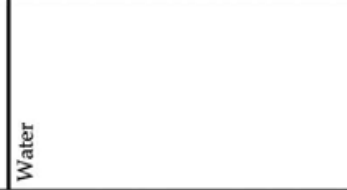 \\
\hline
\end{tabular}




\begin{tabular}{|c|c|c|}
\hline & 浄 & 军 \\
\hline 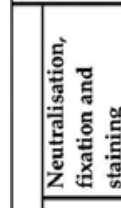 & 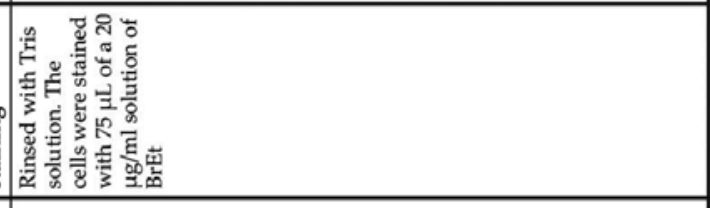 & 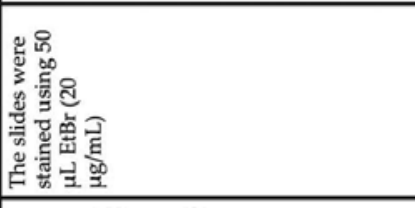 \\
\hline 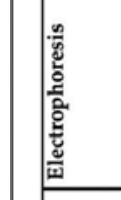 & 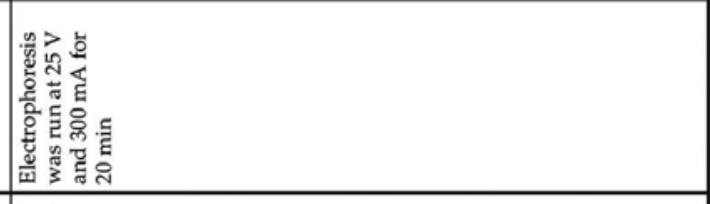 & 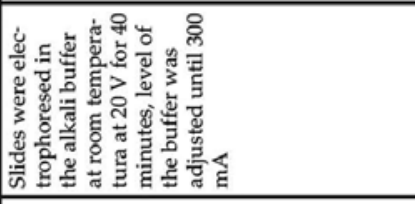 \\
\hline 焉 & 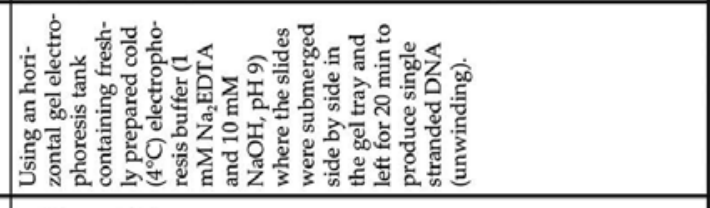 & 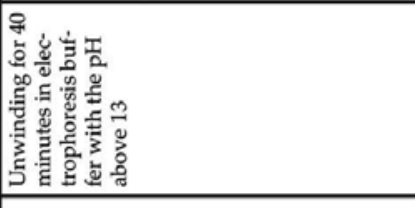 \\
\hline$\frac{-1}{2}$ & 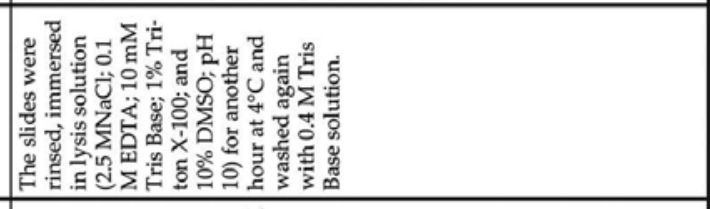 & \\
\hline & 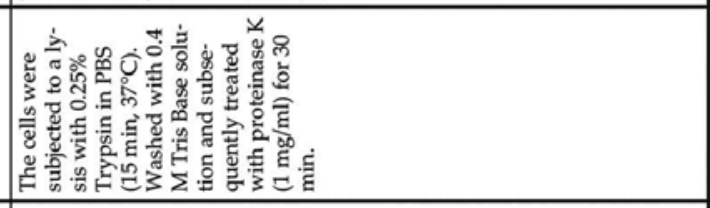 & 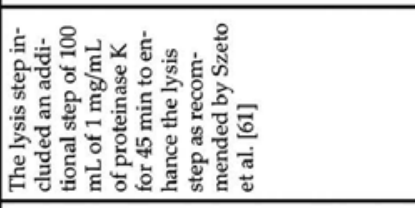 \\
\hline & 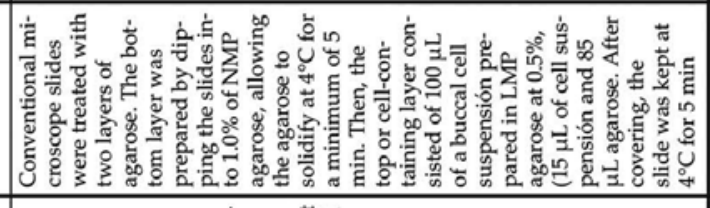 & \\
\hline & 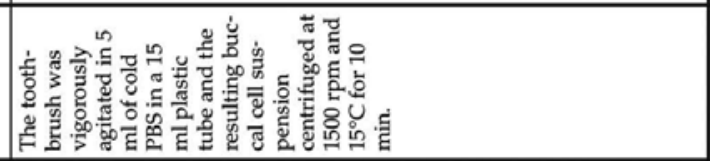 & \\
\hline & & 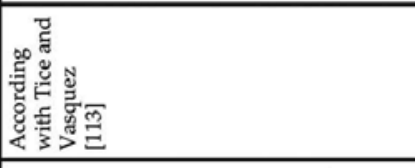 \\
\hline 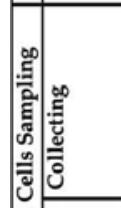 & 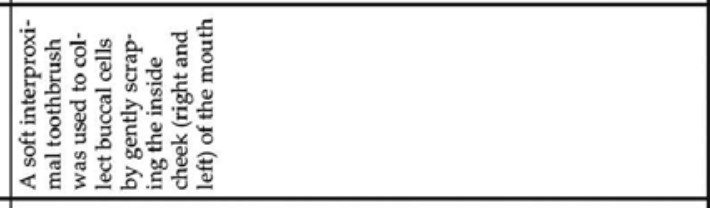 & 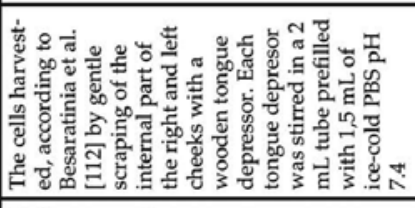 \\
\hline 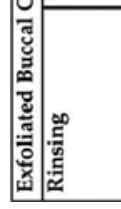 & 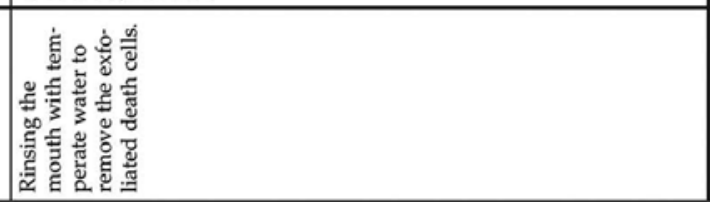 & 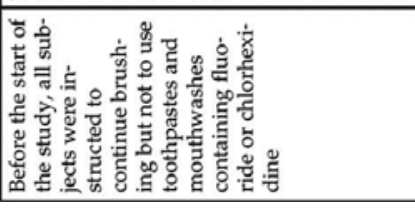 \\
\hline
\end{tabular}




\begin{tabular}{|c|c|c|}
\hline & $\bar{\Omega}$ & $\overline{\underline{\underline{\theta}}}$ \\
\hline & 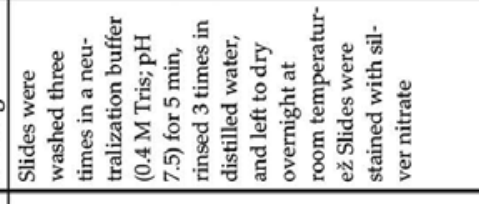 & 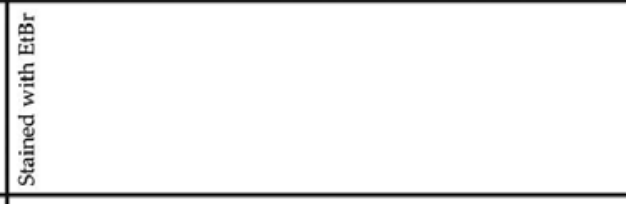 \\
\hline 产 & 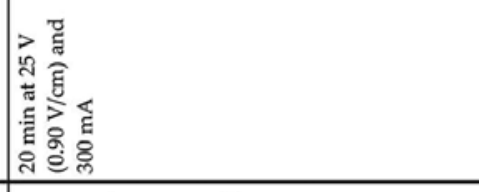 & \\
\hline . & 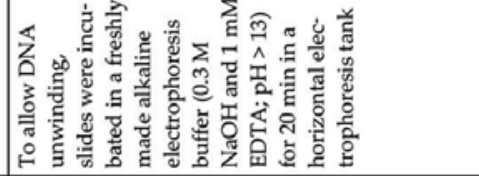 & \\
\hline 变 & 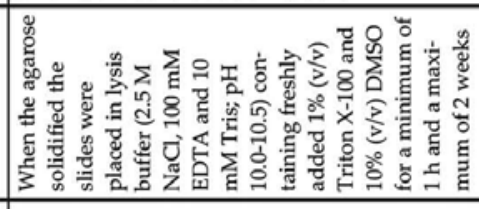 & 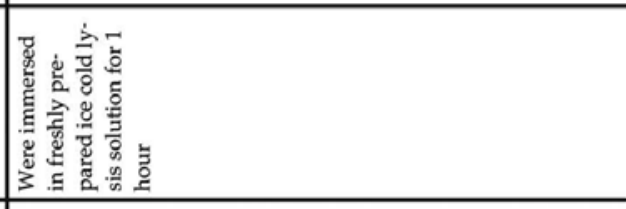 \\
\hline & & \\
\hline 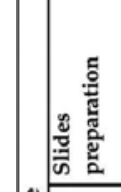 & 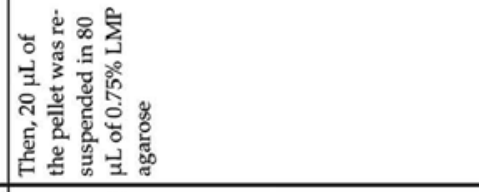 & 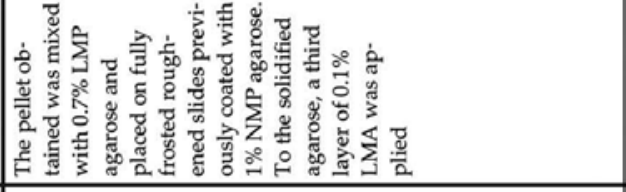 \\
\hline 这 & 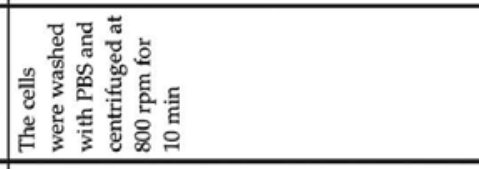 & 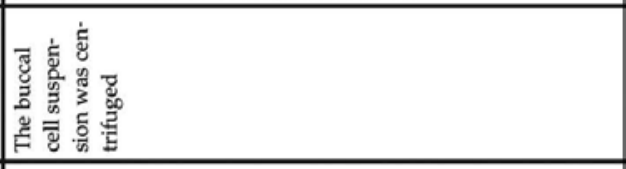 \\
\hline 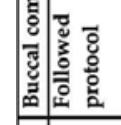 & & \\
\hline 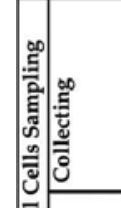 & 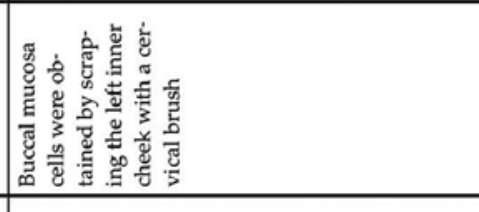 & 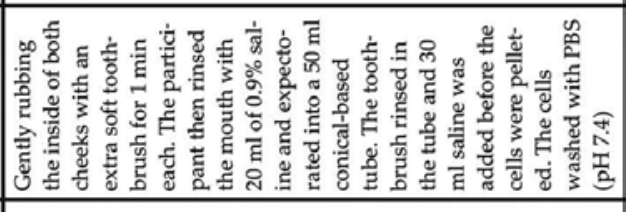 \\
\hline 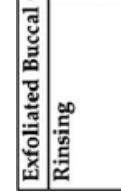 & & 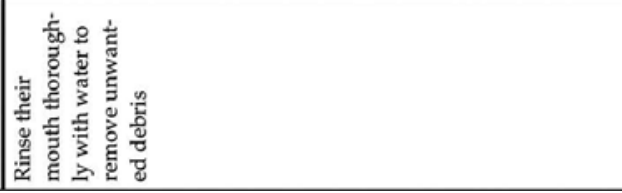 \\
\hline
\end{tabular}




\begin{tabular}{|c|c|c|}
\hline 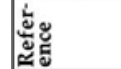 & 拝 & 愛 \\
\hline & 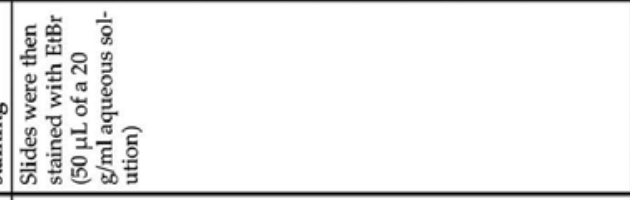 & 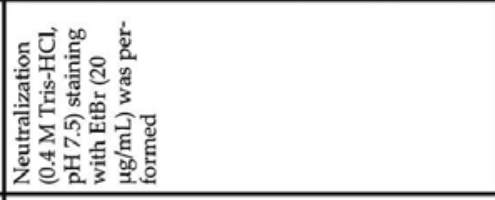 \\
\hline 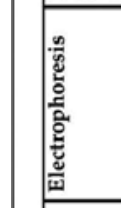 & 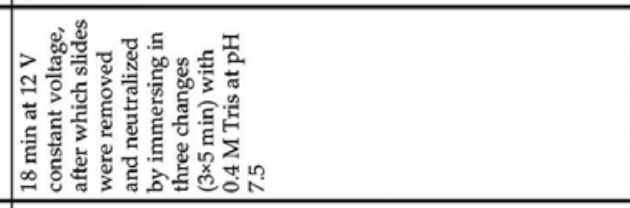 & 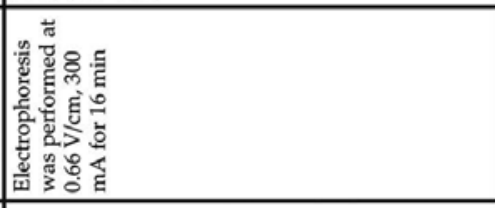 \\
\hline 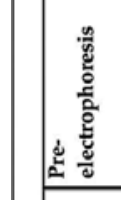 & 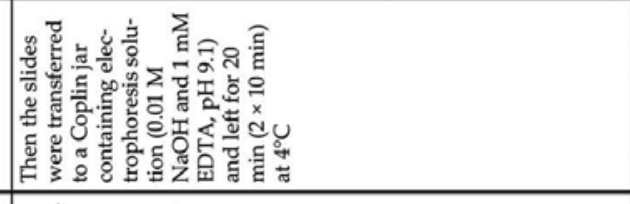 & \\
\hline $\begin{array}{l}\frac{2}{5} \\
\frac{3}{2}\end{array}$ & 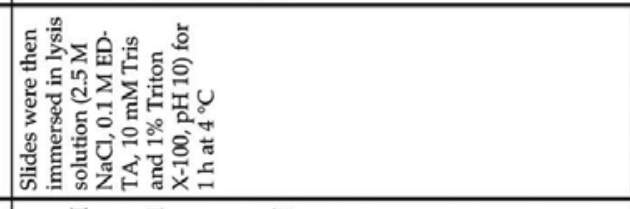 & 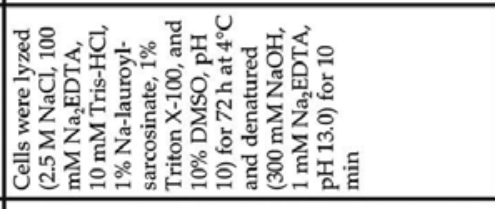 \\
\hline 遥 & 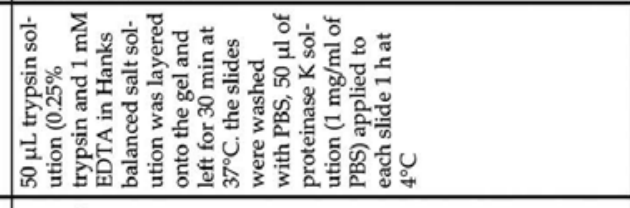 & \\
\hline 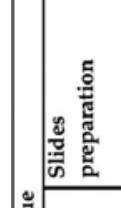 & 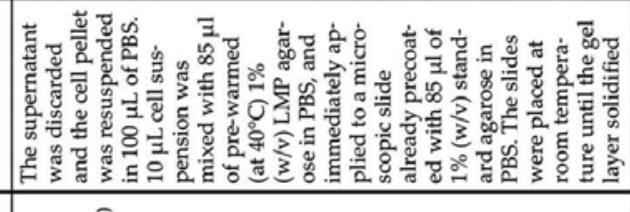 & 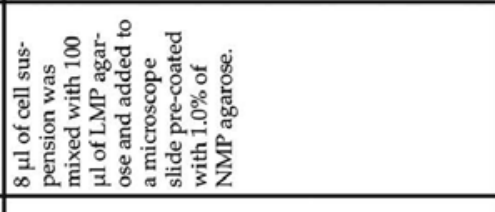 \\
\hline 窟 & 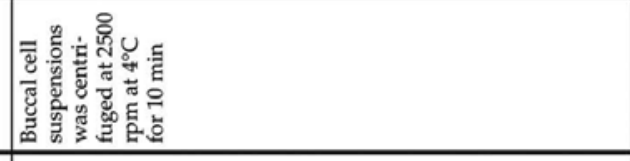 & 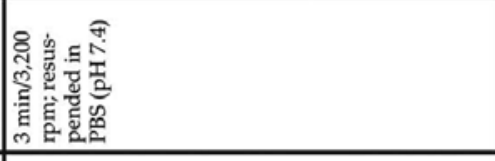 \\
\hline 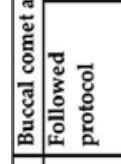 & 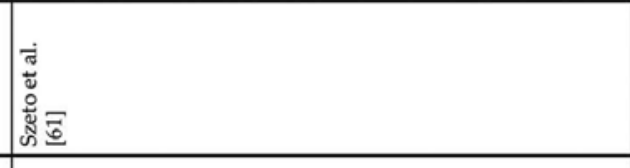 & 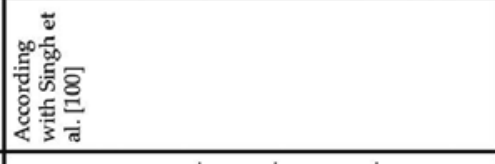 \\
\hline 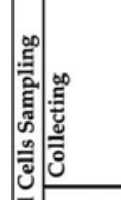 & 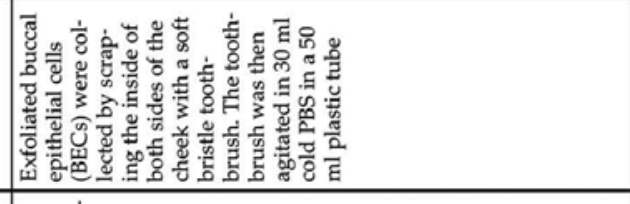 & 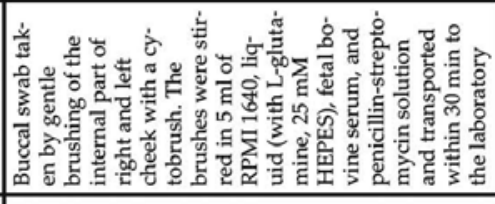 \\
\hline 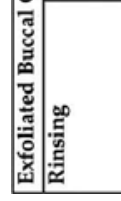 & 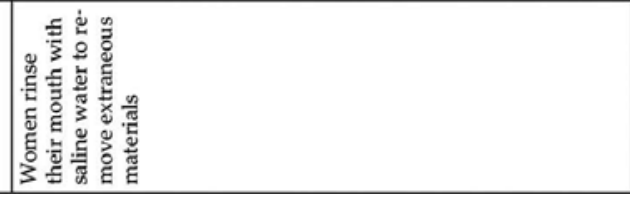 & 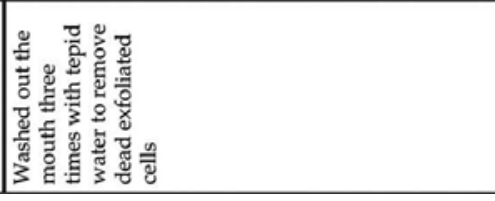 \\
\hline
\end{tabular}




\begin{tabular}{|c|c|c|}
\hline 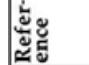 & 鸟 & 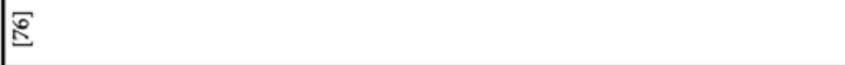 \\
\hline & 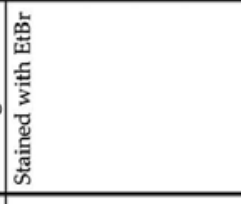 & 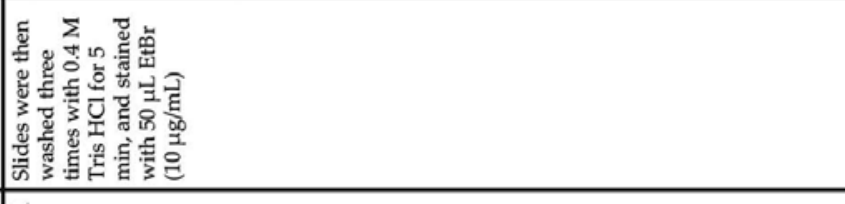 \\
\hline 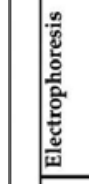 & & 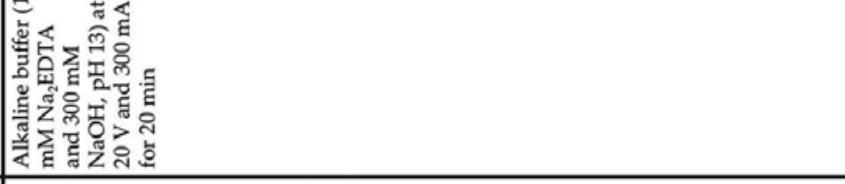 \\
\hline 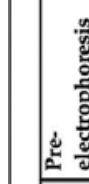 & & 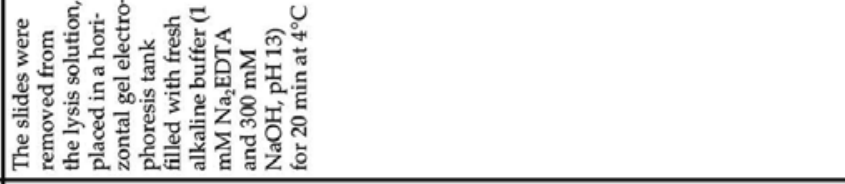 \\
\hline 总 & 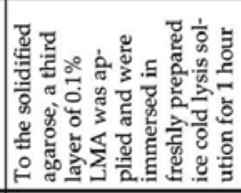 & 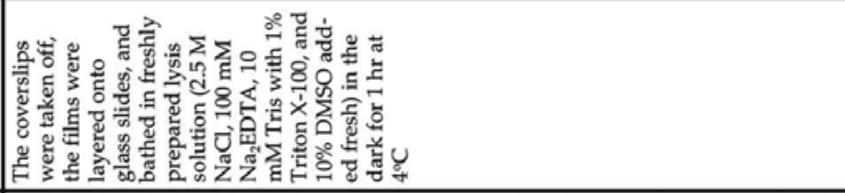 \\
\hline & & \\
\hline 急 & 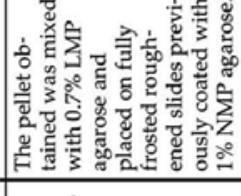 & 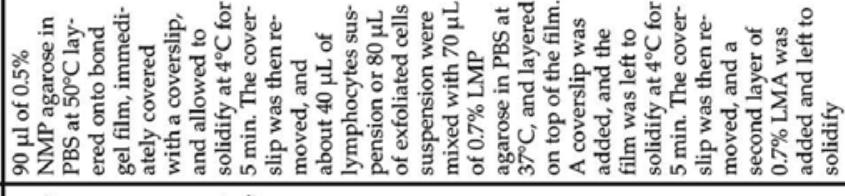 \\
\hline 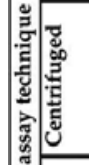 & 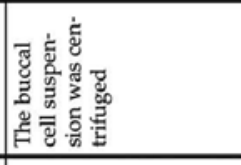 & 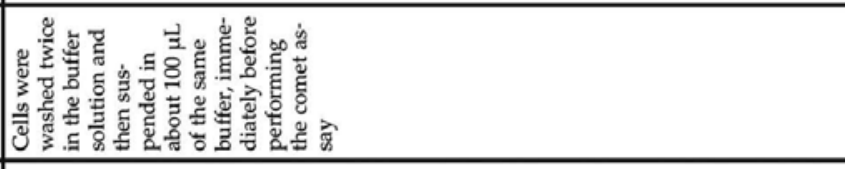 \\
\hline 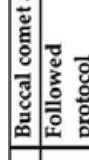 & & 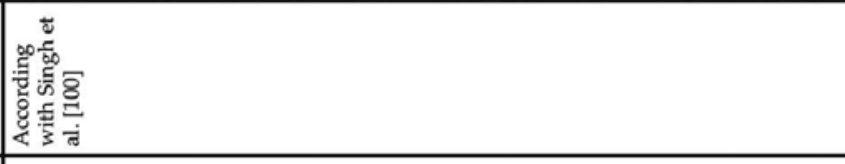 \\
\hline 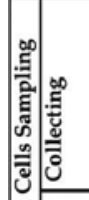 & & 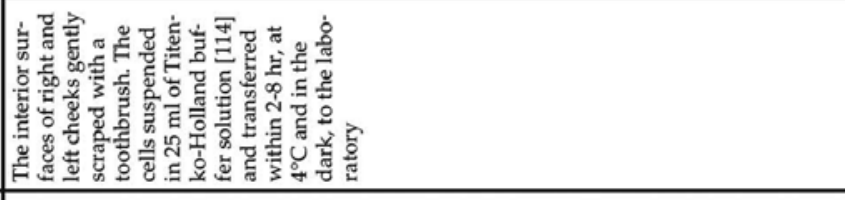 \\
\hline 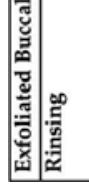 & & 13 \\
\hline
\end{tabular}




\begin{tabular}{|c|c|c|c|}
\hline ֻั๊ & F & Q & 疋 \\
\hline & 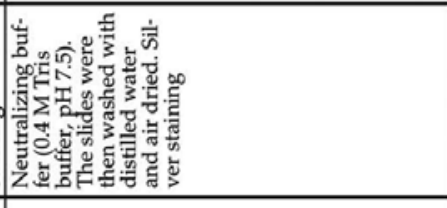 & 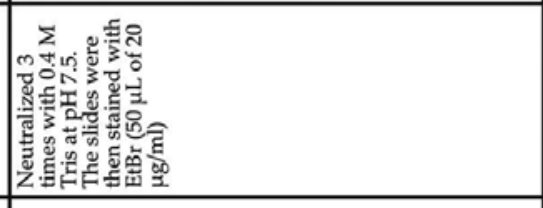 & 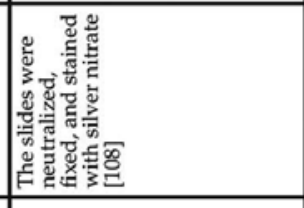 \\
\hline & 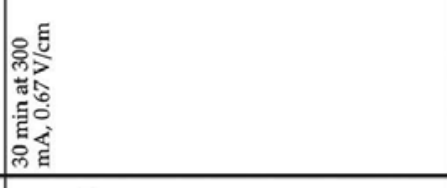 & & 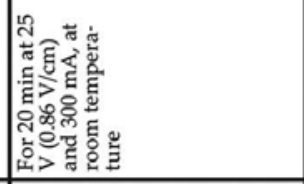 \\
\hline 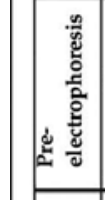 & 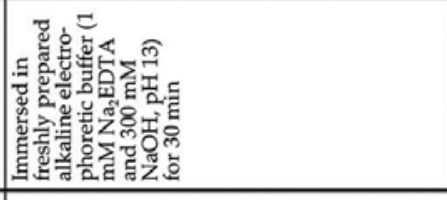 & 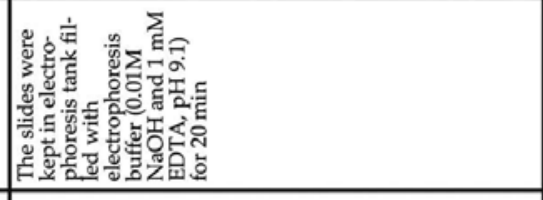 & 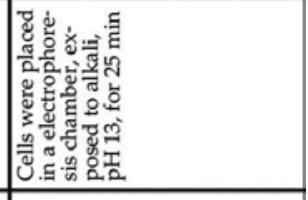 \\
\hline & 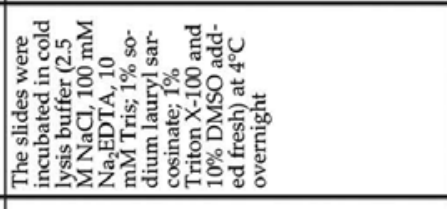 & 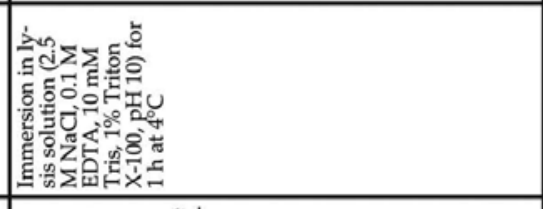 & 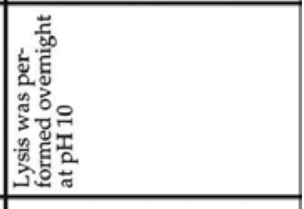 \\
\hline & & 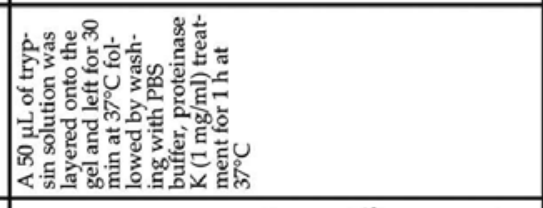 & \\
\hline & 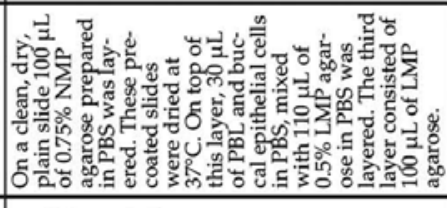 & 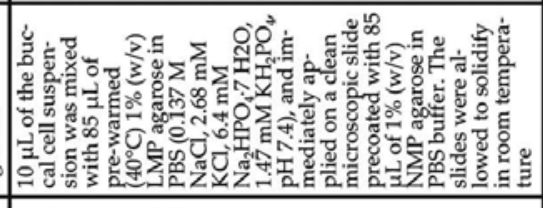 & 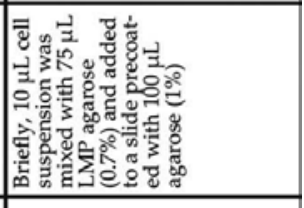 \\
\hline 氮 & 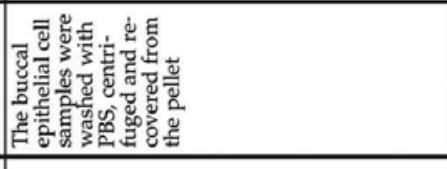 & 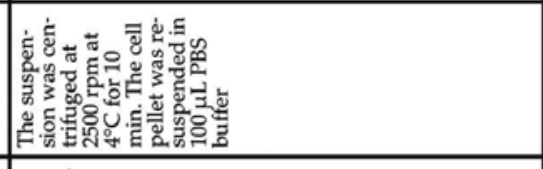 & 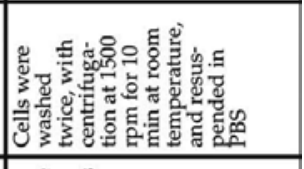 \\
\hline 这. & 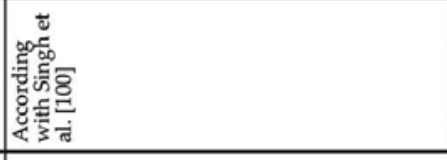 & 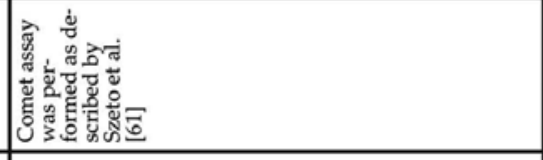 & 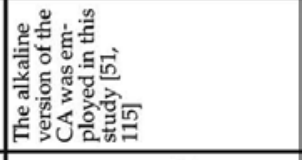 \\
\hline 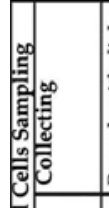 & 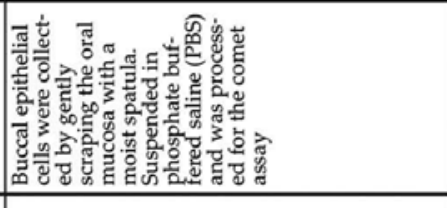 & 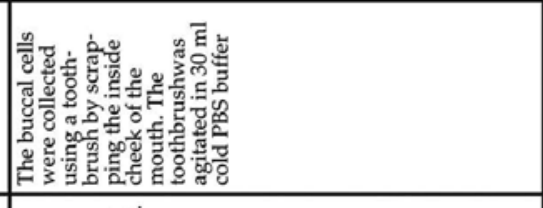 & 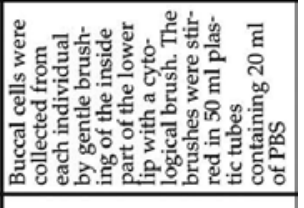 \\
\hline 娐。 & & 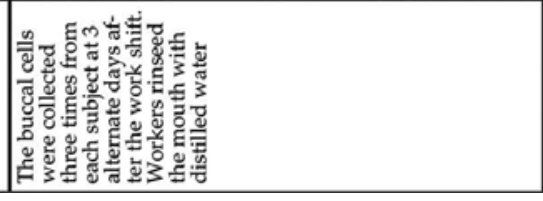 & 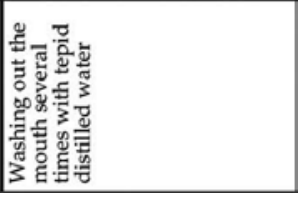 \\
\hline
\end{tabular}




\begin{tabular}{|c|c|c|}
\hline ะ & तु & $E$ \\
\hline 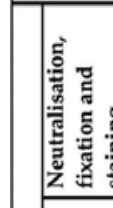 & 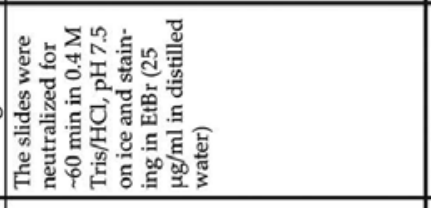 & 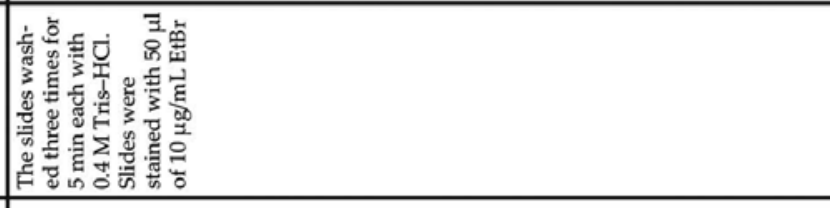 \\
\hline & 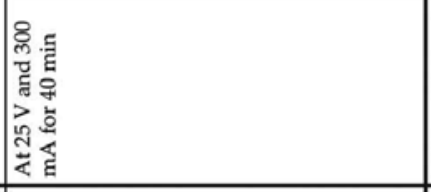 & 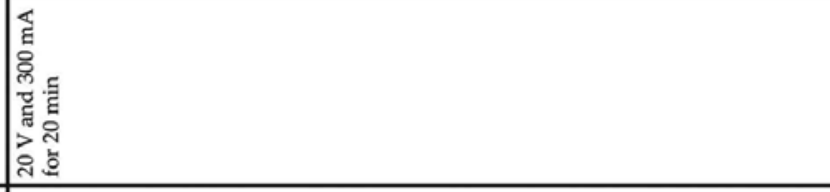 \\
\hline 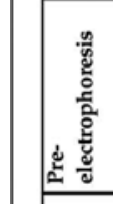 & 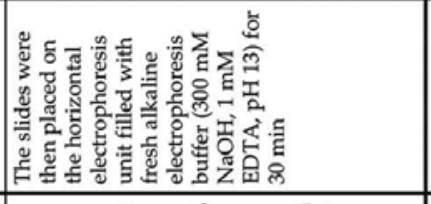 & 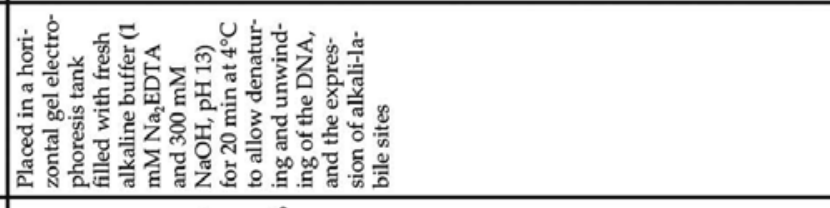 \\
\hline 量 & 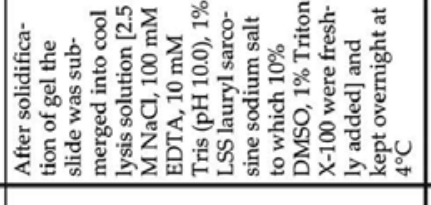 & 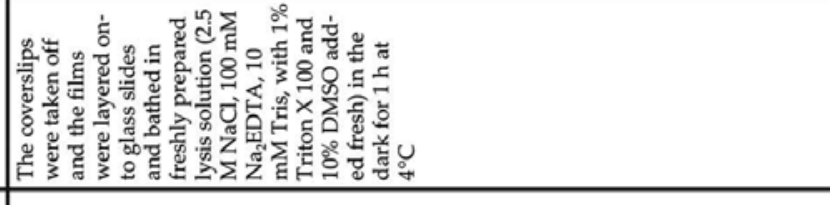 \\
\hline & & \\
\hline & 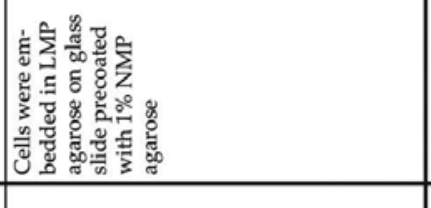 & 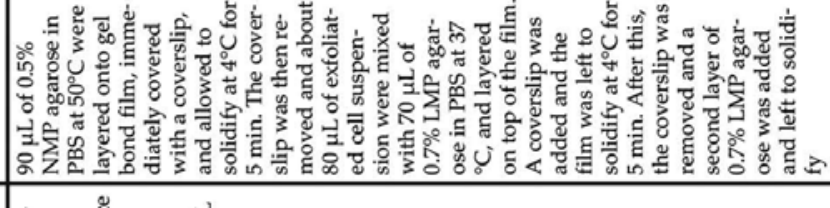 \\
\hline & & 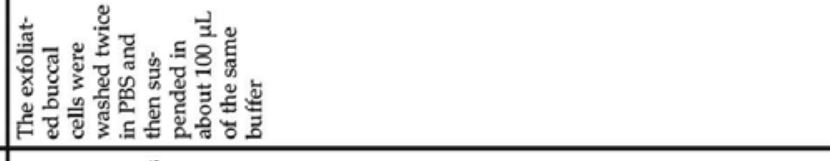 \\
\hline 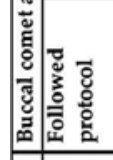 & 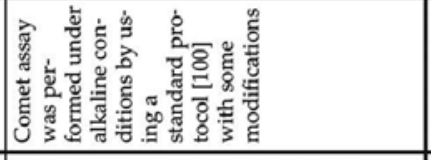 & 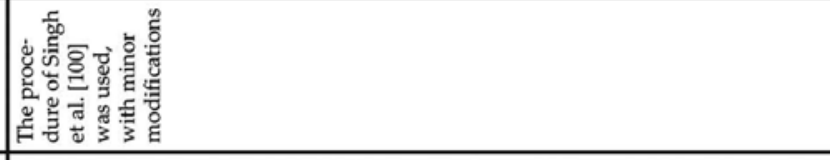 \\
\hline 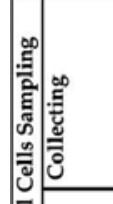 & 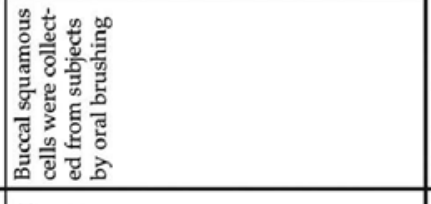 & 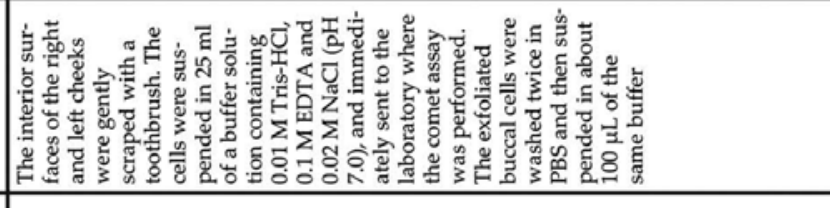 \\
\hline 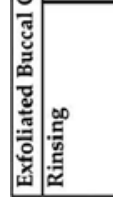 & 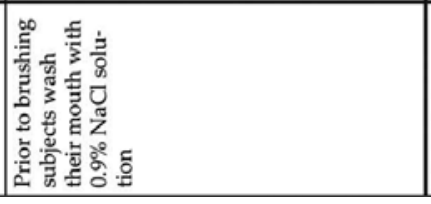 & 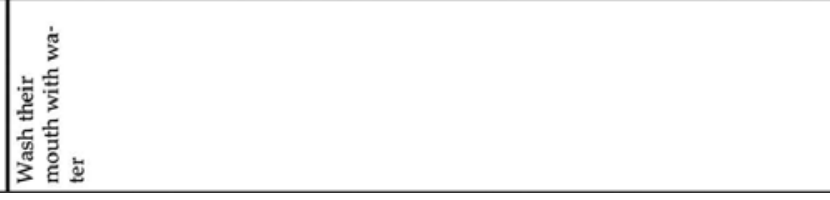 \\
\hline
\end{tabular}




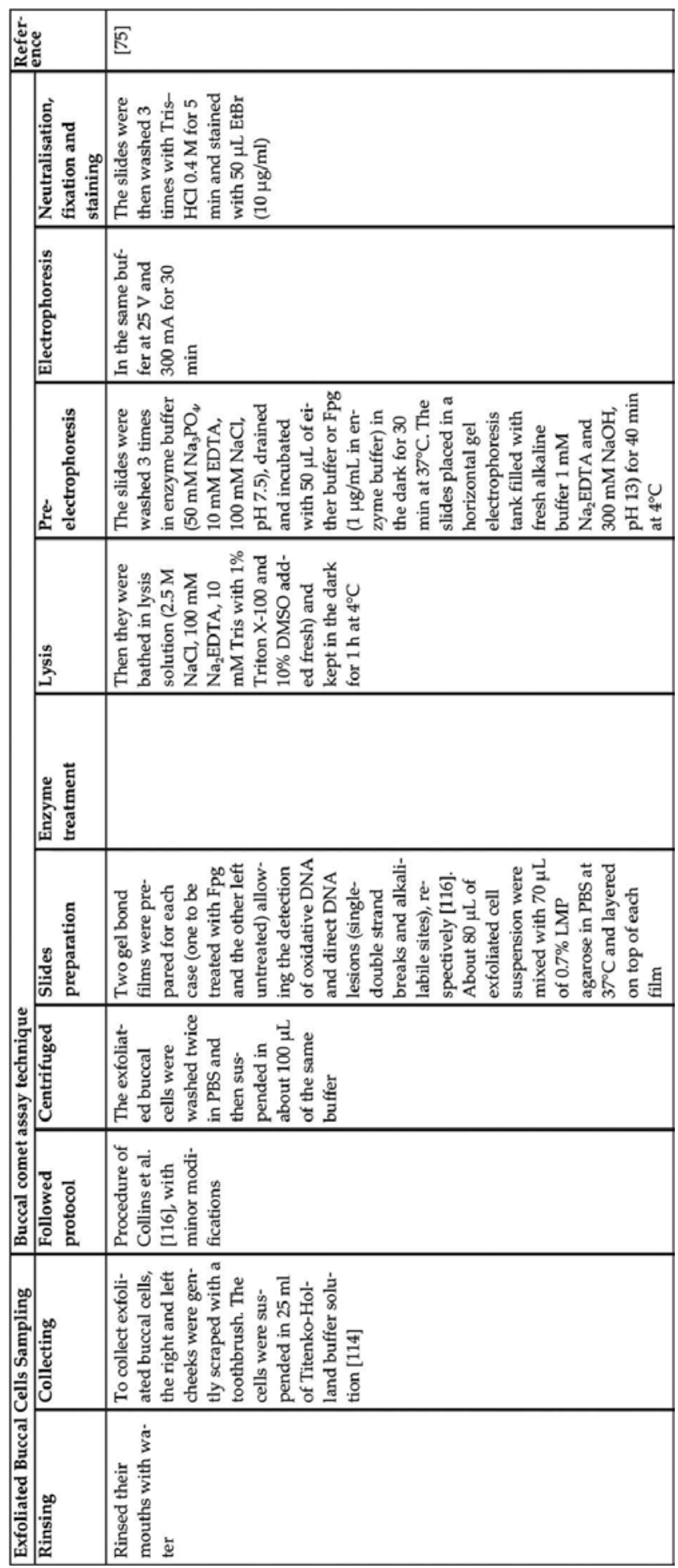




\begin{tabular}{|c|c|}
\hline 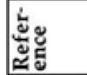 & इ \\
\hline & 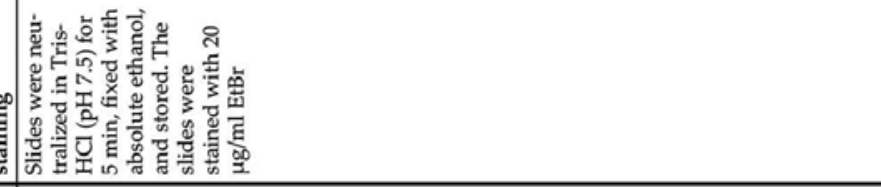 \\
\hline & 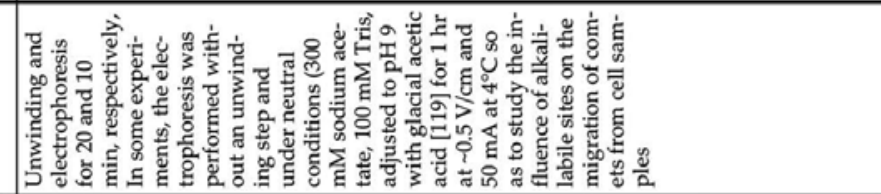 \\
\hline & 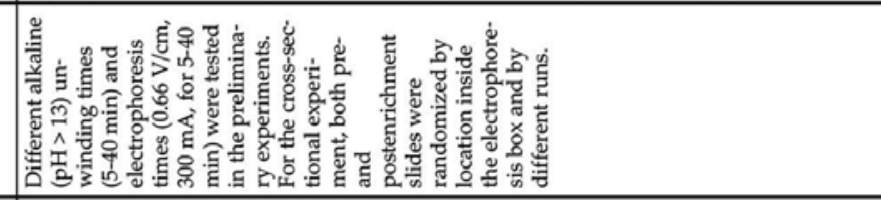 \\
\hline 量 & 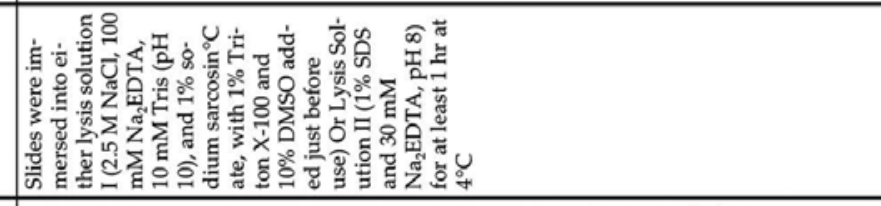 \\
\hline & 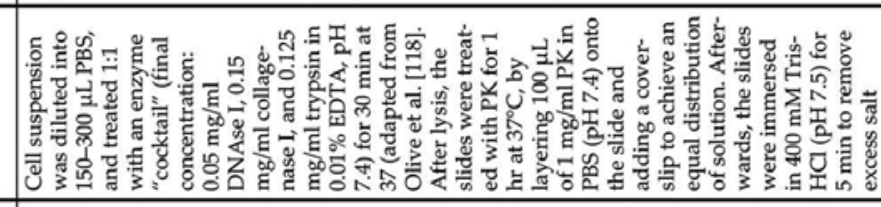 \\
\hline & 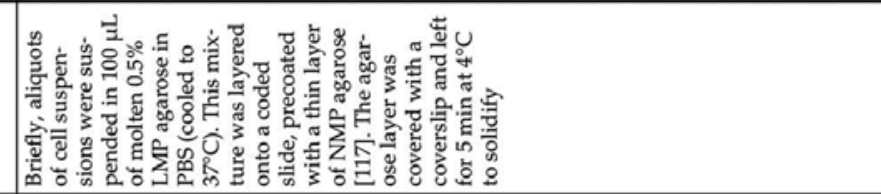 \\
\hline Uू. & 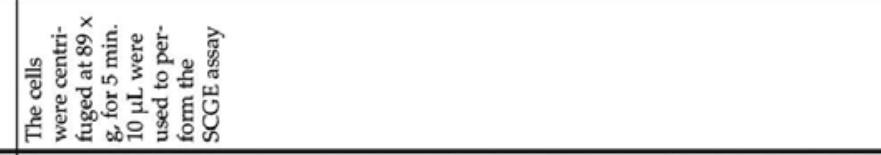 \\
\hline & 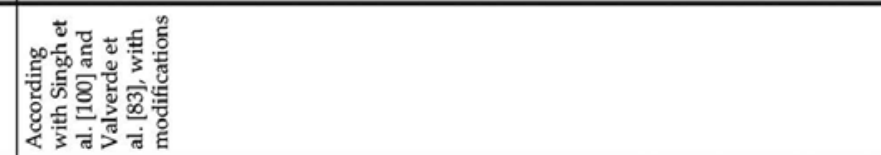 \\
\hline 递 & 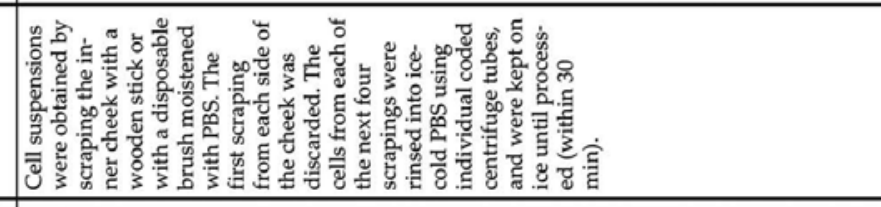 \\
\hline 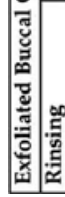 & 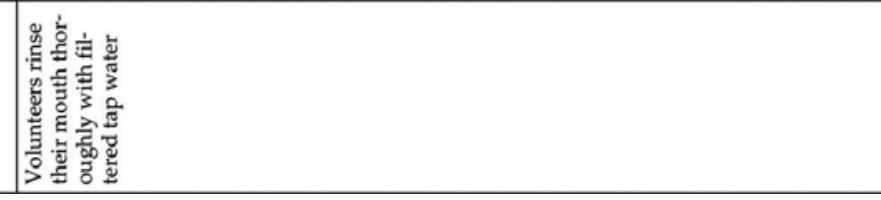 \\
\hline
\end{tabular}




\begin{tabular}{|c|c|}
\hline ธุ้ & $\bar{\sigma}$ \\
\hline 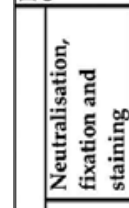 & 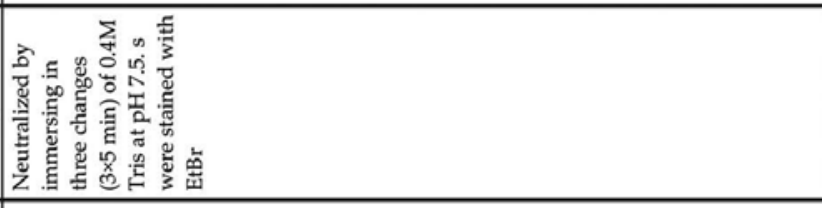 \\
\hline & 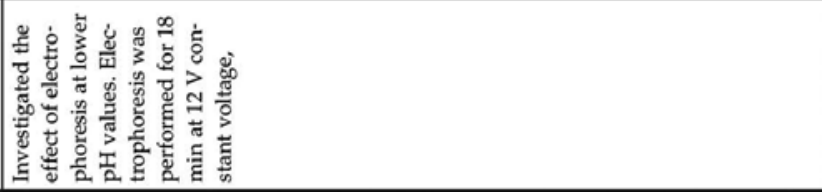 \\
\hline 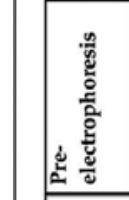 & 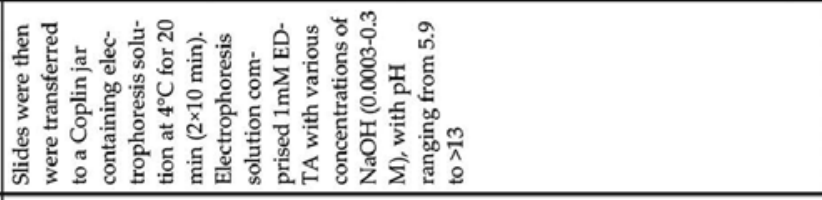 \\
\hline $\begin{array}{l}\frac{2}{20} \\
3\end{array}$ & 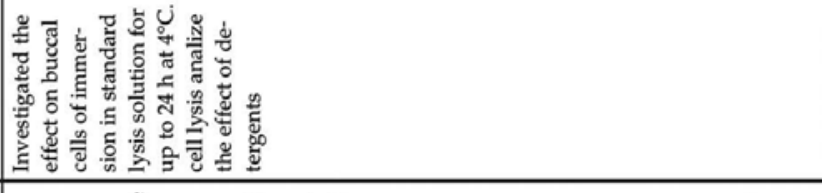 \\
\hline 营 & 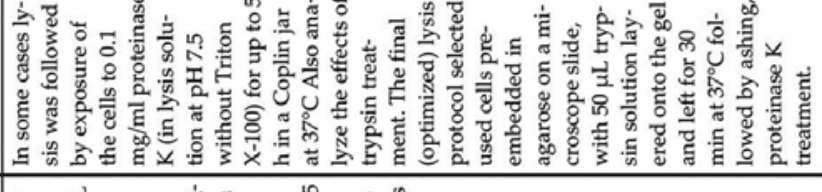 \\
\hline 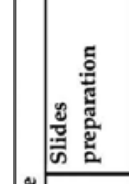 & 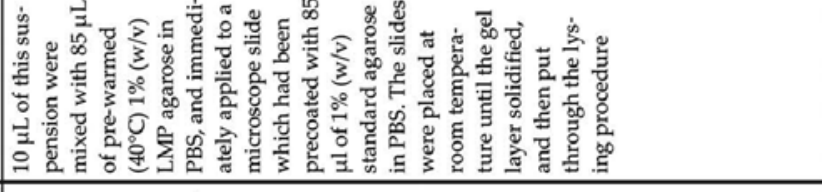 \\
\hline 樆 & 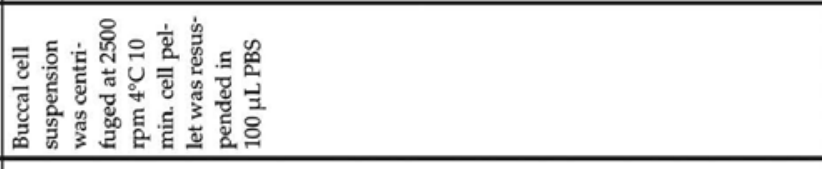 \\
\hline 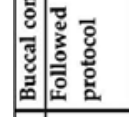 & 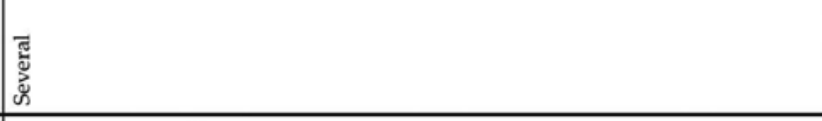 \\
\hline 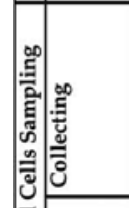 & 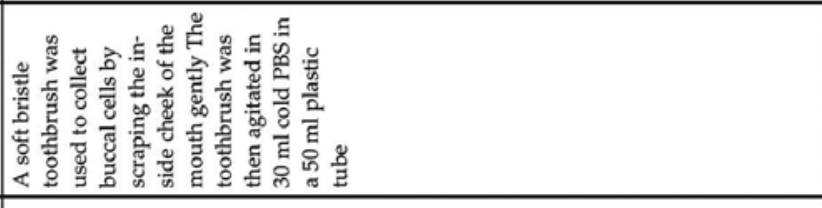 \\
\hline 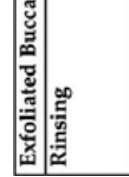 & 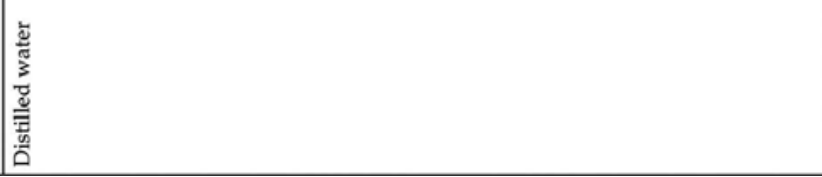 \\
\hline
\end{tabular}




\begin{tabular}{|c|c|}
\hline జัะ్ & 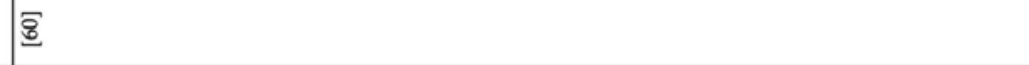 \\
\hline 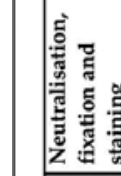 & 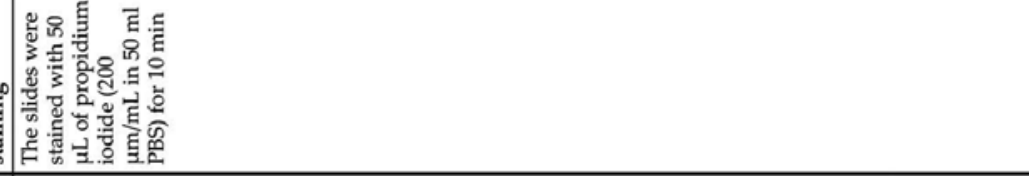 \\
\hline 热 & 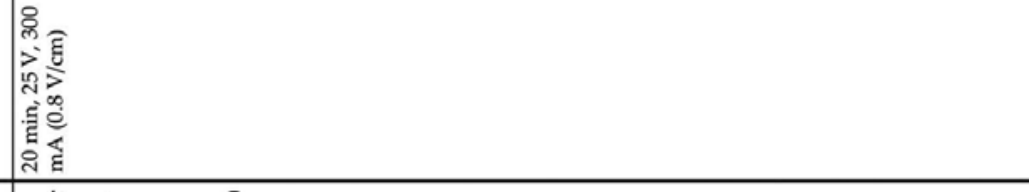 \\
\hline 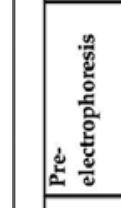 & 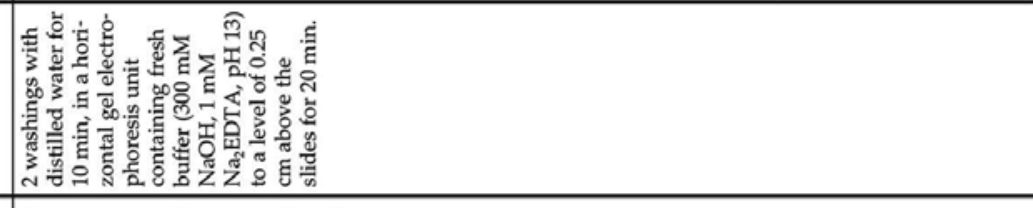 \\
\hline 惫 & 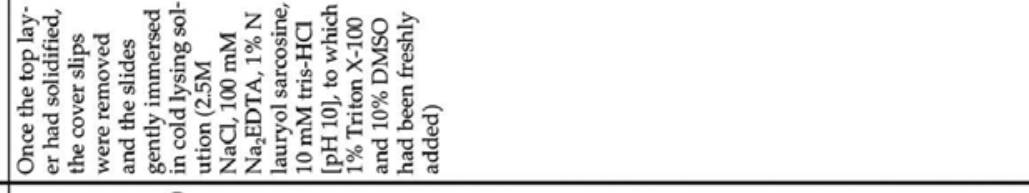 \\
\hline 营 & 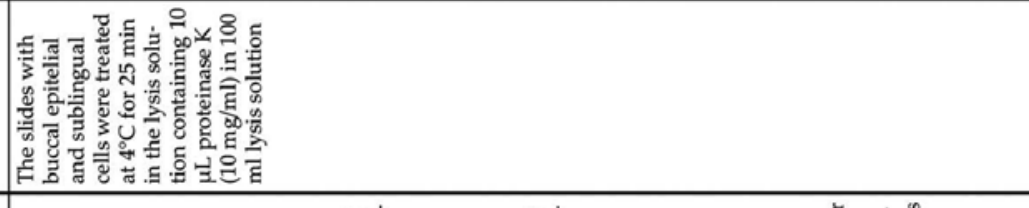 \\
\hline 噌 & 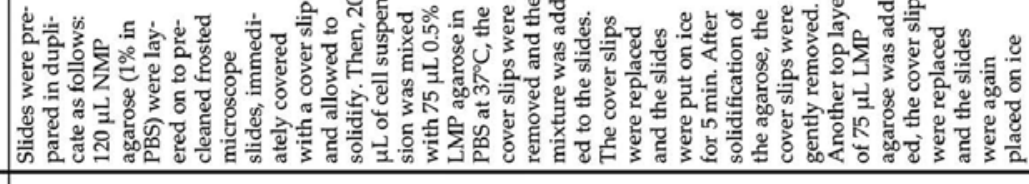 \\
\hline 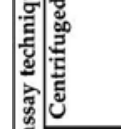 & \\
\hline 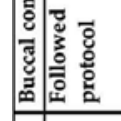 & \\
\hline 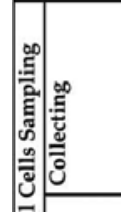 & 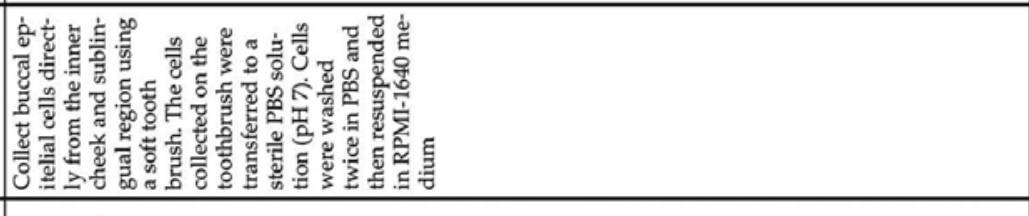 \\
\hline 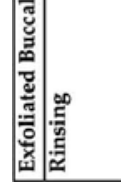 & 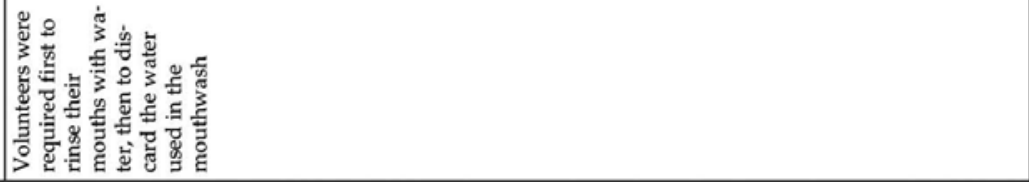 \\
\hline
\end{tabular}




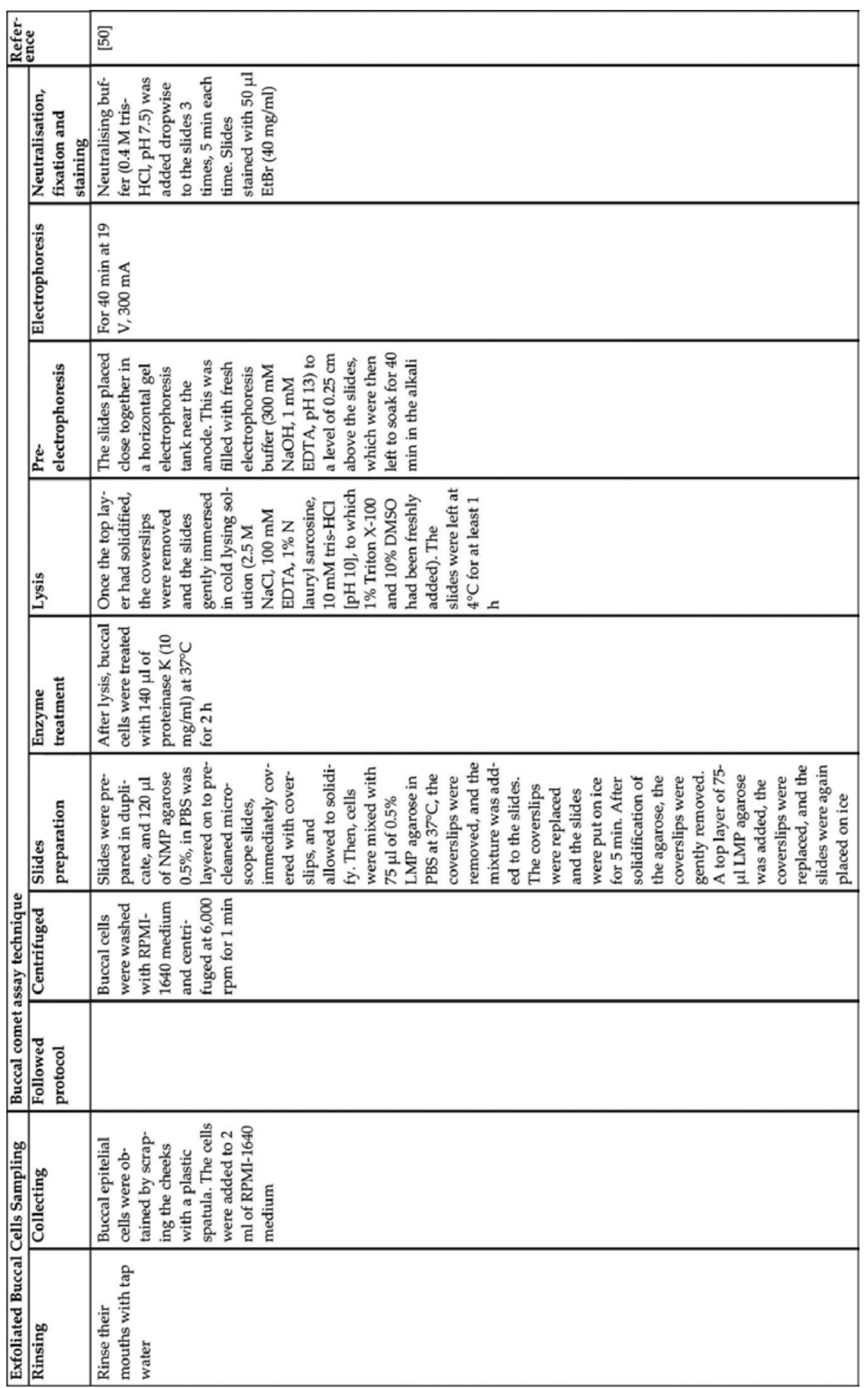




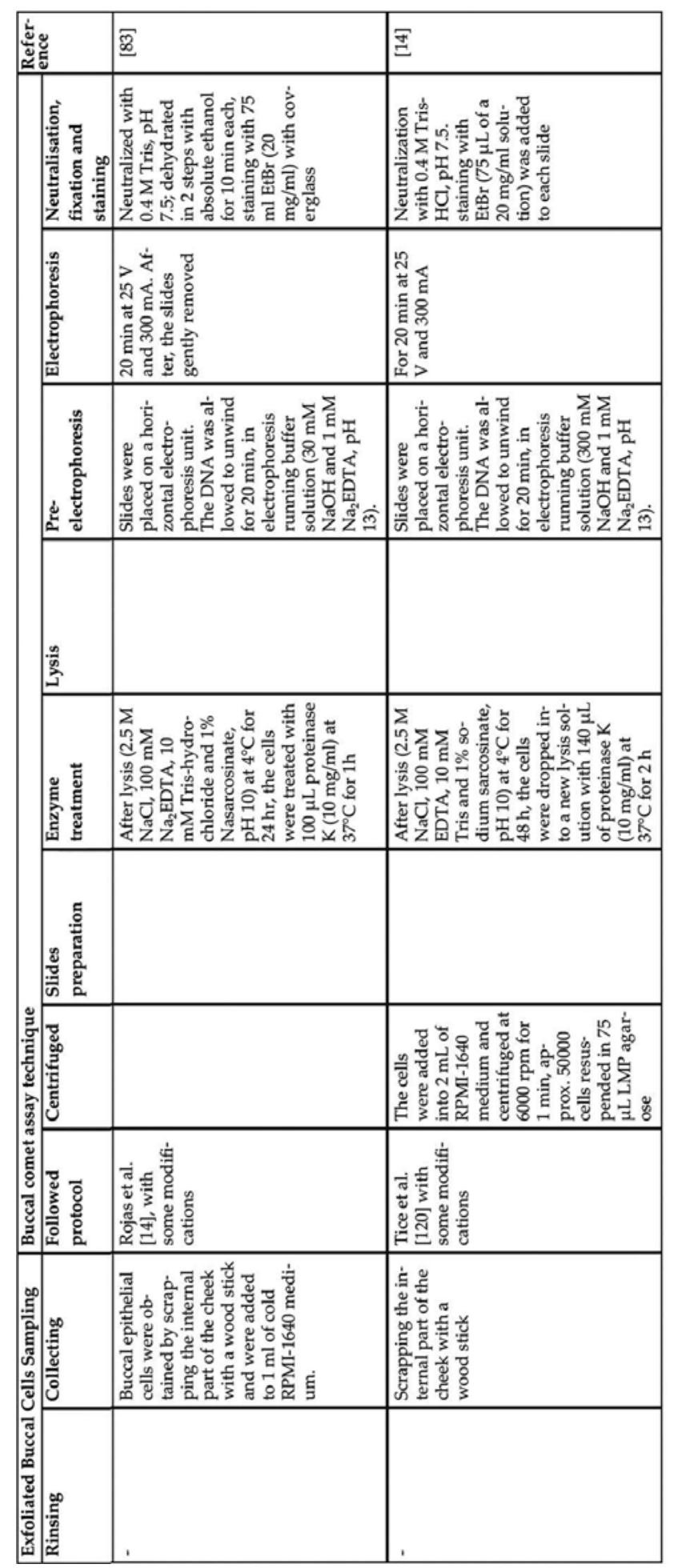

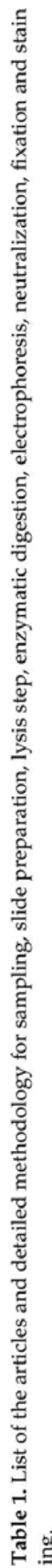




\section{Use of comet assay in buccal cells}

The comet assay in buccal cells has been used to evaluate DNA damage induced by different materials such as mouthrinses [50], metals released from orthodontic appliances [51-59], ionizing radiation [60], as well as assessment of DNA damage, and its modulation by life-style, dietary, genetic and healthy factors [61-74], occupational exposure [66-69,75-82], and environmental exposure [83-86]. Different procedures have been used in collecting and processing the samples that are presented and discussed in Rojas et al. [33]. The Table 2 represents classification according to the type of population study based on exposure and lifestyle factors with the results of comet assay.

\subsection{Mouthrinses and metal released from orthodontic appliances}

The genotoxic properties of mouthrinses and metals from orthodontic appliances are essential for determining the biological safety of those materials in patients. Current in vivo human studies are aimed at representing the real condition of the oral cavity by sampling buccal cells, which are directly exposed to the appliances [51,52].

Eren et al. [50] evaluated the stability of buccal epithelial cells for SCGE assay after the use of chlorhexidine digluconate ( $\mathrm{CHX})$, a mouthrinse used by dentists as disinfecting agent for operation sites washing and for disinfection of root canals. A statistical increase was observed in the DNA damage after the CHX application. Considering orthodontic appliances, the first in vivo study was performed by Faccioni et al. [51], who conducted the alkaline comet assay in orthodontic patients. They reported genotoxic damage and found positive correlations between the concentrations of released cobalt and nickel and the number of comets as well as correlations between Co levels and comet tails. However, Westphalen et al. [52] did not find genetic damage after the placement of the orthodontic appliances.

According to Fernández-Miñano et al. [53], genotoxicity induced in buccal cells could be related to the composition of orthodontic appliances. Orthodontic apparatus made with titanium was not genotoxic for oral mucosa cells, whereas the stainless steel alloy and nickelfree alloy induced DNA damage in buccal mucosa cells. In contrast, Hafez et al. [54] observed that stainless steel brackets with stainless steel archwires produce the least damage, whereas titanium brackets with nickel-titanium archwires produced the highest amount of genotoxicity, assessed with the comet assay. Baričević et al. [55] assessed subjects with Co-Cr-Mo alloy and $\mathrm{Ni}-\mathrm{Cr}$ alloy showed significantly higher comet assay parameters when compared with controls. Gonçalves et al. [59] showed the genotoxic effects of Hyrax auxiliary orthodontic appliances containing silver-soldered joints.

On the other hand, Hafez et al. [54] reported damage to the DNA in mucosa cells at 3 months of orthodontic treatment but not at 6 months. Thus, the difference in exposure period of prosthodontic and orthodontic appliances in oral cavity might explain discrepancies observed between results obtained by Faccioni et al. [51], and those of Westphalen et al. [52] and Baričević et al. [55]. 
Visalli et al. [56] found that both amalgams and resin-based composite fillings can induce genotoxic damage in human oral mucosa cells. They also report that lifestyle variables, including alcohol intake and smoking habits, did not affect the genotoxic response and did not act as confounding factors. Martín-Cameán et al. [57] observed induction of genotoxicity in buccal cells of subjects with orthodontic appliances and orthodontic appliances with microscrews when compared with controls. In addition they found that damage was higher in women.

\subsection{Radiation}

Only one work that analyses and compares the DNA damage and repair following radiation challenge in buccal cells and lymphocytes using SCGE assay was found. The results suggested that baseline DNA damage in oral epithelial cells is greater than that in lymphocytes [60].

\subsection{Life style, dietary, genetic and healthy factors}

As mentioned above in the first work of this type, Rojas et al. [14] found a significantly increased tail length in a smoker group compared with a non-smoker group. Differences between genders either in the smoker or non-smoker group were not observed and were neither related to age or number of cigarettes smoked. Waterpipe smoking (a type of tobacco smoking) and its condensate have been examined for the genotoxic effects on buccal cells. The tail moment in buccal cells of smokers was found to be $186 \pm 26$, which is $371.9 \%$ higher than the tail moment in buccal cells of non-smokers. The other comet parameters such as tail length, $\%$ tail DNA, and fragmented DNA were $456 \pm 71,97.0 \pm 19$, and $32.0 \pm 3.3$, respectively, in buccal cells of smokers, whereas in control group (non-smokers), the values of tail length, $\%$ tail DNA, and fragmented DNA were extremely low [72].

Oral habits have also been associated with DNA damage. Khanna et al. [70] reported a case of a tobacco chewer in which the percentage of damaged cells was significantly higher than in the control. Also the effect of gutkha (a preparation of crushed areca nut, tobacco, catechu, paraffin wax, slaked lime, and sweet or savory flavorings) and pan masala (an herb, nut, and seed mixture that is commonly served in the Middle East countries) chewing along with and without smoking was studied in buccal epithelial cells using single-cell gel electrophoresis [71]. The increase in the mean comet tail length was observed as follows: non users $<$ smokers $<$ pan masala chewers $<$ gutkha chewers $<$ pan masala + smoking $<$ gutkha + smoking. Like Rojas et al. [14], they conclude that these bioassay and biomarker are easier and safe methods to detect DNA damage among humans.

Assessment of DNA damage and its modulation by dietary and genetic factors in smokers using the comet assay has also been developed [87]. Pal et al. [62,63] analyzed the influence of regular black tea consumption on tobacco-associated DNA damage and human papilloma virus (HPV) prevalence in human oral mucosa. The increase in DNA damage was significantly associated with increase in age and tenure of tobacco habit. Reduced DNA damage was found to be significantly associated with increase in tea intake. In case of oral cancer patients, comparatively high frequency of DNA damage was observed. The frequency of DNA damage 
and HPV infection was comparatively high in oral cancer patients than in the normal subjects. These studies indicated a chemopreventive role of black tea against reducing DNA damage risk of buccal cells due to tobacco exposure. Authors concluded that buccal cells could be used as cytological markers for detection of risk and risk reduction in normal population. Since, as mentioned above, more than $90 \%$ of human cancers arise from epithelial cells, it has been postulated that experiments with these cells may have particular relevance for the detection of cancer preventive effects [47].

On the other side, several polymorphisms in DNA repair genes have been reported to be associated with cancer risk [88]. The repair of DNA damage has a key role in protecting the genome from the insults of genotoxic agents. Tobacco-related compounds cause a variety of DNA damage, and DNA repair capacity plays an important role in agent-induced damage genotoxic. Several polymorphisms in genes that participate in different DNA repair pathways, such as XRCC1 399, hOGG1 326 [65], GSTP1 [66], CYP2E1 [67], CYP1A2 [68], and CYP1A1 [69], have been evaluated for their effects on different biomarkers [89], including comet tail length in buccal cells.

DNA damage effects of the used substances were confirmed in mechanical workshops workers, but with no confirmation of the influence of GSTP1 [66] or CYP1A1 [69] gene polymorphism on DNA damage, considering the comet assay performed on buccal cells. Conversely, workers with the wild genotype for CYP2E1 showed statistically significant higher comet tail length at the occupational exposure, while the mutated genotype did not have influence on this biomarker [67]. With CYP1A2 gene, the results showed that DNA damage in cells of workers carrying the mutated genotype was higher than workers carrying the wild genotype [68].

Sellappa et al. [65] found significant differences in the comet scores between smokeless tobacco users and control subjects when XRCC1399 and hOGG1326 polymorphisms and the frequencies of genetic damage among tobacco chewers were studied.

These findings provided evidence for the view that polymorphisms in DNA repair genes may modify individual susceptibility to genotoxic agents and justify additional studies to investigate their potential role in development of genetic damage.

\section{The use of the comet assay in buccal cells in biomonitoring the effect of pollution}

\subsection{Occupational exposure}

Cavallo et al. [75] suggested the use of comet assay on exfoliated buccal cells to assess the occupational exposure to mixtures of inhalable pollutants at low doses since these cells represent the target tissue for this exposure and are obtained by non-invasive procedure. In their study, tail moment values from Fpg-enzyme-treated cells (TMenz) and from untreated cells (TM) were used as parameters of oxidative and direct DNA damage, respectively, and 
found in the exposed group a higher value in respect to controls of mean TM and TMenz. An oxidative DNA damage was found, for exfoliated buccal cells in the $9.7 \%$ of exposed in respect to the absence in controls. On the other side, in healthcare workers in oncology hospital regularly handling antineoplastic drug mixtures, comet assay showed an increase on exfoliated buccal cells, also when it was not statistically significant, of mean TM with respect to controls in day hospital nurses (the group handling the highest amount of drugs during the administration process), while ward nurses and pharmacy technicians did not show the differences [77]. Increased levels of DNA damage were also found among jewellery workers occupationally exposed to nitric oxide using buccal cell comet assay, and also a synergistic effect of DNA damage with the cigarette smoking habit was found among the jewellery workers [78]. On the other hand, Cavallo et al. [76] evaluated two groups of workers, one exposed to antineoplastic drugs and the other exposed to PAHs, but the comet assay on exfoliated buccal cells did not show significant differences between exposed and control groups for comet percentages, whereas the TM value was higher in workers exposed to PAHs. Occupational risk assessment of paint industry workers with the comet assay in epithelial buccal cells showed that the damage index and damage frequency observed in the exposed group were significantly higher relative to the control group [79]. In other study on biomonitoring of genotoxic effects among shielded manual metal arc welders, Sudha et al. [80] showed a significantly larger mean comet tail length values. Among paddy farm workers exposed to mixtures of organophosphates was observed that the tail length formation showed significant increase of tail length differences between farmers compared with the matched control group [81]. Age, smoking status, duration of smoking, and secondhand smoker factors pointed out the significant intragroup variations, among the study population. Smokers and secondhand smokers generally showed higher levels of DNA damage, with increase connected with age and smoking duration increase. The last finding in this study leads again to the hypothesis that occupational risk factors contribute to the main effect on DNA damage. However, Carbajal-López et al. [82] did not find significant effect on genetic damage as a result of age, smoking, and alcohol consumption when genotoxic effect of pesticides in exfoliated buccal cells of workers occupationally exposed in Guerrero, Mexico was evaluated. The study revealed that the tail migration of DNA increased significantly in the exposed group.

\subsection{Environmental exposure}

After the first publication with comet assay in buccal cells by Rojas et al. [14], the same group [83] with this bioassay investigated differences in the level of DNA damage between young adults from the southern and northern areas of Mexico City and compared its effects with the damage induced in leukocytes and nasal epithelial cells. They found an increased DNA damage in leukocytes and nasal cells from individuals who lived in the northern part; however, no differences were observed for buccal epithelial cells, highlighting that it is important to study the genotoxic effects in other cells besides lymphocytes, as well as in cells of those tissues which are the first sites of contact with toxic pollutants. Although in their first work DNA damage in smokers was reported, in this work, they reported that smoking habit did not significantly increase DNA migration when compared with the non-smoker group. 
A study of indoor air pollution from biomass burning was performed on Indian women engaged in biomass cooking (wood, dung, crop residues), and the group was compared with age-matched control women cooking with cleaner fuel liquefied petroleum gas. DNA damage was assessed on buccal epithelial cells (BEC) by comet assay and fast halo assay (FHA). Compared with control, BEC of biomass users showed higher comet tail \% DNA, higher values for comet tail length, and olive tail moment, suggesting marked increase in DNA damage [84].

\section{Clinical application of the comet assay in buccal cells}

Significant stepwise increase in the DNA damage (basal/MNNG-treated/post-repair) was observed in buccal epithelial cells from control to pre-cancer patients and from pre-cancer to cancer patients. Considerable inter-individual and intercellular variability in DNA damage was observed, which also increased from control to pre-cancer patients and from pre-cancer to cancer patients [64]. Similar results were found in patients with oral squamous cell carcinoma (OSCC) and control group and suggested that comet assay may be used effectively to assess the prognosis of OSCC [73].

Among population studies regarding the health effects of air pollution, special attention should be given to children as a high-risk group, since some studies have shown significant correlation between early childhood exposure and development of chronic diseases in adulthood. Genotoxic biomarkers have been studied largely in adult population, but few studies so far have investigated children exposed to air pollution. Children are a high-risk group as regards the health effects of air pollution, and some studies suggest that early exposure during childhood can play an important role in the development of chronic diseases in adulthood. Genotoxic effects among farm children assessed with comet assay in buccal cells showed a significant increase in chromosome breakage and DNA strand breaks [85]. In other similar study, the exposure to pollutants was associated with markers of genotoxicity in exfoliated buccal cells of children living in a region with chipboard industries. The increase of outdoor formaldehyde was associated with a higher comet tail intensity and a higher tail moment [86].

\section{Confounding factors in studies with the comet assay in buccal cells}

A systematic and adequately powered investigation of key variables such as age, gender, genotype, season, diet, oral hygiene and dental health, life-style, smoking, alcohol, and other recreational drugs needs to be performed to identify the variables that have to be controlled [7]. 


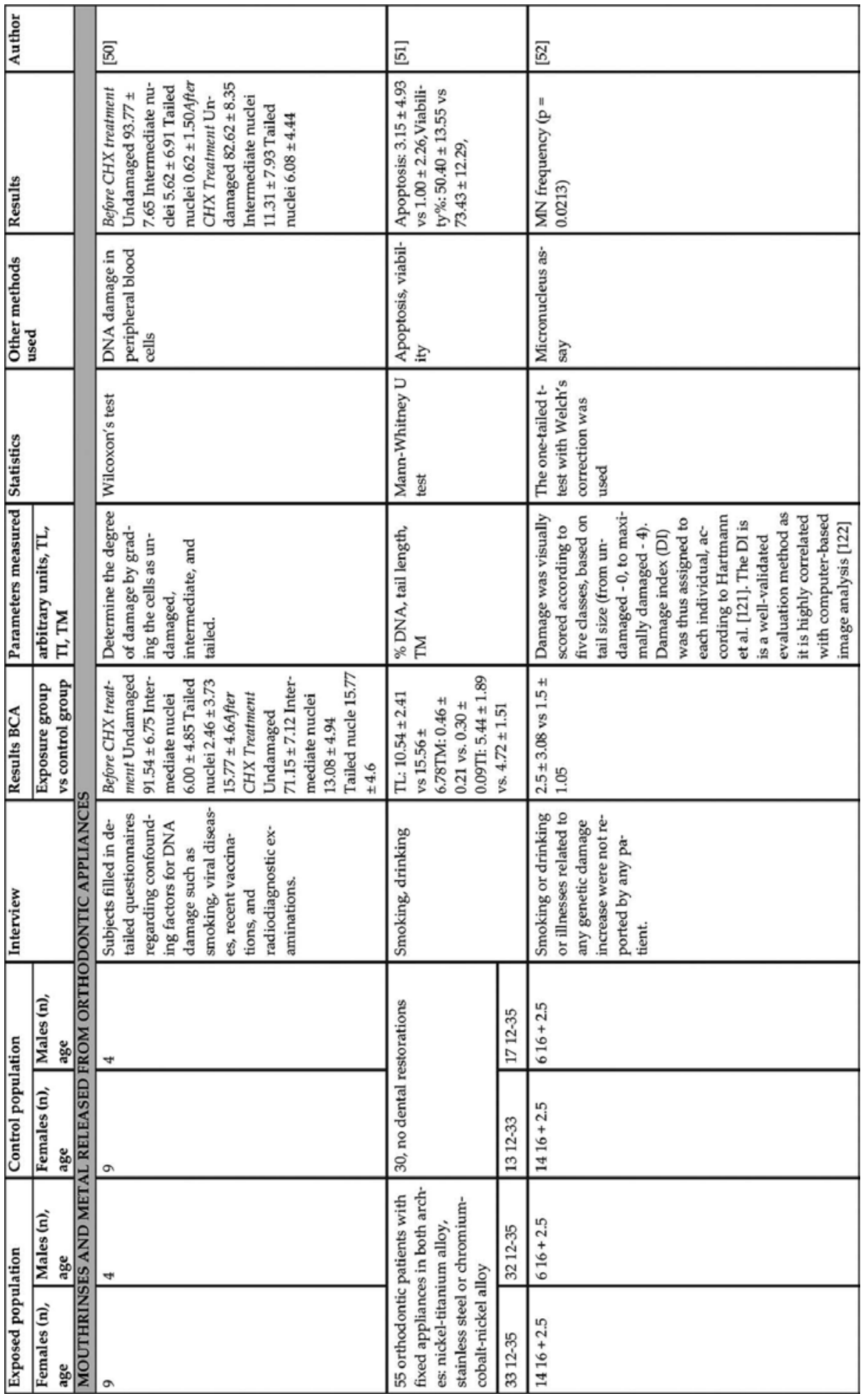




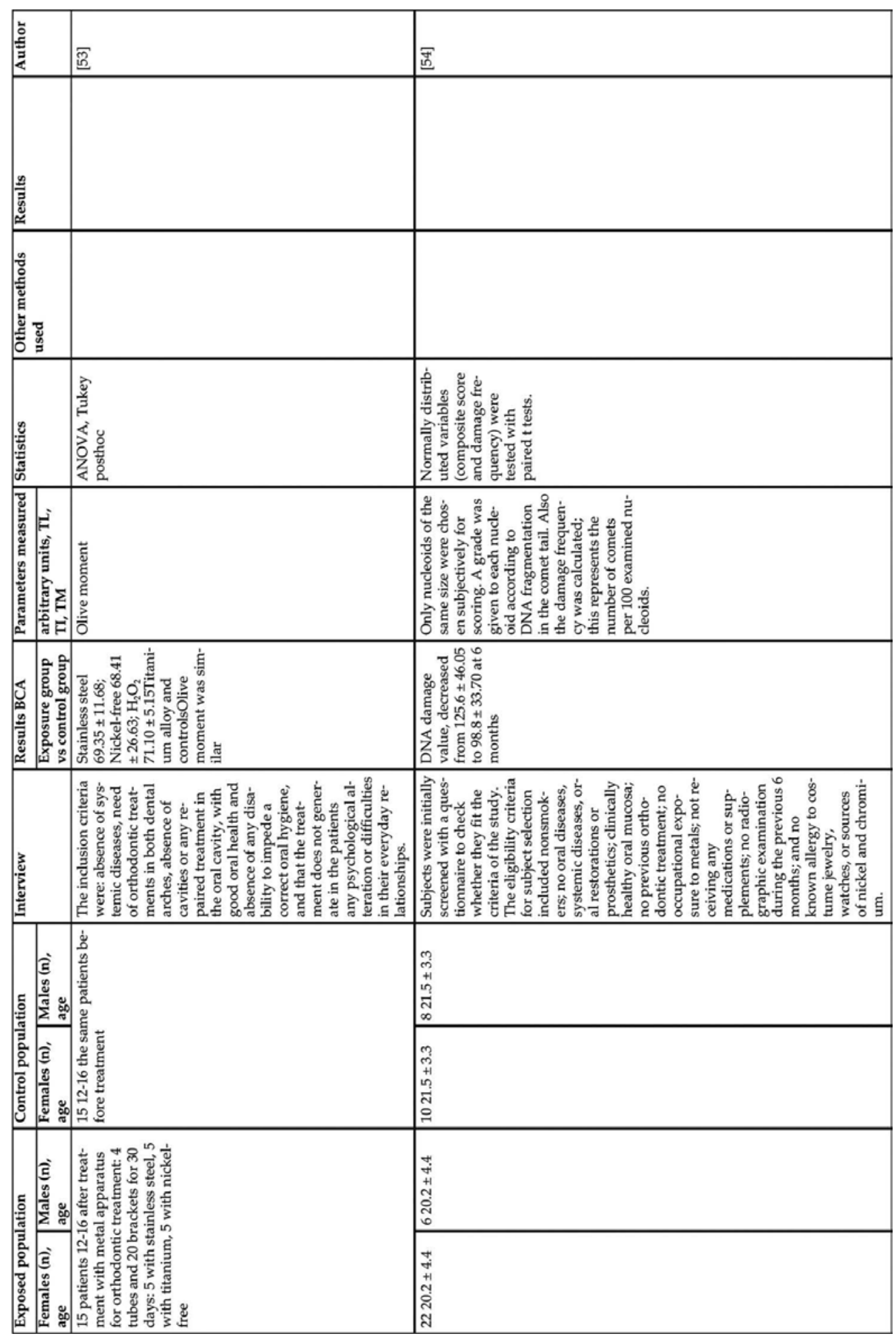




\begin{tabular}{|c|c|c|c|}
\hline 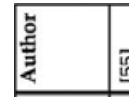 & 㗐 & 㿣 & 熙 \\
\hline 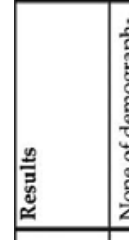 & 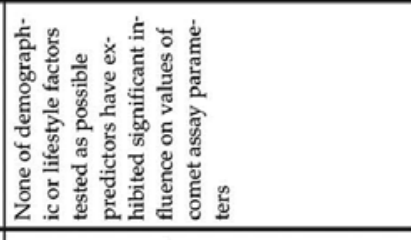 & 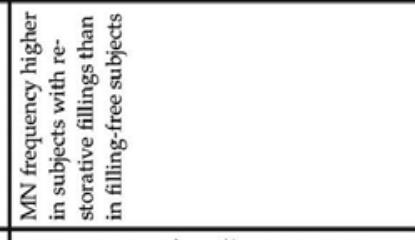 & \\
\hline 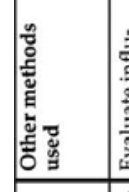 & 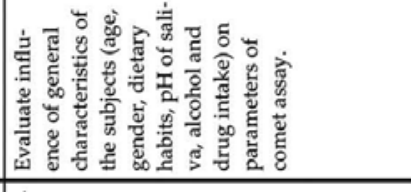 & 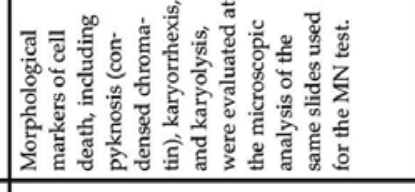 & \\
\hline & 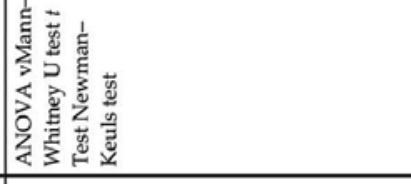 & 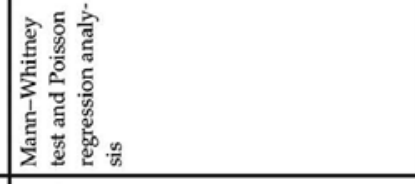 & \\
\hline 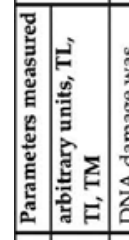 & 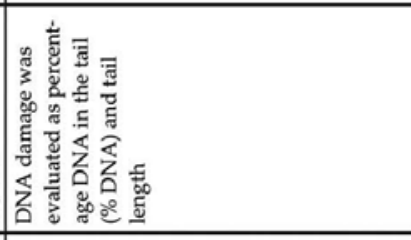 & 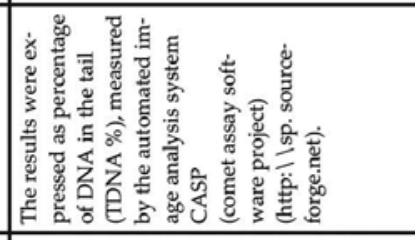 & 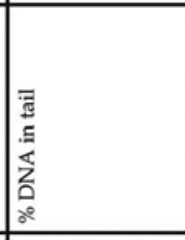 \\
\hline 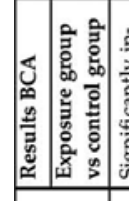 & 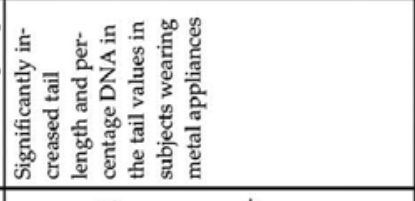 & 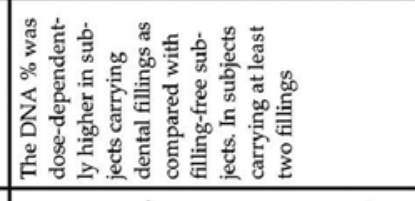 & 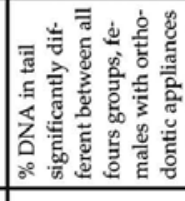 \\
\hline 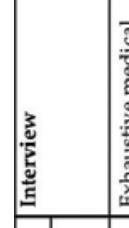 & 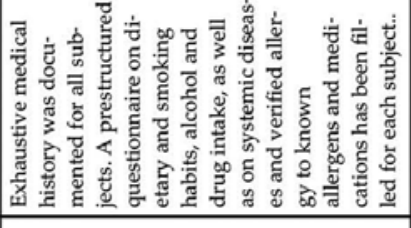 & 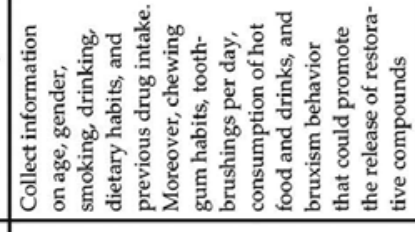 & \\
\hline 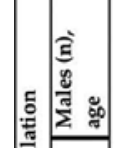 & & 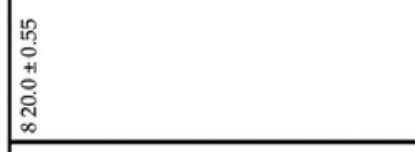 & \\
\hline $\begin{array}{lll}0 \\
0\end{array}$ & & 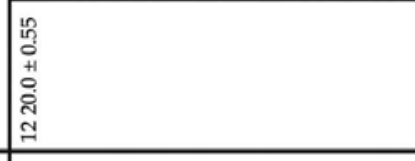 & สิ \\
\hline 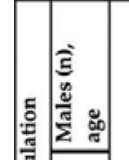 & & 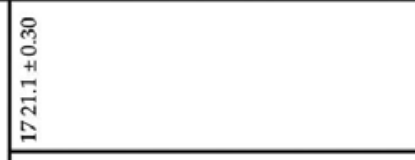 & 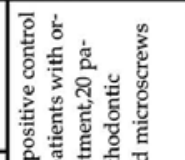 \\
\hline 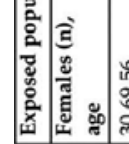 & & 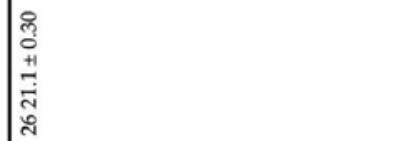 & 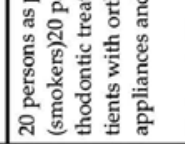 \\
\hline
\end{tabular}




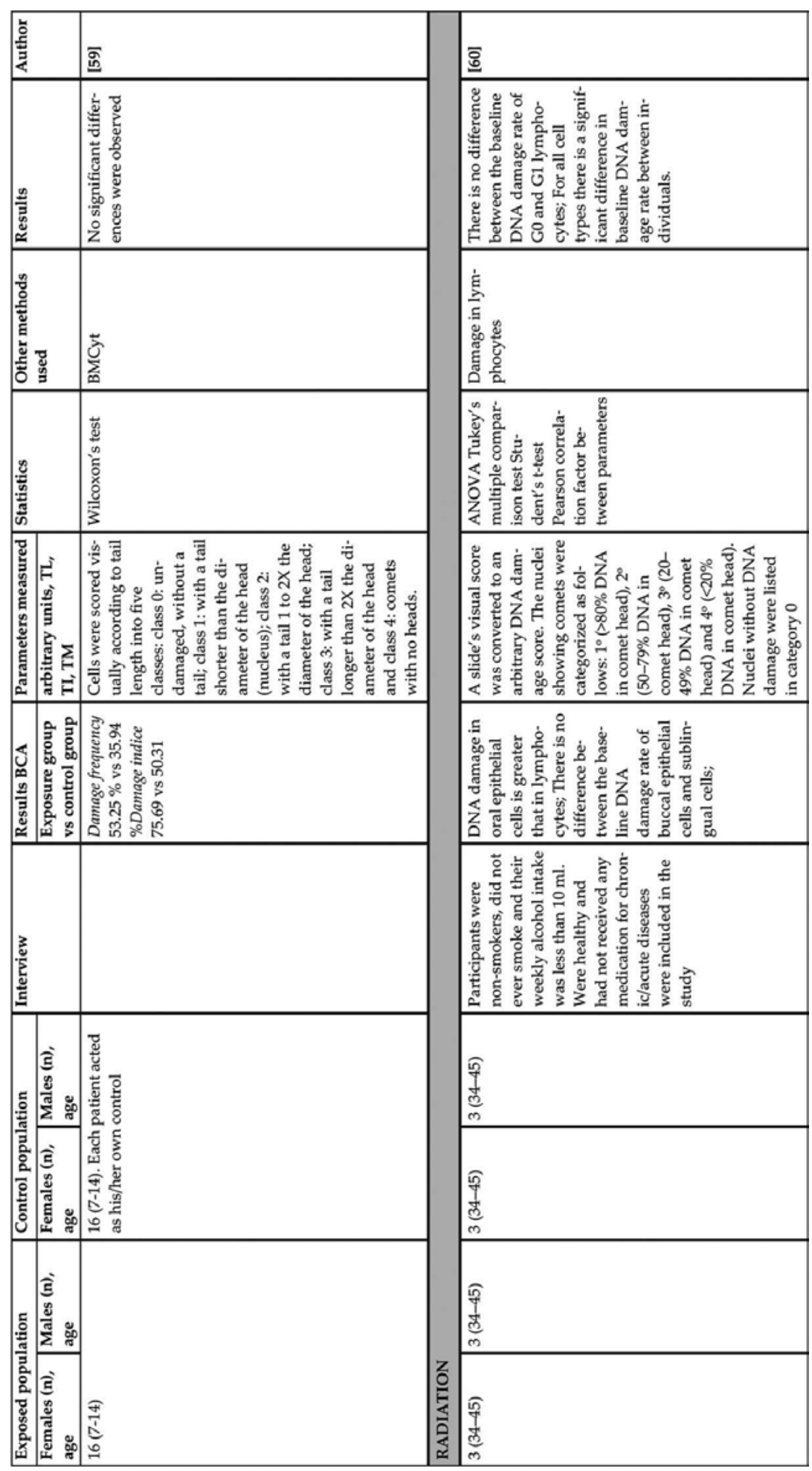




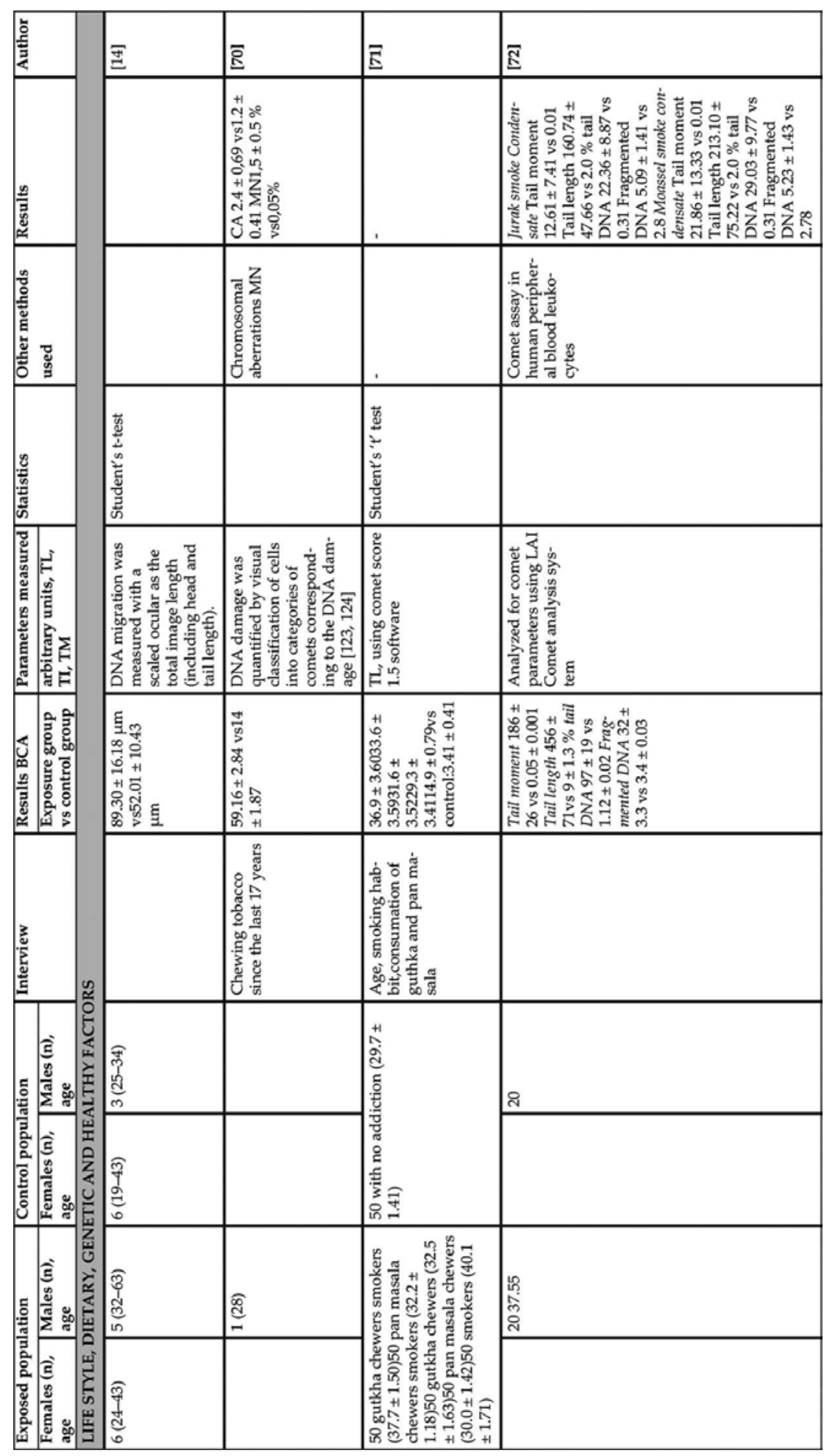




\begin{tabular}{|c|c|c|c|}
\hline \begin{tabular}{|l}
\multirow{2}{*}{} \\
\end{tabular} & 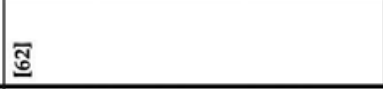 & 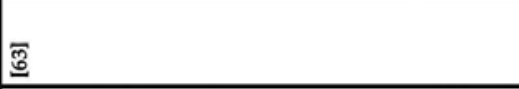 & 葛 \\
\hline 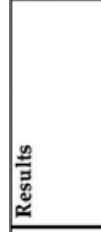 & 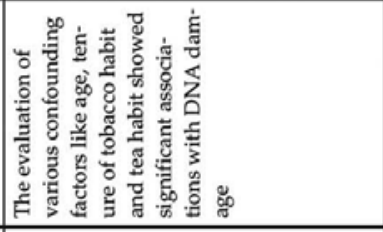 & 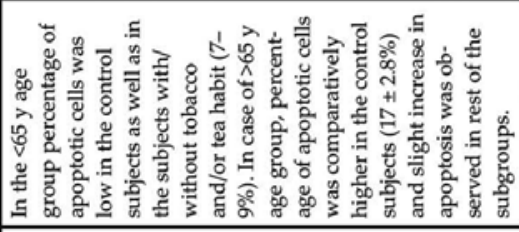 & 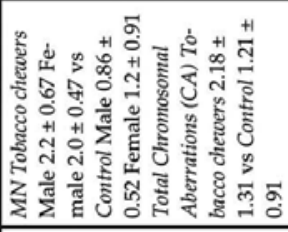 \\
\hline & 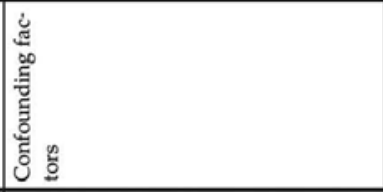 & 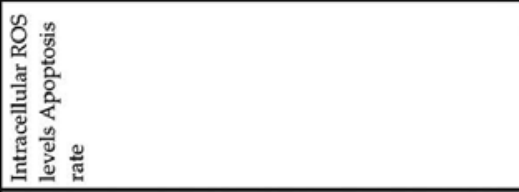 & 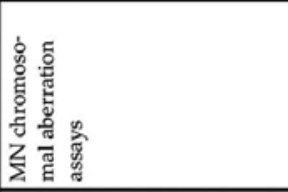 \\
\hline & 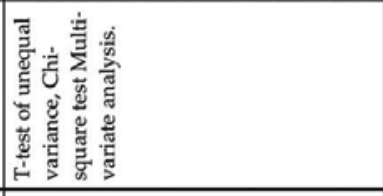 & 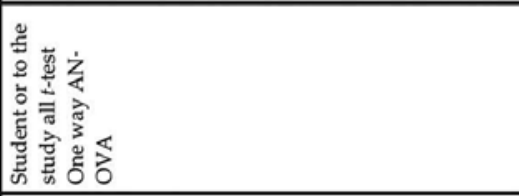 & 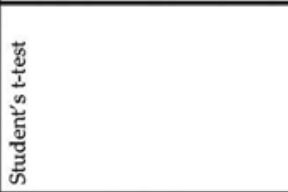 \\
\hline 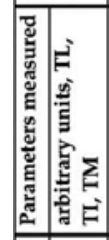 & 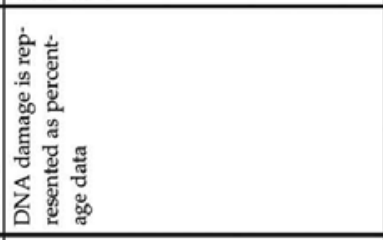 & 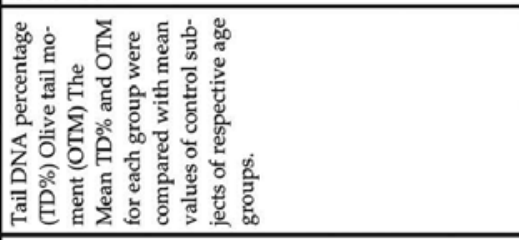 & 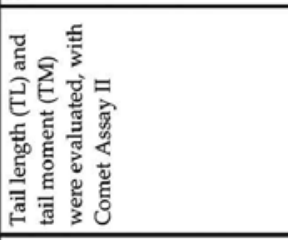 \\
\hline 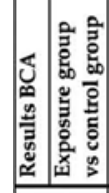 & 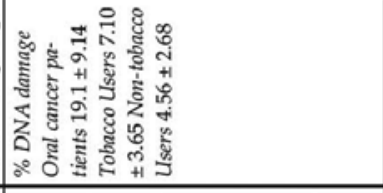 & 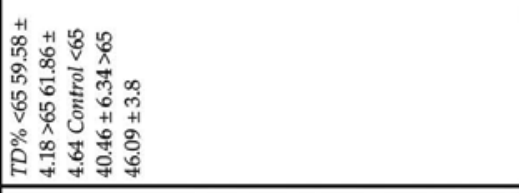 & 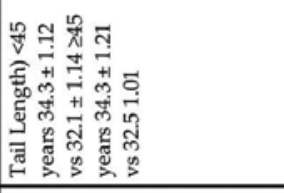 \\
\hline 苋 & 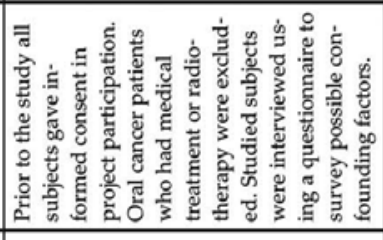 & 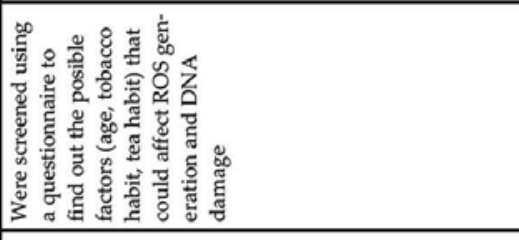 & 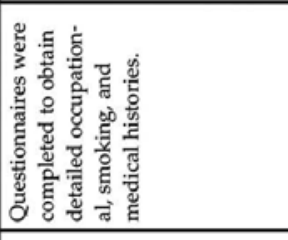 \\
\hline 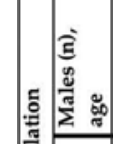 & 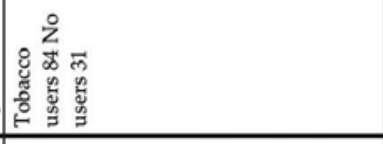 & 8 & 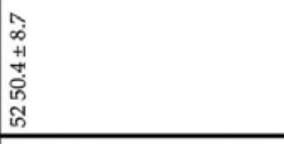 \\
\hline 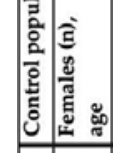 & 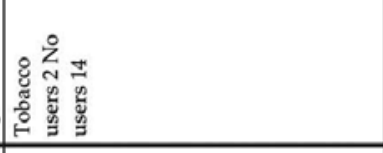 & 2 & 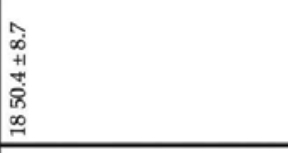 \\
\hline 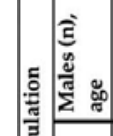 & 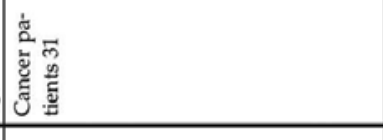 & $\stackrel{2}{2}$ & 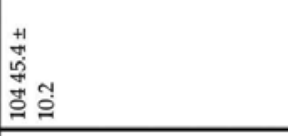 \\
\hline 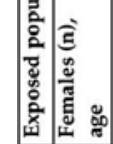 & 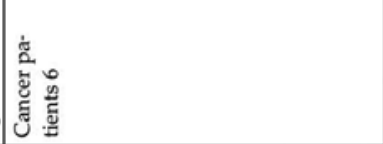 & | & 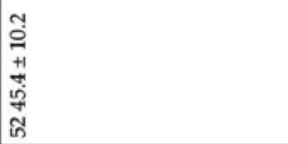 \\
\hline
\end{tabular}




\begin{tabular}{|c|c|c|c|}
\hline $\bar{E}$ & $\bar{g}$ & 喝 & 鉋 \\
\hline & 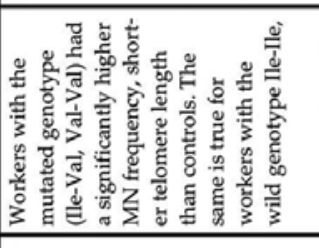 & 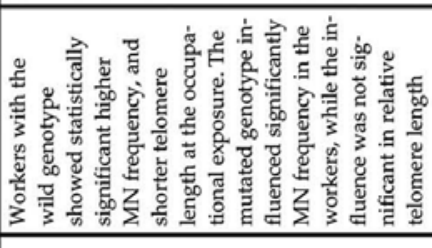 & 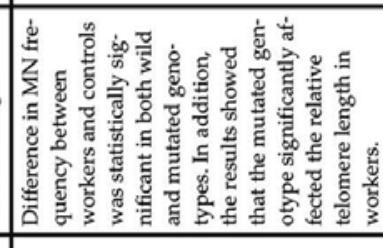 \\
\hline 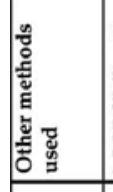 & 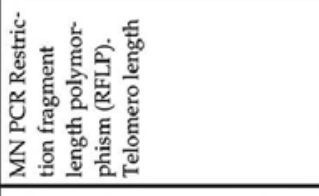 & 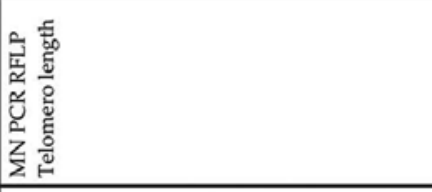 & 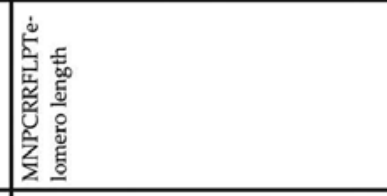 \\
\hline$\frac{8}{8}$ & 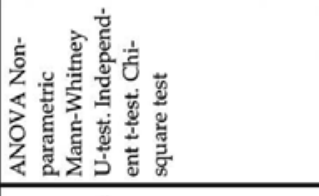 & 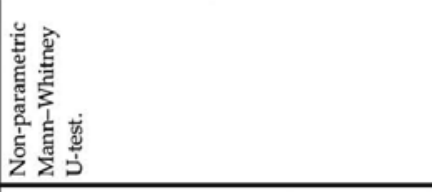 & 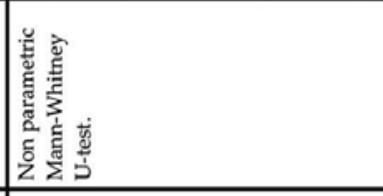 \\
\hline 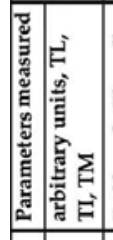 & 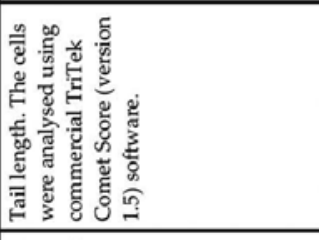 & 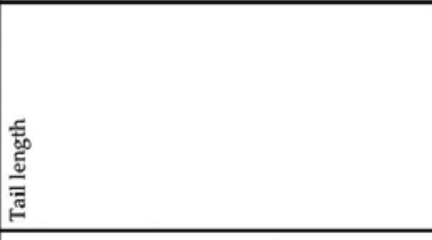 & 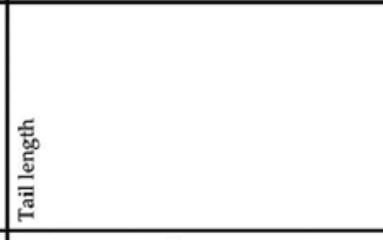 \\
\hline 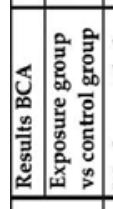 & 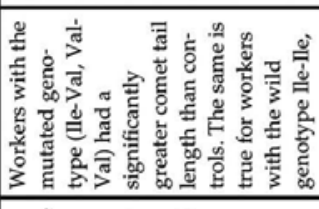 & 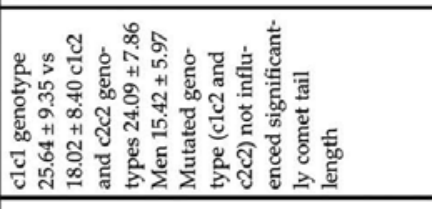 & 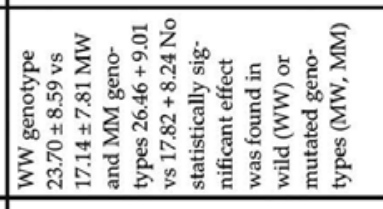 \\
\hline 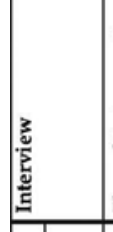 & 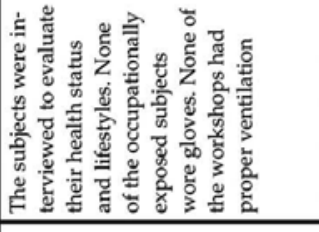 & 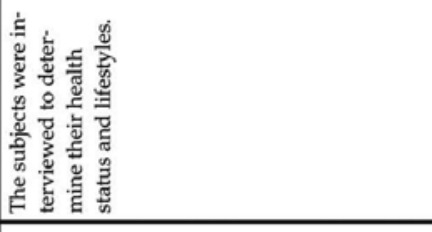 & 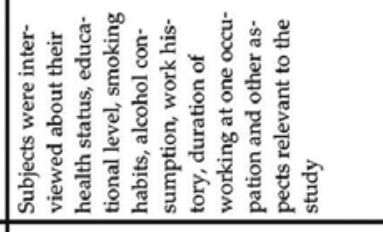 \\
\hline 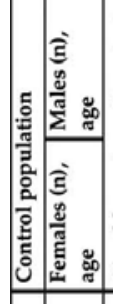 & 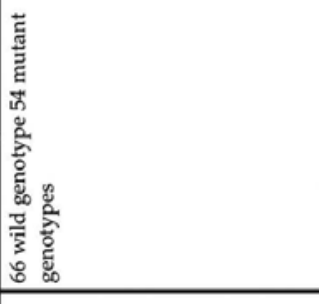 & 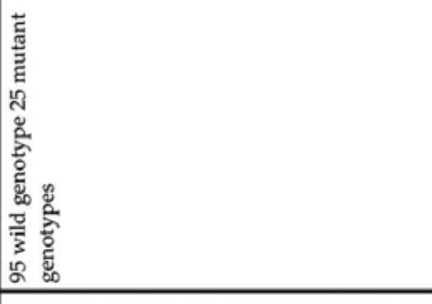 & 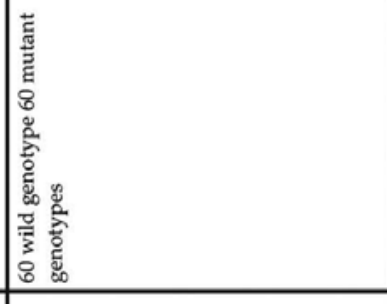 \\
\hline 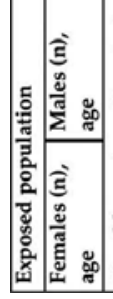 & 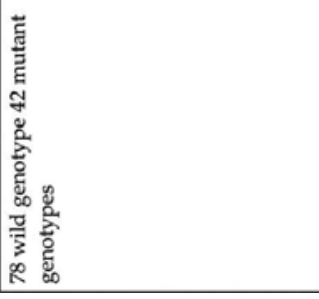 & 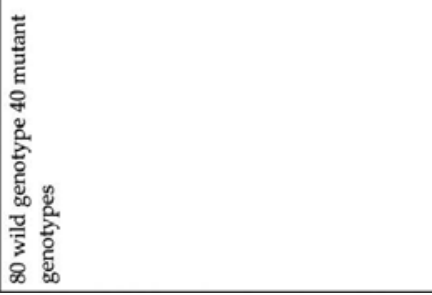 & 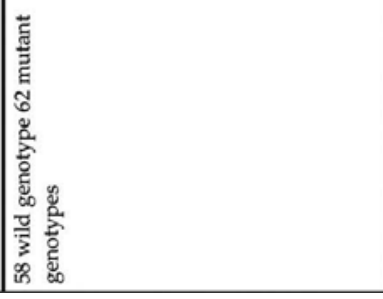 \\
\hline
\end{tabular}




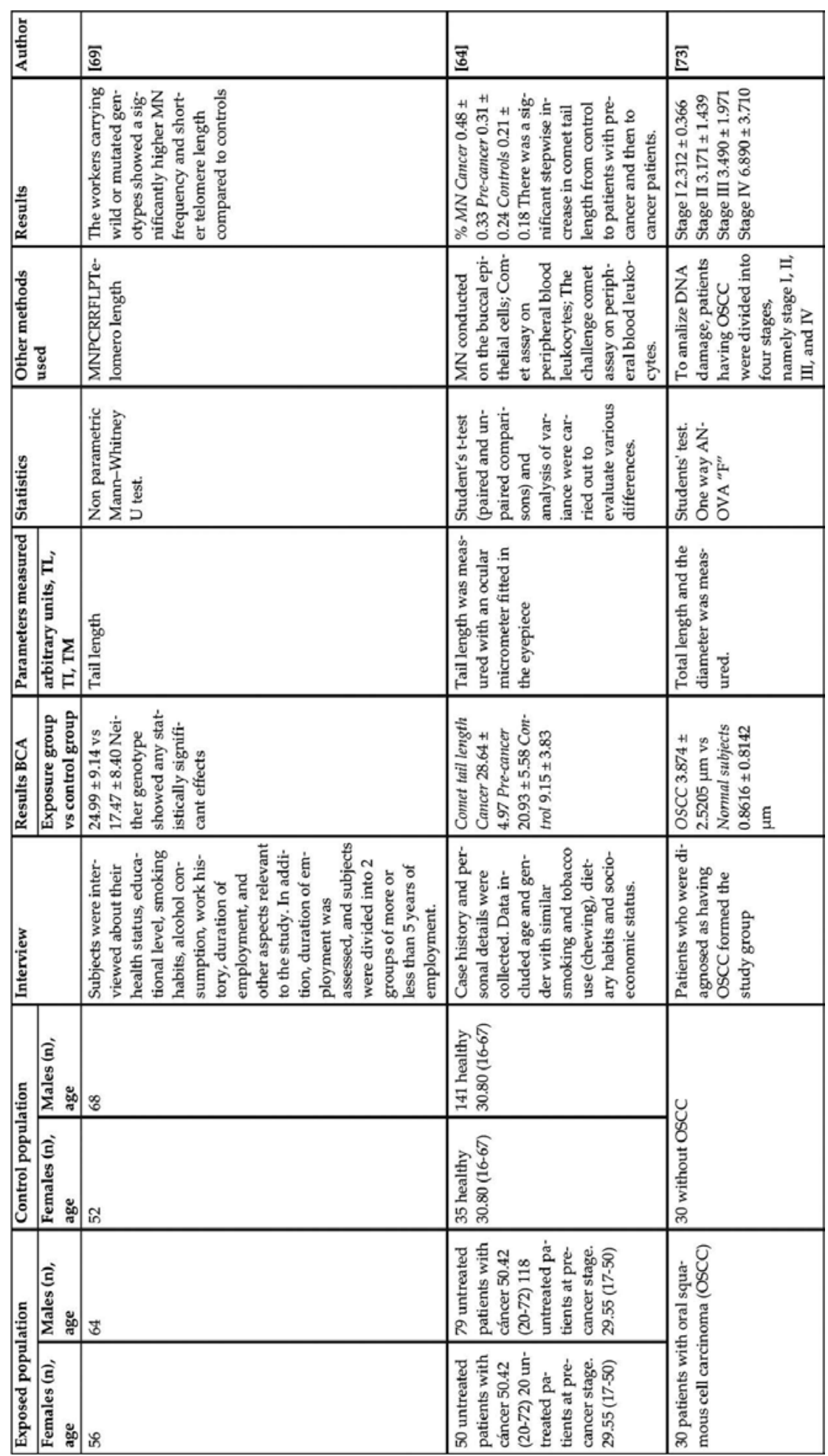




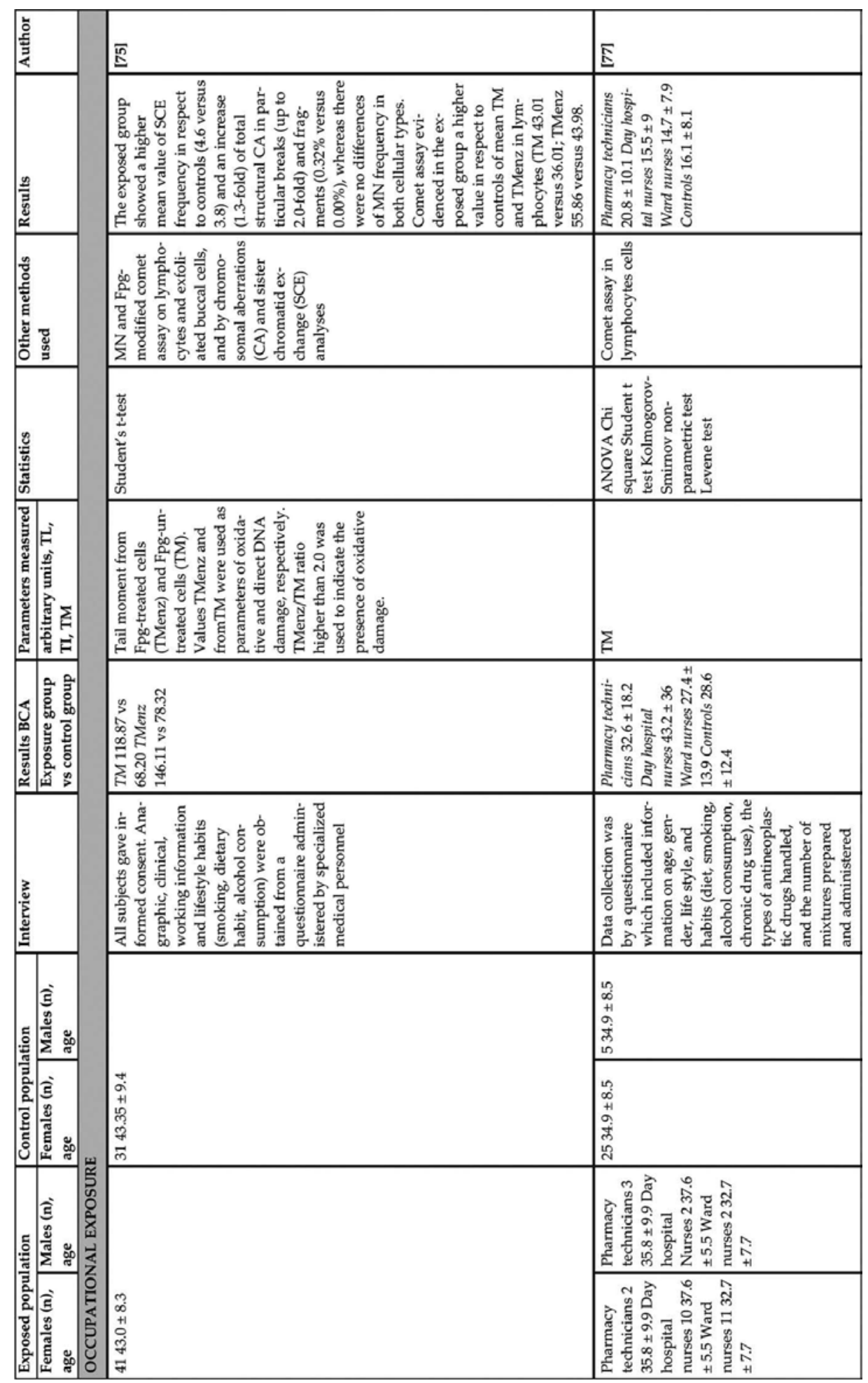




\begin{tabular}{|c|c|c|}
\hline 总 & $\underline{\underline{\Phi}}$ & E \\
\hline 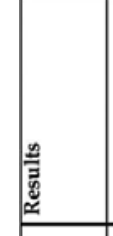 & & 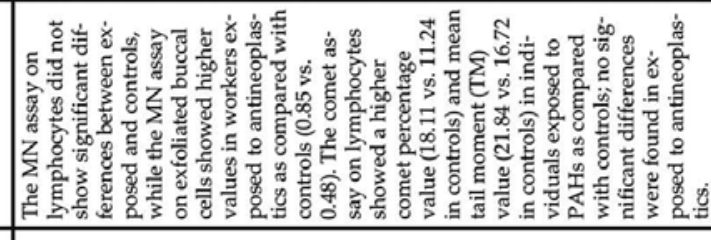 \\
\hline 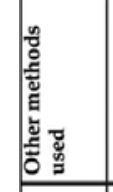 & & 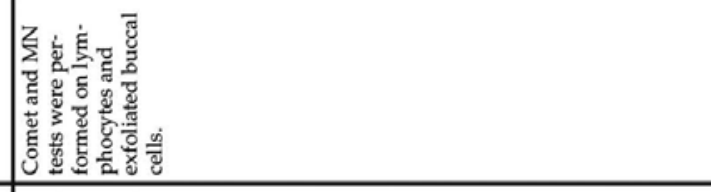 \\
\hline 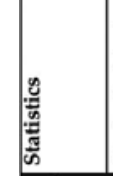 & 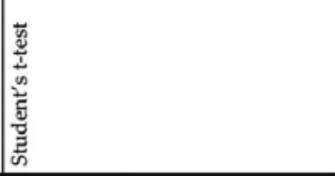 & 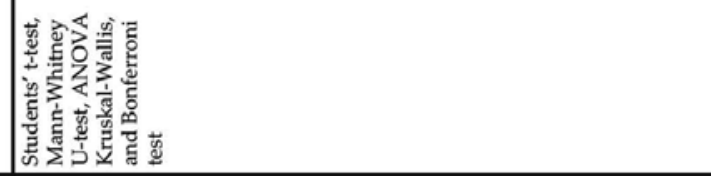 \\
\hline 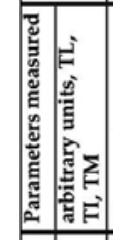 & 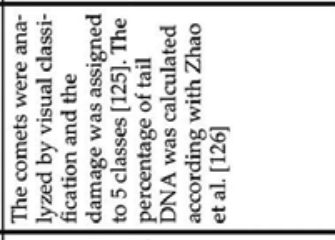 & 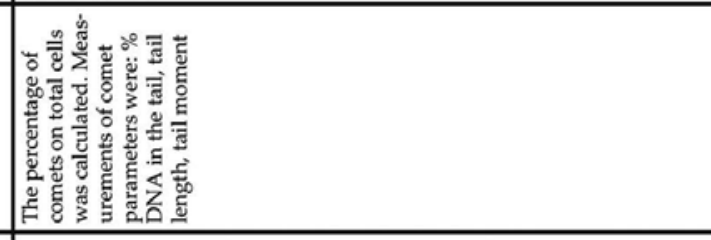 \\
\hline 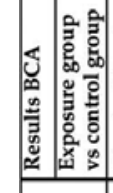 & 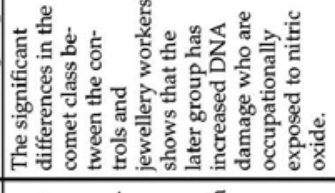 & 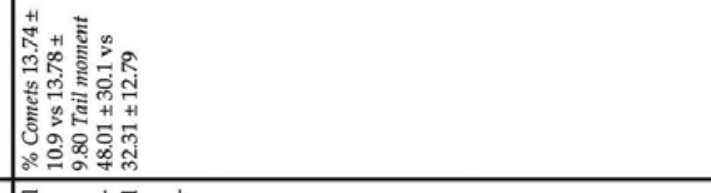 \\
\hline & 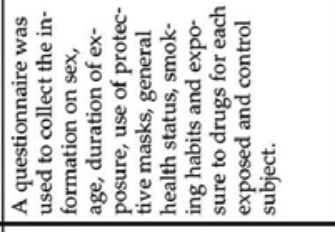 & 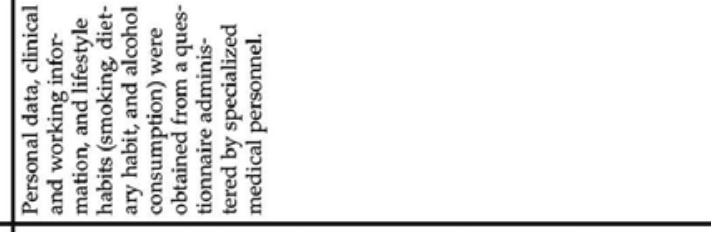 \\
\hline 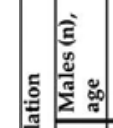 & & \\
\hline 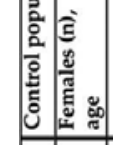 & & 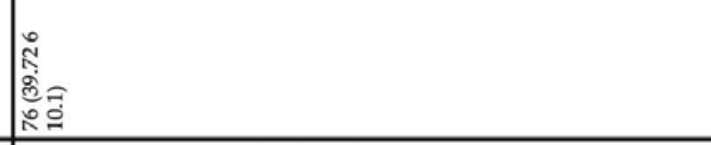 \\
\hline 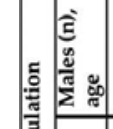 & & \\
\hline 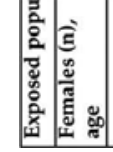 & & 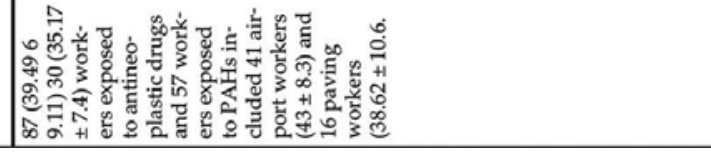 \\
\hline
\end{tabular}




\begin{tabular}{|c|c|c|}
\hline 总 & వ & 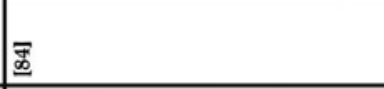 \\
\hline & 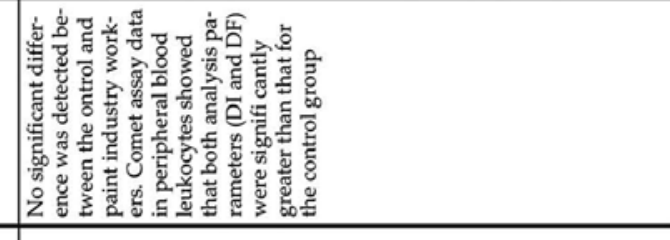 & 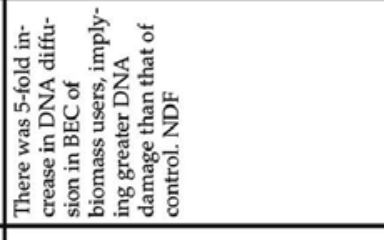 \\
\hline & 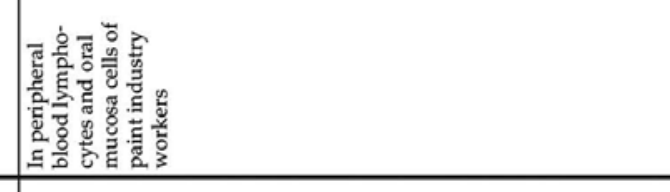 & 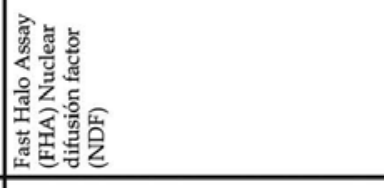 \\
\hline & 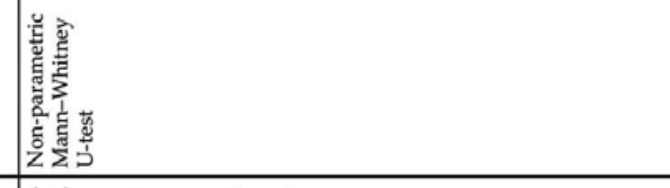 & 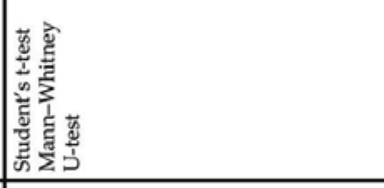 \\
\hline 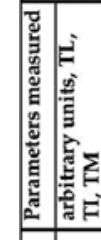 & 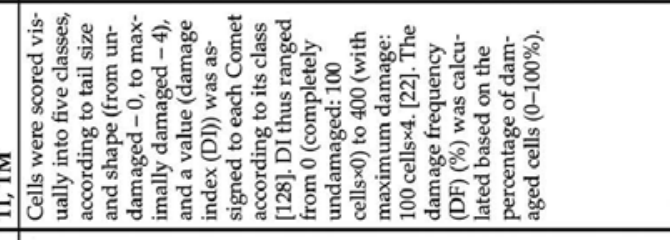 & 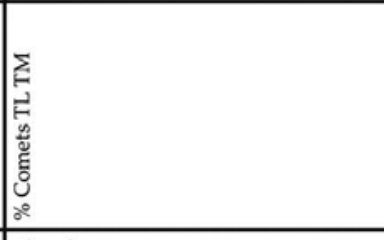 \\
\hline 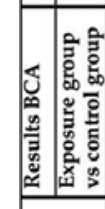 & 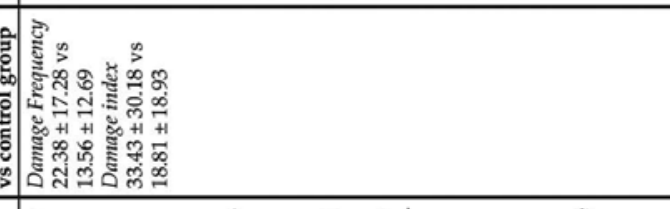 & 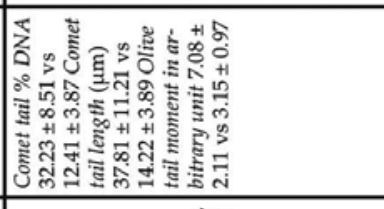 \\
\hline हू & 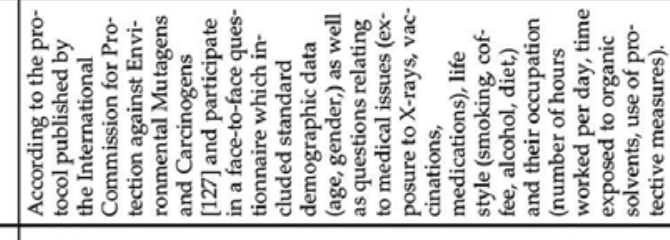 & 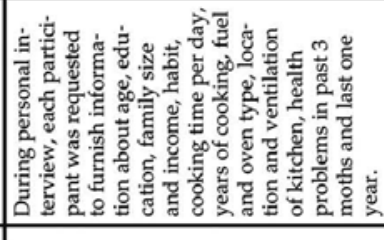 \\
\hline & 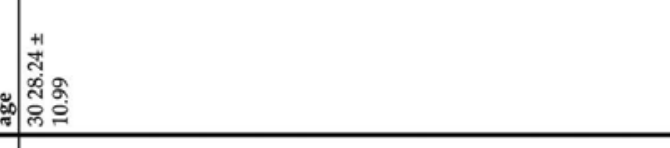 & \\
\hline 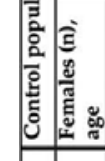 & & 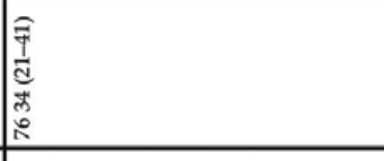 \\
\hline 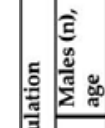 & 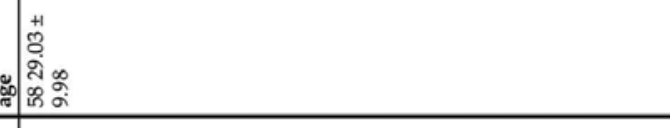 & \\
\hline 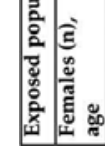 & & \\
\hline
\end{tabular}




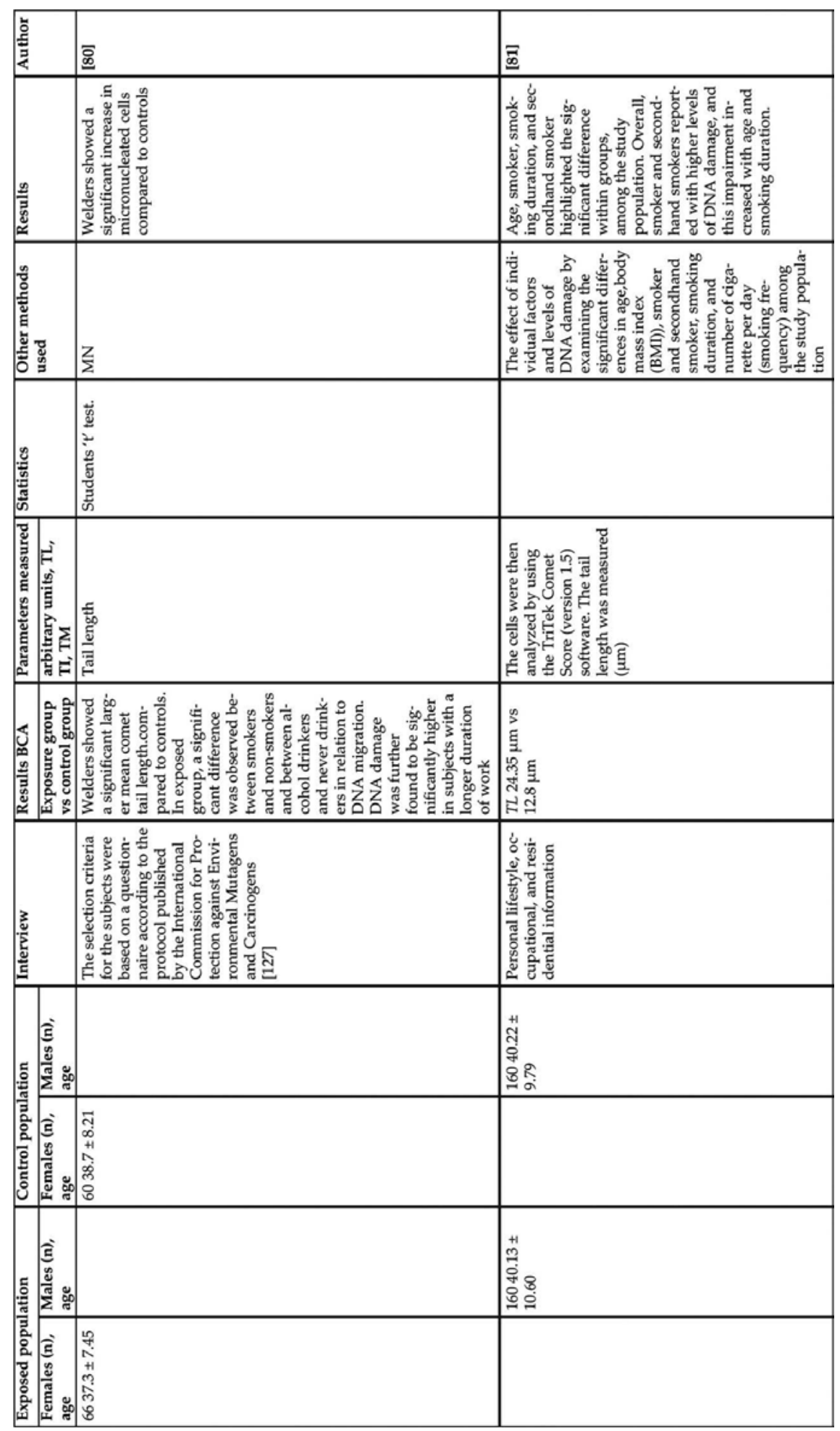




\begin{tabular}{|c|c|c|c|}
\hline \begin{tabular}{|l|l} 
\\
\\
\end{tabular} & $\overline{\underline{\alpha}}$ & $\underline{\underline{\underline{\underline{X}}}}$ & $\underline{\underline{\underline{\underline{D}}}}$ \\
\hline 焉 & 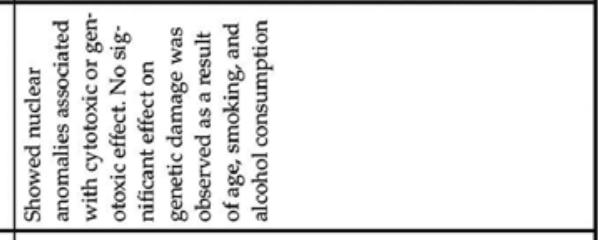 & 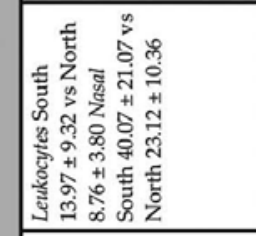 & 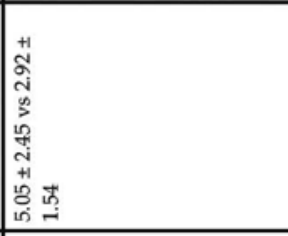 \\
\hline & 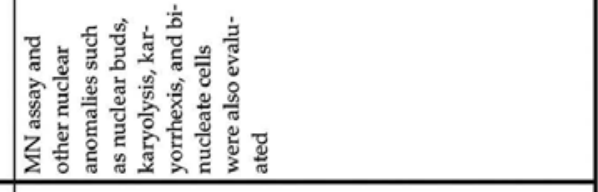 & 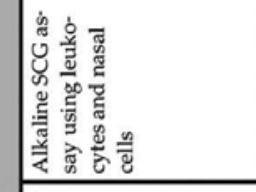 & $\frac{z}{\Sigma}$ \\
\hline 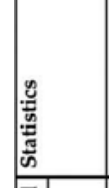 & 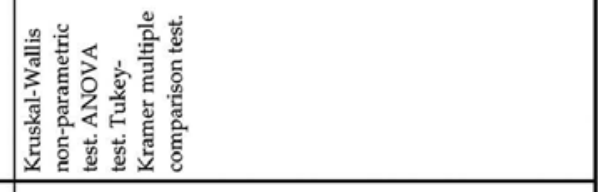 & 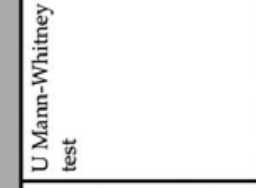 & \begin{tabular}{|l}
$\frac{4}{4}$ \\
$\frac{5}{5}$ \\
5
\end{tabular} \\
\hline 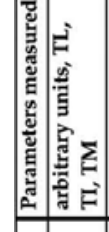 & 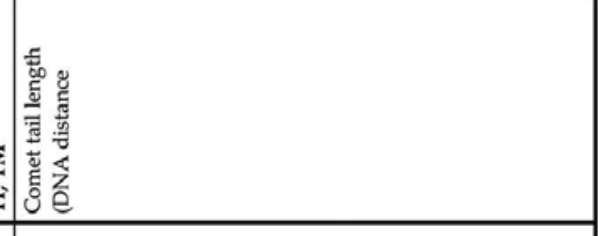 & 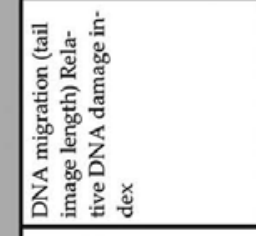 & 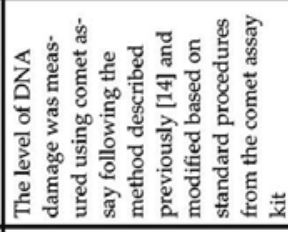 \\
\hline 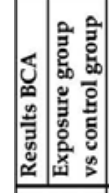 & 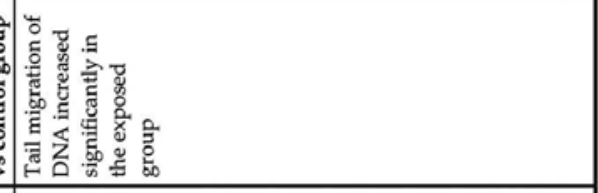 & 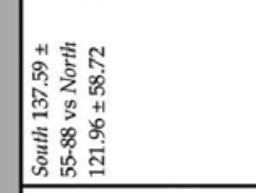 & 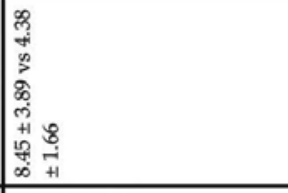 \\
\hline 胥 & 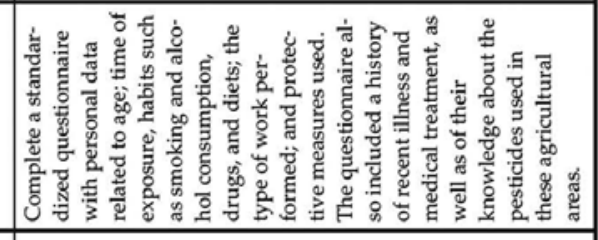 & 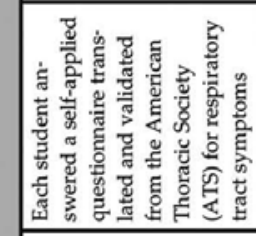 & \\
\hline 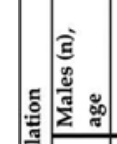 & & & 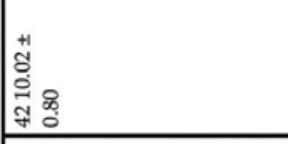 \\
\hline 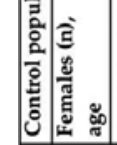 & 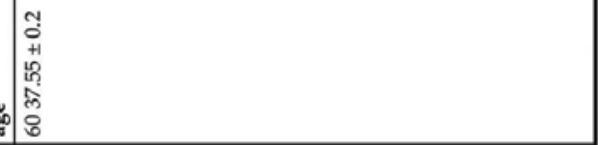 & 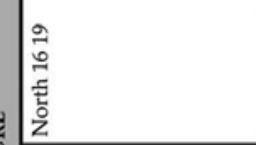 & 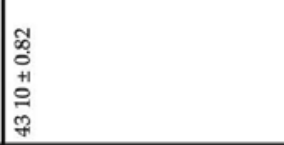 \\
\hline 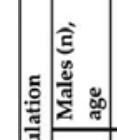 & & & 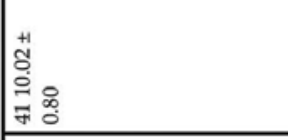 \\
\hline 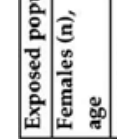 & 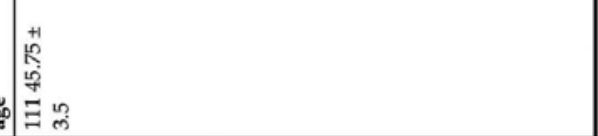 & 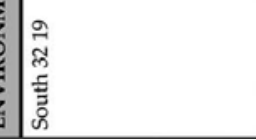 & \\
\hline
\end{tabular}



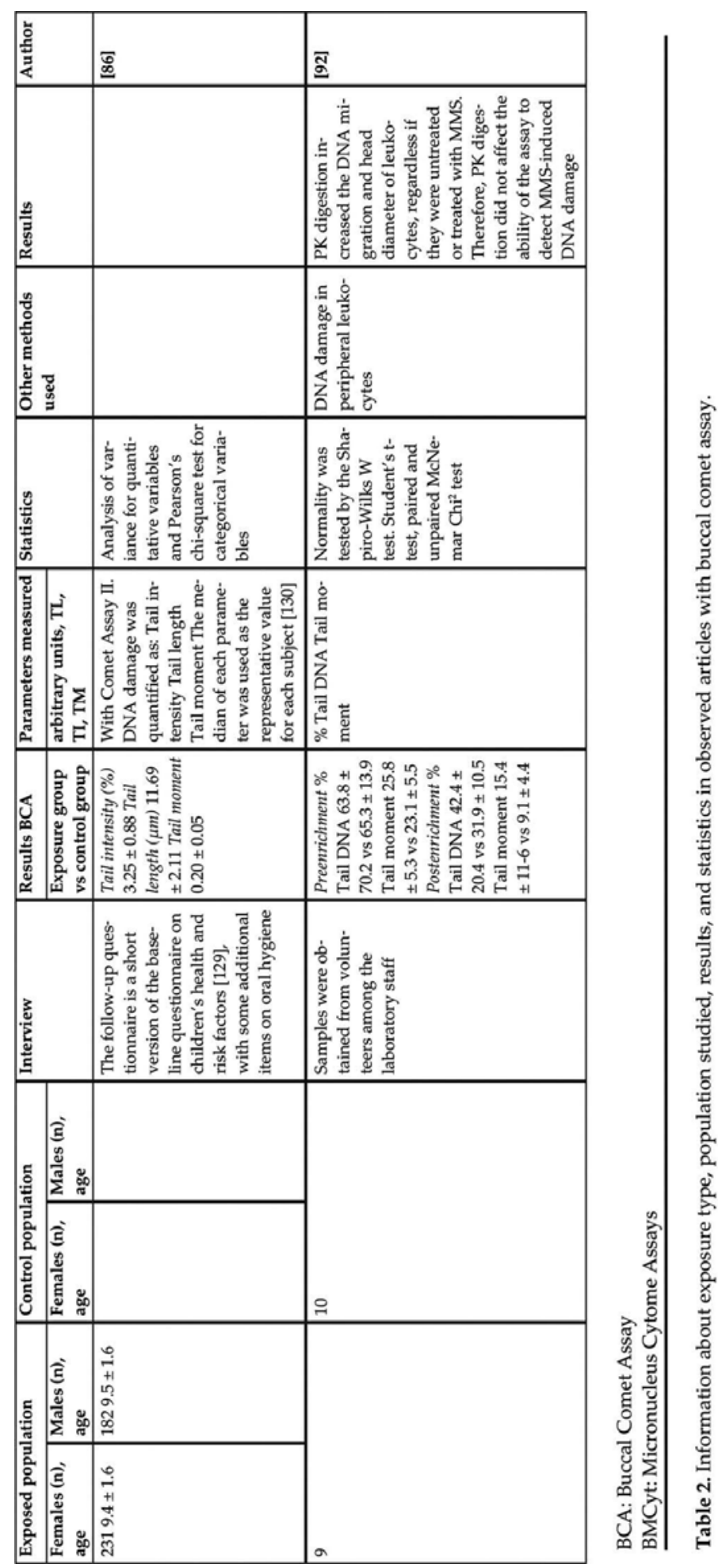
None of demographic or lifestyle factors tested as possible confounding factors (age, gender, dietary habits, $\mathrm{pH}$ of saliva, alcohol, smoking habits, drug intake, and others have exhibited significant influence on values of comet assay parameters in buccal cells [55,56,64,66,67,76,82, $83,85]$. On contrary, Pal et al. [62] in their evaluation of various confounding factors like age, tenure of tobacco habit, and tea habit showed significant associations with DNA damage. In the same line, Sudha et al. [80] showed that the combined exposure to cigarette smoke and $\mathrm{Cr}(\mathrm{VI})$ increased basal DNA damage in buccal epithelial cells of welders. How et al. [81] characterized potential risk factors that influence levels of DNA damage from exposure to mixtures of organophosphates, among all, age, smoking habit, smoking duration, number of cigarettes (per day); and secondhand smokers highlighted the significant differences between subjects and within groups. Martín-Cameán et al. [57] observed that DNA damage in buccal cells induced for orthodontic appliances was higher in women, and Jayakumar and Sasikala [78] found a synergistic effect of the habit of cigarette smoking among the jewellery workers.

\section{Perspectives}

The assessment of genotoxic risk in exfoliated buccal cells is a potentially useful and minimally invasive cytogenetic technique for measuring DNA damage in humans [7,12,17,18,46].

The comet assay is a widely used biomonitoring tool for DNA damage. The most commonly used cells in human studies are peripheral lymphocytes, harvested from venous or capillary blood. However, there is an urgent need to find an alternative target human cell that can be collected from normal subjects with minimal invasion [61].

Buccal cells are becoming an increasingly popular tissue source in human biomonitoring after exposure to occupational and environmental genotoxicants, particularly because they can be obtained non-invasively $[50,61,90,91]$. However, the number of publications referring to the human buccal comet assay is low in the last two decades. This low growing interest may be explained by several factors, including its relative technical problems.

A priority in this field should be to develop a protocol that could enable buccal cell lysis and DNA damage testing in the comet assay and to use the model to evaluate the potential of the buccal cells in human biomonitoring study [61].

Specialized cellular membranes, which make cell lysis difficult, contribute to making buccal mucosa cells a more complicated cell to SCGE assay [92]. As firstly mentioned in the review of Rojas et al. [33], there are studies that use proteinase K together with the lysis step in order to gain free nucleoids, and there are studies that do not use this enrichment, but only lysis solution, and it has been shown that results depend on this step. Szeto et al. [61] described the development of an improved protocol in which agarose embedded cells of epithelial origin from the mouth were digested with trypsin and proteinase $\mathrm{K}$. Their early trials with buccal cells following the published protocol by Rojas et al. [14] were completely unsuccessful. They found that buccal cells sustained massive damage and disintegration at the high $\mathrm{pH}$ used, while at lower $\mathrm{pH}$ values, the cells were extremely resistant to lysis. According to these authors, 
it is not possible to use earlier protocol developed as it leads to extremely high background levels. The adequate experimental design of SCGE trials in buccal cells is still a matter of debate, and the evaluation of the available data shows that there is an urgent need to develop guidelines [93].

Proper collection and storage of human (buccal) cells is essential step in order to preserve their integrity for later analysis by the comet assay [26,27]. After collection, more than $90 \%$ of the cells in a buccal sample are epithelial cells, a cell type with well-known low viability (10\%) [91]. Although a prerequisite for using any cell type in the comet assay is that those cells must be viable $[92,94]$, most of the reported studies did not consider this important factor. Failure in controlling of these confounding variables can lead to an over/under estimation of the DNA damage caused by exposure on work-place or in assessment of exposure to environmental genotoxicants [86]. Cell viability is expected to be low in epithelial tissue with terminally differentiated cell populations and a high renewal rate as buccal cells [95]. Dead or dying cells are extensively damaged (e.g., DNA fragmentation), and therefore, subjecting them to the alkaline conditions of the comet assay only increases DNA loss. Comet assay studies on epithelial buccal cell samples have reported high percentage of DNA "clouds" (>95\%) [96]. Those clouds are excluded from the final quantitative analysis and that generally results in very low numbers of counted comets. Higher percentage of these atypical comets demonstrates that epithelial cells are not suitable for measuring DNA damage by the comet assay. Also enzymatic digestion such as proteinase $\mathrm{K}$ treatment is an essential step to enrich the number of epithelial viable cells, thus promoting necrotic cells destruction that are very numerous in the mucosa epithelium and have a very fast turnover. Enzymatic treatment with proteinase $\mathrm{K}$ caused degradation of leukocytes, mainly polymorphonuclear, which represent a great fraction of cells in the oral mucosa, due to migration from the blood through the gingival crevice [91].

Another problem in cell collection is that final cell suspension usually consists of mixture of epithelial cells and leukocytes with well-known fact that leukocyte fraction is more viable than epithelial cell fraction [91]. Pinhal et al. [92] investigated whether human buccal mucosa cells are suitable for use in the SCGE assay. After comparison of smoker/non-smoker group, there was no correlation of long-term smoking with the number of buccal cells that formed comets and represented damaged cells. They have also concluded that the cells that formed comets are probably leukocytes, and not buccal cells, and that the SCGE assay, used on a commonly performed way, without modifications, may not be useful for genotoxicity monitoring in human epithelial buccal mucosa cells. Similar conclusions were cited by Ribeiro [97].

In contrast, the uniform distribution of DNA within the heads of oral leukocytes and their greater viability indicates that this cell type is more suitable for assessing DNA damage in buccal samples [86]. Thus, recently McCauley et al. [98] and Kisby et al. [99] examined oral leukocytes of agricultural workers by the comet assay and demonstrated that DNA damage is greater in farmworkers who were exposed to pesticides.

As mentioned above, other alternative is to isolate lymphocytes from cells suspensions collected from the mouth and develop a technique for SCGE analyses, like it was followed by 
Osswald et al. [91], and later, it was successfully implemented in an intervention trial with supplemented bread by Glei et al. [87].

The use of buccal epithelial cells to determine genotoxicity using the comet assay according to the procedure outlined by Singh et al. [100] was limited by the inability to obtain free nucleoids. In a recent review, Rojas et al. [33] showed that a broad variety of different protocols has been used in earlier investigations. No effort has been made so far to establish an international consortium which could develop and validate appropriate strategies for the use of SCGE assay in buccal cells. More information is required concerning the time and design of different phases, the duration of wash-out periods, the calibration of enzymes and other important factors which may influence the outcome of the experiments as has been proposed by Hoelzl et al. [93] for the use of SCGE assays for the detection of DNA-protective effects of dietary factors in humans.

\section{Considerations}

According to Rojas et al. [33], the use of alternative biomatrices to assess DNA damage in human populations has advantages and shortcomings focusing on the methodological characteristics of buccal mucosa cells and taking into consideration the sampling protocol, preprocessing, and post-sampling storage, as well as the possibilities of sample freezing and the need to adapt the classical alkaline comet assay protocol.

The use of buccal mucosa cells by comet assay in order to estimate DNA damage levels gives the possibility to obtain samples on cheap, safe, and non-invasive way in order to perform in vivo studies. Direct contact with xenobiotics and endogenous damage inductors makes this type of sample an attractive biomatrice for individual genotoxicity evaluation. Their applicability in clinical diagnostic confers a potential use in patients across time.
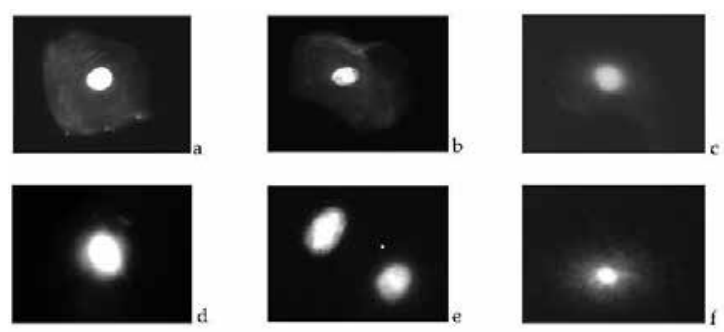

Figure 1. Picture of single buccal mucosa cells: (a) immediately stained after the solidification of agarose gel layer with sample cells, (b) the appearance of cells with cytoplasm after $1 \mathrm{~h}$ of classical lysis solution, (c) the appearance of the cells with cytoplasm after the combined treatment of lysis solution and proteinase $\mathrm{K}(1 \mathrm{mg} / \mathrm{ml})$ for $1 \mathrm{~h}$ at $37^{\circ} \mathrm{C}$, (d) the appearance of cells after $24 \mathrm{~h}$ of normal lysis, (e) the appearance of cells after $24 \mathrm{~h}$ of normal lysis and treatment with proteinase $\mathrm{K} 10 \mathrm{mg} / \mathrm{ml}$ for $1 \mathrm{~h}$ at $37^{\circ} \mathrm{C}$, (f) $0.25 \%$ trypsin $30 \mathrm{~min}$ plus proteinase $\mathrm{K} 1 \mathrm{mg} / \mathrm{ml} 1 \mathrm{~h}, 37^{\circ} \mathrm{C}$. 
The comet assay in exfoliated buccal cells has been used since the 1990s to demonstrate cytogenetic effects of environmental and occupational exposures, lifestyle factors, dietary deficiencies, and different diseases.

The general guideline to perform comet assay in epithelial cells requires the correct sampling procedure, to follow the alkaline version proposed by Singh et al. [100]. In this sense, Rojas et al. [33] proposed protocols specific to sampling protocol and sample storage and comet assay sample preparation for buccal mucosa cells. We have also performed the protocols suggested by Rojas, but there have been some confusing factors. Rojas recommendation did not give free DNA neither in first case of lysis treatment for $1 \mathrm{~h}$ or lysis treatment with proteinase $\mathrm{K}$ for $1 \mathrm{~h}$ (pictures represented in Figure 1). We have also tried the protocols that Szeto et al. [61] have done in order to established the best one, but in our case, we have demonstrated that although cells are embedded on agarose gel, treatment with $0.25 \%$ trypsin and then proteinase $\mathrm{K}$ for 1 $\mathrm{h}$ is too aggressive and still gives cloudy free nuclei. For us, the best results were with lysis and proteinase $\mathrm{K} 10 \mathrm{mg} / \mathrm{ml}$ 1-h treatment on $37^{\circ} \mathrm{C}$. It seems that also high $\mathrm{pH}$ of alkaline denaturation and electrophoresis makes massive DNA damage, as already mentioned in Szeto et al. [61]. As Szeto et al. [61] already mentioned, buccal cells as a type of stratified squamous epithelium do not divide but undergo a terminal differentiation from basal cells on order to form a protective barrier (cell envelope rich in a small prolinerich protein) that will protect the buccal cell from very harmful environment in the mouth and also will give resistance of buccal cells to lysis. On Figure 2, we have represented some pictures of the buccal cells after lysis and electrophoresis in alkaline conditions ( $\mathrm{pH}>13$ ). Szeto el al. [61] suggested that denaturation and electrophoresis in neutral conditions would be more appropriate. According to our

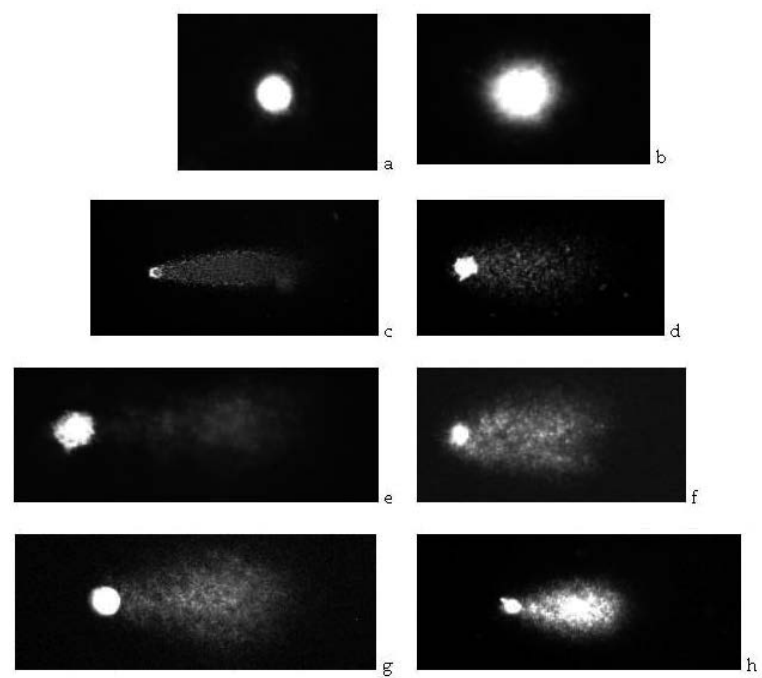

Figure 2. Pictures of buccal cells after different duration and type of lysis step, but all electrophoresis were at $\mathrm{pH}>13$ : (a) treatment of lysis solution for $15 \mathrm{~h} 4^{\circ} \mathrm{C}$, (b) lysis step for $20 \mathrm{~h} 4^{\circ} \mathrm{C}$, (c) treatment with $0.25 \%$ trypsin for 30 min, and lysis for $30 \mathrm{~min}$, both at $37^{\circ} \mathrm{C}$, (d) $15 \mathrm{~min}$ of $0.25 \%$ trypsin a $37^{\circ} \mathrm{C}, 15 \mathrm{~min}$ of proteinase $\mathrm{K} 1 \mathrm{mg} / \mathrm{ml}$, (e) 30 min of proteinase $\mathrm{K} 1 \mathrm{mg} / \mathrm{ml}$ at room temperature, $60 \mathrm{~min}$ of lysis at $4^{\circ} \mathrm{C}$, (f) $24 \mathrm{~h}$ of lysis at $4^{\circ} \mathrm{C},(\mathrm{g}, \mathrm{h}) 20 \mathrm{~h}$ of lysis at $4^{\circ} \mathrm{C}$. 
knowledge, alkaline conditions are also appropriate, but also this part needs further investigation.

A review of risk factors affecting background rates of parameters in the comet assay in cells of oral mucosa should be undertaken with a view to help in the interpretation of genotoxicity biomonitoring studies. Both endogenous factors and those due to methodological variation should be evaluated. Background variation of other indices of genotoxicity in buccal mucosa cells should be also considered as these data likely reflect overlapping causes of DNA damage and may provide some indicators for future research areas. A number of host risk factors, namely age, gender, smoking, vitamin status, alcohol consumption, disease conditions and infections, physical exercise, body mass index, and genotype should be identified, since there are evidences that they have an impact on background levels of genotoxicity biomarkers. Evaluation of these factors should be routinely included in genotoxicity biomonitoring studies [101].

However, important knowledge gaps remain about the methodologic procedures in laboratories around the world. To address these uncertainties, it will be necessary to develop similar projects as the HUMN and HUMNxL for validation of the lymphocytes and buccal cell MN assay, respectively $[7,12,17,18]$. Future research should explore sources of variability in the assay and resolve key technical issues, such as the method of buccal cell sample and sample storage, slide preparation, enzyme treatment, and optimal criteria for the classification of normal and degenerated cells. The harmonization and standardization of the buccal comet assay will allow more reliable comparison of the data among human populations and laboratories, evaluation of the assay's performance, and consolidation of its worldwide use for biomonitoring of DNA damage.

In order that comet assay in buccal cells has widespread acceptance and credibility in human population studies, standardization of analyzed parameters and protocol is necessary and also a better knowledge of critical features affecting the assay outcomes, including the definition of the values of spontaneous DNA damage. Developing the network of laboratories using this technique and performing and international collaborative studies would be an ideal solution. Result of connecting would be the assembly of large databases which would allow a more detailed analysis of the assays performance and study of the biological/clinical events associated with this biomarker.

The need for a careful consideration of factors affecting the comet assay in cells of oral mucosa exists, which, in turn, should aid in the interpretation of studies of environmental and occupational chemical exposures and health risk. There is a need for further collaborative work as in the HUMN collaborative project which has reported data on $~ 7000$ individuals $[15,16,102-104]$. If these measures are achieved, then it would be possible to use the data from biomonitoring studies in risk assessments to derive risk management measures [95]. Based on the experience of the HUMN project [96], the Conference on Environmental Mutagens in Human Populations [105,106], and the HUMNxL project, design of the studies could be similar to (i) identify technical variables that affect the measurement of DNA damage of buccal cells assessed with comet assay, (ii) identify lifestyle variables affecting this damage, (iii) identify protocol variables that affect the recovery of buccal cells and their scoring in comet assay, (iv) 
design intra- and inter-laboratory validation studies based on the results of information collected for the method and scoring criteria, and (v) determine the role of buccal genomic damage monitoring and the prediction of cancer and other degenerative diseases.

The creation of a network of laboratories will allow more focused validation studies, including the design of a classic, historic, prospective cohort study, to explore the link between measures of genetic instability in the buccal mucosa and the risk of cancer and other chronic-degenerative diseases [12]. ComNet project and new COST project are a great step forward.

\section{Acknowledgements}

The authors thank Ana Rosa Flores-Márquez for her technical assistance; MS Makso Herman for English review and Rafael Alexander Valencia-Sánchez for editing assistance.

\section{Author details}

J. Sánchez-Alarcón ${ }^{1}$, M. Milić ${ }^{2}$ S. Gómez-Arroyo 3 , J. M. R. Montiel-González ${ }^{1}$ and R. Valencia-Quintana ${ }^{1 *}$

*Address all correspondence to: prvq2004@yahoo.com.mx

1 Laboratorio “Rafael Villalobos-Pietrini” de Toxicología Genómica y Química Ambiental, Facultad de Agrobiología, Universidad Autónoma de Tlaxcala, Tlaxcala, México

2 Institute for Medical Research and Occupational Health, Mutagenesis Unit, 10, Zagreb, Croatia

3 Laboratorio de Genotoxicología Ambiental, Centro de Ciencias de la Atmósfera, UNAM, Coyoacán, México, D.F., México

\section{References}

[1] International Agency for Research on Cancer. IARC Monographs on the Evaluation of Carcinogenic Risk to Humans [Internet]. 2016 [Updated: 2016]. Available from: http:// monographs.iarc.fr/ [Accessed: 03 Feb 2016]

[2] International Programme on Chemical Safety INCHEM. Environmental Health Criteria Monographs (EHCs) 214 [Internet]. 2000 [Updated: 2000]. Available from: http://www.inchem.org/documents/ehc/ehc/ehc214.htm [Accessed: 03 Feb 2016] 
[3] OECD. OECD Guidelines for the Testing of Chemicals [Internet]. 2015 [Updated: 2015]. Available from: http://www.oecd.org/chemicalsafety/testing/oecdguidelinesforthetestingofchemicals.htm [Accessed: 03 Feb 2016]

[4] Cohen SM. Human carcinogenic risk evaluation: An alternative approach to the twoyear rodent bioassay. Toxicol Sci. 2004; 80:225-229. DOI: 10.1093/toxsci/kfh159

[5] Borràs M, Nadal J. Biomarkers of genotoxicity and other end-points in an integrated approach to environmental risk assessment. Mutagenesis. 2004; 19:165-168. DOI: 10.1093/mutage/geh023

[6] Hattis DB. The promise of molecular epidemiology for quantitative risk assessment. Risk Anal. 1986; 6:181-193. DOI: 10.1111/j.1539-6924.1986.tb00206.x

[7] Holland N, Bolognesi C, Kirsch-Volders M, Bonassi S, Zeiger E, Knasmueller S, Fenech $\mathrm{M}$. The micronucleus assay in human buccal cells as a tool for biomonitoring. DNA damage: the HUMN project perspective on current status and knowledge gaps. Mutat Res. 2008; 659:93-108. DOI: 10.1016/j.mrrev.2008.03.007

[8] Migliore L, Colognato R, Naccarati A, Bergamaschi E. Relationship between genotoxicity biomarkers in somatic and germ cells: findings from a biomonitoring study. Mutagenesis. 2006; 21:149-152. DOI: 10.1093/mutage/gel012

[9] Migliore L, Naccarati A, Coppedè F, Bergamaschi E, De Palma G, Voho A, Manini P, Järventaus H, Mutti A, Norppa H, Hirvonen A. Cytogenetic biomarkers, urinary metabolites and metabolic gene polymorphisms in workers exposed to styrene. Pharmacogenet Genomics. 2006; 16:87-99. DOI: 10.1097/01.fpc.0000182783.70006.44

[10] Ceppi M, Biasotti B, Fenech M, Bonassi S. Human population studies with the exfoliated buccal micronucleus assay: statistical and epidemiological issues. Mutat Res. 2010; 705:11-19. DOI: 10.1016/j.mrrev.2009.11.001.)

[11] Thomas P, Holland N, Bolognesi C, Kirsch-Volders M, Bonassi S, Zeiger E, Knasmueller S, Fenech M. Buccal micronucleus cytome assay. Nat Protoc. 2009; 4:825-837. DOI: 10.1038/nprot.2009.53

[12] Bonassi S, Coskun E, Ceppi M, Lando C, Bolognesi C, Burgaz S, Holland N, KirshVolders M, Knasmueller S, Zeiger E, Carnesoltas D, Cavallo D, da Silva J, de Andrade VM, Demircigil GC, Domínguez Odio A, Donmez-Altuntas H, Gattas G, Giri A, Giri S, Gómez-Meda B, Gómez-Arroyo S, Hadjidekova V, Haveric A, Kamboj M, Kurteshi K, Martino-Roth MG, Montero Montoya R, Nersesyan A, Pastor-Benito S, Favero Salvadori DM, Shaposhnikova A, Stopper H, Thomas P, Torres-Bugarín O, Yadav AS, Zúñiga González G, Fenech M. The HUman MicroNucleus project on eXfoLiated buccal cells $(\mathrm{HUMN}(\mathrm{XL}))$ : the role of life-style, host factors, occupational exposures, health status, and assay protocol. Mutat Res. 2011;728:88-97. DOI: 10.1016/j.mrrev.2011.06.005

[13] OECDLibrary. Test No. 489: In Vivo Mammalian Alkaline Comet Assay [Internet]. 16 Sep 2014 [Updated: 16 Sep 2014]. Available from: http://www.oecd-ilibrary.org/ 
environment/test-no-489-in-vivo-mammalian-alkaline-comet-assay_9789264224179en [Accessed: 03 Feb 2016]. DOI :10.1787/9789264224179-en

[14] Rojas E, Valverde M, Sordo M, Ostrosky-Wegman P. DNA damage in exfoliated buccal cells of smokers assessed by the single cell gel electrophoresis assay. Mutat Res. 1996; 370:115-120. DOI: 10.1016/0165-1218(96)00062-6

[15] Fenech N, Chang WP, Kirsch-Volders M, Holland N, Bonassi S, Zeiger E. HUMN project: detailed description of the scoring criteria for the cytokinesisblock micronucleus assay using isolated human lymphocyte cultures. Mutat Res. 2003; 534:65-75. DOI: $10.1016 /$ S1383-5718(02)00249-8

[16] Fenech M, Bonassi S, Turner J, Lando C, Ceppi M, Chang WP, Holland N, KirschVolders M, Zeiger E, Bigatti MP, Bolognesi C, Cao J, De Luca G, Di Giorgio M, Ferguson LR, Fucic A, Lima OG, Hadjidekova VV, Hrelia P, Jaworska A, Joksic G, Krishnaja AP, Lee TK, Martelli A, McKay MJ, Migliore L, Mirkova E, Müller WU, Odagiri Y, Orsiere T, Scarfi MR, Silva MJ, Sofuni T, Surralles J, Trenta G, Vorobtsova I, Vral A, Zijno A. HUman MicroNucleus project. Intra- and inter-laboratory variation in the scoring of micronuclei and nucleoplasmic bridges in binucleated human lymphocytes. Results of an international slide-scoring exercise by the HUMN project. Mutat Res. 2003; 534:4564. DOI: 10.1016/S1383-5718(02)00248-6

[17] Fenech M, Holland N, Zeiger E, Chang WP, Burgaz S, Thomas P, Bolognesi C, Knasmueller S, Kirsch-Volders M, Bonassi S. The HUMN and HUMNxL international collaboration projects on human micronucleus assays in lymphocytes and buccal cells-past, present and future. Mutagenesis. 2011; 26:239-245. DOI: 10.1093/mutage/geq051

[18] Bolognesi C, Knasmueller S, Nersesyan A, Thomas P, Fenech M. HUMNxL scoring criteria for different cell types and nuclear anomalies in the buccal micronucleus cytome assay - an update and expanded photogallery. Mutat Res. 2013; 753:100-113. DOI: 10.1016/j.mrrev.2013.07.002

[19] Dusinska M, Collins AR. The comet assay in human biomonitoring: gene-environment interactions. Mutagenesis. 2008; 23:191-205. DOI: 10.1093/mutage/gen007

[20] Collins A, Dusinská M, Franklin M, Somorovská M, Petrovská H, Duthie S, Fillion L, Panayiotidis M, Raslová K, Vaughan N. Comet assay in human biomonitoring studies: reliability, validation, and applications. Environ Mol Mutag. 1997; 30:139-146. DOI: 10.1002/(SICI)1098-2280(1997)

[21] Kassie F, Parzefall W, Knasmüller S. Single cell gel electrophoresis assay: a new technique for human biomonitoring studies. Mutat Res. 2000; 463:13-31. DOI: 10.1016/ S1383-5742(00)00041-7

[22] Møller P, Knudsen LE, Loft S, Wallin H. The comet assay as a rapid test in biomonitoring occupational exposure to DNA damaging agents and effect of confounding factors. Cancer Epidemiol Biomarkers Prev. 2000; 9:1005-1015. PMID: 11045781 
[23] Tice RR, Agurell E, Anderson D, Burlinson B, Hartmann A, Kobayashi H, Miyamae Y, Rojas E, Ryu JC, Sasaki YF. Single cell gel/comet assay: guidelines for in vitro and in vivo genetic toxicology testing. Environ Mol Mutagen. 2000; 35:206-221. DOI: 10.1002/ (SICI)1098-2280(2000)

[24] Faust F, Kassie F, Knasmüller S, Boedecker RH, Mann M, Mersch-Sundermann V. The use of the alkaline comet assay with lymphocytes in human biomonitoring studies. Mutat Res. 2004; 566:209-229. DOI: 10.1016/j.mrrev.2003.09.007

[25] Faust F, Kassie F, Knasmüller S, Kevekordes S, Mersch-Sundermann V. Use of primary blood cells for the assessment of exposure to occupational genotoxicants in human biomonitoring studies. Toxicology. 2004; 198:341-350. DOI: 10.1016/j.tox.2004.02.010

[26] Møller P. The alkaline comet assay: towards validation in biomonitoring of DNA damaging exposures. Basic Clin Pharmacol Toxicol. 2006; 98:336-345. DOI: 10.1111/j. 1742-7843.2006.pto_167

[27] Albertini RJ, Anderson D, Douglas GR, Hagmar L, Hemminki K, Merlo F, Natarajan AT, Norppa H, Shuker DE, Tice R, Waters MD, Aitio A. IPCS guidelines for the monitoring of genotoxic effects of carcinogens in humans. International Programme on Chemical Safety. Mutat Res. 2000; 463:111-172. DOI: 10.1016/S1383-5742(00)00049-1

[28] Bates MN, Hamilton JW, LaKind JS, Langenberg P, O'Malley M, Snodgrass W. Workgroup report: biomonitoring study design, interpretation, and communicationlessons learned and path forward. Environ Health Perspect. 2005; 113:1615-1621. DOI: 10.1289/ehp.8197

[29] Bennett DA, Waters MD. Applying biomarker research. Environ Health Perspect. 2005; 108:907-910. PMC2556934

[30] Angerer J, Ewers U, Wilhelm M. Human biomonitoring: state of the art. Int J Hyg Environ Health. 2007; 210:201-228. DOI: 10.1016/j.ijheh.2007.01.024

[31] Au WW. Usefulness of biomarkers in population studies: from exposure to susceptibility and to prediction of cancer. Int J Hyg Environ Health. 2007; 210:239-246. DOI: 10.1016/j.ijheh.2006.11.001

[32] Collins A, Koppen G, Valdiglesias V, Dusinska M, Kruszewski M, Møller P, Rojas E, Dhawan A, Benzie I, Coskun E, Moretti M, Speit G, Bonassi S, ComNet project. The comet assay as a tool for human biomonitoring studies: the ComNet project. Mutat Res. 2014; 759:27-39. DOI: 10.1016/j.mrrev.2013.10.001.

[33] Rojas E, Lorenzo Y, Haug K, Nicolaissen B, Valverde M.. Epithelial cells as alternative human biomatrices for comet assay. In: Azqueta A, Langie S, Collins A, editors. 30 years of the Comet Assay: an overview with some new insights. 1st ed. Switzerland: Frontiers Media SA; 2015. p. 100-122. DOI: 10.3389/fgene.2014.00386 
[34] Autrup H, Seremet T, Arenholt D, Dragsted L, Jepsen A. Metabolism of benzo[a]pyrene by cultured rat and human buccal mucosa cells. Carcinogenesis. 1985; 6:1761-1765. DOI: 10.1093/carcin/6.12.1761

[35] Liu Y, Sundqvist K, Belinsky SA, Castonguay A, Tjalve H, Grafstrom RC. Metabolism and macromolecular interaction of the tobaccospecific carcinogen 4-(methylnitrosamino)-1-(3-pyridyl)-1-butanone in cultured explants and epithelial cells of human buccal mucosa. Carcinogenesis. 1993; 14:2383-2388. DOI: 10.1093/carcin/14.11.2383

[36] Vondracek M, Xi Z, Larsson P, Baker V, Mace K, Pfeifer A, Tjälve H, Donato MT, Gomez-Lechon MJ, Grafström RC. Cytochrome P450 expression and related metabolism in human buccal mucosa. Carcinogenesis. 2001; 22:481-488. DOI: 10.1093/carcin/ 22.3.481

[37] Spivack SD, Hurteau GJ, Jain R, Kumar SV, Aldous KM, Gierthy JF, Kaminsky LS. Geneenvironment interaction signatures by quantitative mRNA profiling in exfoliated buccal mucosal cells. Cancer Res. 2004; 64:6805-6813. DOI: 10.1158/0008-5472.CAN-04-1771

[38] Rosin MP. The use of the micronucleus test on exfoliated cells to identify anticlastogenic action in humans: a biological marker for the efficacy of chemopreventive agents. Mutat Res. 1992; 267:265-276. DOI: 10.1016/0027-5107(92)90071-9

[39] Kashyap B, Reddy PS. Micronuclei assay of exfoliated oral buccal cells: means to assess the nuclear abnormalities in different diseases. J Cancer Res Ther. 2012; 8:184-191. DOI: 10.4103/0973-1482.98968

[40] Tolbert PE, Shy CM, Allen JW. Micronuclei and other nuclear anomalies in buccal smears: methods development. Mutat Res. 1992; 271:69-77. DOI: 10.1016/0165-1161(92)90033-I

[41] Fenech M, Crott JW. Micronuclei, nucleoplasmic bridges and nuclear buds induced in folic acid deficient human lymphocytes-evidence for breakage fusion-bridge cycles in the cytokinesis-block micronucleus assay. Mutat Res. 2002; 504:131-136. DOI: 10.1016/ S0027-5107(02)00086-6

[42] Betti C, Davini T, Giannessi L, Loprieno L, Barale R. Microgel electiophoresis assay (Comet test) and SCE analysis in human lymphocytes from 100 normal subjects. Mutat Res. 1994; 307:323-333. DOI: 10.1016/0027-5107(94)90306-9

[43] Tice RR. The single cell gel/comet assay: a microgel electrophoretic technique for the detection of DNA damage and repair in individual cells. In: Phillips DH, Venitt S, editors. Environmental Mutagenesis. Oxford: Bios Scientific Publishers; 1994. p. 315340

[44] Fairbaim DW, Olive PL O'Neill KL. The comet assay: a comprehensive review. Muat Res. 1995; 339:37-59. DOI: 10.1016/0165-1110(94)00013-3 
[45] Hartmann A, Speit G. Comparative investigations of the genotoxic effects of metals in the single ccl gel (SCG) assay and the sister chromatid exchange (SCE) test. Env Mol Mutag. 1994; 23:299-305. DOI: 10.1002/em.2850230407

[46] Bolognesi C, Bonassi S, Knasmueller S, Fenech M, Bruzzone M, Lando C, Ceppi M. Clinical application of micronucleus test in exfoliated buccal cells: A systematic review and metanalysis. Mutat Res. 2015; 766:20-31. DOI: 10.1016/j.mrrev.2015.07.002

[47] Cairns J. Mutation selection and the natural history of cancer. Nature. 1975; 255:197200. PMID: 1143315

[48] Weinstein LB. The origins of human cancer: molecular mechanisms and their implications for cancer prevention and treatment. Cancer Res. 1988; 48:4135-4143. PMID: 3292040

[49] Nersesyan, Kundi M, Fenech M, Bolognesi C, Misik M, Wultsch G, Hartmann M, Knasmueller S. Micronucleus assay with urine derived cells (UDC): a review of its application in human studies investigating genotoxin exposure and bladder cancer risk. Mutat Res. 2014; 762 37-51. DOI: 10.1016/j.mrrev.2014.04.004

[50] Eren K, Özmeriç N, Sardaş Ş. Monitoring of buccal epithelial cells by alkaline comet assay (single cell gel electrophoresis technique) in cytogenetic evaluation of chlorhexidine. Clin Oral Investig. 2002; 6:150-154. DOI: 10.1007/s00784-002-0168-1

[51] Faccioni F, Franceschetti P, Cerpelloni M, Fracasso ME. In vivo study on metal release from fixed orthodontic appliances and DNA damage in oral mucosa cells. Am J Orthod Dentofacial Orthop. 2003; 124:687-694. DOI: 10.1016/j.ajodo.2003.09.010

[52] Westphalen GH, Menezes LM, Prá D, Garcia GG, Schmitt VM, Henriques JA, MedinaSilva R. In vivo determination of genotoxicity induced by metals from orthodontic appliances using micronucleus and comet assays. Genet Mol Res. 2008; 7:1259-1266. PMID: 19065761

[53] Fernández-Miñano E, Ortiz C, Vicente A, Calvo JL, Ortiz AJ (2011). Metallic ion content and damage to the DNA in oral mucosa cells of children with fixed orthodontic appliances. Biometals. 2011; 24:935-941. DOI: 10.1007/s10534-011-9448-Z

[54] Hafez HS, Selim EM, Kamel Eid FH, Tawfik WA, Al-Ashkar EA, MostafaYA. Cytotoxicity, genotoxicity, and metal release in patients with fixed orthodontic appliances: a longitudinal in-vivo study. Am J Orthod Dentofacial Orthop. 2011; 140:298-308. DOI: 10.1016/j.ajodo.2010.05.025

[55] Baričević M, Ratkaj I, Mladinić M, Zelježić D, Kraljević SP, Lončar B, Stipetić MM. In vivo assessment of DNA damage induced in oral mucosa cells by fixed and removable metal prosthodontic appliances. Clin Oral Investig. 2012; 16:325-331. DOI: 10.1007/ s00784-010-0489-4 
[56] Visalli G, Baluce B, La Maestra S, Micale RT, Cingano L, De Flora S, Di Pietro A. Genotoxic damage in the oral mucosa cells of subjects carrying restorative dental fillings. Arch Toxicol. 2013; 87:179-187. DOI: 10.1007/s00204-012-0915-2

[57] Martín-Cameán A, Puerto M, Jos Á, Azqueta A, Iglesias-Linares A, Solano E, Cameán AM. Utilización de microtornillos en ortodoncia: Evaluación de su genotoxicidad mediante ensayo cometa. II Jornadas de formación en Toxicología 2014. Rev Toxicol. 2014; 31:93-94

[58] Martín-Cameán A, Jos Á, Iglesias-Linares A, Solano E, Cameán AM. In vitro and in vivo evidence of the cytotoxic and genotoxic effects of metal ions released by orthodontic appliances: A review. Environ Toxicol Pharmacol 2015; 40:86-113. DOI: 10.1016/ j.etap.2015.05.007

[59] Gonçalves TS, Menezes LM, Trindade C, Thomas P, Fenechc M, Henriques JA (2015). In vivo evaluation of the genotoxic effects of Hyrax auxiliary orthodontic appliances containing silver-soldered joints. Mutat Res. 2015; 791:25-29. DOI: 10.1016/j.mrgentox. 2015.07.007

[60] Dhillon VS, Thomas P, Fenech M. Comparison of DNA damage and repair following radiation challenge in buccal cells and lymphocytes using single-cell gel electrophoresis. Int J Radiat Biol. 2004; 80:517-528. DOI:10.1080/09553000410001723866

[61] Szeto YT, Benzie IF, Collins AR, Choi SW, Cheng CY, Yow CM, Tse MM. A buccal cell model comet assay: development and evaluation for human biomonitoring and nutritional studies. Mutat Res. 2005; 578:371-281. DOI: 10.1016/j.mrfmmm.2005.06.014

[62] Pal D, Banerjee S, Indra D, Mandal S, Dum A, Bhowmik A, Panda CK, Das S. Influence of regular black tea consumption on tobacco associated DNA damage and HPV prevalence in human oral mucosa. Asian Pac J Cancer Prev. 2007; 8:263-266. PMID: 17696743

[63] Pal D, Sur S, Mandal S, Das S, Panda CK. Regular black tea habit could reduce tobacco associated ROS generation and DNA damage in oral mucosa of normal population. Food Chem Toxicol. 2012; 50:2996-3003. DOI: 10.1016/j.fct.2012.06.005

[64] Saran R, Tiwari RK, Reddy PP, Ahuja YR. Risk assessment of oral cancer in patients with pre-cancerous states of the oral cavity using micronucleus test and challenge assay. Oral Oncol. 2008; 44:354-360. DOI: 10.1016/j.oraloncology.2007.05.002

[65] Sellappa S, Prathyumnan S, Joseph S, Keyan KS, Balakrishnan M, Sasikala K. XRCC1399 and hOGG1326 polymorphisms and frequencies of micronuclei, comet and chromosomal aberrations among tobacco chewers: A South Indian Population Study. Asian Pac J Cancer Prev. 2009; 10:1057-1062. PMID: 20192583

[66] Eshkoor SA, Ismail P, Rahman SA, Moin S. Does GSTP1 polymorphism contribute to genetic damage caused by ageing and occupational exposure? Arh Hig Rada Toksikol. 2011; 62:291-298. DOI: 10.2478/10004-1254-62-2011-2088 
[67] Eshkoor SA, Ismail P, Rahman SS., Adon MY, Devan RV. Contribution of CYP2E1 polymorphism to aging in the mechanical workshop workers. Toxicol Mechan Meth. 2013; 23:217-222. DOI: 10.3109/15376516.2012.743637

[68] Eshkoor S, Ismail P, Rahman S, Moin S, Adon M. Role of the CYP1A2 Gene polymorphism on early ageing from occupational exposure. Balkan J Med Genet. 2013; 16:4552. DOI: 10.2478/bjmg-2013-0031

[69] Eshkoor SA, Ismail P, Rahman SA. Does CYP1A1 gene polymorphism affect cell damage biomarkers and ageing? Turk J Biol. 2014; 38:219-225. DOI: 10.3906/biy-1308-61

[70] Khanna A, Gautam DS, Mukherjee P. Genotoxic effects of tobacco chewing. Toxicol Int. 2012; 19:322-326. DOI: 10.4103/0971-6580.103683

[71] Jyoti S, Khan S, Naz F, Ali F, Siddique YH. Assessment of DNA damage by panmasala, gutkha chewing and smoking in buccal epithelial cells using alkaline single cell gel electrophoresis (SCGE). Egyp J Med Human Genetics. 2013; 14:391-394. DOI: 10.1016/ j.ejmhg.2013.07.004

[72] Al-Amrah HJ, Aboznada OA, Alam MZ, ElAssouli MZ, Mujallid MI, ElAssouli SM. Genotoxicity of waterpipe smoke in buccal cells and peripheral blood leukocytes as determined by comet assay. Inhal Toxicol. 2014; 26:891-896. DOI: 10.3109/08958378.2014.970787

[73] Bhagwath SS, Chandra L. Assessing extent of single stranded DNA damage in oral mucosal cells of patients with oral squamous cell carcinoma and its correlation with TNM staging. Ind J Dental Res. 2014; 25:555. DOI: 10.4103/0970-9290.147075

[74] Katarkar A, Mukherjee S, Khan MH, Ray JG, Chaudhuri K. Comparative evaluation of genotoxicity by micronucleus assay in the buccal mucosa over comet assay in peripheral blood in oral precancer and cancer patients. Mutagenesis. 2014; 29:325-334. DOI: 10.1093/mutage/geu023.

[75] Cavallo D, Ursini CL, Carelli G, Iavicoli I, Ciervo A, Perniconi B, Rondinone B, Gismondi M, Iavicoli S. Occupational exposure in airport personnel: characterization and evaluation of genotoxic and oxidative effects. Toxicology. 2006; 223:26-35. DOI: 10.1016/j.tox.2006.03.003

[76] Cavallo D, Ursini CL, Rondinone B, Iavicoli S. Evaluation of a suitable DNA damage biomarker for human biomonitoring of exposed workers. Environ Mol Mutagen. 2009; 50:781-790. DOI: 10.1002/em.20501.

[77] Ursini CL, Cavallo D, Colombi A, Giglio M, Marinaccio A, Iavicoli S. Evaluation of early DNA damage in healthcare workers handling antineoplastic drugs. Int Arch Occup Environ Health. 2006; 80:134-140. DOI: 10.1007/s00420-006-0111-x

[78] Jayakumar R, Sasikala K. Evaluation of DNA damage in jewellery workers occupationally exposed to nitric oxide. Environ Toxicol Pharmacol. 2008; 26:259-261. DOI: 10.1016/j.etap.2008.03.016. 
[79] de Oliveira HM, Dagostim GP, da Silva AM, Tavares P, da Rosa LA, de Andrade VM. Occupational risk assessment of paint industry workers. Indian J Occup Environ Med. 2011; 15:52-58. DOI: 10.4103/0019-5278.90374.

[80] Sudha S, Kripa SK, Shibily P, Joseph S, Balachandar V. Biomonitoring of genotoxic effects among shielded manual metal arc welders. Asian Pac J Cancer Prev. 2011; 12:1041-1044. PMID: 21790248

[81] How V, Hashim Z, Ismail P, Omar D, Said SM, Tamrin SB. Characterization of risk factors for DNA damage among paddy farm worker exposed to mixtures of organophosphates. Arch Environ Occup Health. 2015; 70:102-109. DOI: 10.1080/19338244.2013.823905

[82] Carbajal-López Y, Gómez-Arroyo S, Villalobos-Pietrini R, Calderón-Segura ME, Martínez-Arroyo A. Biomonitoring of agricultural workers exposed to pesticide mixtures in Guerrero state, Mexico, with comet assay and micronucleus test. Environ Sci Pollut Res Int. 2016; 23:2513-2520. DOI: 10.1007/s11356-015-5474-7

[83] Valverde M, del Carmen López M, López I, Sánchez I, Fortoul TI, Ostrosky-Wegman $\mathrm{P}$, Rojas E. DNA damage in leukocytes and buccal and nasal epithelial cells of individuals exposed to air pollution in Mexico City. Environ Mol Mutagen. 1997; 30:147-52. DOI: 10.1002/(SICI)1098-2280(1997)

[84] Mondal NK, Bhattacharya P, Ray MR. Assessment of DNA damage by comet assay and fast halo assay in buccal epithelial cells of Indian women chronically exposed to biomass smoke. Int J Hyg Environ Health. 2011; 214:311-318. DOI: 10.1016/j.ijheh. 2011.04.003

[85] How V, Hashim Z, Ismail P, Md Said S, Omar D, Bahri Mohd Tamrin S. Exploring cancer development in adulthood: cholinesterase depression and genotoxic effect from chronic exposure to organophosphate pesticides among rural farm children. J Agromedicine. 2014; 19:35-43. DOI: 10.1080/1059924X.2013.866917

[86] Marcon A, Fracasso ME, Marchetti P, Doria D, Girardi P, Guarda L, Pesce G, Pironi V, Ricci P, de Marco R. Outdoor formaldehyde and NO2 exposures and markers of genotoxicity in children living near chipboard industries. Environ Health Perspect. 2014; 122:639-645. DOI: 10.1289/ehp.1307259

[87] Glei M, Habermann N, Osswald K, Seidel C, Persin C, Jahreis G, Pool-Zobel BL. Assessment of DNA damage and its modulation by dietary and genetic factors in smokers using the Comet assay: a biomarker model. Biomarkers. 2005; 10:203-217. DOI: $10.1080 / 13547500500138963$

[88] Ishikawa T, Ogata S, Okumura K, Taguchi H (2005). Detection of DNA damages induced by five model chemicals in goldfish Carassius auratus cells using Comet Assay. Cytologia. 2005; 70:59-64. DOI: 10.1508/cytologia.70.59

[89] Milić M, Rozgaj R, Kašuba V, Jazbec A M, Hrelia P, Angelini S. The influence of individual genome sensitivity in DNA damage repair assessment in chronic profes- 
sional exposure to low doses of ionizing radiation. In: Chen CC, editor. DNA Repair On the Pathways to Fixing DNA Damage and Errors- part II. 1st ed. Rijeka: In Tech; 2011. p. 437-464.

[90] Moore L, Wiencke J, Eng C, Zheng S, Smith A. Evaluation of buccal cell collection protocols for genetic susceptibility studies. Biomarkers. 2001; 6:448-454. DOI: 10.1080/13547500110057416.

[91] Osswald K, Mittas A, Glei M, Pool-Zobel BL. New revival of an old biomarker: characterisation of buccal cells and determination of genetic damage in the isolated fraction of viable leucocytes. Mutat Res. 2003; 544:321-329. DOI: 10.1016/j.mrrev. 2003.06.008

[92] Pinhal D, Gontijo AM, Reyes VA, Salvadori DM. Viable human buccal mucosa cells not yield typical nucleoids: impacts on the single-cell gel electrophoresis/Comet assay. Environ Mol Mutagen. 2006; 47:117-126. DOI: 10.1002/em.20174

[93] Hoelzl C, Knasmüller S, Misík M, Collins A, Dusinská M, Nersesyan A. Use of single cell gel electrophoresis assays for the detection of DNA-protective effects of dietary factors in humans: recent results and trends. Mutat Res. 2009; 681:68-79. DOI: 10.1016/ j.mrrev.2008.07.004

[94] Muniz JF, McCauley LA, Pak V, Lasarev MR, Kisby GE. Effects of sample collection and storage conditions on DNA damage in buccal cells from agricultural workers. Mutat Res. 2011; 720:8-13. DOI: 10.1016/j.mrgentox.2010.11.010.

[95] Gontijo AM, Elias FN, Salvadori DM, de Oliveira ML, Correa LA, Goldberg J, Trindade JC, de Camargo JL. Single-cell gel comet assay detects primary DNA damage in nonneoplastic urothelial cells of smokers and ex-smokers. Cancer Epidemiol Biomark Prev. 2001; 10:987-993. PMID: 11535552

[96] Lewińska D, Palus J, Stepnik M, Dziubałtowska E, Beck J, Rydzyński K, Natarajan AT, Nilsson R. Micronucleus frequency in peripheral blood lymphocytes and buccal mucosa cells of copper smelter workers, with special regard to arsenic exposure. Int Arch Occup Environ Health. 2007; 80:371-380. DOI10.1007/s00420-006-0130-7

[97] Ribeiro DA. Risk assessment of oral cancer in patients with pre-cancerous states of the oral cavity using micronucleus test and challenge assay [letter]. Oral Oncol. 2008; 44: 716-717. DOI: 10.1016/j.oraloncology.2007.12.004

[98] McCauley LA, Lasarev M, Muniz J, Nazar Stewart V, Kisby G.Analysis of pesticide exposure and DNA damage in immigrant farmworkers. J Agromedicine. 2008; 13:23746. DOI: $10.1080 / 10599240802473817$.

[99] Kisby GE, Muniz JF, Scherer J, Lasarev MR, Koshy M, Kow YW, McCauley L. Oxidative stress and DNA damage in agricultural workers. J Agromedicine. 2009; 14:206-14. DOI: $10.1080 / 10599240902824042$ 
[100] Singh NP, McCoy MT, Tice RR, Schneider EL. A simple technique for quantitation of low levels of DNA damage in individual cells. Exp Cell Res. 1988; 175:184-191. 10.1016/0014-4827(88)90265-0

[101] Battershill JM, Burnett K, Bull S. Factors affecting the incidence of genotoxicity biomarkers in peripheral blood lymphocytes: impact on design of biomonitoring studies. Mutagenesis. 2008; 23:423-437. DOI: 10.1093/mutage/gen040

[102] Fenech M, Holland N, Chang WP, Zeiger E, Bonassi S. The HUman MicroNucleus Project-an international collaborative study on the use of the micronucleus technique for measuring DNA damage in humans. Mutat Res. 1999; 428:271-283. DOI: 10.1016/ S1383-5742(99)00053-8

[103] Bonassi S, Fenech M, Lando C, Lin YP, Ceppi M, Chang WP, Holland N, Kirsch-Volders M, Zeiger E, Ban S, Barale R, Bigatti MP, Bolognesi C, Jia C, Di Giorgio M, Ferguson LR, Fucic A, Lima OG, Hrelia P, Krishnaja AP, Lee TK, Migliore L, Mikhalevich L, Mirkova E, Mosesso P, Müller WU, Odagiri Y, Scarffi MR, Szabova E, Vorobtsova I, Vral A, Zijno A. HUman MicroNucleus project: international database comparison for results with the cytokinesisblock micronucleus assay in human lymphocytes: I. Effect of laboratory protocol, scoring criteria, and host factors on the frequency of micronuclei. Environ Mol Mutagen. 2001; 37:31-45. DOI: 10.1002/1098-2280(2001)

[104] Bonassi S, Neri M, Lando C, Ceppi M, Lin YP, Chang WP, Holland N, Kirsch-Volders M, Zeiger E, Fenech M. HUMN collaborative group (2003). Effect of smoking habit on the frequency of micronuclei in human lymphocytes: results from the Human MicroNucleus project. Mutat Res. 2003; 543:155-166. DOI: 10.1016/S1383-5742(03)00013-9

[105] Fenech M, Bolognesi C, Kirsch-Volders M, Bonassi S, Zeiger E, Knasmüller S, Holland N. Harmonisation of the micronucleus assay in human buccal cells-a Human Micronucleus (HUMN) project (www.humn.org) initiative commencing in 2007. Mutagenesis. 2007; 22:3-4. DOI: 10.1093/mutage/gel056

[106] Fenech M, Holland N, Knasmueller S, Burgaz S, Bonassi S. Report on the buccal micronucleus assay workshop organized by the International Human Micronucleus (HUMN) project-Antalya, Turkey 2007. Mutagenesis. 2009; 24:199-201. DOI: 10.1093/ mutage/gen065.

[107] Speit G, Hartmann A. The comet assay: a sensitive genotoxicity test for the detection of DNA damage and repair. Methods Mol Biol. 2006; 314:275-286. doi: 10.1385/1-59259-973-7:275

[108] Nadin SB, Vargas-Roig LM, Ciocca DR. A silver staining method for single-cell gel assay. J Histochem Cytochem. 2001; 49:1183-1186. doi: 10.1177/002215540104900912

[109] Ostling O, Johanson KJ. Microelectrophoretic study of radiationinduced DNA damages in individual mammalian cells. Biochem Biophys Res Commun. 1984; 123:291-298. doi: 10.1016/0006-291X(84)90411-X 
[110] Fracasso ME, Doria D, Carrieri M, Bartolucci GB, Quintavalle S, De Rosa E. DNA singleand double-strand breaks by alkaline- and immuno-comet assay in lymphocytes of workers exposed to styrene. Toxicol Lett. 2009; 185:9-15. doi: 10.1016/j.toxlet.2008

[111] Dhawan A, Bajpai M, Pandey AK, Parmar D. THE SCGE/Comet assay protocol. Protocol for the single cell gel electrophoresis/comet assay for rapid genotoxicity assessment. ITRC. 2003; pp. 41-48. http://www.cometassayindia.org/protocol\%20for $\% 20$ comet $\% 20$ assay.pdf

[112] Besaratinia A, Van Straaten HW, Godschalk RW, Van Zandwijk N, Balm AJ, Kleinjans JC, Van Schooten FJ. Immunoperoxidase detection of polycyclic aromatic hydrocarbonDNA adducts in mouth floor and buccal mucosa cells of smokers and nonsmokers. Environ Mol Mutagen. 2000; 36:127-33. doi: 10.1002/1098-2280(2000)

[113] Tice R, Vasquez M. Protocol for the application of the $\mathrm{pH} \backslash 13$ alkaline single cell gel (SCG) assay to the detection of DNA damage in mammalian cells. 1999; http://cometassay.com/Tice\%20and\%20 Vasques.pdf

[114] Titenko-Holland N, Jacob RA, Shang N, Balaraman A, Smith MT. Micronuclei in lymphocytes and exfoliated buccal cells of postmenopausal women with dietary changes in folate. Mutat Res. 1998; 417:101-114. doi:10.1016/S1383-5718(98)00104-1

[115] Speit G, Hartmann A. The comet assay (single-cell gel test). A sensitive genotoxicity test for the detection of DNA damage and repair. Methods Mol Biol. 1999; 113:203-212. doi:10.1385/1-59259-675-4:203

[116] Collins AR, Duthie SJ, Dobson VL. Direct enzymic detection of endogenous oxidative base damage in human lymphocyte DNA. Carcinogenesis. 1993; 14:1733-1735. doi: 10.1093/carcin/14.9.1733

[117] Klaude M, Eriksson S, Nygren J, Ahnström G. The comet assay: mechanisms and technical considerations. Mutat Res. 1996; 363:89-96. doi:10.1016/0921-8777(95)00063-1

[118] Olive PL, Vikse CM, Vanderbyl S. Increase in the fraction of necrotic, not apoptotic, cells in SiHa xenograft tumours shortly after irradiation. Radiat Oncol. 1999; 50:113119. doi: http://dx.doi.org/10.1016/S0167-8140(98)00104-2

[119] Singh NP, Stephens RE. Microgel electrophoresis: sensitivity, mechanisms, and DNA electrostretching. Mutat Res. 1997; 383:167-175. doi:10.1016/S0921-8777(96)00056-0

[120] Tice RR, Strauss GH, Peters WP. High-dose combination alkylating agents with autologous bone-marrow support in patients with breast cancer: preliminary assessment of DNA damage in individual peripheral blood lymphocytes using the single cell gel electrophoresis assay. Mutat Res. 1992; 271:101-113. doi: 10.1016/0165-1161(92)91083-4

[121] Hartmann A, Agurell E, Beevers C, Brendler-Schwaab S, Burlinson B, Clay P, Collins A, Smith A, Speit G, Thybaud V, Tice RR; 4th International Comet Assay Workshop. 
Recommendations for conducting the in vivo alkaline Comet assay. 4th International Comet Assay Workshop. Mutagenesis. 2003; 18:45-51. doi:10.1093/mutage/18.1.45

[122] Burlinson B, Tice RR, Speit G, Agurell E, Brendler-Schwaab SY, Collins AR, Escobar P, Honma M, Kumaravel TS, Nakajima M, Sasaki YF, Thybaud V, Uno Y, Vasquez M, Hartmann A; In Vivo Comet Assay Workgroup, part of the Fourth International Workgroup on Genotoxicity Testing. Fourth International Workgroup on Genotoxicity testing: results of the in vivo Comet assay workgroup. Mutat Res. 2007; 627:31-35. doi: 10.1016/j.mrgentox.2006.08.011

[123] Nandhakumar S, Parasuraman S, Shanmugam MM, Rao KR, Chand P, Bhat BV. Evaluation of DNA damage using single-cell gel electrophoresis (Comet Assay). J Pharmacol Pharmacother. 2011; 2:107-111. doi:10.4103/0976-500X.81903.

[124] Khanna A, Shukla P, Tabassum S. Role of Ocimum sanctum as a Genoprotective Agent on Chlorpyrifos-Induced Genotoxicity. Toxicol Int. 2011; 18:9-13. doi: 10.4103/0971-6580.75845.

[125] Jaloszynski, P., Kujawski, M., Czub-Swierczek M, Markowska J, Szyfter K. Bleomycininduced DNA damage and its removal in lymphocytes of breast cancer patients studied by comet assay. Mutat Res. 1997; 385:223-233. doi:10.1016/S0921-8777(97)00046-3

[126] Zhao X, Aldini G, Johnson EJ, Rasmussen H, Kraemer K, Woolf H, Musaeus N, Krinsky NI, Russell RM, Yeum KJ. Modification of lymphocyte DNA damage by carotenoid supplementation in postmenopausal women. Am J Clin Nutr. 2006; 83:163-9. PMID: 16400064

[127] Carrano AV, Natarajan AT. Considerations for population monitoring using cytogenetic techniques, International Commission for Protection against Environmental Mutagens and Carcinogens (ICPEMC publication 14). Mutat Res. 1988; 204:379-406. doi:10.1016/0165-1218(88)90036-5

[128] Villela IV, Oliveira IM, Silva J, Henriques JA. DNA damage and repair in haemolymph cells of golden mussel (Limnoperna fortunei) exposed to environmental contaminants. Mutat Res. 2006; 605:78-86. doi:10.1016/j.mrgentox.2006.02.006

[129] de Marco R, Marcon A, Rava M, Cazzoletti L, Pironi V, Silocchi C, Ricci P. Proximity to chipboard industries increases the risk of respiratory and irritation symptoms in children: the Viadana study. Sci Total Environ. 2010; 408:511-517. doi: 10.1016/ j.scitotenv.2009.10.024

[130] Fracasso ME, Doria D, Bartolucci GB, Carrieri M, Lovreglio P, Ballini A, Soleo L, Tranfo G, Manno M. Low air levels of benzene: correlation between biomarkers of exposure and genotoxic effects. Toxicol Lett. 2010; 192:22-28. doi: 10.1016/j.toxlet.2009.04.028. 

Section 3

Specific Evaluation of Some Environmental Toxicants 



\title{
Chapter 5
}

\section{Risks of Environmental Genotoxicants}

\author{
Sabry M. Attia and Gamaleldin I. Harisa \\ Additional information is available at the end of the chapter \\ http://dx.doi.org/10.5772/62454
}

\begin{abstract}
Humans have throughout their development been exposed to various environmental genotoxicants through food, air, water, and soil. Environmental exposure to genotoxic compounds may induce damage to human health and thereby increase risks of human cancers and other diseases. Environmental genotoxic chemicals have the ability to induce mutations. Such mutations can give rise to cancer in somatic cells. However, when germ cells are affected, the damagecanalsohaveaneffecton thenextand successivegenerations. Because of the potential health hazard represented by exposure to genotoxic chemicals, it is important that all chemicals for which there is possible human exposure be screened for genotoxic activity. If genotoxic hazard is detected, then the risks of exposure can be assessed and the use of the chemical controlled and when appropriate eliminated from the market and the environment. In this chapter, a general overview of the genotoxicity and the genotoxicity of some environmental genotoxicants are discussed. This is followed by a description of the genotoxic properties of some environmental genotoxicants such as bisphenols and mycotoxins, which are prominent environmental contaminates, and is believed to be genotoxic agents that contribute to the high incidence of carcinogenicity among populations.
\end{abstract}

Keywords: Environmental genotoxicants, mutations, carcinogenicity, mode of action, risk assessments

\section{Introduction}

DNA is constantly damaged by both endogenous and exogenous sources, and genotoxicity can be considered as an imbalance between DNA damage and DNA repair mechanisms. Maintenance of DNA integrity is essential for proper cellular and organismal function, and the capacity to withstand genotoxic challenge is important to avoid long-term genetic instability and population vulnerability. Unrepaired DNA damage can lead to mutations, cellular senes- 
cence, apoptosis, progression of cancer, and the process of aging [1]. Mutation is a broad term covering a whole range of changes to the informational molecule, DNA packaged into chromosomes, of an organism from gene changes to modifications of the number and/or structure of chromosomes. Mutagenicity in normal cells is one of the most serious problems due to the possibility of inducing secondary malignancies and abnormal reproductive outcomes such as Down, Klinefelter, and Turner syndromes [2]. Such changes can be assessed directly by measuring the interaction of agents with DNA or more indirectly through the assessment of DNA repair or the production of gene mutations or chromosome alterations.

Genotoxicity covers a broader spectrum of endpoints than mutagenicity. For example, unscheduled DNA synthesis, sister chromatid exchanges, and DNA strand breaks are the measures of genotoxicity, not mutagenicity, because they are not themselves transmissible from cell to cell or generation to generation. Mutagenicity on the other hand refers to the production of transmissible genetic alterations. Although all cells of an organism contain the same DNA, somatic cells in different organs and tissues of the adult body become specialized to perform defined functions so that only some parts of the genome are expressed. A common feature of mutations in cancer-causing genes, such as those controlling cell division and proliferation, is that this results in genes being expressed in the wrong tissue at the wrong time. The effect of a mutation will depend upon the position of the mutation within the DNA and the location and activity of the particular gene in which the mutation has been induced. Mutations in the many genes that have been implicated in the multistage events leading to cancer can be produced by a variety of mechanisms and interactions and modifications of the genetic material $[2,3]$.

With the recent focus on environmental problems, increasing awareness of the harmful effects of industrial and agricultural pollution has created a demand for progressively more sophisticated pollutant and toxicity detection methods. In recent years, there has been a growing concern about the increasing number of environmental pollutants that may disrupt normal endocrine function in exposed humans and animals. Endocrine disrupting compounds comprise a large group of synthetic chemicals that mimic the actions of natural hormones, act as antagonist, or block their synthesis, release, or metabolism. The xenoestrogen bisphenols have received much attention due to their high production volume and widespread human exposure. Recent research in various animal models has shown the genotoxic activity of bisphenols using in vivo and in vitro assays. Nevertheless, notable differences have been reported, leading to opposite conclusions, which may well have been caused by differences in the screening test, the organisms used, and the exposure conditions assayed [4].

Many important agricultural products, especially those rich in carbohydrates, are attractive colonization sites for fungi. Some toxic secondary metabolites of fungal growth are identified as mycotoxins and may be found to contaminate agricultural products [5]. Mycotoxins are virtually ubiquitous at some concentration in the average human diet. Mycotoxins are able to resist decomposition or being broken down by mammalian digestion, even by ruminant livestock, allowing these compounds to persist in meat and even dairy products [6]. This gives rise to certain partially metabolized mycotoxins, such as aflatoxin M1, which are present in milk from cows or humans that consumed feed or food contaminated by aflatoxins. Even 
temperature treatments, such as cooking and freezing, do not inactivate some mycotoxins. This section broadly discusses the genotoxic properties of the environmental genotoxicants bisphenols and aflatoxins, which are prominent environmental contaminates, and is believed to be genotoxic agents that contributes to the high incidence of genotoxicity and carcinogenicity among populations.

\section{Bisphenols}

\subsection{Bisphenol $\mathrm{A}$ and its analogues}

Bisphenols are a group of chemicals known as diphenylmethanes, which contain two benzene rings separated by one central carbon atom, usually with a 4-OH substituent on both benzene rings (e.g., bisphenol A, bisphenol F, bisphenol AF, and bisphenol Z). Bisphenol A is employed to make certain plastics and epoxy resins (Figure 1). In some bisphenols, the central carbon atom is replaced by a sulphone group (e.g., bisphenol $S$ or bisphenol 1) or sulphide moiety (e.g., bisphenol 2). Some bisphenol A analogues seem to be safer alternatives to bisphenol A in industrial applications. For example, the production of bisphenol S, which is stable at high temperatures and resistant to sunlight, is increasing from year to year $[7,8]$. The largest US manufacturer of thermal paper has been using bisphenol $\mathrm{S}$ as a replacement for bisphenol $\mathrm{A}$ since 2006. However, insufficient data are available to tell whether these bisphenol S-containing papers are safer than bisphenol A-containing papers. While bisphenol A is moderately susceptible to environmental breakdown, bisphenol S may be more persistent [9].

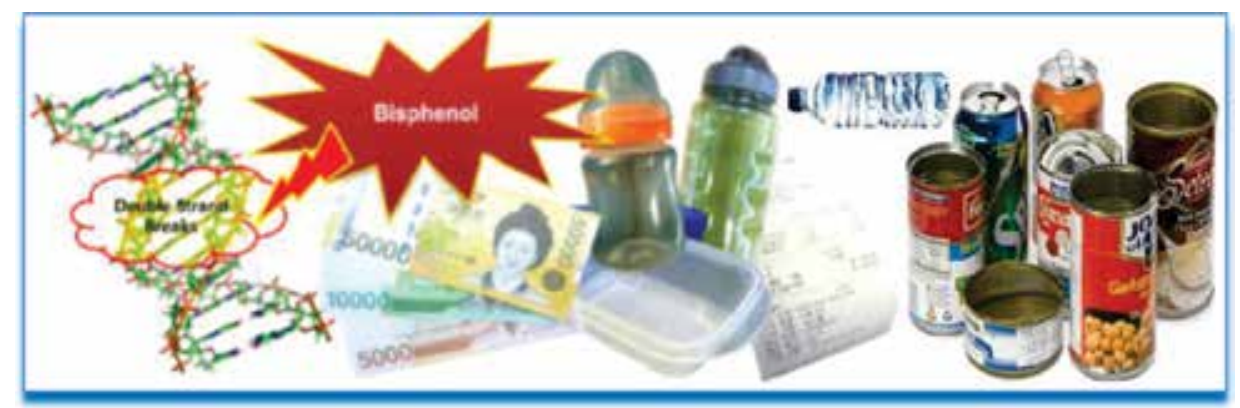

Figure 1. Some industrial applications of bisphenols.

From the viewpoint of biodegradability in the aquatic environment, bisphenol $\mathrm{F}$ is more biodegradable under aerobic and anaerobic conditions than bisphenol $\mathrm{A}$ and may replace bisphenol A to lower environmental risks [10]. Bisphenol AF also occurs as a monomer of phenol-formaldehyde resin. Bisphenol AF is a component of certain plasters and used as a rubber bridging material, while bisphenol A is a monomer that is polymerized to manufacture polycarbonate plastic products, epoxy, and polyester resins (Figure 2). Polycarbonate plastics have many applications including use in some food and drink packaging such as water and 
baby bottles, compact discs, impact-resistant safety equipment, and medical devices including those used in hospital settings. Epoxy resins are used to coat metal products such as food cans, bottle tops, and water supply pipes. Bisphenol A can also be found in certain thermal paper products, including some cash register and ATM receipts. Some dental sealants and composites may also contribute to bisphenol A exposure [11, 12].

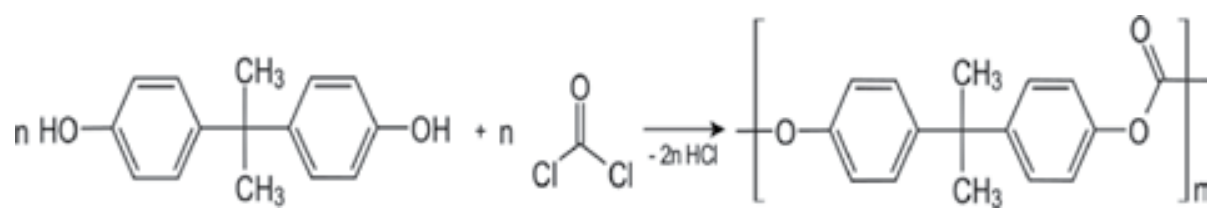

Figure 2. Synthesis of the polymer polycarbonate from bisphenol A and phosgene.

\subsection{Human exposure to bisphenols}

Human exposure to bisphenols may occur in the workplace through inhalation during production, but the most common route of exposure is by oral intake. Small amounts of bisphenol A are eluted from canned beverages, foods, and baby bottles, especially when heated [12]. At higher temperatures, longer contact with, and higher $\mathrm{pH}$ of the contact medium, bisphenol A monomer can hydrolyse and leach into food and beverages. Recent studies also suggest that the public may be exposed to bisphenol A by handling cash register receipts. In accordance with its widespread use in many applications, bisphenol A has been detected in dietary items [13] and human biological samples [14]. Moreover, bisphenol A was detected in environmental media as well [15].

\subsection{Risks of exposure to bisphenols}

In general, bisphenol A levels in humans have measured well below $50 \mathrm{mg} / \mathrm{kg} /$ day, which is the maximum acceptable dose set by the UA EPA [16]. Its ubiquitous presence and widespread distribution have provoked worldwide concerns about its possible association with human diseases such as obesity, diabetes, cardiovascular disease, reproductive disorders, and cancer $[17,18]$. Despite its presence in human populations and its association with reproductive and developmental toxicity in animals, most countries have not imposed regulations on the manufacture, import, or sale of bisphenol A products. That has been due largely to conflicting scientific evidence for a direct association between low-level exposure and adverse health effects in humans. Some countries and regions, including Canada, Europe, Sweden, and the United States, on the other hand, have formally banned bisphenol A from infant and children's products, including, variously, cans of infant formula, baby bottles, and sippy cups. Current efforts are focused on replacing bisphenol A with safer food contact materials. All of these alternative materials need to be assessed for appropriate functionality and safety using stateof-the-art methodology and scientific knowledge.

Bisphenol A is a known endocrine disruptor compound. While initially considered to be a weak environmental estrogen, several recent publications have demonstrated that bisphenol 
A may be similar in potency to estradiol in stimulating some cellular responses. Furthermore, emerging evidence suggests that bisphenol A may affect multiple endocrine-related pathways [19]. In men, exposure to endocrine disruptors may be associated with decreased fertility and increased risk of testicular or prostate cancer [20]. In women, exposure may increase the risk of endometriosis, reproductive or other endocrine-related cancers, and impaired oocyte competence, ovarian function, or menstrual cycle [21]. Because females have higher levels of natural estrogens in their blood, the impact of estrogen-like compounds on females may be different from that on males. In women, high urinary bisphenol A levels were associated with reduced antral follicle counts in a cohort of 209 women undergoing infertility treatments [22], whereas no correlation was found between serum bisphenol A levels and antral follicle counts in another study on a smaller cohort of 44 patients [23]. Nevertheless, several data suggest a negative impact of bisphenol A on woman fertility. Urinary bisphenol A levels were negatively correlated with numbers and quality of oocytes retrieved in stimulated cycles for assisted reproduction [24]. Increased urinary or serum bisphenol A concentrations were also associated with decreased peak oestradiol levels [25]. Moreover, a study on 137 patients undergoing assisted reproduction suggested that high urinary bisphenol A levels might be associated with up to $50 \%$ higher chance of implantation failures, in comparison with patients with low or no evidence of bisphenol A exposure [26].

Because the chemical structure of bisphenol A is similar to that of diethylstilbestrol, which is carcinogenic to mammals, the possible genotoxicity of bisphenol A has been widely tested in a variety of in vitro and in vivo studies, but the results are controversial. Several studies have shown that bisphenol A can induce chromosome aberrations and DNA adducts formation in Syrian hamster embryo cells [27] or micronuclei formation in human MCL-5 cells [28]. Aneugenic properties were also observed in Chinese hamster V79 cells after bisphenol A exposure [29]. Moreover, in estrogen receptor-positive MCF-7 cells, bisphenol A caused DNA strand breaks that were estrogen receptor-dependent [30]. A recent study has reported that the genotoxic and cytogenetic effects of bisphenol A in Chinese hamster ovary cells were manifested in the form of DNA strand breaks, micronucleus formation, and chromosome aberrations [31]. Conversely, bisphenol A is considered non-genotoxic because it was negative to a set of basic genotoxicity tests. It was not mutagenic in the Salmonella/microsome assay [32], did not induce gene mutations [27, 32] or chromosomal aberrations [33] in mammalian cells in vitro, and failed to induce chromosomal aberrations and micronucleus formation in vivo in mice [34]. Bisphenol $\mathrm{A}$ is considered to lead to genotoxicity through oxidative stress. Bisphenol A-3,4-quinone, which is yielded by oxidative metabolism of bisphenol A, may cause genotoxicity by reacting with DNA [35].

By now, there is increasing evidence supports the notion that low bisphenol A concentrations adversely affect the epigenome of mammalian female germ cells, with functional consequences on gene expression, chromosome dynamics in meiosis, and oocyte development and quality [36]. An epigenetic impact of bisphenol A was demonstrated also on male germ cells. Male offspring of rats perinatally exposed to bisphenol A had reduced sperm counts and other changes in phenotypes not only in the first generation but also in the F3 generation [37]. Induction of sperm epimutations and male-mediated trans-generational inheritance of obesity 
and reproductive disturbances were also shown after bisphenol A exposure of rats [38]. When female mice were exposed during gestation and lactation to low bisphenol A doses deregulated, glucose homeostasis in the F2 generation was observed; decreased global methylation and differential methylation of a specific $\mathrm{CpG}$ site in the glucokinase promoter in the $F 1$ sperm suggested that the $F 2$ phenotype could be caused by epigenetic alterations induced in the male paternal germline by bisphenol A prenatal exposure [39].

While comprehensive information is available about the adverse health impacts of bisphenol A, toxicological properties of alternative bisphenols are yet to be investigated. Alternative bisphenols are structurally similar to bisphenol A, and therefore expected to possess similar biological activities. However, most available toxicological information is limited to endocrine disrupting potentials, and only very little is known about the genotoxicity of alternative bisphenols [7]. In turn, bisphenol $\mathrm{F}$ has been reported to induce DNA strand breaks, but not micronuclei, in HepG2 cells [40]. In human HepG2 cells, bisphenol F induced histone H2AX phosphorylation, an indicator of DNA double strand breaks [41]. Moreover, bisphenol F induced metaphase arrest and micronucleus formation in V79 cells [29]. In Syrian hamster embryo cells, bisphenol $\mathrm{F}$ did not induce gene mutation or chromosomal aberrations, but induced aneuploidy and morphological changes [42]. Bisphenol A may cause oxidative stress, and induce DNA adduct and aneuploidy in rodents [43]. Nevertheless, eight bisphenols including bisphenol A showed no positive responses based on $u m u$-test suggesting no genotoxicity [44]. Similarly, other alternative bisphenols are expected, but to date, very little efforts have been made on this aspect.

\section{Aflatoxins}

\subsection{Sources of aflatoxins}

With worldwide increases in population, the need for nutrient-rich food is rising. Contamination of foods by toxins, bacteria, viruses, parasites, allergens, and prions may lead to serious diseases; unhealthy foodstuffs are implicated in approximately one-third of cancer cases. Controlled storage conditions, improved packaging, and strict hygiene regulations for food production, preservation, and distribution are essential to diminish such problems. Aflatoxins are toxic metabolites produced by certain fungi in/on foods and feeds. They are probably the best-known and most intensively researched mycotoxins in the world. The occurrence of aflatoxins is influenced by certain environmental factors; hence, the extent of contamination will vary with geographic location, agricultural, and agronomic practices, and the susceptibility of commodities to fungal invasion during pre-harvest, storage, and/or processing periods. Aflatoxin B1 is a prevalent food pollutant, which is found typically in tropical countries. It imposes great costs on the world's economy and health [45]. Thus, it is important to eliminate aflatoxin B1 from food resources and prevent production of the toxin. Due to lack of infrastructure, poor and third world countries are the major victims of aflatoxin B1. The established carcinogenesis, teratogenesis, and severe multi-organ toxicity associated with aflatoxin B1 have made it a substantial challenge for scientists [46, 47]. 


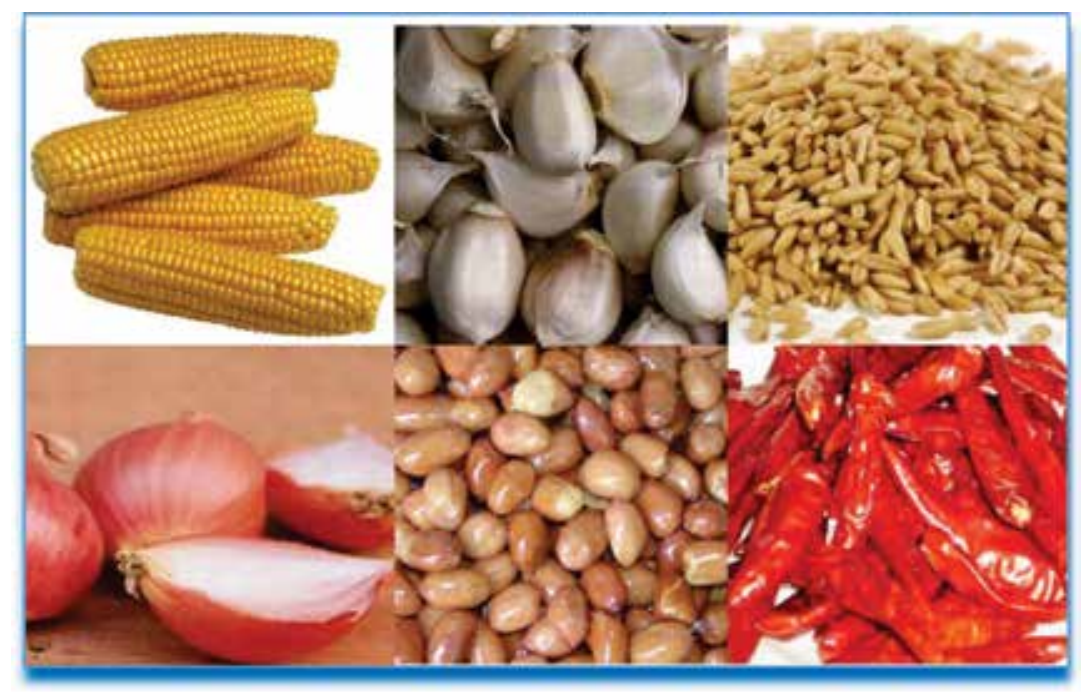

Figure 3. Some major sources of aflatoxins.

\subsection{Human exposure to aflatoxins}

Aflatoxins are a type of mycotoxin produced by Aspergillus species of fungi, such as A. flavus and $A$. parasiticus, which grow in soil, decaying vegetation, hay, and grains [48]. Aflatoxins have received greater attention than any other mycotoxins because of their demonstrated potent carcinogenic effect in susceptible laboratory animals and their acute toxicological effects in humans. Aflatoxins are regularly found in improperly stored staple commodities such as cassava, chili peppers, corn, cottonseed, millet, peanuts, rice, sorghum, sunflower seeds, tree nuts, wheat, and a variety of spices (Figure 3). Aflatoxin B1 is highly resistant to traditional detoxification protocols, such as heat, solvents, and radiation, which have consequences for food quality and safety. However, biological procedures using microbial or enzymatic tools that possess great specificity with minimal consequences are the appropriate choices for the treatment of contaminated foodstuffs; they also offer ease of application, affordability, and environmentally friendly behavior. The use of biological procedures requires optimized conditions, such as $\mathrm{pH}$ and temperature, for maximum efficiency. When contaminated food is processed, aflatoxins enter the general food supply where they have been found in both pet and human foods, as well as in feed stocks for agricultural animals [49]. Moreover, animals fed contaminated food can pass aflatoxin transformation products into eggs, milk products, and meat. The four major naturally produced aflatoxins are known as aflatoxin B1, aflatoxin B2, aflatoxin G1, and aflatoxin G2 (Figure 4), which are based on their fluorescent color when exposed to ultraviolet light on thin-layer chromatography plates $(B=$ blue fluorescence, $\mathrm{G}=$ yellow-green fluorescence), while the subscript numbers 1 and 2 indicate major and minor compounds, respectively. Aflatoxin M1 and M2 compounds are not found on cereal products themselves but are metabolites expressed in milk of mammals whose diet was contaminated by aflatoxins B1 and B2, respectively [50]. 
<smiles>COc1cc2c(c3oc(=O)c4c(c13)CCC4=O)C1C=COC1O2</smiles>

$B_{1}$<smiles>COc1cc2c(c3oc(=O)c4c(c13)CCOC4=O)C1C=COC1O2</smiles>

$\mathrm{G}_{1}$<smiles>COc1cc2c(c3oc(=O)c4c(c13)CCC4=O)C1CCOC1O2</smiles>

$\mathrm{B}_{2}$<smiles>COc1cc2c(c3oc(=O)c4c(c13)CCOC4=O)C1CCOC1O2</smiles>

$\mathrm{G}_{2}$

Figure 4. Chemical structures of the four major naturally produced aflatoxins: aflatoxin B1, aflatoxin B2, aflatoxin G1, and aflatoxin G2.

\subsection{Risks of exposure to aflatoxins}

Aflatoxins have been reported to have several serious deleterious effects in humans and diverse animals with the species reacting differently to the toxicological effects. The target sites of this toxicant are also diverse and effects include hepatotoxicity, teratogenicity, immunotoxicity, hematological disorders, renal dysfunction, induction of chromosome aberrations, and mutations in somatic and germinal cells of animals and humans [51-53]. Aflatoxin B1, the most toxic, is a potent carcinogen and has been directly correlated with adverse health effects, such as liver cancer, in many animal species. Aflatoxin B1 is one of the major risk factors for the occurrence of liver injury and carcinogenesis, especially when it is combined with hepatitis $\mathrm{B}$ infection. Epidemiological investigations revealed that dietary contamination with aflatoxin B1 might be responsible for 5-28\% of global hepatocellular carcinoma cases [54]. A great deal of evidence has demonstrated that aflatoxin B1 belongs to the indirect-acting carcinogens. Aflatoxin B1 is mainly metabolized in the liver to produce the genotoxic intermediate aflatoxin B1-exo-8,9-epoxide by the liver-specific cytochrome P450 enzymes, P4501A2, and 3A4. These epoxides can form aflatoxin B1-guanine adducts by binding covalently to DNA, thereby introducing GC-TA transversion that leads to DNA mutations and genomic instability [55]. For instance, a frequent hotspot mutation at codon 249 in the human p53 gene gives rise to a Ser to Arg substitution in the p53 protein that decreases its tumor suppressor activity [56]. Another major detoxification pathway of aflatoxin B1 in mammalian species is the glutathione conjugation of aflatoxin B1-8,9-epoxide, which is catalyzed by glutathione S-transferases [57]. Experimental studies conducted in rats have shown that rGSTA5, barely expressed in adult male liver, exhibits a greater activity toward aflatoxin B1-8,9-epoxide than other glutathione S-transferases subunits [58]. 
Aflatoxin B1 is a clastogen that has been tested for genotoxicity in vivo and in vitro and giving consistently positive results. It induces chromosomal aberrations, micronuclei formation, sister chromatid exchanges, and DNA strand breaks in several published works [53, 59-61]. An important mechanism responsible for the genotoxic potential of aflatoxin B1 is the formation of DNA adducts. Biotransformation plays a crucial role in the toxicity and carcinogenicity of aflatoxin B1. The enzymatic detoxification of aflatoxin B1 was studied [62], and the pro-oxidant properties and mutagenicity of the detoxification products were compared with those of aflatoxin B1. The results indicated that the metabolized aflatoxin B1 was more toxic than the non-metabolized form of it. A previous study also demonstrated that an epoxide metabolite had an important role in aflatoxin B1-mediated genotoxicity [63]. In the Ames mutagenicity test, the T98 strain exhibits a frame-shift mutation, and T100 exhibits a base-pair substitution. Virtually, all of aflatoxin B1 toxic and carcinogenic effects are attributable to the action of its reactive metabolites that are capable of reacting with cellular macromolecules such as DNA [64]. Furthermore, DNA repair activity and modulation of repair by aflatoxin B1 seem to be also major determinants of susceptibility to aflatoxin B1-induced carcinogenesis [61].

Since the discovery of these deleterious effects induced by aflatoxin B1, a large number of studies have explored the mechanisms and pathways involved in aflatoxin B1-mediated genotoxicity. However, few studies have focused on the epigenetic events involved in the induction of genotoxicity. Recently, several studies reported that cellular epigenetic aberrant changes, such as DNA methylation, histone modifications, and miRNA profiling alterations, also contributed to the hepatotoxicity and genotoxicity induced by chemical toxicants. A genome-wide miRNA-profiling analysis in an acute rat liver injury model induced by aflatoxin B1 predicted that several miRNAs and their potential targets were relevant to acute hepatotoxicity, although functional tests were not performed [65]. However, it is clear from gene expression profiling that the pathways involved in acute poisoning and chronic poisoning are not completely consistent. A recent study investigated alterations in miRNA profiles of rat liver tissues by Illumina deep sequencing and evaluated their roles in aflatoxin B1-induced hepatocellular genotoxicity and hepatotoxicity [66]. The authors demonstrated alterations in the miRNA profile in rat liver tissue, including rnomiR-34a-5p, rno-miR-200b-3p, rno-miR-429, and rno-miR-130a-3p, after aflatoxin B1 exposure. Functional tests showed that the increase in miR-34a-5p by p53 activation after aflatoxin B1 exposure led to cell cycle arrest via inhibiting cell cycle-related genes and affecting the micronuclei formation induced by aflatoxin B1, indicating that rno-miR-34a-5p played a critical role in aflatoxin B1-induced rat hepatogenotoxicity. Furthermore, the combination of circulating miR-34a-5p and the aflatoxin B1 level may be considered as a sensitive method for the detection of the genotoxic stress induced by chronic aflatoxin B1 exposure.

As it is realized that absolute safety is never achieved, many countries have attempted to limit exposure to aflatoxins by imposing regulatory limits on commodities intended for use as food and feed [67]. The FDA has established specific guidelines on acceptable levels of aflatoxins in human food and animal feed by establishing action levels that allow for the removal of violate lots from commerce. The action level for human food is $20 \mathrm{ppb}$ total aflatoxins, with the exception of milk, which has an action level of $0.5 \mathrm{ppb}$ for aflatoxin M1. The action level for 
most feeds is also $20 \mathrm{ppb}$. However, it is very difficult to accurately estimate aflatoxins concentration in a large quantity of material because of the variability associated with testing procedures; hence, the true aflatoxin concentration in a lot cannot be determined with $100 \%$ certainty. However, the ability of aflatoxin-producing fungi to grow on a wide range of food commodities and the stability of aflatoxins in foods mean that control is best achieved by measures designed to prevent the contamination of crops in the field and during storage, or detection and removal of contaminated material from the food supply chain.

\section{Acknowledgements}

This work was funded by the National Plane for Science, Technology, and Innovation (MAARIFAH), King Abdulaziz City for Science and Technology, Kingdom of Saudi Arabia, Award Number (12-MED2648-02).

\section{Author details}

Sabry M. Attia ${ }^{1^{*}}$ and Gamaleldin I. Harisa ${ }^{2}$

*Address all correspondence to: attiasm@ksu.edu.sa

1 Department of Pharmacology and Toxicology, College of Pharmacy, King Saud University, Riyadh, Saudi Arabia

2 Kayyali Chair for Pharmaceutical Industry, College of Pharmacy, King Saud University, Riyadh, Saudi Arabia

\section{References}

[1] Cooke MS, Evans MD, Dizdaroglu M, Lunec J. Oxidative DNA damage: mechanisms, mutation, and disease. FASEB Journal. 2003;17(10):1195-214. doi:10.1096/fj.02-0752rev.

[2] Attia SM. Mutagenicity of some topoisomerase II-interactive agents. Saudi Pharmaceutical Journal. 2008;16:1-24.

[3] Fearon ER, Vogelstein B. A genetic model for colorectal tumorigenesis. Cell. 1990;61(5): 759-67.

[4] Peretz J, Vrooman L, Ricke WA, Hunt PA, Ehrlich S, Hauser R, Padmanabhan V, Taylor HS, Swan SH, VandeVoort CA, Flaws JA. Bisphenol a and reproductive health: update of experimental and human evidence, 2007-2013. Environ Health Perspect. 2014; 122(8): 775-786. doi: 10.1289/ehp.1307728. 
[5] Bennett JW, Klich M. Mycotoxins. Clinical Microbiology Reviews. 2003;16(3):497-516.

[6] Kang'ethe EK, Lang'a KA. Aflatoxin B1 and M1 contamination of animal feeds and milk from urban centers in Kenya. African Health Sciences. 2009;9(4):218-26.

[7] Chen MY, Ike M, Fujita M. Acute toxicity, mutagenicity, and estrogenicity of bisphenolA and other bisphenols. Environmental Toxicology. 2002;17(1):80-6.

[8] Kuruto-Niwa R, Nozawa R, Miyakoshi T, Shiozawa T, Terao Y. Estrogenic activity of alkylphenols, bisphenol $\mathrm{S}$, and their chlorinated derivatives using a GFP expression system. Environmental Toxicology and Pharmacology. 2005;19(1):121-30. doi:10.1016/ j.etap.2004.05.009.

[9] Danzl E, Sei K, Soda S, Ike M, Fujita M. Biodegradation of bisphenol A, bisphenol F and bisphenol $\mathrm{S}$ in seawater. International Journal of Environmental Research and Public Health. 2009;6(4):1472-84. doi:10.3390/ijerph6041472.

[10] Ike M, Chen MY, Danzl E, Sei K, Fujita M. Biodegradation of a variety of bisphenols under aerobic and anaerobic conditions. Water Science and Technology: A Journal of the International Association on Water Pollution Research. 2006;53(6):153-9.

[11] Liao C, Liu F, Kannan K. Bisphenol S, a new bisphenol analogue, in paper products and currency bills and its association with bisphenol a residues. Environmental Science \& Technology. 2012;46(12):6515-22. doi:10.1021/es300876n.

[12] Biedermann S, Tschudin P, Grob K. Transfer of bisphenol A from thermal printer paper to the skin. Analytical and Bioanalytical Chemistry. 2010;398(1):571-6. doi:10.1007/ s00216-010-3936-9.

[13] Lorber M, Schecter A, Paepke O, Shropshire W, Christensen K, Birnbaum L. Exposure assessment of adult intake of bisphenol A (BPA) with emphasis on canned food dietary exposures. Environment International. 2015;77:55-62. doi:10.1016/j.envint.2015.01.008.

[14] Liao C, Liu F, Alomirah H, Loi VD, Mohd MA, Moon HB, et al. Bisphenol S in urine from the United States and seven Asian countries: occurrence and human exposures. Environmental Science \& Technology. 2012;46(12):6860-6. doi:10.1021/es301334j.

[15] Huang YQ, Wong CK, Zheng JS, Bouwman H, Barra R, Wahlstrom B, et al. Bisphenol A (BPA) in China: a review of sources, environmental levels, and potential human health impacts. Environment International. 2012;42:91-9. doi:10.1016/j.envint. 2011.04.010.

[16] Vandenberg LN, Hunt PA, Myers JP, Vom Saal FS. Human exposures to bisphenol A: mismatches between data and assumptions. Reviews on Environmental Health. 2013;28(1):37-58. doi:10.1515/reveh-2012-0034.

[17] Meeker JD, Yang T, Ye X, Calafat AM, Hauser R. Urinary concentrations of parabens and serum hormone levels, semen quality parameters, and sperm DNA damage. Environmental Health Perspectives. 2011;119(2):252-7. doi:10.1289/ehp.1002238. 
[18] Jenkins S, Betancourt AM, Wang J, Lamartiniere CA. Endocrine-active chemicals in mammary cancer causation and prevention. The Journal of Steroid Biochemistry and Molecular Biology. 2012;129(3-5):191-200. doi:10.1016/j.jsbmb.2011.06.003.

[19] Rubin BS. Bisphenol A: an endocrine disruptor with widespread exposure and multiple effects. The Journal of Steroid Biochemistry and Molecular Biology. 2011;127(1-2):2734. doi:10.1016/j.jsbmb.2011.05.002.

[20] Pflieger-Bruss S, Schuppe HC, Schill WB. The male reproductive system and its susceptibility to endocrine disrupting chemicals. Andrologia. 2004;36(6):337-45. doi: 10.1111/j.1439-0272.2004.00641.x.

[21] Nicolopoulou-Stamati P, Pitsos MA. The impact of endocrine disrupters on the female reproductive system. Human Reproduction Update. 2001;7(3):323-30.

[22] Souter I, Smith KW, Dimitriadis I, Ehrlich S, Williams PL, Calafat AM, et al. The association of bisphenol-A urinary concentrations with antral follicle counts and other measures of ovarian reserve in women undergoing infertility treatments. Reproductive Toxicology. 2013;42:224-31. doi:10.1016/j.reprotox.2013.09.008.

[23] Bloom MS, Kim D, Vom Saal FS, Taylor JA, Cheng G, Lamb JD, et al. Bisphenol A exposure reduces the estradiol response to gonadotropin stimulation during in vitro fertilization. Fertility and Sterility. 2011;96(3):672-7 e2. doi:10.1016/j.fertnstert. 2011.06.063.

[24] Ehrlich S, Williams PL, Missmer SA, Flaws JA, Ye XY, Calafat AM, et al. Urinary bisphenol A concentrations and early reproductive health outcomes among women undergoing IVF. Human Reproduction. 2012;27(12):3583-92. doi:10.1093/humrep/ des328.

[25] Fujimoto VY, Kim D, vom Saal FS, Lamb JD, Taylor JA, Bloom MS. Serum unconjugated bisphenol A concentrations in women may adversely influence oocyte quality during in vitro fertilization. Fertility and Sterility. 2011;95(5):1816-9. doi:10.1016/j.fertnstert. 2010.11.008.

[26] Ehrlich S, Williams PL, Missmer SA, Flaws JA, Berry KF, Calafat AM, et al. Urinary bisphenol A concentrations and implantation failure among women undergoing in vitro fertilization. Environmental Health Perspectives. 2012;120(7):978-83.

[27] Tsutsui T, Tamura Y, Yagi E, Hasegawa K, Takahashi M, Maizumi N, et al. BisphenolA induces cellular transformation, aneuploidy and DNA adduct formation in cultured Syrian hamster embryo cells. International Journal of Cancer. 1998;75(2):290-4.

[28] Parry EM, Parry JM, Corso C, Doherty A, Haddad F, Hermine TF, et al. Detection and characterization of mechanisms of action of aneugenic chemicals. Mutagenesis. 2002;17(6):509-21.

[29] Pfeiffer E, Rosenberg B, Deuschel S, Metzler M. Interference with microtubules and induction of micronuclei in vitro by various bisphenols. Mutation Research/Genetic 
Toxicology and Environmental Mutagenesis. 1997;390(1-2):21-31. doi:10.1016/ S0165-1218(96)00161-9.

[30] Iso T, Watanabe T, Iwamoto T, Shimamoto A, Furuichi Y. DNA damage caused by bisphenol A and estradiol through estrogenic activity. Biological \& Pharmaceutical Bulletin. 2006;29(2):206-10.

[31] Xin L, Lin Y, Wang A, Zhu W, Liang Y, Su X, et al. Cytogenetic evaluation for the genotoxicity of bisphenol-A in Chinese hamster ovary cells. Environmental Toxicology and Pharmacology. 2015;40(2):524-9. doi:10.1016/j.etap.2015.08.002.

[32] Schweikl H, Schmalz G, Rackebrandt K. The mutagenic activity of unpolymerized resin monomers in Salmonella typhimurium and V79 cells. Mutation Research. 1998;415(12):119-30.

[33] Ivett JL, Brown BM, Rodgers C, Anderson BE, Resnick MA, Zeiger E. Chromosomal aberrations and sister chromatid exchange tests in Chinese hamster ovary cells in vitro. IV. Results with 15 chemicals. Environmental and Molecular Mutagenesis. 1989;14(3): 165-87.

[34] Pacchierotti F, Ranaldi R, Eichenlaub-Ritter U, Attia S, Adler ID. Evaluation of aneugenic effects of bisphenol A in somatic and germ cells of the mouse. Mutation Research. 2008;651(1-2):64-70. doi:10.1016/j.mrgentox.2007.10.009.

[35] Kolsek K, Sollner Dolenc M, Mavri J. Computational study of the reactivity of bisphenol A-3,4-quinone with deoxyadenosine and glutathione. Chemical Research in Toxicology. 2013;26(1):106-11. doi:10.1021/tx300411d.

[36] Eichenlaub-Ritter U, Pacchierotti F. Bisphenol A effects on mammalian oogenesis and epigenetic integrity of oocytes: a case study exploring risks of endocrine disrupting chemicals. BioMed Research International. 2015;2015: 1-11. doi:10.1155/2015/698795.

[37] Salian S, Doshi T, Vanage G. Perinatal exposure of rats to Bisphenol A affects the fertility of male offspring. Life Sciences. 2009;85(21-22):742-52. doi:10.1016/j.lfs.2009.10.004.

[38] Manikkam M, Tracey R, Guerrero-Bosagna C, Skinner MK. Plastics derived endocrine disruptors (BPA, DEHP and DBP) induce epigenetic transgenerational inheritance of obesity, reproductive disease and sperm epimutations. Plos One. 2013;8(1):e55387. doi: 10.1371/journal.pone.0055387.

[39] Li G, Chang H, Xia W, Mao Z, Li Y, Xu S. F0 maternal BPA exposure induced glucose intolerance of F2 generation through DNA methylation change in Gck. Toxicology Letters. 2014;228(3):192-9. doi:10.1016/j.toxlet.2014.04.012.

[40] Cabaton N, Dumont C, Severin I, Perdu E, Zalko D, Cherkaoui-Malki M, et al. Genotoxic and endocrine activities of bis(hydroxyphenyl)methane (bisphenol F) and its derivatives in the HepG2 cell line. Toxicology. 2009;255(1-2):15-24. doi:10.1016/j.tox. 2008.09.024. 
[41] Audebert M, Dolo L, Perdu E, Cravedi JP, Zalko D. Use of the gammaH2AX assay for assessing the genotoxicity of bisphenol A and bisphenol $\mathrm{F}$ in human cell lines. Archives of Toxicology. 2011;85(11):1463-73. doi:10.1007/s00204-011-0721-2.

[42] Kanai H, Barrett JC, Metzler M, Tsutsui T. Cell-transforming activity and estrogenicity of bisphenol-A and 4 of its analogs in mammalian cells. International Journal of Cancer. 2001;93(1):20-5. doi: 10.1002/Ijc.1303.

[43] Tiwari D, Kamble J, Chilgunde S, Patil P, Maru G, Kawle D, et al. Clastogenic and mutagenic effects of bisphenol A: an endocrine disruptor. Mutation Research/Genetic Toxicology and Environmental Mutagenesis. 2012;743(1-2):83-90. doi:10.1016/j.mrgentox.2011.12.023.

[44] Chen MY, Ike M, Fujita M. Acute toxicity, mutagenicity, and estrogenicity of bisphenolA and other bisphenols. Environmental Toxicology. 2002;17(1):80-6. doi: 10.1002/Tox. 10035

[45] Algul I, Kara D. Determination and chemometric evaluation of total aflatoxin, aflatoxin B1, ochratoxin A and heavy metals content in corn flours from Turkey. Food Chemistry. 2014;157:70-6. doi:10.1016/j.foodchem.2014.02.004.

[46] Partanen HA, El-Nezami HS, Leppanen JM, Myllynen PK, Woodhouse HJ, Vahakangas $\mathrm{KH}$. Aflatoxin B1 transfer and metabolism in human placenta. Toxicological Sciences. 2010;113(1):216-25. doi:10.1093/toxsci/kfp257.

[47] Niknejad F, Zaini F, Faramarzi MA, Amini M, Kordbacheh P, Mahmoudi M, et al. Candida parapsilosis as a potent biocontrol agent against growth and aflatoxin production by Aspergillus species. Iranian Journal of Public Health. 2012;41(10):72-80.

[48] Martins ML, Martins HM, Bernardo F. Aflatoxins in spices marketed in Portugal. Food Additives \& Contaminants. 2001;18(4):315-9. doi: 10.1080/02652030120041.

[49] Mohd Redzwan S, Rosita J, Mohd Sokhini AM, Nurul 'Aqilah AR, Wang JS, Kang MS, et al. Detection of serum AFB1-lysine adduct in Malaysia and its association with liver and kidney functions. International Journal of Hygiene and Environmental Health. 2014;217(4-5):443-51. doi: 10.1016/j.ijheh.2013.08.007.

[50] Dohnal V, Wu Q, Kuca K. Metabolism of aflatoxins: key enzymes and interindividual as well as interspecies differences. Archives of Toxicology. 2014;88(9):1635-44. doi: 10.1007/s00204-014-1312-9.

[51] Guindon KA, Foley JF, Maronpot RR, Massey TE. Failure of catalase to protect against aflatoxin B1-induced mouse lung tumorigenicity. Toxicology and Applied Pharmacology. 2008;227(2):179-83. doi:10.1016/j.taap.2007.10.015.

[52] Fapohunda SO, Ezekiel CN, Alabi OA, Omole A, Chioma SO. Aflatoxin-mediated sperm and blood cell abnormalities in mice fed with contaminated corn. Mycobiology. 2008;36(4):255-9. doi:10.4489/MYCO.2008.36.4.255. 
[53] Anwar WA, Khalil MM, Wild CP. Micronuclei, chromosomal aberrations and aflatoxinalbumin adducts in experimental animals after exposure to aflatoxin B1. Mutation Research. 1994;322(1):61-7.

[54] Liu Y, Wu F. Global burden of aflatoxin-induced hepatocellular carcinoma: a risk assessment. Environmental Health Perspectives. 2010;118(6):818-24. doi:10.1289/ehp. 0901388.

[55] Attia SM. Deleterious effects of reactive metabolites. Oxidative Medicine and Cellular Longevity. 2010;3(4):238-53.

[56] Aguilar F, Hussain SP, Cerutti P. Aflatoxin B1 induces the transversion of G-->T in codon 249 of the p53 tumor suppressor gene in human hepatocytes. Proceedings of the National Academy of Sciences of the United States of America. 1993;90(18):8586-90.

[57] Eaton DL, Gallagher EP. Mechanisms of aflatoxin carcinogenesis. Annual Review of Pharmacology and Toxicology. 1994;34:135-72. doi:10.1146/annurev.pa. 34.040194.001031.

[58] Hayes JD, Nguyen T, Judah DJ, Petersson DG, Neal GE. Cloning of cDNAs from fetal rat liver encoding glutathione S-transferase Yc polypeptides. The Yc2 subunit is expressed in adult rat liver resistant to the hepatocarcinogen aflatoxin B1. The Journal of Biological Chemistry. 1994;269(32):20707-17.

[59] Corcuera LA, Vettorazzi A, Arbillaga L, Perez N, Gil AG, Azqueta A, et al. Genotoxicity of Aflatoxin B1 and Ochratoxin A after simultaneous application of the in vivo micronucleus and comet assay. Food and Chemical Toxicology: An International Journal Published for the British Industrial Biological Research Association. 2015;76:116-24. doi:10.1016/j.fct.2014.12.003.

[60] Turkez H, Geyikoglu F, Aslan A, Karagoz Y, Turkez O, Anar M. Antimutagenic effects of lichen Pseudovernia furfuracea (L.) Zoph. extracts against the mutagenicity of aflatoxin B1 in vitro. Toxicology and Industrial Health. 2010;26(9):625-31. doi: 10.1177/0748233710377779.

[61] Bedard LL, Massey TE. Aflatoxin B1-induced DNA damage and its repair. Cancer Letters. 2006;241(2):174-83. doi:10.1016/j.canlet.2005.11.018.

[62] Zeinvand-Lorestani H, Sabzevari O, Setayesh N, Amini M, Nili-Ahmadabadi A, Faramarzi MA. Comparative study of in vitro prooxidative properties and genotoxicity induced by aflatoxin B1 and its laccase-mediated detoxification products. Chemosphere. 2015;135:1-6. doi:10.1016/j.chemosphere.2015.03.036.

[63] Diaz GJ, Murcia HW, Cepeda SM. Bioactivation of aflatoxin B1 by turkey liver microsomes: responsible cytochrome P450 enzymes. British Poultry Science. 2010;51(6):82837. doi:10.1080/00071668.2010.528752. 
[64] Dohnal V, Wu QH, Kuca K. Metabolism of aflatoxins: key enzymes and interindividual as well as interspecies differences. Archives of Toxicology. 2014;88(9):1635-44. doi: 10.1007/s00204-014-1312-9.

[65] Yang WQ, Lian JW, Feng YJ, Srinivas S, Guo ZN, Zhong H, et al. Genome-wide miRNAprofiling of aflatoxin B1-induced hepatic injury using deep sequencing. Toxicology Letters. 2014;226(2):140-9. doi:10.1016/j.toxlet.2014.01.021.

[66] Liu CX, Yu HH, Zhang Y, Li DC, Xing XM, Chen LP, et al. Upregulation of miR-34a-5p antagonizes AFB1-induced genotoxicity in F344 rat liver. Toxicon. 2015;106:46-56. doi: 10.1016/j.toxicon.2015.09.016.

[67] Edlayne G, Simone A, Felicio JD. Chemical and biological approaches for mycotoxin control: a review. Recent Patents on Food, Nutrition \& Agriculture. 2009;1(2):155-61. 
Chapter 6

\title{
Environmental Effects of Endocrine-Disrupting Chemicals: A Special Focus on Phthalates and Bisphenol
}

\section{A}

\author{
Pinar Erkekoglu and Belma Kocer-Gumusel \\ Additional information is available at the end of the chapter
}

http://dx.doi.org/10.5772/62455

\begin{abstract}
Several environmental chemicals are classified as endocrine-disrupting chemicals (EDCs). Many of them have an impact on reproductive functions and sex hormones because of their estrogenic and/or antiandrogenic properties. Phthalates and bisphenol A (BPA) are two well-known EDCs. They are abundant in the environment. Phthalates are usually classified as antiandrogens, whereas BPA is considered as estrogen-like EDC and xenoestrogen. Other than their endocrine-disrupting effects, these two chemicals are also known to have genotoxic and epigenetic effects. Besides, they are hepatotoxic and have substantial effects on other organs/systems (thyroid, kidney, neuroendocrine system, immune system, etc.). In this chapter, we will mainly focus on the toxic effects of different phthalate esters and BPA by discussing their availability in the environment, mechanism and mode of actions, their biotransformation and reproductive effects, and their effects on other systems (hepatic, renal, etc.). Besides, we discuss epidemiological studies that are conducted to reveal their effects on the reproductive and endocrine systems. This chapter provides the readers a compact piece of knowledge on these abundant substances and helps them to understand the action of these substances at the molecular and cellular levels.
\end{abstract}

Keywords: endocrine-disrupting chemical, antiandrogen, xenoestrogen, phthalate, bisphenol A

\section{Introduction}

Exposure to environmental chemicals, particularly in early life, is among the substantial risks for developmental programming of different diseases in adult life of humans. In a report by 
World Health Organization (WHO), it was estimated that more than 13 million deaths were caused by environmental exposures each year. Moreover, this report also proposed that nearly one third of mortality and morbidity can be due to environmental causes in underdeveloped or developing countries [1].

Many environmental exposures to different chemical, physical, or biological agents can interact with genetic and epigenetic mechanisms and affect the normal growth and development. Among those exposures, endocrine-disrupting chemicals (EDCs) are of particular concern, as humans are abundantly exposed to these chemicals by various means in every period of life. According to the U.S. Environmental Protection Agency (EPA), an EDC was defined as "an exogenous agent that interferes with synthesis, secretion, transport, metabolism, binding action, or elimination of natural bloodborne hormones that are present in the body and are responsible for homeostasis, reproduction, and developmental process" [2]. Several well-known environmental chemicals are classified as EDCs. Many of them act on reproductive functions because of their estrogenic and/or antiandrogenic properties.

In the present chapter, we will mainly focus on the toxic effects of different phthalate esters and bisphenol A (BPA), which are the most abundant environmental chemicals. We will discuss their availability in the environment, mechanism and mode of actions, biotransformation, and effects on reproductive systems and other organs (hepatic, renal, etc.) in different periods of life. Besides, we will address the epidemiological studies that are conducted on these chemicals.

\section{Availability of endocrine disrupting chemicals in the environment}

EDCs are available in polyvinyl chloride (PVC) plastics, polycarbonate materials (type 7 plastics), epoxy resins, medical devices [intravenous (i.v.) bags, dialysis bags, surgical implants, dental fillings sealants], pharmaceuticals (enteric coatings of pharmaceutical pills and nutritional supplements), consumer products (make-up products, fragrances, nail polish, lotions, creams, baby products, soaps, liquid soaps shampoos, conditioners, hair sprays), children's toys, children products (modeling clay, waxes, paints), printing inks, paints, household products (detergents, softeners, surfactants), construction materials (including floorings and PVC windows, wood floor finishes, cements, caulking in buildings), insulating fluids (transformer oils) for transformers and capacitors, lubricating oils, stabilizing additives in flexible PVC coatings of electrical cables and electronic components, textiles (footwear, raincoats, picture printed shirts), vacuum pump fluids, pesticides (insecticides), and flame retardants and, most importantly, in food (packaging materials and in the inner lining of food cans) [3-5].

\section{Classification of EDCs}

From a toxicological perspective, EDCs can be classified according to their sources or their modes of action. 
In the first classification, EDCs can be grouped as [6, 7]:

a. natural (e.g., phytoestrogen: genistein and coumestrol) and

b. synthetic [e.g., phthalates, BPA, polychlorinated biphenyls (PCBs), polybrominated biphenyls (PBBs), dioxins; dichlorodiphenyltrichloroethane (DDT), vinclozolin, and diethylstilbestrol (DES)] compounds.

In the second classifications, EDCs can be classified as $[8,9]$ :

a. EDCs that effect reproductive system

b. EDCs that affect pancreas

c. EDCs that affect thyroid

d. EDCs that effect Central nervous sytem

e. EDCs that affect other systems

The signifacnt effects of EDCs on hormones are suggested to be:

a. Increasing or decreasing effect on the production of hormones (these substances may mimic naturally occurring hormones such as estrogens, androgens, or thyroid hormones or they may potentially cause the overstimulation of hormonal pathways within the body),

b. Increasing or decreasing effect on the transportation of hormones,

c. Increasing or decreasing effect on the metabolism of hormones,

d. Increasing or decreasing effect on the elimination of hormones,

e. Agonistic or antagonistic effect on the target cells of the hormones (by binding to a receptor within a cell and blocking the functions of endogenous hormones; i.e., acting as antiestrogens and antiandrogens), and

f. Altering the homeostatic systems of the organisms and causing their miscommunication or irresponsiveness to their own physiology and the environment.

\section{Modes/mechanisms of actions of EDCs}

a. Effect on hormone, nuclear, and nonnuclear receptors: Our understanding of the mechanisms by which EDCs exert their effect has grown. EDCs were originally thought to exert actions primarily through nuclear hormone receptors [i.e., estrogen receptors (ERs), androgen receptors (ARs), progesterone receptors, thyroid receptors (TRs), and retinoid receptors]. However, recent basic and mechanistic researches show that the underlying mechanisms of their toxicity are much wider than originally envisioned. Thus, other than nuclear receptors, EDCs may also act via nonnuclear steroid hormone receptors (e.g., membrane ERs), nonsteroid receptors (e.g., neurotransmitter receptors such as serotonin 
receptor, dopamine receptor, and norepinephrine receptor), and orphan receptors [e.g., aryl hydrocarbon receptor (AhR)] [9-11].

b. Effect on enzymatic pathways: These chemicals can affect the enzymatic pathways that have substantial roles in steroid biosynthesis and/or biotransformation and several other mechanisms that militate sex-specific physiology/behavior and endocrine and reproductive systems. They can disrupt and inhibit the action of enzymes involved in steroidogenesis, particularly in the metabolism of estrogens. For instance, some PCB metabolites can inhibit sulfotransferase, resulting in an increase of circulating estradiol [12-14].

c. Effects on signaling pathways: EDCs can regulate many cellular signaling pathways. For instances, both BPA and phthalates were shown to induce epithelial-to-mesenchymal transition (EMT). These chemicals can also down-regulate or up-regulate the genes involved in the regulation of signal transduction $[15,16]$.

\section{Toxicity mechanisms of EDCs}

There are a number of toxicity mechanisms/pathways that are suggested to be caused by estrogenic and antiandrogenic EDCs $[17,18]$. These mechanisms are associated with but are not limited to:

\section{Genotoxicity,}

2. Epigenetic mechanisms (hormonal dysregulation, peroxisome proliferation, cytotoxicity, oxidative stress, DNA methylation, histone modification, RNA interfering, apoptosis, and imprinting), and

3. Other mechanisms.

The effects of EDCs on cellular metabolism or functions, cellular organelles (peroxisomes, mitochondria, cytoskeleton), DNA damage, chromosomal aberrations, cell cycle checkpoints, translational control, cell death (apoptosis, autophagy, necrosis), immunology/inflammation response, neurological pathways, and development/differentiation are now being studied extensively. However, their effects were also shown to extend beyond these mechanisms/ pathways and may include multiple functions, tissues, and organs such as the liver, kidney, and spleen. Thus, they may have broader impacts-most of them yet to be identified-on disrupting signaling webs and cellular communication $[17,18]$.

\section{Phthalates}

The word "plastic" originates from the Greek word "plasticos," which expresses "a material's being capable of molding into different shapes." The first plasticizer was synthesized in 1860 . By the progression of technology and increase in the global population growth, plastic materials are now widely used and have very different application fields [19]. Phthalates are dialkyl or alkyl aryl esters of phthalic acid and are abundantly used to make plastic materials 
more flexible. They are synthesized by reacting phthalic anhydride with alcohol(s) [methanol and ethanol (C1/C2) up to tridecyl alcohol (C13)] either as a straight chain or with some branching. Their main use is for the softening of rigid plastics and polymers. Di(2-ethylhexyl)phthalate (DEHP), the most abundant phthalate derivative, is used $1 \%$ to $40 \%$ in plastics by weight [20]. Almost 90\% of DEHP is used to soften PVC plastics, and in the European Union, $95 \%$ of DEHP is used in polymer products as a plasticizer [21].

Phthalates were first synthesized in the 1930s. DEHP was first synthesized in 1933 in Japan and in 1939 in United States in commercial quantities. DEHP was first used in 1949 in United States and has been the most abundantly used phthalate derivative in the Twentieth century. In 1999, the consumption of phthalates were 3.25 million tons and DEHP accounted for 2.1 million tons of the total production. The European Commission reported that 1 million tons of DEHP were used in 2000 [22].

\subsection{Occurrence, uses, and exposure to phthalates}

Phthalates migrate out PVC-containing items into food, air, dust, water, and soils and cause human exposure in various ways [23]. Several studies were conducted in different parts of the world, and human blood and urine (mostly spot urine samples) were used as biological fluids to evaluate the exposure to phthalates. The results of these studies revealed that humans are ubiquitously exposed to different phthalates, mostly in industrialized countries [24-27]. On the contrary, workplace inhalation is also of concern as phthalates; particularly, DEHP has low vapor pressure [28].

Diet is the main source of phthalate exposure in the general population. Particularly, fatty food (e.g., fish and oils) can cause high phthalate exposure if contaminated [29, 30]. One other major source is medical exposure by blood storage bags and blood transfusion equipment during receiving blood transfusion [31,32] or hemodialysis (dialysis bags) [33, 34].

Based on the number of carbon atoms in their alcohol chain, phthalates are divided into two distinct groups, with very different applications, toxicological properties, and classification: high molecular weight (MW) phthalates and low MW phthalates. Their use largely depends on their MW. Higher MW phthalates, such as DEHP, are used in construction materials and in numerous PVC products, including clothing, food and beverage packaging, children products (toys, grip bumpers), and biomedical equipment (e.g., blood transfusion bags, dialysis bags, and umbilical catheterization devices), whereas relatively lower MW phthalates such as dimethyl phthalate (DMP), diethyl phthalate (DEP), and dibutyl phthalate (DBP), are mainly used as odor/color fixatives or as solvents and in cosmetics, textiles, and pharmaceuticals [35].

DEHP has a very low degree of acute toxicity, with oral lethal dose $50\left(\mathrm{LD}_{50}\right)$ values ranging from 26 to $>34 \mathrm{~g} / \mathrm{kg}$ in a variety of species. In a study by Lawrence et al. [36], the lethal effect of this compound appeared to be cumulative, because the $\mathrm{LD}_{50}$ value for intraperitoneal (i.p.) administration to mice five times weekly for 10 weeks was $1.36 \mathrm{~g} / \mathrm{kg}$ in comparison to a singledose value of $37.8 \mathrm{~g} / \mathrm{kg}$. Autian [37] concluded that this was because biotransformation was required before DEHP produces toxic effects. In rats, lethal concentration $50\left(\mathrm{LC}_{50}\right)$ by inhala- 
tion $(1 \mathrm{~h})$ was found to be $>23.670 \mathrm{mg} / \mathrm{m}^{3}(1457 \mathrm{ppm})$ and inhalation $\mathrm{LC}_{50}(6 \mathrm{~h})$ value was $>600$ $\mathrm{mg} / \mathrm{m}^{3}\left(37 \mathrm{ppm}\right.$ ) [37]. The oral administration $\mathrm{LD}_{50}$ value for rats (Wistar, male) was suggested to be between 26.000 and $34.000 \mathrm{mg} / \mathrm{kg}$ body weight and the $\mathrm{LD}_{50}$ value for i.p. administration in rats was found to be between 30.600 to $49.000 \mathrm{mg} / \mathrm{kg}$ body weight [38].

\subsection{Biotransformation of phthalates}

Phthalates are not covalently bound to plastic products and therefore may leak out to contaminate blood or food products and can be ingested. When administered orally to humans and rodents, phthalates are rapidly hydrolyzed by esterases in the gut and other tissues to produce the corresponding active monoesters and their further oxidized metabolites. During phase I biotransformation, the relatively polar and low MW phthalates (e.g., DEP) are primarily metabolized to their hydrolytic monoesters by hydrolysis of one of the ester bonds. In contrast, the high MW phthalates are first metabolized to their respective hydrolytic monoesters and then, after enzymatic oxidation of the alkyl chain, to more hydrophilic, oxidative metabolites [39]. For example, DEHP is metabolized to its monoester metabolite, mono-2-ethylhexyl phthalate (MEHP), which is more toxic than the parent compound. MEHP is further metabolized to secondary oxidative metabolites [40]:

- Mono-(2-ethyl-5-hydroxyhexyl)phthalate (5OH-MEHP, MEHHP), which is then metabolized to mono-(2-ethyl-5- oxohexyl) phthalate (MEOHP, 5oxo-MEHP). MEHP can also be metabolized to different structural isomers of MEHHP, which also have further metabolism to different monoethylphthalate structures.

- Mono-(2-ethyl-5-carboxypentyl)phthalate (5cx-MEPP)

- Mono-[2-(carboxymethyl)hexyl]phthalate (2cx-MMHP)

Some phthalates are subject to phase II (particularly to glucuronidation and, to a lesser extent, sulfation) metabolic reactions. Glucuronidation not only provided higher urinary excretion of phthalate metabolites but also can reduce their biological activity. Monoesters and the oxidative metabolites of phthalates are excreted in urine (95\%) and, to a very lesser extent, eliminated by feces (5\%) [39].

\subsection{Genotoxic effects of phthalates}

The biological effects of phthalates are of major concern but so far elusive. Phthalates are shown to cause cytogenetic damage to animals and humans. In 1980s, phthalates were evaluated as epigenetic carcinogens because of their peroxisome proliferative effects. However, in the 1990s and in the Twenty first century, several studies confirmed their genotoxic effects [41-43].

Chromosomal aberration test, unscheduled DNA synthesis (UDS), Ames test, micronucleus test, and hypoxanthine guanine phosphoribosyltransferase (HPRT) mutation test were applied to evaluate the genotoxic potentials of phthalates. DEHP was shown to induce single chromatid aberrations and sister chromatid exchange (SCE) in human lymphocytes [44]. Besides, DEHP caused lymphatic mitotic inhibition after $4 \mathrm{~h}$ of exposure and caused an increase in the doubling time of human lymphocytes [44]. Later, Stenchever et al. [45] reported that DEHP 
caused chromosomal breaks in human lymphocytes; mitotic rate decreased and DEHP caused polyploidy and aneuploidy in human fetal lung cells.

Phillips et al. [46] reported that, in Chinese hamster ovary (CHO) cells, MEHP caused chromosome damage without affecting in the SCE and HPRT mutation test. However, after DEHP treatment in rat hepatocytes, Astill et al. [47] did not find a change in Ames test, mouse lymphoma activation assay, micronucleus test, UDS, and cell transformation tests. A study performed on both $\mathrm{CHO}$ cells and RL4 liver cells showed that MEHP caused chromosomal aberrations. However, S-9 mix (a mix of cytosolic and microsomal drug-metabolizing enzymes and cofactors) had no effect on the chromosome damage produced by MEHP in CHO cells [48].

A study using mouse hepatocytes evaluated the genotoxicity of these compounds (i.e., DNA repair or UDS). No changes were observed in DNA repair capacity. However, UDS of the hepatocytes obtained from mice treated with DEHP containing diet showed significantly higher UDS compared to control cells [49]. Lindahl-Kiessling et al. [50] showed that DEHP induced SCE in human lymphocytes, which were co-cultured with rat liver cells. MüllerTegethoff et al. [51] observed that peroxisome proliferators (nafenopin, $\mathrm{Wy}-14,643$ ) and DEHP did not induce any changes in micronucleus test in rat hepatocytes. Kim et al. [52] showed that DBP caused both chromatid and chromosomal type chromosomal aberrations (break and exchange) in the lymphocytes of $\mathrm{B} 6 \mathrm{C} 3 \mathrm{~F} 1$ mice and this aberrations showed marked increases and these alterations show marked elevations dependent on the time of exposure. McKee et al. [53] reported that di(isononyl) phthalate (DINP) was not found to be mutagenic in Ames test, in vitro cytogenetic assay, and mouse micronucleus assay. Using Ames test, Lee and Lee [54] observed that the phthalic acid and terephthalic acid did not produce any mutagenic responses in the absence or presence of S9 mix on the Salmonella typhimurium strains in Ames test. Besides, phthalic acid and terephthalic acid did not show any significant cytogenetic effect on CHO cells in the chromosomal aberration test and in the mouse micronucleus test [54].

Many studies are performed on the genotoxicity of phthalates using Comet assay in the last 30 years. Anderson et al. [55] showed that both DEHP and its major metabolite MEHP induced DNA damage in human leukocytes as evidenced by increases in tail moment in Comet assay. Kleinsasser et al. [56] compared susceptibilities to DBP and di-iso-butyl-phthalate (DiBP) in nontumor patients to those in patients with squamous cell cancer (SCC) of the oropharynx or larynx using Comet assay and indicated that DBP and DiBP produced significant differences in the Olive tail moment (OTM) between oropharynx (TO), larynx (TL), and TO plus TL groups and the nontumor donors. The same researchers also determined the correlation between the genotoxic sensitivities to DBP and its isomer DiBP in mucosal epithelial cells or lymphocytes using Comet assay, and both phthalates showed significant genotoxicity on both cells and lymphocytes where the genotoxic effect of DiBP was higher than DBP in both cell types [57]. Biscardi et al. [58] reported that DEHP can leach out of polyethylene terephthalate (PET) bottles in time, especially after almost 10 months of storage, and this phenomenon can cause increases in both total tail length and number of cells in human leukocytes in vitro.

DEHP, BPA, nonylphenol, and paraquat dichloride were tested for their genotoxicity potentials on HeLa cells. DEHP showed genotoxicity $(>90 \mu \mathrm{M})$ with significant increases in tail moment [59]. In a recent study performed on HepG2 cells exposed to various concentrations 
of DEHP for 24 or $48 \mathrm{~h}$, DNA damage increased significantly in a dose-dependent manner [60]. Throughout our studies on DEHP and MEHP, we determined that both DEHP and MEHP were both cytotoxic and genotoxic in LNCaP cells (human prostate cancer cell line) and Leydig cells (mouse Leydig carcinoma cell line). We also observed that selenium supplementation in either organic form (selenomethionine at $10 \mu \mathrm{M}$ ) or inorganic form (sodium selenite at $30 \mathrm{nM}$ ) was highly protective against the cytotoxicity and genotoxicity exerted by these particular phthalate derivatives $[42,43]$.

The correlation between urinary phthalate levels and sperm DNA damage is being investigated by several studies. Duty et al. [61] analyzed semen and urine samples of 141 subjects were for five phthalate metabolites using neutral Comet assay and DNA was only correlated with monoethyl phthalate (MEP) levels, although there was no correlation with other phthalate metabolites [monobenzyl phthalate (MBzP), mono- $n$-butyl phthalate (MBP), MEHP, and monomethyl phthalate (MMP)]. Hauser et al. [62] determined the urinary concentrations of phthalate metabolites among men $(n=379)$ who were admitted to an infertility clinic. Sperm DNA damage was associated with MEP and MEHP. Recently, Ahbab et al. [63] determined the possible genotoxicity of two different phthalate esters, namely, di- $n$-hexyl phthalate (DHP) and dicyclohexyl phthalate (DCHP), at different concentrations using Comet assay in male rat pups from gestational day (GD) 6 to GD19 at different doses [0 (vehicle), 20, 100, and $500 \mathrm{mg}$ / $\mathrm{kg} /$ day]. Male rats were allowed to grow until different ages (prepubertal, pubertal, and adulthood). The Comet assay was performed on blood lymphocytes and testes samples of adult male rats and the results showed that DHP significantly induced genotoxicity at doses of 100 and $500 \mathrm{mg} / \mathrm{kg} /$ day versus control; however, DCHP did not show the same effect [63].

\subsection{Epigenetic effects of phthalates}

The results of many studies strongly point out that that EDC exposure can caused by epigenetic mechanisms, which can lead to cumulative adverse effects on future generations. The epigenetic marks can induce up/down alterations in gene expression that may persist throughout a lifetime. These permanent changes will result in adverse health effects, such as neural and immune disorders, infertility, and late-onset complex diseases (cancers and diabetes) [64].

Phthalates are long suggested to be epigenetic carcinogens because of their peroxisome proliferator effects. The in utero and neonatal exposure to phthalates [particularly to DEHP, MEHP, benz-butyl phthalate (BBP), DBP, and MBP] may cause methylation changes in DNA at $\mathrm{CPG}$ islands near gene promoter regions, different histone modifications (acetylation, methylation, phosphorylation, ubiquitination, sumoylation, and ADP ribosylation), and alterations in the expression of noncoding RNAs, including microRNAs (miRNAs) [65].

The treatment of human breast cancer MCF-7 cells with BBP led to the demethylation of ER $\alpha$ promoter-associated CPG islands, indicating that altered ER $\alpha$ mRNA expression by BBP can induce aberrant DNA methylation in the promoter region of this gene. Maternal exposure to DEHP was shown to induce DNA methylation and different DNA methyltransferase expressions in mouse testis. Fetal testis is suggested to be the main target for DEHP. DEHP can lead to testicular dysgenesis syndrome (TDS) due to a reduction in insulin-like hormone 3 (INSL3) expression and testosterone production [66]. During the period of embryonic sex 
determination, transient exposure to a plastic mixture (BPA and phthalates) of gestating female rats was shown to promote early-onset puberty transgenerationally ( $\mathrm{F}_{3}$ generation) and decrease the pool size of ovarian primordial follicles in female pups. On the contrary, in male pups, spermatogenic cell apoptosis was also affected transgenerationally, and differential DNA methylation of the $\mathrm{F}_{3}$ generation sperm promoter regions was also observed [67].

\subsection{Carcinogenicity of phthalates}

Phthalates are well-known peroxisome proliferators that can alter gene and protein expressions. This capability may result in the promotion of hepatic carcinogenesis in rodents [68]. On the contrary, there are data in the literature that indicate that phthalates increase oxidative stress in the rodent liver even before peroxisomal oxidases are induced. In addition, Kupffer cells have been suggested to be a potential source of oxidants in rodent liver after treatment with DEHP $[69,70]$. It appears that molecular events, which may be a consequence of increase oxidative stress, could interact with other pathways activated by peroxisome proliferation in rodent liver $[69,70]$. Although several studies including the studies by our group (in the last decade) pointed out that DEHP can induce reactive oxygen species (ROS) production and lead to increased cellular oxidative stress both in vivo and in vitro, there are no convincing data to prove whether the induction of ROS production is a one of the major pathways or whether ROS elimination is not efficiently achieved after a series of molecular events induced by phthalates, particularly by DEHP [42, 43, 70, 71].

In the 1980s, the hepatocarcinogenic effects of DEHP, due to its peroxisome proliferator effect, was shown by several studies. Back then, some concerns started rising about the safety of this substance. In 2000, the International Agency for Research on Cancer (IARC) classified DEHP as a Group III carcinogen (not classifiable as to its carcinogenicity to humans), as peroxisome proliferation has not been documented in human hepatocyte cultures exposed to DEHP nor in the liver of exposed nonhuman primates [71]. Therefore, the mechanism by which DEHP increases the incidence of hepatocellular tumors in rats and mice is not relevant to humans. However, later in 2013, DEHP was classified as a Group IIB carcinogen due to some concerns [72]. On the contrary, butyl benzyl phthalate (BBP) is classified as a Group III carcinogen in 1999 [73]. Blom et al. [74] showed that exposure to different phthalate esters, particularly to DBP, can lead to high proliferation of human breast cancer cell lines, which was explained in part by the potency of phthalates in terms of a "xenoestrogenic impact," although phthalates are usually classified as "antiandrogens" and not "xenoestrogens" [74, 75]. This effect is suggested to be related to a direct ER binding of some, but not all, phthalates [76, 77].

\subsection{Reproductive toxicity of phthalates}

Recent in vivo and in vitro studies on phthalates are mainly focusing on their reproductive toxicity potential. Phthalates were suggested to target mainly male reproductive system. The "TDS hypothesis" proposes that a proportion of the male reproductive disorders-cryptorchidism, hypospadias, decline infertility (or loss of fertility), and testicular cancer-may be symptoms of TDS, which is most likely a result of disturbed gonadal development in the embryo. There is a decline in male fertility and increase in the number of cases with TDS in 
the last decades, and phthalates are suggested to be the major underlying factors. Several studies have shown that fetal exposures to DEHP or DBP induce TDS-like effects and reduce anogenital distance (AGD) in rodents [78].

In testis, Leydig and Sertoli cells are the main targets of phthalates. Many researchers observed that DEHP caused disruption in the function of both cell types. The administration of MEHP to Wistar rats at a single oral dose $(400 \mathrm{mg} / \mathrm{kg}$ body weight) was toxic to Sertoli cells and caused detachment of germ cells [79]. In fact, Richburg and Boekelheide [80] demonstrated histopathological disturbances and alterations of cytoplasmic distribution of vimentin in Sertoli cells in testis of 28-day-old Fisher rats after a single oral dose of MEHP (2000 mg/kg). Tay et al. [81] also observed a correlation between the increase in TUNEL-positive cells and the vimentin disruption in treated mice. We also determined that DEHP exposure caused disruption and collapse of vimentin filaments and significantly induced apoptotic death of germ cells [82].

Exposure to phthalates, particularly to DEHP, resulted in decreased testicular testosterone production in rodents, and most of the reprotoxic effects are suggested to be related to their antiandrogenic potential [83, 84]. In our studies, we determined that DEHP caused abnormal sperm production, decreases in sperm count, and motility when administered to 10-week-old rats at 1000 ppm dose for 10 days. Moreover, we also observed that DEHP caused decreases in testosterone, luteinizing hormone (LH), and follicle stimulating hormone (FSH) levels [84]. Moreover, DEHP induced oxidative stress in rat testis, as evidenced by the significant decrease in GSH/GSSG redox ratio, marked increase in lipid peroxidation, and a significant decrease in GPx4 activity [85].

\subsection{Hepatotoxic effects of phthalates}

DEHP and other phthalates, such as di-(2-ethylhexyl) adipate (DEHA) and DINP, are shown to be hepatocarcinogenic in both sexes in mice and rats. These substances were shown to cause both hepatocellular carcinomas and adenomas [86-88]. There are a number of molecular events that underlie the hepatocarcinogenic potential of these substances: Their genotoxicity, peroxisome proliferative property, and epigenetic effects are the most studied mechanisms. Collectively, it appears that, in rodent liver, oxidative stress-related molecular events could interact with other pathways that can be activated by peroxisome proliferation. Previously, we have also shown that DEHP caused peroxisome proliferation, alterations in antioxidant enzyme activities (decreases in glutathione peroxidase 1, glutathione peroxidase 4, superoxide dismutase, and glutathione $S$-transferase activities; increase in thioredoxin reductase activity), and liver enzymes when administered to 10 -week-old rats at 1000 ppm dose for 10 days. Besides, DEHP caused cellular disorganization, increases in catalase activity/immunoreactivity, and lipid peroxidation [89].

\subsection{Effects of phthalates on other organs/systems}

Other than testis and liver, phthalates were suggested to be toxic to kidneys and thyroid [90, 91]. Moreover, phthalates were also shown to affect the neuroendocrine system and the hypothalamus-pituitary-ovarian/testicular axis in rats [92-94]. 


\subsection{Epidemiological studies concerning the effects of phthalates on reproductive/endocrine systems}

In the last five decades, a gradual decline in global semen quality has been reported [95]. The effects of phthalate exposure on male fertility has been attracting the attention of researchers for a long period of time, although phthalates exert serious health effects on different organs/ systems. Semen quality defines the sperm count, motility, and morphology. An early study described sperm concentration and DBP measured in the seminal fluid of American students $(N=21)$ recruited and these students were classified as low metabolizers $(n=12)$ and high metabolizers $(n=9)$. Seminal DBP levels were associated with decreased sperm concentration, and an overall analysis indicated a positive association between DBP and sperm concentration [95]. Total semen phthalates were higher among 21 men with an infertility diagnosis compared to 32 men without $(p<0.05)$ in a cross-sectional study of infertility clinic patients in India. Among the infertile men, seminal phthalates were associated with increased sperm abnormality but not with sperm count or motility [96]. Later, in a cross-sectional study of 234 Swedish military conscripts aged 18 to 21 years, Jönsson et al. [97] observed that urinary MEP concentrations were associated with decreased sperm motility. No associations were determined between semen quality and MBP, MBzP, or MEHP. A positive association between sperm motility and phthalic acid was found, and this finding suggested that an increased ability to metabolize phthalates may be protective. Besides, the researchers reported a cross-sectional association between urinary MEP concentrations and decreased LH levels when comparing the quartile of highest exposure to the lowest [97].

Among 52 Chinese men attending a reproduction clinic in Shanghai, no associations were detected for sperm count or morphology and semen concentrations of DEP, DEHP, and DBP [98]. The majority of studies of phthalate exposure and semen quality have been conducted among infertile populations. In 2006, an American study was conducted on 443 men undergoing infertility therapy. Higher urinary MBP levels were associated with decreased sperm concentration and motility after adjusting for age, abstinence time, and smoking status. No associations with semen quality were suggested for MEP, MMP, MEHP, MEOHP, or MEHHP [99].

Pant et al. [100] measured the phthalate diesters levels in the semen of 300 Indian men, and correlations were detected between DBP, DEHP, and decreased motility in unadjusted analyses. Unadjusted associations were also reported between DBP, DEHP, DEP, and decreased sperm concentration and for DEHP and increased abnormal morphology. No associations were reported for semen DMP or di-n-octyl phthalate (DnOP) levels and sperm parameters [100]. Wirth et al. [101] determined the urinary phthalate levels in 45 men who were admitted to an infertility clinic. Urinary MEP levels were associated with decreased sperm concentration (after adjusting for race and for urine specific gravity) and abnormal morphology (after adjusting for urine specific gravity). Urinary mono-3-carboxypropyl phthalate (MCPP) levels were also associated with an increased proportion of morphologically abnormal sperm, and an association was suggested for urinary MEHP with low sperm concentration. However, no associations were indicated for MMP, MBP, MiBP, MBzP, MEHP, MEOHP, and MEHHP [101]. 
Another study on 349 men who were recruited from a German andrology clinic reported no associations between urinary DEHP metabolites (MEHP, MEHHP, MEOHP, and 5cx-MEPP) and any semen parameters after adjusting for age, smoking, abstinence period, and urine creatinine [102]. In another cross-sectional study, the median semen DBP concentration was higher in oligoasthenospermic men $(n=65)$ compared to fertile men $(n=50)$, and median DEHP concentration was also higher in oligoasthenospermic men versus in fertile men. In addition, sperm motility was inversely associated with DBP and DEHP in oligoasthenospermic $(n=65)$ and asthenospermic $(n=65)$ men, respectively. However, the associations were not adjusted for potential confounding variables [103]. Another cross-sectional study recruited 97 men undergoing infertility treatment in China and found the top tertile of urinary MBP to be strongly associated with decreased sperm concentration after adjusting for age, abstinence time, body mass index (BMI), smoking, alcohol consumption, and education. There were no associations reported for sperm parameters and MMP, MEP, MBzP, MEHP, or MEOHP [104]. A more recent work suggested that urinary MBP levels were inversely associated with sperm concentrations in a general population sample of 232 men residing in a heavily industrialized urban area in China. However, no such associations were found for MEP (median=3.10 $\mathrm{ng} / \mathrm{mL})$ or MEHP (1.10 ng/mL) or for motility and morphology [105]. A Polish study on men $(n=269)$ under 45 years of age and attending a infertility clinic measured urinary MEHP, MEHHP, monoisononyl phthalate (MiNP), MBzP, MBP, and MEP levels. Inverse associations were detected between sperm motility and log-transformed MEHP, MEHHP, and MiNP levels after adjusting for age, smoking, abstinence period, past diseases, and creatinine as confounding covariates. No adjusted associations were detected between sperm concentration and morphology and urinary MBzP and MEP levels [106].

There are several studies that were conducted to understand the relationship between sex or reproductive hormones and different phthalate derivatives. One cross-sectional study in China quantified exposure using urinary metabolites in occupationally exposed workers $(n=74)$ and unexposed referent workers $(n=63)$ matched by age and smoking. Decreases in free testosterone, but not FSH, were associated with MBP exposure in all the men after adjusting for age and alcohol consumption [107]. An earlier work performed on 295 men reported an association between an interquartile range (IQR) increase in urinary MBzP concentrations and decreased FSH levels and a nonsignificant association between an IQR increase in MEHP and decreased testosterone after adjusting for age, BMI, and time of specimen collection [108]. Furthermore, MBP was nonsignificantly associated with increased inhibin B after adjustment for covariates. The results of this study are in contradiction with the results obtained from a study that recruited 118 men seeking infertility treatment in China. Sex steroid hormones were assessed in association with urinary MEP, MBP, MBzP, MEHP, MEHHP, and MEOHP levels among 425 men. The molar sum of DEHP metabolites and percentage MEHP were assessed, and an IQR increase for MEHP was associated with decreased serum estradiol and testosterone levels after adjusting for age, BMI, smoking, and time of specimen collection. A significant association between percentage MEHP and an increase in the testosterone/estradiol ratio was also determined. Adjusted decreases in the free androgen index [FAI; describes the ratio of testosterone to sex hormone binding globulin (SHBG)] were also reported for MEHHP, $\mathrm{MEOHP}$, and the sum of DEHP metabolites. No associations were reported between MBP or 
MBzP and serum prolactin, FSH, or LH. However, no associations between concentrations of the other phthalate metabolites and concentrations of the other hormones, including testosterone, estradiol, FSH, inhibin B, and SHBG, were found [109]. Another study performed on 425 men recruited through a U.S. infertility clinic found limited inverse association between MEHP and FAI by the proportion of DEHP metabolites in the urine measured as MEHP (MEHP\%), a phenotypic marker of less efficient metabolism of DEHP to its oxidized metabolites. Finally, the ratio of testosterone to estradiol was positively associated with MEHP and $\mathrm{MEHP} \%$, suggesting potential relationships with aromatase suppression [110]. In a crosssectional study of 363 fertile men participating in a multicenter U.S. study, inverse associations were described for urine DEHP metabolites (MEHP, MEHHP, MEOHP, and MECPP) and FAI after adjusting for age, BMI, smoking, ethnicity, urine creatinine, and time of sample collection. A positive correlation was also found between MEHP and SHBG, and the FAI/LH ratio after adjustment for covariates. However, no associations were reported for FSH, estradiol, or LH [111]. A recent study compiled data from two investigations of phthalate exposure and reproductive hormones, combining men from the Massachusetts General Hospital and multicenter U.S. studies. In a combined total of 783 men, there were no associations with urinary concentrations of $\mathrm{MEP}, \mathrm{MBP}$, or $\mathrm{MBzP}$ and any reproductive hormone measured. However, metabolites of DEHP (MEHP, MEHHP, and MEOHP) were associated with decreased free testosterone and increased SHBG levels [112].

A study performed by our group recruited 40 newly diagnosed pubertal gynecomastia cases and 20 controls. Plasma DEHP and MEHP levels were found to be statistically significantly higher in the pubertal gynecomastia group compared to the control group. There was a statistically significant correlation between plasma DEHP and MEHP levels $(r=0.58 ; P<0.001)$. In the pubertal gynecomastia group, no correlation was determined between plasma DEHP and MEHP levels and any of sex hormone levels [24]. However, as a part of the Copenhagen Puberty Study, Mieritz et al. [113] did not find any difference between the urinary phthalate levels of Danish boys $(n=555)$ versus control.

\section{Bisphenol A}

BPA is used to harden plastics and to manufacture polycarbonate plastics and epoxy resins. It has high abundance in the environment and considered as estrogen-like EDC or as a xenoestrogen. It was shown that BPA acts similarly to $17-\beta$ estradiol [114, 115]. BPA induces ERs (weakly to ER $\alpha$ and ER $\beta$ and strongly to ERR $\gamma$ ) but in the concentrations approximately 1000 higher $\left(10^{-6}-10^{-4} \mathrm{M}\right)$ in comparison to estradiol [116]. BPA was classified as a weak environmental estrogen before. However, newer studies determined that, even in very low concentrations (picomolar and nanomolar), BPA exerted divergent effects on the physiology of different cells and tissues and can bind to both nuclear and nonnuclear receptors [117]. Furthermore, most of BPA metabolites were shown to exert stronger estrogenic activities than the main compound [118]. Apart from the estrogenic effects, BPA was shown to bind to ARs, which can be related to excessive stimulation prostate and can lead to cancer. BPA was 
suggested to modulate androgen-dependent prostate cancer cell proliferation even in the concentrations corresponding to its level determined in human blood [119].

Metal food and beverage cans have a thin coating of BPA on the interior surface, which is essential to prevent corrosion of the can and contamination of food. Moreover, fetuses and young infants are commonly exposed to BPA by transplacental transfer of maternal BPA and through ingestion of maternal milk or formula in BPA containing plastic bottles [120].

BPA exhibits moderate acute toxicity to vertebrates. Through the oral, i.p., and i.v. routes, $\mathrm{LD}_{50}$ doses of BPA in rats were found to be 3250,841 , and $35.26 \mathrm{mg} / \mathrm{kg}$ body weight, respectively $[121,122]$. On the contrary, $\mathrm{LD}_{50}$ doses in mice were found to be 2400 and $150 \mathrm{mg} / \mathrm{kg}$ via oral and i.p. routes, respectively. Moreover, the U.S. EPA estimated the reference dose as $50 \mu \mathrm{g}$ $\mathrm{BPA} / \mathrm{kg}$ body weight/day [123]. Studies concerning the toxic effects of BPA suggested that humans are more susceptible than rodents to the deleterious action of this substance [124]. Recently, intensive investigations are being realized that refer to toxic, teratogenic, carcinogenic, and particularly estrogenic mechanisms of BPA action.

\subsection{Biotransformation of Bisphenol A}

BPA can be biotransformed in vertebrates, invertebrates, and plants and it is also biodegraded by microorganisms including bacteria, fungi, and algae. There are differences of species or strain in the metabolism of BPA. It was reported that, in primates, BPA can more easily be absorbed orally or subcutaneously (s.c.) compared to rats, and primates need a longer period of time to eliminate BPA from serum than rats [125]. Moreover, human liver microsomes do not have the ability to glucuronidate BPA as extensively as rat liver microsomes [126]. The metabolism of BPA is faster in female rats than in male rats [127]. It was suggested that gender differences in serum BPA concentrations of adult humans may be caused by differences in the androgen-related metabolism of BPA [128]. In addition, Kim et al. reported higher levels of BPA glucuronide in men than in women [129]; however, the levels of BPA sulfate were higher in women than in men [130].

BPA glucuronide is the major metabolite of BPA. Other metabolites (BPA sulfate conjugate, BPA diglucuronide, 5-hydroxy BPA, and the corresponding sulfate conjugate) were also reported. BPA glucuronide has lower estrogenic effect compared to the main compound [131134]. 5-Hydroxy BPA is also less estrogenic than BPA $[132,133]$. The sulfate metabolite of BPA does not show an estrogenic effect up to $1 \mathrm{mM}$ [134].

\subsection{Genotoxic effects of Bisphenol A}

BPA did not show any mutagenic effect in Ames test even after metabolic activation [135]. However, BPA was shown to cause DNA damage in eukaryotic cells, that is, BPA induced DNA strand breaks in L5178Y mouse lymphoma cells [136] and induced aneuploidy and structural chromosomal aberrations in ER-positive MCF-7 cells and in CHO-K1 cells [132, 133, 137]. The genotoxic potential of BPA was also evaluated by Lee et al. [138]. In mutant chicken DT40 cell lines (deficient in DNA repair pathways), researchers determined chromosomal aberrations and double-strand breaks [138]. BPA was shown to induce ROS generation, which 
in turn caused an induction of the production of DNA oxidative bases [139]. However, Audebert et al. [140] did not observe any genotoxicity when BPA was administered to three human cell lines [human intestinal cell line (LS174T), hepatoma cell line (HepG2), and renal cell line $(\mathrm{ACHN})]$. On the contrary, BPA metabolites (BPA-quinone) were shown to induce DNA damage by forming covalent adducts with DNA and adducts with deoxyguanosine [131, 141].

BPA was also suggested to alter gene and protein expression. Recently, Fernandez et al. [142] showed that BPA increased the expression of some genes (i.e., BRCA1, BRCA2, BRCC3, and BCL2L11) that are involved in DNA repair and apoptosis in human breast epithelial cells. The authors suggested that women who have BRCA1 or BRCA2 mutations may be more susceptible to such effects of BPA [142].

\subsection{Epigenetic effects of Bisphenol A}

In utero or neonatal exposure to low doses of BPA may cause alterations in DNA methylation, modifications in histones, and changes in the expression patterns of noncoding RNAs. These changes can up-regulate or down-regulate different gene expressions, which in turn may result in permanent health effects such as neural and immune disorders, infertility, and late onset of complex diseases. BPA induced permanent alterations in DNA methylation patterns of different genes that are responsible for cellular signaling [64, 143].

The epigenetic effect of BPA was clearly demonstrated in viable yellow mice [144]. By decreasing $\mathrm{CpG}$ methylation in the IAP retrotransposable sequence inserted upstream of the Agouti gene, the maternal exposure to BPA shifted the coat color distribution of viable yellow mouse offspring toward yellow. This effect was completely prevented by maternal supplementation with folic acid or the phytoestrogen genistein, both of which are sources of methyl group [145].

BPA was suggested to induce mainly breast and prostate cancer in both animals and humans. Keri et al. [146] suggested that BPA may increase the risk of such cancers by affecting various cell processes such as DNA methylation and chromatin remodeling during development. BPA exposure was shown to cause epigenetic alterations in rodent prostate and have been postulated to be the underlying cause of neoplastic development in later life [147]. Neonatal exposure of rats to BPA resulted in an increased incidence of prostate intraepithelial neoplasia, and the prostate tissues showed consistent methylation changes. For example, the phosphodiesterase type 4 variant 4 (Pde4d4) gene was found to be hypomethylated at the regulatory CpG island and started to have an elevated expression in the adult rat prostate $[148,149]$. On the contrary, neonatal BPA exposure was also reported to alter the promoter methylation and expression of nucleosome binding protein-1 (Nsbp1) and hippocalcin-like 1 (Hpcal1) genes in rats [150]. Also, the neonatal exposure to BPA was shown to induce hypermethylation of ER promoter regions in rat testis. This phenomenon mediated epigenetic changes that in turn induced adverse effects on spermatogenesis and fertility [151].

Concerning miRNAs, BPA exposure of human placental cell lines has been shown to alter miRNA expression levels; particularly, miR-146a was strongly induced after BPA application. 
Induction of miR-146a caused slower cellular proliferation rates and higher sensitivity to bleomycin, which strongly induces DNA strand breaks [152]. In mouse Sertoli cell line (TM4), $24 \mathrm{~h}$ BPA exposure leads to up-regulation or more often to down-regulation of 37 miRNAs [153].

\subsection{Carcinogenicity of Bisphenol A}

Currently, there is no evaluation of the IARC for BPA. However, "bisphenol A diglycidyl ether" is classified as a Group III carcinogen (not classifiable as to its carcinogenicity to humans) by the IARC [154].

At low doses, BPA was shown to alter mammary gland development and increased incidence of tumors in Sprague-Dawley rats [155]. Besides, at the comparable amounts to a reference dose, BPA caused development of breast, prostate, and nipple cancers in both mice and rats [146]. Acevedo et al. [156] recently evaluated the malignant potential of BPA in rats and showed that suggested that BPA acted as a mammary gland carcinogen at doses comparable to those present amounts in human urine and blood determined by epidemiological studies. BPA was also suggested to cause the development of hematopoietic cancers and induced testicular cancer in mice and rats [157].

It was also shown that BPA promoted proliferation of human epithelial ovarian cancer cells (OVCAR-3), increased the susceptibility of endometrial cells to the effects of estradiol, and inhibited the 17- $\beta$-estradiol-induced genomic activity of ER $\beta$ in DLD-1 colon cells [158-161].

\subsection{Reproductive toxicity of Bisphenol A}

Perinatal exposure to environmentally relevant BPA doses may predispose the tissue to earlier onset of disease, reductive fertility, and mammary and prostate cancers, as BPA may cause morphological and functional alterations in both male and female genital tracts and mammary glands. The estrogenicity of BPA has been shown by many rodent studies. When pregnant mice were exposed to environmentally relevant doses of BPA, earlier vaginal opening and earlier first estrous cyclicity in their offspring were observed. BPA elevated prostate weight in mice. An advanced reproductive aging was also observed [162]. BPA was also shown to disturb the development of reproductive organs, testosterone excretion, and sperm production in mice [163].

Some studies have suggested that BPA may not alter estrogenic function in rodents. Ryan et al. [164] showed that BPA exposure of male and female rats (2-200 $\mu \mathrm{g} / \mathrm{kg}$ body weight/day) did not affect maternal pregnancy or weight gain or $\mathrm{F}_{1}$ female birth weight as well as reproductive morphology, fertility, fecundity, or sexual dimorphic behaviors. Recently, Ziv-Gal et al. [165] suggested that BPA at low doses (110-438 $\mu \mathrm{M})$ decreased estradiol levels and inhibited growth of follicles isolated from wild-type and AhR knockout mice and that AhR signaling pathways may be significantly involved in the modulatory effect of BPA on follicular growth. 


\subsection{Hepatotoxic effects of Bisphenol A}

Atkinson and Roy [130] found that the BPA metabolite, bisphenol-o-quinone, could bind DNA in vitro and in vivo, leading to the induction of hepatotoxicity. Besides, BPA was also shown to cause damage to hepatocytes by oxidative stress. BPA markedly decreased antioxidant enzymes and glutathione $S$-transferase activities as well as depleted reduced glutathione levels in rats. Moreover, BPA $(50 \mathrm{mg} / \mathrm{kg})$ significantly increased the biochemical levels of liver enzymes and reduced the expression of hepatic antioxidant genes. The authors concluded that BPA generated ROS and reduced the antioxidant gene expression causing hepatotoxicity.

Huc et al. [166] observed that low BPA doses of BPA led to hepatic (HepG2) cell damage and this effect might be due to significant mitochondrial dysfunction including ROS production, mitochondrial transmembrane hyperpolarization, lipid peroxidation, and release of proinflammatory cytokines. Moon et al. [167] also observed that BPA exposure caused oxidative and proinflammatory damage in rat hepatocytes. The researchers observed a decrease in glutathione peroxidase activity, an increase in lipid peroxidation, and decreases in the proinflammatory cytokines [i.e., interleukin (IL)- 6 and tumor necrosis factor- $\alpha$ ]. Moreover, the researchers showed that, at low doses, BPA decreased the oxygen rate and ATP production and caused mitochondrial dysfunction. Based on these studies, they concluded that BPA induced hepatic mitochondrial dysfunction below the no observed effect (NOEL) value (5 mg $\mathrm{BPA} / \mathrm{kg}$ body weight/day) [167].

\subsection{Effects of Bisphenol A on other organs/systems}

BPA was proven to affect not only estrogenic system but also functions of androgens, prolactin, insulin, and thyroid hormones [117, 168]. Gentilcore et al. [169] observed that BPA at low doses $\left(10^{-9} \mathrm{M}\right)$ affected the expression of the genes involved in thyroid hormone synthesis, thyroid follicular cells, and altered thyroid-specific transcriptional factors in zebrafish.

In vitro experiments showed that BPA may cause toxicity in nervous system cells. BPA in high concentrations $(>100 \mu \mathrm{M})$ was shown to induce apoptosis of hippocampal neuronal cells by increasing calcium and ROS levels and then by activating caspase- 3 and mitogen-activated protein kinases (MAPK) [170]. In rat embryonic midbrain cells, at relatively low concentrations $\left(10^{-12}\right.$ to $\left.10^{-4} \mathrm{M}\right)$, BPA caused S- and $\mathrm{G}_{2} / \mathrm{M}$-phase arrests and elevated the percentage of apoptotic cells. BPA also lowered the phosphorylation of c-Jun N-terminal kinase and increased the mRNA expression level of proapoptotic proteins (i.e., Bax and p53) [171].

BPA did not cause morphological and neurobehavioral changes in $\mathrm{F}_{1}$ offspring of rats treated with different doses (0.15-2250 ppm) [172]. BPA (administrated 2-200 $\mu \mathrm{g} / \mathrm{kg} / \mathrm{body}$ weight/day by gavage) did not have any impact on the sensory system and neurobehavioral activity in Long-Evans rats [163]. However, some studies showed that BPA may have an effect on the neurotransmitter levels of rodents. Nakamura et al. (2010) observed that BPA $(20 \mu \mathrm{g} / \mathrm{kg}$ s.c.) had increased brain levels of dopamine and its metabolite 3,4-dihydroxyphenylacetic acid (DOPAC), whereas the levels of serotonin and its derivative, 5-hydroxyindoleacetic acid (5HIAA), decreased in pregnant mice [173]. 
BPA was suggested to both stimulate and inhibit the activity of immune system cells. It is postulated that BPA can modulate the immune activity by affecting ERs, AhR, and probably peroxisome proliferator-activated receptor (PPAR) [174]. Youn et al. [175] showed that BPA (in drinking water) caused increases in interferon- $\gamma$ and decreases in IL-4 production in T lymphocytes of mice, whereas Lee and Lim [176] observed that BPA elevated IL-4 and IL-8 levels in mouse T lymphocytes. Exposure of mouse splenic lymphocytes to low BPA concentrations $(1 \mu \mathrm{M})$ could inhibit mitogenesis, particularly the mitogenesis of B lymphocytes [177]. Goto et al. [178] observed that BPA produced lymphocytes with higher amounts of immunoglobulin A (IgA) and IgG2a in mice. Sugita-Konishi et al. [179] reported that BPA caused depletion in neutrophil activity and inhibited IL-6 formation in mice infected with nonpathogenic Escherichia coli.

Roy et al. [180] showed that offspring of female mice exposed to BPA were more susceptible to infection by influenza A virus because of the modulation of their innate immunity by BPA. However, the researchers did not observe impairment in antiviral adaptive immune response, which is a crucial response for virus clearance and survival.

\subsection{Epidemiological studies concerning the effects of Bisphenol A on reproductive/ endocrine systems}

Most of the epidemiological studies on BPA mainly focus on its effects on endocrine and reproductive systems. Meeker et al. [181] analyzed urinary BPA concentrations of men $(n=167)$ who were admitted to an infertility clinic. The researchers reported that their urinary BPA levels were inversely correlated with their estradiol/testosterone ratio [181]. In a cross-sectional study, Melzer et al. [182] determined the urinary BPA levels of subjects from Chianti, Italy $(\mathrm{n}=1453$, age $=20-102$ years $)$, and observed positive associations between higher urinary BPA concentrations and higher expression of two estrogen-responsive genes, encoding ER $\beta$ and estrogen-related receptor $\alpha(E R R \alpha)$. Li et al. [183] examined the urinary BPA levels of 218 men with and without BPA exposure in the workplace. Increasing urinary BPA levels were statistically significantly associated with decreased sperm concentration, total sperm count, sperm vitality and sperm motility after adjustment for potential confounders using linear regression. Men with detectable urinary BPA concentrations had more than risk of decreased sperm concentration, sperm vitality, count, and motility compared to men who had undetectable urinary BPA levels. However, urinary BPA levels were not associated with semen volume or abnormal sperm morphology [183].

Takeuchi and Tsutsumi [127] investigated serum BPA concentrations of men $(n=11)$, women $(n=14)$, and women with polycystic ovary syndrome (PCOS; $n=16)$. Serum BPA levels were significantly higher in normal men and in women with PCOS. There were significant positive correlations between serum BPA and total testosterone and free testosterone concentrations in all subjects and between serum BPA and total testosterone $(r \underline{5} 0.559 ; P<0.01)$ and free testosterone concentrations in all female subjects; however, there was no association between serum BPA and other sex-related hormone concentrations in any group. The researchers determined that there were gender differences in serum BPA concentrations, where men had higher serum BPA levels $(1.49 \pm 0.11 \mathrm{ng} / \mathrm{mL}$ in men, $1.04 \pm 0.10 \mathrm{ng} / \mathrm{mL}$ in women with PCOS, 
and $0.64 \underline{6} ; 0.10 \mathrm{ng} / \mathrm{mL}$ in women) possibly due to the differences in the androgen-related metabolism of BPA [27].

Miao et al. [184] conducted a cross-sectional study among female workers from BPA-exposed $(\mathrm{n}=106)$ and unexposed $(n=250)$ factories in China. They observed a significant positive association between increased urine BPA concentration and higher prolactin and progesterone levels. Among exposed workers, a positive association between urine BPA and estradiol was also determined. In addition, a statistically significant inverse correlation between urinary BPA concentration and FSH was found among unexposed group. The researchers suggested that BPA exposure may lead to alterations in female reproductive hormone levels [184]. MínguezAlarcón et al. [185] conducted a prospective cohort study at the Massachusetts General Hospital Fertility Center, which included 256 women ( $n=375$ in vitro fertilization cycles) who provided up to two urine samples before oocyte retrieval (total $N=673$ ) between 2004 and 2012. Urinary BPA concentrations were not associated with endometrial wall thickness, peak estradiol levels, proportion of high-quality embryos, or fertilization rates. The researchers did not observe any correlation between urinary BPA concentrations and implantation, clinical pregnancy, or live birth rates per initiated cycle or per embryo transfer. Women older than 37 years had thinner endometrial thickness across increasing quartiles of urinary BPA concentrations, whereas women younger than 37 years had thicker endometrial thickness across increasing quartiles of urinary BPA concentrations [185]. A cross-sectional study was carried out by Liu et al. [186] to determine the associations between urinary BPA levels serum reproductive hormone levels among male Chinese adults $(n=592)$. A multiple linear regression and log-binomial model was used to examine the associations between urinary BPA level and hormone levels after controlling for age and smoking status. Increased urinary BPA levels were positively and significantly correlated with prolactin, estradiol, and SHBG levels and were negatively and significantly associated with androstenedione and free androgen index levels. The researchers suggested that high urinary BPA levels were associated with increased prolactin, estradiol, and SHBG level in males and these associations may contribute to male infertility [186]. Liu et al. [187] conducted a cross-sectional study to investigate the correlations between maternal phenolic exposure and cord sex steroid hormones and AGD in male newborns. Mother-infant pairs from each of two hospitals [one in a polluted town (Guiyu; $n=77$ ) and the other in a cleaner town (Haojiang; $n=60$ )] were recruited in the study. Maternal urinary BPA concentrations ( $\log _{2}$ transformed) were negatively correlated with testosterone levels and testosterone/estradiol ratio in male fetal cord blood samples (after adjustment for potential confounders in linear regression models). No significant associations between AGD or anogenital index (AGI) and BPA or cord hormone levels were found [187].

Another study by our group recruited nonobese girls newly diagnosed with idiopathic central precocious puberty (ICPP; $n=28$; ages $4-8$ years) and 25 healthy age-matched girls with no history of ICPP or any other endocrine disorder. Urinary BPA levels were significantly higher in ICPP group compared to the control group. There were no significant associations between urinary BPA levels and serum LH, FSH, and estradiol levels [188]. 


\section{Conclusion}

EDCs are widely available in the environment. Although exposure to these chemicals can be reduced by not using plastics, the total prevention of exposure is not feasible. Serious measures must be taken to reduce the availability of EDCs and regulatory authorities must be aware of their toxic effects and the outcomes. Parents should avoid using plastic materials and EDCcontaining materials (phthalate containing gum shields, toys, and paints; BPA-containing feeding bottles and water bottles) for children, particularly for newborns. Therefore, the reduction of the use of phthalates and BPA must seriously be taken into concern, and chemical companies must be encouraged to synthesize and produce nontoxic alternatives of these substances.

\section{Author details}

Pinar Erkekoglu* and Belma Kocer-Gumusel

*Address all correspondence to: erkekp@yahoo.com

*Address all correspondence to: belmagumusel@yahoo.com

Hacettepe University, Faculty of Pharmacy, Department of Toxicology, Ankara, Turkey

\section{References}

[1] World Health Organization (WHO) Report. Almost a quarter of all disease caused by environmental exposure. 2006. Available from: http://www.who.int/mediacentre/ news/releases/2006/pr32/en/

[2] Diamanti-Kandarakis E, Bourguignon JP, Giudice LC, Hauser R, Prins GS, Soto AM, Zoeller RT, Gore AC. Endocrine-disrupting chemicals: an Endocrine Society scientific statement. Endocr Rev. 2009;30:293-342. DOI: 10.1210/er.2009-0002.

[3] Bradley EL, Burden RA, Bentayeb K, Driffield M, Harmer N, Mortimer DN, Speck DR, Ticha J, Castle L. Exposure to phthalic acid, phthalate diesters and phthalate monoesters from foodstuffs: UK total diet study results. Food Addit Contam Part A Chem Anal Control Expo Risk Assess. 2013;30:735-742. DOI: 10.1080/19440049.2013.781684.

[4] Mikołajewska K, Stragierowicz J, Gromadzińska J. Bisphenol A-Application, sources of exposure and potential risks in infants, children and pregnant women. Int J Occup Med Environ Health. 2015;28:209-241. DOI: 10.13075/ijomeh.1896.00343. 
[5] Erickson MD, Kaley RG 2nd. Applications of polychlorinated biphenyls. Environ Sci Pollut Res Int. 2011;18:135-151. DOI: 10.1007/s11356-010-0392-1.

[6] Tavares RS, Escada-Rebelo S, Correia M, Mota PC, Ramalho-Santos J. The non-genomic effects of endocrine-disrupting chemicals on mammalian sperm. Reproduction. 2016;151:R1-R13. DOI: 10.1530/REP-15-0355.

[7] Zawatski W, Lee MM. Male pubertal development: Are endocrine-disrupting compounds shifting the norms? J Endocrinol. 2013;218:R1-R12. DOI: 10.1530/JOE-12-0449

[8] Whaley DA, Keyes D, Khorrami B. Incorporation of endocrine disruption into chemical hazard scoring for pollution prevention and current list of endocrine disrupting chemicals. Drug Chem Toxicol. 2001;24:359-420. DOI: 10.1081/DCT-100106265

[9] Lee HR, Jeung EB, Cho MH, Kim TH, Leung PC, Choi KC. Molecular mechanism(s) of endocrine-disrupting chemicals and their potent oestrogenicity in diverse cells and tissues that express oestrogen receptors. J Cell Mol Med. 2013;17:1-11. DOI: 10.1111/j. 1582-4934.2012.01649.x.

[10] Hampl R, Kubátová J, Stárka L. Steroids and endocrine disruptors-History, recent state of art and open questions. J Steroid Biochem Mol Biol. 2016;155:217-223. DOI: 10.1016/j.jsbmb.2014.04.013.

[11] Kolšek K, Mavri J, Sollner Dolenc M, Gobec S, Turk S. Endocrine disruptome-An open source prediction tool for assessing endocrine disruption potential through nuclear receptor binding. J Chem Inf Model. 2014;54:1254-1267. DOI: 10.1021/ci400649p.

[12] Chen X, Zhou QH, Leng L, Chen X, Sun ZR, Tang NJ. Effects of di(n-butyl) and monobutyl phthalate on steroidogenesis pathways in the murine Leydig tumor cell line MLTC-1. Environ Toxicol Pharmacol. 2013;36:332-338. DOI: 10.1016/j.etap.2013.04.013.

[13] Piché CD, Sauvageau D, Vanlian M, Erythropel HC, Robaire B, Leask RL. Effects of di(2-ethylhexyl) phthalate and four of its metabolites on steroidogenesis in MA-10 cells. Ecotoxicol Environ Saf. 2012;79:108-115. DOI: 10.1016/j.ecoenv.2011.12.008.

[14] Andric NL, Kostic TS, Zoric SN, Stanic BD, Andric SA, Kovacevic RZ. Effect of a PCBbased transformer oil on testicular steroidogenesis and xenobiotic-metabolizing enzymes. Reprod Toxicol. 2006;22:102-110. DOI: 10.1016/j.reprotox.2005.12.002

[15] Zhang XL, Wang HS, Liu N, Ge LC. Bisphenol A stimulates the epithelial mesenchymal transition of estrogen negative breast cancer cells via FOXA1 signals. Arch Biochem Biophys. 2015;585:10-16. DOI: 10.1016/j.abb.2015.09.006

[16] Hsieh TH, Tsai CF, Hsu CY, Kuo PL, Lee JN, Chai CY, Hou MF, Chang CC, Long CY, Ko YC, Tsai EM. Phthalates stimulate the epithelial to mesenchymal transition through an HDAC6-dependent mechanism in human breast epithelial stem cells. Toxicol Sci. 2012;128:365-376. DOI: 10.1093/toxsci/kfs163 
[17] Kiyama R, Zhu Y. DNA microarray-based gene expression profiling of estrogenic chemicals. Cell Mol Life Sci. 2014;71:2065-2082. DOI: 10.1007/s00018-013-1544-5

[18] Kiyama R, Wada-Kiyama Y. Estrogenic endocrine disruptors: Molecular mechanisms of action. Environ Int. 2015; 83:11-40. DOI: 10.1016/j.envint.2015.05.012.

[19] Benjamin S, Pradeep S, Josh MS, Kumar S, Masai E. A monograph on the remediation of hazardous phthalates. J Hazard Mater. 2015;298:58-72. DOI: 10.1016/j.jhazmat. 2015.05.004.

[20] Toxics Use Reduction Institute Five Chemicals Alternatives Reduction Study, Final Report, Chapter 7, DEHP. 2005. Lowell, MA: University of Massachusetts Lowel. Available at: http://www.turi.org/library/

[21] European Commission. Bis(2-ethylhexyl)phthalate (DEHP) - Summary Risk Assessment Report EUR 23384EN/2-European Chemicals Bureau-Institute for Health and Consumer Protection-Toxicology and Chemical Substance (TCS). 2008. I-21027 Ispra (VA), Italy.

[22] Towae FK, Enke W, Jackh R, Bhargava K, Phthalalic acid and derivatives. In: Ullmann's Encyclopedia for Industrial Chemistry. Vol A2. 5th revision. Elvers B, Hawkins S, Schulz G, editors. New York: VCH Publishers; 1992. pp. 181-222.

[23] Waring RH, Harris RM. Endocrine disrupters: A human risk? Mol Cell Endocrinol. 2005;244:2-9. DOI: 10.1016/j.mce.2005.02.007

[24] Durmaz E, Ozmert EN, Erkekoglu P, Giray B, Derman O, Hincal F, Yurdakök K. Plasma phthalate levels in pubertal gynecomastia. Pediatrics. 2010;125:e122-e129. DOI: 10.1542/peds.2009-0724.

[25] Frederiksen H, Jensen TK, Jørgensen N, Kyhl HB, Husby S, Skakkebæk NE, Main KM, Juul A, Andersson AM. Human urinary excretion of non-persistent environmental chemicals: An overview of Danish data collected between 2006 and 2012. Reproduction. 2014;147:555-565. DOI: 10.1530/REP-13-0522.

[26] Serrano SE, Karr CJ, Seixas NS, Nguyen RH, Barrett ES, Janssen S, Redmon B,Swan SH, Sathyanarayana S. Dietary phthalate exposure in pregnant women and the impact of consumer practices. Int J Environ Res Public Health. 2014;11:6193-6215. DOI: 10.3390/ ijerph110606193.

[27] Johns LE, Ferguson KK, Soldin OP, Cantonwine DE, Rivera-González LO, Del Toro LV, Calafat AM, Ye X, Alshawabkeh AN, Cordero JF, Meeker JD. Urinary phthalate metabolites in relation to maternal serum thyroid and sex hormone levels during pregnancy: A longitudinal analysis. Reprod Biol Endocrinol. 2015;13:4. DOI: 10.1186/1477-7827-13-4.

[28] International Agency for Research on Cancer (IARC). Monographs on the Evaluation of Carcinogenic Risks to Humans: Some Chemicals Present in Industrial and Consumer 
Products. Monograph 101. World Health Organization. Lyon: France; 2012. ISBN: 978 9283213246.

[29] Meek ME, Chan PKL. Bis(2-ethylhexyl)phthalate: Evaluation of risks to health from environmental exposure in Canada. Environ Carcinog Rev. 1994;C12:179-194. DOI: $10.1080 / 10590509409373434$.

[30] Wormuth M, Scheringer M, Vollenweider M, Hungerbühler K. What are the sources of exposure to eight frequently used phthalic acid esters in Europeans? Risk Anal. 2006;26:803-824.

[31] Labow RS, Tocchi M, Rock G. Contamination of platelet storage bags by phthalate esters. J Toxicol Environ Health. 1986;19:591-598.

[32] Shintani H. Determination of phthalic acid, mono-(2-ethylhexyl) phthalate and di-(2ethylhexyl) phthalate in human plasma and in blood products. J Chromatogr. 1985;337:279-290.

[33] Mettang T, Alscher DM, Pauli-Magnus C, Dunst R, Kuhlmann U, Rettenmeier AW. Phthalic acid is the main metabolite of the plasticizer di(2-ethylhexyl) phthalate in peritoneal dialysis patients. Adv Perit Dial. 1999;15:229-233.

[34] Nässberger L, Arbin A, Ostelius J. Exposure of patients to phthalates from polyvinyl chloride tubes and bags during dialysis. Nephron. 1987;45:286-290.

[35] Heudorf U, Mersch-Sundermann V, Angerer J. Phthalates: Toxicology and exposure. Int J Hyg Environ Health. 2007;210:623-634.

[36] Lawrence WH, Malik M, Turner JE, Singh AR, Autian J. A toxicological investigation of some acute, short-term, and chronic effects of administering di-2-ethylhexyl phthalate (DEHP) and other phthalate esters. Environ Res. 1975;9:1-11.

[37] Autian J. Antifertility effects and dominant lethal assays for mutagenic effects of DEHP. Environ Health Perspect. 1982;45:115-118.

[38] Public Health Goal for Di(2-Ethylhexyl)Phthalate (DEHP) in Drinking Water. Pesticide and Environmental Toxicology Section Office of Environmental Health Hazard Assessment California Environmental Protection Agency; 1997. Available from: http:// oehha.ca.gov/water/phg/pdf/DEHP_c.pdf.

[39] Hauser R, Calafat AM. Phthalates and human health. Occup Environ Med. 2005;62:806818.

[40] Silva MJ, Samandar E, Preau JL Jr, Needham LL, Calafat AM. Urinary oxidative metabolites of di(2-ethylhexyl) phthalate in humans. Toxicology. 2006;219:22-32.

[41] Kleinsasser NH, Kastenbauer ER, Wallner BC, Weissacher H, Harréus UA. Genotoxicity of phthalates. On the discussion of plasticizers in children's toys. HNO. 2001;49:378-381. 
[42] Erkekoglu P, Rachidi W, Yuzugullu OG, Giray B, Favier A, Ozturk M, Hincal F. Evaluation of cytotoxicity and oxidative DNA damaging effects of di(2-ethylhexyl)phthalate (DEHP) and mono(2-ethylhexyl)-phthalate (MEHP) on MA-10 Leydig cells and protection by selenium. Toxicol Appl Pharmacol. 2010;248:52-62. DOI: 10.1016/ j.taap.2010.07.016.

[43] Erkekoğlu P, Rachidi W, De Rosa V, Giray B, Favier A, Hincal F. Protective effect of selenium supplementation on the genotoxicity of di(2-ethylhexyl)phthalate and mono(2-ethylhexyl)phthalate treatment in LNCaP cells. Free Radic Biol Med. 2010;49:559-566. DOI: 10.1016/j.freeradbiomed.2010.04.038.

[44] Turner JH, Petricciani JC, Crouch ML, Wenger S. An evaluation of the effects of diethylhexyl phthalate (DEHP) on mitotically capable cells in blood packs. Transfusion 1974;14:560-566.

[45] Stenchever MA, Allen MA, Jerominski L, Petersen RV. Effects of bis(2-ethylhexyl) phthalate on chromosomes of human leukocytes and human fetal lung cells. J Pharm Sci 1976;65:1648-1651.

[46] Phillips BJ, James TE, Gangolli SD. Genotoxicity studies of di(2-ethylhexyl)phthalate and its metabolites in CHO cells. Mutat Res 1982;102:297-304.

[47] Astill B, Barber E, Lington A, Moran E, Mulholland A, Robinson E, Scheider B. Chemical industry voluntary test program for phthalate esters: health effects studies. Environ Health Perspect 1986;65:329-336.

[48] Phillips BJ, Anderson D, Gangolli SD. Studies on the genetic effects of phthalic acid esters on cells in culture. Environ Health Perspect. 1986;65:263-266.

[49] Smith-Oliver T, Butterworth BE. Correlation of the carcinogenic potential of di(2ethylhexyl)phthalate (DEHP) with induced hyperplasia rather than with genotoxic activity. Mutat Res 1987;188:21-28.

[50] Lindahl-Kiessling K, Karlberg I, Olofsson AM. Induction of sister-chromatid exchanges by direct and indirect mutagens in human lymphocytes, co-cultured with intact rat liver cells. Effect of enzyme induction and preservation of the liver cells by freezing in liquid nitrogen. Mutat Res 1989;211:77-87.

[51] Müller-Tegethoff K, Kasper P, Müller L. Evaluation studies on the in vitro rat hepatocyte micronucleus assay. Mutat Res. 1995;335:293-307.

[52] Kim MY, Kim YC, Cho MH. Combined treatment with 4-( $N$-methyl- $N$-nitrosamino)-1(3-pyridyl)-1-butanone and dibutyl phthalate enhances ozone-induced genotoxicity in B6C3F1 mice. Mutagenesis. 2002;17:331-336.

[53] McKee RH, Przygoda RT, Chirdon MA, Engelhardt G, Stanley M. Di(isononyl) phthalate (DINP) and di(isodecyl) phthalate (DIDP) are not mutagenic. J Appl Toxicol. 2000;20:491-497. 
[54] Lee KH, Lee BM. Study of mutagenicities of phthalic acid and terephthalic acid using in vitro and in vivo genotoxicity tests. J Toxicol Environ Health A 2007;70:1329-1335.

[55] Anderson D, Yu TW, Hinçal F. Effect of some phthalate esters in human cells in the Comet assay. Teratog Carcinog Mutagen. 1999;19:275-280.

[56] Kleinsasser NH, Weissacher H, Kastenbauer ER, Dirschedl P, Wallner BC, Harréus UA. Altered genotoxicity in mucosal cells of head and neck cancer patients due to environmental pollutants. Eur Arch Otorhinolaryngol. 2000;257:337-342.

[57] Kleinsasser NH, Wallner BC, Kastenbauer ER, Weissacher H, Harréus UA. Genotoxicity of di-butyl-phthalate and di-iso-butyl-phthalate in human lymphocytes and mucosal cells. Teratog Carcinog Mutagen. 2001;21:189-196.

[58] Biscardi D, Monarca S, De Fusco R, Senatore F, Poli P, Buschini A, Rossi C, Zani C. Evaluation of the migration of mutagens/carcinogens from PET bottles into mineral water by Tradescantia/micronuclei test, Comet assay on leukocytes and GC/MS. Sci Total Environ. 2003;302:101-118.

[59] Park SY, Choi J. Cytotoxicity, genotoxicity and ecotoxicity assay using human cell and environmental species for the screening of the risk from pollutant exposure. Environ Int. 2007;33:817-822.

[60] Choi S, Park SY, Jeong J, Cho E, Phark S, Lee M, Kwak D, Lim JY, Jung WW, Sul D. Identification of toxicological biomarkers of di(2-ethylhexyl) phthalate in proteins secreted by HepG2 cells using proteomic analysis. Proteomics. 2010;10:1831-1846. DOI: 10.1002/pmic.200900674.

[61] Duty SM, Singh NP, Silva MJ, Barr DB, Brock JW, Ryan L, Herrick RF, Christiani DC, Hauser R. The relationship between environmental exposures to phthalates and DNA damage in human sperm using the neutral Comet assay. Environ Health Perspect. 2003;111:1164-1169.

[62] Hauser R, Meeker JD, Singh NP, Silva MJ, Ryan L, Duty S, Calafat AM. DNA damage in human sperm is related to urinary levels of phthalate monoester and oxidative metabolites. Hum Reprod. 2007;2:688-695. DOI: 10.1093/humrep/del428

[63] Ahbab MA, Ündeğer Ü, Barlas N, Başaran N. In utero exposure to dicyclohexyl and di$n$-hexyl phthalate possess genotoxic effects on testicular cells of male rats after birth in the Comet and TUNEL assays. Hum Exp Toxicol. 2014;33:230-239. DOI: 10.1177/0960327113494903.

[64] Singh S, Li SS. Epigenetic effects of environmental chemicals bisphenol A and phthalates. Int J Mol Sci. 2012;13:10143-10153. DOI: 10.3390/ijms130810143.

[65] Chan Kang S, Mu Lee B. DNA methylation of estrogen receptor $\alpha$ gene by phthalates. J Toxicol Environ Health A. 2005;68:1995-2003. 
[66] Wu S, Zhu J, Li Y, Lin T, Gan L, Yuan X, Xu M, Wei G. Dynamic effect of di-2-(ethylhexyl) phthalate on testicular toxicity: Epigenetic changes and their impact on gene expression. Int J Toxicol. 2010;29:193-200. DOI: 10.1177/1091581809355488.

[67] Manikkam M, Guerrero-Bosagna C, Tracey R, Haque MM, Skinner MK. Transgenerational actions of environmental compounds on reproductive disease and identification of epigenetic biomarkers of ancestral exposures. PLoS One. 2012;7: e31901. DOI: 10.1371/journal.pone.0031901.

[68] Huber WW, Grasl-Kraupp B, Schulte-Hermann R. Hepatocarcinogenic potential of di(2-ethylhexyl)phthalate in rodents and its implications on human risk. Crit Rev Toxicol. 1996;26:365-481.

[69] Rusyn I, Kadiiska MB, Dikalova A, Kono H, Yin M, Tsuchiya K, Mason RP, Peters JM, Gonzalez FJ, Segal BH, Holland SM, Thurman RG. Phthalates rapidly increase production of reactive oxygen species in vivo: Role of Kupffer cells. Mol Pharmacol. 2001;59:744-750.

[70] Rusyn I, Peters JM, Cunningham ML. Modes of action and species-specific effects of di-(2-ethylhexyl)phthalate in the liver. Crit Rev Toxicol. 2006;36:459-479.

[71] International Agency for Research on Cancer (IARC) Monographs. Di(2-ethylhexyl) phthalate. IARC Monogr Eval Carcinog Risks Hum 2000;77: 41-148.

[72] International Agency for Research on Cancer (IARC). Agents Classified by the IARC Monographs, Volumes 1-112. Di(2-ethylhexyl)phthalate. Group 2B. Monograph 101, Supplement 7, 73. 2013. Available from: http://monographs.iarc.fr/ENG/Classification/ ClassificationsAlphaOrder.pdf

[73] International Agency for Research on Cancer (IARC). Agents Classified by the IARC Monographs, Volumes 1-112. Butyl benzyl phthalate (Group 3). Monograph 101. 1999. Supplement 7, 73 .

[74] Blom A, Ekman E, Johannisson A, Norrgren L, Pesonen M. Effects ofxenoestrogenic environmental pollutants on the proliferation of a human breast cancer cell line (MCF-7). Arch Environ Contam Toxicol. 1998;34:306-310.

[75] Fisher JS. Environmental anti-androgens and male reproductive health: Focus on phthalates and testicular dysgenesis syndrome. Reproduction. 2004;127:305-315.

[76] Nakai M, Tabira Y, Asai D, Yakabe Y, Shimyozu T, Noguchi M, Takatsuki M, Shimohigashi Y. Binding characteristics of dialkyl phthalates for the estrogen receptor. Biochem Biophys Res Commun. 1999;254:311-314.

[77] Zacharewski TR, Meek MD, Clemons JH, Wu ZF, Fielden MR, Matthews JB. Examination of the in vitro and in vivo estrogenic activities of eight commercial phthalate esters. Toxicol Sci. 1998;46:282-293. 
[78] Sharpe RM, Skakkebaek NE. Testicular dysgenesis syndrome: Mechanistic insights and potential new downstream effects. Fertil Steril. 2008;89:e33-e38. DOI: 10.1016/j.fertnstert.2007.12.026.

[79] Dalgaard M, Ostergaard G, Lam HR, Hansen EV, Ladefoged O. Toxicity study of di(2ethylhexyl)phthalate (DEHP) in combination with acetone in rats. Pharmacol Toxicol. 2000;86:92-100.

[80] Richburg JH, Boekelheide K. Mono-(2-ethylhexyl) phthalate rapidly alters both Sertoli cell vimentin filaments and germ cell apoptosis in young rat testes. Toxicol Appl Pharmacol. 1996;137:42-50.

[81] Tay TW, Andriana BB, Ishii M, Tsunekawa N, Kanai Y, Kurohmaru M. Disappearance of vimentin in Sertoli cells: A mono(2-ethylhexyl) phthalate effect. Int J Toxicol. 2007;26:289-295.

[82] Erkekoglu P, Zeybek ND, Giray B, Asan E, Hincal F. The effects of di(2-ethylhexyl)phthalate exposure and selenium nutrition on Sertoli cell vimentin structure and germ-cell apoptosis in rat testis. Arch Environ Contam Toxicol. 2012;62:539-547. DOI: 10.1007/s00244-011-9712-9.

[83] Jones HB, Garside DA, Liu R, Roberts JC. The influence of phthalate esters on Leydig cell structure and function in vitro and in vivo. Exp Mol Pathol. 1993;58:179-193.

[84] Erkekoglu P, Zeybek ND, Giray B, Asan E, Arnaud J, Hincal F. Reproductive toxicity of di(2-ethylhexyl) phthalate in selenium-supplemented and selenium-deficient rats. Drug Chem Toxicol. 2011;34:379-389. DOI: 10.3109/01480545.2010.547499

[85] Erkekoglu P, Giray B, Rachidi W, Hininger-Favier I, Roussel AM, Favier A, Hincal F. Effects of di(2-ethylhexyl)phthalate on testicular oxidant/antioxidant status in selenium-deficient and selenium-supplemented rats. Environ Toxicol. 2014;29:98-107. DOI: 10.1002/tox.20776.

[86] Astill BD, Gingell R, Guest D, Hellwig J, Hodgson JR, Kuettler K, Mellert W, Murphy SR, Sielken RL Jr, Tyler TR. Oncogenicity testing of 2-ethylhexanol in Fischer 344 rats and B6C3F1 mice. Fundam Appl Toxicol. 1996;31:29-41.

[87] Kaufmann W, Deckardt K, McKee RH, Butala JH, Bahnemann R. Tumor induction in mouse liver: Di-isononyl phthalate acts via peroxisome proliferation. Regul Toxicol Pharmacol. 2002;36:175-183.

[88] Kluwe WM, Huff JE, Matthews HB, Irwin R, Haseman JK. Comparative chronic toxicities and carcinogenic potentials of 2-ethylhexyl-containing compounds in rats and mice. Carcinogenesis. 1985;6:1577-1583.

[89] Erkekoglu P, Zeybek ND, Giray BK, Rachidi W, Kızılgün M, Hininger-Favier I, Favier A, Asan E, Hincal F. The effects of di(2-ethylhexyl)phthalate on rat liver in relation to selenium status. Int J Exp Pathol. 2014;95:64-77. DOI: 10.1111/iep.12059. 
[90] Erkekoglu P, Giray BK, Kizilgun M, Hininger-Favier I, Rachidi W, Roussel AM, Favier A, Hincal F. Thyroidal effects of di-(2-ethylhexyl) phthalate in rats of different selenium status. J Environ Pathol Toxicol Oncol. 2012;31:143-153. DOI: 10.1615/JEnvironPatholToxicolOncol.v31.i2.60.

[91] Erkekoglu P, Giray BK, Kızilgün M, Rachidi W, Hininger-Favier I, Roussel AM, Favier A, Hincal F. Di(2-ethylhexyl)phthalate-induced renal oxidative stress in rats and protective effect of selenium. Toxicol Mech Methods. 2012;22:415-423. DOI: 10.3109/15376516.2012.666652.

[92] Liu T, Li N, Zhu J, Yu G, Guo K, Zhou L, Zheng D, Qu X, Huang J, Chen X, Wang S, Ye L. Effects of di-(2-ethylhexyl) phthalate on the hypothalamus-pituitary-ovarian axis in adult female rats. Reprod Toxicol. 2014;46:141-147. DOI: 10.1016/j.reprotox. 2014.03.006.

[93] Moody S, Goh H, Bielanowicz A, Rippon P, Loveland KL, Itman C. Prepubertal mouse testis growth and maturation and androgen production are acutely sensitive to di- $n$ butyl phthalate. Endocrinology. 2013;154:3460-3475. DOI: 10.1210/en.2012-2227

[94] Carlsen E, Giwercman A, Keiding N, Skakkebaek NE. Evidence for decreasing quality of semen during past 50 years. BMJ. 1992;305:609-613.

[95] Murature DA, Tang SY, Steinhardt G, Dougherty RC. Phthalate esters and semen quality parameters. Biomed Environ Mass Spectrom. 1987;14:473-477.

[96] Rozati R, Reddy PP, Reddanna P, Mujtaba R. Role of environmental estrogens in the deterioration of male factor fertility. Fertil Steril. 2002;78:1187-1194.

[97] Jönsson BA, Richthoff J, Rylander L, Giwercman A, Hagmar L. Urinary phthalate metabolites and biomarkers of reproductive function in young men. Epidemiology. 2005;16:487-493.

[98] Zhang YH, Zheng LX, Chen BH. Phthalate exposure and human semen quality in Shanghai: A cross-sectional study. Biomed Environ Sci. 2006;19:205-209.

[99] Hauser R, Meeker JD, Duty S, Silva MJ, Calafat AM. Altered semen quality in relation to urinary concentrations of phthalate monoester and oxidative metabolites. Epidemiology. 2006;17:682-691.

[100] Pant N, Shukla M, Kumar Patel D, Shukla Y, Mathur N, Kumar Gupta Y, Saxena DK. Correlation of phthalate exposures with semen quality. Toxicol Appl Pharmacol. 2008;231:112-116. DOI: 10.1016/j.taap.2008.04.001.

[101] Wirth JJ, Rossano MG, Potter R, Puscheck E, Daly DC, Paneth N, Krawetz SA, Protas BM, Diamond MP. A pilot study associating urinary concentrations of phthalate metabolites and semen quality. Syst Biol Reprod Med. 2008;54:143-154. DOI: 10.1080/19396360802055921.

[102] Herr C, zur Nieden A, Koch HM, Schuppe HC, Fieber C, Angerer J, Eikmann T, Stilianakis NI. Urinary di(2-ethylhexyl)phthalate (DEHP)-Metabolites and male 
human markers of reproductive function. Int J Hyg Environ Health. 2009;212:648-653. DOI: 10.1016/j.ijheh.2009.08.001.

[103] Pant N, Pant A, Shukla M, Mathur N, Gupta Y, Saxena D. Environmental and experimental exposure of phthalate esters: The toxicological consequence on human sperm. Hum Exp Toxicol. 2011;30:507-514. DOI: 10.1177/0960327110374205.

[104] Liu L, Bao H, Liu F, Zhang J, Shen H. Phthalates exposure of Chinese reproductive age couples and its effect on male semen quality: A primary study. Environ Int. 2012;42:7883. DOI: 10.1016/j.envint.2011.04.005.

[105] Han X, Cui Z, Zhou N, Ma M, Li L, Li Y, Lin H, Ao L, Shu W, Liu J, Cao J. Urinary phthalate metabolites and male reproductive function parameters in Chongqing general population, China. Int J Hyg Environ Health. 2014;217:271-278. DOI: 10.1016/ j.ijheh.2013.06.006.

[106] Jurewicz J, Radwan M, Sobala W, Ligocka D, Radwan P, Bochenek M, Hawuła W, Jakubowski L, Hanke W. Human urinary phthalate metabolites level and main semen parameters, sperm chromatin structure, sperm aneuploidy and reproductive hormones. Reprod Toxicol. 2013;42:232-241. DOI: 10.1016/j.reprotox.2013.10.001.

[107] Pan G, Hanaoka T, Yoshimura M, Zhang S, Wang P, Tsukino H, Inoue K, Nakazawa $\mathrm{H}$, Tsugane S, Takahashi K. Decreased serum free testosterone in workers exposed to high levels of di- $n$-butyl phthalate (DBP) and di-2-ethylhexyl phthalate (DEHP): a cross-sectional study in China. Environ Health Perspect. 2006;114:1643-1648.

[108] Duty SM, Calafat AM, Silva MJ, Ryan L, Hauser R. Phthalate exposure and reproductive hormones in adult men. Hum Reprod. 2005;20:604-610.

[109] Li S, Dai J, Zhang L, Zhang J, Zhang Z, Chen B. An association of elevated serum prolactin with phthalate exposure in adult men. Biomed Environ Sci. 2011;24:31-39. DOI: 10.3967/0895-3988.2011.01.004.

[110] Meeker JD, Calafat AM, Hauser R. Urinary metabolites of di(2-ethylhexyl)phthalate are associated with decreased steroid hormone levels in adult men. J Androl. 2009;30:287-297. DOI: 10.2164/jandrol.108.006403.

[111] Mendiola J, Jørgensen N, Andersson AM, Calafat AM, Silva MJ, Redmon JB, Sparks A, Drobnis EZ, Wang C, Liu F, Swan SH. Associations between urinary metabolites of di(2-ethylhexyl) phthalate and reproductive hormones in fertile men. Int J Androl. 2011;34:369-378. DOI: 10.1111/j.1365-2605.2010.01095.x.

[112] Mendiola J, Meeker JD, Jørgensen N, Andersson AM, Liu F, Calafat AM, Redmon JB, Drobnis EZ, Sparks AE, Wang C, Hauser R, Swan SH. Urinary concentrations of di(2ethylhexyl) phthalate metabolites and serum reproductive hormones: pooled analysis of fertile and infertile men. J Androl. 2012;33:488-498. DOI: 10.2164/jandrol.111.013557.

[113] Mieritz MG, Frederiksen H, Sørensen K, Aksglaede L, Mouritsen A, Hagen CP, Skakkebaek NE, Andersson AM, Juul A. Urinary phthalate excretion in 555 healthy 
Danish boys with and without pubertal gynaecomastia. Int J Androl. 2012;35:227-235. DOI: 10.1111/j.1365-2605.2012.01279.x.

[114] Vandenberg LN, Hauser R, Marcus M, Olea N, Welshons WV. Human exposure to bisphenol A (BPA). Reprod Toxicol. 2007;24:139-177.

[115] Flint S, Markle T, Thompson S, Wallace E. Bisphenol A exposure, effects, and policy: a wildlife perspective. J Environ Manage. 2012;104:19-34. DOI: 10.1016/j.jenvman. 2012.03.021.

[116] Iso T, Watanabe T, Iwamoto T, Shimamoto A, Furuichi Y. DNA damage caused by bisphenol A and estradiol through estrogenic activity. Biol Pharm Bull. 2006;29:206210.

[117] Wetherill YB, Akingbemi BT, Kanno J, McLachlan JA, Nadal A, Sonnenschein C, Watson CS, Zoeller RT, Belcher SM. In vitro molecular mechanisms of bisphenol A action. Reprod Toxicol. 2007;24:178-198.

[118] Alonso-Magdalena P, Ropero AB, Soriano S, García-Arévalo M, Ripoll C, Fuentes E, Quesada I, Nadal Á. Bisphenol-A acts as a potent estrogen via non-classical estrogen triggered pathways. Mol Cell Endocrinol. 2012;355:201-207. DOI: 10.1016/j.mce. 2011.12.012.

[119] Wetherill YB, Fisher NL, Staubach A, Danielsen M, de Vere White RW, Knudsen KE. Xenoestrogen action in prostate cancer: Pleiotropic effects dependent on androgen receptor status. Cancer Res. 2005;65:54-65.

[120] Hoekstra EJ, Simoneau C. Release of bisphenol A from polycarbonate: A review. Crit Rev Food Sci Nutr. 2013;53:386-402. DOI: 10.1080/10408398.2010.536919.

[121] Pant J, Deshpande SB. Acute toxicity of bisphenol A in rats. Indian J Exp Biol. 2012;50:425-429.

[122] Vogel SA. The politics of plastics: the making and unmaking of bisphenol a "safety". Am J Public Health. 2009;99 :S559-S566. DOI: 10.2105/AJPH.2008.159228.(Suppl 3)

[123] Rubin BS. Bisphenol A: An endocrine disruptor with widespread exposure and multiple effects. J Steroid Biochem Mol Biol. 2011;127:27-34. DOI: 10.1016/j.jsbmb. 2011.05.002.

[124] Negishi T, Tominaga T, Ishii Y, Kyuwa S, Hayasaka I, Kuroda Y, Yoshikawa Y. Comparative study on toxicokinetics of bisphenol A in F344 rats, monkeys (Macaca fascicularis), and chimpanzees (Pan troglodytes). Exp Anim. 2004;53:391-394.

[125] Elsby R, Maggs JL, Ashby J, Park BK. Comparison of the modulatory effects of human and rat liver microsomal metabolism on the estrogenicity of bisphenol A: Implications for extrapolation to humans. J Pharmacol Exp Ther. 2001;297:103-113. 
[126] Takeuchi T, Tsutsumi O, Nakamura N, Ikezuki Y, Takai Y, Yano T, Taketani Y. Gender difference in serum bisphenol A levels may be caused by liver UDP-glucuronosyltransferase activity in rats. Biochem Biophys Res Commun. 2004;325:549-554.

[127] Takeuchi T, Tsutsumi O. Serum bisphenol a concentrations showed gender differences, possibly linked to androgen levels. Biochem Biophys Res Commun. 2002;291:76-78.

[128] Kim YH, Kim CS, Park S, Han SY, Pyo MY, Yang M. Gender differences in the levels of bisphenol A metabolites in urine. Biochem Biophys Res Commun. 2003;312:441-448.

[129] Pottenger LH, Domoradzki JY, Markham DA, Hansen SC, Cagen SZ, Waechter JM Jr. The relative bioavailability and metabolism of bisphenol $\mathrm{A}$ in rats is dependent upon the route of administration. Toxicol Sci. 2000;54:3-18.

[130] Atkinson A, Roy D. In vitro conversion of environmental estrogenic chemical bisphenol A to DNA binding metabolite(s). Biochem Biophys Res Commun. 1995;210:424-433.

[131] Lacroix MZ, Puel S, Collet SH, Corbel T, Picard-Hagen N, Toutain PL, Viguié C, Gayrard V. Simultaneous quantification of bisphenol A and its glucuronide metabolite (BPA-G) in plasma and urine: Applicability to toxicokinetic investigations. Talanta. 2011;85:2053-2059. DOI: 10.1016/j.talanta.2011.07.040.

[132] Nakagawa Y, Suzuki T. Metabolism of bisphenol A in isolated rat hepatocytes and oestrogenic activity of a hydroxylated metabolite in MCF-7 human breast cancer cells. Xenobiotica. 2001;31:113-123.

[133] Shimizu M, Ohta K, Matsumoto Y, Fukuoka M, Ohno Y, Ozawa S. Sulfation of bisphenol A abolished its estrogenicity based on proliferation and gene expression in human breast cancer MCF-7 cells. Toxicol In Vitro. 2002;16:549-556.

[134] Bursztyka J, Perdu E, Pettersson K, Pongratz I, Fernández-Cabrera M, Olea N, Debrauwer L, Zalko D, Cravedi JP. Biotransformation of genistein and bisphenol A in cell lines used for screening endocrine disruptors. Toxicol In Vitro. 2008;22:1595-1604. DOI: 10.1016/j.tiv.2008.06.013.

[135] Schweikl H, Schmalz G, Rackebrandt K. The mutagenic activity of unpolymerized resin monomers in Salmonella typhimurium and V79 cells. Mutat Res. 1998;415:119-130.

[136] Naik P, Vijayalaxmi KK. Cytogenetic evaluation for genotoxicity of bisphenol-A in bone marrow cells of Swiss albino mice. Mutat Res. 2009;676:106-112. DOI: 10.1016/ j.mrgentox.2009.04.010.

[137] Tayama S, Nakagawa Y, Tayama K. Genotoxic effects of environmental estrogen-like compounds in CHO-K1 cells. Mutat Res. 2008;649:114-125.

[138] Lee S, Liu X, Takeda S, Choi K. Genotoxic potentials and related mechanisms of bisphenol A and other bisphenol compounds: A comparison study employing chicken DT40 cells. Chemosphere. 2013;93:434-40. DOI: 10.1016/j.chemosphere.2013.05.029. 
[139] Kovacic P. How safe is bisphenol A? Fundamentals of toxicity: Metabolism, electron transfer and oxidative stress. Med Hypotheses. 2010;75:1-4. DOI: 10.1016/j.mehy. 2010.03.002.

[140] Audebert M, Dolo L, Perdu E, Cravedi JP, Zalko D. Use of the $\gamma \mathrm{H} 2 \mathrm{AX}$ assay for assessing the genotoxicity of bisphenol $\mathrm{A}$ and bisphenol $\mathrm{F}$ in human cell lines. Arch Toxicol. 2011;85:1463-1473.

[141] Kolšek K, Mavri J, Sollner Dolenc M. Reactivity of bisphenol A-3,4-quinone with DNA. A quantum chemical study. Toxicol In Vitro. 2012;26:102-106. DOI: 10.1016/j.tiv. 2011.11.003.

[142] Fernandez SV, Huang Y, Snider KE, Zhou Y, Pogash TJ, Russo J. Expression and DNA methylation changes in human breast epithelial cells after bisphenol A exposure. Int J Oncol. 2012;41:369-377. DOI: 10.3892/ijo.2012.1444.

[143] Ferreira LL, Couto R, Oliveira PJ. Bisphenol A as epigenetic modulator: Setting the stage for carcinogenesis? Eur J Clin Invest. 2015;45 :32-36. DOI: 10.1111/eci.12362.(Suppl 1)

[144] Morgan HD, Sutherland HGE, Martin DIK. Whitelaw E. Epigenetic inheritance at the agouti locus in the mouse. Nat Genet. 1999;23:314-318.

[145] Dolinoy DC, Huang D, Jirtle RL. Maternal nutrient supplementation counteracts bisphenol A-induced DNA hypomethylation in early development. Proc Natl Acad Sci U S A. 2007;104:13056-13061.

[146] Keri RA, Ho SM, Hunt PA, Knudsen KE, Soto AM, Prins GS. An evaluation of evidence for the carcinogenic activity of bisphenol A. Reprod Toxicol. 2007;24:240-252.

[147] Doherty LF, Bromer JG, Zhou Y, Aldad TS, Taylor HS. In utero exposure to diethylstilbestrol (DES) or bisphenol-A (BPA) increases EZH2 expression in the mammary gland: An epigenetic mechanism linking endocrine disruptors to breast cancer. Horm Cancer. 2010;1:146-155. DOI: 10.1007/s12672-010-0015-9

[148] Ho SM, Tang WY, Belmonte de Frausto J, Prins GS. Developmental exposure to estradiol and bisphenol a increases susceptibility to prostate carcinogenesis and epigenetically regulates phosphodiesterase type 4 variant 4 . Cancer Res. 2006;66:56245632.

[149] Prins GS, Tang WY, Belmonte J, Ho SM. Developmental exposure to bisphenol a increases prostate cancer susceptibility in adult rats: Epigenetic mode of action is implicated. Fertil Steril. 2008;89: e41.

[150] Tang W-Y, Morey LM, Cheung YY, Birch L, Prins GS, Ho S-M. Neonatal exposure to estradiol/bisphenol A alters promoter methylation and expression of Nsbp1 and Hpcal1 genes and transcriptional programs of Dnmt3a/b and $\mathrm{Mbd} 2 / 4$ in the rat prostate gland throughout life. Endocrinology. 2012;153:42-55. 
[151] Doshi T, Mehta SS, Dighe V, Balasinor N, Vanage G. Hypermethylation of estrogen receptor promoter region in adult testis of rats exposed neonatally to bisphenol A. Toxicology. 2011;289:74-82.

[152] Avissar-Whiting M, Veiga KR, Uhl KM, Maccani MA, Gagne LA, Moen EL, Marsit CJ. Bisphenol A exposure leads to specific microRNA alterations in placental cells. Reprod Toxicol. 2010;29:401-406.

[153] Cho H, Kim S, Park HW, Oh MJ, Yu S, Lee S, Park C, Han J, Oh JH, Hwang S, Yoon SJ. A relationship between miRNA and gene expression in the mouse Ssertoli cell line after exposure to bisphenol A. BioChip J. 2010;4:75-81.

[154] International Agency for Research on Cancer (IARC). Monographs on the Evaluation of Carcinogenic Risks to Humans. Volume 71. Re-evaluation of Some Organic Chemicals, Hydrazine and Hydrogen Peroxide. Lyon; 1999. Available from: http://monographs.iarc.fr/ENG/Monographs/vol71/mono71.pdf.

[155] Soto AM, Brisken C, Schaeberle C, Sonnenschein C. Does cancer start in the womb? Altered mammary gland development and predisposition to breast cancer due to in utero exposure to endocrine disruptors. J Mammary Gland Biol Neoplasia. 2013;18:199_ 208. DOI: 10.1007/s10911-013-9293-5.

[156] Acevedo N, Davis B, Schaeberle CM, Sonnenschein C, Soto AM. Perinatally administered bisphenol a as a potential mammary gland carcinogen in rats. Environ Health Perspect. 2013;121:1040-1046. DOI: 10.1289/ehp.1306734.

[157] Huff J. Carcinogenicity of bisphenol-A in Fischer rats and B6C3F1 mice. Odontology. 2001;89:12-20.

[158] Ptak A, Wróbel A, Gregoraszczuk EL. Effect of bisphenol-A on the expression of selected genes involved in cell cycle and apoptosis in the OVCAR-3 cell line. Toxicol Lett. 2011;202:30-35. DOI: 10.1016/j.toxlet.2011.01.015.

[159] Ptak A, Gregoraszczuk EL. Bisphenol A induces leptin receptor expression, creating more binding sites for leptin, and activates the JAK/Stat, MAPK/ERK and PI3K/Akt signalling pathways in human ovarian cancer cell. Toxicol Lett. 2012;210:332-337. DOI: 10.1016/j.toxlet.2012.02.003.

[160] Bolli A, Bulzomi P, Galluzzo P, Acconcia F, Marino M. Bisphenol A impairs estradiolinduced protective effects against DLD-1 colon cancer cell growth. IUBMB Life. 2010;62:684-687. DOI: 10.1002/iub.370.

[161] Cobellis L, Colacurci N, Trabucco E, Carpentiero C, Grumetto L. Measurement of bisphenol A and bisphenol B levels in human blood sera from healthy and endometriotic women. Biomed Chromatogr. 2009;23:1186-11890. DOI: 10.1002/bmc.1241.

[162] Markey CM, Coombs MA, Sonnenschein C, Soto AM. Mammalian development in a changing environment: exposure to endocrine disruptors reveals the developmental 
plasticity of steroid-hormone target organs. Evol Dev. 2003;5:67-75. DOI: 10.1046/j. 1525-142X.2003.03011.x

[163] Richter CA, Birnbaum LS, Farabollini F, Newbold RR, Rubin BS, Talsness CE, Vandenbergh JG, Walser-Kuntz DR, vom Saal FS. In vivo effects of bisphenol A in laboratory rodent studies. Reprod Toxicol. 2007;24:199-224. DOI: 10.1016/j.reprotox.2007.06.004

[164] Ryan BC, Hotchkiss AK, Crofton KM, Gray LE Jr. In utero and lactational exposure to bisphenol A, in contrast to ethinyl estradiol, does not alter sexually dimorphic behavior, puberty, fertility, and anatomy of female LE rats. Toxicol Sci. 2010;114:133-148. DOI: 10.1093/toxsci/kfp266.

[165] Ziv-Gal A, Craig ZR, Wang W, Flaws JA. Bisphenol A inhibits cultured mouse ovarian follicle growth partially via the aryl hydrocarbon receptor signaling pathway. Reprod Toxicol. 2013;42:58-67. DOI: 10.1016/j.reprotox.2013.07.022.

[166] Huc L, Lemarié A, Guéraud F, Héliès-Toussaint C. Low concentrations of bisphenol A induce lipid accumulation mediated by the production of reactive oxygen species in the mitochondria of HepG2 cells. Toxicol In Vitro. 2012;26:709-717.

[167] Moon MK, Kim MJ, Jung IK, Koo YD, Ann HY, Lee KJ, Kim SH, Yoon YC, Cho BJ, Park KS, Jang HC, Park YJ. Bisphenol A impairs mitochondrial function in the liver at doses below the no observed adverse effect level. J Korean Med Sci. 2012;27:644-652. DOI: 10.3346/jkms.2012.27.6.644.

[168] Fenichel P, Chevalier N, Brucker-Davis F. Bisphenol A: An endocrine and metabolic disruptor. Ann Endocrinol (Paris). 2013;74:211-220. DOI: 10.1016/j.ando.2013.04.002.

[169] Gentilcore D, Porreca I, Rizzo F, Ganbaatar E, Carchia E, Mallardo M, De Felice M, Ambrosino C. Bisphenol A interferes with thyroid specific gene expression. Toxicology. 2013;304:21-31. DOI: 10.1016/j.tox.2012.12.001.

[170] Lee S, Suk K, Kim IK, Jang IS, Park JW, Johnson VJ, Kwon TK, Choi BJ, Kim SH. Signaling pathways of bisphenol A-induced apoptosis in hippocampal neuronal cells: role of calcium-induced reactive oxygen species, mitogen-activated protein kinases, and nuclear factor-kappaB. J Neurosci Res. 2008;86:2932-2942. DOI: 10.1002/jnr.21739.

[171] Liu R, Xing L, Kong D, Jiang J, Shang L, Hao W. Bisphenol A inhibits proliferation and induces apoptosis in micromass cultures of rat embryonic midbrain cells through the JNK, CREB and p53 signaling pathways. Food Chem Toxicol. 2013;52:76-82. DOI: 10.1016/j.fct.2012.10.033.

[172] Stump DG, Beck MJ, Radovsky A, Garman RH, Freshwater LL, Sheets LP, Marty MS, Waechter JM Jr, Dimond SS, Van Miller JP, Shiotsuka RN, Beyer D, Chappelle AH, Hentges SG. Developmental neurotoxicity study of dietary bisphenol A in SpragueDawley rats. Toxicol Sci. 2010;115:167-182. DOI: 10.1093/toxsci/kfq025. 
[173] Nakamura K, Itoh K, Yoshimoto K, Sugimoto T, Fushiki S. Prenatal and lactational exposure to low-doses of bisphenol A alters brain monoamine concentration in adult mice. Neurosci Lett. 2010;484:66-70. DOI: 10.1016/j.neulet.2010.08.021.

[174] Rogers JA, Metz L, Yong VW. Review: Endocrine disrupting chemicals and immune responses: a focus on bisphenol-A and its potential mechanisms. Mol Immunol. 2013;53:421-430. DOI: 10.1016/j.molimm.2012.09.013.

[175] Youn JY, Park HY, Lee JW, Jung IO, Choi KH, Kim K, Cho KH. Evaluation of the immune response following exposure of mice to bisphenol A: Induction of Th1 cytokine and prolactin by BPA exposure in the mouse spleen cells. Arch Pharm Res. 2002;25:946953.

[176] Lee J, Lim KT. Plant-originated glycoprotein (36 kDa) suppresses interleukin-4 and -10 in bisphenol A-stimulated primary cultured mouse lymphocytes. Drug Chem Toxicol. 2010;33:421-429. DOI: 10.3109/01480541003739229.

[177] Sakazaki H, Ueno H, Nakamuro K. Estrogen receptor alpha in mouse splenic lymphocytes: Possible involvement in immunity. Toxicol Lett. 2002;133:221-229. DOI: 10.1016/ S0378-4274(02)00203-5

[178] Goto M, Takano-Ishikawa Y, Ono H, Yoshida M, Yamaki K, Shinmoto H. Orally administered bisphenol A disturbed antigen specific immunoresponses in the naïve condition. Biosci Biotechnol Biochem. 2007;71:2136-2143.

[179] Sugita-Konishi Y, Shimura S, Nishikawa T, Sunaga F, Naito H, Suzuki Y. Effect of Bisphenol A on non-specific immunodefenses against non-pathogenic Escherichia coli. Toxicol Lett. 2003;136:217-227.

[180] Roy A, Bauer SM, Lawrence BP. Developmental exposure to bisphenol A modulates innate but not adaptive immune responses to influenza A virus infection. PLoS One. 2012;7: e38448. DOI: 10.1371/journal.pone.0038448.

[181] Meeker JD, Calafat AM, Hauser R. Urinary bisphenol A concentrations in relation to serum thyroid and reproductive hormone levels in men from an infertility clinic. Environ Sci Technol. 2010;44:1458-1463. DOI: 10.1021/es9028292

[182] Melzer D, Harries L, Cipelli R, Henley W, Money C, McCormack P, Young A, Guralnik J, Ferrucci L, Bandinelli S, Corsi AM, Galloway T. Bisphenol A exposure is associated with in vivo estrogenic gene expression in adults. Environ Health Perspect. 2011;119:1788-1793. DOI: 10.1289/ehp.1103809

[183] Li DK, Zhou Z, Miao M, He Y, Wang J, Ferber J, Herrinton LJ, Gao E, Yuan W. Urine bisphenol-A (BPA) level in relation to semen quality. Fertil Steril. 2011;95:625-630. DOI: 10.1016/j.fertnstert.2010.09.026

[184] Miao M, Yuan W, Yang F, Liang H, Zhou Z, Li R, Gao E, Li DK. Associations between bisphenol A exposure and reproductive hormones among female workers. Int J Environ Res Public Health. 2015;12:13240-13250. DOI: 10.3390/ijerph121013240 
[185] Mínguez-Alarcón L, Gaskins AJ, Chiu YH, Williams PL, Ehrlich S, Chavarro JE, Petrozza JC, Ford JB, Calafat AM, Hauser R; EARTH Study Team. Urinary bisphenol A concentrations and association with in vitro fertilization outcomes among women from a fertility clinic. Hum Reprod. 2015;30:2120-2128. DOI: 10.1093/humrep/dev183

[186] Liu X, Miao M, Zhou Z, Gao E, Chen J, Wang J, Sun F, Yuan W, Li DK. Exposure to bisphenol-A and reproductive hormones among male adults. Environ Toxicol Pharmacol. 2015;39:934-941. DOI: 10.1016/j.etap.2015.03.007

[187] Liu C, Xu X, Zhang Y, Li W, Huo X. Associations between maternal phenolic exposure and cord sex hormones in male newborns. Hum Reprod. 2016. pii:dev327. DOI: 10.1093/ humrep/dev327

[188] Durmaz E, Aşçı A, Erkekoğlu P, Akçurin S, Gümüşel BK, Bircan I. Urinary bisphenol a levels in girls with idiopathic central precocious puberty. J Clin Res Pediatr Endocrinol. 2014;6:16-21. DOI: 10.4274/Jcrpe.1220 
Chapter 7

\title{
Occupational Exposure to Coal, Genotoxicity, and Cancer Risk
}

\author{
Grethel León-Mejía, Milton Quintana Sosa, \\ Paula Rohr, Katia Kvitko, \\ João Antonio Pêgas Henriques and Juliana da Silva
}

Additional information is available at the end of the chapter

http://dx.doi.org/10.5772/62486

\begin{abstract}
Coal is a heterogeneous mixture containing large quantities of organic and inorganic matter, including carbon, hydrogen, oxygen, sulfur, nitrogen, and organometallic forms. The presence of mineral matter in coal may result in a number of environmental and human health problems related to its mining, preparation, and combustion. During coal mining activities, large quantities of coal dust, ashes, polycyclic aromatic hydrocarbons (PAHs), and heavy metals are released into the environment, forming a complex mixture. This mixture becomes one of the most important occupational risks for the health and safety of workers due to its synergistic, additive, and enhancing effects. Once inside the organism, this cocktail-like mixture can interact with cellular mechanisms related to the production of reactive oxygen species (ROS) and can cause damage in important macromolecules such as DNA, lipids, and proteins. In this review, human populations exposed to coal and coal burning were analyzed. Data from different studies were evaluated in relation to the effect of complex mixture exposure on DNA damage and mechanisms, and the background factors, such as gender, age, or smoking habit. The high temperatures that occur in combustion processes affect the characteristics of the resulting particles. The coal fly ash is released by combustion and its composition varies depending on the coal type and the method of collection used such as electrostatic precipitators. Compounds such as PAHs once activated by the organisms have been shown to have mutagenic and carcinogenic activity due to its ability to form adducts with purines. Moreover, metals that commonly are evaporated during the cooling process increase its toxicity. The particles when inhaled can pass from the alveoli into the bloodstream and affect extrapulmonary organs. Several studies have described the inflammatory cascade that triggers exposure to coal and coal fly ash particles; they have a complex composition capable of generating a persistent inflammatory process, resulting in diseases widely described asemphysema, bronchitis, pneumoconiosis, asthma, and cancer.Severalhuman biomonitoring studies have been conducted evaluating the inflammatory process and
\end{abstract}


the release of cytokines, polymorphisms involved in detoxification mechanisms, different biomarkers associated with occupational exposure, DNA damage, and the influence of oxidative stress in disease development. The relationship between chronic exposure to coal and coal ash particles and cancer is still widely debated. This review gave us a broad assessment about the associated mechanisms between cancer and exposure to coal and different findings around the world.

Keywords: coal, biomonitoring, DNA damage, ROS, PAHs, diseases

\section{Introduction}

In the last decades, the human population genetics integrity has been compromised by the great industrial activity, which exposes people to a variety of chemicals and genotoxic agents. As a result, it is important to determine what is considered as an "acceptable" level of genetic damage in a concrete population, carry out assay genotoxicity as a routine and also monitor those who, by their occupation or lifestyle, are more exposed or with a bigger risk of having alterations on their genetics stability [1].

One method to quantify the exposure to those substances, as well as its possible impact on the organism, is the use of biological monitoring procedures, or biomonitoring, through biomarkers. Biomonitoring studies try to establish a connection between the environmental factors and the diseases. They detect first alterations in nonmalignant phases, so as to prevent health problems by recognizing the environmental cause of them.

The biological markers, or biomarkers, are the measurable changes (biochemical, physiological, or morphological) that associate to a toxic exposure or any early biochemical alteration, whose study on the biological fluids, tissues, or exhaled air that allow to assess the health risk exposure intensity. The identification of genotoxicity markers believed to cause genome damage is useful, since it can define a prepathogenesis state, such as cancer. It is of vital importance for different diseases prevention, which is the final goal of biomonitoring. In order to achieve it, there must be two stages: 1) detecting human exposure to environment carcinogenic agents; 2) determining genotoxic effects in vivo [2].

The combined use of genetic biomarkers and classic epidemiology tools (clinic history and questionnaires) has enabled the identification of early effects to the occupational exposure to distinct pollutant around the world [2-4]. Many biomarkers are used to assess genotoxic effects on human populations exposed to complex mixtures of chemicals. Although there are different possibilities, micronuclei (MN) frequency, chromosomal aberrations (CAs), and comet assay are the most commonly chosen biomarkers. MN originates from chromosome fragments or whole chromosomes that are not included in the main daughter nuclei during nuclear division $[5,6]$. MN induction reflects clastogenic and aneugenic damage and is a predictive biomarker of cancer risk [7]. Comet assay detects DNA lesions in individual cells obtained under a variety of experimental conditions; the technique can also be used to evaluate DNA repair $[8,9]$. 
The large inter-individual variability in the capacity to activate or inactivate potential genotoxic and carcinogenic compounds is probably influenced by polymorphisms of the genes encoding the metabolizing enzymes. Genes and proteins involved in metabolization/detoxification of xenobiotics, as well as those involved in DNA repair, are usually used as potential markers of susceptibility for the development of several diseases in which the etiology is related to exposure to environmental hazards. Polymorphisms in such genes have been linked with an increased risk of cancer in several case-control studies [10].

Biomonitoring studies in populations exposed to complex mixtures of chemicals considering individual susceptibility are quite complicated due to inadequate toxicity data, and the unpredictable nature of interaction effects that may be synergistic, additive, or enhancers.

\section{Occupational exposure to coal}

The coal reserves in a worldwide level is up to 847.5 billion of tons, enough amount to serve the current production for 119 years. This prediction is different from the ones related to oil and gas, which have available supplies for less time [11]. According to data from the International Energy Agency (IEA), coal is the most used resource for energy generation in the world, responsible for $41 \%$ of the total production. Nowadays, the main application of mineral coal is to generate energy through thermal power plants. These reserves are considered to have a 109-year lifespan and their coalfields are located in 75 countries. The main world coal producers are China, the United States, India, Australia, Indonesia, Russia, South Africa, Germany, Poland, and Kazakhstan, which are responsible for $91 \%$ of the world's production [12]. If those projections are right, the consequences of coal mining and combustion will have large effects in the environment. Thus, the exposed populations monitoring is fundamental with the aim of contributing to the state of knowledge about the health risk and motivate the establishment of control, hygiene, and prevention strategies.

It is well known that coal mining activities are one of the biggest resources of contamination due to the large quantity of substances liberated in the environment. The content of the coal dust and ashes produced by burning are not always homogeneous and this depends on the source and rank of the coal $[13,14]$. Coal dust is constituted from carbon, hydrogen, oxygen, nitrogen, quartz (crystalline silica), and inorganic minerals, such as beryllium, cadmium, cobalt, chromium, iron, boron, copper, nickel, antimony, zinc, aluminum, titanium, magnesium, manganese, mercury, and lead [15]. As observed, coal is a mixture of a variety of chemicals, including hydrocarbons, which may raise polycyclic aromatic hydrocarbons (PAHs). All technological processes associated with open fire or temperatures between 400 and $600^{\circ} \mathrm{C}$, that may lead to PAHs, should be considered potentially hazardous [16, 17].

In relation to coal mining residues exposure, studies in which biomarkers of effect, susceptibility, and exposure are used as epidemiological tools remain rare and a big part of them come from studies on underground coal mining $[18,19]$. The effects generated by open coal mining are little explored, though. In open coal mining, the residues pass directly to the atmosphere, where complex mixtures are formed, and the coal exposure to environmental factors such as 
sunlight facilitates the processes of spontaneous combustion and, therefore, the release of PAHs [20].

Studies about the coal exposure and its harmful effects have been conducted around the world [21-23]. The main way for exposure of the coal mining workers to the potentially dangerous residues is through the inhaling of coal dust particles from mining and manipulation. It is a known fact that the coal mining continuous exposure can cause a variety of diseases, such as coal workers pneumoconiosis (CWP), silicosis, cancer, and chronic obstructive pulmonary disease (COPD), as emphysema and chronic bronchitis [24].

Many studies have established that some of those diseases could have been originated from the genotoxic damage generated by the inhalation of those mineral particles, able to interact with macrophages, epithelial cells, and other cells generating the production of large amount of reactive oxygen species (ROS) [24-26]. The continuous inhalation of coal dust and fly ashes particles is an important cell and non-cell source of ROS in the lung. This may be associated to the damage of target cells of that tissue and other cell lines, after spreading through the bloodstream [27].

Coal-induced DNA damage is related to macrophage activation and the recruitment of polymorphonuclear cells. This cell activation induces the release of inflammatory mediators, such as cytokines, ROS and reactive nitrogen species (RNS). The proinflammatory properties of ROS and RNS include endothelial cell damage, lipid peroxidation and oxidation, the release of chemostatic factors, the recruitment of neutrophils, and DNA damage [26, 28]. Interaction of ROS with DNA can result in DNA structural and transcriptional errors [29, 30]. Damage caused by ROS is recognized by DNA glycosylases, apurinic/apyrimidinic endonucleases of the base excision repair (BER) mechanism, and in some cases, by the nucleotide excision repair (NER) machinery, leading to DNA strand-breaks [31, 32].

Although chronic exposure may continue to damage the DNA, it has been suggested that inorganic elements can induce DNA single-strand breaks, possibly via the generation of ROS and that this type of damage is soon repaired. Metals are also known to modulate gene expression of enzymes [33]. In addition, PAHs can induce DNA lesions as single-strand breaks via DNA repair mechanisms, related with increased adduct formation and electrophilic metabolites [34-36]. Electrophilic metabolites covalently interact with the DNA [37, 38], and adducts are formed with purines, especially guanine, after metabolic activation by enzymatic complex P450 [39]. The International Agency for Research on Cancer (IARC) classified quartz, main constituent of coal, into IARC Group 1 (carcinogen), due to sufficient evidence for carcinogenicity in experimental animals and in humans $[40,41]$. The other factor that could lead to different results in coal dust exposure, with positive and negative results, might be explained by the possible differences in composition, in which the proportion of the metals, PAHs, and silica (quartz) content may have an influence on the genotoxicity. Despite those findings, coal dust remains classified as non-carcinogen for human (Group 3) in IARC [40, 41]. The importance of coal as an energy source makes its characterization and estimation of risks of extreme importance to the safety of those individuals and the environment. 
Several factors may explain conflicting results among different studies with human exposed to coal, e.g. cigarettes smoked, age, gender, nutritional status, and individual polymorphisms $[6,42]$. Susceptibility is critical to an understanding of coal diseases, including cancer, and many xenobiotic agents act to alter susceptibility. Unknown individual susceptibility, inadequate toxicity data, and the unpredictable nature of interaction effects make the implementation of a human biomonitoring assessment for complex mixtures of chemicals extremely complicated.

\section{Oxidative stress and genotoxic damage related with coal exposure}

One important aspect to consider about the coal exposure is the amount of products generated during the coal combustion. The burning of coal, in order to generate electricity, produces flue gasses and particulate materials like coal fly ashes and residues as scoria and bottom ash. The finer particles (coal fly ash) are obtained by mechanical or electrostatic precipitation of the dust in suspension in the gases produced by combustion, while the coarser particles fall to the bottom by gravity and are removed at the bottom of the boiler $[43,44]$.

The combustion temperature is an important factor that determines the physical properties of the particles. In the combustion of conventional high temperature $\left(>1400^{\circ} \mathrm{C}\right)$, the main aluminosilicate melts and condenses to form spherical particles. The coal fly ash particles produced are mostly irregularly shaped and contain a complex mixture consisting of unburned carbon; oxides; quartz; elements such as aluminum, silicon, calcium, iron, nickel, arsenic, chromium, copper, lead, cadmium, zinc [45, 46], and PAHs [47].

The coal fly ash has a relatively low toxicity as compared with coal or quartz [45]. Studies have determined the role of coal fly ash particle size and the release of iron, which leads to generation of radicals and oxidative stress. In this context, it was demonstrated the ability of coal fly ash release of bioavailable iron, which triggers processes and redox oxidant production [48]. In addition, it was shown that interleukin 8 (IL-8) levels in human lung epithelial cells are increased in response to coal fly ash and vary with the bioavailability of iron, as a function of source of coal and particle size [49]. The smaller size fraction had more stimulatory activity, which may be related to the fact that iron is more concentrated in this fraction. Particle size is a critical factor because a larger surface area allows more significant transport of metal and other adsorbed components, increasing the pulmonary toxicity of particulate matter (PM) [50].

The particles are classified according to their aerodynamic diameter (in micrometer) in coarse (PM 10), fine (PM 2.5), ultrafine (PM 0.1) [51]. The smaller particles are more harmful with respect to health effects because of their very high alveolar deposition fraction, large surface area, chemical composition, ability to induce inflammation, and potential to translocate to the circulation to extrapulmonary organs [52-54]. These particles could trigger persistent lung inflammation compared to the coarse particles in addition to the exposure to genotoxic compounds, which are contained in the particles [26, 55].

Depending on the toxicity, the chemical properties, and the concentration in air, coal and coal fly ash particles can constitute a risk to exposed workers. When these particles are inhaled and 
deposited in the lungs, they can lead to health risks due to the leaching of genotoxic compounds and altered immunological mechanisms affecting the lung parenchyma causing diseases [56]. These nanometric particles are very small, which allows them to penetrate the biological organs and affect its normal function. More specifically, as the particle load in the lung increases the alveolar macrophages and epithelial cells are activated, leading to the release of inflammatory mediators, ROS, enzymes (elastases, proteases, collagenases), cytokines [tumor necrosis factor alpha (TNF- $\alpha$ ), interleukins], and growth factors (TGF- $\beta$ ) that control and stimulates the fibrosis, genotoxic events, and cell death $[45,57,58]$.

Persistent inflammatory processes have been accepted as a crucial factor in the pathogenesis. In Zhai et al. [59], was investigated whether systemic TNF- $\alpha$, soluble TNF- $\alpha$ receptors (p55, p75), IL-6, and soluble IL-6 receptor could be markers of biological activities of Chinese CWP. Interestingly, those results suggest that serum levels of TNF receptors and IL-6 are associated with the fibrotic process of CWP and serum cytokine levels may be correlated with the severity of CWP. In the pathogenesis of these respiratory diseases related with coal exposure, oxidative damage plays a key role. Either acting in association or independently, the chemical and physical characteristics can lead to the generation of ROS and oxidative stress [60,61].

These particles are chemically heterogeneous and can be a source of oxidants by themselves ("acellular" mechanisms), due to their composition, such as oxides, metals, and PAHs [26]. Soluble metals (transition) associated to the particle can increase the generation of ROS by Haber-Weiss reactions. PAHs may be metabolically activated and induce ROS and oxidative stress, also forming bulky adducts or strand breaks on DNA [50, 62, 63].

Another way of generating oxidants is via cellular. Once in the lungs, alveolar macrophages are activated and generate large amounts of ROS, and chemoattractant factors of other inflammatory cells such as monocytes and neutrophils are released, which amplify this response generating more oxidants [64]. The particle size is a critical factor, because very large particles are difficult to phagocytose, leading to the process of incomplete or "frustrated" phagocytosis aggravating the response $[65,66]$.

Considering three different scenarios with respect to exposure to particles, the generation of oxidative stress, inflammation, and oxidative DNA damage, several authors questioned whether the lung inflammation may be related to secondary genotoxic effects. They also questioned if phenomena of oxidative stress, inflammation and DNA damage are independent or interrelated, whether oxidative stress stimulates inflammatory processes, or inflammation mediated by particles cause oxidative stress, or even if it is possible that particles may cause both phenomena of oxidative stress and inflammation but for different mechanisms of action $[26,61]$.

In normal physiological conditions, there is a balance between ROS generation and antioxidant defenses. However, the continuous inhalation of particles may interfere in this equilibrium leading to oxidative stress process in the lung. Consequently, a high loading of particles alters the oxidant-antioxidant balance, leading to oxidative damage and the beginning of pathological processes [67]. The most important effects of ROS in the lung include damage to cell 
membranes by lipid peroxidation process, protein oxidation, and DNA damage in target cells [27].

As seen in Figure 1, oxidative DNA damage can have many consequences, from cell death and tissue destruction to cell proliferation. Furthermore, ROS can also act as regulators in signaling pathways intracellularly and transcription factors of a variety of genes including those of proinflammatory cytokines, adhesion molecules, and proto-oncogenes [68].

In vitro effects induced by coal exposure have been described in different cells such as murine alveolar type II epithelial cells (C10) [69] and in 7TD1 cells [70]. ROS generation and oxidative damage by coal fly ash particles have been described in different cell lines, in human peripheral blood mononuclear cells [71], in rat alveolar macrophages (NR8383) [72], in BEAS-2B human lung epithelial cells [73], and in rat lung epithelial (RLE) cells [74].

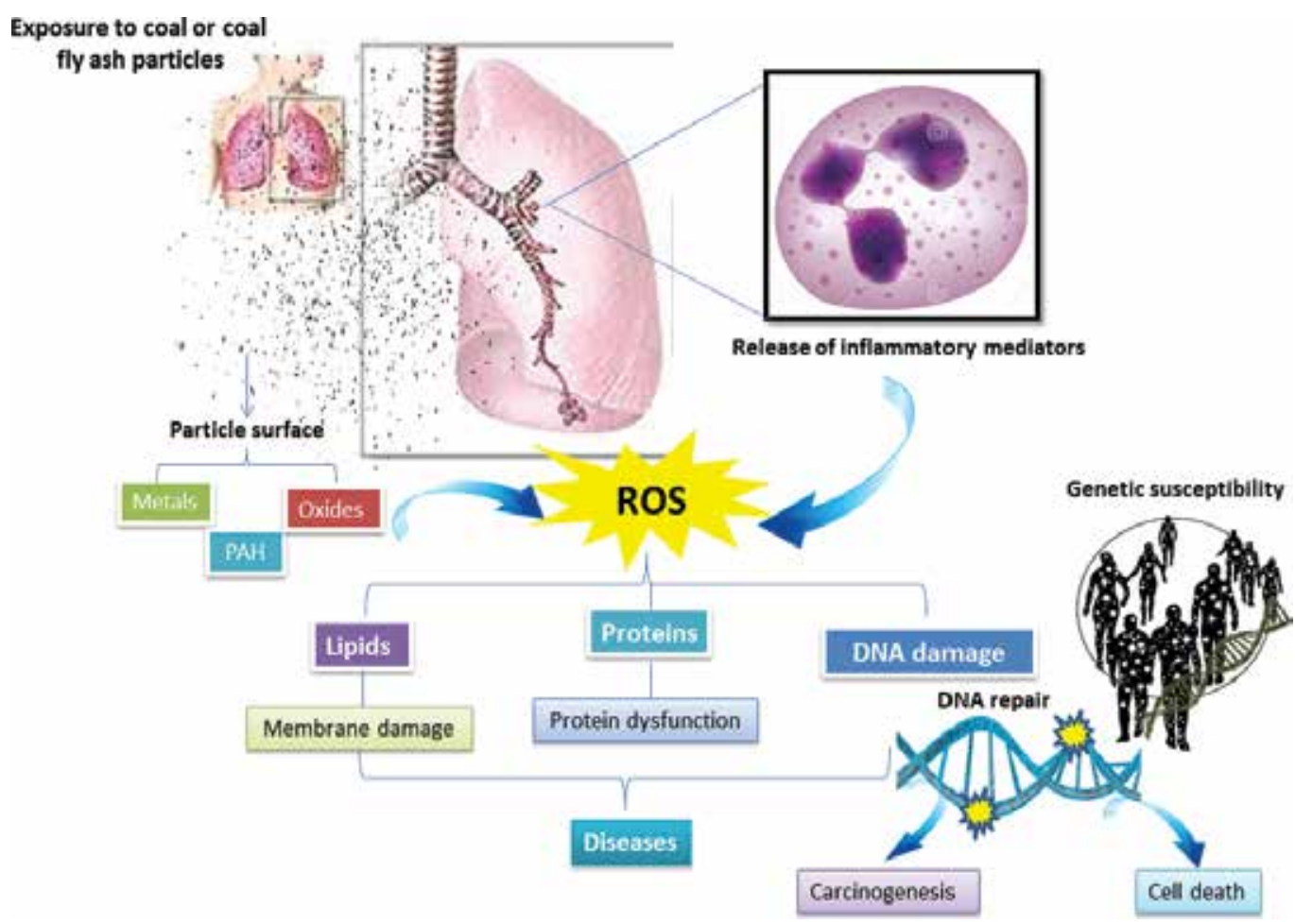

Figure 1. Main pathways associated with the generation of oxidative damage and the development of diseases induced by coal and coal fly ash particles.

ROS induce point mutations and CAs in cells. Many inhaled toxic substances contained in the particles contribute to oxidative modification that has as target of attack specific components of the cytoplasm and the nucleus. Such changes include DNA breakage, DNA oxidative modification, base modifications, alterations in the DNA sequence, poly-ADP ribosylation, activation of kinases, activation of proto-oncogenes, and inactivation of tumor suppressor 
genes. Persistent generation of ROS generated by mineral particles indestructible or engulfed incompletely leads to damage to organelles keys [59, 61, 75]. The oxidation of C8 deoxyguanosine $(\mathrm{dG})$, resulting in 7-dihydro-8-oxo-2'-deoxyguanosine (8-oxodG), is the most common oxidative lesion generated by ROS. The proportion of 8 -oxodG/dG has been considered as a biomarker of oxidative stress and has been studied in relation to exposure to mineral particles in vitro and in vivo [76].

Human biomonitoring studies about the effects of exposure to coal and residues using different biomarkers have been conducted around the world. In this context, our group has obtained interesting findings in workers exposed to coal mining in Colombia and Brazil. In Rohr et al. [77], was found that Brazilian workers with occupational exposure to coal had significantly increased genetic damage in peripheral blood lymphocytes compared with unexposed individuals. Exposed workers presented lower average levels of thiobarbituric acid reactive substances (TBARS) and catalase activity (CAT). In addition, DNA damage evaluated by human buccal micronucleus cytome (BMCyt) assay was observed in mine workers, which could be a consequence of oxidative damage resulting from exposure to coal residue mixtures [78].

In Colombia, DNA damage in lymphocytes of coal open-cast mining workers using the cytokinesis-blocked micronucleus test and the comet assay were observed [79]. Also, in buccal mucosa samples, the micronucleus frequencies and nuclear buds were significantly higher in the exposed group than in non-exposed control group. Interestingly, blood samples of Colombian mining workers analyzed showed higher values of silicon and aluminum characteristic elements of coal particles, compared with the control group [80]. All these studies converge to a point: the compounds contained in the particles may be related to ROS generation, DNA damage, and formation of pro-mutagenic adducts.

These are important findings if we consider that oxidative DNA damage can lead to long-term risk of cancer and other diseases caused by air pollution by these particles. In Table 1, can be observed an overview of key studies on the genotoxicity in human population exposed to coal and coal combustion products. These studies demonstrated DNA damage using different methods, related with inorganic elements and oxidative stress.

\begin{tabular}{|c|c|c|c|}
\hline References Country & Exposure(s) & Biomarker & Outcome(s) \\
\hline Slovenia & - & $\begin{array}{l}\text { Sister-chromatid exchanges } \\
\text { (SCE), unstable chromosome } \\
\text { and chromatid aberrations } \\
\text { and micronuclei in } \\
\text { blood lymphocytes }\end{array}$ & $\begin{array}{l}\text { Significantly higher levels of } \\
\text { chromosomal aberrations, SCE and } \\
\text { micronuclei in exposed group } \\
\text { compared with the control group. }\end{array}$ \\
\hline Brazil & $\begin{array}{l}\text { Underground } \\
\text { workers } \\
\text { directly } \\
\text { exposed, } \\
\text { surface }\end{array}$ & $\begin{array}{l}\text { Oxidative stress } \\
\text { biomarkers (TBARS, GSH/ } \\
\text { GSSG, } \alpha \text {-tocopherol, } \\
\text { GST, GR, GPx, SOD, } \\
\text { CAT ). }\end{array}$ & $\begin{array}{l}\text { The results showed that subjects } \\
\text { directly and indirectly exposed to coal } \\
\text { dust face an oxidative stress } \\
\text { condition. They also indicate } \\
\text { that people living in the }\end{array}$ \\
\hline
\end{tabular}




\begin{tabular}{|c|c|c|c|c|}
\hline References & Country & Exposure(s) & Biomarker & Outcome(s) \\
\hline & & $\begin{array}{l}\text { workers } \\
\text { indirectly } \\
\text { exposed, } \\
\text { residents } \\
\text { living } \\
\text { near the } \\
\text { mines. }\end{array}$ & & $\begin{array}{l}\text { vicinity of the mine plant } \\
\text { are in health risk } \\
\text { regarding coal mining-related } \\
\text { diseases. }\end{array}$ \\
\hline [22] & Turkey & $\begin{array}{l}\text { Coal } \\
\text { combustion } \\
\text { products }\end{array}$ & $\begin{array}{l}\text { Chromosomal aberrations } \\
\text { (CAs), polyploidy, sister- } \\
\text { chromatid exchanges (SCEs), } \\
\text { and micronuclei (MN) } \\
\text { in blood cells. }\end{array}$ & $\begin{array}{l}\text { Significantly higher levels of CA, } \\
\text { polyploidy, SCE, and MN in peripheral } \\
\text { blood lymphocytes of workers compared } \\
\text { with controls. }\end{array}$ \\
\hline [83] & Turkey & $\begin{array}{l}\text { Underground } \\
\text { coal } \\
\text { mining }\end{array}$ & $\begin{array}{l}\text { SCE, CA, and micronuclei } \\
\text { frequencies in peripheral } \\
\text { lymphocytes. }\end{array}$ & $\begin{array}{l}\text { Increase in sister chromatid exchanges, } \\
\text { chromosomal aberrations, and micronucleus } \\
\text { frequencies found in underground coal } \\
\text { miners as compared to control } \\
\text { group. }\end{array}$ \\
\hline [21] & China & $\begin{array}{l}\text { Indoor smoky } \\
\text { coal emissions } \\
\text { that contain } \\
\text { high levels } \\
\text { of polycyclic } \\
\text { aromatic } \\
\text { hydrocarbons } \\
\text { (PAHs) }\end{array}$ & $\begin{array}{l}\text { GSTM1 and GSTT1 } \\
\text { genotypes. Expression } \\
\text { of p53 protein in } \\
\text { sputum samples. }\end{array}$ & $\begin{array}{l}\text { The GSTM1 null genotype may enhance } \\
\text { susceptibility to lung cancer due to } \\
\text { these indoor coal combustion emissions. } \\
\text { Smoky coal use was strongly } \\
\text { associated with overexpression of p53 } \\
\text { in tumor cells among highly } \\
\text { exposed women. }\end{array}$ \\
\hline [79] & Colombia & $\begin{array}{l}\text { Open cast } \\
\text { mining }\end{array}$ & $\begin{array}{l}\text { (MN) frequency and } \\
\text { DNA damage (comet } \\
\text { assay) in lymphocytes. }\end{array}$ & $\begin{array}{l}\text { The biomarkers evaluated showed } \\
\text { statistically significant higher values } \\
\text { in the exposed group compared to the } \\
\text { non-exposed control group. }\end{array}$ \\
\hline [80] & Colombia & $\begin{array}{l}\text { Open cast } \\
\text { mining }\end{array}$ & $\begin{array}{l}\text { Micronucleus (MN) } \\
\text { frequencies, nuclear } \\
\text { buds, karyorrhectic } \\
\text { and karyolytic } \\
\text { cells in buccal } \\
\text { mucosa samples and } \\
\text { content of inorganic } \\
\text { elements in blood } \\
\text { samples by PIXE. }\end{array}$ & $\begin{array}{l}\text { MN frequencies and nuclear buds in } \\
\text { buccal mucosa samples were significantly } \\
\text { higher in the exposed group than in } \\
\text { the non-exposed control group. } \\
\text { In addition, karyorrhectic and karyolytic } \\
\text { cells were also significantly higher } \\
\text { in the exposed group (cell death). } \\
\text { Blood samples showed higher } \\
\text { values of silicon (Si) and } \\
\text { aluminum (Al) in the exposed group. }\end{array}$ \\
\hline [84] & Russian & $\begin{array}{l}\text { Underground } \\
\text { coal }\end{array}$ & $\begin{array}{l}\text { Chromosomal and } \\
\text { chromatid type }\end{array}$ & $\begin{array}{l}\text { A higher frequency of chromosomal } \\
\text { aberrations in the exposed group }\end{array}$ \\
\hline
\end{tabular}




\begin{tabular}{|c|c|c|c|c|}
\hline References & Country & Exposure(s) & Biomarker & Outcome(s) \\
\hline & & mining & $\begin{array}{l}\text { aberrations in } \\
\text { blood lymphocytes }\end{array}$ & compared with the control group. \\
\hline [77] & Brazil & $\begin{array}{l}\text { Open coal } \\
\text { mining }\end{array}$ & $\begin{array}{l}\text { MN and nucleoplasmic } \\
\text { bridge frequencies } \\
\text { in peripheral } \\
\text { lymphocytes, damage } \\
\text { index and damage } \\
\text { frequency (comet assay). }\end{array}$ & $\begin{array}{l}\text { Increased MN and nucleoplasmic bridge } \\
\text { frequencies in peripheral lymphocytes, } \\
\text { increased damage index and damage } \\
\text { frequency (comet assay). Lower } \\
\text { average levels of TBARS and } \\
\text { catalase activity (CAT), while } \\
\text { the mean superoxide dismutase } \\
\text { activity (SOD) levels were higher in } \\
\text { the exposed group. }\end{array}$ \\
\hline [78] & Brazil & $\begin{array}{l}\text { Open coal } \\
\text { mining }\end{array}$ & $\begin{array}{l}\text { Buccal micronucleus } \\
\text { cytome (BMCyt) DNA } \\
\text { damage, cell death, } \\
\text { and basal cell frequency } \\
\text { in buccal cells. }\end{array}$ & $\begin{array}{l}\text { The exposed group presented a significantly } \\
\text { higher frequency of basal cells, } \\
\text { micronuclei in basal and differentiated } \\
\text { cells, and binucleated cells } \\
\text { compared to the non-exposed group. } \\
\text { No correlation between DNA damage } \\
\text { and metal concentration in the blood } \\
\text { of mine workers. }\end{array}$ \\
\hline [19] & Peru & $\begin{array}{l}\text { Underground } \\
\text { coal } \\
\text { mining }\end{array}$ & $\begin{array}{l}\text { Chromosomal aberrations } \\
\text { in peripheral lymphocytes }\end{array}$ & $\begin{array}{l}\text { Miners occupationally exposed to underground } \\
\text { mining activity have an increased frequency } \\
\text { of chromosomal aberrations compared with } \\
\text { the controls. }\end{array}$ \\
\hline [85] & - & $\begin{array}{l}\text { Coal fly ash } \\
\text { particles }\end{array}$ & $\begin{array}{l}\text { SCE frequencies in } \\
\text { peripheral blood } \\
\text { lymphocytes. }\end{array}$ & $\begin{array}{l}\text { No increased SCE frequencies were found } \\
\text { in PBLs of workers potentially exposed } \\
\text { to coal fly ash when compared to } \\
\text { the control group. No differences } \\
\text { were observed between the exposed } \\
\text { and control groups for frequencies of } \\
\text { gene mutations at the HPRT locus } \\
\text { in PBLs, for micronucleus } \\
\text { frequencies using the cytokinesis } \\
\text { block method, or for urinary mutagen } \\
\text { excretion measured with Salmonella } \\
\text { typhimurium tester strains } \\
\text { TA98 and TA97. }\end{array}$ \\
\hline [86] & Germany & $\begin{array}{l}\text { Underground } \\
\text { coal } \\
\text { mining }\end{array}$ & $\begin{array}{l}\text { Structural chromosomal } \\
\text { aberrations in } \\
\text { peripheral lymphocytes }\end{array}$ & $\begin{array}{l}\text { Coal miners had significantly higher } \\
\text { frequencies of chromosomal aberrations compared } \\
\text { with controls. }\end{array}$ \\
\hline [87] & Turkey & $\begin{array}{l}\text { Underground } \\
\text { coal }\end{array}$ & $\begin{array}{l}\text { Sister chromatid } \\
\text { exchange (SCE) and }\end{array}$ & $\begin{array}{l}\text { SCE and MN frequencies in CWP patients } \\
\text { were found significantly higher than }\end{array}$ \\
\hline
\end{tabular}




\begin{tabular}{llll}
\hline References Country & Exposure(s) & Biomarker & Outcome(s) \\
\hline mining & micronucleus (MN) & in coal workers and unexposed groups. \\
& frequency in & \\
& lymphocytes of & \\
& Turkish CWP patients. \\
\hline
\end{tabular}

Table 1. Overview of key studies on the genotoxicity in human population exposed to coal and coal combustion products.

\section{Conclusions}

The coal mining activities generate different types of compounds that are released into the environment. Once into the atmosphere, these compounds form a complex mixture that consists of metals, oxides, and PAHs. These compounds can interact with "acellular" and cellular mechanisms related with ROS production. The metals found in the coal fly ash and coal particles by different ways lead to the ROS formation. Important macromolecules as DNA, proteins, and lipids can suffer oxidative modifications. The PAHs contained in the particles also influence the particles toxicity. A second indirect way for excessive ROS formation is related to cellular mechanisms, which is consequence of oxidative burst of macrophages and neutrophils during phagocytosis of particles and inflammation produced.

If we think in exposed populations, we cannot ignore the social and environmental impact associated with coal mining. The continuous inhalation, the high load of particles in phagocytic cells, the oxidant-antioxidant imbalance which are linked to the origin of pathological processes; this whole scenario is worrisome to biologic level for these populations. In addition, in recent years, coal mining had a remarkable increase in demand; international mining companies have increased their investments in exploration around the world. For this reason, human biomonitoring studies in exposed populations become really necessary to contribute to knowledge state about the risk for those people in order to motivate the design of control, hygiene, and prevention strategies, besides epidemiological surveillance.

\section{Author details}

Grethel León-Mejía ${ }^{1,2}$, Milton Quintana Sosa ${ }^{2}$, Paula Rohr ${ }^{3}$, Katia Kvitko ${ }^{4}$, João Antonio Pêgas Henriques ${ }^{1,5^{*}}$ and Juliana da Silva ${ }^{6^{*}}$

*Address all correspondence to: pegas.henriques@gmail.com and juliana.silva@ulbra.br

1 Laboratory of Molecular Radiobiology, Center of Biotechnology, Postgraduate Program in Cell and Molecular Biology (PPGBCM), Federal University of Rio Grande do Sul (UFRGS), Porto Alegre, Rio Grande do Sul, Brazil 
2 Simon Bolivar University, Faculty of Basic Sciences, Unit of Research, Development and Innovation in Genetics and Molecular Biology, Barranquilla, Colombia

3 Laboratory of Celular and Molecular Biology, Academic Unit of Health Sciences, Universidade do Extremo Sul Catarinense (UNESC) - Criciúma SC), Brazil

4 Postgraduate Program in Genetics and Molecular Biology (PPGBM), Federal University of Rio Grande do Sul (UFRGS) Porto Alegre, Rio Grande do Sul, Brazil

5 Laboratory of Molecular Radiobiology, Center of Biotechnology, Federal University of Rio Grande do Sul (UFRGS) Porto Alegre, Rio Grande do Sul, Brazil

6 Laboratory of Genetic Toxicology, Postgraduate Program in Molecular and Cell Biology Applied to Health (PPGBioSaúde), Lutheran University of Brazil (ULBRA), Canoas, Rio Grande do Sul, Brazil

\section{References}

[1] Zalacain, M; Sierrasesumaga, L; Patino, A. (2005). The cytogenetic assay as a measure of genetic instability induced by genotoxic agents. An Sist Sanit Navar. 28(2);227-36.

[2] Pastor, S; Lucero, L; Gutierrez, S; Durban, R; Gomez, C; Parron, T; et al. (2002). A followup study on micronucleus frequency in Spanish agricultural workers exposed to pesticides. Mutagenesis. 17(1);79-82.

[3] Martino-Roth, M.G; Viegas, J; Roth, D.M. (2003). Occupational genotoxicity risk evaluation through the comet assay and the micronucleus test. Genet Mol Res. 2(4); $410-7$.

[4] Cassini, C; Calloni, C; Bortolini, G; Garcia, SC; Dornelles, MA; Henriques, JÁ; Erdtmann B; Salvador M. (2011). Occupational risk assessment of oxidative stress and genotoxicity in workers exposed to paints during a working week. Int J Occup Med Environ Health. 24(3);308-19.

[5] Fenech, M; Morley, A. (1985). Solutions to the kinetic problem in the micronucleus assay. Cytobios. 43;233-46.

[6] Mateuca, R; Lombaert, N; Aka, P.V; Decordier, I; Kirsch-Volders, M. (2006). Chromosomal changes: induction, detection methods and applicability in human biomonitoring. Biochimie. 88(11);1515-31.

[7] Bonassi, S; Znaor, A; Ceppi, M; Lando, C; Chang, W.P; Holland, N; et al. (2007). An increased micronucleus frequency in peripheral blood lymphocytes predicts the risk of cancer in humans. Carcinogenesis. 28(3);625-31. 
[8] Tice, R.R; Agurell, E; Anderson, D; Burlinson, B; Hartmann, A; Kobayashi, H; et al. (2000). Single cell gel/comet assay: guidelines for in vitro and in vivo genetic toxicology testing. Environ Mol Mutagen. 35(3);206-21.

[9] Collins, A.R. (2014). Measuring oxidative damage to DNA and its repair with the comet assay. Biochim Biophys Acta 1840;794-800. doi: 10.1016/j.bbagen.2013.04.022.

[10] International Agency for Research on Cancer (IARC), Monographs on the Evaluation of Carcinogenic Risk to Humans, Reevaluation of Some Organic Chemicals, Hydrazine and Hydrogen Peroxide Agency for Research on Cancer, Toluene, World Health Organization. (1999). Lyon 71;829-864. Online: http://monographs.iarc.fr/ENG/ Monographs/vol71/mono71.pdf

[11] Cerrejón-responsible mining. Uses of coal. (2013). Online, in Spanish: http:// www.cerrejon.com/site/mas-sobre-el-carbon/usos-del-carbon.aspx

[12] International Energy Agency (IEA). (2016). Online: http://www.iea.org/

[13] Aneel- National Electric Energy Agency. Atlas Electric Power in Brazil. Chapter 9 Mineral Coal. (2009). Online, in Portuguese: www.aneel.gov.br/arquivos/pdf/ atlas_par3_cap9.pdf

[14] Caballero, A.L; Médico, O.A. (2013). Characterization and possible use of coal ash resulting from coal combustion in thermocentral of bed fluidized. Río Turbio (Argentina). National University of Austral Patagonia. Online, in Spanish: http:// www.redisa.uji.es/artSim2013/CaracterizacionDeResiduosSolidos/Caracterizacion \%20Cenizas\%20Combustion\%20Carbon.pdf

[15] Kalkreuth, W; Holz, M; Kern, M; Machado, G; Mexias, A; Silva, M.B; Willett, J; Finkelman, R; Burger, H. (2006). Petrology and chemistry of permian coals from the Paraná basin: Santa Terezinha, Leão-Butiá and Candiota Coal fields, Rio Grande do Sul, Brazil. Intern. J. Coal Geol. 68;79-116.

[16] Kvitko, K; Bandinelli, E; Henriques, J; Heuser, V; Rohr, P; Da Silva, F; Schneider, N; Fernandes, S; Ancines, C; Da Silva, J. (2012). Susceptibility to DNA damage in workers occupationally exposed to pesticides, to tannery chemicals and to coal dust during mining. Genet. Mol. Biol. 35;1060-68.

[17] Jarvis, I.W; Dreij, K; Mattsson, Å; Jernström, B; Stenius, U. (2014). Interactions between polycyclic aromatic hydrocarbons in complex mixtures and implications for cancer risk assessment. Toxicology. 3(321);27-39.

[18] Agostini, J; Otto P; Wajntal A. (1996). Chromosome damage in underground coal miners: detection by conventional cytogenetic techniques and by submitting lymphocytes of unexposed individuals to plasma from at-risk groups. Braz J Genet. 19;641-6.

[19] Santa Maria, S.R; Arana, M; ,Ramirez O. (2007). Chromosomal aberrations in peripheral lymphocytes from male native miners working in the Peruvian Andes. Genet Mol Biol. 30;1135-8. 
[20] León, G; Perez, L.E; Linares, J.C; Hartmann, A; ,Quintana M. (2007). Genotoxic effects in wild rodents (Rattus rattus and Mus musculus) in an open coal mining area. Mutat Res. 630;42-9.

[21] Lan, Q; ,He X. (2004). Molecular epidemiological studies on the relationship between indoor coal burning and lung cancer in Xuan Wei, China. Toxicology. 198;301-5.

[22] Celik, M; Donbak, L; Unal, F; Yüzbasioglu, D; Aksoy, H; Yilmaz, S. (2007). Cytogenetic damage in workers from a coal-fired power plant. Mutat Res. 627(2);158-63.

[23] Karami, S; Boffetta, P; Brennan, P; Stewart, P.A; Zaridze, D; Matveev, V; Janout, V; Kollarova, H; Bencko, V; Navratilova, M; Szeszenia-Dabrowska, N; Mates, D; Gromiec, J.P; Sobotka, R; Chow, W.H; Rothman, N; Moore, L.E. (2011). Renal cancer risk and occupational exposure to polycyclic aromatic hydrocarbons and plastics. J Occup Environ Med. 53(2);218-223; 1076-2752.

[24] Petsonk, E.L; Rose, C; ,Cohen R. (2013). Coal mine dust lung disease. New lessons from old exposure. Am J Respir Crit Care Med. 187(11);1178-85.

[25] Vallyathan, V; Shi, X; Castranova, V. (1998). Reactive oxygen species: their relation to pneumoconiosis and carcinogenesis. Environ Health Perspect. 106(Suppl. 5);1151-5.

[26] Knaapen, A.M; Borm, P.J; Albrecht, C; ,Schins R.P. (2004). Inhaled particles and lung cancer. Part A: Mechanisms. Int J Cancer 109;799-809.

[27] Schins, R.P; ,Borm P.J. (1999). Mechanisms and mediators in coal dust induced toxicity: a review. Ann Occup Hyg. 43(1);7-33.

[28] Ba, X; Aguilera-Aguirre, L; Rashid, QT; Bacsi, A; Radak, Z; Sur, S; Hosoki, K; Hegde, ML; Boldogh I. (2014). The role of 8-oxoguanine DNA glycosylase-1 in inflammation. Int J Mol Sci. 15(9);16975-97.

[29] Schottenfield, D; Bebe-Dimmer, J. (2006). Chronic inflammation: a common and important factor in the pathogenesis of neoplasia. CA: Cancer J. Clin. 56;69-83.

[30] Svilar, D; Goellner, EM; Almeida, KH; Sobol, RW. (2011). Base excision repair and lesion-dependent subpathways for repair of oxidative DNA damage. Antioxid Redox Signal. 14(12);2491-507.

[31] Sander, M; ,Wilson S. (2005). Base Excision Repair, AP Endonucleases and DNA Glycosylases, John Wiley \& Sons Ltd, Chichester.

[32] Storr, S.J; Woolston, C.M; Zhang, Y; ,Martin S.G. (2013). Redox environment, free radical, and oxidative DNA damage. Antioxid Redox Signal. 18(18);2399-408.

[33] Jomova, K; ,Valko M. (2011). Advances in metal-induced oxidative stress and human disease. Toxicology. 283;65-87.

[34] Brescia, G; Celotti, L; Clonfero, E; Neumann, G.H; Forni, A; Foa, V; Pisoni, M; Ferri, G.M; Assennato, G. (1999). The influence of cytochrome P450 1A1 and glutathioneS- 
transferase M1 genotypes on biomarker levels in coke-oven workers. Arch. Toxicol. 73;431-9.

[35] Rojas, M; Cascorbi, I; Alexandrov, K; Kriek, E; Auburtin, G; Mayer, L; Kopp-Schneider, A; Roots, I; Bartsch, H. (2000). Modulation of benzo[a]pyrene diolepoxide-DNA adduct levels in human white blood cells by CYP1A1, GSTM1 and GSTT1 polymorphism. Carcinogenesis 21;35-41.

[36] Pavanello, S; Pulliero, A; Lai, A; Gaiardo, A; Mastrangelo, G; Clonfero, E. (2005). Anti$\mathrm{B}$ [a]PDE-DNA formation in lymphomonocytes of humans environmentally exposed to polycyclic aromatic hydrocarbons, G. Ital. Med. Lav. Ergon. 27;312-4.

[37] Pereira-Neto, A.D; Moreira, J.C; Dias A.E.X.O; Arbilla G; Ferreira L.F.V; Oliveira A.S; Barek J. (2000). Assessment of human contamination by polycyclic aromatic hydrocarbons (PAHs) and nitrated derivatives (NPAHs): a methodological review. Quim. Nova 23;9. In Portuguese.

[38] Singh, R; Sram, R.J; ,Binkova B; Kalina, I; Popov, T.A; ,Georgieva T; ,Garte S; Taioli, E; ,Farmer P.B. (2007). The relationship between biomarkers of oxidative DNA damage, polycyclic aromatic hydrocarbon DNA adducts, antioxidant status and genetic susceptibility following exposure to environmental air pollution in humans. Mutat. Res. 620;83-92.

[39] Baird, W.M; Hooven, L.A; ,Mahadevan B. (2005). Carcinogenic polycyclic aromatic hydrocarbon-DNA adducts and mechanism of action. Environ. Mol. Mutagen. 45;10614.

[40] International Agency for Research on Cancer (IARC). (2012). Arsenic, metals, fibres, and dusts: a review of human carcinogens. Lyon. 100C;526. Online: http://monographs.iarc.fr/ENG/Monographs/vol100C/mono100C.pdf

[41] International Agency for Research on Cancer (IARC). (1997). Silica, some silicates, coal dust and para-aramid fibrils, IARC Monographs on the Evaluation of the Carcinogenic Risks of Chemicals to Humans. Lyon. 68;528. Online: http://monographs.iarc.fr/ENG/ Monographs/vol68/mono68.pdf

[42] Bonassi, S; Coskun, E; Ceppi, M; Lando, C; Bolognesi, C; Burgaz, S; et al. (2011). The HUman MicroNucleus project on eXfoLiated buccal cells (HUMN $(X L))$ : the role of lifestyle, host factors, occupational exposures, health status, and assay protocol. Mutat Res. 728(3);88-97.

[43] Silva, L; Ward, C.R; ,Hower J; ,Izquierdo M; ,Waanders F; ,Oliveira M; ,Li Z; Hatch, R; ,Querol X. (2010). Mineralogy and leaching characteristics of coal ash from a major Brazilian power plant. Coal Combust Gasificat Prod. 2;51-65.

[44] Martinez, J. (2012). Coal fly ash and bottom ash or scoria. Technical file, Spain. On line, in Spanish: http://www.cedexmateriales.es/catalogo-de-residuos/24/cenizas-volantesde-carbon-y-cenizas-de-hogar-o-escorias/ 
[45] Borm, P.J. (1997). Toxicity and occupational health hazards of coal fly ash (CFA). A review of data and comparison to coal mine dust. Ann Occup Hyg. 41;659-76.

[46] Swaine, D.J; ,Goodarzi F. (1997). Environmental Aspects of Trace Elements in Coal. Kluwer, Dordrecht.

[47] Ruwei, W; Jiamei, Z; Jingjing, L; Liu, G. (2013). Levels and patterns of polycyclic aromatic hydrocarbons in coal-fired power plant bottom ash and fly ash from Huainan, China. Arch Environ Contam Toxicol. 65(2);193-202.

[48] Ball, B.R; Smith, K.R; Veranth, J.M; ,Aust A.E. (2000). Bioavailability of iron from coal fly ash: mechanisms of mobilization and of biological effects. Inhal Toxicol. 12(Suppl. 4);209-25.

[49] Smith, K.R; Veranth, J.M; Hu, A.A; Lighty, J.S; ,Aust A.E. (2000). Interleukin-8 levels in human lung epithelial cells are increased in response to coal fly ash and vary with the bioavailability of iron, as a function of particle size and source of coal. Chem Res Toxicol. 13(2);118-25.

[50] Mazzoli-Rocha, F; Fernandes, S; Einicker-Lamas, M;Zin, W.A. (2010). Roles of oxidative stress in signaling and inflammation induced by particulate matter. Cell Biol Toxicol. 26(5);481-98.

[51] Donaldson, K; ,Stone V. (2003). Current hypotheses on the mechanisms of toxicity of ultrafine particles. Ann Ist Super Sanità;. 39;405-10.

[52] Oberdörster, G; Sharp, Z; Atudorei, V; Elder, A; Gelein, R; Kreyling, W; Cox, C. (2004). Translocation of inhaled ultrafine particles to the brain. Inhal Toxicol. 16(6-7);437-45.

[53] Schins, R.P; Lightbody, J.H; Borm, P.J; ,Shi T; Donaldson, K; ,Stone V. (2004). Inflammatory effects of coarse and fine particulate matter in relation to chemical and biological constituents. Toxicol. Appl. Pharmacol. 195;1-11.

[54] Mani, U; Prasad, A.K; ,Suresh Kumar V; Lal, K; Kanojia, R.K; Chaudhari, B.P; Murthy R.C. (2007). Effect of fly ash inhalation on biochemical and histomorphological changes in rat liver. Ecotoxicol Environ Saf. 68(1);126-33.

[55] Donaldson, K; Tran, L; Jimenez, L.A; Duffin, R; Newby, D.E; Mills, N. (2005). Combustion-derived nanoparticles: a review of their toxicology following inhalation exposure. Part Fibre Toxicol. 2;10.

[56] Carbone, F; Pagliara, R; Barone, A.C; Beretta, F; D'Anna, A. (2009). Characterization of nano-ashes generated during pulverized coal combustion. Report Ricerca Sistema Elettrico. Online: http://www.enea.it/it/Ricerca_sviluppo/documenti/ricerca-disistema-elettrico/centrali-carbone-rendimenti/rse109.pdf.

[57] Gilmour, M.I; O'Connor, S; Dick, C; Miller, C.A; ,Linak W.P. (2004). Differential pulmonary inflammation and in vitro cytotoxicity of size-fractionated fly ash particles from pulverized coal combustion. J Air Waste Manag Assoc. 54;286-95. 
[58] Sambandam, B; Devasena, T; Islam, V.I; Prakhya, B.M. (2015). Characterization of coal fly ash nanoparticles and their induced in vitro cellular toxicity and oxidative DNA damage in different cell lines. Indian J Exp Biol. 53(9);585-93.

[59] Zhai, R; Liu, G; Ge, X; Bao, W; Wu, C; Yang, C; Liang, D. (2002). Serum levels of tumor necrosis factor-alpha (TNF-alpha), interleukin 6 (IL-6), and their soluble receptors in coal workers' pneumoconiosis. Respir Med. 96(10);829-34.

[60] Bonner, J.C. (2007). Lung fibrotic responses to particle exposure. Toxicol Pathol. 35(1); 148-53.

[61] Møller, P; Danielsen, P.H; Karottki, D.G; ,Jantzen K; ,Roursgaard M; Klingberg, H; Jensen, D.M; Christophersen, D.V; Hemmingsen, J.G; Cao, Y; ,Loft S. (2014). Oxidative stress and inflammation generated DNA damage by exposure to air pollution particles. Mutat Res Rev Mutat Res. 762;133-66.

[62] Risom, L; Møller, P; Loft, S. (2005). Oxidative stress-induced DNA damage by particulate air pollution. Mutat. Res. 592;119-37.

[63] Valavanidis, A; Vlachogianni, T; Fiotakis, K; Loridas, S. (2013). Pulmonary oxidative stress, inflammation and cancer: respirable particulate matter, fibrous dusts and ozone as major causes of lung carcinogenesis through reactive oxygen species mechanisms. Int J Environ Res Public Health. 10;3886-907.

[64] Fubini, B; ,Hubbard A. (2003). Reactive oxygen species (ROS) and reactive nitrogen species (RNS) generation by silica in inflammation and fibrosis. Free Radic Biol Med. 34;1507-16.

[65] Champion, J.A; ,Mitragotri S. (2006). Role of target geometry in phagocytosis. Proc Natl Acad Sci U S A. 103(13);4930-4.

[66] Schinwald, A; ,Donaldson K. (2012). Use of back-scatter electron signals to visualise cell/nanowires interactions in vitro and in vivo; frustrated phagocytosis of long fibres in macrophages and compartmentalisation in mesothelial cells in vivo. Particl Fibre Toxicol. 9;34.

[67] Porter, D.W; Leonard, S.S; Castranova V. (2006). Particles and Cellular Oxidative and Nitrosative Stress. Chapter 6. National Institute for Occupational Safety and Health. pp. 119-138

[68] Porter, D.W; Leonard, S.S; Castranova V. (2006). Particles and Cellular Oxidative and Nitrosative Stress. Chapter 6. National Institute for Occupational Safety and Health. Particle toxicology. Chapter 6. pp 119-138.

[69] Albrecht, C; Borm, P.J.A; Adolf, B; Timblin, C.R; ,Mossman B.T. (2002). In vitro and in vivo activation of extracellular signal-regulated kinases by coal dusts and quartz silica. Toxicol Appl Pharmacol. 184;37-45. 
[70] Gosset, P; Lassalle, P; Vanhée, D; Wallaert, B; Aerts, C; Voisin, C; Tonnel, A.B. (1991). Production of tumor necrosis factor-alpha and interleukin-6 by human alveolar macrophages exposed in vitro to coal mine dust. Am J Respir Cell Mol Biol. 5;431-6.

[71] Dwivedi, S; Saquib, Q; Al-Khedhairy, A.A; Ali, A.Y; Musarrat, J. (2012). Characterization of coal fly ash nanoparticles and induced oxidative DNA damage in human peripheral blood mononuclear cells. Sci Total Environ. 15;331-8.

[72] Diabaté, S; Mülhopt, S; Paur, H.R; Wottrich, R; Krug, H.F. (2002). In vitro effects of incinerator fly ash on pulmonary macrophages and epithelial cells. Int J Hyg Environ Health. 204;323-6.

[73] Diabaté, S; Bergfeldt, B; Plaumann, D; Ubel, C; Weiss, C. (2011). Anti-oxidative and inflammatory responses induced by fly ash particles and carbon black in lung epithelial cells. Anal Bioanal Chem. 401(10);3197-212.

[74] van Maanen, J.M; Borm, P.J; ,Knaapen A; van Herwijnen, M; Schilderman, P.A; Smith, K.R; Aust, A.E; Tomatis, M; Fubini, B. (1999). In vitro effects of coal fly ashes: hydroxyl radical generation, iron release, and DNA damage and toxicity in rat lung epithelial cells. Inhal Toxicol. 11;1123-41.

[75] Liou, G.Y; ,Storz P. (2010). Reactive oxygen species in cancer. Free Radic Res. 44(5);47996.

[76] Haghdoost S, Czene S, Näslund I, Skog S, Harms-Ringdahl M. (2005). Extracellular 8oxo-dG as a sensitive parameter for oxidative stress in vivo and in vitro. Free Radic Res. 39(2);153-62.

[77] Rohr, P; Kvitko, K; da Silva, F.R; Menezes, A.P; Porto, C; Sarmento, M; Decker, N; Reyes, J.M; Allgayer, Mda C; Furtado, T.C; Salvador, M; Branco, C; da Silva, J. (2013a). Genetic and oxidative damage of peripheral blood lymphocytes in workers with occupational exposure to coal. Mutat Res. 758(1-2); 23-8.

[78] Rohr, P; da Silva, J; da Silva, F.R; Sarmento, M; Porto, C; Debastiani, R; Dos Santos, C.E; Dias, J.F; Kvitko, K. (2013b). Evaluation of genetic damage in open-cast coal mine workers using the buccal micronucleus cytome assay. Environ Mol Mutagen. 54(1);6571.

[79] León-Mejía, G; Espitia-Pérez, L; Hoyos-Giraldo, L.S; Da Silva, J; Hartmann, A; Henriques, J.A; Quintana, M. (2011). Assessment of DNA damage in coal open-cast mining workers using the cytokinesis-blocked micronucleus test and the comet assay. Sci Total Environ. 409(4);686-91.

[80] León-Mejía, G; Quintana, M; Debastiani, R; Dias, J; Espitia-Pérez, L; Hartmann, A; Henriques, J.A; Da Silva, J. (2014). Genetic damage in coal miners evaluated by buccal micronucleus cytome assay. Ecotoxicol Environ Saf. 107;133-9. 
[81] Al-Sabti, K; Lloyd, D.C; Edwards, A; ,Stegnar P. (1992). A survey of lymphocyte chromosomal damage in Slovenian workers exposed to occupational clastogens. Mutat. Res. 280;215-23.

[82] Avila Júnior,S; Possamai, FP; Budni, P; Backes, P; Parisotto, EB; Rizelio, VM; Torres, MA; Colepicolo, P; Wilhelm Filho, D. (2009). Occupational airborne contamination in south Brazil: 1. Oxidative stress detected in the blood of coal miners. Ecotoxicology 18(8);1150-7.

[83] Donbak, L; Rencuzogullari, E; Yavuz, A; Topaktas, M. (2005). The genotoxic risk of underground coal miners from Turkey. Mutat Res. 588(2);82-7.

[84] Minina, V.I; Kulemin, I.E; Tolotchko, T.A; Meǐer, A.V; Savtchenko, I.A; Volobaev, V.P; Gafarov, N.I; ,Semenikhina M.V. (2015). Genotoxic effects of occupational environment in Kuzbass miners. Med. Tr. Prom. Ekol. 5; 4-8.

[85] Stierum, R; Hageman, G; Welle, I; Albering, H; Schreurs, J; Kleinjans, J. (1993). Evaluation of exposure reducing measures on parameters of genetic risk in a population occupationally exposed to coal fly ash. Mutat Res. 319;245-55.

[86] Wolf, G; Arndt, D; Kotschy-Lang, N; Obe, G. (2004). Chromosomal aberrations in uranium and coal miners. Int J Radiat Biol. 80(2);147-53.

[87] Ulker, O; Ustundag, A; Duydu, Y; Yucesoy, B; Karakaya, A. (2008). Cytogenetic monitoring of coal workers and patients with coal workers' pneumoconiosis in Turkey. Environ Mol Mutagen. 49;232-7. 

Chapter 8

\title{
Immunological Risks Caused by Fibrous and Particulate Substances
}

\author{
Hidenori Matsuzaki, Suni Lee, \\ Naoko Kumagai-Takei, Shoko Yamamoto, \\ Tamayo Hatayama, Kei Yoshitome, Hiroaki Hayashi, \\ Megumi Maeda and Takemi Otsuki
}

Additional information is available at the end of the chapter

http://dx.doi.org/10.5772/62749

\begin{abstract}
The immunological risks caused by fibrous and particulate substances, especially the effects caused by asbestos fibers and silica particles, are discussed in this chapter. Patients with silicosis often suffer from autoimmune diseases, such as rheumatoid arthritis, systemic sclerosis, and antineutrophil cytoplasmic antibody-related vasculitis. Silica particles, $\mathrm{SiO}_{2}$, may influence directly various immune cells resulting in the production of many autoantibodies and imbalance between responder and regulatory $\mathrm{T}$ cells. The core chemical content of asbestos fibers is $\mathrm{Si}$ and $\mathrm{O}$, although the physical feature is different.Considering the complications in asbestos-exposed patients, malignant tumors, such as lung cancer and malignant mesothelioma, are the most important. To think about these situations, asbestos fibers may cause the reduction of antitumor immunity. The experimental findings and measurements of various immunological parameters in silicosis patients, as well as asbestos-exposed population, such as patients with pleural plaque and mesothelioma, are demonstrated and discussed in this chapter.
\end{abstract}

Keywords: asbestos, silica, autoimmune diseases, antitumor immunity, regulatory $\mathrm{T}$ cell

\section{Introduction}

Regarding environmental factors that cause health risks, exposure to fibrous and particulate substances, such as asbestos fibers and silica particles, represent classic examples, and the 
investigation of other materials that lead to health impairment following exposure is ongoing [1-10]. In addition to pulmonary effects, such as fibrosis, chronic inflammations, and cancers, such as lung malignancies and pleural mesothelioma, in asbestos-exposed patients, there may be certain effects on immunological cells [11-16]. Among people who have been exposed to asbestos fibers or silica particles, people exposed to silica and have developed silicosis often suffer from complicated autoimmune diseases, such as rheumatoid arthritis, systemic sclerosis, and antineutrophil cytoplasmic antigen (ANCA)-related vasculitis [17-20]. The core chemical components of asbestos fibers are $\mathrm{Si}$ and $\mathrm{O}_{2}$, and although the physical makeup of fibrous and particulate matter differs, asbestos fibers may affect the immune system. Therefore, we have been investigating the immunological effects of silica and asbestos [11-16].

Regarding silica particles, the mechanism of silica-induced dysregulation of autoimmunity is thought to involve silica acting as an adjuvant [21-24]. However, silica particles may also act by directly stimulating on circulating peripheral immune cells, which cause certain alterations in the cellular or molecular functions of these cells, since silica particles may remain in pulmonary lesions and lymph nodes after inhalation [11-16]. Since these direct effects may change the characteristics of immune cells and consequently facilitate the dysregulation of immune tolerance, clarification of these cellular and molecular mechanisms may be useful in the prevention of immune disorders that occur in silicosis patients (SIL), in addition to contributing toward an understanding of the etiology of various autoimmune diseases.

We have been focusing on the immunological effects of silica using human peripheral blood immune cells derived from healthy donors (HD) and SIL [11-14]. We will summarize our findings which indicate that silica is an environmental immune stimulator, and chronic activation of immune cells induced by recurrent and chronic exposure to silica causes an imbalance in the regulation of $\mathrm{T}$ cell responses.

Regarding asbestos fibers, asbestos-related cancers, such as malignant mesothelioma (MM) and lung cancer, have been a major global concern in Japan [25-29]. Given the conflict that has arisen due to economic considerations and the medical evidence, there is a confusion concerning the pathological mechanisms of asbestos-induced cancers, and in particular, an uncertainty concerning the dangers of iron-absent chrysotile (white) asbestos compared with iron-present crocidolite (blue) and amosite (brown) asbestos [30-33]. However, regarding the poor prognosis of $\mathrm{MM}$, novel medical approaches to investigate the biological effects of asbestos and pathological mechanisms of asbestos-induced carcinogenesis, as well as clinical trials to detect early stages of MM, should be implemented to assist in the development of improved prevention strategies and cure of asbestos-related malignancies [34-36]. From this standpoint, our group has been investigating the immunological effects of asbestos with respect to the reduction of tumor immunity $[11,12,15,16]$. In this chapter, cellular and molecular approaches to clarify the immunological effects of asbestos are described, and all findings indicate that a reduction of tumor immunity is caused by asbestos exposure and is involved in asbestos-induced cancers. In addition to confirming the well-known biological effects of asbestos, these investigations provide a basis for the development of a novel procedure for the early detection of previous asbestos exposure, mesothelioma and the chemoprevention of asbestos-related cancers. 
As shown in Figure 1, both silica particles and asbestos fibers cause pulmonary fibrosis known as pneumoconiosis, silicosis, and asbestosis. Additionally, both can affect various immune cells, such as B cells, CD4 T helper (Th1), regulatory T (Treg), cytotoxic T lymphocyte (CTL), natural killer (NK) cells, and other immune cells [11, 12, 15, 16].

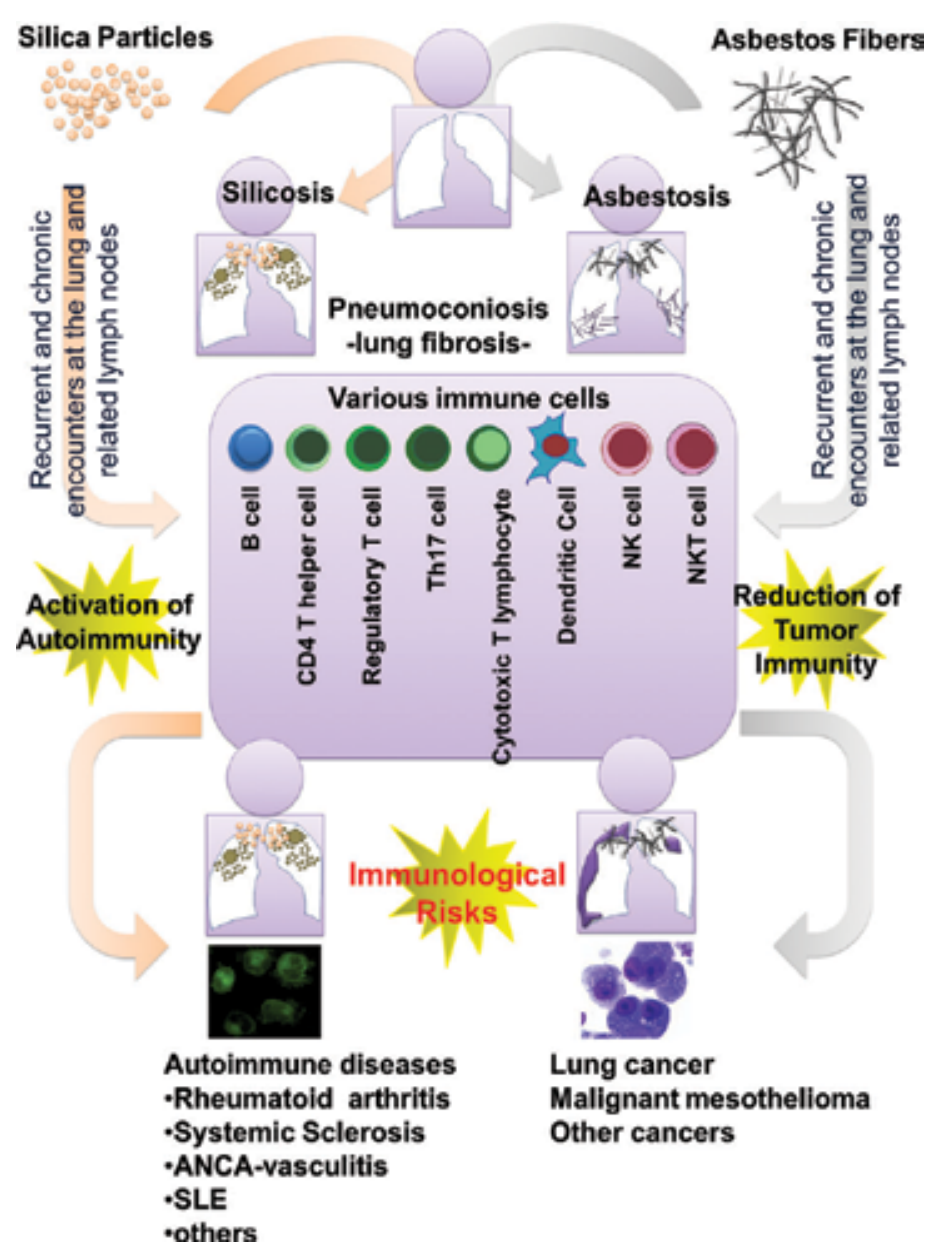

Figure 1. Schematic representation of immunological risks caused by exposure to silica particles and asbestos fibers. The immunological risks induced crucial complications, such as autoimmune diseases, in silicosis patients, as well as malignant tumors, such as lung cancer and malignant mesothelioma, in asbestos-exposed populations.

In this chapter, the immunological effects on various immune cells caused by silica particles and asbestos fibers as investigated in our laboratory will be presented and discussed with respect to the detection of immunological risks of particulate and fibrous environmental factors [11-16]. These summarized findings may be helpful in the development of future risk management strategies, including cases related to newly developed fibrous and particulate matter, such as nanoparticles and nanotubes. 


\section{Immunological risks caused by silica particles}

As shown in Table 1, there are various immunological risks associated with exposure to silica particles. These findings were established by in vitro assays using peripheral blood mononuclear cells (PBMC) derived from HD cultured with silica particles as well as freshly isolated immune cells derived from SIL. Additionally, various autoantibodies (aAbs) were detected from SIL [11-14]. All SIL comprised Japanese workers of a firebrick factory located at Bizen City, Okayama Prefecture, Japan, diagnosed with silicosis according to the International Labor Organization (ILO) 2000 guidelines for pneumoconiosis and monitored at Kusaka Hospital or Hinase Urakami Iin/Clinic at Bizen City. All SIL showed no symptoms related to autoimmune diseases or cancers.

\begin{tabular}{|c|c|c|c|}
\hline Risk manifestation & Target cells/molecules & Findings & References \\
\hline \multirow[t]{7}{*}{ Unusual autoantibody } & B cell & Detection of autoantibodies against & \\
\hline & & > Fas/CD95 & 61 \\
\hline & & > Caspase 8 & 62 \\
\hline & & > Scl-70/Topoisomerase I & $56-58$ \\
\hline & & $\checkmark$ Specific HLA type & \\
\hline & & $>$ CENP-B/centromere & 64 \\
\hline & & >Desmoglein & 65 \\
\hline \multirow[t]{16}{*}{ Dysregulated apoptosis } & $\mathrm{T}$ cell & Increased level of molecules against & \\
\hline & & Fas-mediated apoptosis & \\
\hline & & $>$ Soluble Fas & \\
\hline & & $\diamond$ Serum soluble Fas & 69 \\
\hline & & $\downarrow$ mRNA expression in PBMC & 70 \\
\hline & & > Variant Fas, alternatively spliced variants & 71 \\
\hline & & $>$ Decoy receptor 3 & 74 \\
\hline & & $\downarrow$ mRNA expression in PBMC & \\
\hline & & Chronic activation & 80 \\
\hline & & $>$ Soluble IL-2 receptor & 78 \\
\hline & & $>$ PD-1 expression & 79 \\
\hline & & > CD69 surface expression & \\
\hline & & Increase in Fas-mediated apoptosis & 61 \\
\hline & & $>$ Autoantibody for Fas & 75 \\
\hline & & $>$ Decreased expression of physiological & \\
\hline & & inhibitors of Fas-mediated apoptosis & \\
\hline
\end{tabular}




\begin{tabular}{llll}
\hline Risk manifestation & Target cells/molecules & Findings & References \\
\hline & Regulatory T cell & Chronic activation & \\
& & $>$ Excess expression of Fas/CD95 & $>78$ \\
\hline
\end{tabular}

IL, interleukin; PBMC, peripheral blood mononuclear cells; and PD-1, program death protein 1

Table 1. Immunological risks caused by silica particles.

\section{1. aAbs detected in SIL}

First, the risk of dysregulated autoimmunity assessed by the detection of particular aAbs will be discussed. Various aAbs have been detected in SIL, such as antinuclear antibody (ANA) [37-40], antismooth muscle aAb [41], antiglomerular basement membrane (GBM) aAb [41], antineutrophil cytoplasmic aAb (MPO-ANCA) [37, 42-48], rheumatoid factor (RF) [37-39, 4953], anti-Scl-70/topoisomerase I aAb [37, 54-60], anti-Fas/CD95 aAb [61], anticaspase 8 aAb [62], anticentromere/CENP-B (centromere protein B) aAb [63], antidesmoglein aAb [64], antiPL 12 (aminoacyl tRNA synthetase) aAb [65], and anticollagen aAb [39], as found in publications located via PubMed.

Of these aAbs, we investigated several Abs of interest, such as anti-Fas/CD95 Ab [61], anticaspase $8 \mathrm{Ab}$ [62], anti-Scl-70 $\mathrm{Ab}$ with respect to specific human leukocyte antigen (HLA) types [56-58], and anti-CENP-B Ab [63] and reported the case of antidesmoglein Ab-positive SIL [64].

We detected anti-Fas/CD95 aAb in approximately one-fourth of SIL [61]. Since T cells in SIL tend to be categorized into two classes, Fas/CD95-mediated apoptosis prone and resistant groups as described later in this chapter, it is important to determine whether the detected anti-Fas/CD95 aAb is functional in terms of the induction of Fas/CD95-mediated apoptosis. To examine this issue, we employed our established human sister myeloma cell lines, KMS-12PE and KMS-12BM. The former cell line was established from the pleural effusion of a myeloma patient, which showed high expression of Fas/CD95 on its surface as a result of apoptosis and growth inhibition caused by anti-Fas/CD95 agonistic antibody. The latter cell line was derived from bone marrow obtained from the same patients, who showed very low expression of Fas/ CD95 and no apoptosis caused by Fas/CD95 agonistic antibody [66]. Following cultivation of both cell lines with anti-Fas/CD95 aAb-positive serum from SIL, the growth of KMS-12PE was reduced by apoptosis, whereas the growth of KMS-12BM was unaffected [61]. These results indicated that anti-Fas/CD95 aAb is functional. Additionally, epitope mapping employing 12amino acid polypeptides with the SPOT system of anti-Fas/CD95 aAb was analyzed. As a result, a minimum of four and a maximum of ten epitopes were found, and several amino acid residues involved in binding Fas ligand, such as C66, R87, L90 E93, and H126, were identified [61].

As in the case of anti-Fas/CD95 aAb, anticaspase $8 \mathrm{aAb}$ was investigated in terms of the dysregulation of Fas/CD95-mediated apoptosis of lymphocytes in SIL [62]. The association of anticaspase $8 \mathrm{aAb}$ with HLA types was examined. As a result, the frequencies of HLADRB1*0406 were significantly higher in aAb-positive SIL $(16.7 \%)$ compared with control individuals $(3.0 \%, \mathrm{p}<0.001)$. Additionally, HLA-DR4; DQB1*0302 was found in one-fourth of 
positive SIL, and DPB1*0601 was also higher in positive SIL (5.9\%) compared with controls $(0.6 \%, p<0.05)$, whereas DQB1*0401 was lower in positive SIL $(0 \%)$ compared with controls $(13.3 \%, \mathrm{p}<0.001)$. Furthermore, epitope mapping showed that a minimum of four and a maximum of thirteen polypeptides seemed to be involved. Among these, two important catalytic cysteine residues were found, cysteine Cys287 and Cys360, located in the unique pentapeptide motif QACQG [62].

Regarding the relationship between $\mathrm{aAb}$ and specific HLA type, we reported HLA types among anti-Scl70/topoisomerase I aAb-positive SIL [56-58]. Results indicated that the allelic frequency of HLA-DQB1*0402 was significantly higher in aAb-positive SIL (28.6\%) than in aAb-negative SIL $(1.5 \%, \mathrm{p}<0.001)$, as well as in controls $(0.8 \%, \mathrm{p}<0.001)$. Additionally, DQDB1*0301, DQB1*0601, and DPB1*1801 were higher in aAb-positive SIL than in aAbnegative SIL, whereas no significant differences were found compared with controls [56-58].

In terms of anti-CENP-B/centromere $\mathrm{aAb}$, the titer index (Log10) of anti-CENP-B autoantibody in SIL was higher than that of HV, and patients with systemic sclerosis (SSc) was higher than those of HV and SIL. This titer index was positively correlated with an assumed immune status for $\mathrm{HV}$ as 1, SIL as 2, and SSc as 3. Moreover, although the titer index of anti-CENP-B autoantibody formed the same factor with anti-Scl-70 autoantibody, the Ig G value, and age of SIL, the property of other factors extracted indicated that anti-Scl-70 antibody was positively related with the Ig A value, while the converse was true for anti-CENP-B from the results of factor analysis. Those results indicated that the titer index of anti-CENP-B autoantibody may be employed as a biomarker in identifying dysregulation in SIL cases.

Taken together, various aAbs found in SIL have indicated that dysregulation of autoimmunity was caused by chronic and recurrent exposure to silica particles that remained in lung and related lymph nodes of various human cells, especially B cells. Some of these aAbs may be related to Fas/CD95-mediated apoptosis of lymphocytes and cause further dysregulation of autoimmunity such as in the case of long-surviving self-antigen recognizing clones in $\mathrm{T}$ cells [11-14].

Furthermore, examination of HLA types seemed to be important in revealing several aAbs in SIL. Although it can be mentioned that repeated and continuous screening of aAbs as well as the initial screening of HLA types seems to be necessary among workers in contact with silicarelated substances for the detection of dysregulation of autoimmunity, the use of genotyping, such as determining HLA types, is not permitted during employee selection procedures. However, a consideration of particular occupational health risks together with individual sensitivities is required in an effort to prevent occupational health hazards and associated future hardships.

\subsection{Fas/CD95-mediated apoptosis-related molecules in SIL}

Fas/CD95-related molecules analyzed in SIL are shown in Table 1 [11-14, 67]. Regarding molecules that inhibit Fas/CD95-mediated apoptosis, the level of soluble Fas/CD95 was higher in the serum of SIL compared with HD, and similar to the level in systemic lupus erythematosus (SLE) [68], while higher mRNA expression, determined as the ratio of soluble to wild- 
type Fas/CD95, was present in SIL compared with HD in PBMC [69]. Additionally, higher amounts of various alternatively spliced variant messages of the Fas/CD95 gene were detected in PBMC from SIL compared with HD [70]. All of these variant messages, including soluble Fas/CD95, possess a Fas ligand-binding domain but lack a membrane-binding domain. Hence all of these translation products are secreted into the extracellular space and bind with Fas ligand, thereby protecting cells against membrane Fas-mediated apoptosis [70]. Furthermore, the expression of the protective molecule decoy receptor 3 (DcR3), which acts against the Trail molecule and similarly induces apoptosis via a Trail receptor and the same intracellular signaling molecules for apoptosis, such as caspase 8 and 10 [71, 72], was higher in SIL PBMC compared with HD [73]. These findings indicated that some types of T cells in PBMC from SIL provide protection against Fas/CD95- and Trail-induced apoptosis, which leads to long survival of these $\mathrm{T}$ cells and self-antigen recognizing clones [67].

However, several findings that showed accelerated Fas/CD95- and Trail-mediated apoptosis in PBMC of SIL were investigated. Messenger RNA expression in PBMC of several genes which act as physiological inhibitors of Fas/CD95- and Trail-mediated apoptosis, such as I-Flice (inhibitor of FADD-like interleukin-1 $\beta$-converting enzyme), surviving, sentrin, and inhibitor of caspase-activated DNase (ICAD) was lower in SIL compared with HD [67, 74]. In addition to the aforementioned detection of functional anti-Fas/CD95 autoantibody, some types of T cells in PBMC from SIL possess enhanced Fas/CD95-mediated apoptosis [61]. Further studies revealed that this fraction may include Treg cells $[13,14]$. Thus, a decrease in the number of Treg cells by apoptosis and an increase in the number of responder $\mathrm{T}$ cells caused by silica exposure may be the cellular biological mechanisms at work in SIL, which consequently impart susceptibility to autoimmune diseases in SIL.

We found higher expression of Fas/CD95 in Treg (CD4+, CD25+, and forkhead box P3 (FoxP3) +) $[75,76]$ and sensitivity to Fas-agonistic antibody-induced apoptosis in Treg cells from SIL [77]. Furthermore, when PBMC from HD were cultured with silica particles in vitro, Treg cell numbers were selectively reduced by apoptosis and the population of responder T cells was enhanced [77]. Thus, the aforementioned $\mathrm{T}$ cell population prone to Fas/CD95-mediated apoptosis seems to comprise Treg cells, and the imbalance that occurs as a result of a decreased Treg and surviving responder T cell population in SIL induces dysregulation of autoimmunity $[13,14,77]$.

Moreover, there is evidence showing chronic activation of responder T cells. For example, CD69, an early activating marker of T cells, was gradually expressed in T cells when PBMC from HD were cultured in vitro with silica particles [78]. Expression of the program death protein 1 (PD-1) gene, another activation marker of T cells, in CD4+ CD25+ as well as in CD4+ CD25- T cell populations was higher in SIL compared with HD, which showed negligible expression [78]. Expression of serum soluble interleukin (IL)-2 receptor (sIL-2R) was also higher in SIL compared with HD [79].

Taken together, SIL possess a risk of developing dysregulation of autoimmunity. This risk can be detected using various markers mentioned above, such as serum soluble Fas, sIL-2R, and serum DcR3 (recently, the enzyme-linked immunosorbent assay (ELISA) kit is available for laboratory use), in SIL during their early clinical phases. 


\section{Immunological risks caused by asbestos fibers}

As shown in Figure 1, the most important and critical complications that arise in asbestosexposed patients concern the development of malignancies, such as lung cancer and MM [2529]. Of course, asbestos fibers possess carcinogenic-related activities, such as oxygen stress caused by iron in the asbestos fibers, frustrated macrophages incapable of phagocytosing asbestos fibers, chromosome tangling, and the absorption of other carcinogenic substances inhaled in the lung, such as materials from tobacco smoke and other air pollutants [34-36]. However, given the long latency period that precedes the onset of MM following initial exposure to asbestos, it was considered that asbestos fibers cause alterations in antitumor immunity by recurrent and chronic encounters with various immune cells at the lung and related lymph nodes.

As shown in Table 2, our findings show altered immune cell function and manifestations from experimental settings as well as PBMC derived from pleural plaque and MM [11, 12, 15, 16, $80,81]$.

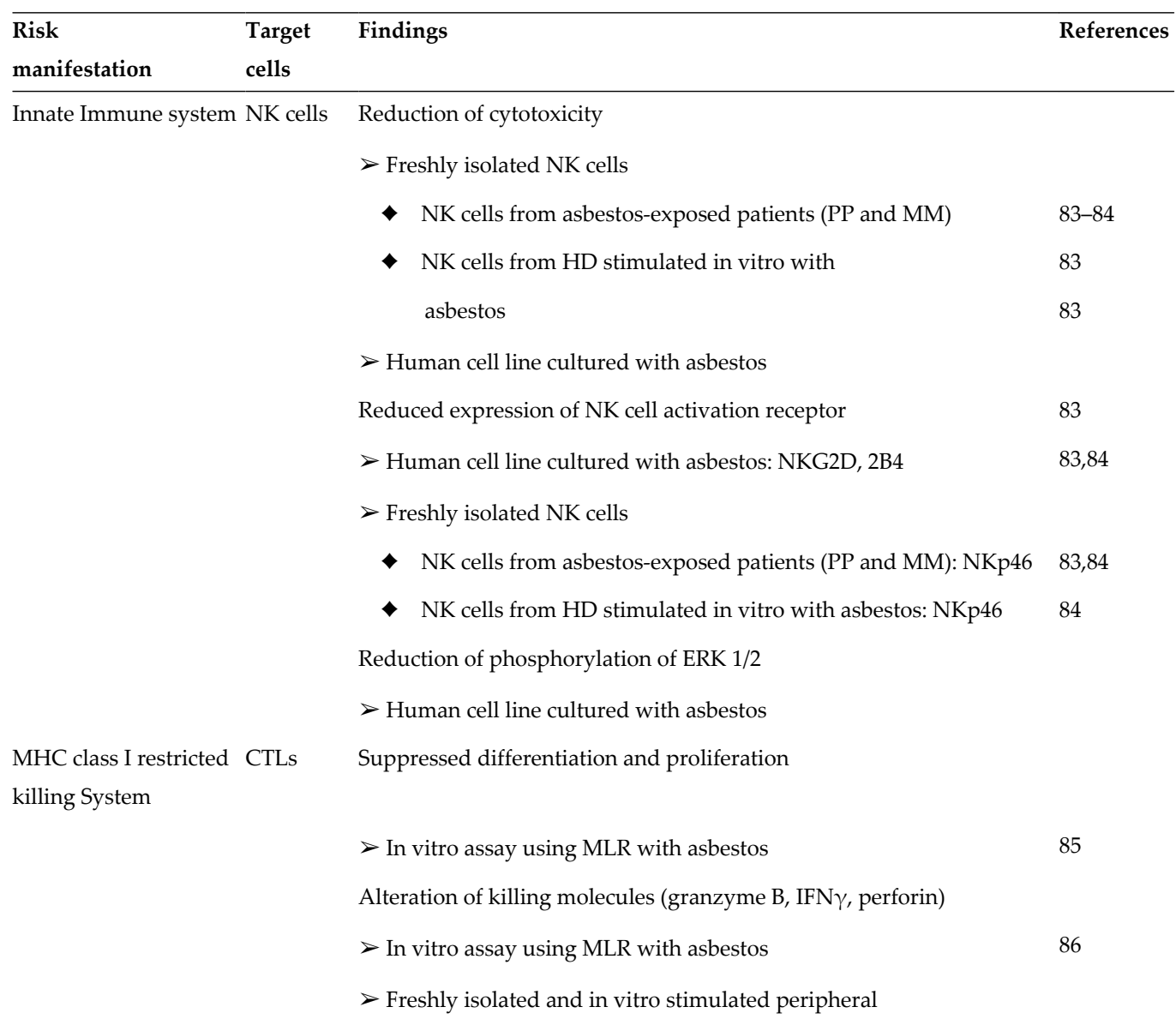




\begin{tabular}{|c|c|c|c|}
\hline $\begin{array}{l}\text { Risk } \\
\text { manifestation }\end{array}$ & $\begin{array}{l}\text { Target } \\
\text { cells }\end{array}$ & Findings & References \\
\hline & & $\begin{aligned} & \text { CD8+ cells from PP } \\
> & \text { Freshly isolated and in vitro stimulated peripheral } \\
& \text { CD8+ cells from MM }\end{aligned}$ & 86 \\
\hline \multirow{4}{*}{$\begin{array}{l}\text { MHC class II restricted } \\
\text { killing system }\end{array}$} & Th1 cells & Decrease in CXCR3 expression, IFN $\gamma$ & \\
\hline & & $\begin{array}{l}>\text { Cell line model continuously cultured with } \\
\text { asbestos }\end{array}$ & 87 \\
\hline & & $\begin{array}{l}\text { Freshly isolated and cultured in vitro with } \\
\text { asbestos from HD }\end{array}$ & 88 \\
\hline & & $>$ Freshly isolated CD4+ T cells from PP and MM & 88 \\
\hline \multirow[t]{10}{*}{$\begin{array}{l}\text { Regulation of } \\
\text { T cell response }\end{array}$} & $\begin{array}{l}\text { Regulatory } \\
\mathrm{T} \text { (Treg) } \\
\text { cells }\end{array}$ & Enhanced function & \\
\hline & & $>$ Cell line model continuously cultured with asbestos & \\
\hline & & $\begin{array}{l}- \text { Increased suppressive function via cell-cell contacts } \\
- \text { Excess production of soluble factors }\end{array}$ & 91 \\
\hline & & $\checkmark \quad$ IL-10 & 91 \\
\hline & & $\times$ Enhanced suppressive function & 89 \\
\hline & & $\times$ Phosphorylation of STAT3 with over-expression of & \\
\hline & & Bcl-2 causing resistance against asbestos-induced apoptosis & \\
\hline & & $\checkmark$ TGF $\beta$ & 91 \\
\hline & & $\times$ Enhanced suppressive function & 90 \\
\hline & & $\begin{array}{l}\times \text { Increased phosphorylation of p38 and SMAD3 causing } \\
\text { resistance against TGF } \beta \text {-induced growth inhibition }\end{array}$ & \\
\hline
\end{tabular}

CXCR3, CXC chemokine receptor 3; HD, healthy donor; IFN, interferon; IL, interleukin; MLR, mixed lymphocyte reaction; MM, malignant mesothelioma; NK, natural killer; $\mathrm{PP}$, pleural plaque; TGF, transforming growth factor; SMAD, vertebrate homologues of Sma and Mad [Drosophila protein; mothers against decapentaplegic (MAD) and the Caenorhabditis elegans protein SMA (from the sma gene for small body size)]; and Th1, T helper.

Table 2. Immunological risks caused by asbestos fibers.

\subsection{NK cells}

Regarding NK cells, cytotoxicity was reduced in peripheral NK cells from pleural plaque (PP) and MM, in NK cells from HD cultured in vitro with asbestos fiber, and in a human NK cell line continuously exposed to asbestos [82]. Additionally, the expression of various NK cell activating receptors, such as NKG2D, 2B4, and NKp46, was reduced in a human NK cell line 
cultured continuously with asbestos, in freshly isolated NK cells from HD cultured in vitro with asbestos, and in fresh NK cells from PP and MM [82, 83]. Among these receptors, NKp46 was thought to be an important marker for impaired function of NK cells exposed to asbestos. Moreover, reduced cytotoxicity in NK cells exposed to asbestos was accompanied with reduced phosphorylation of extracellularly regulated kinases (ERK) 1 and 2 and reduced degranulation of perforin and granzyme $B$, which are the killing small molecules secreted from NK cells $[82,83]$.

\subsection{Cytotoxic T lymphocytes}

Other types of cytokilling immune cells, CTLs, are also involved and have their functional and cellular properties altered by asbestos exposure. From in vitro analyses using peripheral CTLs in a mixed lymphocyte reaction (MLR), it was found that differentiation and proliferation of CD8+ naïve T cells were disturbed by the presence of cocultured asbestos fibers with decreased expression of killing small molecules, such as granzyme B and interferon $\gamma$ (IFN $\gamma$ ) [84]. Moreover, alteration of killing molecules, as well as the phenotype of CD8+ cells, was manifested by CD45RA as the marker of effector/memory T cells. Freshly isolated CD8+ cells derived from asbestos-exposed patients, such as PP and MM, showed a higher predominance of CD45RA-negative cells compared with HD [85]. However, the cytokilling activity differed between isolated and in vitro-stimulated CD8+ cells. CD8+ cells from PP and MM revealed an increase in the number of perforin-positive cells; however, after in vitro stimulation, only CD8+ cells from MM showed a decrease in the perforin-positive cell population when subtracted from the unstimulated base line [85].

These findings indicated that asbestos exposure caused dysfunction of CTLs, while specific cell functions differed depending on disease status, for example, PP patients do not carry any malignant tumors, whereas MM patients suffer from mesothelioma. However, the impact of asbestos fibers on CTLs is considered to involve a reduction of tumor immunity, as we showed in NK cells mentioned above [84, 85].

\subsection{Th 1 cells}

Asbestos fibers are also known to modify Th1 cells. We developed continuously exposed sublines using a cell line model. The cDNA microarray data were examined of the original cell line, which has had no contact with asbestos fibers, and six independently established sublines, which were continuously exposed to asbestos fibers for more than 8 months using an asbestos concentration that did not induce apoptosis in more than half of the cells by transient exposure. The microarray showed a decrease in IFN $\gamma$ and related molecules, such as IFN regulatory factor 9 (IRF9) and IFN-stimulating gene factor-3 (ISGF3), in addition to a decrease in CXC chemokine receptor 3 (CXCR3), which is regulated by IRF9 [86].

CXCR3 is important in antitumor immunity to summon IFN $\gamma$-positive tumor antigen recognizing Th1 cells to the tumor. Thus, the asbestos-induced reduction of CXCR3 and IFN $\gamma$ seems to cause a reduction of antitumor immunity in asbestos-exposed patients. As we assumed, examination of freshly isolated CD4+ cells from HD stimulated in vitro and cocultured with 
asbestos fibers as well as peripheral CD4+ cells from PP and MM revealed a decrease in the cell surface expression of CXCR3 in addition to a decrease in the number of intracellular IFN $\gamma$ positive cells [87].

Taken together, one of the immunological risks resulting from asbestos exposure concerns a reduction of Th1-type T cell-derived antitumor immunity.

\subsection{Treg cells}

Treg cells are important in antitumor immunity. If the function and number of Treg cells are enhanced, immune cells responding to tumor antigen show suppressed function, which causes a reduction of antitumor immunity $[75,76]$.

Our cell line model continuously exposed to asbestos fibers using MT-2, a human T-lymphotropic virus type 1 , which causes adult $\mathrm{T}$ cell leukemia/lymphoma, showed excess production of transforming growth factor (TGF) $\beta$ and IL-10, typical soluble factors examined to reveal the function of Treg cells [88, 89]. Overproduction of IL-10 is regulated by the Src-family receptor and is used by the IL-10 receptor via autocrine mechanisms, which then causes activation of the signal transducer and activator of transcription 3 (STAT 3) and upregulation of antiapoptotic molecule Bcl-2 located downstream of STAT3 [88]. Continuously exposed sublines acquire resistance to apoptosis induced via transient exposure to asbestos [88]. Furthermore, overproduction of TGF $\beta$ induces resistance to TGF $\beta$-induced growth inhibition in continuously exposed sublines with phosphorylation of p38, one of the signaling molecules in the mitogen-activated protein kinase (MAPK) signaling pathway, as well as phosphorylation of SMAD3 [SMAD; vertebrate homologues of Sma and Mad [Drosophila protein, mothers against decapentaplegic (MAD) and the Caenorhabditis elegans protein SMA (from the sma gene for small body size)] [89].

In addition to the two aforementioned typical soluble factors, continuous exposure of MT-2 sublines to asbestos resulted in markedly higher suppressive activity when mixed with cultures of CD4+ responder cells activated with anti-CD3 antibody and autologous peripheral blood monocyte-derived dendritic cells compared with the original MT-2 cell line, which has had no contact with asbestos [90].

Taken together, exposure to asbestos results in enhanced Treg function, which is manifested by a reduction of antitumor immunity [11, 12, 15, 16, 80, 81].

\subsection{Risks of asbestos on antitumor immunity}

As mentioned above and shown in Table 2, all of the examined effects of asbestos on NK cells, CTLs, Th1, and Treg cells indicate that asbestos exposure can cause a reduction of antitumor immunity. These findings are considerable and the risks associated with asbestos exposure may be used as early detection markers for the occurrence of asbestos-induced malignancies. Additionally, the ability to mitigate the observed reduction of antitumor immunity through the use of chemopreventive substances derived from foods or plants may be an important strategy in the treatment of high-risk groups exposed to asbestos, such as residents who have 
a history of living near factories handling asbestos and workers in the building demolition and rubble processing fields.

\section{Conclusion}

Risks associated with exposure to fibers, such as asbestos, and particulates, such as silica, were discussed based on our experimental findings and analyzed using cell lines, freshly isolated peripheral immune cells from HD, as well as patients exposed to silica particles, exposed to asbestos fibers, and patients with silicosis, PP, and MM. The immunological risks manifested in different directions, in that silica caused dysregulation of autoimmunity, whereas asbestos induced a reduction of antitumor immunity. Both cellular and molecular alterations contributed to the complications of silica exposure, the occurrence of autoimmune diseases and asbestos exposure, and the development of malignant tumors.

These risks may be detected using findings described in this chapter, and early detection of these risks may assist workers, as well as other exposed populations, in avoiding further exposure and therefore prevent the onset of various pathological states caused by exposure to fibrous and particulate substances. Recently, although exposure to silica and asbestos has been reduced through the improvement of work-related environments as well as banning the use of asbestos, new substances, such as nanomaterials, which are widely used in the industrial fields, are now feared to cause health risks. It should be reiterated that risks, and particularly immunological ones which hitherto have not received a great deal of attention, caused by classical types of particulate and fibrous substances, such as silica and asbestos, require continued and greater consideration in an effort to further prevent the health impairment caused by environmental substances.

\section{Acknowledgements}

The authors express their gratitude to the former Professor of our Department, Prof. Ayako Ueki, MD, PhD, as well as former members Drs. Akiko Tomokuni-Takata, Fuminori Hyodoh, Takaaki Aikoh, and Yasuhiko Kawakami for their excellent achievement in analyzing the risks of particulate and fibrous substances. Additionally, we thank Ms. Minako Katoh, Naomi Miyahara, Satomi Hatada, Keiko Yamashita, Keiko Kimura, Tomoko Sueishi, Misao Kuroki, and Haruko Sakaguchi for their technical assistance.

\section{Author details}

Hidenori Matsuzaki ${ }^{1}$, Suni Lee ${ }^{1}$, Naoko Kumagai-Takei ${ }^{1}$, Shoko Yamamoto ${ }^{1}$, Tamayo Hatayama ${ }^{1}$, Kei Yoshitome ${ }^{1}$, Hiroaki Hayashi ${ }^{2}$, Megumi Maeda ${ }^{3}$ and Takemi Otsuki ${ }^{{ }^{*}}$ 
*Address all correspondence to: takemi@med.kawasaki-m.ac.jp

1 Department of Hygiene, Kawasaki Medical School, Kurashiki, Japan

2 Department of Dermatology, Kawasaki Medical School, Kurashiki, Japan

3 Division of Bioscience Department of Biofunctional Chemistry Okayama University Graduate School of Natural Science and Technology, Okayama, Japan

\section{References}

[1] Sirajuddin A, Kanne JP. Occupational lung disease. J Thorac Imaging. 2009;24:310-320. doi: 10.1097/RTI.0b013e3181c1a9b3.

[2] Weston A. Work-related lung diseases. IARC Sci Publ. 2011;163:387-405.

[3] Leung CC, Yu IT, Chen W. Silicosis. Lancet. 2012;379:2008-2018. doi: 10.1016/ S0140-6736(12)60235-9.

[4] Petsonk EL, Rose C, Cohen R. Coal mine dust lung disease. New lessons from old exposure. Am J Respir Crit Care Med. 2013;187:1178-1185. doi: 10.1164/rccm. 201301-0042CI.

[5] Cullinan P, Reid P. Pneumoconiosis. Prim Care Respir J. 2013;22:249-252. doi: 10.4104/ pcrj.2013.00055.

[6] Laney AS, Weissman DN. Respiratory diseases caused by coal mine dust. J Occup Environ Med. 2014;56:S18-22. doi: 10.1097/JOM.0000000000000260.

[7] Moolgavkar SH, Anderson EL, Chang ET, Lau EC, Turnham P, Hoel DG. A review and critique of U.S. EPA's risk assessments for asbestos. Crit Rev Toxicol. 2014;44:499-522. doi: 10.3109/10408444.2014.902423.

[8] Banks DE. Clinical aspects of asbestos-related diseases-What are the unresolved topics? J Occup Environ Med. 2014;56:S8-12. doi: 10.1097/JOM.0000000000000242.

[9] Wolff H, Vehmas T, Oksa P, Rantanen J, Vainio H. Asbestos, asbestosis, and cancer, the Helsinki criteria for diagnosis and attribution 2014: recommendations. Scand J Work Environ Health. 2015;41:5-15. doi: 10.5271/sjweh.3462.

[10] Norbet C, Joseph A, Rossi SS, Bhalla S, Gutierrez FR. Asbestos-related lung disease: a pictorial review. Curr Probl Diagn Radiol. 2015;44:371-382. doi: 10.1067/j.

[11] Otsuki T, Maeda M, Murakami S, Hayashi H, Miura Y, Kusaka M, Nakano T, Fukuoka K, Kishimoto T, Hyodoh F, Ueki A, Nishimura Y. Immunological effects of silica and asbestos. Cell Mol Immunol. 2007;4:261-268.

[12] Maeda M, Nishimura Y, Kumagai N, Hayashi H, Hatayama T, Katoh M, Miyahara N, Yamamoto S, Hirastuka J, Otsuki T. Dysregulation of the immune system caused by 
silica and asbestos. J Immunotoxicol. 2010;7:268-278. doi: 10.3109/1547691X. 2010.512579 .

[13] Lee S, Matsuzaki H, Kumagai-Takei N, Yoshitome K, Maeda M, Chen Y, Kusaka M, Urakami K, Hayashi H, Fujimoto W, Nishimura Y, Otsuki T. Silica exposure and altered regulation of autoimmunity. Environ Health Prev Med. 2014;19:322-329. doi: 10.1007/ s12199-014-0403-9.

[14] Lee S, Hayashi H, Maeda M, Chen Y, Matsuzaki H, Takei-Kumagai N, Nishimura Y, Fujimoto W, Otsuki T. Environmental factors producing autoimmune dysregulationChronic activation of T cells caused by silica exposure. Immunobiology. 2012;217:743748. doi: 10.1016/j.imbio.2011.12.009.

[15] Kumagai-Takei N, Maeda M, Chen Y, Matsuzaki H, Lee S, Nishimura Y, Hiratsuka J, Otsuki T. Asbestos induces reduction of tumor immunity. Clin Dev Immunol. 2011;2011:481439. doi: 10.1155/2011/481439.

[16] Matsuzaki H, Maeda M, Lee S, Nishimura Y, Kumagai-Takei N, Hayashi H, Yamamoto S, Hatayama T, Kojima Y, Tabata R, Kishimoto T, Hiratsuka J, Otsuki T. Asbestosinduced cellular and molecular alteration of immunocompetent cells and their relationship with chronic inflammation and carcinogenesis. J Biomed Biotechnol. 2012;2012:492608. doi: 10.1155/2012/492608.

[17] Uber CL, McReynolds RA. Immunotoxicology of silica. Crit Rev Toxicol. 1982;10:303319.

[18] Shanklin DR, Smalley DL. The immunopathology of siliconosis. History, clinical presentation, and relation to silicosis and the chemistry of silicon and silicone. Immunol Res. 1998;18:125-173.

[19] Iannello S, Camuto M, Cantarella S, Cavaleri A, Ferriero P, Leanza A, Milazzo P, Belfiore F. Rheumatoid syndrome associated with lung interstitial disorder in a dental technician exposed to ceramic silica dust. A case report and critical literature review. Clin Rheumatol. 2002;21:76-81.

[20] Ghahramani N. Silica nephropathy. Int J Occup Environ Med. 2010;1:108-115

[21] Stone OJ. Autoimmunity as a secondary phenomenon in scleroderma (and so-called human adjuvant disease). Med Hypotheses. 1991;34:127-130.

[22] Lappe MA. Silicone-reactive disorder: a new autoimmune disease caused by immunostimulation and superantigens. Med Hypotheses. 1993;41:348-352.

[23] Parks CG, Conrad K, Cooper GS. Occupational exposure to crystalline silica and autoimmune disease. Environ Health Perspect. 1999;107:S793-802.

[24] Stratta P, Messuerotti A, Canavese C, Coen M, Luccoli L, Bussolati B, Giorda L, Malavenda P, Cacciabue M, Bugiani M, Bo M, Ventura M, Camussi G, Fubini B. The 
role of metals in autoimmune vasculitis: epidemiological and pathogenic study. Sci Total Environ. 2001;270:179-190.

[25] Greillier L, Astoul P. Mesothelioma and asbestos-related pleural diseases. Respiration. 2008;76:1-15. doi: 10.1159/000127577.

[26] Yang H, Testa JR, Carbone M. Mesothelioma epidemiology, carcinogenesis, and pathogenesis. Curr Treat Options Oncol. 2008;9:147-157. doi: 10.1007/s11864-008-0067z.

[27] Ray M, Kindler HL. Malignant pleural mesothelioma: an update on biomarkers and treatment. Chest. 2009;136:888-896. doi: 10.1378/chest.08-2665.

[28] Bianchi C, Bianchi T. Malignant mesothelioma in Eastern Asia. Asian Pac J Cancer Prev. 2012;13:4849-3853.

[29] Stayner L, Welch LS, Lemen R. The worldwide pandemic of asbestos-related diseases. Annu Rev Public Health. 2013;34:205-216. doi: 10.1146/annurev-publhealth-031811-124704.

[30] Quinlan TR, Marsh JP, Janssen YM, Borm PA, Mossman BT. Oxygen radicals and asbestos-mediated disease. Environ Health Perspect. 1994;102:S107-110.

[31] Schins RP. Mechanisms of genotoxicity of particles and fibers. Inhal Toxicol. 2002;14:57-78.

[32] Shukla A, Gulumian M, Hei TK, Kamp D, Rahman Q, Mossman BT. Multiple roles of oxidants in the pathogenesis of asbestos-induced diseases. Free Radic Biol Med. 2003;34:1117-1129.

[33] Toyokuni S. Mechanisms of asbestos-induced carcinogenesis. Nagoya J Med Sci. 2009;71:1-10.

[34] Tomasetti M, Amati M, Santarelli L, Alleva R, Neuzil J. Malignant mesothelioma: biology, diagnosis and therapeutic approaches. Curr Mol Pharmacol. 2009;2:190-206.

[35] Tsujimura T, Torii I, Sato A, Song M, Fukuoka K, Hasegawa S, Nakano T. Pathological and molecular biological approaches to early mesothelioma. Int J Clin Oncol. 2012;17:40-47. doi: 10.1007/s10147-011-0369-1.

[36] Rodríguez Portal JA. Asbestos-related disease: screening and diagnosis. Adv Clin Chem. 2012;57:163-185.

[37] Zaghi G, Koga F, Nisihara RM, Skare TL, Handar A, Rosa Utiyama SR, Silva MB. Autoantibodies in silicosis patients and in silica-exposed individuals. Rheumatol Int. 2010;30:1071-1075. doi: 10.1007/s00296-009-1116-z.

[38] Aminian O, Sharifian SA, Mehrdad R, Haghighi KS, Mazaheri M. Antinuclear antibody and rheumatoid factor in silica-exposed workers. Arh Hig Rada Toksikol. 2009;60:185190. doi: 10.2478/10004-1254-60-2009-1892. 
[39] Nagaoka T, Tabata M, Kobayashi K, Okada A. Studies on production of anticollagen antibodies in silicosis. Environ Res. 1993;60:12-29.

[40] Doll NJ, Bozelka BE. Immunologic techniques utilized in the diagnosis of occupational lung disease. Clin Lab Med. 1984;4:523-538.

[41] Beshir S, Shaheen WA, Elserougy S, Aziz HM. Serum autoantibodies in silicosis and non-silicosis cement workers. Am J Ind Med. 2015;58:238-244. doi: 10.1002/ajim.22413.

[42] Shibuya H, Sano H, Osamura K, Kujime K, Hara K, Hisada T. Microscopic polyangiitis accompanied by pleuritis as the only pulmonary manifestation of occupational silica exposure. Intern Med. 2010;49:925-929.

[43] Bartůnková J, Pelclová D, Fenclová Z, Sedivá A, Lebedová J, Tesar V, Hladíková M, Klusácková P. Exposure to silica and risk of ANCA-associated vasculitis. Am J Ind Med. 2006;49:569-576.

[44] Rihova Z, Maixnerova D, Jancova E, Pelclova D, Bartunkova J, Fenclova Z, Vankova Z, Reiterova J, Merta M, Rysava R, Tesar V. Silica and asbestos exposure in ANCAassociated vasculitis with pulmonary involvement. Ren Fail. 2005;27:605-608.

[45] Saeki T1, Fujita N, Kourakata H, Yamazaki H, Miyamura S. Two cases of hypertrophic pachymeningitis associated with myeloperoxidase antineutrophil cytoplasmic autoantibody (MPO-ANCA)-positive pulmonary silicosis in tunnel workers. Clin Rheumatol. 2004;23:76-80.

[46] Bartůnková J, Tesar V, Sedivá A. Diagnostic and pathogenetic role of antineutrophil cytoplasmic autoantibodies. Clin Immunol. 2003;106:73-82.

[47] Stratta P, Messuerotti A, Canavese C, Coen M, Luccoli L, Bussolati B, Giorda L, Malavenda P, Cacciabue M, Bugiani M, Bo M, Ventura M, Camussi G, Fubini B. The role of metals in autoimmune vasculitis: epidemiological and pathogenic study. Sci Total Environ. 2001;270:179-190.

[48] Cojocaru M1, Niculescu T, Spătaru E. Antineutrophil cytoplasm antibodies in patients with silicosis. Rom J Intern Med. 1996;34:233-237.

[49] Nigam SK, Saiyed HN, Malaviya R, Suthar AM, Desai UM, Venkaiah K, Sharma YK, Kashyap SK. Role of circulating immune complexes in the immunopathogenesis of silicosis. Toxicol Lett. 1990;51:315-320.

[50] Kreiss K, Danilovs JA, Newman LS. Histocompatibility antigens in a population based silicosis series. Br J Ind Med. 1989;46(6):364-9.

[51] Sluis-Cremer GK, Hessel PA, Hnizdo E, Churchill AR. Relationship between silicosis and rheumatoid arthritis. Thorax. 1986;41:596-601.

[52] Youinou P, Ferec C, Cledes J, Zabbe C, Philippon P, Dewitte JD, Guillerm D, Clavier J. Immunological effect of silica dust analyzed by monoclonal antibodies. J Clin Lab Immunol. 1985;16:207-210. 
[53] Doll NJ, Stankus RP, Hughes J, Weill H, Gupta RC, Rodriguez M, Jones RN, Alspaugh MA, Salvaggio JE. Immune complexes and autoantibodies in silicosis. J Allergy Clin Immunol. 1981;68:281-285.

[54] Herrmann K, Schulze E, Heckmann M, Schubert I, Meurer M, Ziegler V, Haustein UF, Mehlhorn J, Krieg T. Type III collagen aminopropeptide and laminin P1 levels in serum of patients with silicosis-associated and idiopathic systemic scleroderma. Br J Dermatol. 1990;123:1-7.

[55] Yasuda M, Amano H, Yamanaka M, Tamura A, Ishikawa O. Coincidental association of mycosis fungoides and occupational systemic sclerosis? J Dermatol. 2008;35:21-24. doi: 10.1111/j.1346-8138.2007.00405.x.

[56] Tomokuni A, Otsuki T, Sakaguchi H, Isozaki Y, Hyodoh F, Kusaka M, Ueki A. Detection of anti-topoisomerase I autoantibody in patients with silicosis. Environ Health Prev Med. 2002;7:7-10. doi: 10.1007/BF02898059.

[57] Ueki A, Isozaki Y, Tomokuni A, Ueki H, Kusaka M, Tanaka S, Otsuki T, Sakaguchi H, Hyodoh F. Different distribution of HLA class II alleles in anti-topoisomerase I autoantibody responders between silicosis and systemic sclerosis patients, with a common distinct amino acid sequence in the HLA-DQB1 domain. Immunobiology. 2001;204:458-465.

[58] Ueki A, Isozaki Y, Tomokuni A, Tanaka S, Otsuki T, Kishimoto T, Kusaka M, Aikoh T, Sakaguchi H, Hydoh F. Autoantibodies detectable in the sera of silicosis patients. The relationship between the anti-topoisomerase I antibody response and HLA-DQB1*0402 allele in Japanese silicosis patients. Sci Total Environ. 2001;270:141-148.

[59] Whyte J, Earnshaw WC, Champoux JJ, Parker LH, Stewart L, Hall ND, McHugh NJ. Detection of anti-topoisomerase I antibodies using a full length human topoisomerase I recombinant protein purified from a baculovirus expression system. Clin Exp Immunol. 1995;100(2):214-218.

[60] McHugh NJ, Whyte J, Harvey G, Haustein UF. Anti-topoisomerase I antibodies in silica-associated systemic sclerosis. A model for autoimmunity. Arthritis Rheum. 1994;37:1198-1205.

[61] Takata-Tomokuni A, Ueki A, Shiwa M, Isozaki Y, Hatayama T, Katsuyama H, Hyodoh F, Fujimoto W, Ueki H, Kusaka M, Arikuni H, Otsuki T. Detection, epitope-mapping and function of anti-Fas autoantibody in patients with silicosis. Immunology. 2005;116:21-29.

[62] Ueki A, Isozaki Y, Tomokuni A, Hatayama T, Ueki H, Kusaka M, Shiwa M, Arikuni H, Takeshita T, Morimoto K. Intramolecular epitope spreading among anti-caspase-8 autoantibodies in patients with silicosis, systemic sclerosis and systemic lupus erythematosus, as well as in healthy individuals. Clin Exp Immunol. 2002;129:556-561. 
[63] McHugh NJ, Whyte J, Harvey G, Haustein UF. Anti-topoisomerase I antibodies in silica-associated systemic sclerosis. A model for autoimmunity. Arthritis Rheum. 1994;37:1198-1205.

[64] Ueki H, Kohda M, Nobutoh T, Yamaguchi M, Omori K, Miyashita Y, Hashimoto T, Komai A, Tomokuni A, Ueki A. Antidesmoglein autoantibodies in silicosis patients with no bullous diseases. Dermatology. 2001;202:16-21.

[65] Osterode W, Rüdiger H, Graninger W, Petzl DH, Rappersberger K, Dekan G, Weihs A, Graninger W. Anti-PL 12 and pulmonary fibrosis in a patient ten years after silica/ silicate dust exposure. Clin Exp Rheumatol. 1998;16:622.

[66] Ohtsuki T, Yawata Y, Wada H, Sugihara T, Mori M, Namba M. Two human myeloma cell lines, amylase-producing KMS-12-PE and amylase-non-producing KMS-12-BM, were established from a patient, having the same chromosome marker, $t(11 ; 14)$ (q13;q32). Br J Haematol. 1989;73(2):199-204.

[67] Otsuki T, Miura Y, Nishimura Y, Hyodoh F, Takata A, Kusaka M, Katsuyama H, Tomita M, Ueki A, Kishimoto T. Alterations of Fas and Fas-related molecules in patients with silicosis. Exp Biol Med (Maywood). 2006;231:522-533.

[68] Tomokuni A, Aikoh T, Matsuki T, Isozaki Y, Otsuki T, Kita S, Ueki H, Kusaka M, Kishimoto T, Ueki A. Elevated soluble Fas/APO-1 (CD95) levels in silicosis patients without clinical symptoms of autoimmune diseases or malignant tumours. Clin Exp Immunol. 1997;110:303-309.

[69] Otsuki T, Sakaguchi H, Tomokuni A, Aikoh T, Matsuki T, Kawakami Y, Kusaka M, Ueki H, Kita S, Ueki A. Soluble Fas mRNA is dominantly expressed in cases with silicosis. Immunology. 1998;94:258-262.

[70] Otsuki T, Sakaguchi H, Tomokuni A, Aikoh T, Matsuki T, Isozaki Y, Hyodoh F, Kawakami Y, Kusaka M, Kita S, Ueki A. Detection of alternatively spliced variant messages of Fas gene and mutational screening of Fas and Fas ligand coding regions in peripheral blood mononuclear cells derived from silicosis patients. Immunol Lett. 2000;72:137-143.

[71] Pitti RM, Marsters SA, Lawrence DA, Roy M, Kischkel FC, Dowd P, Huang A, Donahue CJ, Sherwood SW, Baldwin DT, Godowski PJ, Wood WI, Gurney AL, Hillan KJ, Cohen RL, Goddard AD, Botstein D, Ashkenazi A. Genomic amplification of a decoy receptor for Fas ligand in lung and colon cancer. Nature. 1998;396:699-703.

[72] Lin WW, Hsieh SL. Decoy receptor 3: a pleiotropic immunomodulator and biomarker for inflammatory diseases, autoimmune diseases and cancer. Biochem Pharmacol. 2011;81:838-847. doi: 10.1016/j.bcp.2011.01.011.

[73] Otsuki T, Tomokuni A, Sakaguchi H, Aikoh T, Matsuki T, Isozaki Y, Hyodoh F, Ueki $\mathrm{H}$, Kusaka M, Kita S, Ueki A. Over-expression of the decoy receptor 3 (DcR3) gene in 
peripheral blood mononuclear cells (PBMC) derived from silicosis patients. Clin Exp Immunol. 2000;119:323-327.

[74] Otsuki T, Tomokuni A, Sakaguchi H, Hyodoh F, Kusaka M, Ueki A. Reduced expression of the inhibitory genes for Fas-mediated apoptosis in silicosis patients. J Occup Health 2000;42:163-168.

[75] Ferguson TA, Stuart PM, Herndon JM, Griffith TS. Apoptosis, tolerance, and regulatory T cells--old wine, new wineskins. Immunol Rev. 2003;193:111-123.

[76] Bouillet P, O'Reilly LA. CD95, BIM and T cell homeostasis. Nat Rev Immunol. 2009;9:514-519. doi: 10.1038/nri2570.

[77] Hayashi H, Miura Y, Maeda M, Murakami S, Kumagai N, Nishimura Y, Kusaka M, Urakami K, Fujimoto W, Otsuki T. Reductive alteration of the regulatory function of the CD4(+)CD25(+) T cell fraction in silicosis patients. Int J Immunopathol Pharmacol. 2010;23:1099-1109.

[78] Wu P, Hyodoh F, Hatayama T, Sakaguchi H, Hatada S, Miura Y, Takata-Tomokuni A, Katsuyama H, Otsuki T. Induction of CD69 antigen expression in peripheral blood mononuclear cells on exposure to silica, but not by asbestos/chrysotile-A. Immunol Lett. 2005;98:145-152.

[79] Hayashi H, Maeda M, Murakami S, Kumagai N, Chen Y, Hatayama T, Katoh M, Miyahara N, Yamamoto S, Yoshida Y, Nishimura Y, Kusaka M, Fujimoto W, Otsuki T. Soluble interleukin-2 receptor as an indicator of immunological disturbance found in silicosis patients. Int J Immunopathol Pharmacol. 2009;22:53-62.

[80] Nishimura Y, Kumagai-Takei N, Matsuzaki H, Lee S, Maeda M, Kishimoto T, Fukuoka K, Nakano T, Otsuki T. Functional alteration of natural killer cells and cytotoxic T lymphocytes upon asbestos exposure and in malignant mesothelioma patients. Biomed Res Int. 2015;2015:238431. doi: 10.1155/2015/238431.

[81] Nishimura Y, Maeda M, Kumagai-Takei N, Lee S, Matsuzaki H, Wada Y, NishiikeWada T, Iguchi H, Otsuki T. Altered functions of alveolar macrophages and NK cells involved in asbestos-related diseases. Environ Health Prev Med. 2013;18:198-204. doi: 10.1007/s12199-013-0333-y.

[82] Nishimura Y, Miura Y, Maeda M, Kumagai N, Murakami S, Hayashi H, Fukuoka K, Nakano T, Otsuki T. Impairment in cytotoxicity and expression of NK cell- activating receptors on human NK cells following exposure to asbestos fibers. Int J Immunopathol Pharmacol. 2009;22:579-590.

[83] Nishimura Y, Maeda M, Kumagai N, Hayashi H, Miura Y, Otsuki T. Decrease in phosphorylation of ERK following decreased expression of NK cell-activating receptors in human NK cell line exposed to asbestos. Int J Immunopathol Pharmacol. 2009;22:879-888.

[84] Kumagai-Takei N, Nishimura Y, Maeda M, Hayashi H, Matsuzaki H, Lee S, Hiratsuka J, Otsuki T. Effect of asbestos exposure on differentiation of cytotoxic T lymphocytes 
in mixed lymphocyte reaction of human peripheral blood mononuclear cells. Am J Respir Cell Mol Biol. 2013;49:28-36. doi: 10.1165/rcmb.2012-0134OC.

[85] Kumagai-Takei N, Nishimura Y, Maeda M, Hayashi H, Matsuzaki H, Lee S, Kishimoto T, Fukuoka K, Nakano T, Otsuki T. Functional properties of CD8(+) lymphocytes in patients with pleural plaque and malignant mesothelioma. J Immunol Res. 2014;2014:670140. doi: 10.1155/2014/670140.

[86] Maeda M, Nishimura Y, Hayashi H, Kumagai N, Chen Y, Murakami S, Miura Y, Hiratsuka J, Kishimoto T, Otsuki T. Reduction of CXC chemokine receptor 3 in an in vitro model of continuous exposure to asbestos in a human T-cell line, MT-2. Am J Respir Cell Mol Biol. 2011;45:470-479. doi: 10.1165/rcmb.2010-0213OC.

[87] Maeda M, Nishimura Y, Hayashi H, Kumagai N, Chen Y, Murakami S, Miura Y, Hiratsuka J, Kishimoto T, Otsuki T. Decreased CXCR3 expression in CD4+ T cells exposed to asbestos or derived from asbestos-exposed patients. Am J Respir Cell Mol Biol. 2011;45:795-803. doi: 10.1165/rcmb.2010-0435OC.

[88] Miura Y, Nishimura Y, Katsuyama H, Maeda M, Hayashi H, Dong M, Hyodoh F, Tomita M, Matsuo Y, Uesaka A, Kuribayashi K, Nakano T, Kishimoto T, Otsuki T. Involvement of IL-10 and Bcl-2 in resistance against an asbestos-induced apoptosis of T cells. Apoptosis. 2006;11:1825-35.

[89] Maeda M, Chen Y, Hayashi H, Kumagai-Takei N, Matsuzaki H, Lee S, Nishimura Y, Otsuki T. Chronic exposure to asbestos enhances TGF- $\beta 1$ production in the human adult T cell leukemia virus-immortalized T cell line MT-2. Int J Oncol. 2014;45:25222532. doi: 10.3892/ijo.2014.2682.

[90] Ying C, Maeda M, Nishimura Y, Kumagai-Takei N, Hayashi H, Matsuzaki H, Lee S, Yoshitome K, Yamamoto S, Hatayama T, Otsuki T. Enhancement of regulatory T celllike suppressive function in MT-2 by long-term and low-dose exposure to asbestos. Toxicology. 2015;338:86-94. doi: 10.1016/j.tox.2015.10.005. 
Chapter 9

\title{
Environmental Factors in Causation of Diabetes Mellitus
}

\author{
P.G. Raman \\ Additional information is available at the end of the chapter \\ http://dx.doi.org/10.5772/62543
}

\begin{abstract}
Environmental factors play a role in etiopathogenesis of diabetes. Environmental factors include polluted water, soil, unhealthy diet, stress, lack of physical activity, vitamin D deficiency, exposure to enteroviruses, and damage to immune cells.
\end{abstract}

Keywords: diabetes, virus, diet, stress, pollutants, prenatal factors, cow's milk, vitamin D deficiency

\section{Introduction}

India is currently experiencing an epidemic of diabetes mellitus (DM). According to the World HealthOganization, Indiahas theunique distinction of being the country with thelargestnumber of diabetic patients in the world. Type-2 DM accounts for more than $90 \%$ of all patients with diabetes worldwide. The prevalence of diabetes in adults is showing an upward trend worldwide [ $4 \%$ in 1995 to $5.4 \%$ in 2025 (projected)]. The majority of this increase will however occur in developing countries. Asians, particularly from the Indian subcontinent, will be mostly affected. Reports from different parts of India show a rising trend in the prevalence of diabetes. In 1995, prevalence of diabetes was 19.4 million and is projected to increase to nearly 80 million in 2030. Migrants have a higher risk of developing type-2 diabetes. The long-term impact of obesity and change in diet are two main causes of increased prevalence of diabetes in migrant Indians. The migrants are shifting from the high-fiber staple diet to polished and milled rice.

Diabetes is a heterogeneous syndrome where it is impossible to formulate a unified etiopathogenesis. In our country (India), diabetes of the young is often seen. Type-2 diabetes occurs a decade earlier and type- 1 occurs a decade later. In type-2, strong genetic basis exists. But the 
time of onset depends on the environmental factors. It is triggered by obesity, increase in age, and diet indiscretion.

In type-1 diabetes, in a susceptible individual (HLA B8), interaction between environmental factors triggers autoimmune response.

Environmental factors play a role in the etiopathogenesis of diabetes. They include polluted air, soil, water, unhealthy diet, stress, lack of physical activity, vitamin-D deficiency, exposure to enteroviruses, and damage to immune cells.

\section{Diet}

Unhealthy food rich in saturated fatty acids, refined carbohydrates, and sweets cause obesity and DM. Three major dietary toxins that trigger diabesity are cereal grains (especially refined flour), omega-6 industrial seed oils (corn, cottonseed, safflower, and soybean), and fructose (high-fructose in corn syrup). These nutrients in excessive quantities increase the risk of obesity and diabetes, especially if there is genetic risk. These dietary factors increase inflammation and act as potential risk factors for diabetes. A recent study showed that a diet with an omega 6:3 ratio of 28 (meaning 28 times more omega- 6 than omega- 3 fats) increased obesity in mice in experimental studies $[1,2]$.

Fructose is found primarily in fruits, vegetables, and sweeteners. Fructose is shunted directly to the liver where it is converted to fat. Excess fructose consumption causes a condition called nonalcoholic fatty liver disease, which is directly linked to both diabetes and obesity. Shifting $25 \%$ of dietary calories from glucose to fructose caused a fourfold increase in abdominal fat. Abdominal fat is an independent predictor of insulin sensitivity, impaired glucose tolerance, high blood pressure, high cholesterol and triglyceride. Fructose reacts with polyunsaturated fat and protein to form advanced glycation end-products (AGEs). A donut is the perfect diabesity food. It has refined flour, trans-fatty acids, and plenty of high-fructose corn syrup.

\section{Food practices and diabetes}

Diet and related factors that promote diabetogenesis:

- Calorie (energy) intake in excess of physical needs leading to obesity

- Preferential and excess consumption of high-glycemic index carbohydrate rich-food

- Refined flour, pasta, raw rice

- Overcooked products of the above by baking or roasting

- Aerated soft drinks

- Sweets and free sugar

- High-fat diet with greater content of saturated fats, such as dairy and/or meat fat 
- Coconut or palm kernel oil

- Vanaspathi-Hydrogenated oil

- High omega-6 fatty acid intake, particularly corn oil, sunflower oil, and saffola

- Energy-dense fat- and sugar-rich snacks and meals at fast-food outlets

- Reduced consumption of legume, fresh fruits, and vegetables

\section{Secondary causes}

Low protein diet impairs beta-cell function. This phenomenon is shown in rats and rhesus monkeys. Such beta-cell dysfunction in case of malnutrition in utero as well as in infancy and early childhood has been projected as the basic mechanism in the pathogenesis of malnutritionmodulated DM seen among the poor in some tropical areas [3].

Stress hormones like adrenalin and cortisol can increase blood sugar. Stress causes the liver to release more glucose. In individuals with family history of diabetes, stress can definitely precipitate DM.

\subsection{Infant nutrition and type-1 DM}

Autoimmune damage to islet cells responsible for type-1 diabetes may have a nutritional basis. Clinical presentation of type- 1 DM peaks around puberty or sometime later, but islet cell antibodies are seen by the age of 5 years. The implication is that the involvement of type- 1 islet is early in life but may burn faster in some than in others. An association between bottle-feeding and type-1 DM has been found in Finland. It is hypothesized that molecular mimicry between islets antigen P69 and bovine serum albumin in cow's milk may occur.

\subsection{Fibrocalculous pancreatic diabetes (FCPD)}

\begin{tabular}{ll}
\hline Chemicals & Altered beta-cell function \\
\hline a) Rodenticide & a) Calcific fibrosis \\
b) Streptozotocin & b) Cassava \\
c) Nitrosamine & c) Protein malnutrition \\
\hline
\end{tabular}

Table 1. Beta cell damage caused by:

Malnutrition $=$ Cassava intake

Cassava (tapioca) contains linamarim, a cyanogenic glycoside, which on hydrolysis releases hydrocyanic acid. This hydrocyanic acid is normally inactivated by conjugation with sulfhydryl radicals derived from aminoacids-methionine and cysteine, and combines with hydrocyanic acid to form thiocyanate, which is excreted in urine. In protein-calorie malnutri- 
tion, there is a deficiency of these aminoacids, and accumulation of hydrocyanic acid occurs which may damage the pancreas.

\subsubsection{Rich food sources of cyanide}

Cassava (Tapioca), sorghum, yam, millet, some varieties of beans are some of the rich sources of cyanide.

\subsection{Prenatal infections and diabetes}

Child whose mother is type- 1 is less likely to develop DM than when the father is affected. Risk is increased with higher birth weight in elderly parents.

\subsection{Role of demographic factors in diabetes etiology}

There is an increased incidence of incidence of type $1 \mathrm{DM}$ in spring and autumn season; probably related to viral infection. Viral infections through autoimmune mechanisms or directly damaging beta cell may precipitate diabetes. Most of the viral infections are aymptomatic and may precipitate diabetes even after several years of diabetes. Prenatal infections of viruses such as congenital Rubella, cytomegalovirus, and enterovirus are known to be diabetogenic.

\subsubsection{Virus and beta-cell damage}

- Virus persists in host, leading to protracted beta-cell dysfunction

- Virus directs acute beta-cell destruction

- Virus activates beta-cell defense mechanism, leading to inflammatory cytokines

- Virus produces immune-mediated beta-cell destruction [4]

\subsection{Insulitis}

Activated T-lymphocytes infiltrate the pancreatic islets prior to or spontaneous with the development of diabetes. Islet inflammation leading to beta-cell failure is a factor in pathogenesis. Interleukin (IL)-1 is central to this insulitis. Islet infiltrating macrophages are a major source of IL-1 and other cytokines in response to elevated levels of glucose and saturated fatty acids. IL-17A exacerbates proinflammatory chemokine expression and secretion by human islets exposed to cytokines. This suggests that IL-17A contributes to the pathogenesis of type-1 diabetes by two mechanisms, namely the exacerbation of beta-cell apoptosis and increased local production of chemokines, thus potentially aggravating insulitis.

- Exposure to cow's milk in infancy may precipitate DM. Coeliac disease and type-1 DM can overlap with the haplotypes [5-8]. 
- Vitamin D: Type-1 DM patients have low vitamin D levels, and lack of sunlight correlates well with increased incidence of type-1 DM at higher altitudes [9-14]. Young people who have higher vitamin D levels have lesser chances of developing T2DM later in life, compared to people who have lower vitamin D levels. People with newly diagnosed type-2 diabetes often have low vitamin D levels than people without diabetes. Vitamin D may have a role in pancreatic beta-cell function, insulin action, and inflammation. There are some specific receptors in pancreatic beta-cell that start turning on if they get enough vitamin $\mathrm{D}$. There is an association between low vitamin D and decreased insulin sensitivity. Vitamin D plays an important part in the regulation of calcium. Calcium helps to control the release of insulin; so, alterations in calcium can have a negative effect on beta-cell function. People with higher vitamin $\mathrm{D}$ in blood, that is, over $25 \mathrm{ng} / \mathrm{ml}$ had a decreased chance of getting type-2 DM later in life compared to those with lowest levels, that is, below $14 \mathrm{ng} / \mathrm{ml}$. A person with highest vitamin D level in blood had a 19\% decreased chance of developing type-2 DM. For every $4 \mathrm{ng} / \mathrm{ml}$ increase in vitamin $\mathrm{D}$, there was $4 \%$ lower risk of developing type-2 DM. In one study, it was shown that vitamin $\mathrm{D}$ supplementation improved pancreatic beta-cell function [15-18].

- High vitamin E levels are associated with diabetes, and beta-carotene, the precursor of vitamin $\mathrm{A}$, is a protective factor in diabetes prevention.

- Overweight and inactivity results in insulin resistance and diabetes.

- Age: with increasing age, risk of diabetes increases. Increased triglyceride increases the risk of type-2 diabetes.

\subsection{Drugs}

Drugs like thiazide diuretics, diphenylhydantoin, pentamidine, and cyclosporin may cause diabetes. Experimental chemical agents that induce diabetes are afloxan and streptozotocin.

\subsubsection{Advanced glycation and lipoxidation end-products ( $A G E s$ and $A L E s$ ) as dysmetabolic risk factors}

AGEs are not only endogenously produced but also have an exogenous origin. Thermally processed food products contain high amounts of heat-accelerated protein and lipid-associated pro-oxidant. Foods rich in exogenous AGEs and ALEs are foods cooked at high temperature, roasted foods, fried foods, and dairy products processed with sugar [19].

AGEs and ALEs add to the systemic toxic pool of these powerful pro-oxidants. The glycoxidation product may be considered an important risk factor for insulin resistance, diabetes, and other chronic illness. Increased concentrations of reactive carbonyl compounds have been observed in patients with diabetes, leading to the formation of various AGEs in the body. Both AGER1 (advanced glycation receptor-1) and SIRT1 (survival factor sirtuin 1) were independently found to be suppressed in chronic oxidative stress conditions like diabetes and ageing. AGEs may contribute to insulin resistance. It seems plausible that excess intra-adipose AGEs could impair normal lipolysis via suppression of SIRT1, a factor implicated in fatty acid mobilization. AGEs deplete host defenses, raise basal oxidative stress and inflammation, and 
increase susceptibility to dysmetabolic insulin resistance. Pyridoxamine was observed to decrease AGEs accumulation. AGEs are increasingly considered in the pathogenesis of cardiomyopathy, retinopathy, and nephropathic complications of diabetes. AGE levels correlate with these complications.

Restriction of AGEs would result in increased expression of SIRT1 and AGER1 and reduction in insulin resistance. AGE inhibition and Sirtuin activation will be the targets of treatment in future for DM.

Urbanization has been recognized as a potent environmental predisposing factor for the development of type-2 DM. Urban rural differences in the prevalence of diabetes in the same community have been highlighted in most of the epidemiological studies.

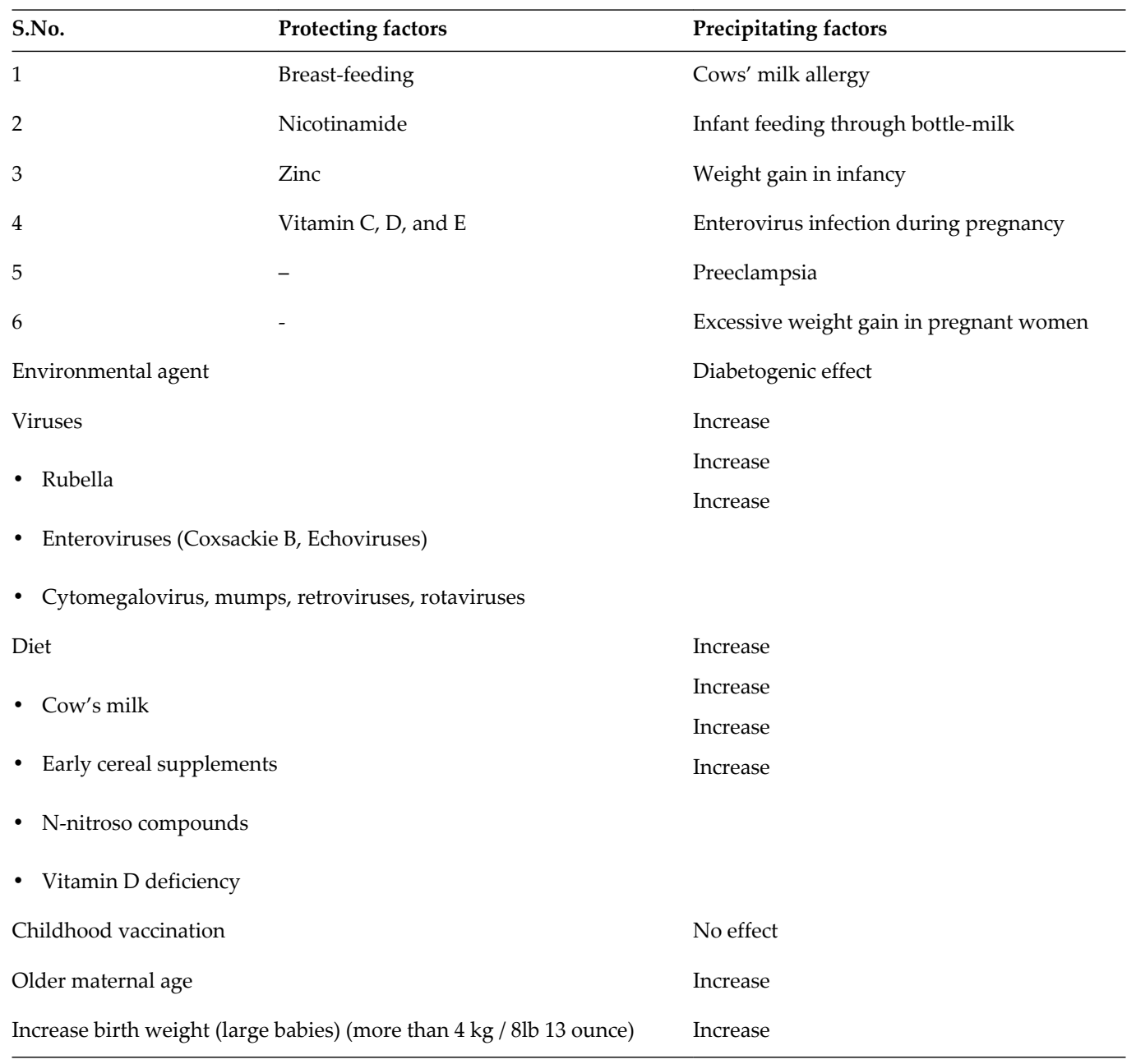

Table 2. Nutritional risk factors in type-1 DM. 


\subsection{Gut microbes and type-2 diabetes}

Gut microbiota-host interactions control energy homeostasis, glucose metabolism, and lipid metabolism. In addition to genetic and environmental factors, gut microbes may play an important role in the modulation of metabolic diseases. It was found in type- 2 diabetes by a moderate degree of gut microbial dysbiosis, decrease in the abundance of some universal butyrate-producing bacteria and increase in various opportunistic pathogens, conferring sulfate reduction and oxidative stress resistance in a Chinese study. Obese people with insulin resistance have in their gut elevated firmicutes/bacteroidetes ratio when compared with healthy people. Change in gut microbes in obese people modulates intestinal permeability and increases metabolic endotoxin secretion that leads to chronic low-level inflammation, leading to insulin resistance and type- 2 diabetes. Probiotic strains modulate immune system, downregulate inflammatory interferon (IFN)- $\alpha$ and IL-2 or IL-1 $\beta$, and enhance anti-inflammatory IL-10 production [20].

It was found that Saccharomyces boulardii-treated mice exhibited reduced fat mass, reduced hepatic steatosis, and reduced inflammatory reaction, thereby concluding this probiotic will prove beneficial to the treatment of obesity and type- 2 diabetes.

Nutrition during fetal life and infancy may be crucial to the development of DM; infants who are small for dates (a marker for poor intrauterine nutrition) have fewer beta-cells. Impaired glucose tolerance and type-2 DM may both result from poor nutrition early in life interacting adversely with abundant nutrition later on. Obesity in late years leads to insulin resistance.

\subsubsection{Night-shift workers and diabetes}

Men who work on shifts face a massively increased risk of developing diabetes. Shift-working men face a $37 \%$ increased risk of developing diabetes compared to general population with an overall increased risk of $9 \%$. Shift workers tend to put on weight and suffer from increased appetite. Rotating shifts make it harder for people to adjust to a regular sleep-wake cycle. Lack of sleep or poor quality of sleep may worsen insulin resistance. Night-shift workers have higher risk of developing obesity, DM, and sleep problems [21].

While multiple genetic loci may operate in combination with environmental factors to produce diabetes, other determining factors are age of onset, severity, and rate of progress. Developments in diabetogenesis occur slowly to manifest characteristic abnormalities like IFG, IGT, frank diabetes, and lipid abnormalities. These changes take 7-8 years to progress into diabetes.

The most important promoters of metabolic syndrome and diabetes identified among environmental factors are lifestyle changes and dietary practice. Principal changes in diet consists of greater consumption of calorie-dense foods, particularly fast-foods with greater fat and refined carbohydrate contents, and decreased preference for natural fiber-containing whole grain products, fruits, and vegetables with low glycemic index. These dietary changes lead to obesity and dyslipidemia and glucose intolerance, which are characteristic of type- 2 diabetes. 


\subsubsection{Physical inactivity}

Sedentary life style with constant use of automobiles even for short distances, sitting long hours at office/study table, and more so in watching television and using computers have transformed the lives of most urbanites, starting from childhood throughout the rest of their life. These practices have increased the incidence of diabetes and heart disease. Increased physical activity by regular walking, gardening, and doing both endurance and resistance types of exercises have been found to prevent the onset of diabetes.

\subsubsection{Obesity and BMI}

Risk of diabetes is estimated to increase by $9 \%$ for every increase in $1 \mathrm{~kg}$ body weight. Obesity alone accounts for nearly $64 \%$ of diabetes in men and $74 \%$ in women. Independent of BMI, android distribution of fat and waist circumference predict diabetes risk. Obesity predisposes to insulin resistance and beta-cell failure.

\subsubsection{Exposure to chemicals}

Chemicals from water pollution, plastic packaging, cleaning and beauty care products have all been found to increase insulin resistance and diabetes.

Persistent organic pollutants (POPs) are pollutants that accumulate in the environment due to extensive use of pesticides and industrial chemical products. Pollutants in the environment, consumer products, and cosmetics may all increase risk of diabetes. Endocrine-disrupting chemicals are the substances present in the environment, food, and consumer products, which have the ability to affect hormone production and metabolism among other functions. Type- 1 $\mathrm{DM}$ is seen more in people who consume fish that have higher amounts of heavy metal pollutants like cadimum and lead present in them. Plastic bottles used for water-storing are known to give out Endocrine-Disrupting Chemical (EDC) [22-25]. Europe has moved away from plastic to glass. There is a connection between pollution and obesity. They are implicated in immune dysfunction and type-2 DM. The organic pollutants are present in animal fats, which when consumed can cause diabetes by producing insulin resistance. Obesity per se may not cause DM, but the presence of POPs in obese people make them susceptible for the development of diabetes. The best preventive measure against POP-induced diabetes will be to minimise the use of pesticides and saturated fats [26-31].

POPs include hundreds of different chemical compounds with common properties, such as long-term persistence, widespread diffusion in the environment, and bioaccumulation through the food chain. These POPs which are cytochrome P450 enzyme inducers are found in the environment, either in the air, soil, or water. They accumulate in the body as white adipose tissue (WAT), which acts as a reservoir of lipophilic environmental pollutants. They are resistant to biological and chemical degradation, leading to their accumulation. They are detectable in virtually all of the general population, most of who experience only background exposure through food consumption, but their persistence has led to multiple health effects, including diabetes. A total of 12 POPs, all chlorine-containing organic compounds, have been 
chosen as priority pollutants by the United Nations Environment Program (UNEP) for their impact on human health and environment. These POPs have been divided as follows:

- Pesticides: Aldrin, dieldrin, endrin, chlordane, DDT, heptachlor, mirex, toxaphene and hexachlorobenzene (HCB) [32-38]

- Industrial chemical products: Polychlorinated biphenyls (PCBs), hexachlorobenzene (HCB)

- Unwanted by-products: Polychlorinated dibenzo-p-dioxins (PCDDs), polychlorinated dibenzofurans (PCDFs), polychlorinated biphenyls (PCBs), hexachlorobenzene (HCB)

\subsection{Adverse effects on human health}

High-dose acute exposure results from accidental fires or explosions of electrical capacitors or other PCB-containing equipment, or food contamination.

Mid-level chronic exposure is predominantly due to the occupational exposure or increased consumption of POP-contaminated dietary source, such as fish or other marine animals.

Chronic, low-dose exposure is seen worldwide in most of the population in different quantities, depending on the variations of diet, geography, and the level of the industrial pollution.

Short-term exposure to high concentrations of certain POPs has been shown to result in illness and death. In 1990, Rice farmers and mango sprayers of Phillippines suffered acute endosulfan poisoning.

Chronic exposure to sublethal concentrations of POPs over prolonged exposure can cause the following:

- Immune dysfunction

- Dermatological effects like chloracne

- Neurodevelopmental and neurobehavioral effects

- Reproductive anomalies

- Endocrine problems

- Rheumatological disorders like arthritis

- Carcinogenesis

Swedish investigations have reported that dietary intake of PCBs (polychlorinated biphenyls), dioxins, and furans may be linked to important reductions in the population of natural killer cells (lymphocytes). Studies of high-level exposure also indicate that some biochemical changes, for example, in enzyme and hormone levels may be induced.

Very high levels of dioxin (2, 3, 7, 8-TCDD), hundreds of times greater than natural levels, are known to cause a reversible skin condition known as chloracne (acne-like eruption of blackheads, cysts, and pustules). Lifetime presence of chloracne, abnormal nails, hyperkeratosis, 
skin allergy, goiter, headache, gum pigmentation, and broken teeth were observed more frequently in the men and women exposed to PCB/PCDF. The exposed women reported anemia 2.3 times more than controls. The exposed men reported arthritis and herniated intervertebral disks 4.1 and 2.9 times, respectively, more than controls. The developing fetuses and neonates are particularly vulnerable to POPs' exposure due to transplacental and lactational transfer of maternal POP, some of which can potentially affect neurodevelopment.

\subsection{POPs and diabetes}

Dae-Hee Lee and colleagues were the first to analyze serum concentrations of POPs which showed the prevalence of DM more than five times higher in groups with higher concentrations of PCB153, oxychlordane, or trans-Nonachlor than in those with lower concentrations. In a study, they found a strong dose-response relationship between diabetes and the six POPs (one PCB (hexachlorobiphenyl), two dioxins (heptadioxin and OCD dioxin), two pesticides (oxychlordane and trans-Nonachlor), and a pesticide metabolite (DDE, a metabolite of DDT)) [5]. In general, older people had higher levels of individual contaminants than younger people. Men tended to have lower concentrations compared to women. For all but one contaminant (PCB153), Hispanics tended to have higher levels as did poorer people [36-38].

The various mechanisms implicated by these POPs in causing diabetes are as follows:

- Insulin resistance

- Obesity

- Decreased insulin production

- Disrupted glucose homeostasis

\subsubsection{Insulin resistance}

Serum concentrations of organochlorine (OC) pesticides were found to be strongly and positively associated with insulin resistance among nondiabetic subjects. Results suggest that the background environmental exposure to some POPs, especially OC pesticides, may be critically involved in the pathogenesis of diabetes through a pathway involving insulin resistance. Among several OC pesticides, both oxychlordane (metabolites of chlordane) and trans-Nonachlor (impurity of chlordane) were most strongly associated with insulin resistance. Individuals with high levels of POPs (DDT, dioxins, PCBs, and chlordane, among others) in their body were found up to 38 times more likely to be insulin-resistant than individuals with low levels of these pollutants, though a cause and effect relationship could not be established.

\subsubsection{Obesity}

Because POPs are lipophilic, people with higher body mass index may be more likely to store higher levels of these organic pollutants than people with lower body mass index with equivalent exposure. A study by the National Health and Nutrition Examination Survey on 
population found that obesity and diabetes were associated only among participants with detectable levels of POPs [5]. The diabetogenic effect due to dioxin exposure has also been shown to be stronger among obese compared with lean individuals. Another possibility is that insulin resistance causes increased accumulation of POPs. Obesity was associated with diabetes only in people who tested high for these pollutants. Lee et al. found no association between obesity and diabetes in individuals with nondetectable levels of POPs. Obesity was a risk factor for diabetes only if people had blood concentrations of these pollutants above a certain level. Thus, this indicates that obesity is only a vehicle for the accumulation of POPs in the body which eventually results in diabetes.

\subsubsection{Decreased insulin production}

Pancreatic $\beta$-cells contain muscarinic acetylcholine receptors, which are involved in the glucose-dependent production of insulin. Organophosphate insecticides are known inhibitors of acetylcholinesterase, the enzyme responsible for the degradation of acetylcholine. Thus, exposure to sufficiently high levels of organophosphate insecticides would be expected to result in increased accumulation of acetylcholine, potentially leading to overstimulation and eventual downregulation of its receptors and reduction in insulin production.

\subsubsection{Disrupted glucose homeostasis}

Dioxins are known to be a frequent contaminant of herbicides and have been used in the past as a contaminant by the name of Agent Orange (a code name used by the military) [16, 17]. It involves an estrogen-dependent peroxisome proliferator-activated receptor (PPAR) pathway and thereby upregulates insulin-like growth factor binding protein-1 (IGFBP-1) in MCF-7 cells. Studies have suggested that exposure to these contaminated herbicides increased the risk of diabetes by disrupting the glucose and insulin homeostasis.

\subsection{Prevention and control}

International efforts to minimize exposure to these compounds include the banning of their use. With the exception of DDT, few, if any, of these compounds have been authorized for use. PCBs, which were widely used in capacitors, transformers, and lubricating oils, have not been manufactured for several decades, but linger in the environment. Chlorinated dibenzodioxins and dibenzofurans are by-products of products made from chlorophenols.

\subsubsection{At the individual level}

Since fetuses and infants are especially sensitive to the effects of toxic compounds, efforts should be made to reduce girls' and women's exposure to dioxins in foods during the years well before childbearing, so that lesser amounts of these compounds accumulate in their bodies and are passed on through the placenta and breast-milk. Fats in meat, poultry, fatty fish, whole milk, and full-fat dairy products are the principal sources of most people's exposure, and their ingestion should be minimized. Choosing a balanced diet that is low in saturated and total fats 
helps minimize any potential exposure to dioxin from food, because dioxins are found mostly in animal fats (due to the fat-soluble properties of the dioxin compound).

- Choose leaner cuts of beef, pork, and poultry; trim the fat and remove skin from chicken before cooking.

- Choose nonfat and low-fat milk and milk products.

- Choose a diet high in fruits, vegetables, whole grains, and lean proteins.

These strategies help lower the intake of saturated fats and total fats and therefore help reduce the risk of exposure to dioxins.

\subsubsection{At the industry level}

The industries should make an effort to produce alternatives to the banned pesticides which are biodegradable. Research and development for new products should be undertaken rigorously by industries. Training of farmers in terms of efficient and judicious use of pesticides should be undertaken.

Research in the following direction may be useful:

- Serum concentration of POPs in genders, obese and nonobese diabetics, type-1 and gestational diabetics should be studied to find the relationship between POPs and DM.

- Relationship between fatty foods, oil, and water levels of POPs in humans should be studied.

\subsubsection{At the government level}

The government plays an important role in the prevention of POPs. They should improve the surveillance system to monitor any manufacturing, import, or export of banned pesticides. Carrying out changes according to the POP elimination programs should be their main goal.

\section{Conclusion}

Environmental factors have a major role both in type-1 and type-2 DM. Even when there is genetic proneness, environmental factors precipitate diabetes. These environmental factors are reviewed in detail. The accumulation of POPs in the environment and their various effects on humans in general have been given in short. Their implications in the causation of type-2 DM, with a special reference to their mechanism, including preventive measures, have been discussed. Further study is needed regarding urban and rural concentrations of POPs as well as study of POPs in type-1 DM, type-2 DM, obese DM, and gestational DM. 


\section{Author details}

P.G. Raman

Address all correspondence to: drpgraman@yahoo.com

Devi Ahilya University, Indore, India

\section{References}

[1] Tripathy BB, Tripathy D, Pathogenesis of type-2 diabetes, RSSDI Textbook of Diabetes Mellitus, 2nd Edition, Vol. 1, 2012, pp. 223-249.

[2] Knip M, Akerblom HK. Putative environmental factors in type-1 diabetes. Diabetes Metab Res 1998;14:31-67.

[3] Das AK, Tripathy BB. Etiology of diabetes: an overview, RSSDI Textbook of Diabetes Mellitus, 2nd Edition, Vol. 1, 2012, pp. 205-209.

[4] Wing-Chi GY et al. Enterovirus infection and type 1 diabetes systematic review and meta-analysis of observational molecular studies. BMJ 2011;342:d35.

[5] Scott FW. Milk and type 1 diabetes. Diabetes Care 1996;10:379-383.

[6] Gerstein H. Cow's milk exposure and type 1 diabetes mellitus? A critical overview of the clinical literature. Diabetes Care 1994;17:13-19.

[7] Harrison LC, Honeyman MC. Cow's milk and type 1 diabetes. The real debate is about mucosal immune function. Diabetes 1999;48:1501-1507.

[8] Ellis TM, Atkinson MA. Early infant diets and insulin-dependent diabetes. Lancet 1996;347:1464-1465.

[9] Cooper JD, et al. Inherited variation in vitamin D genes is associated with predisposition to autoimmune type 1 diabetes. Diabetes 2011;60:1624-1631.

[10] Cardwell CR, et al. Maternal age at birth and childhood type 1: a pooled analysis of 30 observational studies. Diabetes 2010;59:486-494.

[11] Scragg R, Sowers M, Bell C; Third National Health and Nutrition Examination Survey. Serum 25-hydroxyvitamin D, diabetes, and ethnicity in the Third National Health and Nutrition Examination Survey. Diabetes Care. 2004 Dec;27(12):2813-8.

[12] Chiu KC, Chu A, Go VL, Saad MF. Hypovitaminosis D is associated with insulin resistance and beta cell dysfunction. Am J Clin Nutr. 2004 May;79(5):820-5

[13] Mitri J, Muraru MD, Pittas AG. Vitamin D and type 2 diabetes: a systematic review. Eur J Clin Nutr. 2011 Sep;65(9):1005-15. Review. 
[14] Khan H, Kunutsor S, Franco OH, Chowdhury R. Vitamin D, type 2 diabetes and other metabolic outcomes: a systematic review and meta-analysis of prospective studies. Proc Nutr Soc. 2013 Feb;72(1):89-97.

[15] Song Y, Wang L, Pittas AG, Del Gobbo LC, Zhang C, Manson JE, Hu FB. Blood 25hydroxy vitamin $\mathrm{D}$ levels and incident type 2 diabetes: a meta-analysis of prospective studies. Diabetes Care. 2013 May;36(5):1422-8.

[16] Davidson MB, Duran P, Lee ML, Friedman TC. High-dose vitamin D supplementation in people with prediabetes and hypovitaminosis D. Diabetes Care. 2013 Feb;36(2):260 6.

[17] Belenchia AM, Tosh AK, Hillman LS, Peterson CA. Correcting vitamin D insufficiency improves insulin sensitivity in obese adolescents: a randomized controlled trial. Am J Clin Nutr. 2013 Apr;97(4):774-81

[18] Pittas AG, Chung M, Trikalinos T, Mitri J, Brendel M, Patel K, Lichtenstein AH, Lau J, Balk EM. Systematic review: Vitamin D and cardiometabolic outcomes. Ann Intern Med. 2010 Mar 2;152(5):307-14

[19] Ottum MS, Mistry AM. Advanced glycation end-products: modifiable environmental factors profoundly mediate insulin resistance. J Clin Biochem Nutr 2015:57(i):1-12.

[20] Faraha Keramat, SH, Hashermi, AM, Shatiram, HD et al. The association between diabetes and H. Pylorus infection. Int J Diabetes Develop Countries 2013:33(3):155-160.

[21] Gan Y, Yang C, Tong X, Sun H, Cong Y, Yin X, Li L, Cao S, Dong X, Gong Y, Shi O, Deng J, Bi H, Lu Z. Shift work and diabetes mellitus: a meta-analysis of observational studies. Occup Environ Med. 2015 Jan;72(1):72-8

[22] Needham LL, Barr DB, Caudill SP, Pirkle JL, Turner WE, Osterloh J, et al. Concentrations of environmental chemicals associated with neurodevelopmental effects in US population. Neurotoxicology 2005;26:531-545.

[23] Guo YL, Yu ML, Hsu CC, Rogan WJ. Chloracne, goiter, arthritis, and anemia after polychlorinated biphenyl poisoning: 14-year follow-up of the Taiwan Yucheng cohort. Environ Health Perspect 1999;107:715-719.

[24] Lee DH, Lee IK, Jin SH, Steffes M, Jacobs DR Jr. Association between serum concentrations of persistent organic pollutants and insulin resistance among nondiabetic adults: results from the National Health and Nutrition Examination Survey 1999-2002. Diabetes Care 2007;30:622-628.

[25] Ritter L, Solomon KR, Forget J, Stemeroff M, O'Leary C. Persistent organic pollutants. United Nations Environment Programme 1995. Available from: http:// www.chem.unep.ch/pops/ritter/en/ritteren.pdf. 
[26] Fujiyoshi PT, Michalek JE, Matsumura F. Molecular epidemiologic evidence for diabetogenic effects of dioxin exposure in U.S. Air Force veterans of the Vietnam War. Environ Health Perspect 2006;114:1677-1683.

[27] Porta M. Persistent organic pollutants and the burden of diabetes. Lancet 2006;368:558559.

[28] Montgomery MP, Kamel F, Saldana TM, Alavanja MC, Sandler DP. Incident diabetes and pesticide exposure among licensed pesticide applicators: Agricultural Health Study, 1993-2003. Am J Epidemiol 2008;167:1235-1246.

[29] Henriksen GL, Ketchum NS, Michalek JE, Swaby JA. Serum dioxin and diabetes mellitus in veterans of Operation Ranch Hand. Epidemiology 1997;8:252-258.

[30] Michalek JE, Akhtar FZ, Kiel JL. Serum dioxin, insulin, fasting glucose, and sex hormone-binding globulin in veterans of Operation Ranch Hand. J Clin Endocrinol Metab 1999;84:1540-153.

[31] Country situation of persistent organic pollutants (POPs) in India. International POPs Elimination Project. New Delhi: toxics link; 2006;25-51. Available from: http:// www.ipen.org/ipepweb1/library/ipep_pdf_reports/4ind\%20india\%20country\%20situation\%20report.pdf.

[32] Institute of Medicine (IOM), Food and Nutrition Board (FNB). Dioxins and dioxin-like compounds in the food supply: strategies to decrease exposure [Internet]. Washington: The National Academies Press; 2003 [cited December 10, 2009]. Available from: http:// www.nap.edu/ openbook.php?record_id=10763\#description.

[33] Schafer KS, Kegley SE. Persistent toxic chemicals in the food supply. J Epidemiol Community Health 2002;56:813-817.

[34] Hansen LG. Stepping backward to improve assessment of PCB congener toxicities. Environ Health Perspect 1998;106(Suppl 1):171-189.

[35] Müllerová D, Kopecký J. White adipose tissue: storage and effector site for environmental pollutants. Physiol Res 2007;56:375-381.

[36] Lee DH, Lee IK, Song K, Steffes M, Toscano W, Baker BA, et al. A strong dose-response relation between serum concentrations of persistent organic pollutants and diabetes: results from the National Health and Examination Survey 1999-2002. Diabetes Care 2006;29:1638-1644.

[37] Stride P. Dioxin, diet and disease on St Kilda. J R Coll Physicians Edinb 2009;39:370374.

[38] Lee DH, Jacobs DR Jr, Porta M. Could low-level background exposure to persistent organic pollutants contribute to the social burden of type 2 diabetes? J Epidemiol Community Health 2006;60:1006-1008. 



\title{
Amoxicillin in the Aquatic Environment, Its Fate and Environmental Risk
}

\author{
Armando Elizalde-Velázquez, \\ Leobardo Manuel Gómez-Oliván, \\ Marcela Galar-Martínez, Hariz Islas-Flores, \\ Octavio Dublán-García and Nely SanJuan-Reyes
}

Additional information is available at the end of the chapter

http://dx.doi.org/10.5772/62049

\begin{abstract}
Amoxicillin is a broad-spectrum antibiotic widely used for treating both human and animal diseases, and it belongs to a group that are excreted unchanged within urine and faeces; therefore, it is possible to find traces of this drug or its degradation products in environmental water bodies. In water, it is rapidly degraded by biotic and abiotic factors, yielding different intermediate products; these are suspected of being more resistant to degradation, and potentially more toxic, than the parent compound. In the water bodies, these compounds may produce toxic effects on the aquatic organisms from different trophic levels and produce an ecological imbalance. Amoxicillin may bioaccumulate in fish muscle tissues, with the possibility of the occurrence of these drugs in food, leading to a passive consumption of this antibiotic resulting in undesirable effects on consumer health such as immunoallergic responses. However, the main problem related with the presence of this antimicrobial compounds in fish tissues is the possibility of inducing bacterial resistance genes. At present, the available scientific knowledge is less than what is needed to fully assess the risks that amoxicillin pose to the environment, and it is still necessary to conduct large amount of research works before a thorough understanding of this severe environmental issue.
\end{abstract}

Keywords: Amoxicillin, risk, toxicology, occurrence, analytical methods 


\section{Introduction}

In the recent decades, the term "emerging pollutants" have been used widely to refer to a variety of chemical compounds without regulatory status in the environment and its impact on the environment and human health are poorly understood. Within the category of emerging pollutants, the antibiotics are one of the most significant groups.

Antibiotics are among the most successful drugs used for human therapy; however, these drugs are also recognized by its use and benefits in many different activities such as agriculture, aquaculture, bee keeping and livestock as growth promoters. Wise in 2002, estimated that the consumption in the market of antibiotics at worldwide level, was between 100,000 and 200,000 tonnes annually; however, the World Health Organization states that the amount of antibiotics is not precisely known because only a few countries have national statistics of the use, amounts and patterns of antibiotics [1-9].

Due to the extensive use in human and veterinary medicine, it is a reality that antibiotic compounds may be found in different environmental compartments. Indeed, in the last few years, antibiotics have been detected and reported by several researchers around the world in the $\mu \mathrm{g} / \mathrm{L}$ range in municipal sewage, hospital effluents, sewage treatment plants effluents, surface water, ground water, marine water and drinking water [10-23]. The excretion of incompletely metabolized antibiotics by human and animals is the primary source of antibiotics in the environment, and other sources include the disposal of unused antibiotics and waste from pharmaceutical manufacturing process; residential (private residences, dormitories, hotels and residential care facilities) and commercial facilities (including hospitals) are also known as contributors of antibiotics to municipal wastewater. Other potential contributors of antibiotics to surface and groundwater are effluents from wastewater treatment plants and industrial facilities, and surface runoff from concentrated animal feeding operations [22, 24].

The occurrences of these compounds in different water bodies represent a potential threat to the environment, since these drugs are designed to have a pharmacological effect and to be persistent; moreover, the greatest concern about the presences of antibiotics in the environment is the emergence and dissemination of antibiotic resistance genes $[1,4,12,13,16,25-28]$.

In addition, antibiotics are of concern due to their high toxicity to algae and bacteria at low concentrations, potential genotoxic effects, disruption of aquatic ecology, promotion of antibiotic resistance and possibly even increased human health risks [20, 22, 29].

As a result, Sanderson et al. in 2004 classifies the antibiotics as pollutants of high priority for measuring environmental risk due to the probability of potential effects on human and environmental health, even more than sex hormones, cardiovascular drugs and antineoplastics [30].

Risk analysis is the scientific methodology used internationally to assess toxic effects on the environment [31-33]. In 2002, Jones et al. reported that the risk quotient (RQ) for amoxicillin in the United Kingdom exceeded the 1.00 unit, as well as, Park and Choi in 2008 reported that 
amoxicillin has a risk quotient (RQ) in Korea of 1.62, suggesting the need for further research to this antibiotic as an ongoing and future environmental monitoring toxicological investigations $[34,35]$.

Likewise in 2004, Boxall et al. scored the amoxicillin as "high priority" in environmental monitoring and prioritization of toxicological studies [34-36].

\section{Amoxicillin}

Originally introduced in the early 1970's for oral use in United Kingdom, this drug has found gradually a regular place as a broad-spectrum antibiotic. In 1981, SmithKline Beecham patented amoxicillin/clavulanate potassium tablets, and first sold the antibiotic in 1998 under the trade names of amoxicillin, amoxil and timox [37-39].

The amoxicillin is a semi-synthetic drug, which belongs to a class of antibiotics called the penicillins ( $\beta$-lactam antibiotics). This drug has been shown to be effective against a wide range of infections caused by gram-positive and gram-negative bacteria and is used for the treatment and prevention of respiratory, gastrointestinal, urinary and skin bacterial infections due to its pharmacological and pharmacokinetics properties [37, 40,41]. Besides its use in human medicine, amoxicillin is also used for treating and preventing animal diseases as well as it is used as growth promoters for many domestic and food animals, including dogs, cats, pigeons, horses, broiler chickens, pigs, goats, sheep, pre-ruminating calves, cattle and fishes [42, 43]. It is well absorbed from gastrointestinal tract. The apparent volume of distribution of amoxicillin is approximately $0.26-0.31 \mathrm{~L} / \mathrm{Kg}$ and widely distributed to many tissues, including liver, lungs, prostate muscle, bile, ascetic, pleural and synovial fluids, and ocular fluids, accumulates in the amniotic fluid and crosses the placenta but penetrates poorly into the central nervous system unless inflammation is present. It is approximately $17-20 \%$ bound to human plasma proteins, primarily to albumin $[44,45]$.

Amoxicillin is very closely related to ampicillin with the same spectrum of activity and potency but is much better absorbed when given orally, achieving blood concentrations approximately twice as high as those obtained with ampicillin [37].

It acts binding to penicillin binding protein (PBP-1A) located inside the bacterial cell wall, the amoxicillin acylate the penicillin-sensitive transpeptidase C-terminal domain by opening the lactam ring causing inactivation of the enzyme, prevents the formation of a cross-link of two linear peptidoglycan strands, inhibiting the third and last stage of bacterial cell wall synthesis, which is necessary for cell division and cell shape and other essential processes, producing as a consequence the lisis of the bacteria cells [37, 46-49]. The two major metabolites of amoxicillin are amoxicilloic acid and piperazine-2, 5-dione (diketopiperazine). These metabolites have lost antibacterial activity of the parent component, but the amoxicilloic acid could have potential allergic properties [50-52]. 
The drug's terminal half-life of elimination is 1 to 1.5 hours. Excretion of amoxicillin is predominantly renal, more than $80 \%$ of the original drug is recovered unchanged in the urine, leading to very high urinary concentrations and is also secreted in milk [53-55].

\section{Amoxicillin sales and occurrence in water bodies}

Amoxicillin acts against a broad spectrum of gram-positive and gram-negative microorganisms; therefore, it is used as first-line antibiotic both in human medicine and in veterinary medicine in many different countries [56-59]. Table 1 is listed numbers of data reported of sales of amoxicillin in different countries around the globe.

\begin{tabular}{llc}
\hline Country & Amount (kg) & Reference \\
\hline Italy & 209,500 in 2001 & {$[60]$} \\
UK & 71,467 & {$[34]$} \\
Korea & 106,673 & {$[61]$} \\
Australia & 959,000 & {$[62]$} \\
Australia & 4 million scripts filled for amoxicillin which equates to approximately 40, 000kg of this & {$[63]$} \\
& antibiotic & {$[64]$} \\
UK & 170, 432 & {$[65]$} \\
Brazil & In Brazil, it is the most commonly prescribed antibiotic and have been sold 6 billions units of & {$[18]$} \\
& amoxicillin between 2007-2011 & {$[25]$} \\
China & In China, Amoxicillin and Penicillin are the two most prescribed antibiotics \\
Nederland Reported that amoxicillin and ampicillin are the two most consumed antimicrobial drugs in 71
\end{tabular}

Table 1. Sales of amoxicillin in different countries around the world.

Besides to the numbers of sales and use of this drug that have been mentioned above, amoxicillin belongs to a group of drugs that are excreted unchanged in urine and faeces at high rates; therefore, it is likely to find amoxicillin concentrations traces in the environment. Table 2 is listed the occurrence and quantity of amoxicillin that have been found in different water bodies of different countries around the world.

\begin{tabular}{llll}
\hline Country & Water body & $\begin{array}{l}\text { Concentrations } \\
\left(\mathbf{n g ~ L}^{-1}\right)\end{array}$ & Reference \\
\hline Italy (Cagliari) & Effluents of sewage treatment plants & 7.40 & {$[66]$} \\
Italy (Cosenza) & & 1.80 & \\
Italy (Palermo) & & 120.35 & \\
Italy (Roma) & & 15.20 \\
Italy (Napoli) & & 1.80 &
\end{tabular}




\begin{tabular}{|c|c|c|c|}
\hline Country & Water body & $\begin{array}{l}\text { Concentrations } \\
\left(\text { ng L L }^{-1}\right)\end{array}$ & Reference \\
\hline Italy (Torino) & & 4.74 & \\
\hline Italy (Varese Olona) & & 4.68 & \\
\hline Italy (Varese Lago) & & 4.68 & \\
\hline Italy (Palermo) & Effluents of sewage treatment plants & 120 & [67] \\
\hline Italy (Latina) & & 15 & \\
\hline Italy (Varese Olona) & & 25 & \\
\hline UK (Merthyr Tydfil) & Surface waters & $39-49$ & {$[68]$} \\
\hline UK (Trefforest Estate) & & $198-245$ & \\
\hline UK (Cardiff) & & $56-60$ & \\
\hline Australia & Raw sewage & 280 & [69] \\
\hline Australia (Brisbane) & Effluent of conventional treatment plant & 30 & \\
\hline \multirow[t]{4}{*}{ Australia } & Hospital effluent & 900 & [20] \\
\hline & Wastewater treatment Plant influent & 6940 & \\
\hline & Wastewater treatment Plant effluent & 50 & \\
\hline & Surface waters & 200 & \\
\hline Italy & Wastewater of sewage treatment plants & 622 & [26] \\
\hline \multirow[t]{3}{*}{ Spain } & Surface water & 200 & [70] \\
\hline & Hospital effluent & 900 & \\
\hline & Urban effluent & 1670 & \\
\hline
\end{tabular}

Table 2. Occurrence of amoxicillin in different water bodies around the world.

Although amoxicillin is an antibiotic drug highly consumed for human and veterinary medicine, and therefore is expected to be found at a relatively high concentration in wastewater and surface water, it is worth noting that there is no much information available in the literature regarding with its occurrence in environmental compartments. This can be explained by the clear fact that the chemical structure of this compound has an unstable $\beta$-lactam ring causing it readily undergo hydrolysis shortly after excretion; moreover, this might be the consequence of the incapability of the analysis to assess the presence of all antibiotic compounds presents in the different samples or even that its concentration in the aquatic media is lower than the limits of detection and quantification of the analytical methods.

\subsection{Methods of analysis for amoxicillin}

British, India and US Pharmacopoeia recommended liquid chromatography and potentiometric methods for the analysis of pure amoxicillin in pharmaceutical dosage forms (tablet, capsule, oral suspension and injection) [71-73].

However, the extensive literature survey showed that there are several methods, which can be used for assaying amoxicillin in drug substances, formulation products, biological fluids and environmental water samples, that is ultraviolet spectroscopy methods, colorimetric 
methods, bienzimetic UV-spectrophotometric methods, polarography methods, spectrofluorometric methods, microbiological assays, enzyme linked immunosorbent assays (ELISA), and high-performance liquid chromatography methods (HPLC) [37].

The literature are reported several high-performance liquid chromatography methods with fluorescence, UV or mass spectrometry detection for the determination of amoxicillin residues in edible tissues of cattle, pig, sheep and goat as well as for cow and sheep milk [75-78].

Table 3 is summarized methods to measure amoxicillin residues in animal tissues that are reported in the literature.

\begin{tabular}{|c|c|c|c|}
\hline Tissue & Method & Limit of detection and limit of quantification & Reference \\
\hline Catfish and salmon tissues & HPLC & LOQ: $1.2 \mathrm{ng} / \mathrm{g}$ & [79] \\
\hline Pig, cattle and chicken muscle & $\begin{array}{l}\text { HPLC } \\
\text { Fluorescence }\end{array}$ & LOQ: $5 \mu \mathrm{g} / \mathrm{Kg}$ & [80] \\
\hline Pig liver, kidney, muscle and fat & LC-MS/MS & $\begin{array}{l}\text { LOD: } 2.3-12 \mu \mathrm{g} / \mathrm{Kg} \\
\text { LOQ: } 25 \mu \mathrm{g} / \mathrm{Kg}\end{array}$ & [81] \\
\hline Chicken muscle, kidney, liver, fat. & LC-MS/MS & $\begin{array}{l}\text { CC } \alpha: 51.6-57.0 \mu \mathrm{g} / \mathrm{Kg} \\
\mathrm{CC} \beta: 72.4 \mu \mathrm{g} / \mathrm{Kg}\end{array}$ & [82] \\
\hline Pig kidney, liver, fat and muscle & LC-ESI-MS/MS & $\begin{array}{l}\text { LOD: } 1.5-3.5 \mathrm{ng} / \mathrm{g} \\
\text { LOQ: } 25 \mathrm{ng} / \mathrm{g}\end{array}$ & [83] \\
\hline Sheep serum and tissue cage fluid & $\begin{array}{l}\text { HPLC } \\
\text { Fluorescence }\end{array}$ & $\begin{array}{l}\text { LOD: } 0.06-0.10 \mu \mathrm{g} / \mathrm{mL} \\
\text { LOQ: } 0.10-0.20 \mu \mathrm{g} / \mathrm{mL}\end{array}$ & [84] \\
\hline Bovine milk & UHPLC-MS/MS & $\begin{array}{l}\text { LOD: } 1.0 \mathrm{ng} / \mathrm{mL} \\
\text { LOQ: } 5 \mathrm{ng} / \mathrm{mL}\end{array}$ & [85] \\
\hline Bovine muscle & LC-MS/MS & $\begin{array}{l}\text { CC } \alpha: 61.2 \mu \mathrm{g} / \mathrm{Kg} \\
\text { CC } \beta: 72.4 \mu \mathrm{g} / \mathrm{Kg}\end{array}$ & {$[86]$} \\
\hline Chicken muscle, kidney and liver & HRMS & $\begin{array}{l}\text { LOD: } 10 \mu \mathrm{g} / \mathrm{Kg} \\
\text { LOQ: } 15-25 \mu \mathrm{g} / \mathrm{Kg}\end{array}$ & [87] \\
\hline Eggs chicken & LC-MS/MS & $\begin{array}{l}\text { LOD: } 0.6 \mu \mathrm{g} / \mathrm{Kg} \\
\text { LOQ: } 1.8 \mu \mathrm{g} / \mathrm{Kg}\end{array}$ & [88] \\
\hline
\end{tabular}

Notes: CC $\alpha$ : Decision limit; CC $\beta$ : Detection capability

Table 3. Methods to measure amoxicillin residues in food animal tissues.

The literature are also reported a few high-performance liquid chromatography methods with fluorescence, UV or mass spectrometry detection for the determination of amoxicillin in effluents and environmental water samples [60,67]. Table 4 summarises some methods to measure amoxicillin and its degradation products in water samples.

The chromatographic methods for amoxicillin analysis in animal tissues and environmental water samples play a significant role in the regulation of the use of this drug in livestock as 


\begin{tabular}{llll}
\hline Molecule & Method & Limit of detection or quantification & Reference \\
\hline Amoxicillin & HPLC-MS-MS & LOQ: $6 \mathrm{ng} / \mathrm{L}$ & [60] \\
Amoxicillin & HPLC-MS/MS & LOQ: $2.08 \mathrm{ng} / \mathrm{L}$ & {$[67]$} \\
Amoxicillin & UPLC-MS/MS & LOD: $2.5 \mu \mathrm{g} / \mathrm{L}$ & {$[68]$} \\
& LOQ: $10 \mu \mathrm{g} / \mathrm{L}$ & [69] \\
Amoxicillin & LC-MS/MS & LOD: $14 \mathrm{ng} / \mathrm{mL}$ & [20] \\
Amoxicillin & HPLC-MS/MS & LOD: $20 \mathrm{ng} / \mathrm{mL}$ & [89] \\
Amoxicillin, & No reported & \\
Penicilloic acid, & & \\
$\begin{array}{l}\text { Penilloic acid, } \\
\text { AMX diketopiperazine }\end{array}$ & & & \\
AMX-S-oxide & & & \\
Amoxicillin & & LOD: $3.54 \mu \mathrm{g} / \mathrm{L}$ & \\
& & LOQ: $10 \mu \mathrm{g} / \mathrm{L}$ & \\
\hline
\end{tabular}

Table 4. Methods to measure amoxicillin and metabolites in water samples.

well as in the creation of future regulations and monitoring programs for this drug in effluents from wastewater treatment plants, hospitals and households. Regulatory agencies rely on data generated from these methods to establish regulatory actions. Therefore, it is necessary to develop sensitive, accurate and reliable methods to support regulatory programs.

\section{Environmental degradation of amoxicillin}

Several processes can affect the fate and transport of organic compounds in the environment including 1) sorption, 2) biotic transformation and 3) abiotic transformation. The knowledge of the chemical properties and structures of compounds can allow preliminary estimation of their fate and persistence in the environment [91].

Despite that it is well known that $\beta$-lactam drugs contain a lactam ring, which is unstable and easily opened by $\beta$-lactamases (a widespread enzyme in bacteria) [24] as well as have shown thermal degradation with the hydrolytic cleavage and ultimate mineralisation to $\mathrm{CO}_{2}$ and water [20], there was no detailed information regarding to the transformation of this antimicrobial compound in the environment until recent years.

In 2013, Gozlan et al., suggested a full degradation pathway of amoxicillin in aqueous medium. This starts with the opening of the four-membered $\beta$-lactam ring by hydrolysis to yields the intermediate AMX-penicilloic acid, which contains an extra free carboxylic acid group. Also it was reported that various metal ions such as mercury, zinc, cadmium, cobalt and copper might catalyse the degradation of the $\beta$-lactam ring. Subsequently depending of the $\mathrm{pH}$ of the medium, this intermediate compound could yield two different more stable compounds [89, 92, 93]. 
At high $\mathrm{pH}$, the lone pair electrons on the amine group of the AMX-penicilloic acid are available for nucleophilic attack on the carbonyl group to yield a six membered stable diketopiperazine ring and the AMX diketopiperazine degradation product [89]. In the other hand, at low $\mathrm{pH}$, the AMX-penicilloic acid suffers a decarboxylation process yielding the AMX penicilloic acid degradation product [89].

Another metabolite of amoxicillin is yield under sunlight irradiation merely as an indirect photolysis process enhanced by the presence of natural photo-sensitisers like humic acids, which activate the oxygen dissolved in water to oxidise the amoxicillin, forming the AMX-Soxide degradation product; also this product is obtained under ozonation process. It is worth noting that the presence of this compound in aquatic environments is of great concern, because the AMX-S-oxide $\beta$-lactam ring is still active and may lead to the development of resistant bacteria and even cause other possible health hazards to human and wild and domestic animals [93].

To sum up, it is important to remark that these degradation products are suspected of being more resistant to degradation, and potentially more toxic, than the parent compound [36, 66, $70,93]$.

\section{Bioaccumulation and bacteria resistance genes}

Antibiotics like amoxicillin are used not only for treating human health issues; they are also wide used in livestock farming and fish farming for treating diseases. The improper administration of theses pharmaceutical compounds may lead to the occurrence of these drugs in food supplies $[4,78,94]$. Over the last decades, the occurrence of antibiotics in tissues of aquatic organisms has raised the interest of different organisations around the globe, particularly the FDA in USA. It has been reported that continuous exposure to these pharmaceutical compounds may result in accumulation of the parent compound, their metabolites or both in tissues of aquatic organisms [95].

Due to the risk associated with direct and indirect effects on human health due to both passive and active consumption of antibiotics has lead to set regulations on the use of some antibiotics and the establishment of maximum residue limits. The US official limit tolerance for amoxicillin residues is $0.01 \mathrm{ppm}$ (10 ppb o $10 \mathrm{ng} / \mathrm{g})$ in milk and uncooked cattle tissue; however, no tolerance has been established for amoxicillin residues in fish tissues at the present time [78, 95, 96].

It is important to remark that the presence of these drugs in animal tissues can have undesirable effects on consumer health such as allergies; however, the main problem related with the presence of this antimicrobial compounds in fish tissues is the non-controlled ingestion of antibiotics, possibly inducing resistance in bacterial strains [4, 66, 94, 95].

It has been recently shown an exchange of genes for resistance to antibiotics between bacteria in the aquaculture environment and bacteria in the terrestrial environment, including bacteria of animals and human pathogens [4, 97-99]. Therefore, the presence of antibiotics in the aquatic 
environment can result in the appearances of resistance among human pathogens forming part of its microbiota [4, 100-102].

To sum up the unrestricted use of antibiotics like amoxicillin for any purpose in any country has the potential to affect human and animal health on a global scale; hence, this problem should be dealt through unified local and global preventive approaches $[4,103,104]$.

\section{Immuno-allergic potential}

In the literature, it is reported that antibacterial drugs like amoxicillin are not considered as important toxics substances, even at high concentrations; however, an frequent use or exposure to this drugs may produce allergic reactions. Currently, the widely prescribed $\beta$-lactam antibiotics are among the drugs most frequently eliciting allergic reactions in human populations [105-108].

Protein haptenation plays a key role in immunological reactions to amoxicillin. The haptenation process occurs through the nucleophilic opening of the $\beta$-lactam ring by the attack of free amino groups in proteins, particularly modelling molecular studies found that the most reactive residues towards to amoxicillin is the Lysine, favouring the amoxicilloyl-protein adduct formation, which is able to elicit an immune response [109-112].

Clinically, drug allergy is characterized by a spectrum of immune reactions ranging from mild skins rashes to angio-oedema or life-threatening anaphylaxis, meaning a serious and potentially life-threatening problem, causing injury to tissues throughout the body. Moreover, diagnosis is complicated and requires a careful medical history, laboratory studies and in many cases oral food challenge to confirm a diagnosis. Particularly, some people have hypersensitive immune systems that overreact to these types of drugs, and without immediate medical treatment, allergic reactions may be fatal $[113,114]$. Residues of many antibiotics and antibacterial agents, or haptenised macromolecules, for example penicilloylated proteins in meat and other dietary products from food animals and farmed fish might be responsible for hypersensitivity reactions in human population. Up to $7-10 \%$ of the general population in the world has true allergic sensitivity to penicillin and their related compounds due to prior medical treatment. However, in the literature, only a very small number of cases of hypersensitivity reactions related to food containing residues of penicillin have been reported [115-117]. Even though these cases are very rare, they remark the continuing need to control antibiotic residues vigilantly [117].

\section{Toxicological risk of amoxicillin}

In aquatic environments, few studies have reported the effects of amoxicillin in fish, probably because it is not described as a toxic substance important in the scientific literature reporting that the $\mathrm{LC}_{50}$ at 96 hours for Oryzias latipes was $1000 \mathrm{mg} / \mathrm{L}$ [35]. 
However, Andreozzi et al., in 2004, reported a high toxicity of amoxicillin in the blue green algae S. leopoliensis $(\mathrm{NOEC}=0.78 \mu \mathrm{g} / \mathrm{L} ; \mathrm{LOECs}=1.56 \mu \mathrm{g} / \mathrm{L} ; \mathrm{EC} 50=2.22 \mu \mathrm{g} / \mathrm{L}$ ) at 96 hours in concentrations between of $50 \mathrm{ng} / \mathrm{L}$ and $50 \mathrm{mg} / \mathrm{L}$ [66].

Furthermore, in 2013 at the University of Aveiro Portugal, Oliveira et al., measured the effects of amoxicillin in embryos and adults of Danio rerio; the effects found in embryos exposed with amoxicillin were premature hatching, malformations such as edema and deformities in the tail as well as abnormal development of fish. In the other hand, in adults exposed to amoxicillin, they found that amoxicillin produce the inhibition on the activity of the enzyme catalase (CAT) in certain tissues such as gills and brain, as well as produce an induction of the activity of the enzyme glutathione transferase (GTS) in tissues such as muscle, gills and brain, indicating that this antibiotic is capable of modifying the normal enzyme activity in fish [118].

In addition, Liu et al., in 2015, reported that the exposure of the photosynthetic cyanobacteria Microcystis aeruginosa to different concentrations of amoxicillin produced a significant increase in reactive oxygen species (ROS) and an increase in the activity of superoxide dismutase (SOD), peroxidase (POD) and glutathione-S-transferase (GST) as well as an increase in the content of glutathione (GSH) and malondialdehyde (MDA) [119].

Similarly, Li, et al., in 2007 reported that amoxicillin has the potential to produce genomic injuries in human deoxyribonucleic acid (DNA), possibly by intracellular induction of reactive oxygen species (ROS) [120].

Although the full extent and consequences of antibiotics in the aquatic environment are still largely unknown, their biological activity and toxicology is of concern [70]. However, despite being an issue of global concern, research regarding toxicological testing and biological activity is still insufficient and necessary.

\section{Conclusion}

Due to the lack of information regarding with environmental occurrence, ecotoxicity tests and it unstable structure, $\beta$-lactam drugs like amoxicillin are not generally thought could be of concern as environmental pollutants, however, amoxicillin is one of the most consumed antibiotics in the world, hence this pharmaceutical compound could be present at concentrations of concern by continual infusion in to the environment.

In the literature, there have been found traces of this antimicrobial compound in different water bodies; furthermore, some toxicological tests reported toxic effects in algae and fishes as well as the calculation of the risk quotient (RQ) in UK and Korea suggest that amoxicillin should be consider as a pollutant of high priority in the environment.

However, at present, the available scientific knowledge is less than what is needed to fully assess the risks that amoxicillin pose to the environment; therefore, future works will need to focus on more detailed ecotoxicity testing, using a wide range of aquatic organisms, in order to fully understand the environmental toxicity of this antimicrobial product and how may 
affect both the aquatic and terrestrial environments and indicate possible remediation strategies; future works are needed in the development of new analytical methods that are more sensitive, accurate and reliable in order to assess the occurrence of the amoxicillin and its metabolites in different water bodies.

A large amount of research work is necessary before a thorough understanding of this severe environmental issue.

\section{Author details}

Armando Elizalde-Velázquez ${ }^{1}$, Leobardo Manuel Gómez-Oliván ${ }^{1^{*}}$, Marcela Galar-Martínez², Hariz Islas-Flores ${ }^{1}$, Octavio Dublán-García ${ }^{1}$ and Nely SanJuan-Reyes ${ }^{1}$

*Address all correspondence to: lgolivan74@gmail.com

1 Laboratorio de Toxicología Ambiental, Facultad de Química, Universidad Autónoma del Estado de México. Paseo Colón intersección Paseo Tollocan s/n. Col. Residencial Colón, 50120 Toluca, Estado de México, , México.

2 Laboratorio de Toxicología Acuática, Sección de Graduados e Investigación, Escuela Nacional de Ciencias Biológicas, Instituto Politécnico Nacional. Plan de Ayala y Carpio s/n, 11340 México D.F., México.

\section{References}

[1] Wise, R., 2002 Antimicrobial resistance: priorities for action. Journal of Antimicrobial Chemotherapy. 49, 585-586.

[2] Gothwal, R. and Shashidhar, T., 2014 Antibiotic Pollution in the Environment: A Review. Clean Soil Air Water. doi: 10.1002/clen.201300989.

[3] MartinezJ.L., 2009 Environmental pollution by antibiotics and by antibiotic resistance determinants. Environmental Pollution. 157, 2893-2902.

[4] Cabello, F.C., 2006 Heavy use of prophylactic antibiotics in aquaculture: a growing problem for human and animal health and for the environment. Environmental Microbiology, 8, 1137-1144.

[5] Kümmerer, K, 2003 Significance of antibiotics in the environment Journal of Antimicrobial Chemotheraphy. 52, 5-7.

[6] Singer, R.S., Finch, R., Wegener, H.C., Bywater, R., Walters, J., Lipstich, M., 2003 Antibiotic resistance: the interplay between antibiotic use in animals and human beings. Lancet Infectious Disease. 3, 47-51. 
[7] McManus, P.S., Stockwell, V.O., Sundin, G.W., Jones, A.L., 2002 Antibiotic use in plant agriculture. Annual Review Phytopathology, 40, 443-465.

[8] Smith, D.L., Harris, A.D., Johnson, J.A., Sildberg, E.K., MorrisJ.G.Jr., 2002 Animal antibiotic use has an early but important impact on the emergence of antibiotic resistance in human commensal bacteria. Proceedings of the National Academy of Science. 99, 6434-6439.

[9] WHO, 2002. Overcoming Antibiotic Resistance, World Health Organization Report in Infectious Diseases. WHO, Geneva. Fact sheet No. 268.

[10] Johnson, A. C., Keller, V., Dumont, E., Sumpter, J. P., 2015 Assessing the concentrations and risks of toxicity from the antibiotics ciprofloxacin, sulfamethoxazole, trimethoprim and erythromycin in European rivers. Science of the Total Environment. 511, 747-755.

[11] Ma, Y., Li, M., Wu, M., Li, Z., \& Liu, X., 2015 Occurrences and regional distributions of 20 antibiotics in water bodies during groundwater recharge. Science of the Total Environment. 518-519C, 498-506.

[12] Rodriguez-MozazS., ChamorroS., MartiE., HuertaB., GrosM., Sanchez-MelsioA., BorregoC.M., BarceloD., and BalcazarJ.L., 2015 Occurrence of antibiotics and antibiotic resistance genes in hospital and urban wastewaters and their impact on the receiving river. Water Research. 69: 234-242.

[13] Birosova, L., Mackulak, T., Bodik, I., Ryba, J., Skubak, J., Grabic, R. 2014 Pilot study of seasonal occurrence and distribution of antibiotics and drug resistant bacteria in wastewater treatment plants in Slovakia. Science of the Total Environment. 490, 440444.

[14] Chen, C., Li, J., Chen, P., Ding, R., Zhang, P., \& Li, X., 2014 Occurrence of antibiotics and antibiotic resistances in soils from wastewater irrigation areas in Beijing and Tianjin, China. Environmental Pollution. 193, 94-101.

[15] Gibs, J., Heckathorn, H. A., Meyer, M. T., Klapinski, F. R., Alebus, M., \& Lippincott, R. L. 2013. Occurrence and partitioning of antibiotic compounds found in the water column and bottom sediments from a stream receiving two wastewater treatment plant effluents in northern New Jersey. Science of the Total Environment. 458-460, 107-116.

[16] Huerta, B., Marti, E., Gros, M., Lopez, P., Pompeo, M., Armengol, J., Barcelo, D., BalcazarJ.L., Rodriguez-MozazS., Marce, R. 2013 Exploring the links between antibiotic occurrence, antibiotic resistance, and bacterial communities in water supply reservoirs. Science of the Total Environment. 456-457, 161-170.

[17] Na, G., Fang, X., Cai, Y., Ge, L., Zong, H., Yuan, X., Yao, Z., Zhang, Z. 2013 Occurrence, distribution, and bioaccumulation of antibiotics in coastal environment of Dalian, China. Marine Pollution Bulletin. 69(), 233-237.(1-2) 
[18] Zhang, R., Tang, J., Li, J., Zheng, Q., Liu, D., Chen, Y., Zou, Y., Chen, X., Luo, C., Zhang, G. 2013 Antibiotics in the offshore waters of the Bohai Sea and the Yellow Sea in China: occurrence, distribution and ecological risks. Environmental Pollution, 174, 71-77.

[19] Behera, S. K., Kim, H. W., Oh, J. E., \& Park, H. S., 2011 Occurrence and removal of antibiotics, hormones and several other pharmaceuticals in wastewater treatment plants of the largest industrial city of Korea. Science of the Total Environment. 409(20), 4351-4360.

[20] Watkinson, A. J., Murby, E. J., Kolpin, D. W., \& Costanzo, S. D., 2009 The occurrence of antibiotics in an urban watershed: from wastewater to drinking water. Science of the Total Environment. 407(8), 2711-2723.

[21] Tamtam, F., Mercier, F., Le Bot, B., Eurin, J., Tuc Dinh, Q., Clement, M., Chevreuil, M., 2008 Occurrence and fate of antibiotics in the Seine River in various hydrological conditions. Science of the Total Environment. 393(1), 84-95.

[22] Brown, K. D., Kulis, J., Thomson, B., Chapman, T. H., Mawhinney, D. B., 2006 Occurrence of antibiotics in hospital, residential, and dairy effluent, municipal wastewater, and the Rio Grande in New Mexico. Science of the Total Environment. 366(2-3), 772783.

[23] Karthikeyan, K. G., and Meyer, M. T., 2006 Occurrence of antibiotics in wastewater treatment facilities in Wisconsin, USA. Science of the Total Environment. 361(1-3), 196207.

[24] HirschR, TernesT, HabererK, KratzKL., 1999 Occurrence of antibiotics in the aquatic environment. Science of the Total Environment. 225(1-2): 109-18.

[25] Van Boeckel, T. P., Gandra, S., Ashok, A., Caudron, Q., Grenfell, B. T., Levin, S. A., Laxminarayan, R., 2014 Global antibiotic consumption 2000 to 2010: an analysis of national pharmaceutical sales data. The Lancet Infectious Diseases, 14(8): 742-750.

[26] ZuccatoE, CastiglioniS, BagnatiR, MelisM, FanelliR., 2010 Source, occurrence and fate of antibiotics in the Italian aquatic environment. Journal of Hazardous Materials.179: 1042-1048.

[27] KümmererK. 2009a Antibiotics in the aquatic environment - a review - part I. Chemosphere. 75: 417-34.

[28] KümmererK. 2009b Antibiotics in the aquatic environment - a review - part II. Chemosphere. 75: 435-41.

[29] DaughtonC, TernesT. 1999 Pharmaceuticals and personal care products in the environment: agents of subtle change? Environmental Health Perspective. 107: 907-38.

[30] Sanderson, H., Brain, R.A., Jhonson, D.J., Wilson, C.J., Solomon, K.R., 2004 Toxicity classification and evaluation of four pharmaceuticals classes: antibiotics, antineoplastics, cardiovascular, and sex hormones Toxicology, 203, 27-40. 
[31] Van der Oost, R., Beyer, J., Vermeulen, N.P.E., 2003 Fish bioaccumulation and biomarkers in environmental risk assessment: a review. Environmental Toxicology and Pharmacology, 13, 57-149.

[32] División de Protección Pecuaria, 2011 Evaluación de riesgo ambiental de productos farmaceuticos de usos veterinario. Boletín Veterinario Oficial, XIV, 1-9.

[33] Suter, G.W., 1993 Ecological Risk Assessment. Lewis Publishers, Boca Raton, FL, USA, 538.

[34] Jones, O.A.H., Voulvoulis, N., Lester, J.N., 2002 Aquatic environmental assessment of the top 25 English prescription pharmaceuticals. Water Research, 36, 5013-5022.

[35] Park, S., Choi, K., 2008. Hazard assessment of commonly used agricultural antibiotics on aquatic ecosystems. Ecotoxicology 17, 526-538.

[36] BoxallABA, SinclairCJ, FennerK, KolpinD, MaundSJ. 2004. Peer reviewed: when synthetic chemicals degrade in the environment. Environmental Science \& Technology; 38: 368A-75A.

[37] Rao, R., Kaur, P.S., Nanda, S., 2011 Amoxicillin: a broad-spectrum antibiotic. International Journal of Pharmacy and Pharmaceutical Scinces, 3(3), 30-37.

[38] Subhas, C.M., Harsha, R., Dinesha, R., THammanna, G.S.S., 2010 Antibacterial activity of Coleus aromatics leaves. International Journal of Pharmacy and Pharmaceutical Sciences, 2(3), 63-66.

[39] Garau, J., 2005 Role of the $\beta$-lactam agents in the treatment of community-acquired pneumonia. European Journal of Clinical microbiology and Infectious Diseases, 24, 8399.

[40] Soussa, J.C., 2005 Manual de antibióticos antibacterianos. Fernando Pessoa University, Oporto, Portugal. See, 219-221.

[41] Bush, K., $\beta$-lactam antibiotics: Penicillin, and other $\beta$-lactam antibiotics. In: Finch, R.G., Greenwood, D., Norrby, S.R., and Whitley, R.J., Antibiotic and Chemotherapy: antiinfective agents and their use in therapy. $8^{\text {th }}$ ed. Philadelphia (USA): Churchill Livingstone, an imprint of Elsevier Science Limited; 2003, p. 224-278.

[42] Pfizer, 2004 Clavamox ${ }^{\circledR}$ for cats and dogs. See: http://animalhealth.pfizer.com/sites/ pahweb/US/EN/Products/Documents/AIF0504022.pdf Accessed July 2015.

[43] Schering-Plough, 2007 Amoxi-Mast, lacting cow formula. Intramammary infusion. Union, NJ07083, USA. Available at: http://www.merck-animal-health-usa.com/ binaries/Amoxi-Mast_tcm130-164276.pdf Accessed July 2015.

[44] Eppes, S.C., Childs, J.A., 2002 Comparative study of cefuroxime axetil versus amoxicillin in children with early Lyme disease. Pediatrics, 109(6), 1173-1177. 
[45] Shah, S.H., Shah, I.S., Turnbull, G., Cunningham, K., 1994 Cefuroxime axetil in the treatment of bronchitis: comparison with amoxicillin in a multicentre study in genera practice patients. The British Journal of Clinical Practice, 48(4), 185-189.

[46] Torres, R.F., Consentino, M.O., Lopez, M.A.B., Mochon, M.C., 2010 Simultaneous determination of 11 antibiotics and their main metabolites from four different groups by reversed phase high-performance liquid chromatography-diode array-fluorescence (HPLC-DAD-FLD) in human urine samples. Talanta, 81, 871-880.

[47] Dousa, M., Hosmanova, R., 2005 Rapid determination of amoxicillin in premixes by HPLC. Journal of Pharmaceutical and Biomedical Analysis, 37, 373-377.

[48] Nagralli, B.S., Seetharamappa, J., Melwanki, M.B., 2002 Sensitive spectrophotometric methods for the determination of amoxicillin, ciprofloxacin, and piroxicam in pure and pharmaceutical formulations. Journal of Pharmaceutical and Biomedical Analysis, 29, 859-864.

[49] Amin, A.S., El-Ansary, A.L., Issa, Y.M., 1994 Colorimetric determination of amoxicillin in pure form and in pharmaceutical preparations. Talanta, 41(5), 691-694.

[50] Fujiwara, K., Shin, M., Miyazaki, T., Maruta, Y., 2011 Immunochemistry for amoxicillin and its use for studying uptake of the drug in the intestine, liver, and kidney of rats. Antimicrobial agents asn chemotherapy, 55(1), 62-71.

[51] Reyns, T., De Boever, S., Schauvliege, S., Gasthuys, F., Meissonnier, G., Oswald, I., De Backer, P., Croubels, S., 2009 Influence of administration route on the biotransformation of amoxicillin in the pig. Journal of Veterinary Pharmacology and Therapeutics, 32(3): 241-248.

[52] Reyns, T., De Boever, S., De BaereS., De Backer, P., Croubels, S., 2008a Tissue depletion of amoxicillin ant its major metabolites in pigs; influence of the administration route and simultaneous dosage of clavulanic acid. Journal of Agricultural and Food Chemistry, $56,448-454$.

[53] Brodie, D.P., Griggs, J.V., Cunningham, K., 1990 Comparative study of cefuroxime axetil suspension and amoxicillin syrup in the treatment of acute otitis media in general practice. Journal of International Medical Research, 18(3), 235-239.

[54] Dattwyler, R.J., Volkman, D.J., Conaty, S.M., Platkin, S.P., Luft, B.J., 1990 Amoxicillin plus probenecid versus doxycycline for treatment of erythema migrans borreliosis. Lancet, 336 (8728), 1404-1406.

[55] Paavonen, J., Roberts, P.L., Stevens, C.E., Wolner-Hanssen, P., Brunham, R.C., Hillier, S., 1989 Randomized treatment of mucopurulent cervicitis with doxycycline or amoxicillin. American Journal of Obstetrics \& Gynecology, 161(1), 128-135.

[56] Calvo J., Martínez L., 2009 Mecanismos de acción de los antimicrobianos Enfermedades infecciosas y microbiología clínica. 27, 44-52. 
[57] Iannacone J., Alvariño L., 2009 Evaluación del riesgo acuático de siete productos farmacéuticos sobre Daphnia magna. Ecología Aplicada, 8(2), 71-80.

[58] Suarez, C., Gudiol, F., 2009 Antibióticos betalactámicos. Enfermedades infecciosas y microbiología clínica., 27(2), 116-129.

[59] Valdés Lozano, D., Muguercia Larrondo, H., Herrera Torres Ma. L., Arias Rivero, E., Marín Zamora, R., Praderes Araujo, J.L., 1998 Penicilinas. ACTA MEDICA, 8(1), 28-39.

[60] Calamari, D., Zuccato, E., Castiglioni, S., Bagnati, R., Fanelli, R., 2003 Strategic, survey of therapeutic drugs in the rivers Po and Lambro in Northern Italy. Environmental Science and Technology, 37, 1241-1248.

[61] Lee, Y., Lee, S., Lee, D., Kim, Y., 2008 Risk assessment of human antibiotics in Korean aquatic environment. Environmental Toxicology and Pharmacology, 26. 216-221.

[62] Therapeutic Goods Administration (TGA). 2003. Import volumes of antibiotics into Australia for human, veterinary and feed application 1992-2003. Canberra: Therapeutic Goods Administration.

[63] Australian Bureau of Statics (ABS). 2004. Highest volume PBS drugs by generic name, year ending: June 2004. Canberra: Australian Bureau of Statistics; p. 3.

[64] Sarmah, A. K., Meyer, M. T., \& Boxall, A. B. 2006 A global perspective on the use, sales, exposure pathways, occurrence, fate and effects of veterinary antibiotics (VAs) in the environment. Chemosphere, 65(5), 725-759.

[65] Magalhaes, J.L., Borschiver, S., 2012 Amoxicillin and Ampicillin: Import trends and increasing use in Brazil. Chemistry Today; 30 (5): 91-93.

[66] Andreozzi, R., Caprio, V., Ciniglia, C., De Champdoré, M., Lo Giudice, R., Marotta, R., Zucatto, E., 2004 Antibiotics in the Environment: Occurrence in Italian STPs, fate, and preliminary assessment on algal toxicity of amoxicillin Environmental Science and Technology. 38, 6832-6838.

[67] Castiglioni, S., Bagnati, R., Calamari, D., Fanelli, R., \& Zuccato, E. 2005 A multiresidue analytical method using solid-phase extraction and high-pressure liquid chromatography tandem mass spectrometry to measure pharmaceuticals of different therapeutic classes in urban wastewaters. Journal of Chromatography A, 1092(2), 206-215.

[68] Kazprzyk-Horden, B., Dinsdale, R., Guwy, A., 2007 Multiresidue method for the formation of basic/neutral pharmaceuticals and illicit drugs in surface water solidphase extraction and ultra performance liquid chromatography-positive Electro spray ionization tandem mass spectrometry. Journal of Chromatography Association, 1161, 132-145.

[69] Watkinson, A., Murby, E., Constanzo, S., 2007 Removal of antibiotics in conventional and advance wastewater treatment: Implications for environmental discharge and wastewater recycling. Water Research, 41, 4164-4176. 
[70] Fatta-Kassinos ,D., Meric, S., Nikolau, A., 2011 Pharmaceutical residues in environmental waste and wastewater: current state of knowledge and future research. Analytical and Bioanalytical Chemistry, 399, 251-275.

[71] British Pharmacopoeia, 2009 ed. Vol I and II. London: British Pharmacopoeia Commission, 2009, 353-367.

[72] United States Pharmacopoeia-30 and National Formulary-25: The Official Compendia of Standards. Rockville (US): United States Pharmacopoeia Convention; 2007, 14021407.

[73] Indian Pharmacopoeia 5th ed. Vol. 2. Ghaziabad (INDIA): Indian Pharmacopoeia Commission; 2007, 100-107.

[74] Adam, G., Rorberts, S., 2007a. Report No. 1541N-03-04-165. Depletion of tissues residues following i.m. administration of clamoxyl TRU (amoxicillin) to sheep. Unpublished report submitted to FAO by Pfizer Animal Health.

[75] Adam, G., Roberts, S., 2007b. Report No. 1820N-03-04-219. Development and validation of an analytical method for the determination of amoxicillin in swine liver, kidney, muscle and skin with fat. Unpublished reports submitted to FAO by Pfizer Animal Health.

[76] Doran, A., Adam, G., 2005 Report No. 1840N-03-03-154. Development and validation of an analytical method for the determination of amoxicillin in ovine liver, kidney, muscle, fat and milk. Unpublished report submitted to FAO by Pfizer Animal Health.

[77] Neely, M., Conolly, P., 2004. Report No. 1830N-60-03-405. Validation of analytical methods for the determination of amoxicillin in bovine tissues (liver, kidney, muscle, fat) and milk. Unpublished report submitted to FAO by Pfizer Animal Health.

[78] Ang. W.Y.C., Liu, F.F., Lay, O.J., Luo, W., McKim, K., Ghering, T., Lochmann, R., 2000. Liquid chromatography analysis of incurred amoxicillin residues in catfish muscle following oral administration of the drug. Journal of Agriculture and Food Chemistry, 48. 1673-1677.

[79] Ang, C.Y.W., Luo, W., Hansen, E.B., Freeman, J.P., Thompson, H.C., 1996 Determination of amoxicillin in catfish and salmon tissues by liquid chromatography with precolumn formaldehyde derivatization. Journal of AOAC International, 79(2), 389396.

[80] Luo, W., Ang, C.Y.W., 2000 Determination of amoxicillin residues in animal tissues by solid phase extraction and liquid chromatography with fluorescence detection. Journal of AOAC International, 83, 20-25.

[81] De Baere, S., Cherlet, M., Baert, K., De Backer, P., 2002 Quantitative analysis of amoxicillin and its major metabolites in animal tissues by liquid chromatography combined with electrospray ionization tandem mass spectrometry. Analytical Chemistry, 74(6), $1393-1401$. 
[82] De Baere, S., Wassink, P., Croubels, S., De Boever, S., Baert, K. \& De Backer, P., 2005. Quantitative liquid chromatographic-mass spectrometric analysis of amoxycillin in broiler edible tissues. Analytica Chimica Acta, 529, 221-227.

[83] Reyns, T., De Boever, S., De BaereS., De Backer, P., Croubels, S., 2008b Rapid method for the quantification of amoxicillin and its major metabolites in pig tissues y liquid chromatography-tandem mass spectrometry with emphasis on stability issues. Journal of Chromatography, B, 861, 108-116.

[84] Delis, G., Batzias, G., Kounenis, G., \& Koutsoviti-Papadopoulou, M., 2009 Application and validation of a LC/fluorescence method for the determination of amoxicillin in sheep serum and tissue cage fluid. Journal of Pharmaceutical and Biomedical Analysis, 49(2), 375-380.

[85] Liu, C., Wang, H., Jiang, Y., \& Du, Z., 2011 Rapid and simultaneous determination of amoxicillin, penicillin $\mathrm{G}$, and their major metabolites in bovine milk by ultra-highperformance liquid chromatography-tandem mass spectrometry. Journal of chromatography. B, Analytical technologies in the biomedical and life sciences, 879(7-8), 533540.

[86] Lugoboni, B., Gazzotti, T., Zironi, E., Barbarossa, A., \& Pagliuca, G., 2011 Development and validation of a liquid chromatography/tandem mass spectrometry method for quantitative determination of amoxicillin in bovine muscle. Journal of chromatography. B, Analytical technologies in the biomedical and life sciences 879(21), 1980-1986.

[87] Hermo, M. P., Saurina, J., Barbosa, J., \& Barron, D., 2014 High-resolution mass spectrometry applied to the study of metabolome modifications in various chicken tissues after amoxicillin administration. Food Chemistry, 153, 405-413.

[88] Sun, L., Jia, L., Xie, X., Xie, K., Wang, J., Liu, J., Wang, J., Cui, L., ZhangnG., Dai, G., Wang, J., 2015 Quantitative Analysis of Amoxicillin, Its Major Metabolites and Ampicillin in Eggs by Liquid Chromatography Combined with Electrospray Ionization Tandem Mass Spectrometry. Food Chemistry. Accepted manuscript.

[89] Gozlan, I., Rotstein, A., Avisar, D., 2013 Amoxicillin degradation products formed under controlled environmental conditions: Identification and determination in the aquatic environment. Chemosphere, 91, 985-992.

[90] Gbylik-Sikorska, M., Posyniak, A., Sniegocki, T., Zmudzki, J., 2015 Liquid chromatography-tandem mass spectrometry multiclass method for the determination of antibiotics residues in water samples from water supply systems in food-producing animal farms Chemosphere, 119, 8-15.

[91] HuangCH, RenewJE, SmebyKL, PinkerstonK, SedlakDL., 2001 Assessment of potential antibiotic contaminants in water and preliminary occurrence analysis. Water Resources Update. 120:30-40. 
[92] Lamm, A., Gozlan, I., Rotstein, A., Avisar, D., 2009 Detection of amoxicillin-diketopiperazine-2', $5^{\prime}$ in wastewater samples. Journal of Environmental Science and Health Part. 44, 1512-1517.

[93] Gozlan, I., Rotstein, A., Avisa, D., 2010 Investigation of an amoxicillin oxidative degradation product formed under controlled environmental conditions. Environmental Chemistry. 7, 435-442.

[94] Tittlemier, S. A.; Van de Riet, J.; Burns, G.; Potter, R.; Murphy, C.; Rourke, W.; Pearce, H.; Cao, X. L.; Dabekai, R. W.; Dufresne, G., 2007 Analysis of veterinary drug residues in fish and shrimp composites collected during the Canadian Total Diet Study, 19932004. Food Additives and Contaminants, 24 (1), 14-20.

[95] Fernandez-Torres, R., Bello Lopez, M. A., Olias Consentino, M., Callejon Mochon, M., Perez-Bernal, J. L., 2010 Application of enzymatic probe sonication extraction for the determination of selected veterinary antibiotics and their main metabolites in fish and mussel samples. Analytica Chimica Acta, 675(2), 156-164.

[96] CFR. U.S. Code of Federal Regulations, Part 21. $\delta$ 556.38, Amoxicillin; U.S. GPO: Washington, DC, 1991.

[97] Sørum, H., and L'Abée-Lund, T.M., 2002 Antibiotic resistance in food related bacteria a result of interfering with the global web of bacterial genetics. International Journal of Food Microbiology, 78: 43-56.

[98] Sørum, H., 2006 Antimicrobial drug resistance in fish pathogens. In Antimicrobial Resistance in Bacteria of Animal Origin. Aarestrup, F.M. (ed.). Washington, DC, USA: American Society for Microbiology Press, pp. 213-238 (Chapter 13).

[99] Schmidt, A.S., Bruun, M.S., Dalsgaard, I., Pedersen, K., and Larsen, J.L., 2000 Occurrence of antimicrobial resistance in fish pathogenic and environmental bacteria associated with four Danish rainbow trout farms. Applied Environmental Microbiology 66: 4908-4915.

[100] Angulo, F.J. 2000 Antimicrobial agents in aquaculture: potential impact on health. APUA Newsletter 18: 1-6.

[101] Angulo, F.J., and Griffin, P.M., 2000 Changes in antimicrobial resistance in Salmonella enterica serovar Typhimurium. Emerging Infectious Disease Journal. 6: 436-438.

[102] Angulo, F.J., Nargund, V.N., and Chiller, T.C., 2004 Evidence of an association between use of anti-microbial agents in food animals and anti-microbial resistance among bacteria isolated from humans and the human health consequences of such resistance. Journal of Veterinary Medicine 51: 374-379.

[103] Cabello, F.C., 2003 Antibiotics and aquaculture: An analysis of their potential impact upon the environment, human and animal health in Chile. Fundación Terram. Analisis de Politicas Publicas, 17, pp. 1-16. See: http://www.terram.cl/docs/App17_Antibioticos_y_Acuicultura.pdf Accessed in July 2015. 
[104] Cabello, F.C., 2004 Antibiotics and aquaculture in Chile: implications for human and animal health. Revista Medica Chilena 132: 1001-1006.

[105] ArizaA., GarzonD., AbanádesD.R., Vivian de los Rios., Vistoli G., Torres M.J., Carini M., Aldini G., Perez-Sala D., 2012 Protein hapetanation by amoxicillin: High resolution mass spectrometry analysis and identification of target proteins in serum. Journal of Proteomics, 77, 504-520.

[106] AlpízarOlivares Y., 2000 La penicilina y sus derivados como agentes desencadenantes de la respuesta immune. Revista Cubana de Hematología, Inmunología y Homoterapia, 16(2), 99-104.

[107] Vega, J.M., Blanca, M., Garcia, J.J., Carmona, M.J., Miranda, A., Perez-Estrada, M., Fernandez, S., Acebes, J.M., Terrados, S., 1994 Immediate allergic reactions t amoxicillin. Allergy, 49, 317-322.

[108] Anderson, J.A., Adkinson, N.F., 1989 Reacciones alergicas a fármacos y agentes biológicos. Compendio de Enfermedades alérgicas e inmunológicas, Washington DC, 82-95.

[109] ArizaA., MontañezM.I., Pérez-SalaD., 2011 Proteomics in immunological reactions to drugs" Current Opinion in Allergy and Clinical Immunology. 11, 305-312.

[110] Meng, X., Jenkins, R.E., Berry, N.G., Maggs, J.L., Farrell, L., Lane, C.S., ., 2011 Direct evidence for the formation of diasteroisomeric benzylpenicilloyl haptens from benzilpenicillin and benzilpenicillenic acid in patients. Journal of Pharmacology and Experimental Therapeutics, 338, 841.849.

[111] Yvon, M., Wal, J.M., 1988 Identification of lysine residue 199 of human serum albumin as binding site for benzilpenicilloyl groups. FEBS Letters, 239, 23-240.

[112] Yvon, M., Anglade, P., Wal, J.M., 1990 Identification of the binding sites of benzyl penicilloyl, the allergenic metabolite of penicillin on the serum albumin molecule. FEBS Letters, 263, 237-240.

[113] Woodward, K., 2012 Toxicological Effects of Veterinary Medicinal Products in Humans. Royal Society of Chemistry.

[114] Sicherer, S.H., Sampson, A.H, 2010 Food allergy. Primer on Allergic and Immunologic Disease, 125(2), S116-S125.

[115] Graham, F., Paradist, L., Bégin, P., Paradis, J., Babin, Y., Des Roches, A., 2014 Risk of allergic reactions an sensitization to antibiotics in foods. Annals of Allergy, Asthma and Immunology, 113(3), 329.

[116] Dayan, A.D., 1993 Allergy to antimicrobial residues in food: assessment of the risk to man. 35(3-4), 213-226.

[117] Dewdney, J.M., Maes, L., Raynaud, J.P., Blanc, J.P., Scheid, T., Jackson, T., Lens, S., Verschueren, C., 1991 Risk assessment of antibiotic residues of $\beta$-lactams and macro- 
lides in food products with regard to their immuno-allergic potential. Food and Chemical Toxicology, 29(7), 477-483.

[118] OliveiraR., McDonoughS., LadewigC.L.J., SoaresM.V.M.A., NogueiraJ.A.A., DominguesI. 2013. Effects of oxytetracycline and amoxicillin on development and biomarkers activities of zebrafish (Danio rerio). Environmental Toxicology and Pharmacology, 36. 903-912.

[119] Liu, Y., Wang, F., Chen, X., Zhang, J., Gao, B., 2015 Cellular responses and biodegradation of amoxicillin in Microcystis aeruginosa at different nitrogen levels. Ecotoxicology and Environmental Safety. 111, 138-145.

[120] Li, P.Y., Chang, Y.C., Tzang, B.S., Chen, C.C., Liu, Y.C., 2007, Antibiotic amoxicillin induces DNA lesions in mammalian cells possibly via the reactive oxygen species. Mutation Research. 629 (2007) 133-139. 


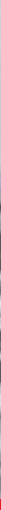

\section{Edited by Marcelo L. Larramendy and Sonia Soloneski}

This book, Environmental Health Risk - Hazardous Factors to Living Species, is intended to provide a set of practical discussions and relevant tools for making risky decisions that require actions to reduce environmental health risk against environmental factors that may adversely impact human health or ecological balances.

We aimed to compile information from diverse sources into a single volume to give some real examples extending concepts of those hazardous factors to living species that may stimulate new research ideas and trends in the relevant fields.

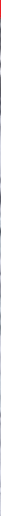

